فى رجاب البيانا القرآنىى

ورلسة خليلية بلاغية

لسورة المرثر

ولمتور

(أمر سعر ناهيى

"كلية اللئة العربية بايتيتاى الباروو

جاعة الأزهر 

الحمد الله حمداً طيباً مباركأ فيه . حمدأ يوافى نعمه ويكـافئ مزيـده وإحسانه .أنزل على عبده الكتاب ولم يجعل له عوجاً قيماً . فتح به أعينـاً

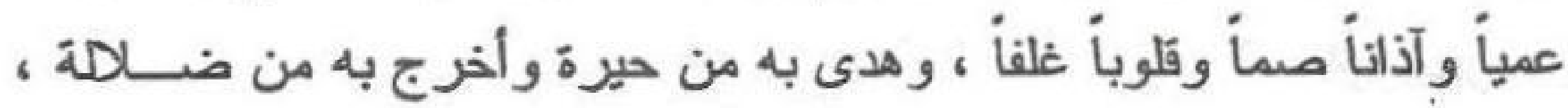

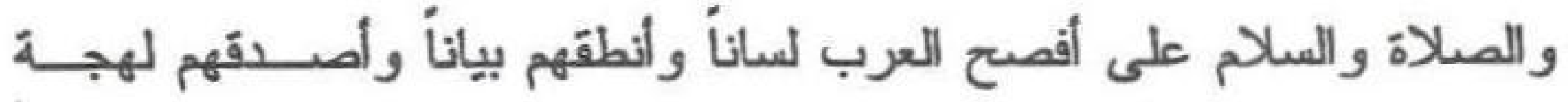
وعلى آله وصحبه أطواد العلم الراسخة ومثاقيل الحكم الراجحة. وبعد فهذه دراسة بعنوان "فى رحاب البيان القرآنى دراســـة بلاغيــة لسورة المدثر "ولما كانت هذه السورة متتوعة الأغر اض و المقاصد آثرت أن تكون رحلتى معها لتجلية الأسرار البلاغية التى الثنملتها هذه الأغراض لِقف القارى لها على جمال النظم القرآنى ومدى تعبيره عن هدفــــه الإعجــازى ومقصده البيانى ، وقد جاءت هذه الدرامة فى مقدمة ، وتمهيد ــ أما التمهيد فكان عبارة عن مدخل خاص بهذه السورة من حيــث تســميتها ومكيتهــا وصلتها بسورة المزمل ووقت نزولها و الأغر اض التى احتّتها ـ ثُ تلى هذا التمهيد الدراسة البلاغية فى أربعة مباحث :

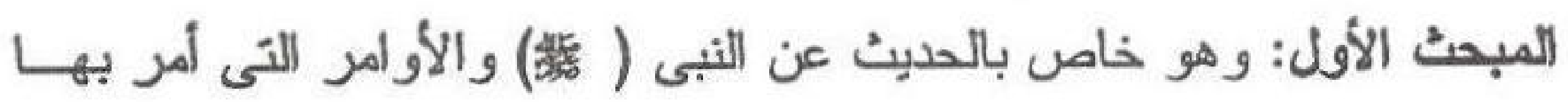

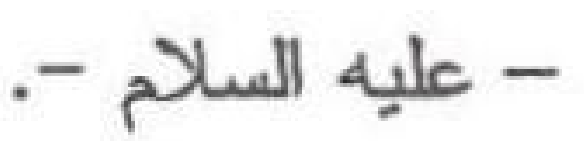

المبحث الثانى : و هو خاص بالحنيث عن أحوال يوم القِيامة ، وسرد قصــة

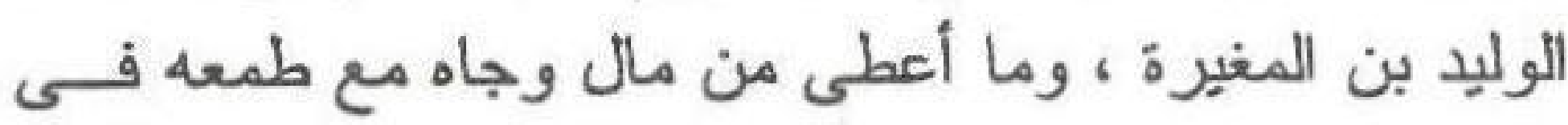

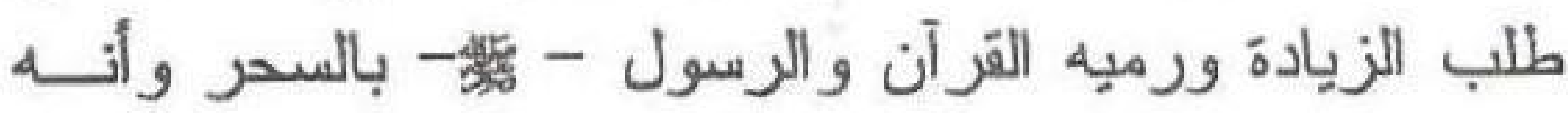
اكتسب هذا من أهل بابل أو غير هم.

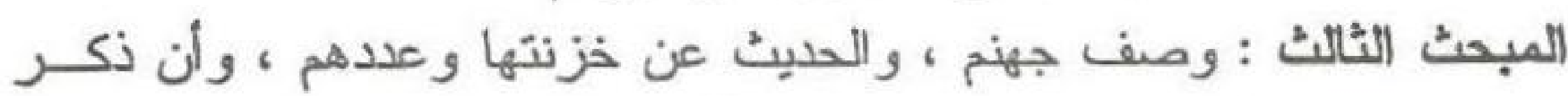

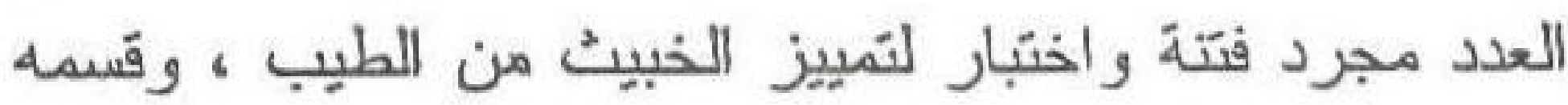

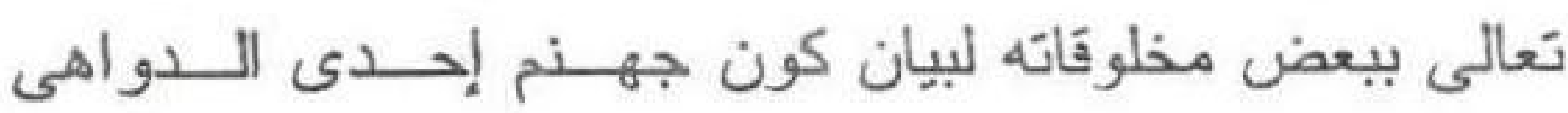




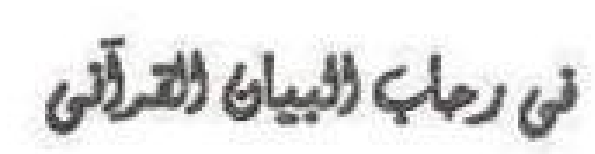

[ध]

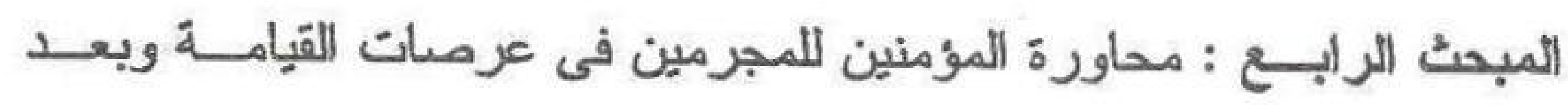

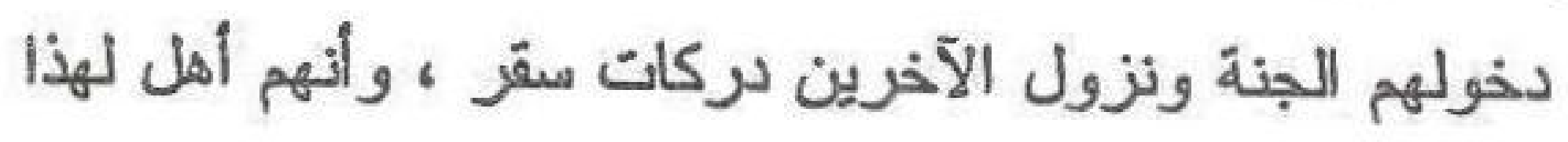

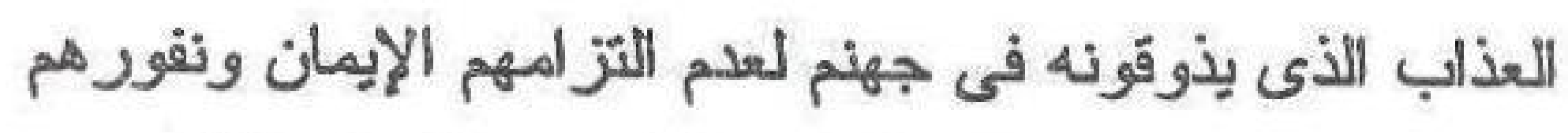

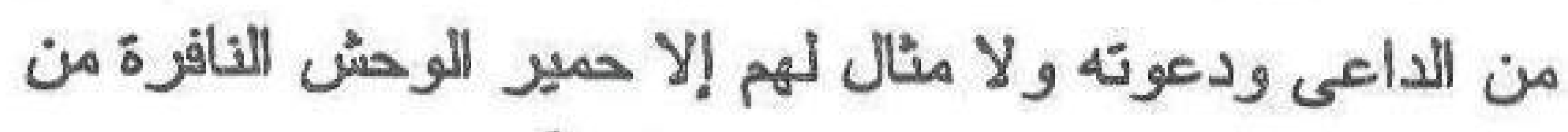

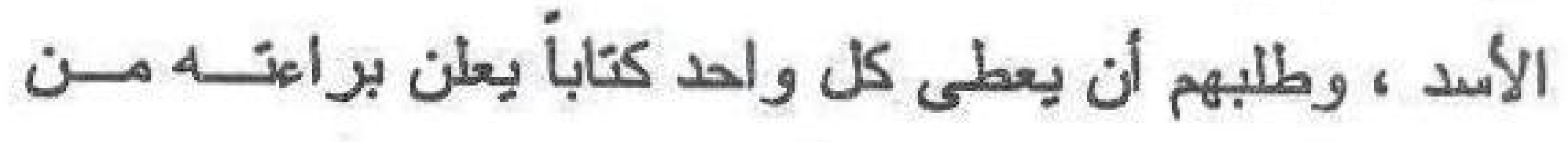

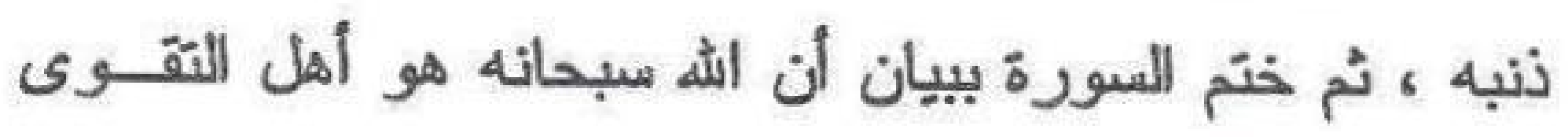

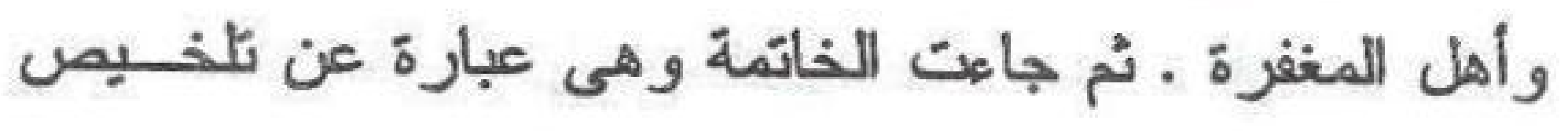
لما جاء فى هذه الدر اسة ثم ثبت بالمراجع.

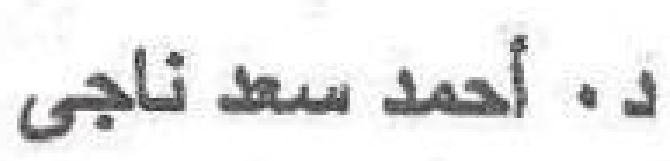

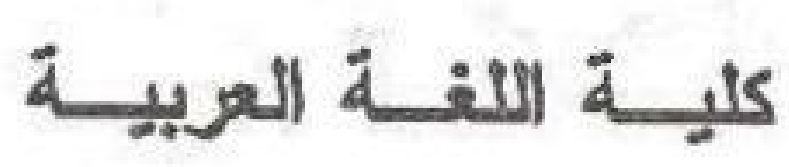
جامعة الأزهر 
بل2 كلئ2 الثعرية

\section{(سورة المدثر)}

\section{مسميات السورة}

أجمعت كتب التقسير والمنة على تسميتها بسورة المــدر ، وكـذللك سميت فى المصاحف الواردة ، ومنها كتب فى القيروان فى القرن الخـامس

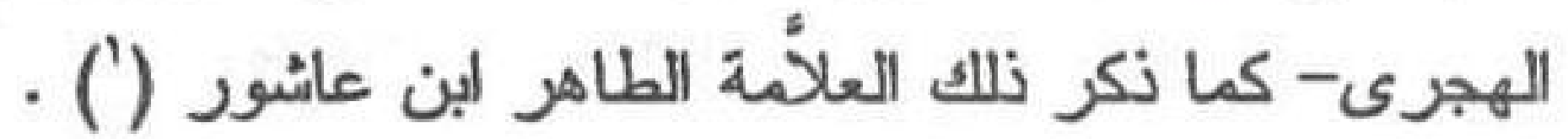
مكية السورة ومدنيتها : هذه السورة مكية حكى الاتفاق على مكينهــا

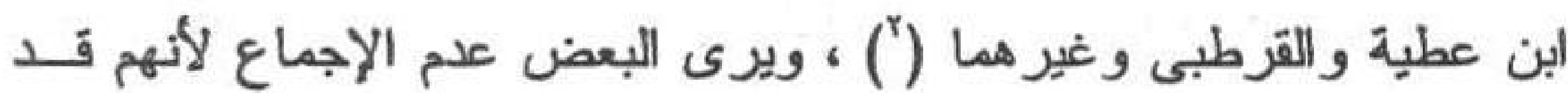

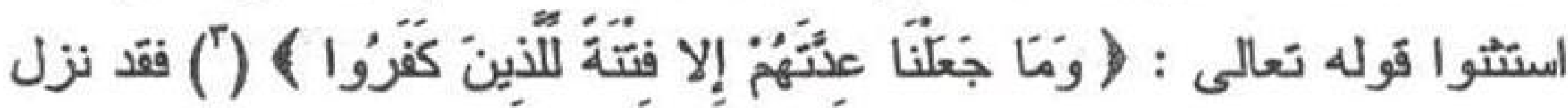
(). بالمدينة رواية عن مقاتل وعدد آياتها ستُ وخمسون آية فى عدًّ أهل البصرة و الكوفة ، وأهـلـ المدينة فى عددهم الأول الذى رجعوا عنه ، و عدًّ آياتها أهل المدينة فى عددّم

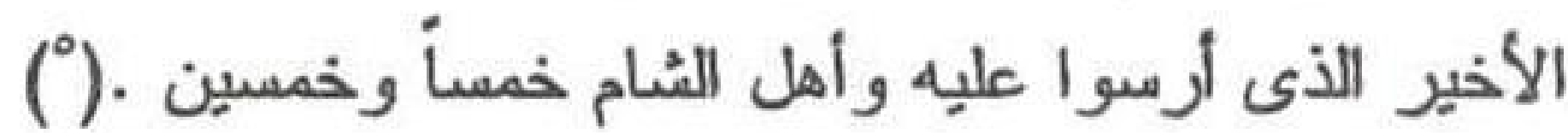
متى نزلت هذه السورة ؟ روى الشيخان البخارى ومسلم عن أبى سلمة

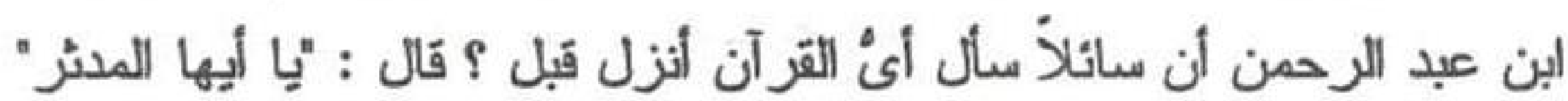
فقتّ : أو اقرأ ؟ فقال : مألت جابر بن عبد الله: أئ القرآن أنزل قبل؟ قال "يا أيها المدثر" فقلت : أو اقرأ ؟ قال جابر أحدثم ما حدثا ريول اله -

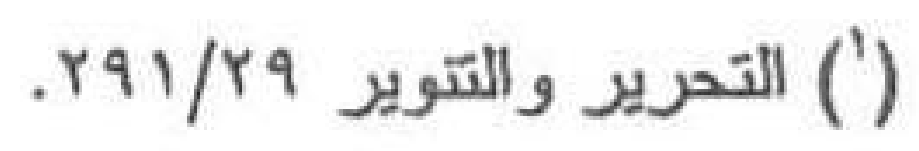

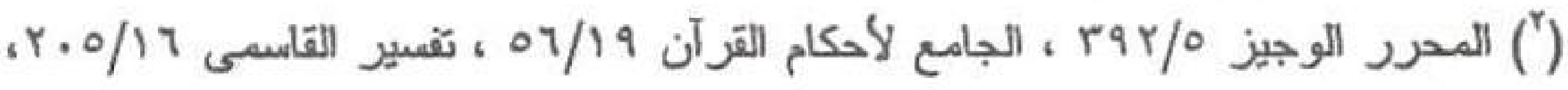

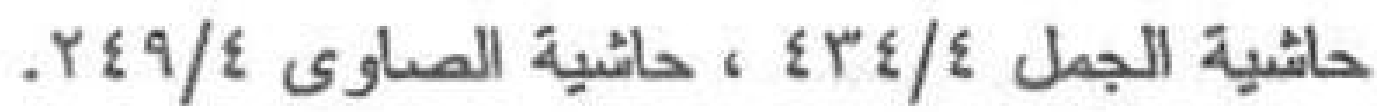

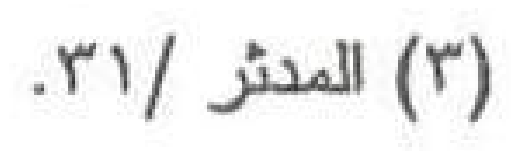

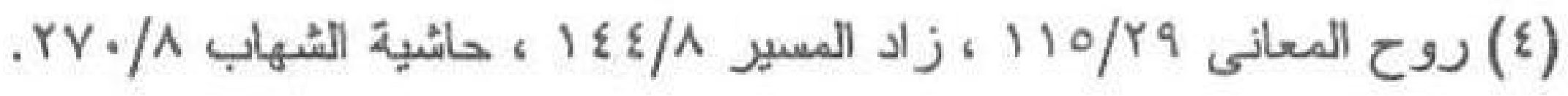

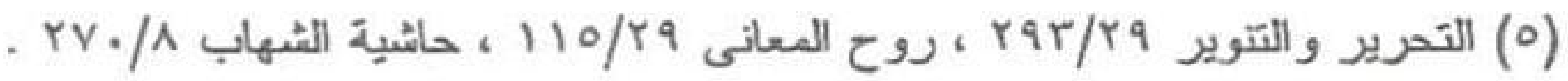




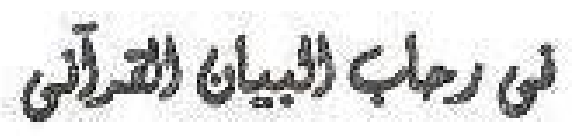

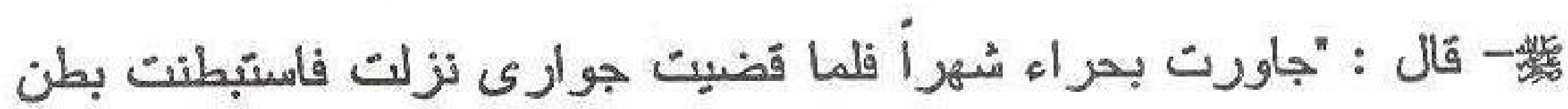

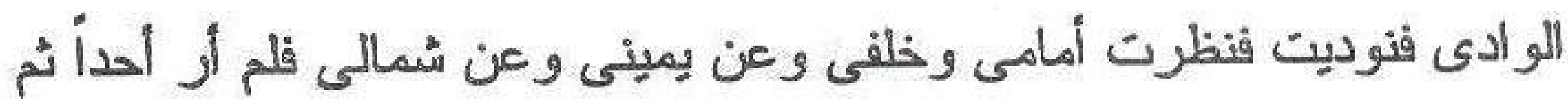

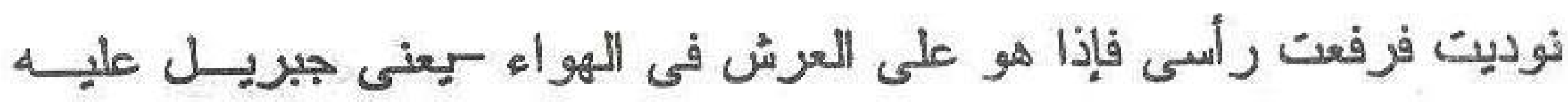

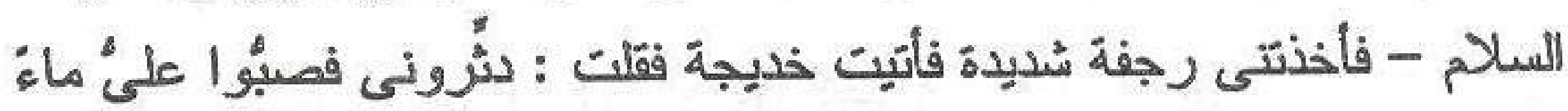

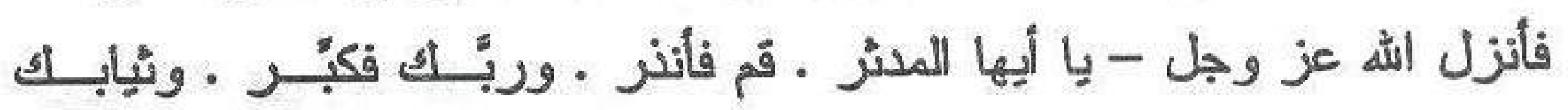

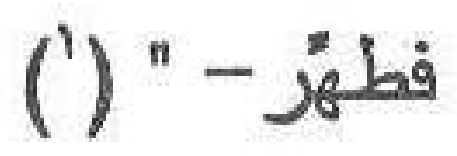

تعليق : قوله إن أول ما أنزل قوله تعالى - أى قول الراوى - "يا أيها

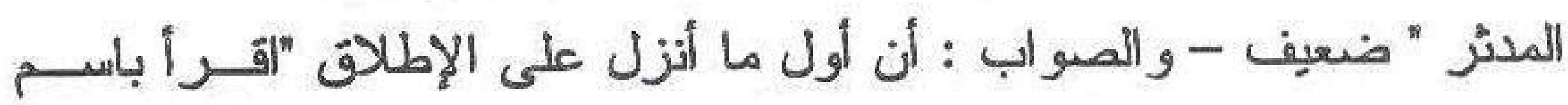

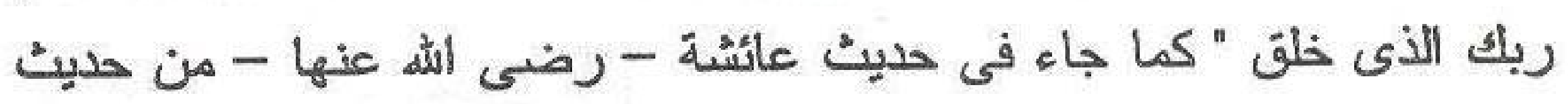

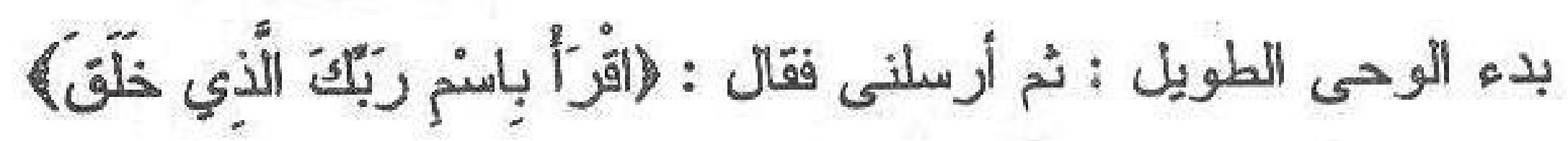
الآيات الفمس من سورة العقى: (")

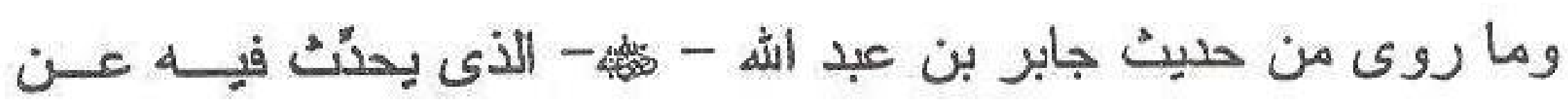

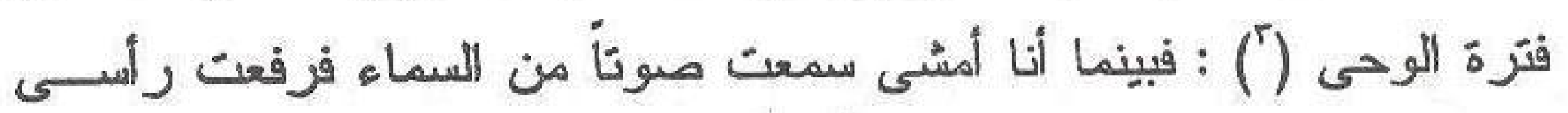

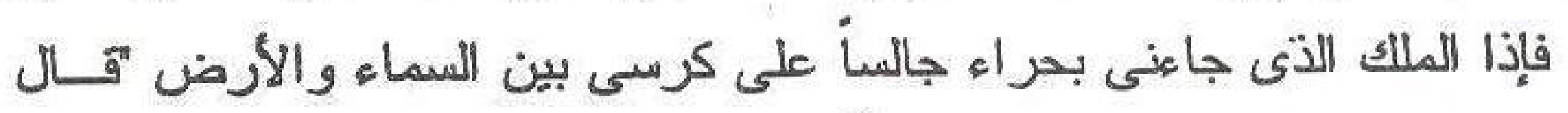

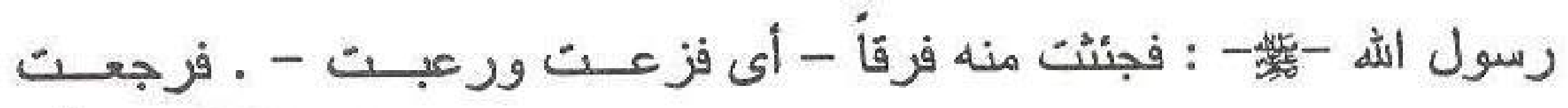

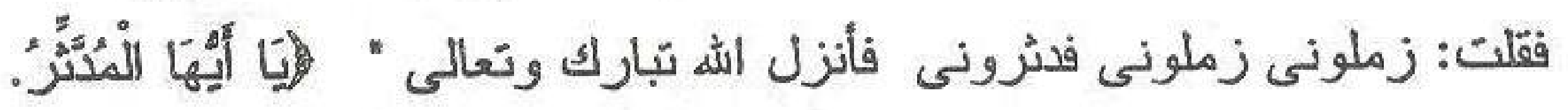

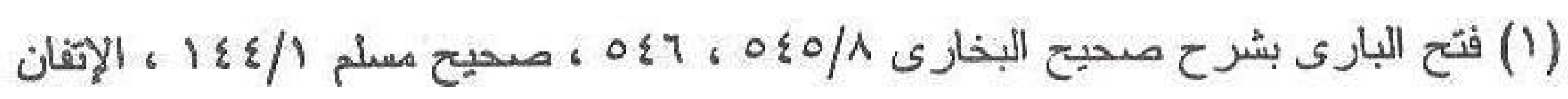
. rr/l

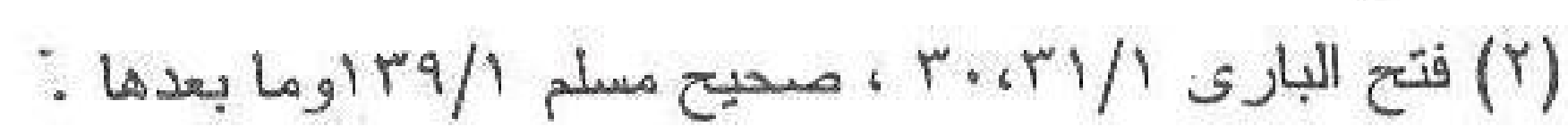

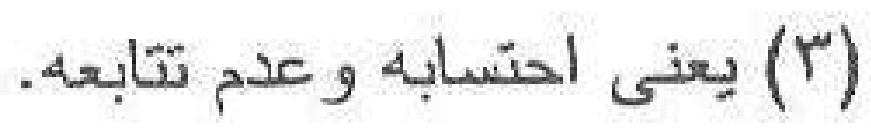




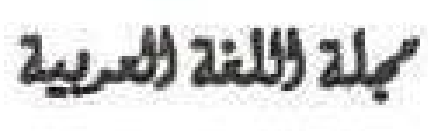

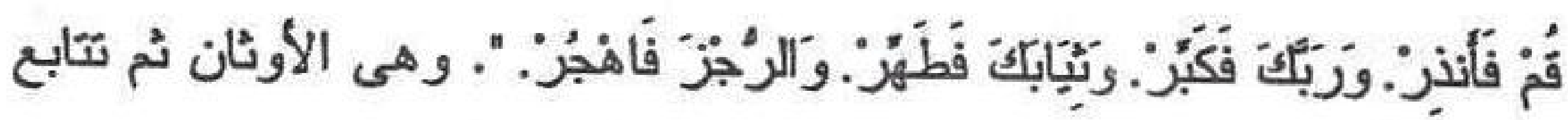

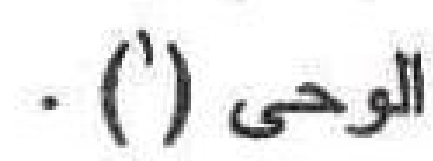

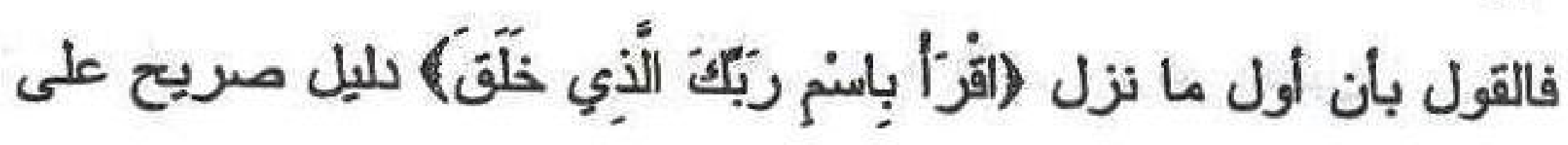

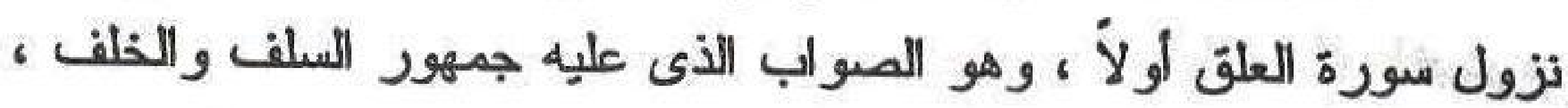

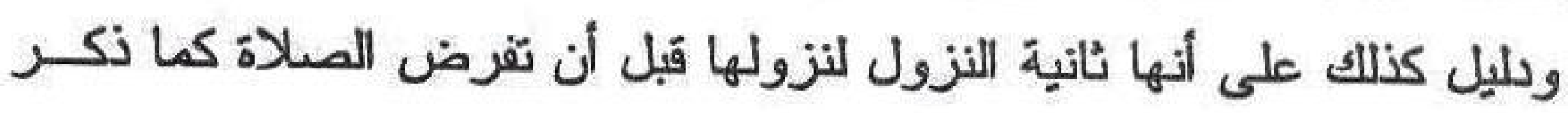

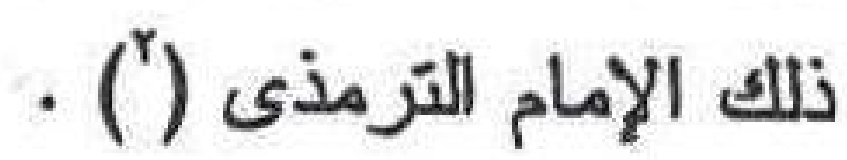

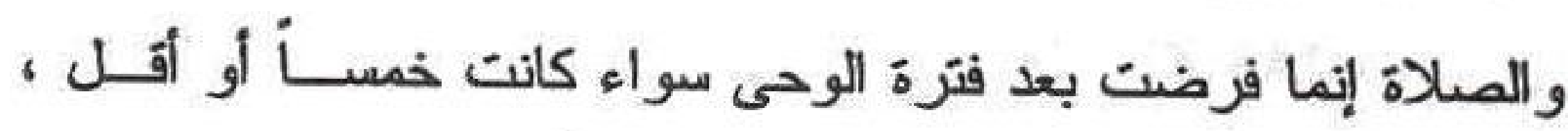

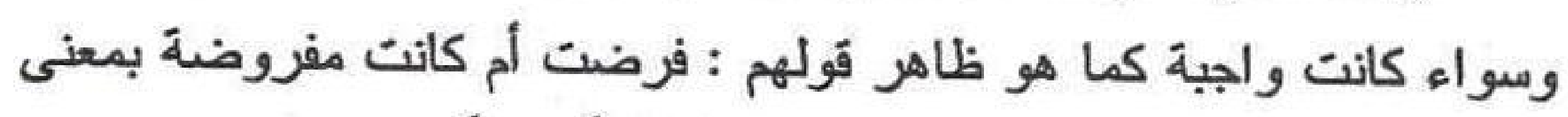

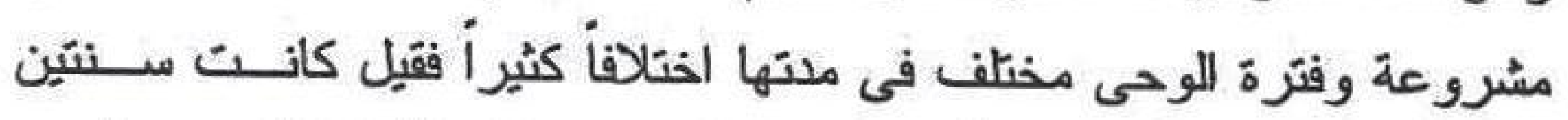

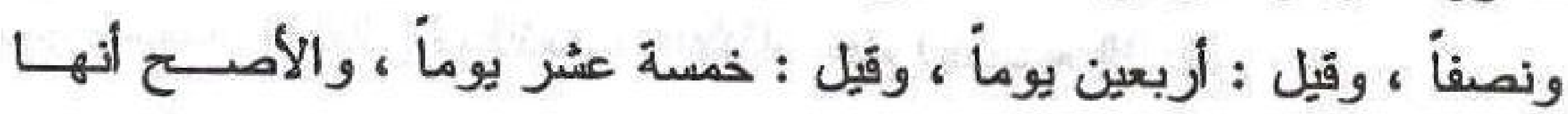

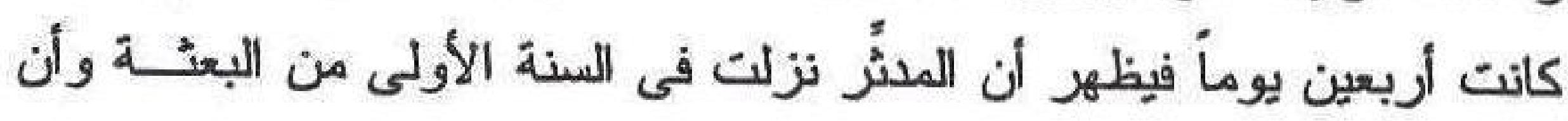

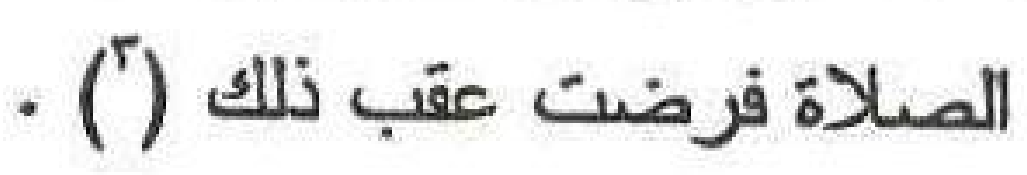

ويرى الإمام السيوطى تأييداً لذلك أن قصنة المجاورة بحر اء منــأخرة

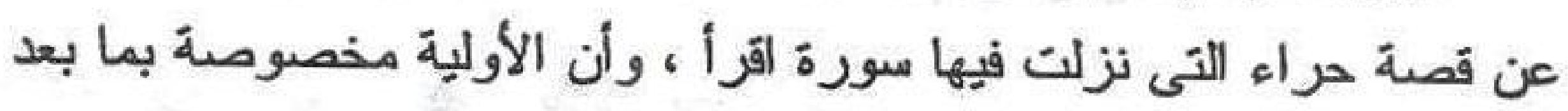
فترة الوحى لا أولية مطلقة (أ).

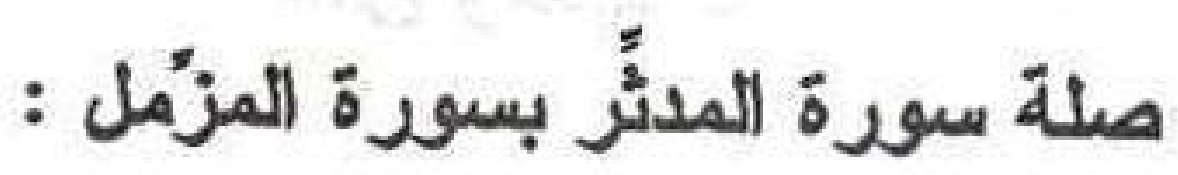
ترتبط سورة المدُّر بسورة المزمل ارتباطاً وثيقاً وتتصل بها للكأهـور

التالية :

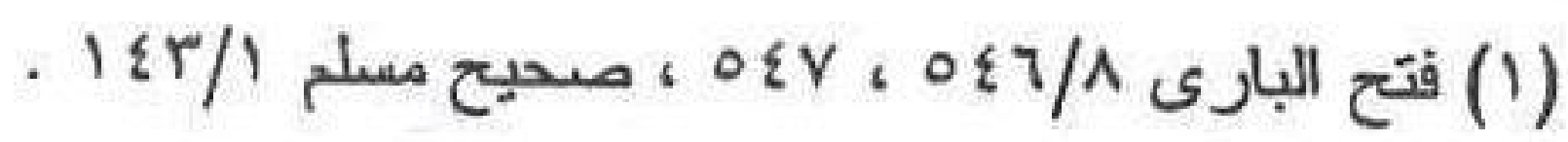

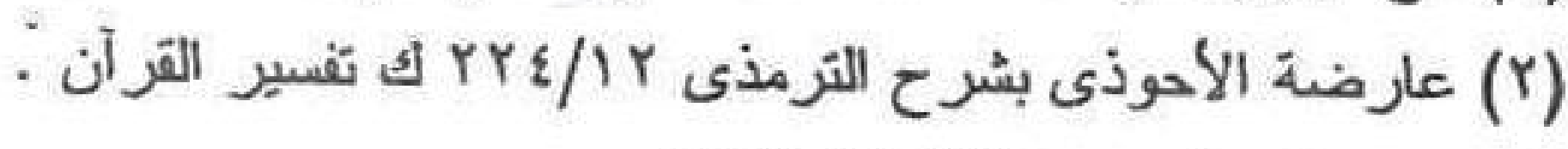

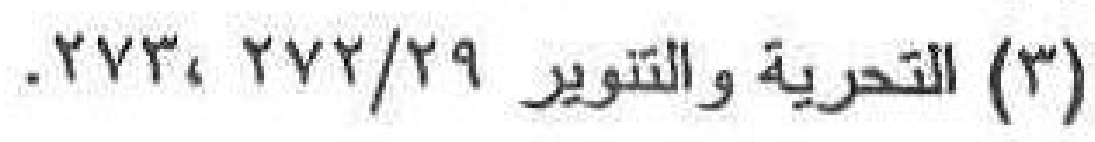

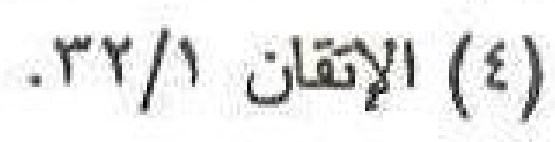




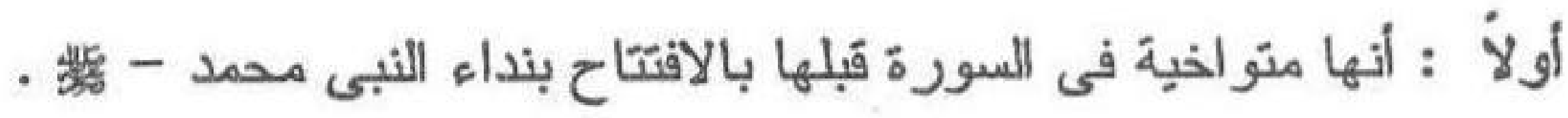

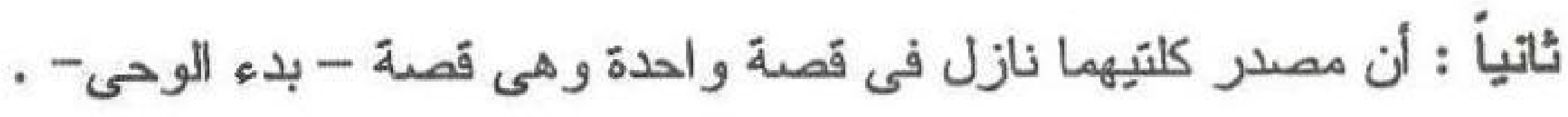

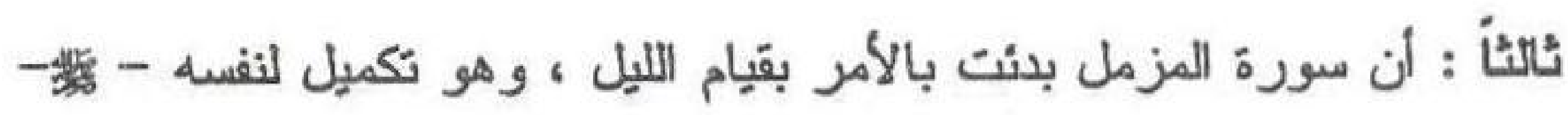
بعبارة خاصة ، وهذه - أعنى سورة المدثر - بدئت بالإنــذار لغيــره

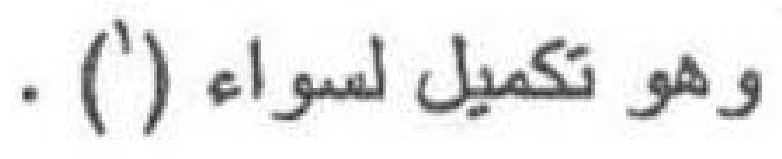

ويقول الشيخ أبو حيان : هذه السورة مكية ؟، ومناسبتها لما قبلها أن

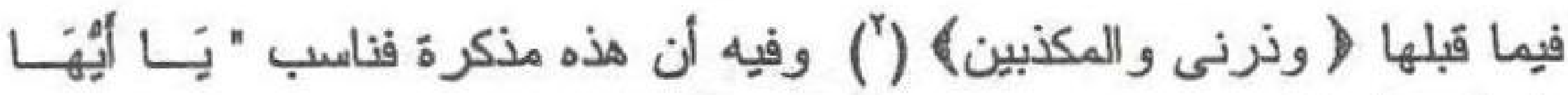

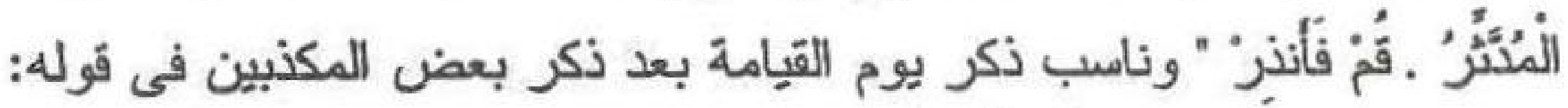

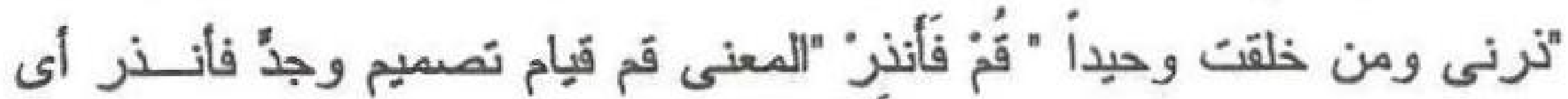

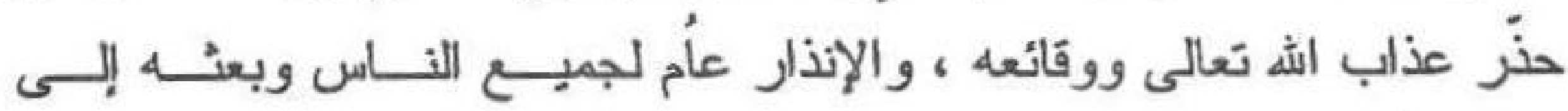

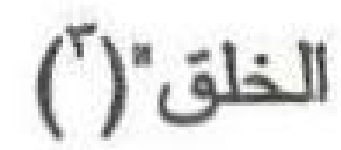

\section{الأغر اض التى تضمنتها سورة المشر}

تضمنَّت هذه السورة أغراضاً ومقاصد تهـف إليها ومن ذلك :

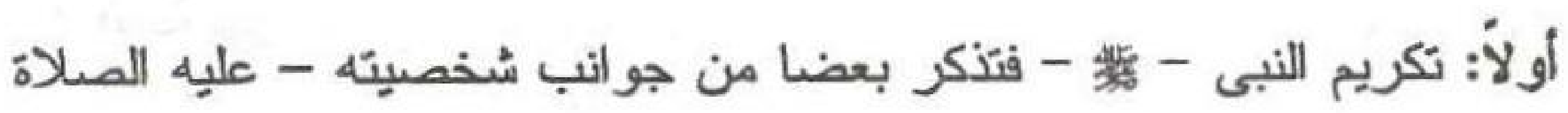

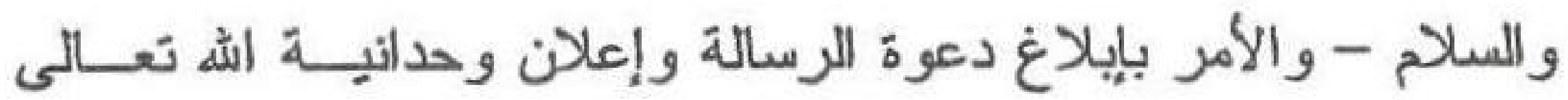
ووصفه سبحانه بالألو هية المطلقة .

ثاثياً: الأمر بالنهوض بأتقال الدعوة ، و القيام بمهمة البلاغ بالجدٍ و النثــاط ، و الأمر بالتطهير الحسى و المعنوى ، وترك عبادة الأصنام . 
ثُالثًا : الإكثار من الصدقات ، والأمر بـالتحلى بصــفة الصــبر ، وإنــذار المشركين بهول البعث وتهيد المجرمين بيوم القيامة وهو يوم عصبيب شُديد لا راحة لهؤلاء فيه لما يرون فيه من الأهوال التى يُّيب منهـا الولدان ، والرد على هؤلاء في استخفافه بها وبقلة عدد الحفظة مــن

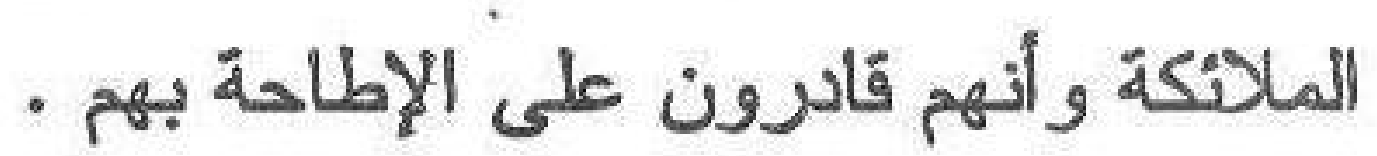
رابعأ: تهديد من تصدَّى للطَّن فى القرآن الكريم وزعمهم أنه من قول البشّر

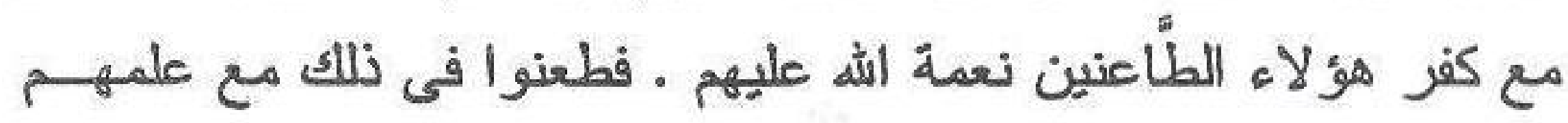
بكونه حقاً لا مراء فيه ، وتأييس هوُ لاء من الخلاصن من العذاب .

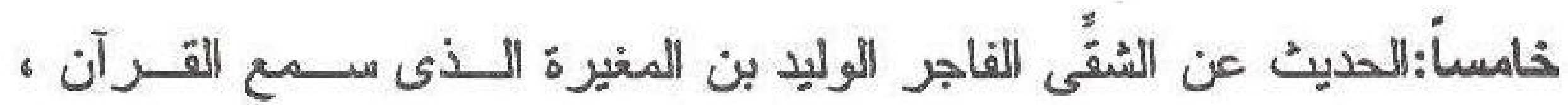
وعرف أنه كلام الله تعالى إلا أن كبره وصلفه صرفه عن ذلك زعماً

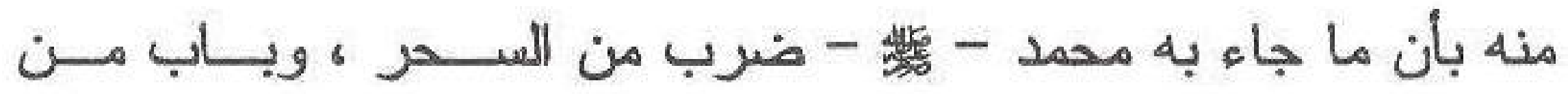
التمويه و التخييل الباطل.

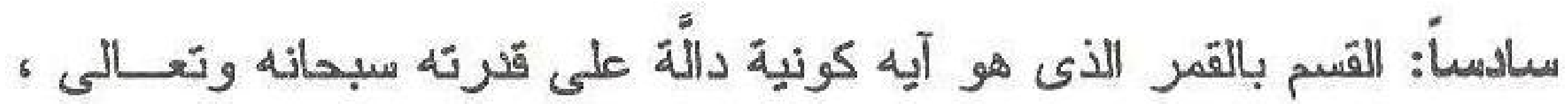
و الصبع حين يسفر ه وجواب هـــا القســم أن جهــنم أمُ المصــائب

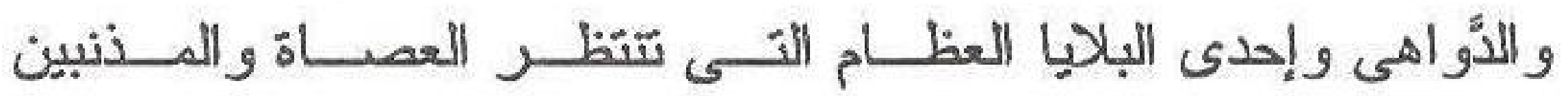
و و المتكبرّنين سابعاً: حكاية الحوار الذى يقع بين المؤمنين و المجرمين عن سبب دخــولهم جهنم و اصطلائهم بجديمها ، ومقابلة حال المجرمين بحال المــؤمنين المهتدين الذين هم أهل الصلاة و الزئاة و المصــدقون بيــوم الجــز اء 


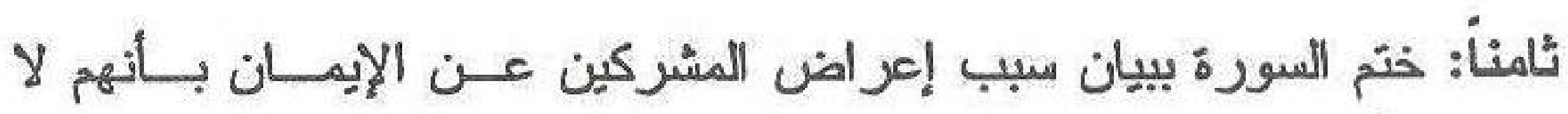

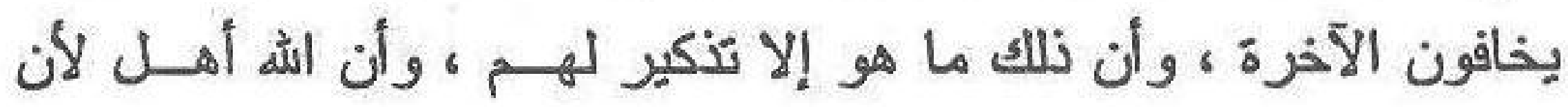

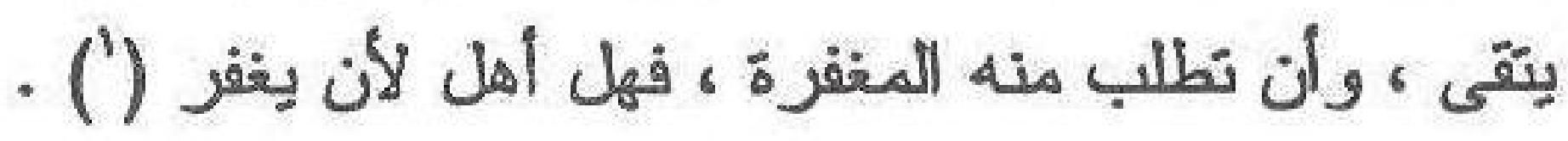


المبيجه (الأور

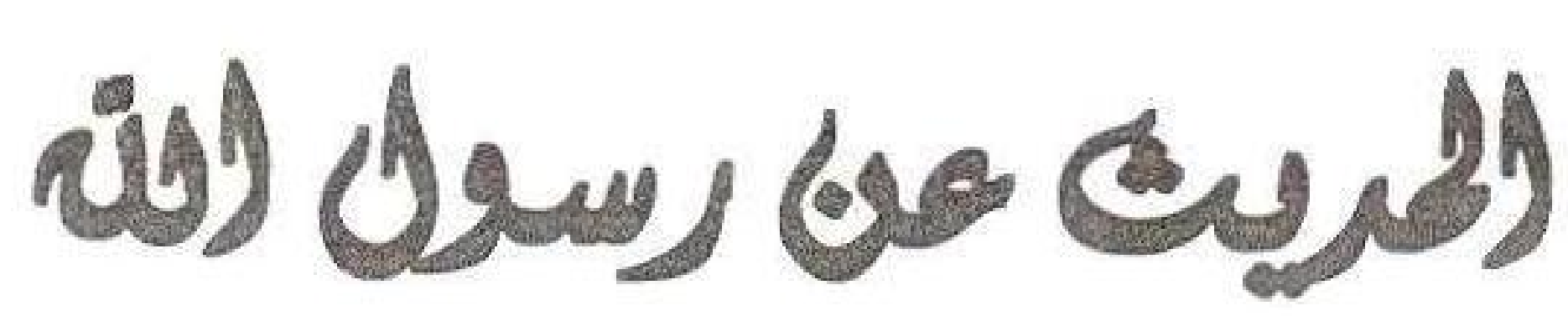

صلى الأه ملية وسلم 
" أعوذ بالله من الثشيطلان الرجيم "

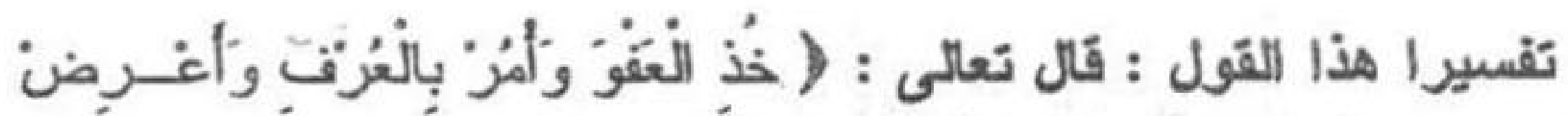

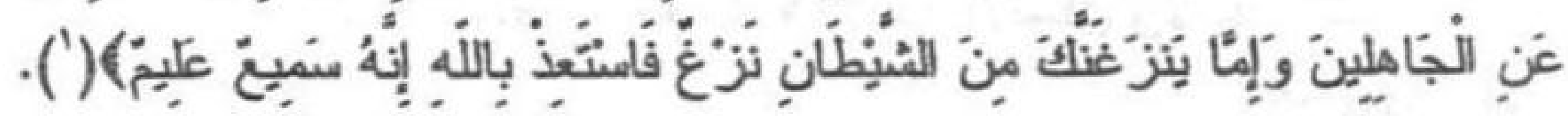

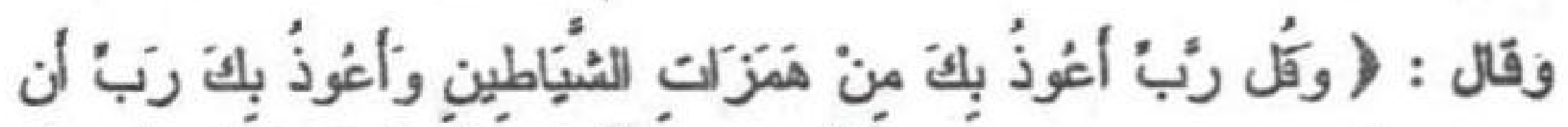

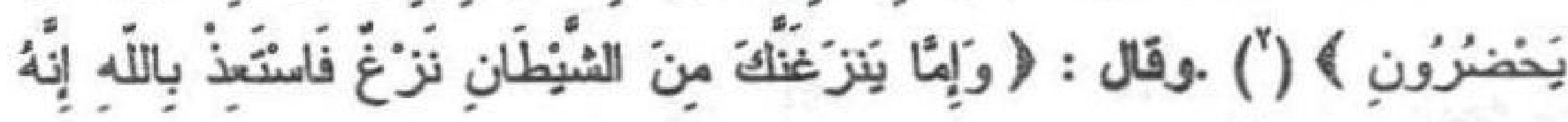

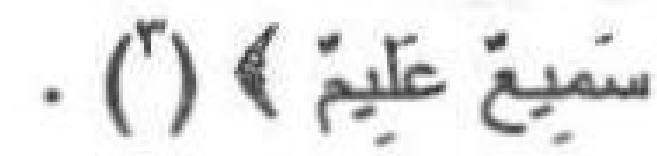

يقول العلأمة البن كثير : فهذه ثلاث آيات ليس لهن رابعة فى معناهــا

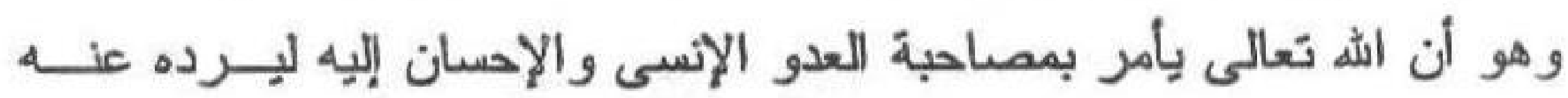

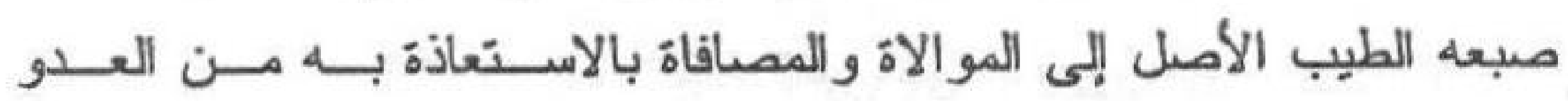

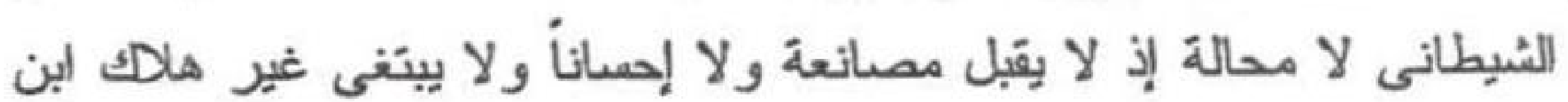
آدم لعُدة العداوة بينه وبين أبيه آدم (أ) . والاستعاذة : هى الالتجاء إلى الله تعالى والالتصاق بجنابه من شر كل ذى شر ، و العياذة تكون لدفع الشر ، و اللياذ يكون لطلب جلب الخير . كما قال أبو الطيب المتنبى (م) :

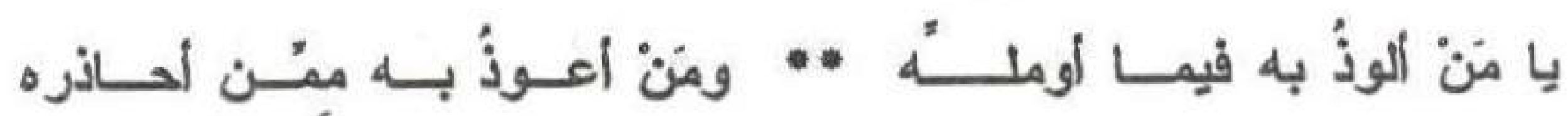

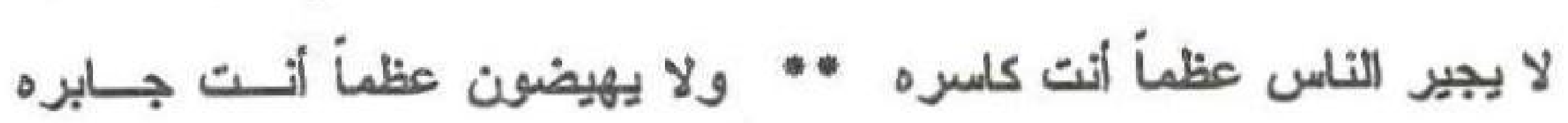

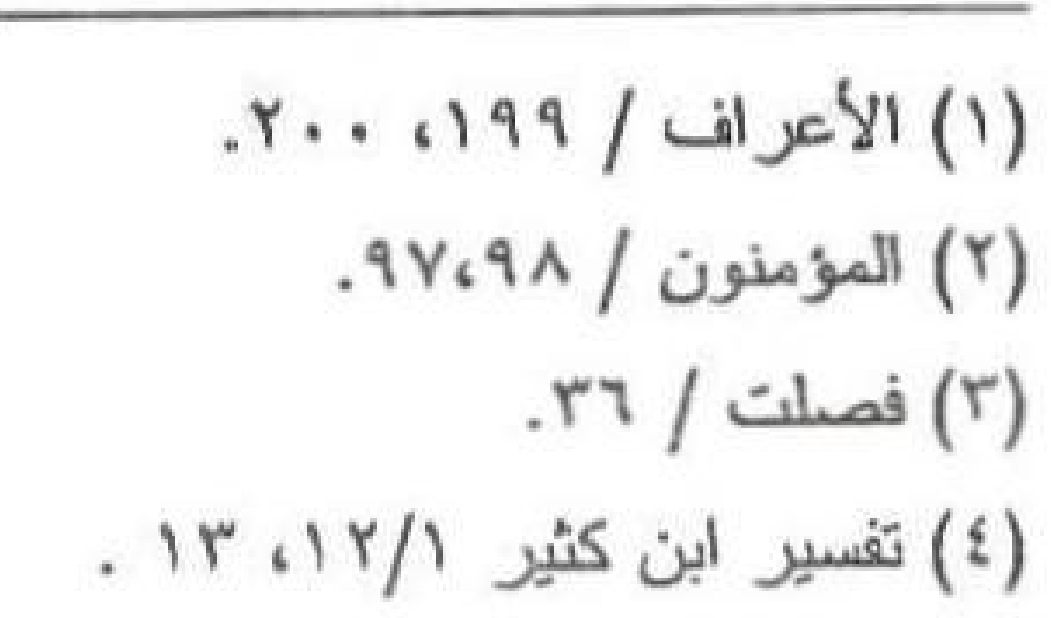

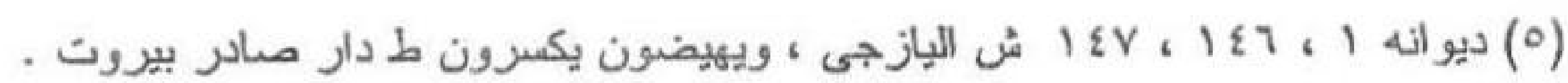




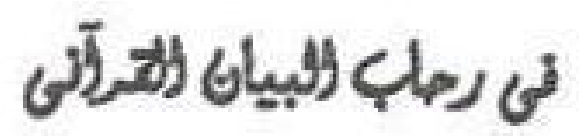

ويقولون عاذ فلان بفلان إذا التجأ إلى غيره وتعلق به (') والمراد بـ "أعوذ باله " أستجير بجناب الهه ، و إضضافة العياذ إلــى الله إضافة حقيقية إذ لا يسنطيع دفع الشيطان عن الإنسان ولا يقدر عليـه إلا الشه

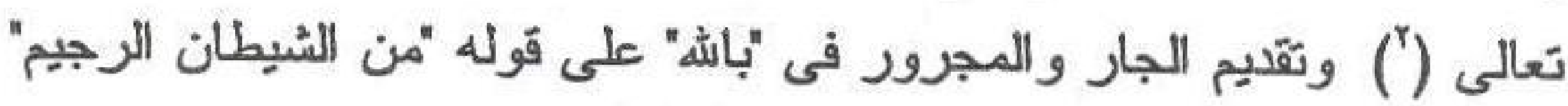
لإقادة القصر والاختصاص أى أعوذ به لا بغيره . و "الشيطان" مشتق من شطن فلان إذا بعد ، و الشيطان بعيد بطبحه عن طباع البشر وبعيد بفسقه عن كل خير . يقول النابغة الذبيانى (آ) .

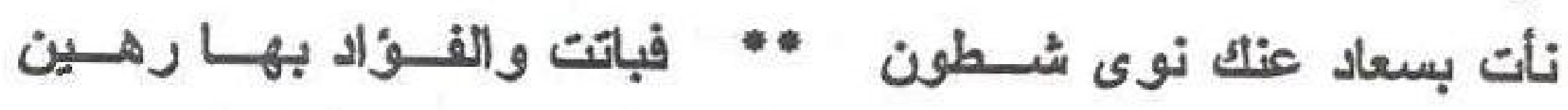
وقال سييويه : العرب تقول تشيطن فلان إذا فعل فعل الشياطين هـذذا سـان

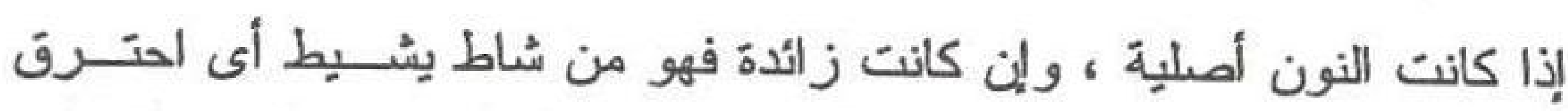
غضباً فالشيطان مخلوت من النار (أ) أنون و "الرجيم" أى المرجوم فهو فعيل بمعنى مفعول ، وهو مــأخوذ مـنـن

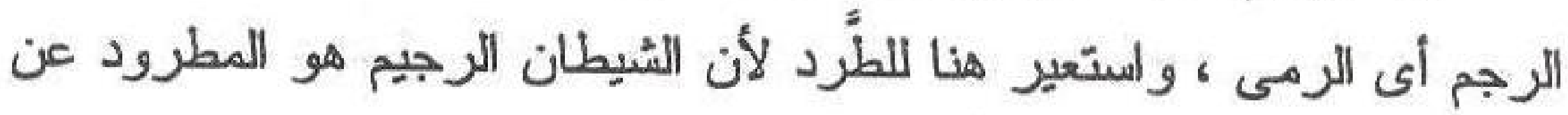

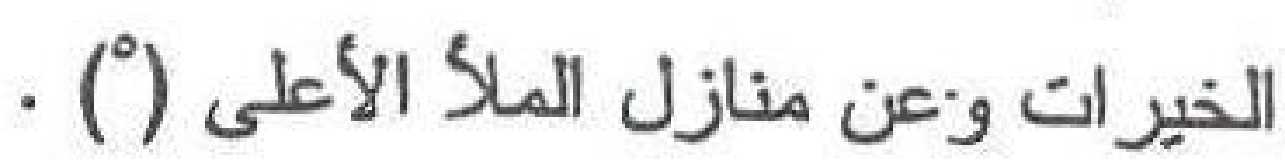

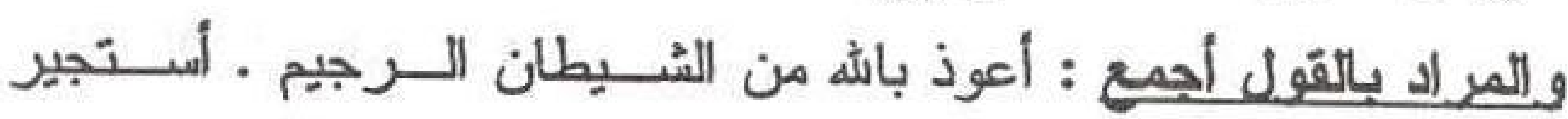
بجناب الله من الشيطان الرجيم أن يضرًّنى فى دينى أو دنياى أو يصــرفنى عن فعل ما أمرت به ، أو بحثتى على فعل ما نهيت عنه.

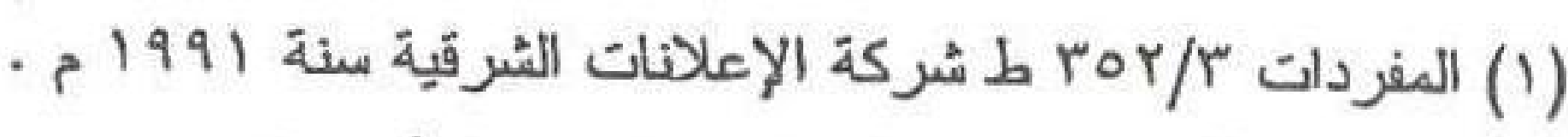

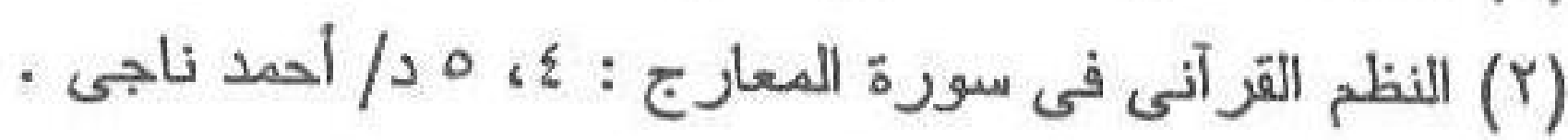

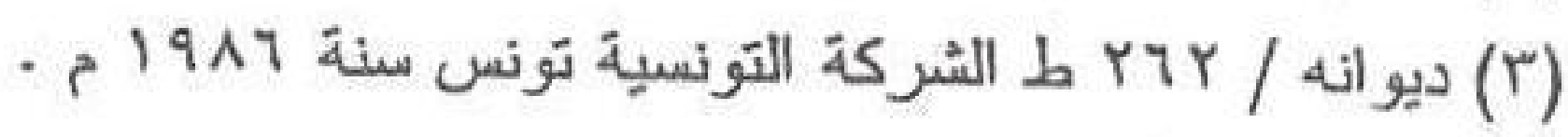

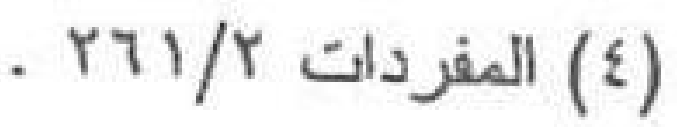

$$
\begin{aligned}
& \text { (0) المفردات r/ / 19. }
\end{aligned}
$$




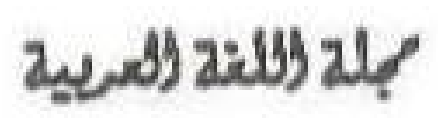

[10]

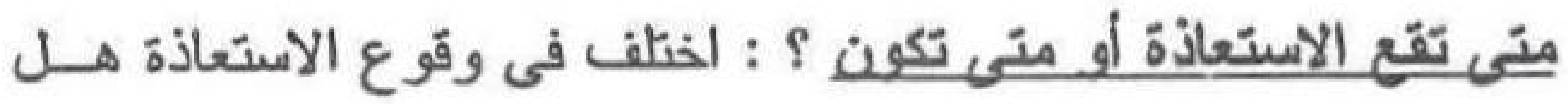

هى قَل القر اعة أو بعدها على أقو ال فى ذلك ؟ نذكر منها :

أولاً : اتفقَ أكثر العلماء على أن وقت قراعة الاستعاذة قبل قراعة الفاتحـــة ،

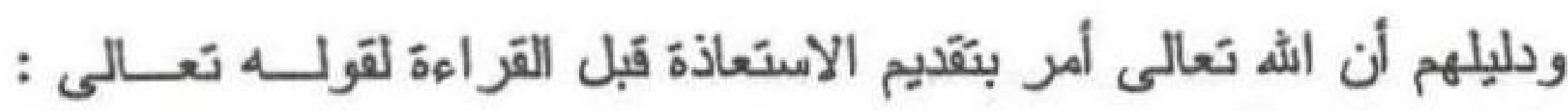

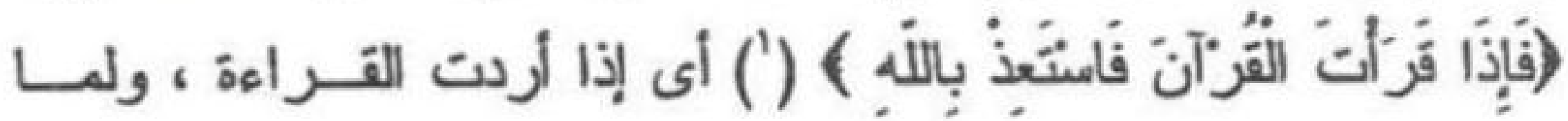

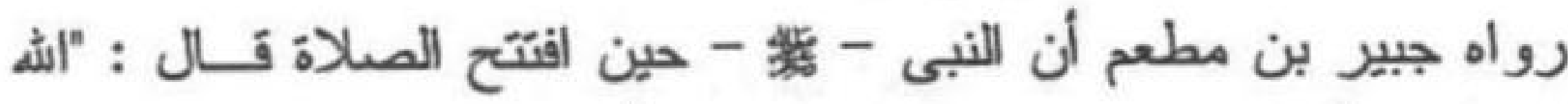

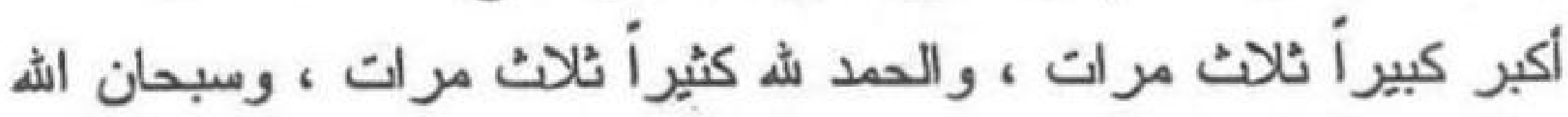
بكرة و أصيلذ ثلاث مرات ، ثم قال : أعوذ باله من الشيطان الــرجيم

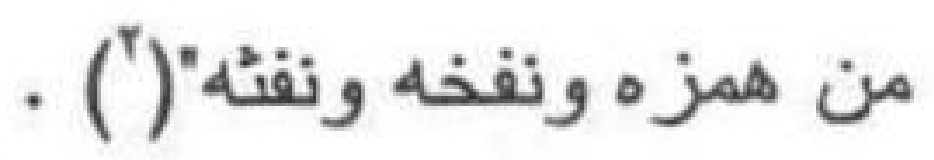

ثانياً : عند النخعى وداوود الأصفهانى وإحدى الروايتين عن ابن سيرين أن

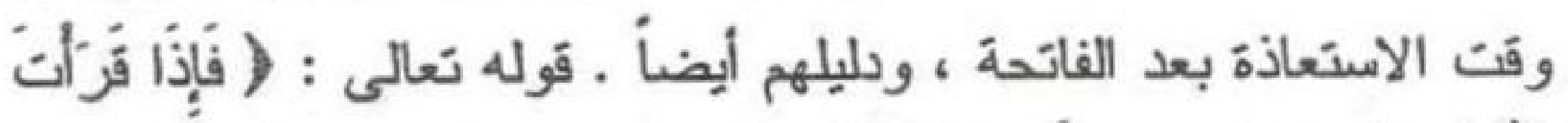

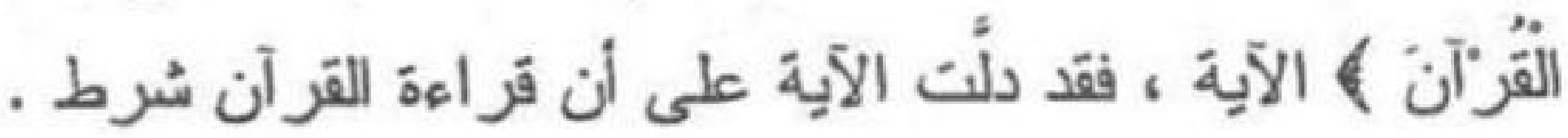

وذكر الاستعاذة جزاء ، والجزاء متأخًٌ عن الشُرط ـ فوجب أن تكون

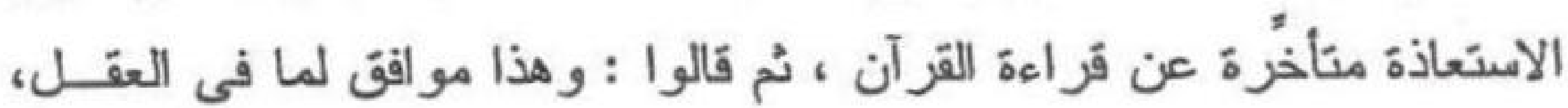

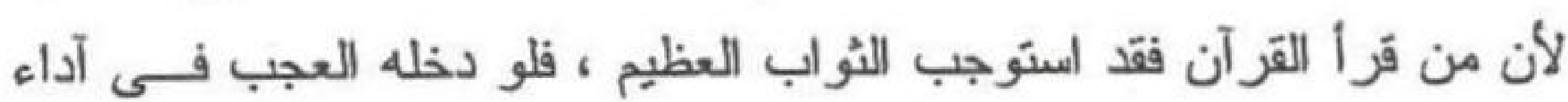

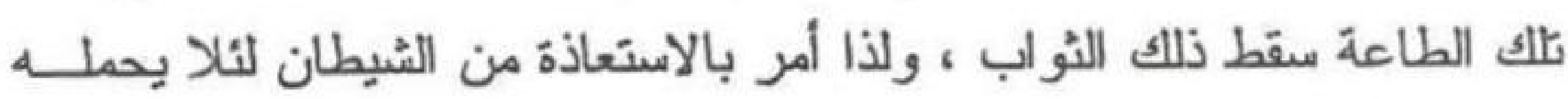

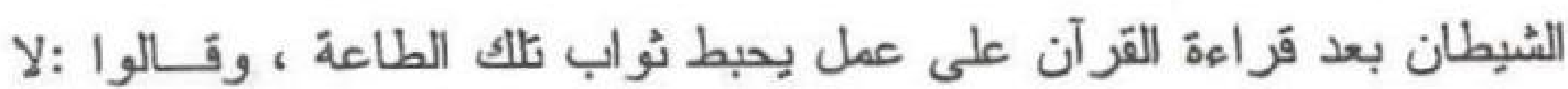

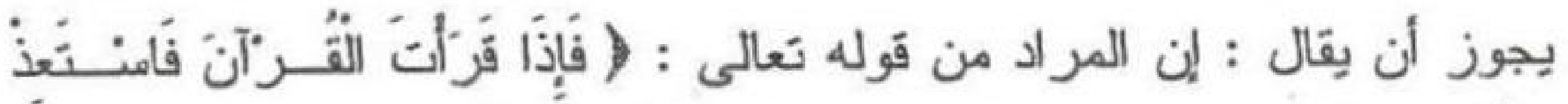

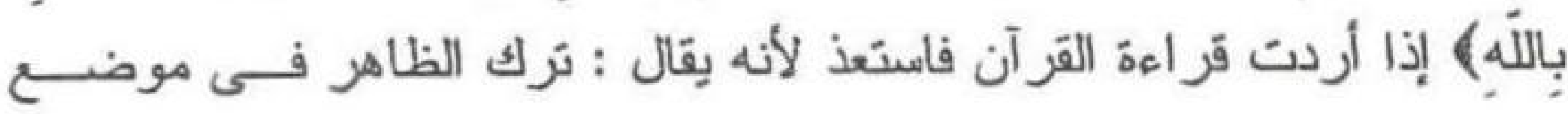


الدليل لا يوجب تركه فى سائر المواضع لغير دليل ، وهو من باب المجـــاز

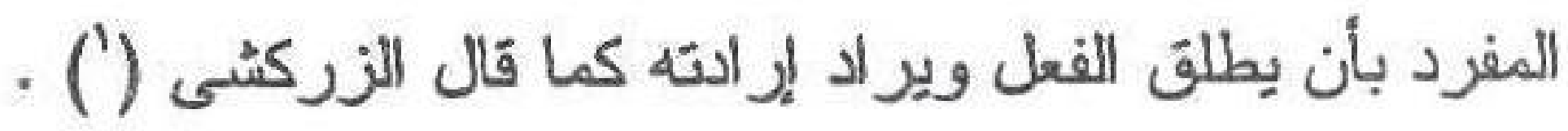

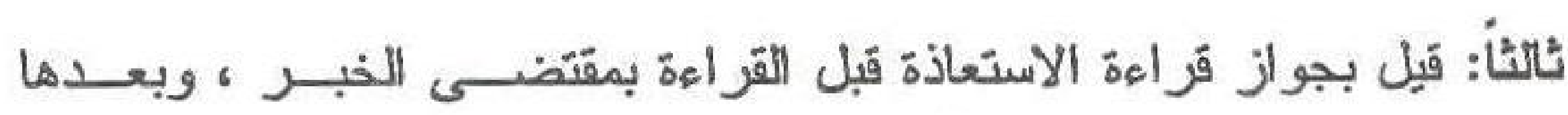
بمقتضى القرآن ، وجمعاً بين الدليلين بقدر الإمكان (') . لالثبسلة : "بسم الله الرحمن الرحيم"

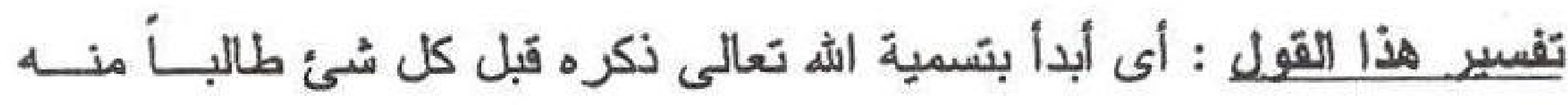

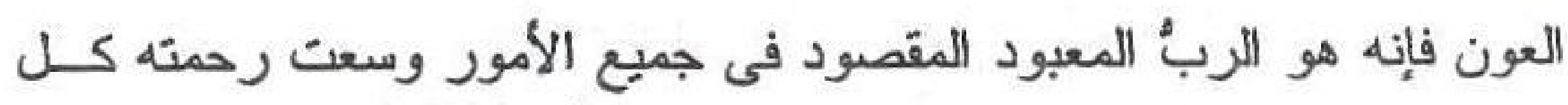

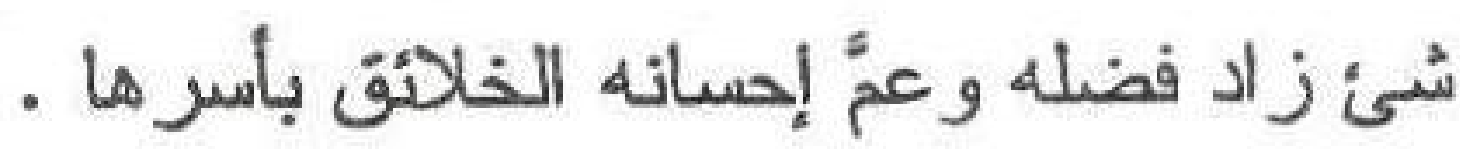

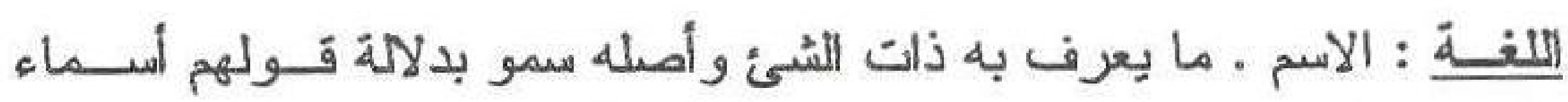
وسمى ، وأصله من السمو و هو الأى به رفع ذكر المسمى فيعرف به به (") . .

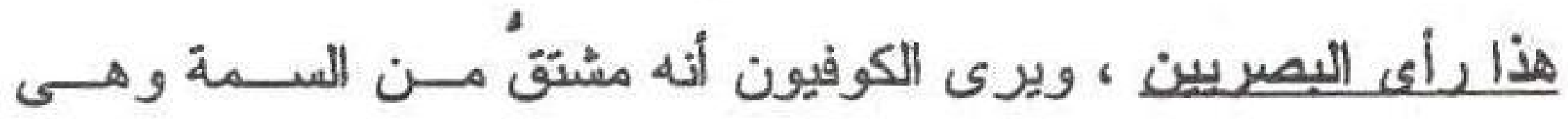

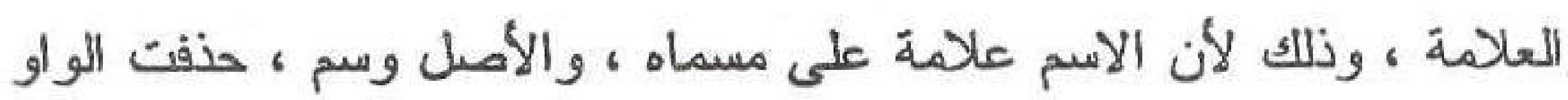

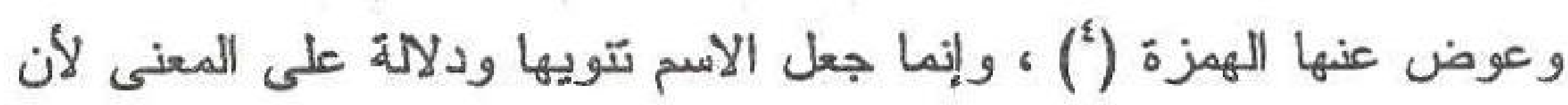

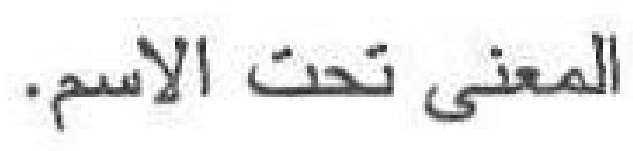
و "الله" الأصل فيه "إلاه" من ألكه إذا عبد على فعال بمعنـى مفعـول ،

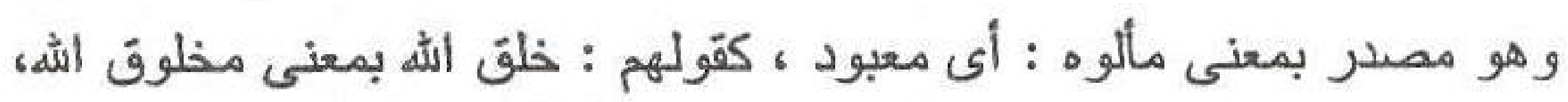

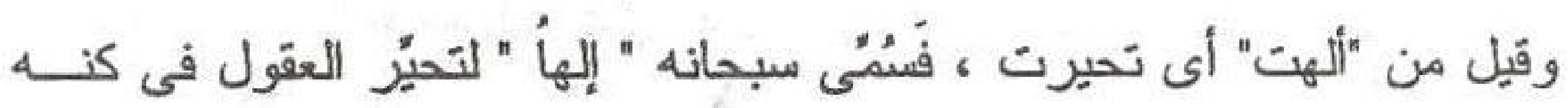

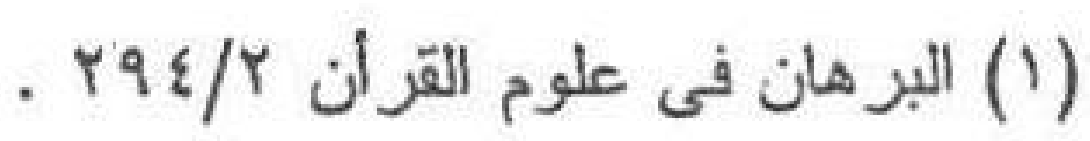

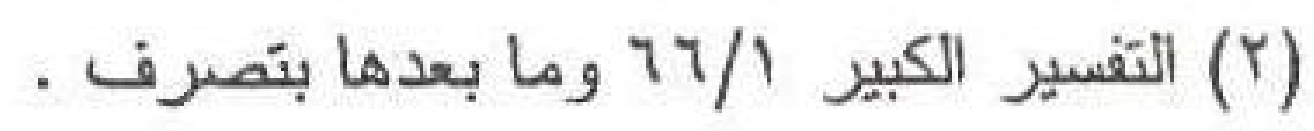

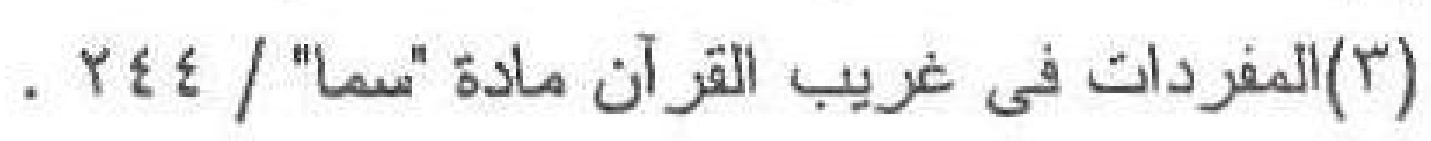

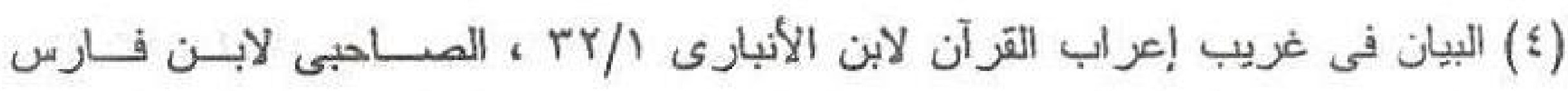

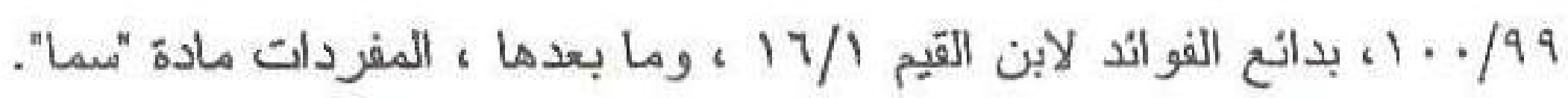




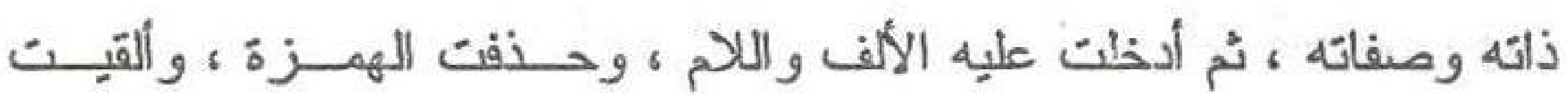

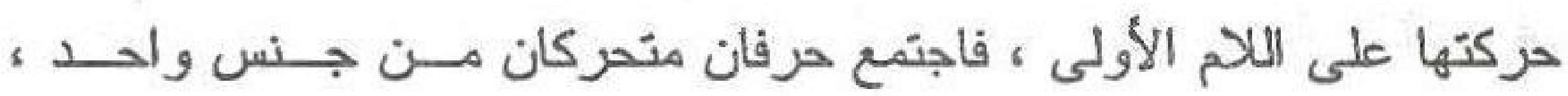

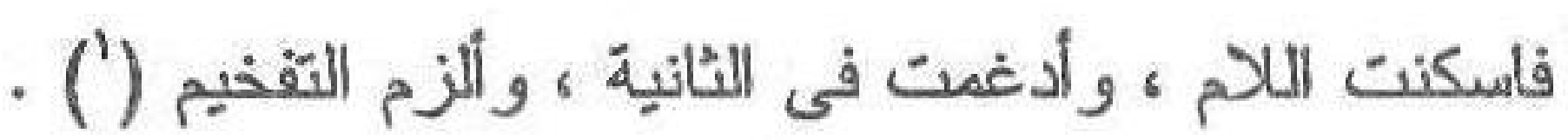
"وقيل أصله" "و لاه" هن الوله ، لأنه يوله إليّه فى الحوائج ، فأبدلو أمن

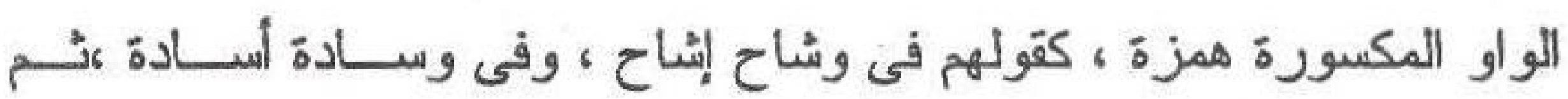

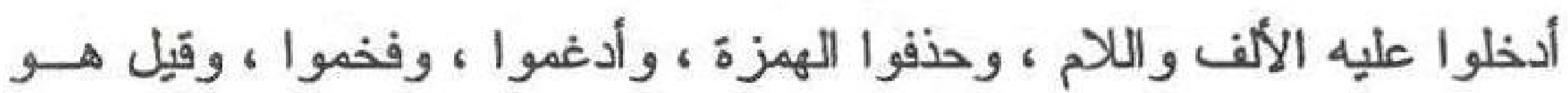

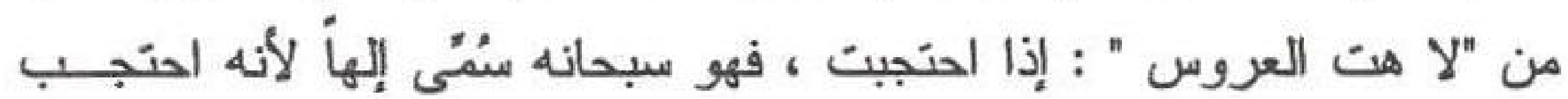

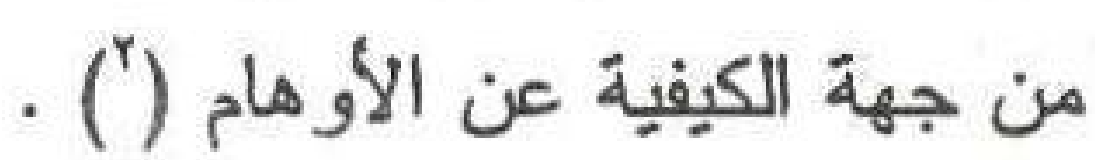
"وقيل : أصله "لاه" والألف فيه منقلبة عن ياء كقولهم : لهى أبـوك . بريدون لله أبوك ، فأخرت اللحم إلى موضع العين لكثرة الاستعمال ، و الــلام من "الله" ها هنا مرققة لمكان الكسرة قبلها ، فإن العرب تفخمها إذا كان قبلها

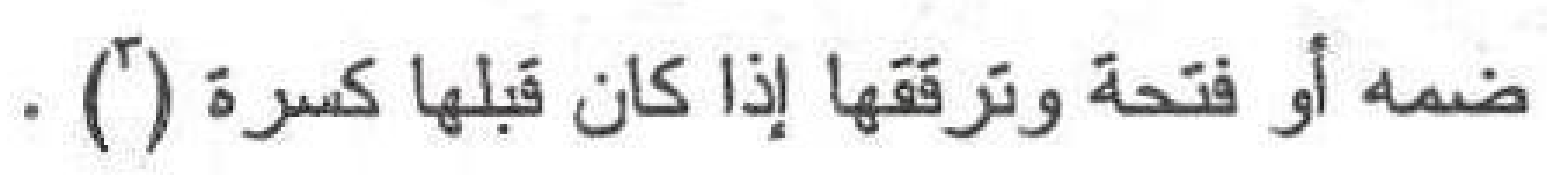
ونكى ابن الأبليارى : أن النحويين قد اختلفـورا فـى موضــع الجــار" والمجزور "بسم الله" على وجهين : فذهب البصريون اللىى أنه فـى موضــع

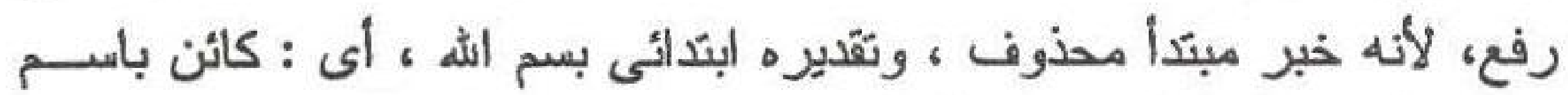

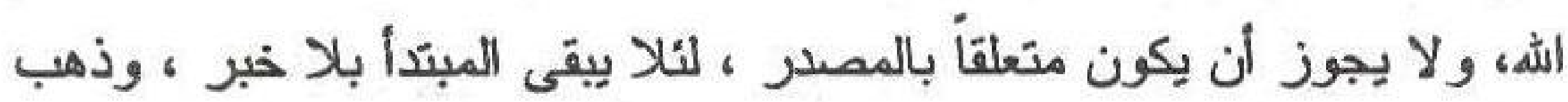

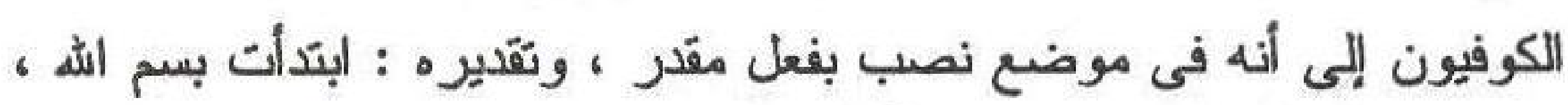
وحذفت الألف من "بسم الل" تخفيفاً لكثرة الاستعمال ، ولا تحذف إلا معهاء(). 
وقله الين الققيم (') ومن المجاز إطلاق الاسم على المسمى ، ومسنن جعل الاسم هو المسمى فى قوله "بسم الله الرحمن الرحيم" كان التقدير فيسـه

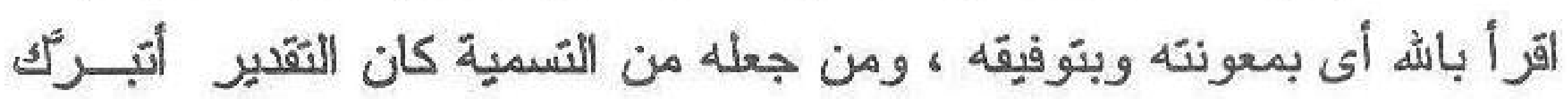

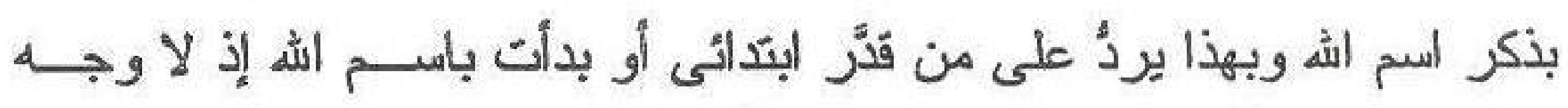

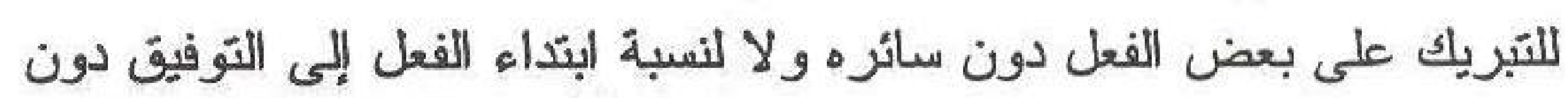

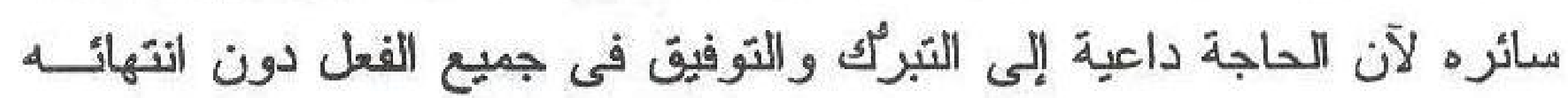

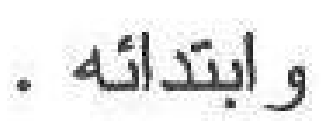

و "الرحمن" فعلان من رحم كندمان وغضبان من ندم وغضــب ، و لا

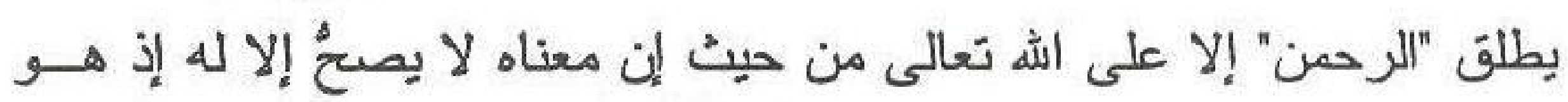

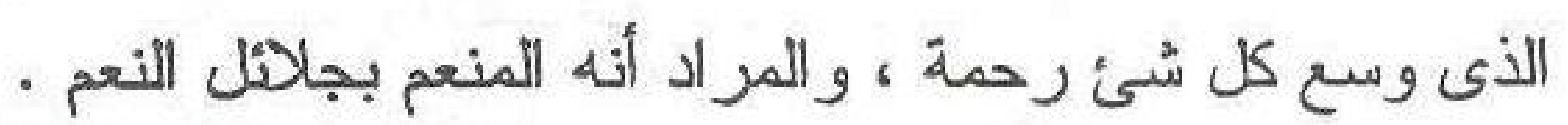

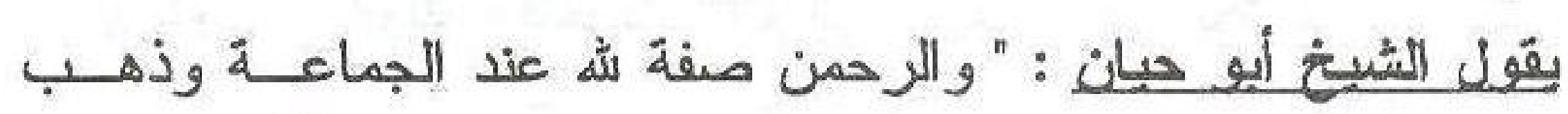

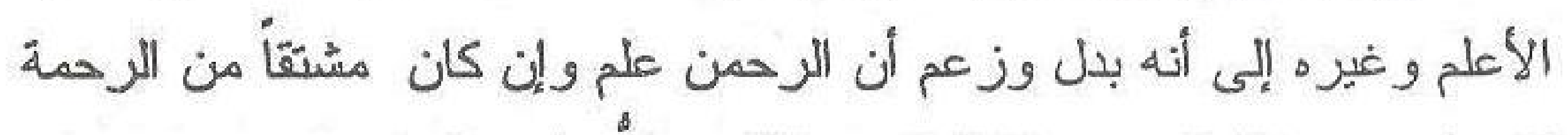

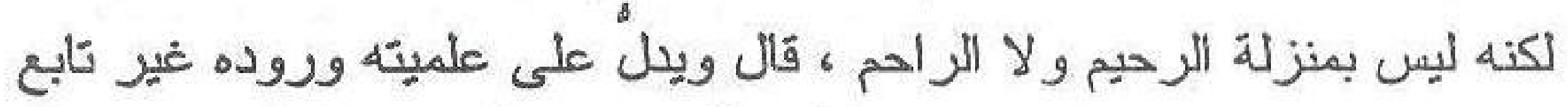

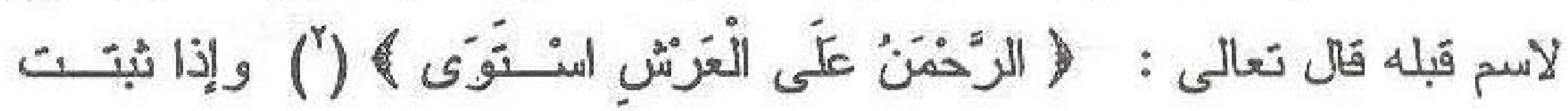

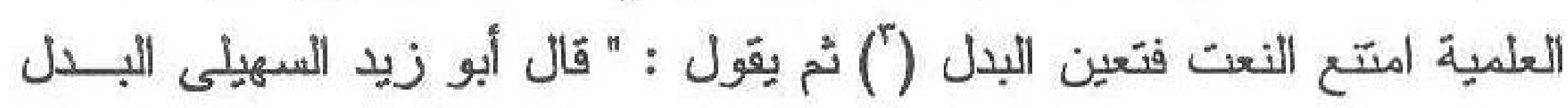
فيه عندى ممتنع وكذلك عطف البيان لأن الاسم الأول لا يفتقر إلى تبيين لأنه

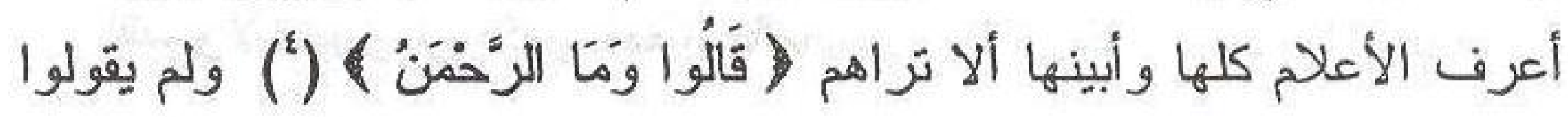
وما الله ؟ فهو وصف يراد به الثناء وإن كان يجرى مجرى الأعلام ( ) . 


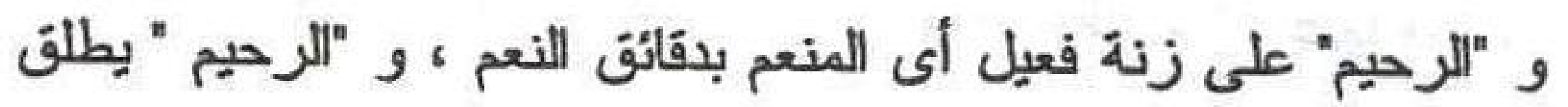

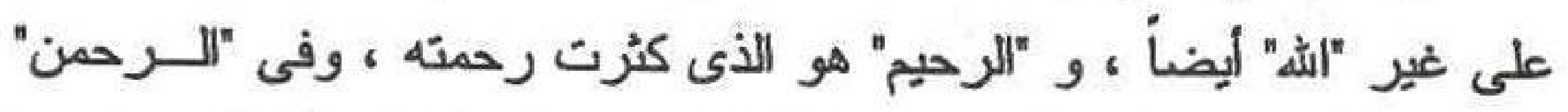

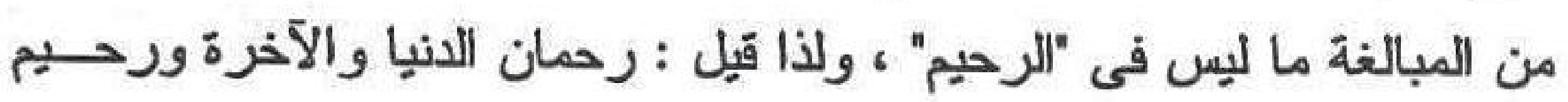

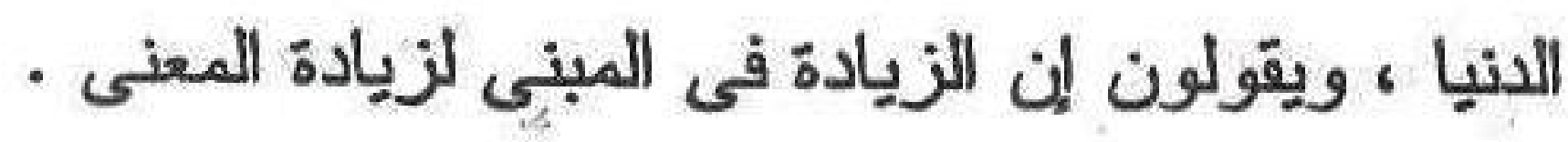

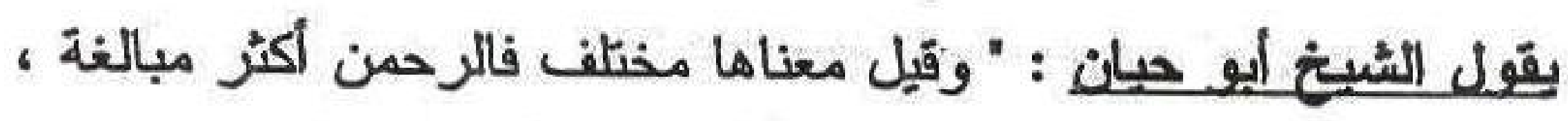

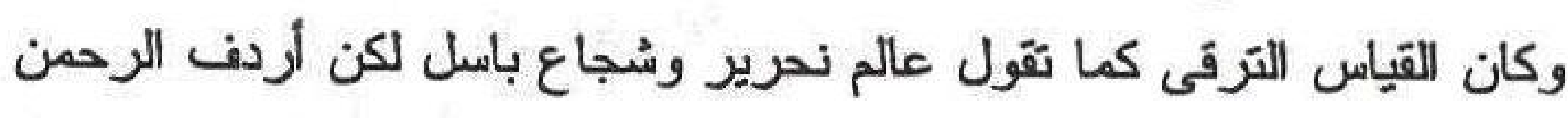

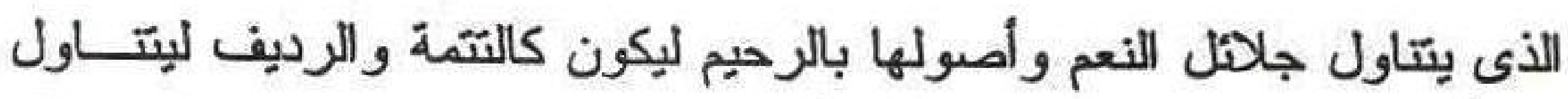

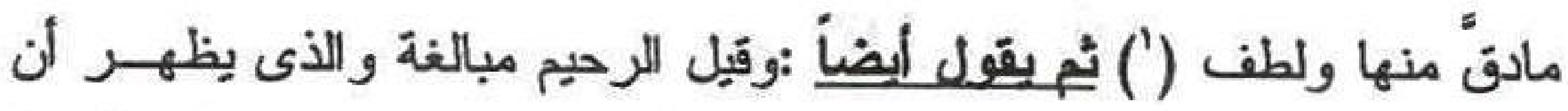

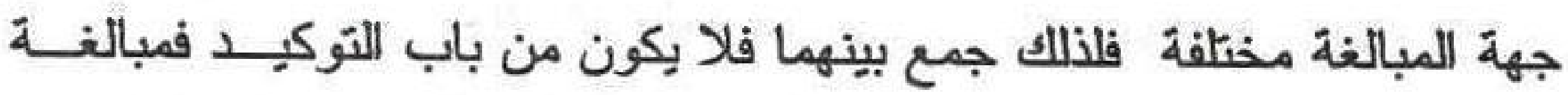
فعلان مثل غضبان وسكران من حيث الامتلاء و الغلبة ، ومبالغة فعيل مـن بابن

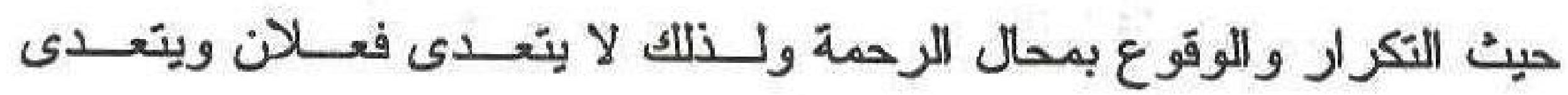

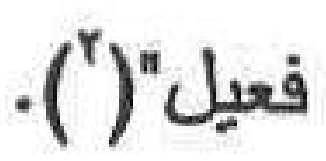

رأى العلامة الزمخشرى فى وصف اله تعالى بالرحمة : يقول رحمه

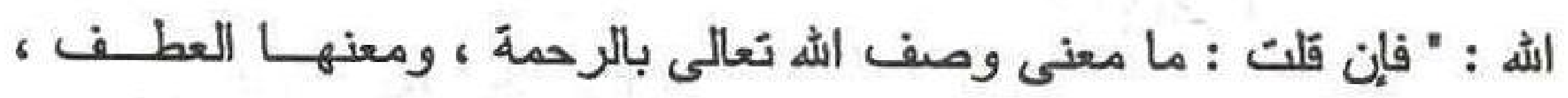

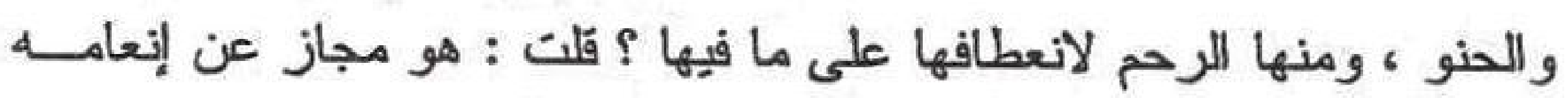

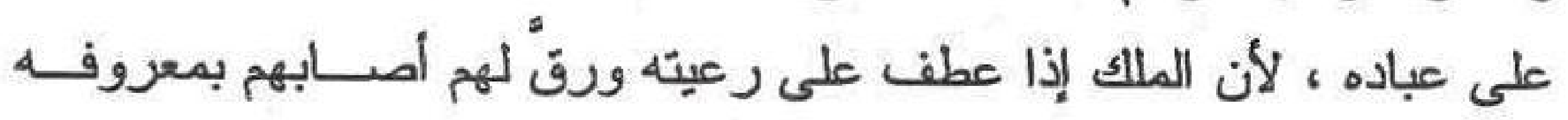

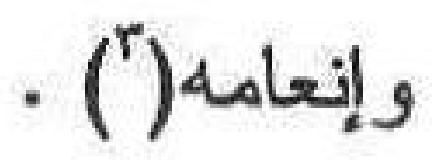

تطليق العلامة البن المنير على ما ذكره الإمام الزمفيُرى : يقـول رحمه اله : قوله ومعناها العطف والدنو - أر اد الميل النفسانى أى الثــفقة

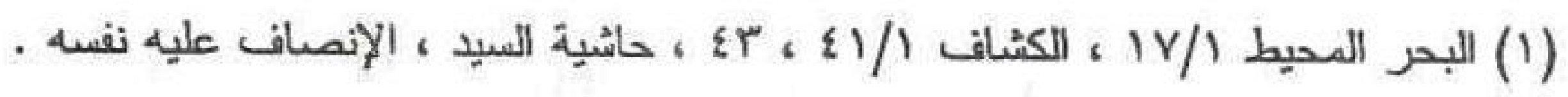

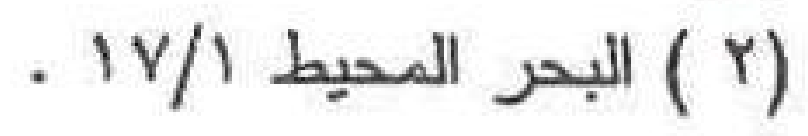

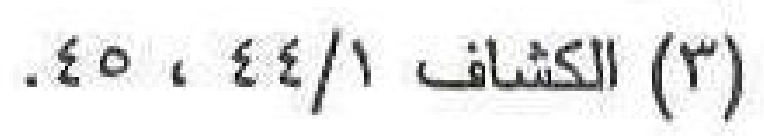


و الرقةَة وهى من الكيفيات التابعة للمزاج ، والهل نعالى منزه عنها فهو مجـاز

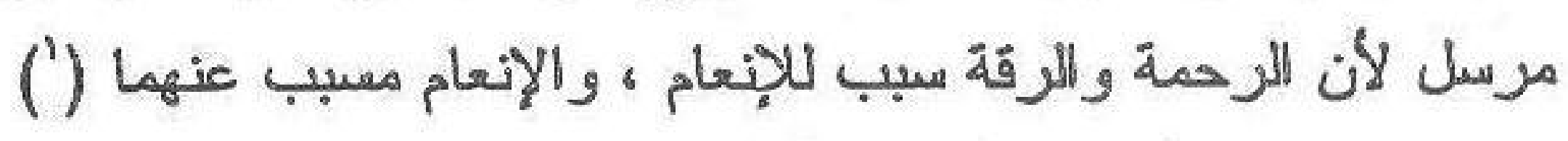

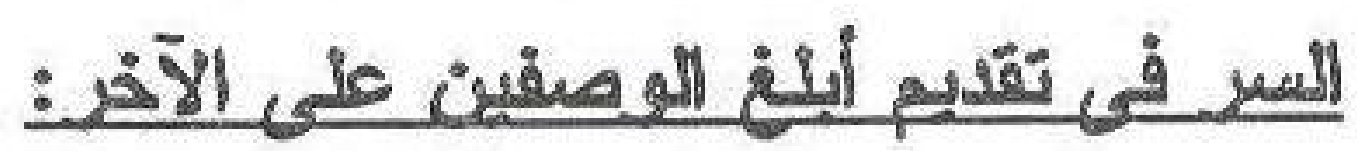

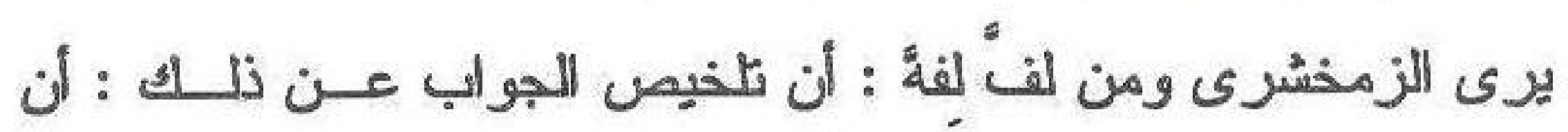

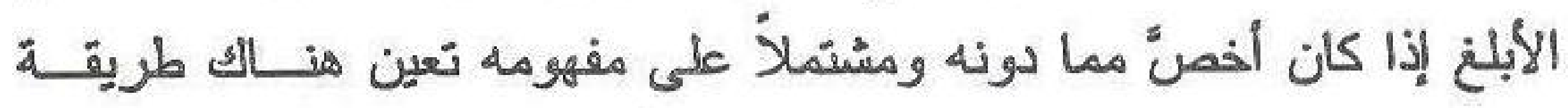

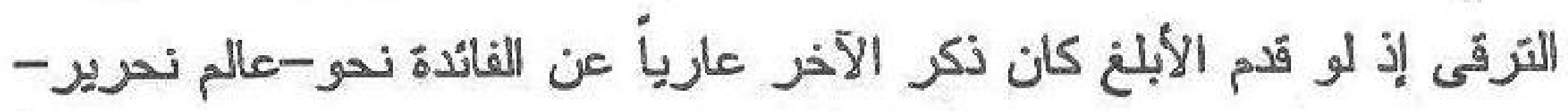

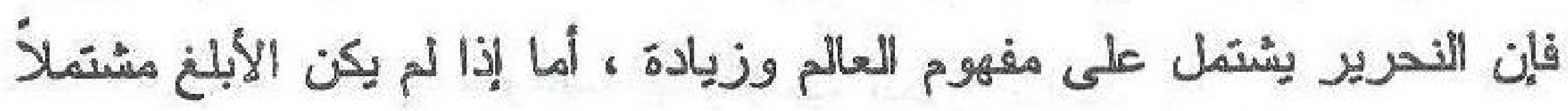

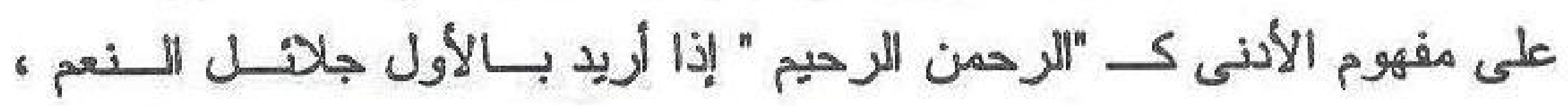

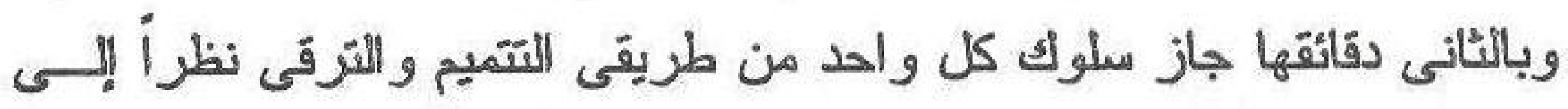

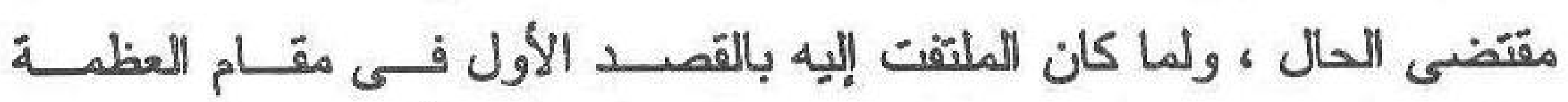

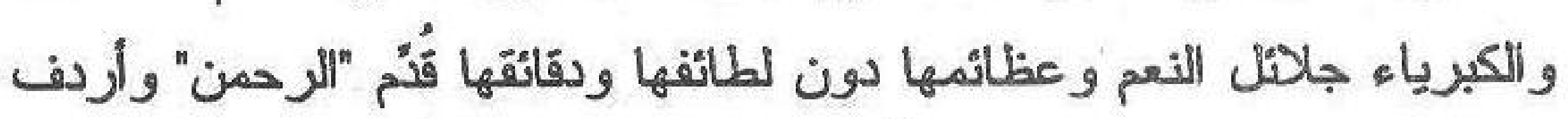

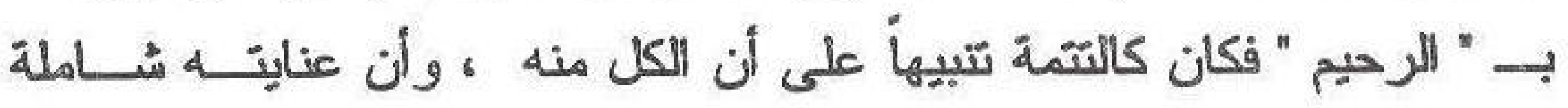

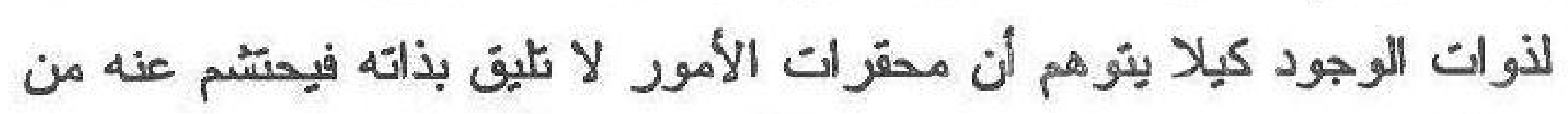

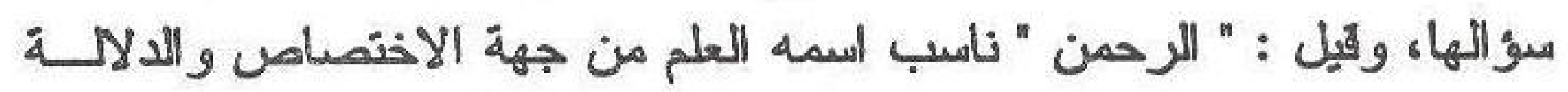

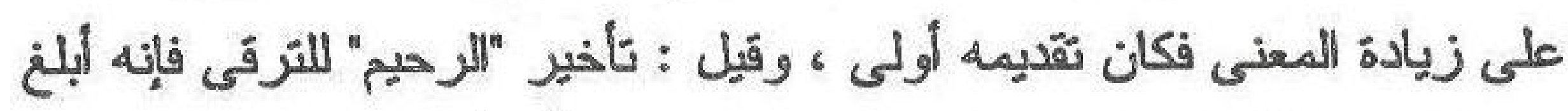

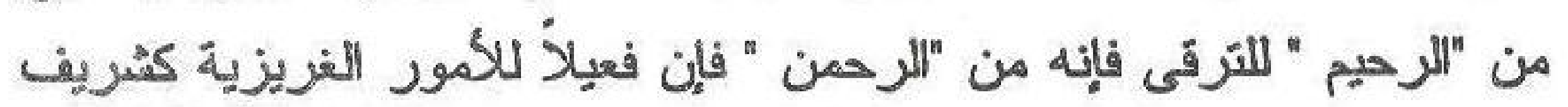

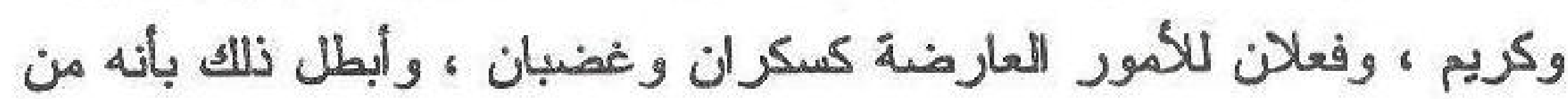

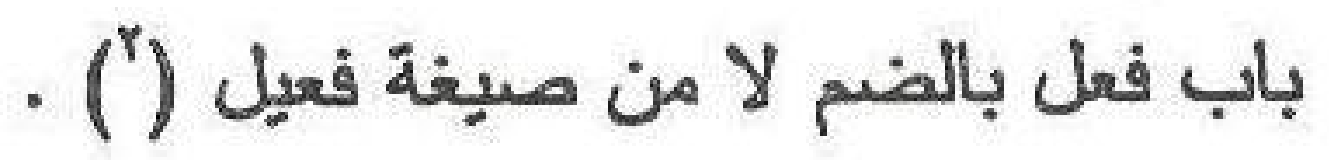

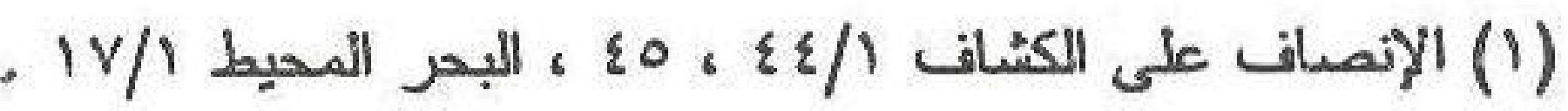

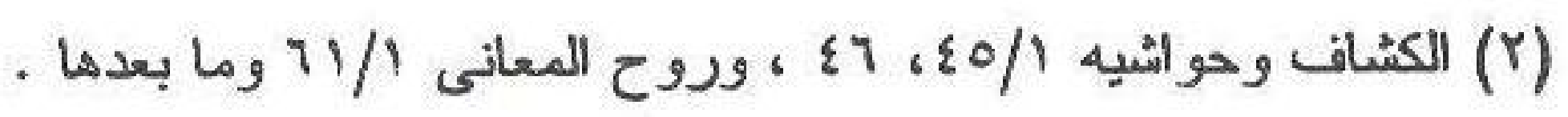




\section{معنى الباء فُى "بسم اللهّ" : قيل : زائدة ، ومعناها الإلصات كوكسرت}

لوجهين : أحدهما : لتكون حركتها من جنس عطها ، والثانى : للتفرقة بينها

وبين ما لا يلتزم الجر فيه كالكاف (')

ويرى الزمخشرى ومن تبع مذهبه : أن الباء للاستعانة كما فى كتبت

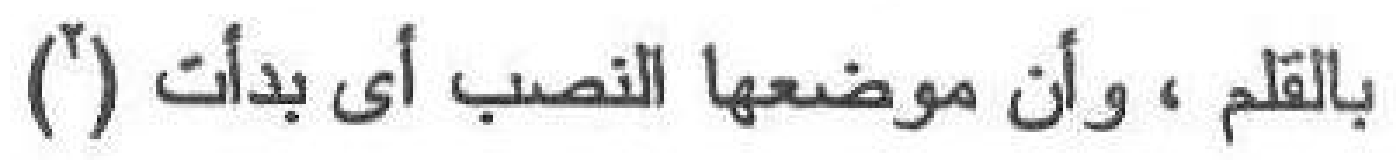

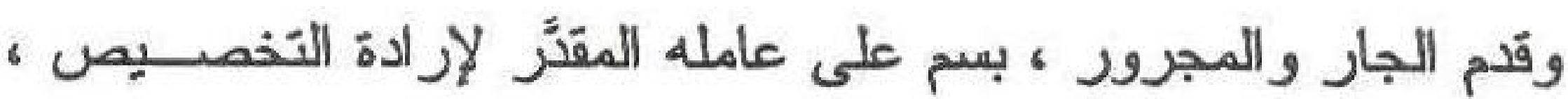

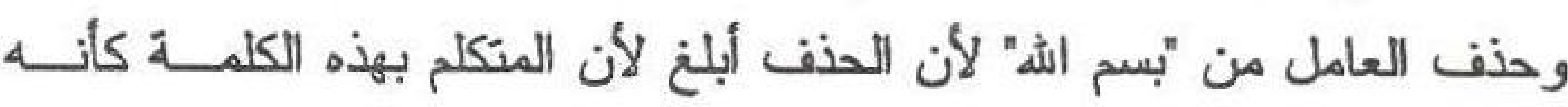

يدَّّى الاسنغناء بالمشاهدة عن النطق بالفعل فلا حاجة إلى النطق (") .

$$
\text { ويسمى هذا القول أجمع "بسم الله الرحمن الرحيم" }
$$

اللبسملة : فيقال : بسمل الرجل إذا كتب بسم الله وأكثر من قوله بســم

اله (أ) · وقد تضمًّنت البسملة نوعين من البلاغة : الحذف و هو ماينعلق بـــ الباء فى "بسم" و الحذف قيل لتخفيف اللفظ ، وذلك أنه موطن ينبغى أن لا يقدم فيه سوى ذكر الله تعالى قلو ذكر الفعل وهو لا يستغنى عن فاعله لــــــــن

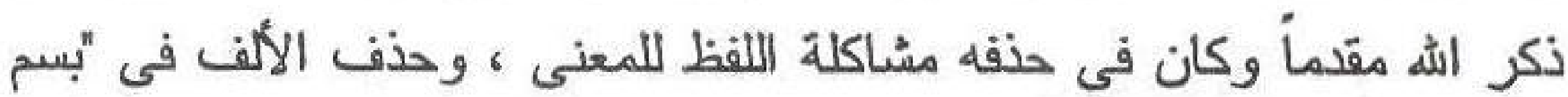
اله " وفى "الرحمن" فى الخط لكثرة الاستعمال ، و النوع الثانى : التكرار فى في

الوصف ويكون إما لتعظيم الموصوف أو للتأكيد ليتقرر فى النفس(") .

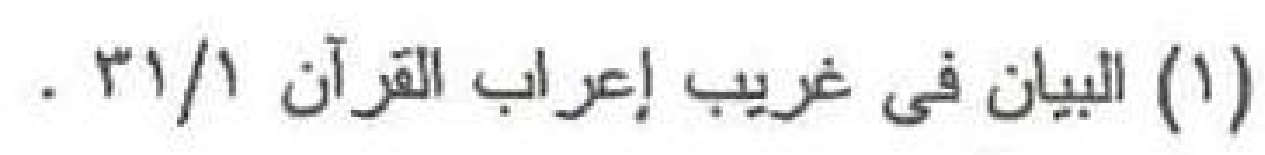

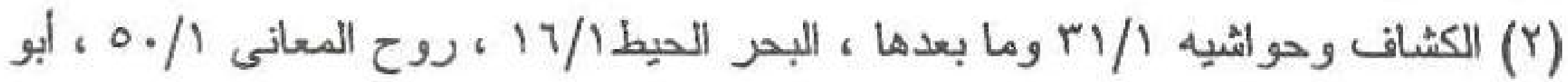

$$
\begin{aligned}
& \text { السعود 19/1، .1. } \\
& \text { (r) بدائع الفو ائد / ro/ }
\end{aligned}
$$

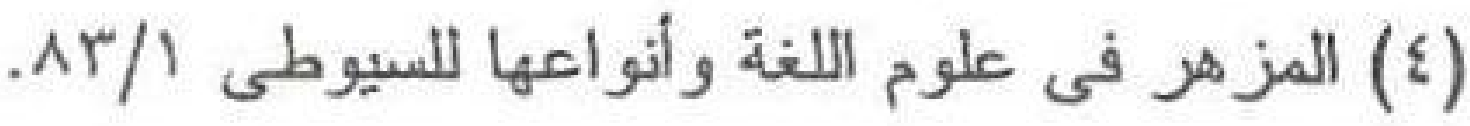

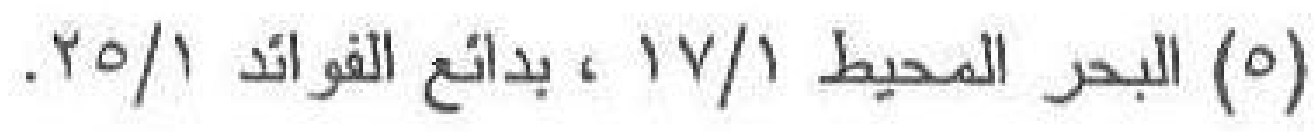


3ى رهاب (لبيان (لقر)

\section{هل البسملة آيه من القرأن؟؟}

اختف العلماء فى عدُ البسملة آية من القران على ثلائة أقوال :

الأول : أنها ليست بأيه ، ولا من الفاتحة ولا من غير ها ، وهو قَول الإمسام مالك والمشهور هن مذهب الحنفية ، وإنما هى آية مستقلة أنزلت لبيان

رؤوس اللسور و الفصل بينها.

الثانىى : أنها آية من الفاتحة ومن كل سورة غير التوبة ، وهو مذهب جمهور

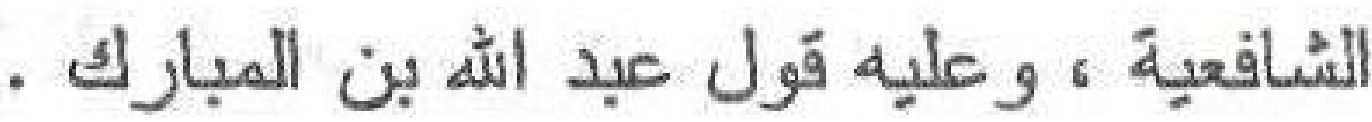

الثشاتث: أنها آية من الفاتحةَ فقط دون غيرها ، و هو منسوب للإمام أحمد بـن

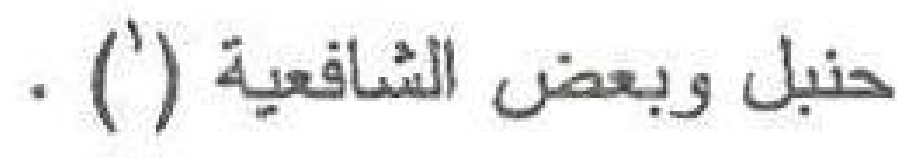

\section{سي" عدمرعدد البسمطة أول سورة براعة :}

اختف فى العبب فى سقوط البسملة أول براءة ، فقيل : كان من شان

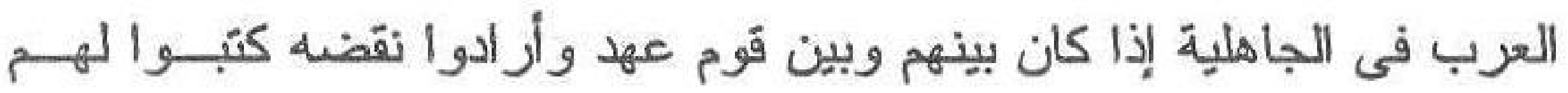

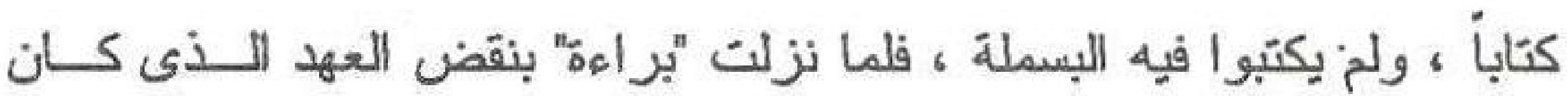

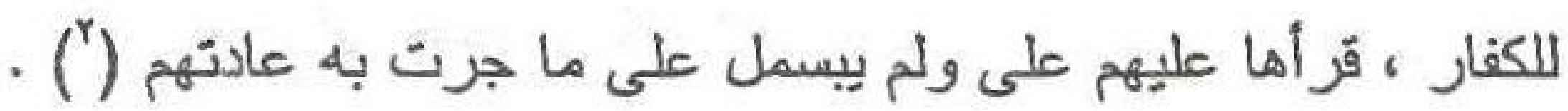
روى الحاكم عن ابن عباس - رضى الله عنهما - قال : قلت لعثـــان

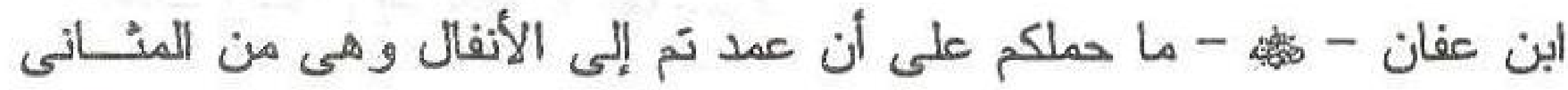

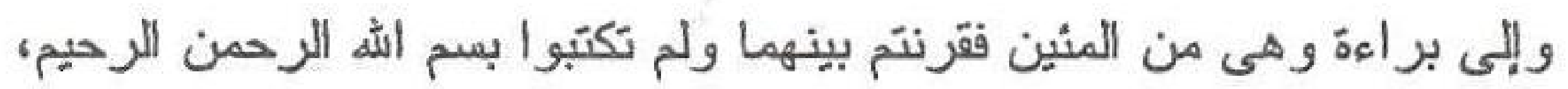

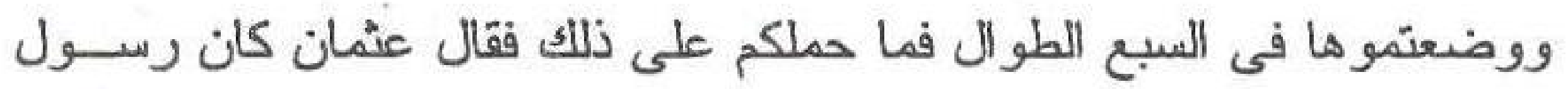

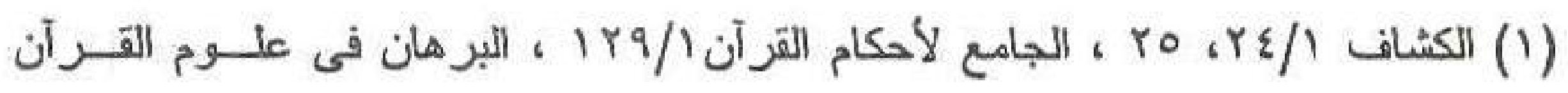
. $21 \cdot / 1$

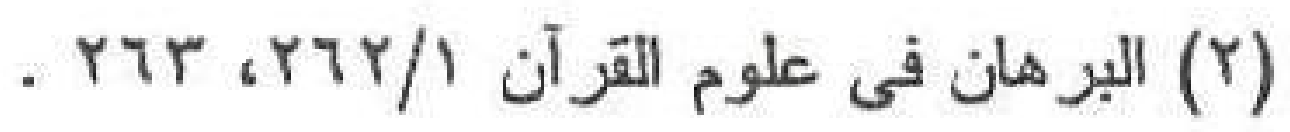


- - مأ - يأتى عليه الزمان وهو ينزل عليه من السور ذوات العـدد قــال

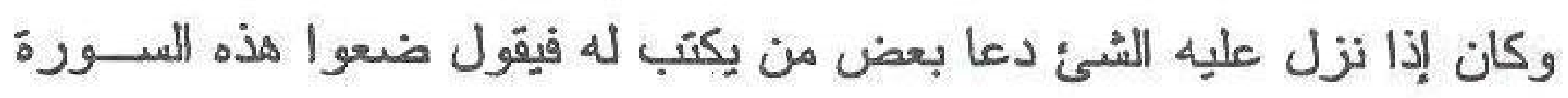

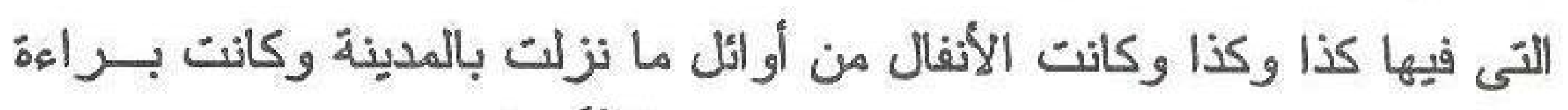

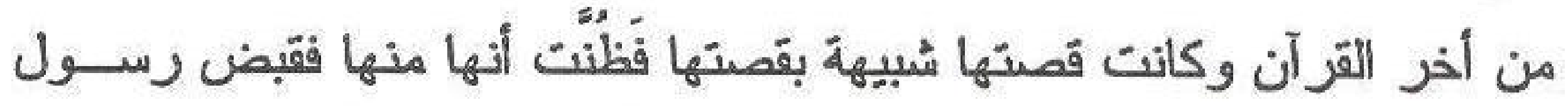
الله - صلى الله عليه وآله وسلم- ولم بيِين لنا أنها منها فلم أكتب بينهما سطر بسم اله الرحمن الرحيم (')لهحيح الإسناد.

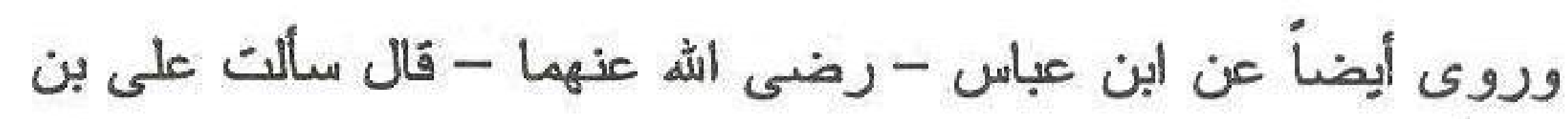

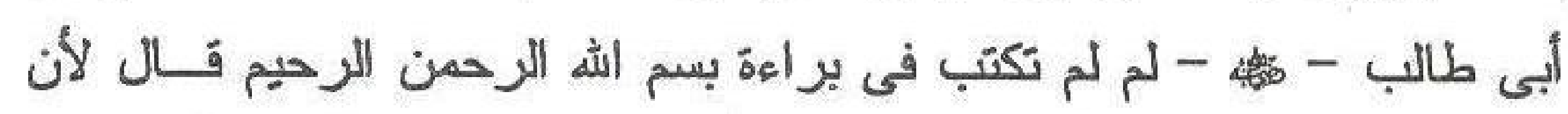

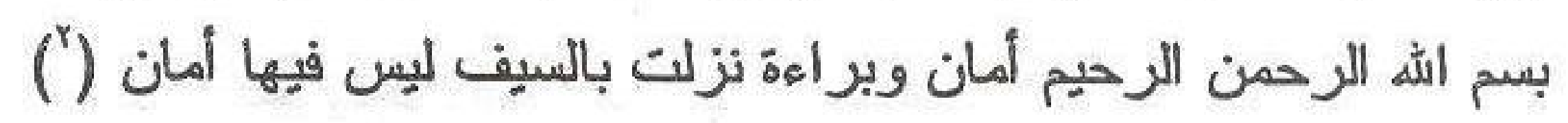

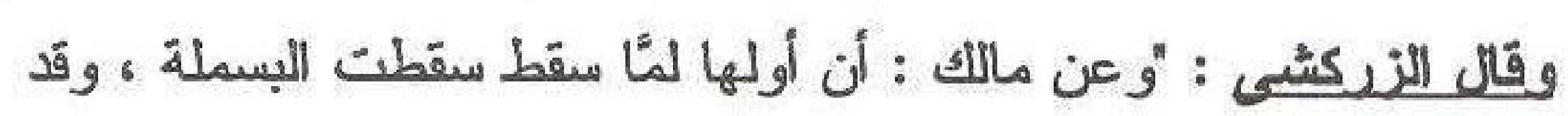

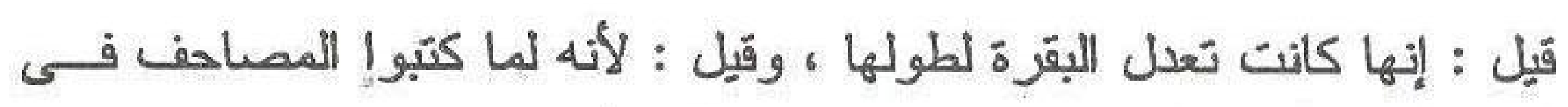

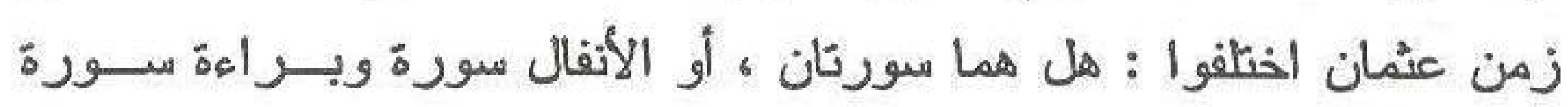

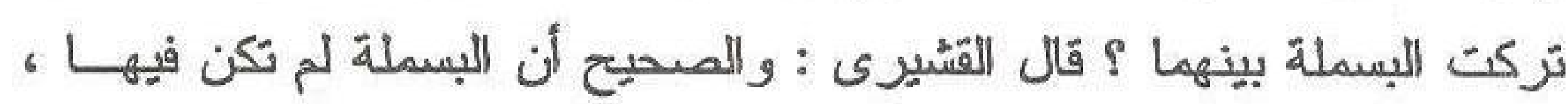

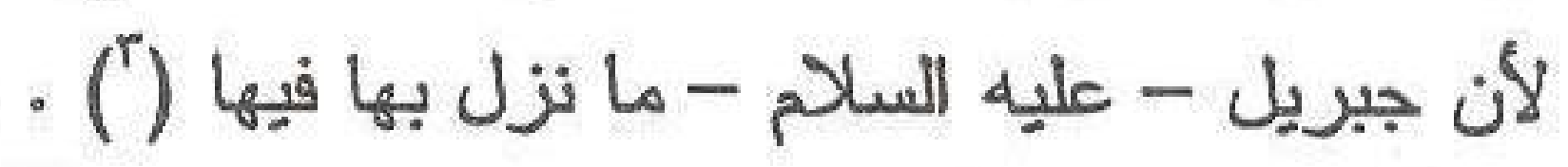
فضل البسملة : روى ابن أبى حاتم - رحمه الله - عن ابن عباس -

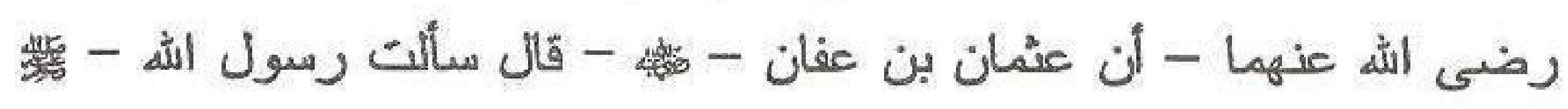
- عن - بسم الله الرحمن الرحيم - فقال : " هو السم من أسماء اله وما بينه

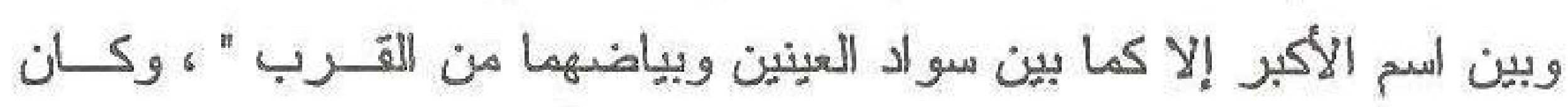

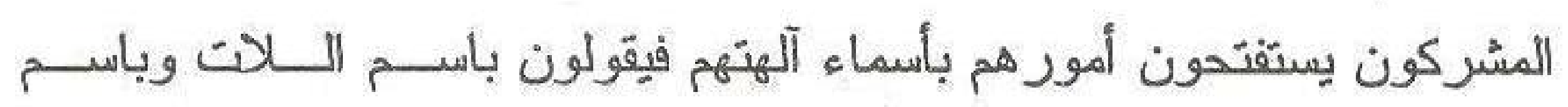

(1) المستدرك Y / بr ، ، والثلخيص للذهبى عليه ـ تقسير سورة التوبة . (Y) المستررك Y / 


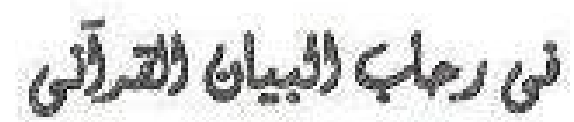

العزى ـ فأمر المسلم أن يستفتح باسم الله وفى الحديث : " كل أمر ذى بال لا

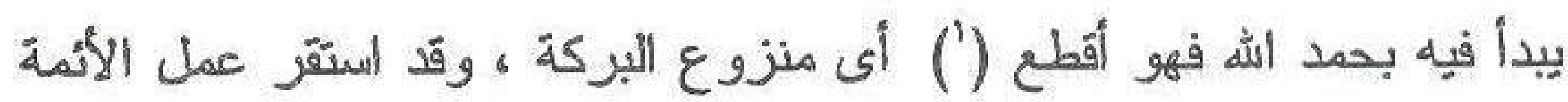

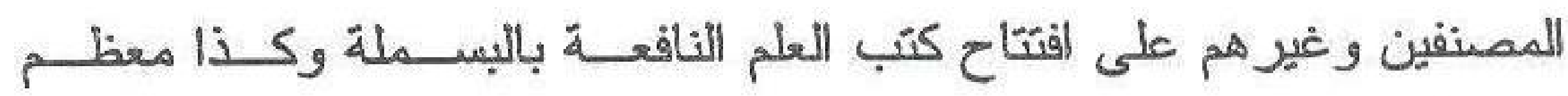

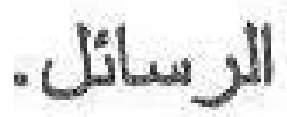

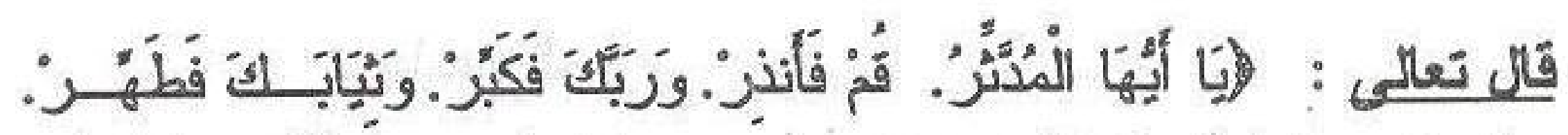

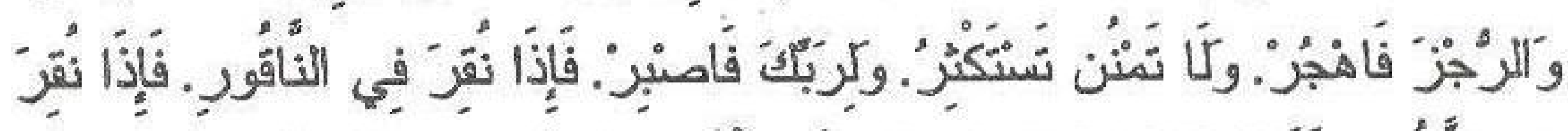

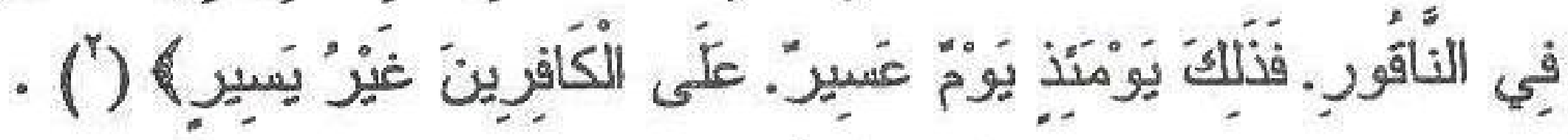

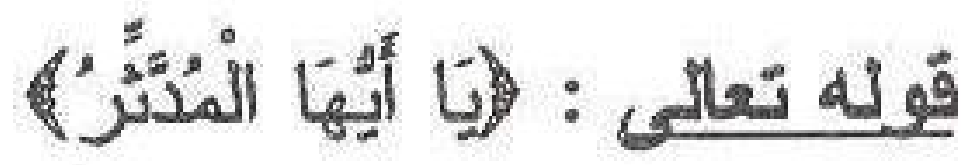

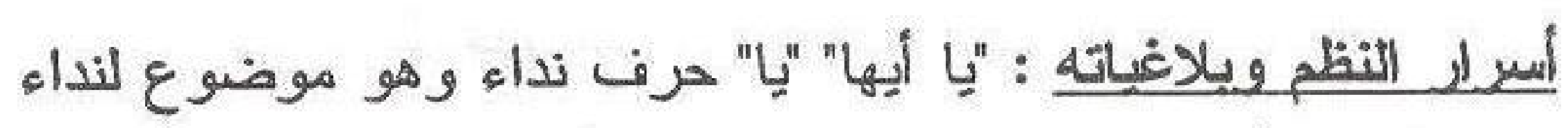

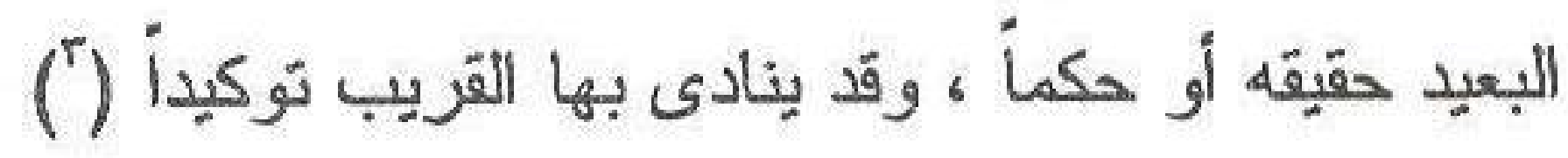
فينادى بها القريب لنكتة ـ منها إظهار الحرص فى وقوعه على إقبال

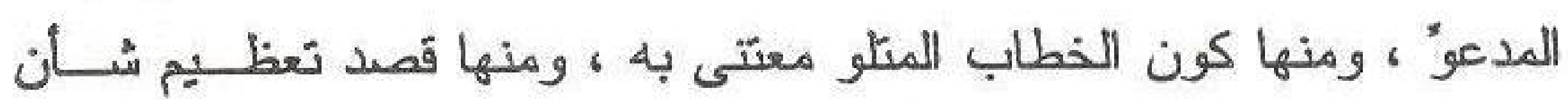

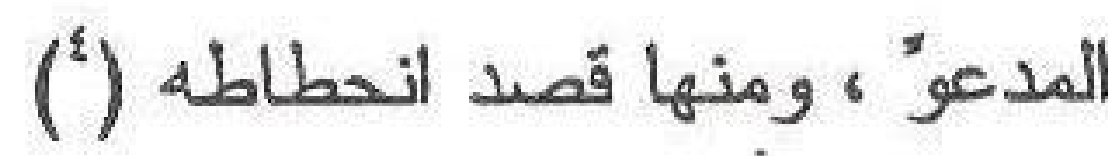

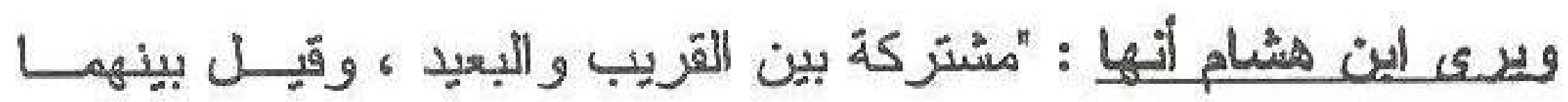

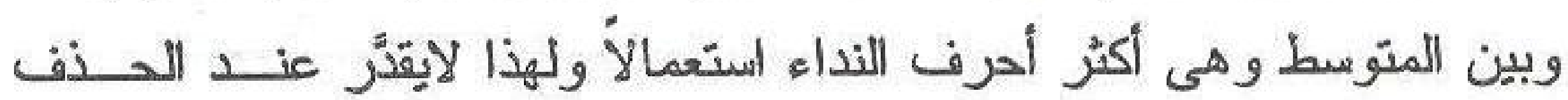

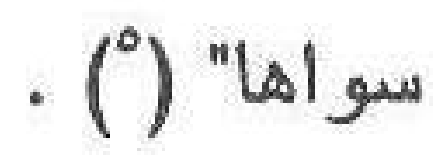

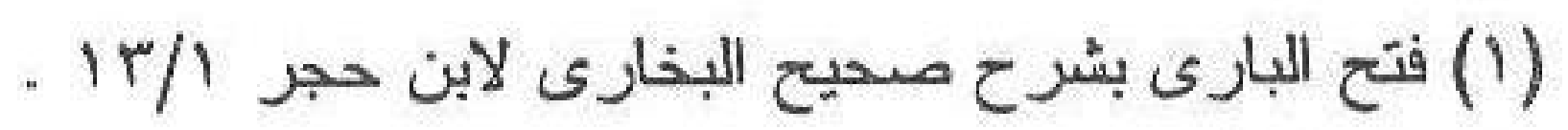

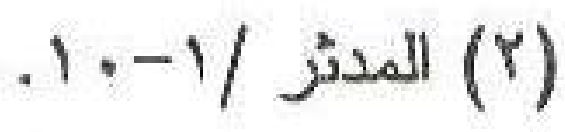

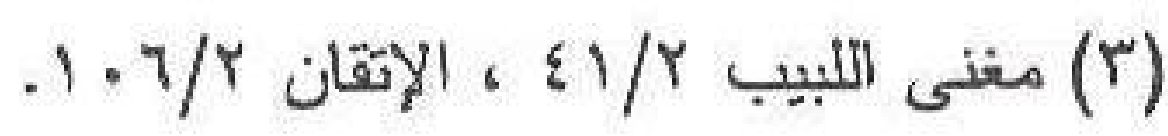

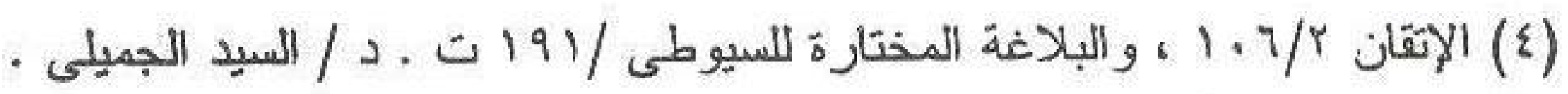

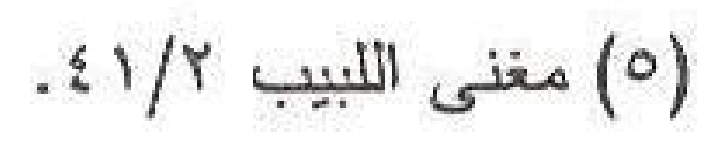




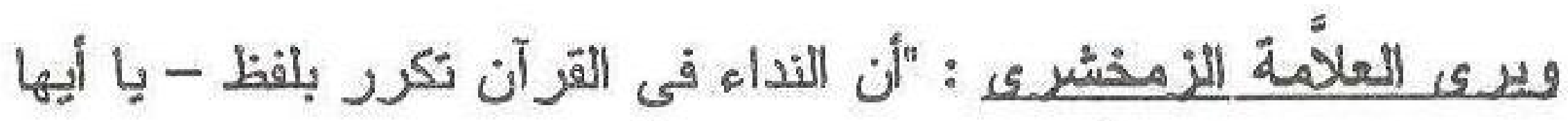

دون ضيره ، لأن فيه أوجهاً هن الثأكيد ، وأسباباً هن المبالغة ، ومنها فى "يا"

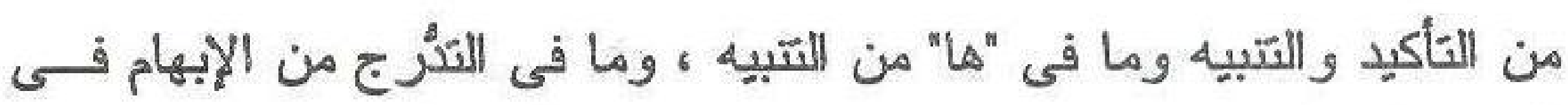
"أى " إلى التوضيح ، و المقام يناسب المبالغة و التأكيد لأن ما نادى الهه عباده من أو امره ونواهيه وعظاته وزواجره وو عده ور عيده ومن اقتصاص أخبار

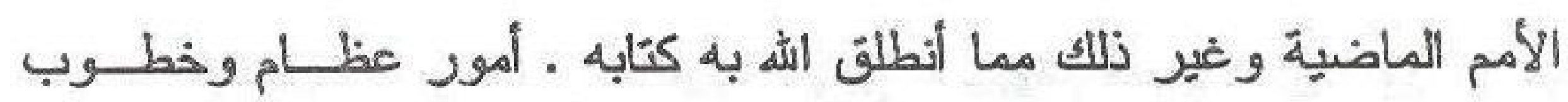
جسام ومعان" واجب عليهم أن يتيقظو الها ، ويميلو ا بقلوبهم ويصائرهم إليها

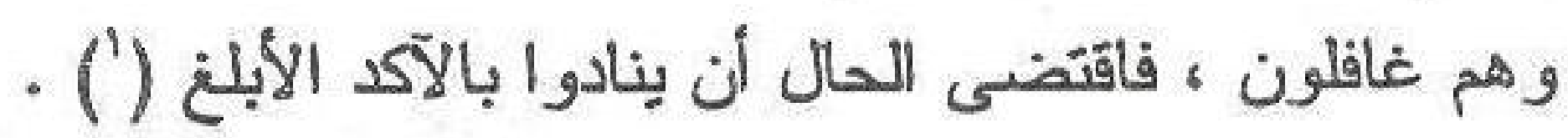

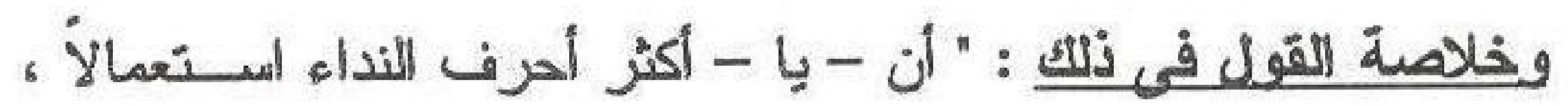

وأنه لا بِنادى اسم الله - عز وجل - إلا بها ، وحين يقتضى السيات جملأ من التوكيد كإضافة عناصر لغوية ذات تأثير فى اللفت والإيقاظ - كأى - التـى ونى للإبهام - ها - التى للتتبيه هين ذلإ لا تسنعمل من الأدوات سواها فيقولون:

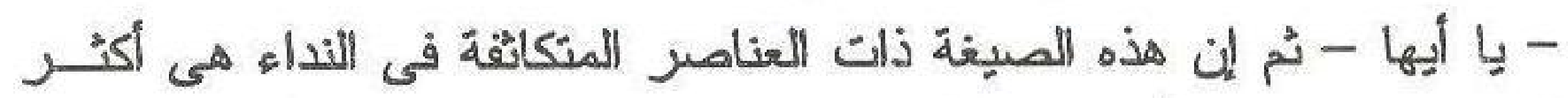

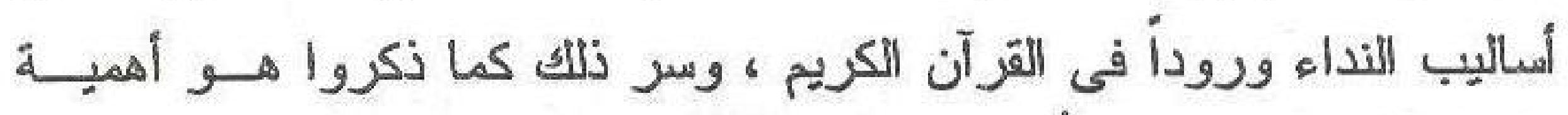

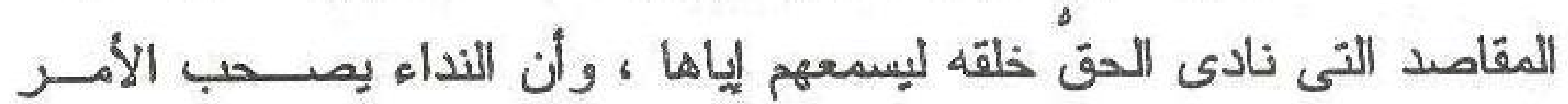
والنهى غالباً وكأنه إعداد النفس لهما ، وأن الأكثر أن بيتّدَم عليهما ('). فالنداء أسلوب من أساليب الإنشاء ، وهو إنشاء نسبة النــداء بحــرف يقوم مقامها ليقيل المخاطب به إلى المتكلم به بقلبه ، وليس مقصودأ بذاتــه ،

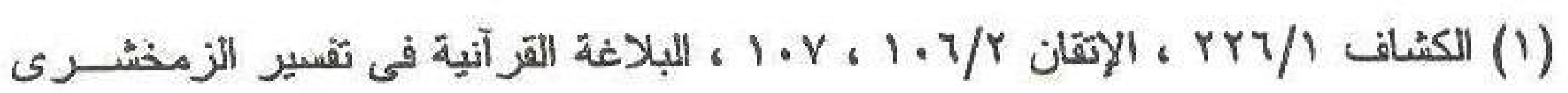

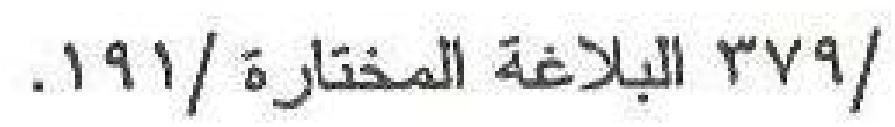

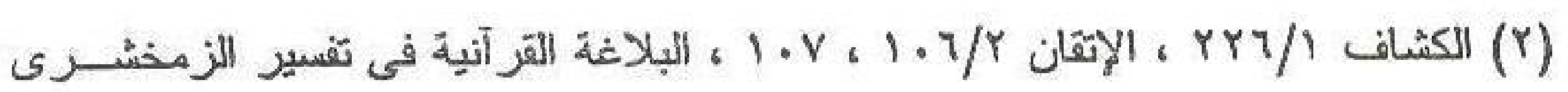
191/ البلاغة المختارة 


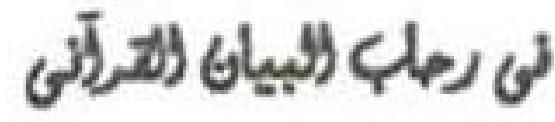

و إنما ينادى ليبدأ بكلام بعده ، أو ليعلم حضوره أو غيبته أو لنسبة صفة إليه، فيكثى بإطلاق مشُقَ منها - من الصفة - على المخاطب ، وعليه فنداؤه هنا بوصفه فى حالة خاصة تلبس بها "عليه الصلاة والعلام" حين نزول هذه السورة ، وفى هذا النداء من الكرامة واللطف وإعداد النفس لتلقـى الأهــر

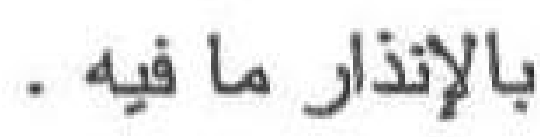

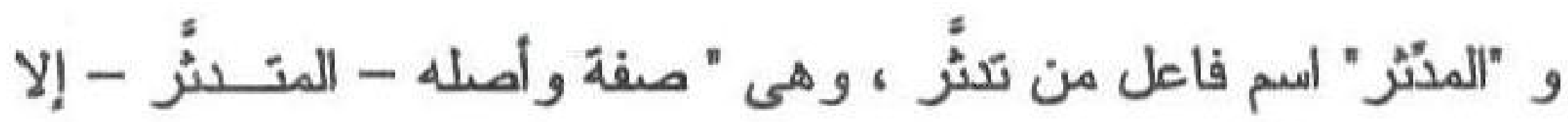

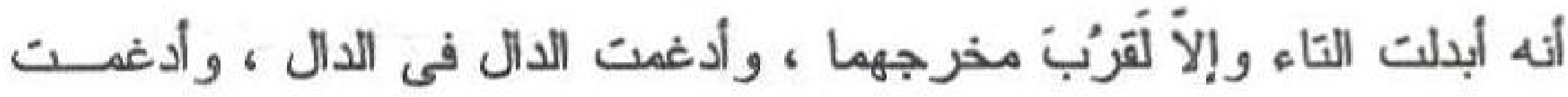

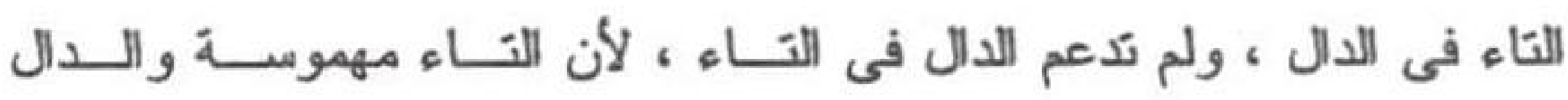
مجهورة، والمجهور أقوى من المهموس ، والمهموس أضعف ، فكان إدغام الأضعف فى الأوىى أولى من إدغام الأقوى فى الاضنعف (')

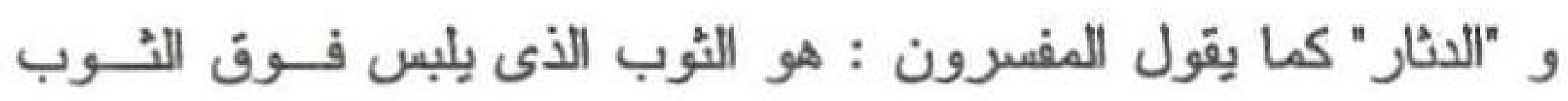

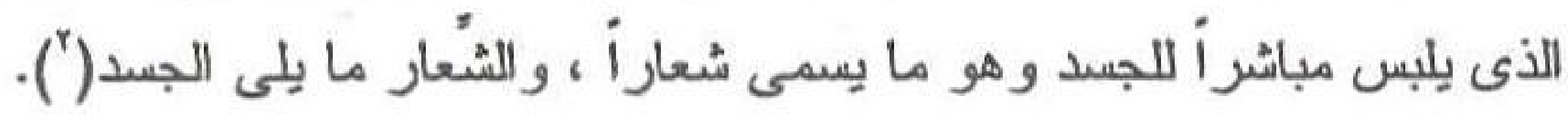

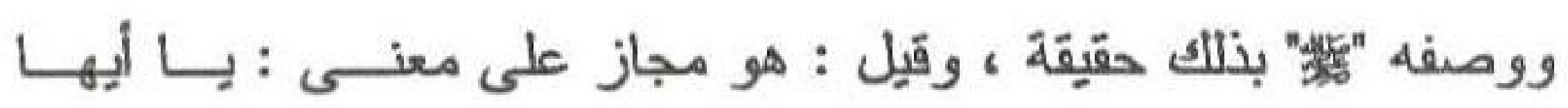

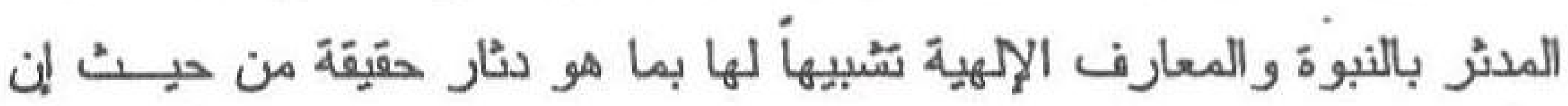

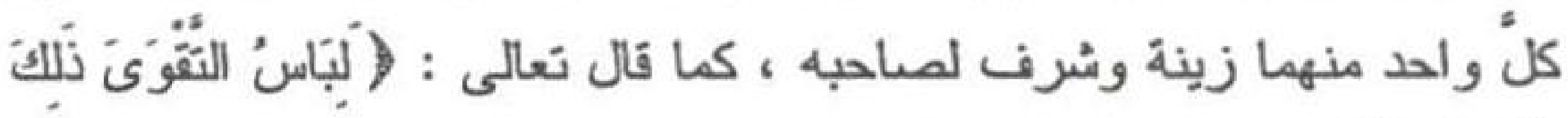

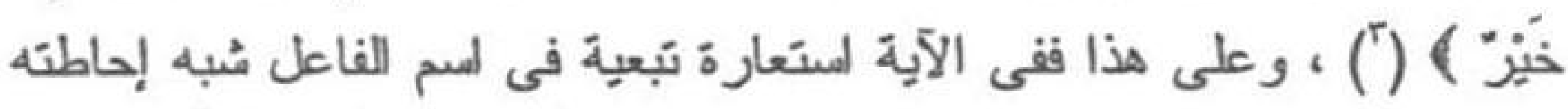

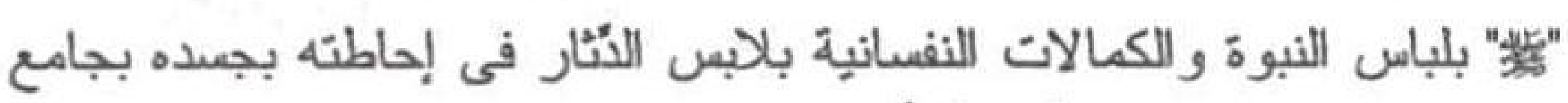

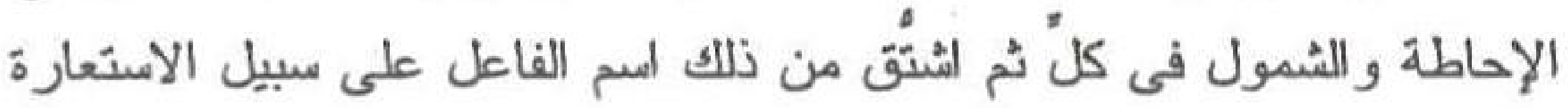

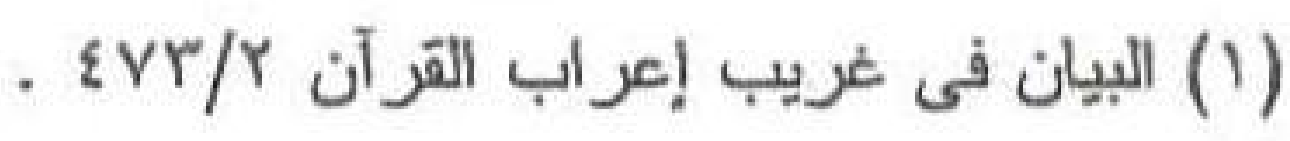

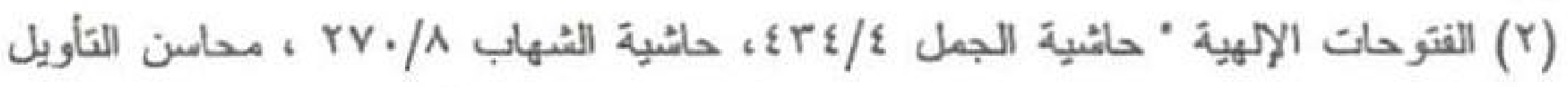

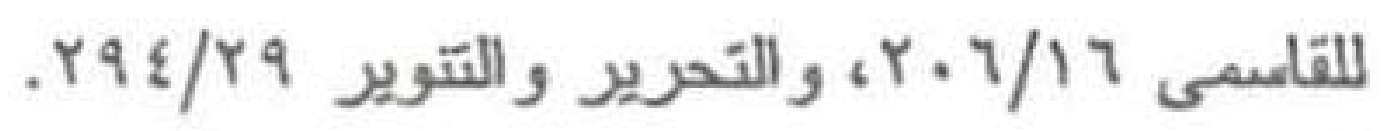




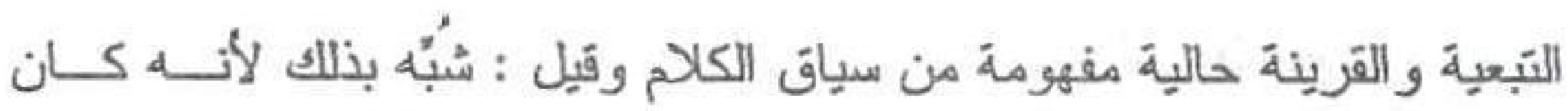

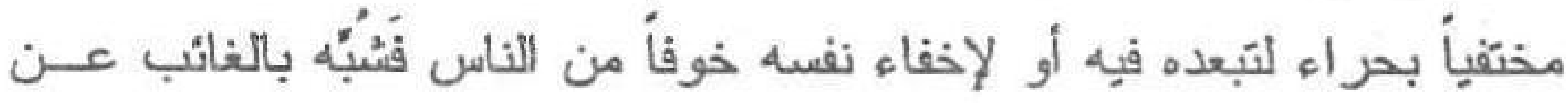

- النظر

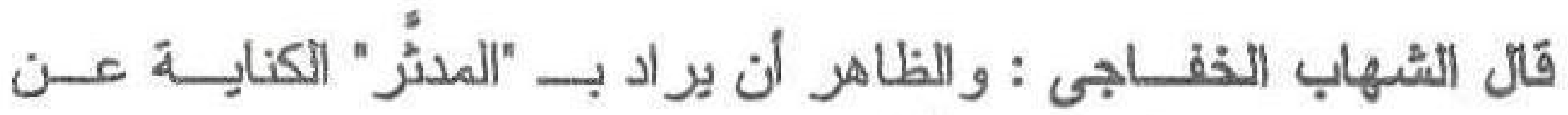
المستريح الفارغ لأنه فى أول البعثة فكأنه قيل له قد مضنى زمسـن الراحسـة

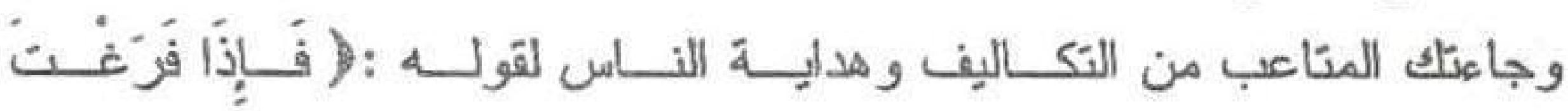

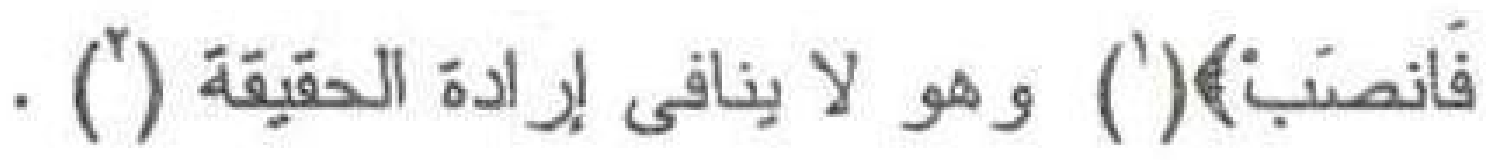

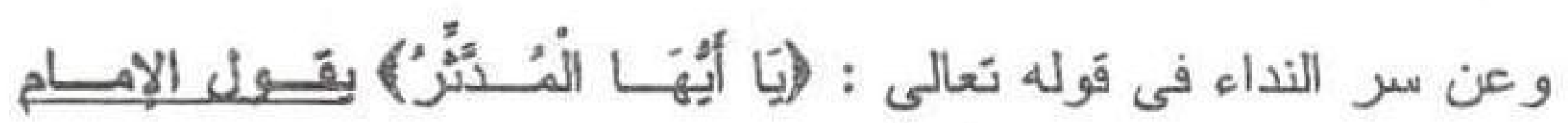

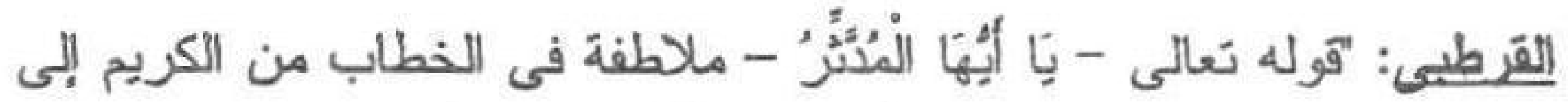

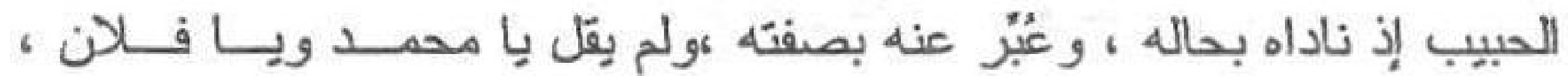
ليستشعر الللين و الملاطفة من ربه (أ) .

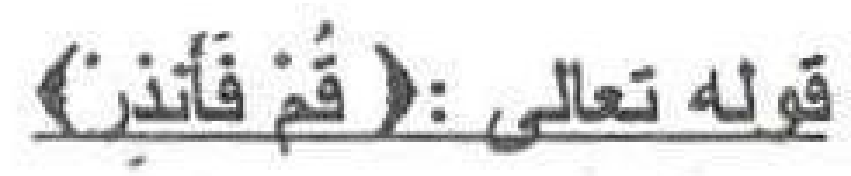
اللنظم البلاغى : القيام المأمور به "هنا" ليس مستعملأ فى حقيقتــه لأن

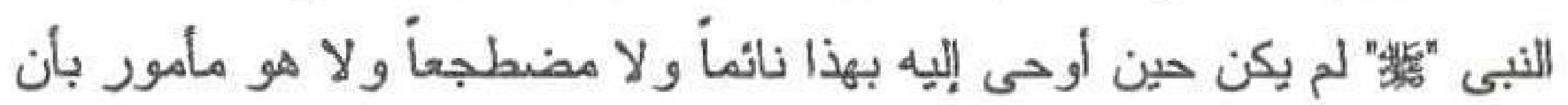
ينهض على قدميه و إنما هو مستعمل فى الأمر بالمبادرة والإقبـال بالإنــار مجاز أى أن الأمر خرج فيه عن حقيقته إلى المعنى المجازى لما ذكرنا ، أو أن القيام هنا كناية عن النُشاط والجدٌ وقوة العزيمة كناية عن الصفة ، وقيل :

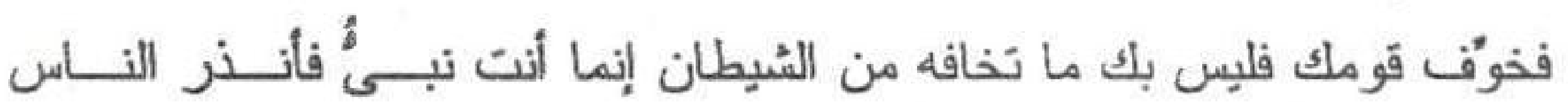
و ادعهم إلى التوحيد ، والش تعالى لا يوحى إلى رسوله إلا بالبر اهين الليــرة

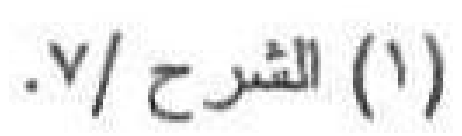

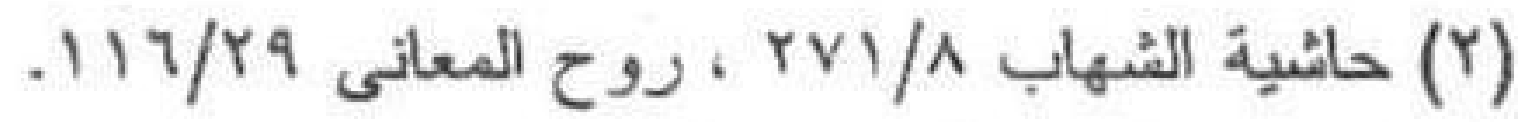

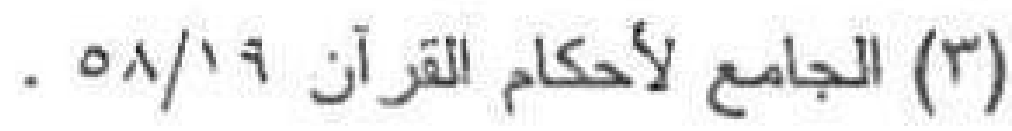


و الآيات البينة على أن ما يوحى إليه إنما هو من اله نعالى فلا يحتــاج إلـى لـى

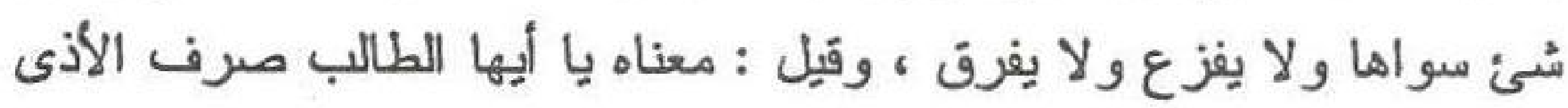

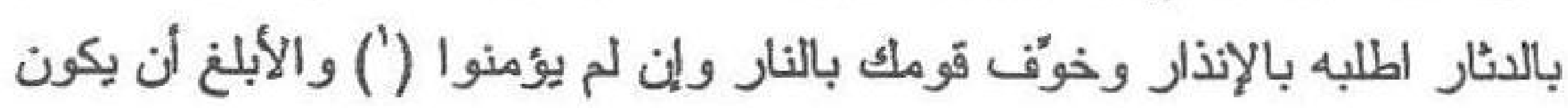

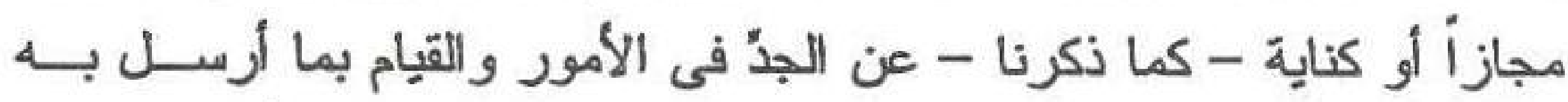

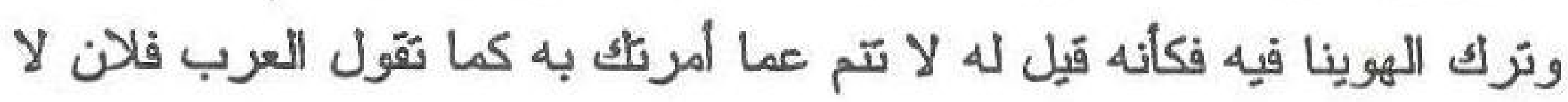

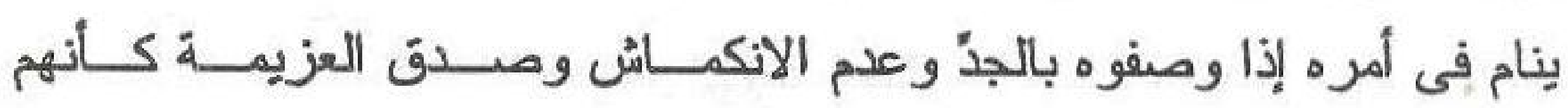
يحظرون النوم على ذى الحاجة حتى يبلغ حاجته .

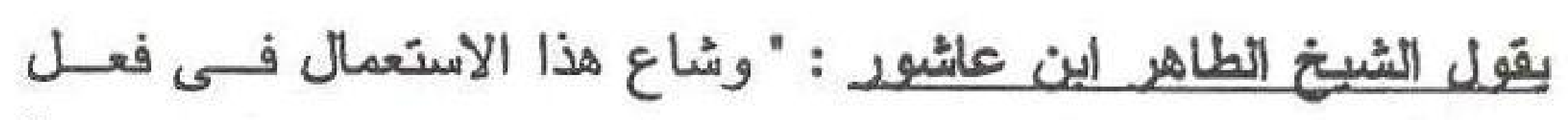
القيام حتى صار معنى الشرور فى العمل من معانى مــادة القيــام مســاوياً للحقيقة ، وجاء بهذا المعنى فى كثير من كلامهم ، وعدً ابن مالك فى التسهيل

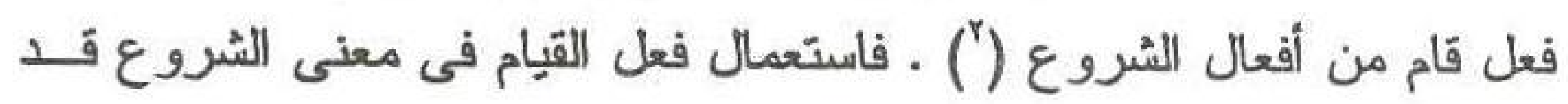

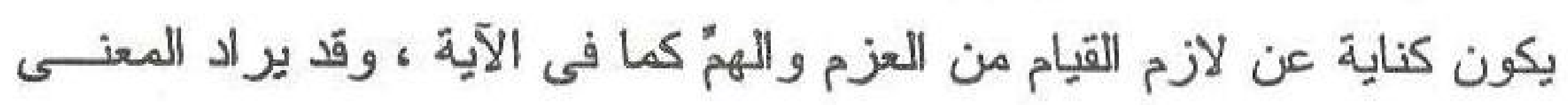

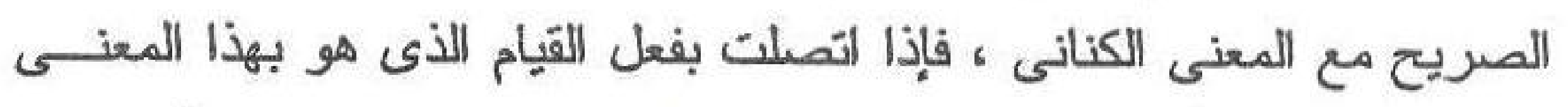

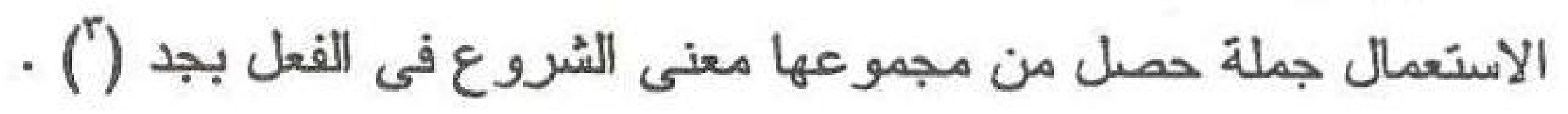

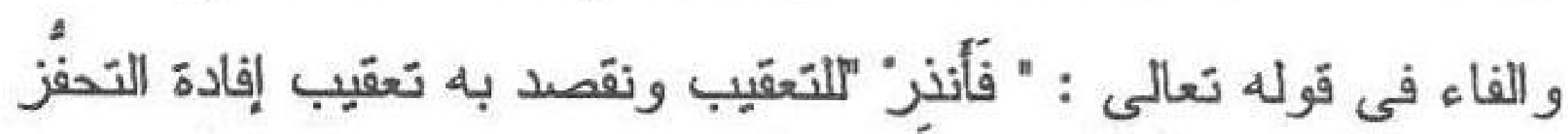

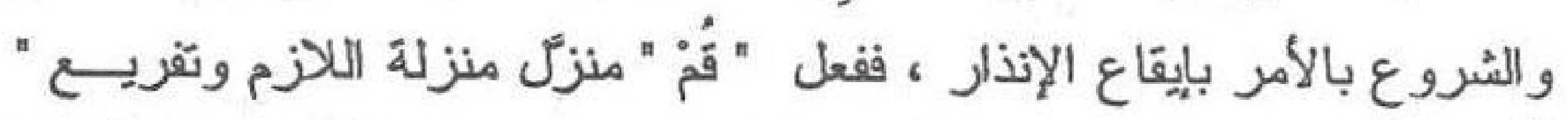

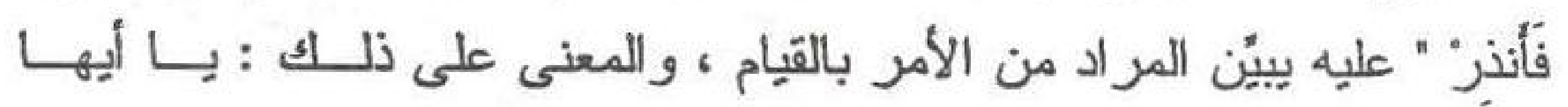

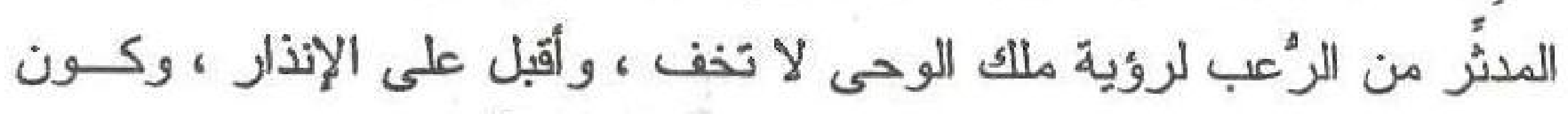

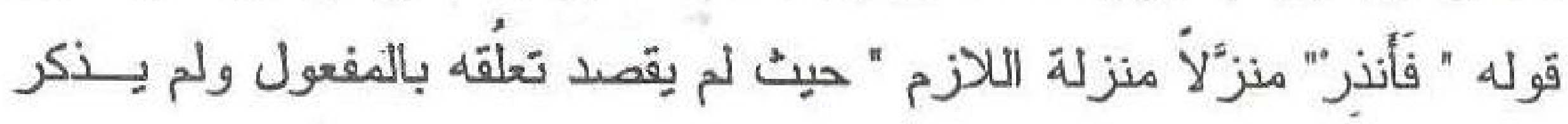

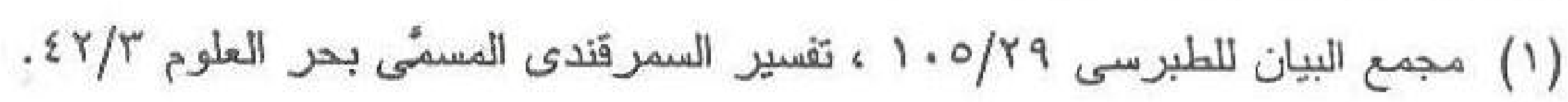

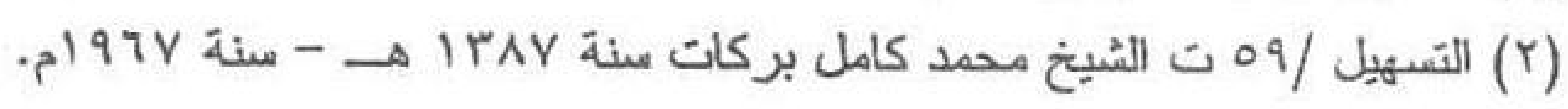

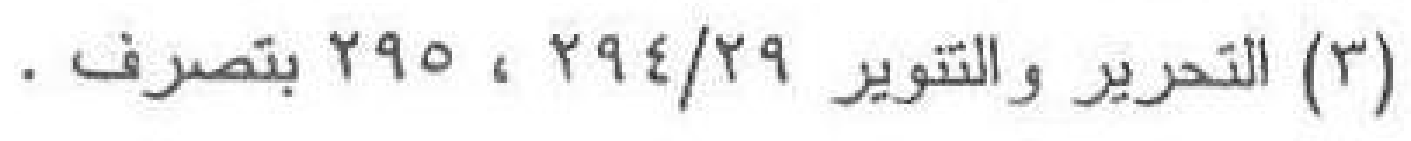


لفظاً ولا تقديرأ للتعميم والاختصار أى فأنذر عشيرثك الأقربين العـذاب أو أنذر البشر كافة من غير تخصيص أحد (') فمفعول "أنذر" محذوف لإقادة العموم ، أى أنذر الناس كلهــم وهـــم يومنذ جميع الناس ما عدا خديجة "رضى الله عنها " قإنها آمنت فهى جــديرة

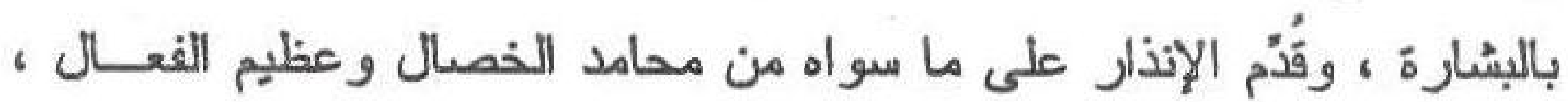

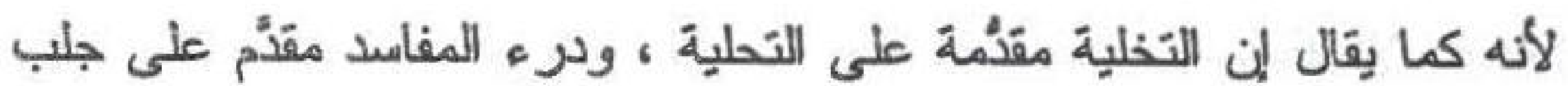
المصالح ، ولان غالب أحوال الناس ، وعامة أمرهم يومثذ محتاجـة إلــى لـى • الإنذار و التحذير والانذار هو "إعلام بتخويف ، فهو أخصن" من مطلق الإعلام ، وهـــو متعدّ لمفعولين المنذر باسم المفعول و المنذر به ، ولم يذكر هنا واحد منهمــا

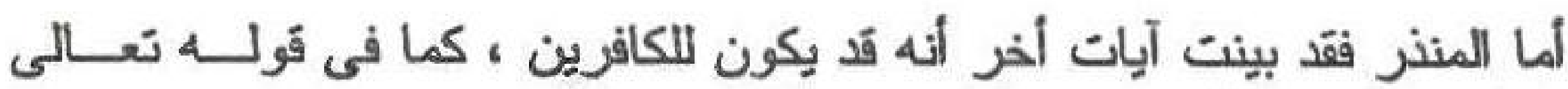

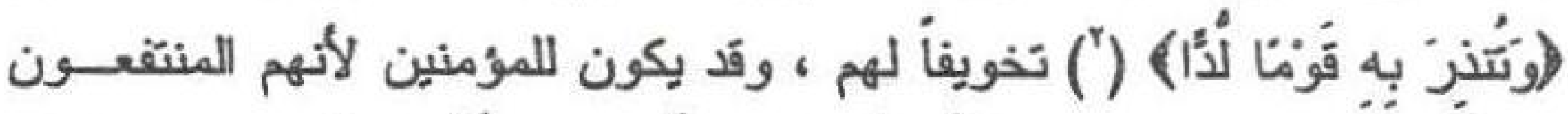

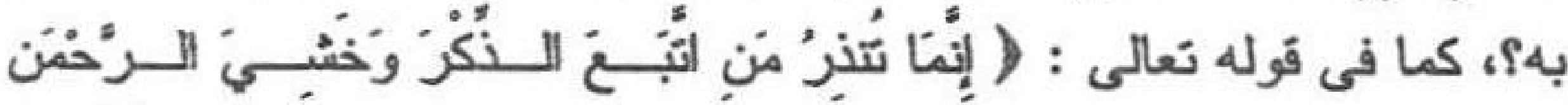

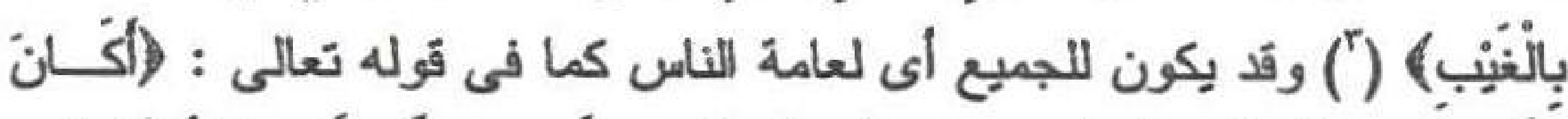

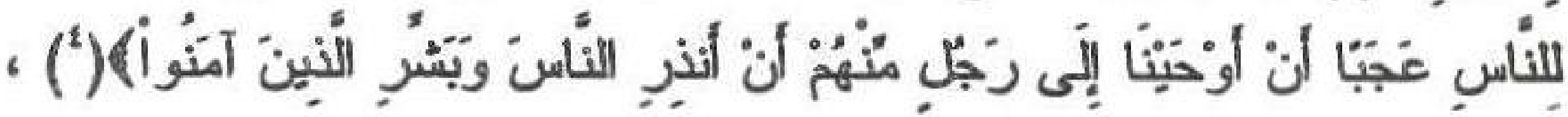
وأما المنذر به فهو ما يكون يوم القيامة ، وقد قدّر الأمرين هنا ابن جريـر

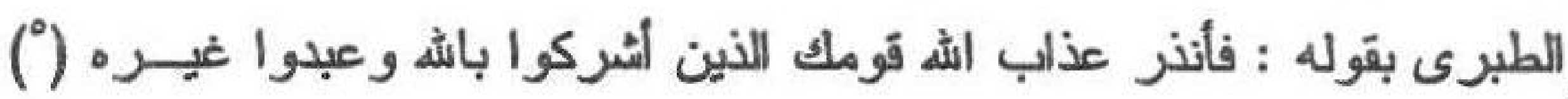
فالإنذار إخبار فيه تخويف.

$$
\begin{aligned}
& \text { (1) حاثية الشيخ زادة على البيضاوى /879. }
\end{aligned}
$$

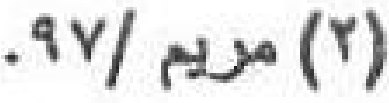

$$
\begin{aligned}
& \text { (r) (r) (11) }
\end{aligned}
$$

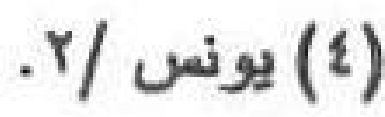

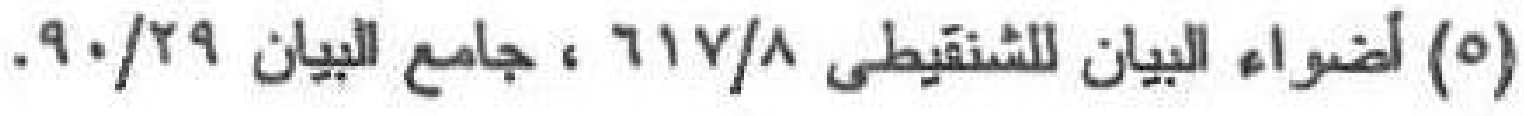




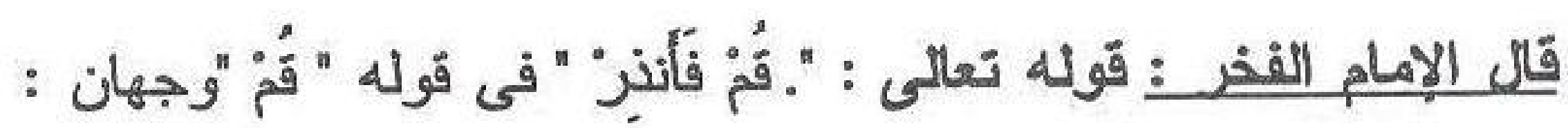

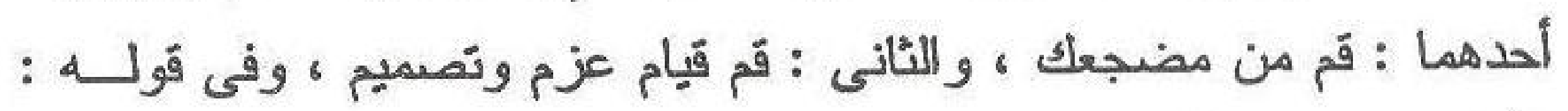

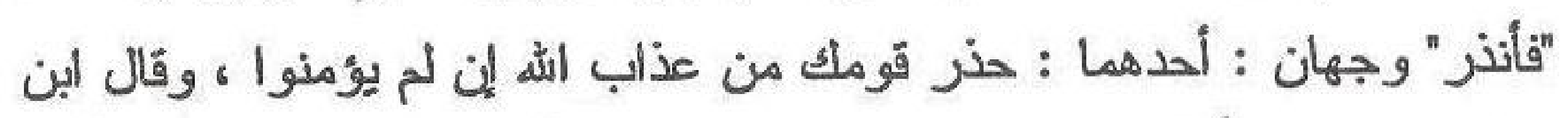

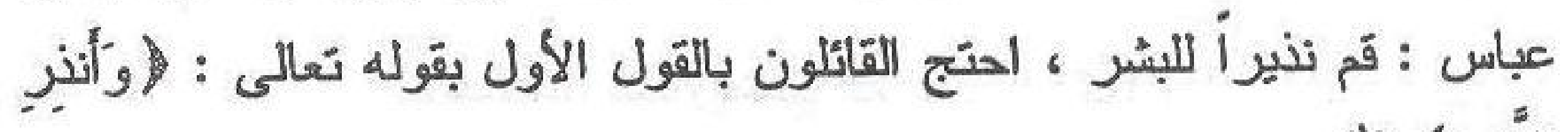
الثَّاسن) (') (")

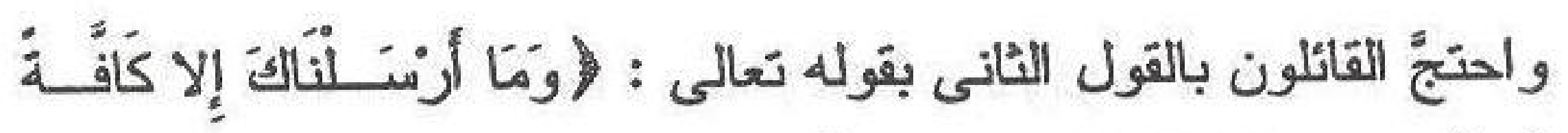

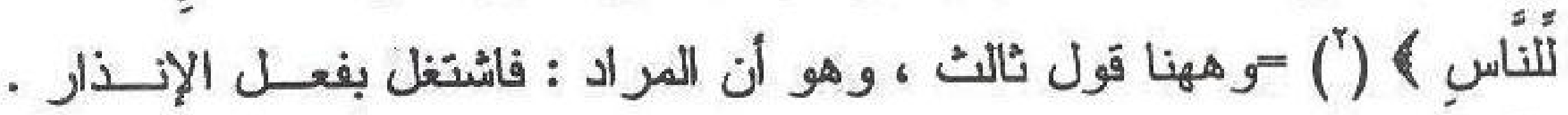

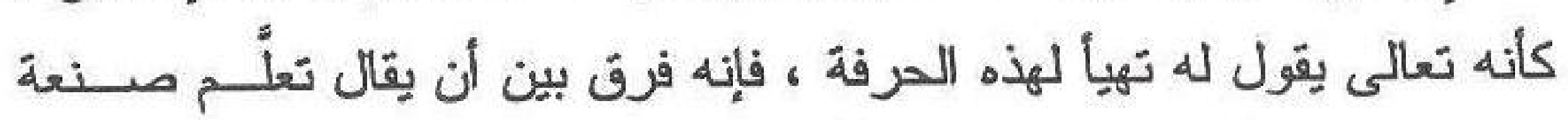

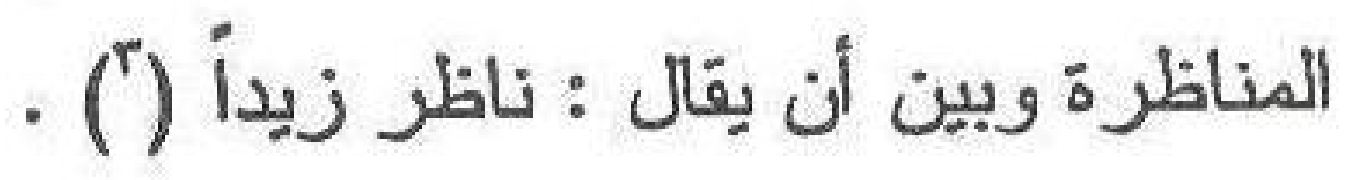

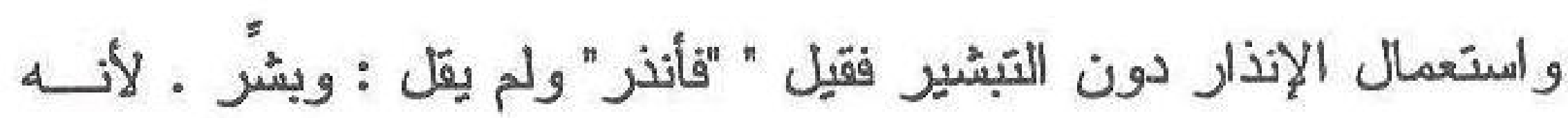

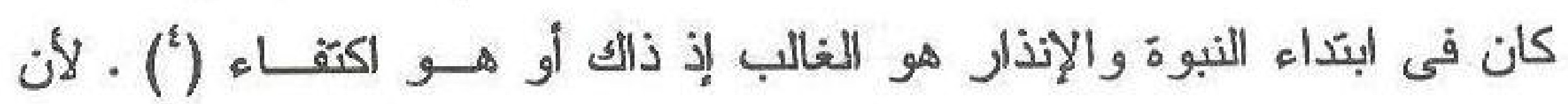

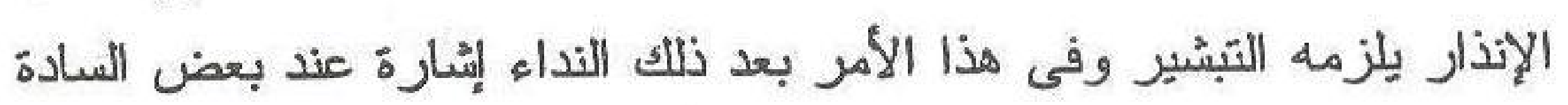

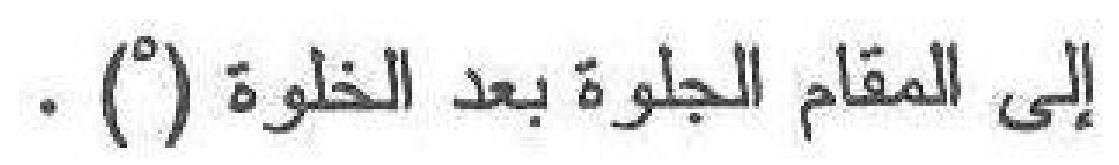

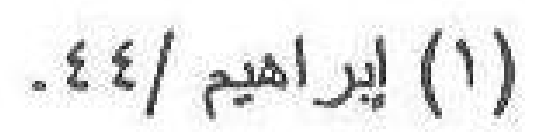

$$
\begin{aligned}
& \text { (Y) (Y) (Y) (Y) }
\end{aligned}
$$

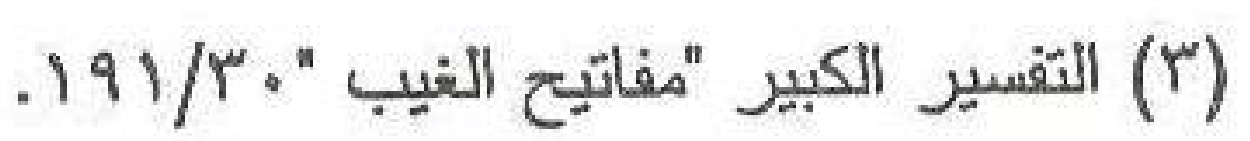

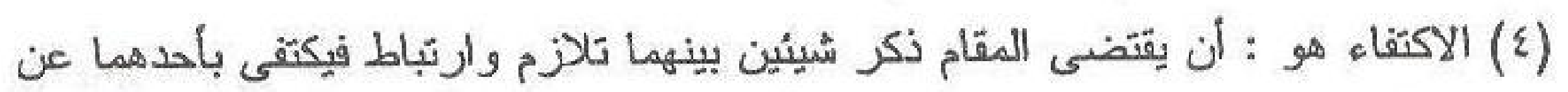

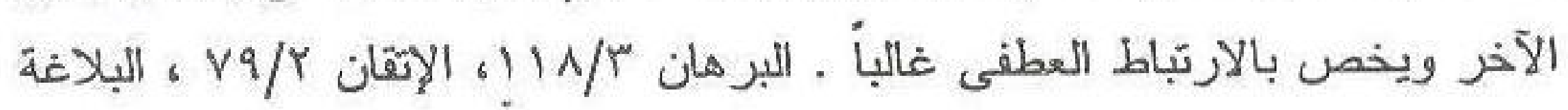




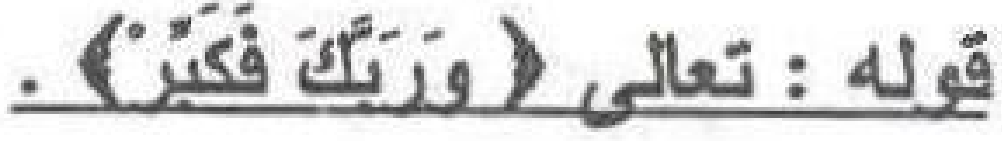

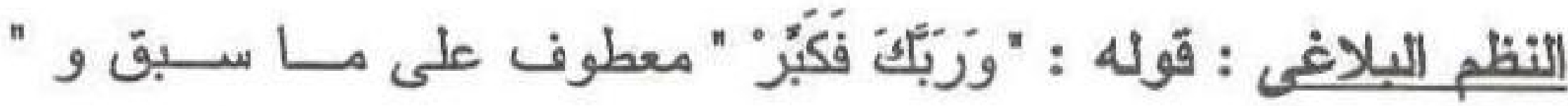

ورَبَكَّ" مفعول به مقدَّم والفاء رابطة للشرط مقدَّر يقتضيه السياق كأنه قَيل :

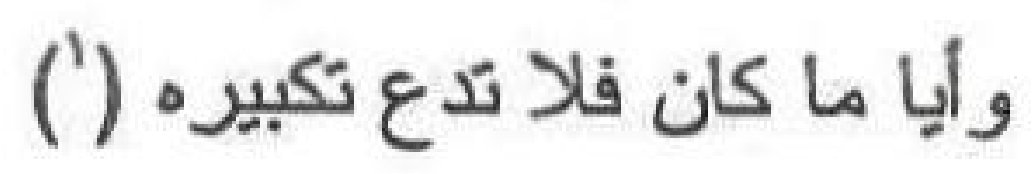

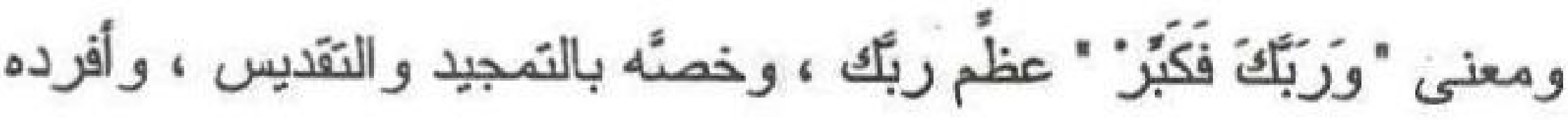

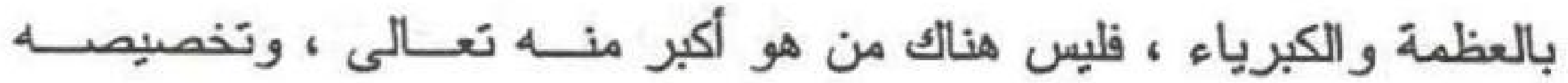

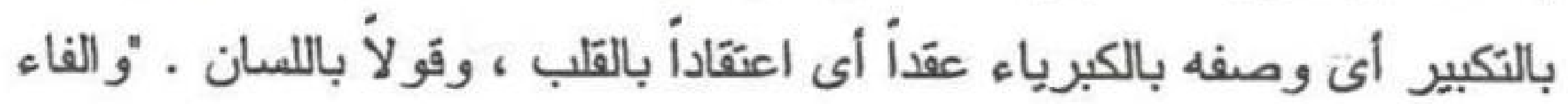
فيه وفيما بأنى بَغُْ لإفادة معنى المُرط ، أو للالالة على أن المقصــود الأول

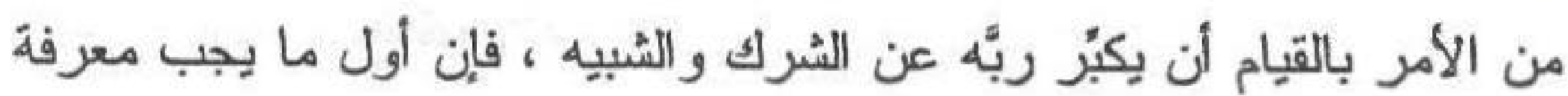

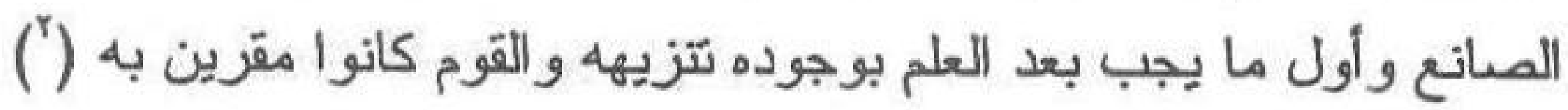
و السر" فى تقديم المفعول "ربكّك" على عامله فكبرّ" لإقادة الاختصاص ، أى لا تكبّر غيره ، وهو أسلوب قصر طريقه تقديم ما حقه التأخير من بـاب

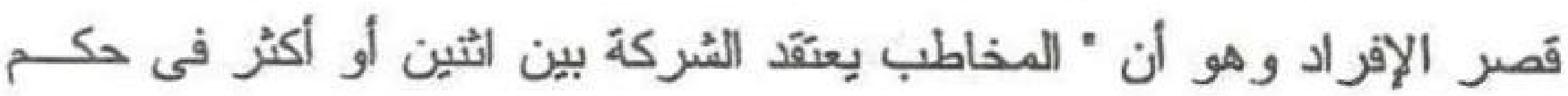
واحد ، فيقتصر هذا الحكم على فرد واحد دون غيره " (") و المراد هنا : كبّر ربّك وحده دون غيره من الأصنام ، وتعظيمه نعالى وتكبيره مجاز من باب الاستعارة بتشبييه الشئ المعظم بشئ كبير فى نوعه بجامع الفضل على غيره

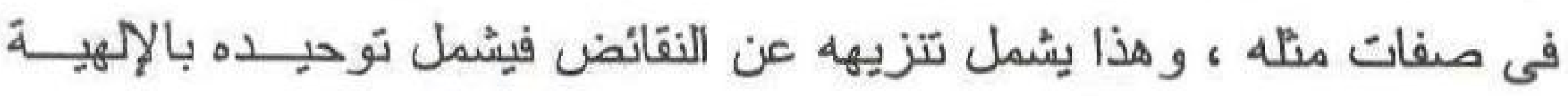

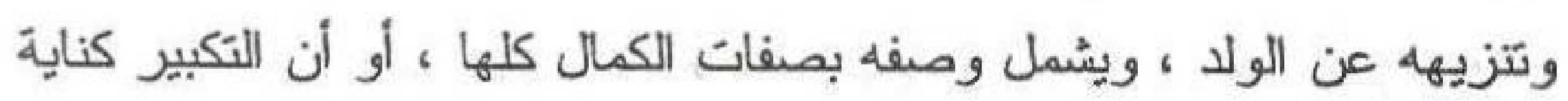

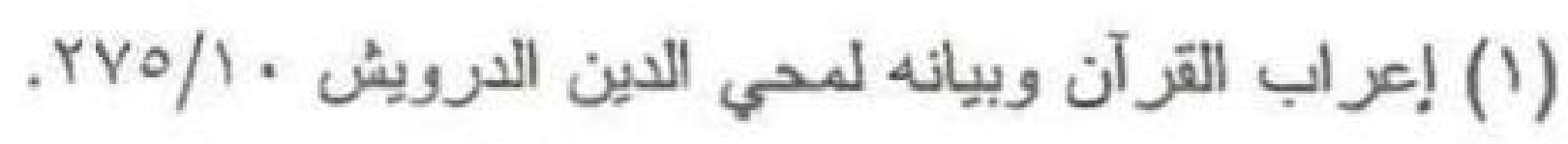

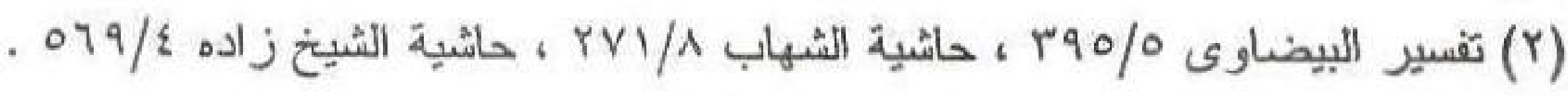

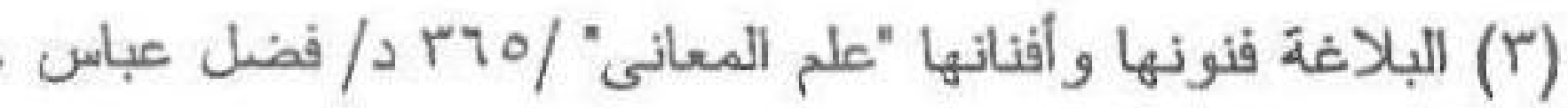


عن التتزيه عن الشريك فالأمر بالتكبير نهى عما ذكــر ، والنهـى بحسـب

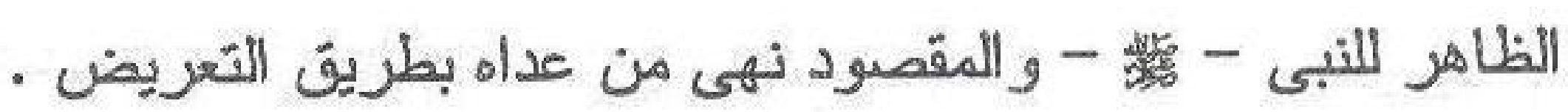
وذكرت هذه الجملة "ورَبَّكَ فَكَبرَ" "بعد جملة الأمر بالإنذار ومقدمسـة

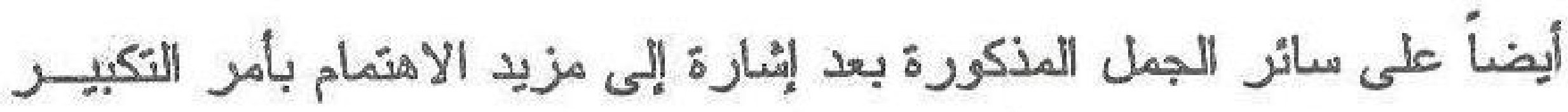

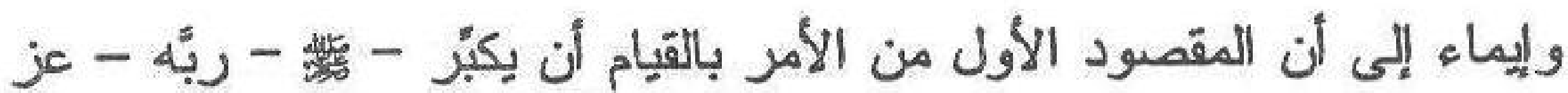

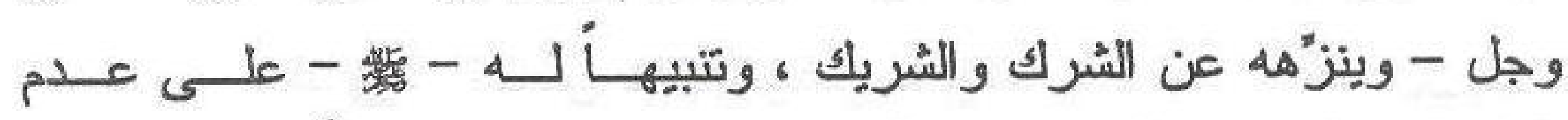
الاكتراث بأحد من الخلق ، ولا أن يرهب سوى اله ، فإن كلَّ كبير مقهـور تحت عظمته تعالى وكبريائه فلا يعظم فى عينيك غيره ويصغر فى قلبك كل ما سو اه بمشاهدة كبريائه .

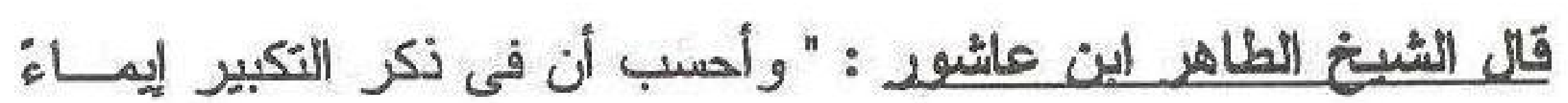

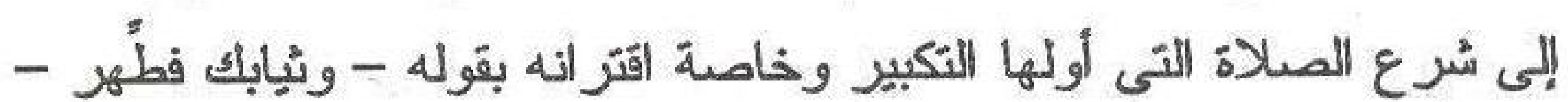

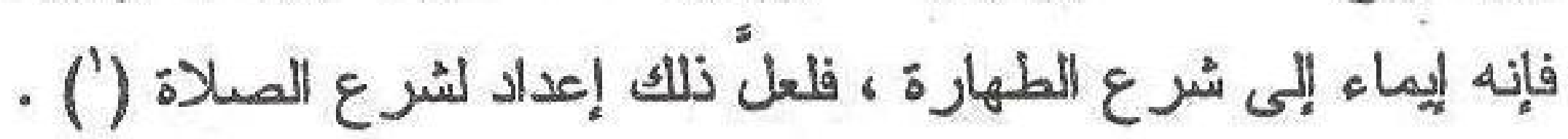

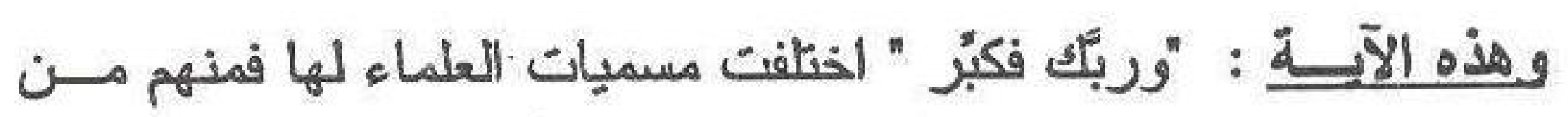

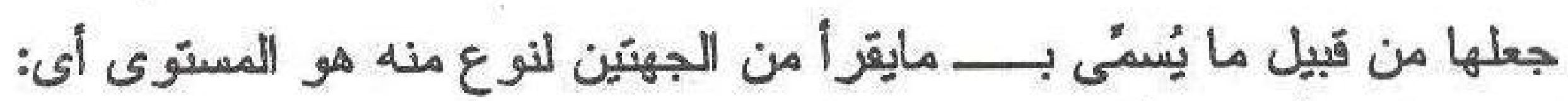

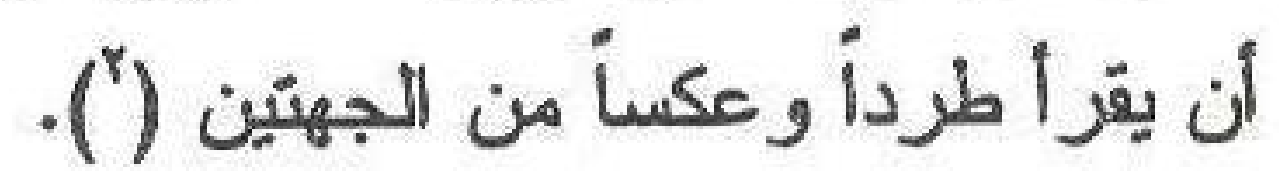
فالكلمتان مكونتان من الر اء و الباء و الكاف ، ومنهم من جعلها من باب

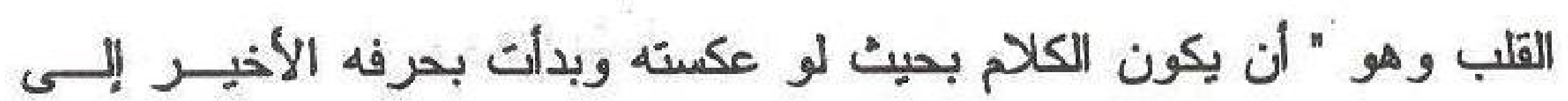

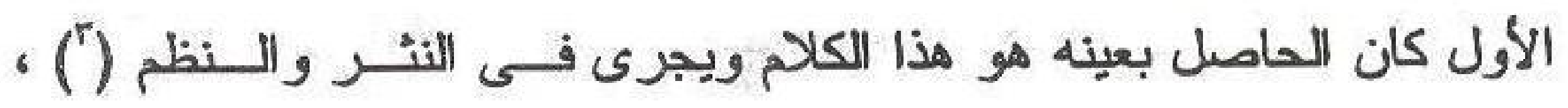

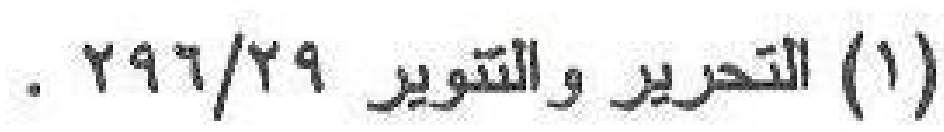

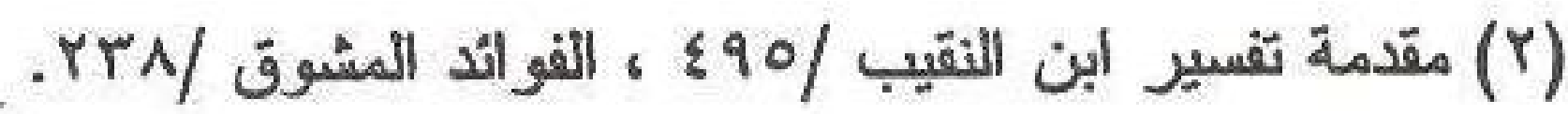

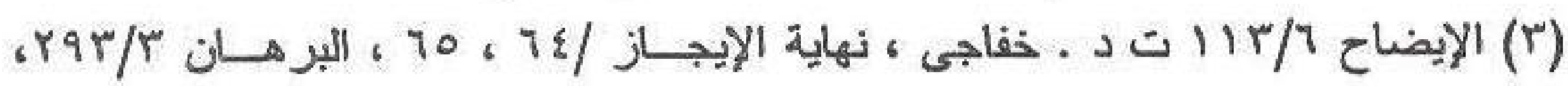

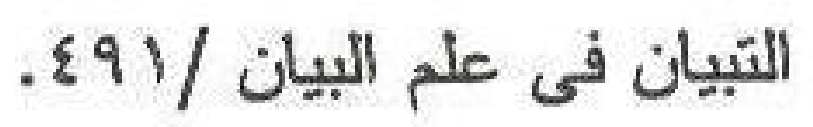


ومنهم من جعلها من قبيل المقلوب المستوى وما لا يستحيل بالانعكاس • وهو

" أن تقرأ الكلمة من آخرها إلى أولها كما تقرأ من أولها إلى آخرها (') . وقد دندن الفخر - رحمه الله - حول هذه الآية : فكان من ذلك قوله :

" واعلم أنه ما أمرك بهذا الإنذار إلا لحكمة بالغة ، ومهمات عظبيمة لا بيجوز

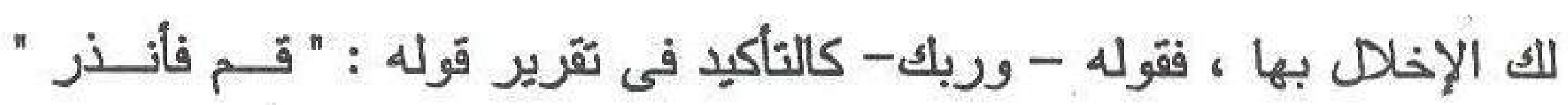
وعندى وجه آخر - هنا - وهو أنه لما أمره بالإنذار فكأن سائلاً سأل وقال : بماذا ينذر ؟ فقال : أن يكبّر ربَّه عن الشركاء والأضداد والأنداد ومشــابهة

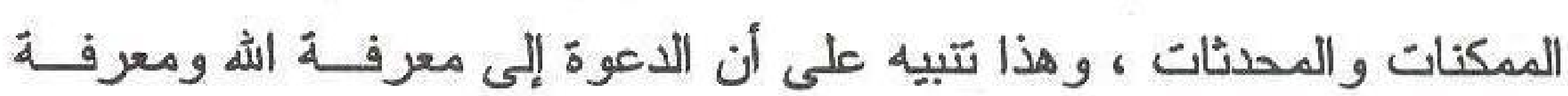

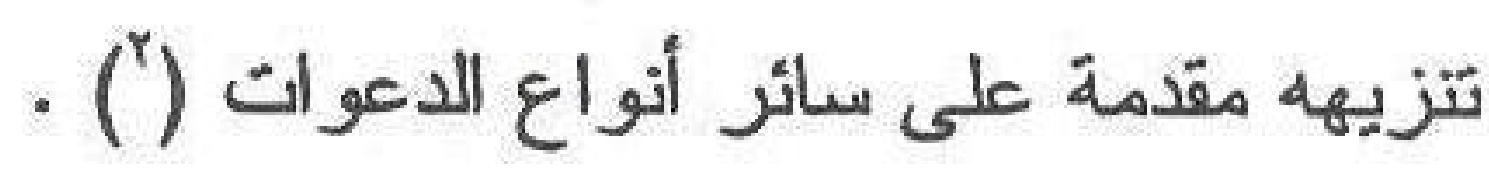

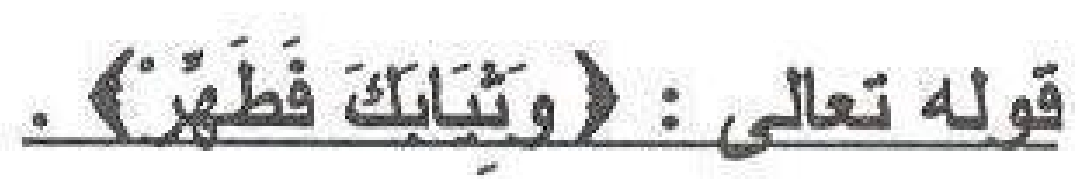

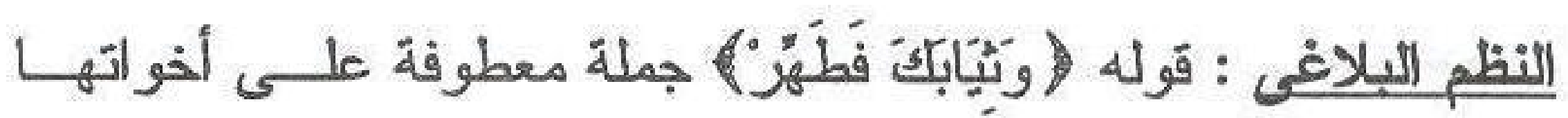
موصولة بها لا تفاقها جميعاً فى الإنشائية إذ هى من أساليب الأمر التى أهر

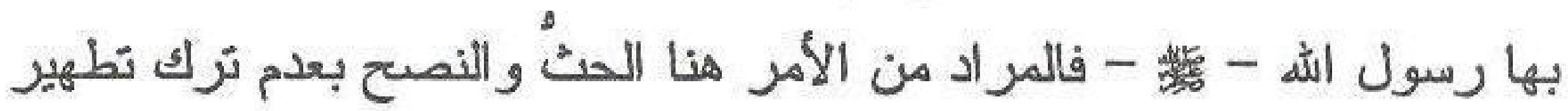

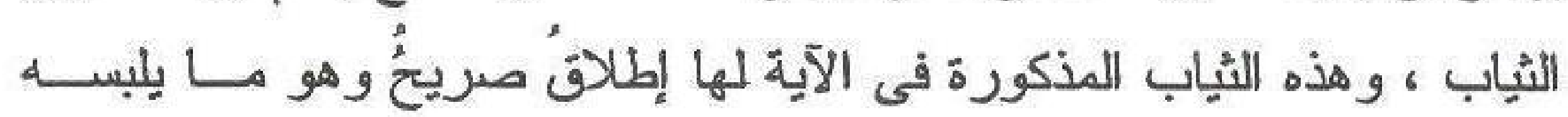

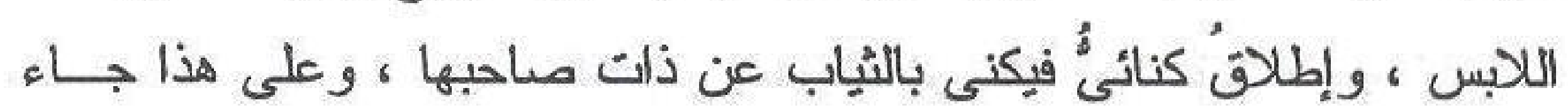
قول عنترة بن شداد العبسى : () وائي

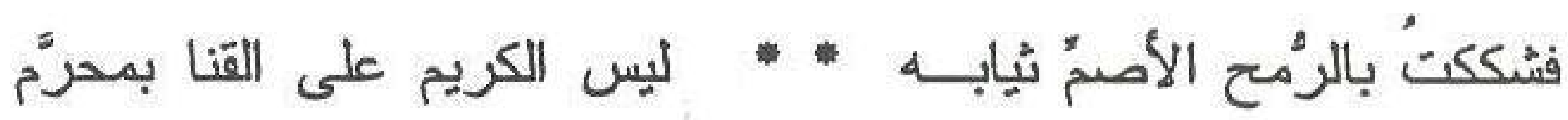


فالمر اد من البيت الكناية عن طعنه بالزمحح ، وقيل : هو مسن قبيـلـ المجاز المرسل لعلاقة المجاورة التى هى تسمية الشئ باسم مجـاوره ، لأن

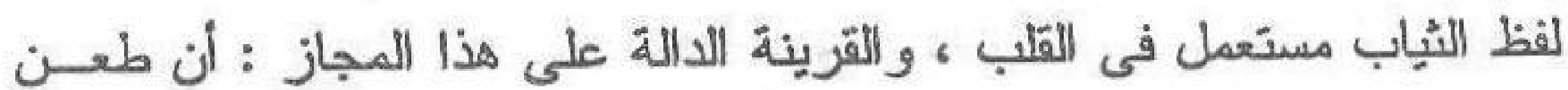

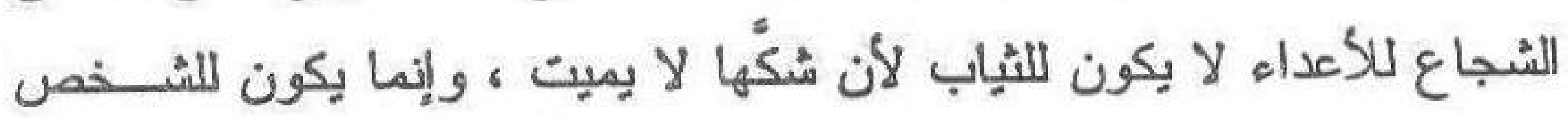

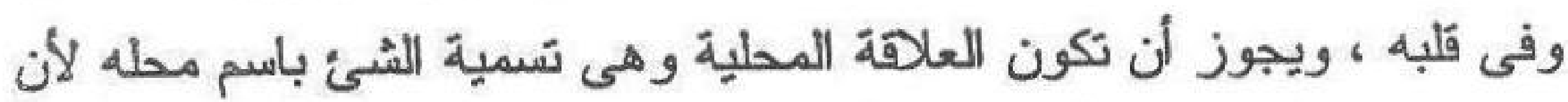

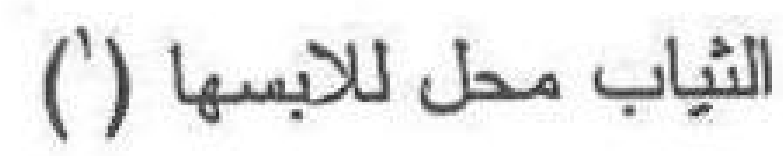

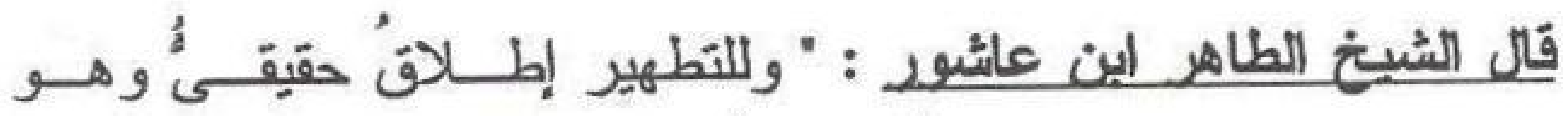

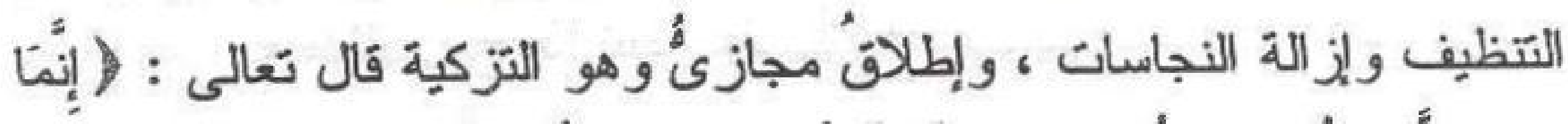

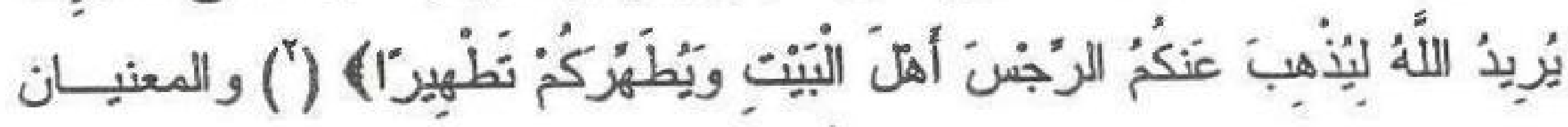

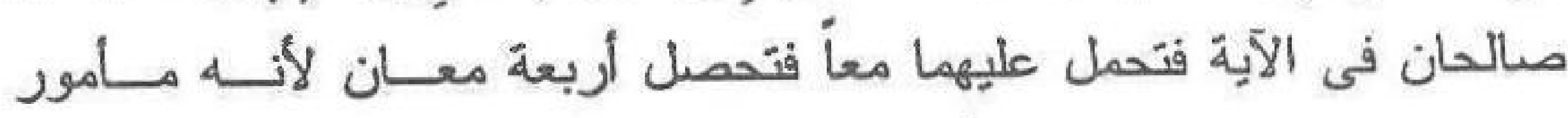

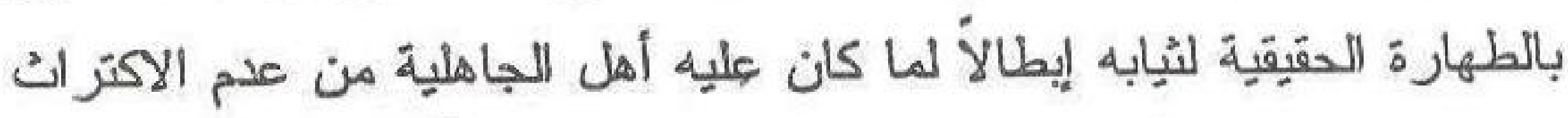

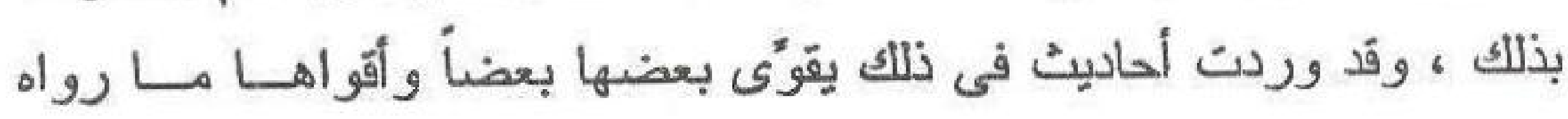

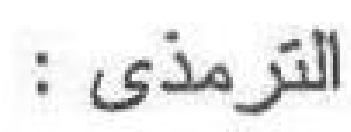

" إن "اله نظيف يحبُ النظافة "وقال : هو غريسب (") ، والطهـارة

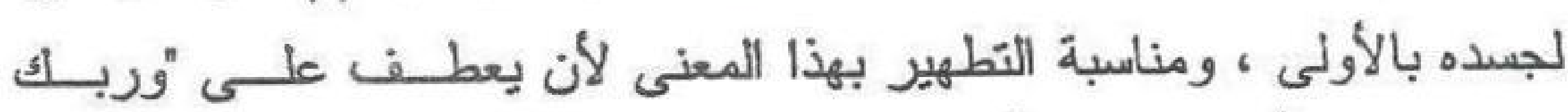

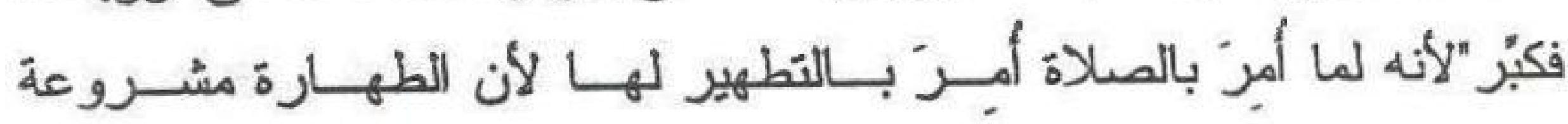

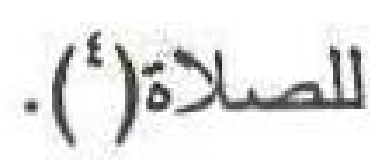

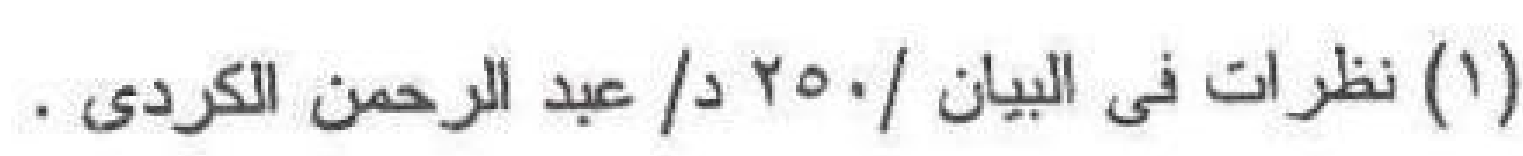

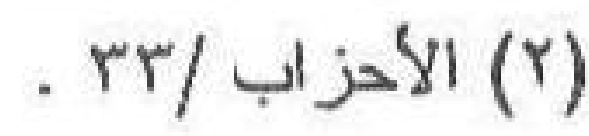

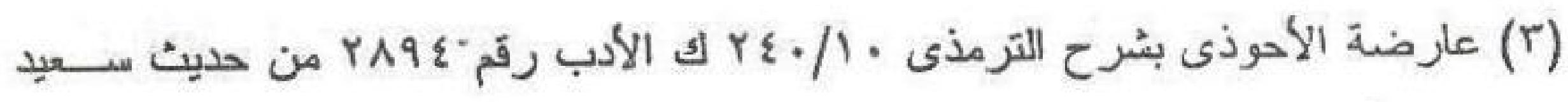

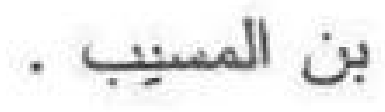


يُم يقول - رحهه الله - : "وليس فى القرآن ذكر طهارة الثُوب إلا فى هذه الآية فى أحد محاملها وهو مأمور بتزكية نفسه ، و المعنى المركَّب مسن

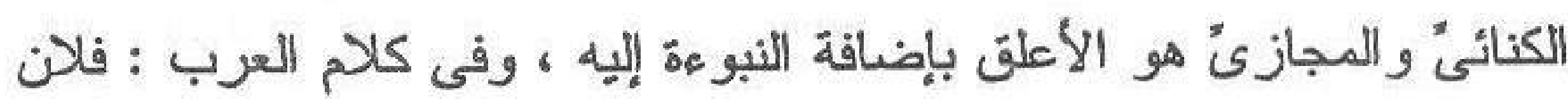

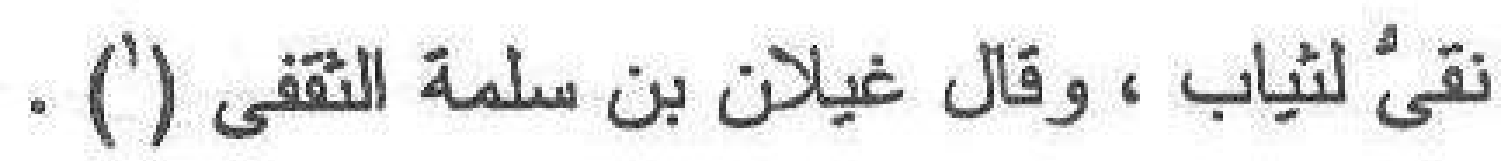

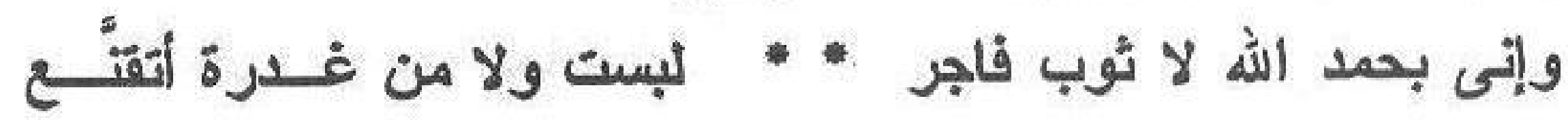
وأنشدوا قول أبى كبشة ، وينسب إلى امرى القيس (r)

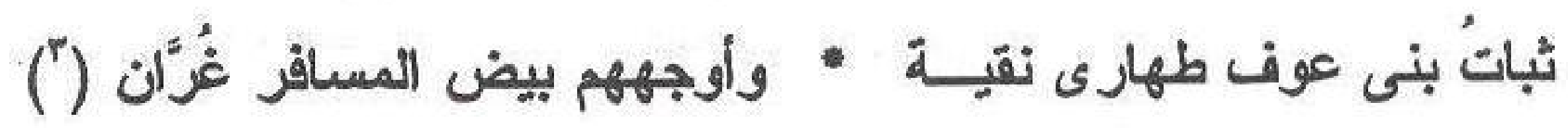

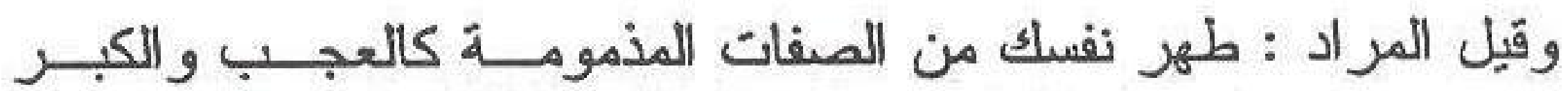
و الرياء ونحو ذلك ، مأخوذ من قولهم فلان طلهر الثياب والــذيل إذا أرادوا وصفه بالنقاء من أدناس الأخلاق ، وقيل المراد بالثياب الأهل . أى طهرهم

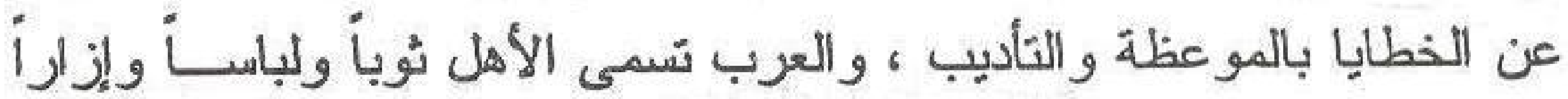

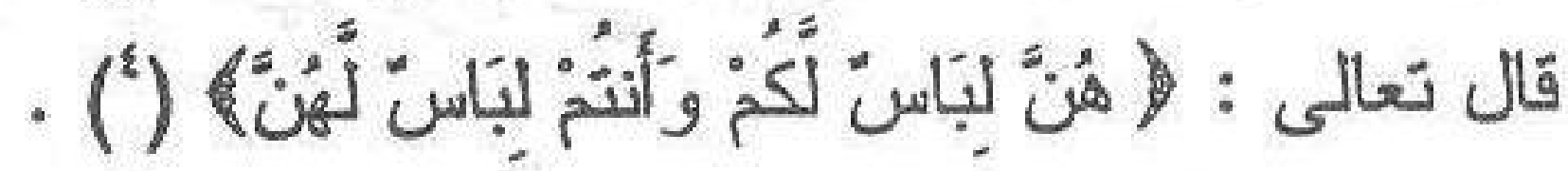

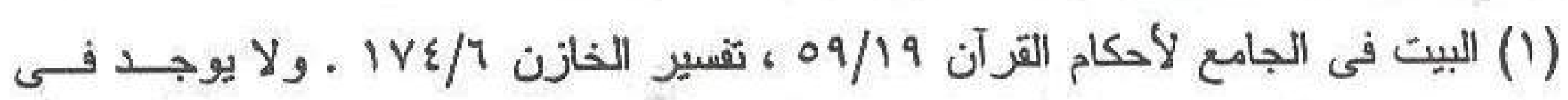
الحماسة ولا فى ديوان الهذليين .

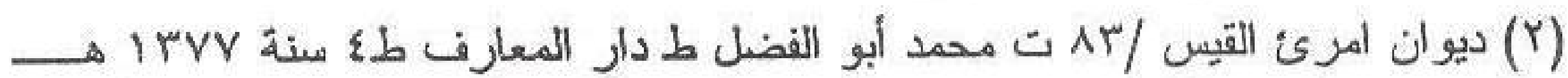
- م) 901 rqv/rq التحريز و التتويز (r)

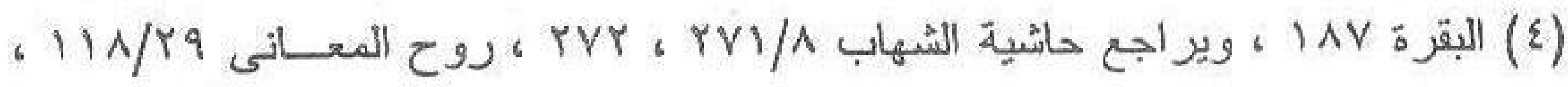

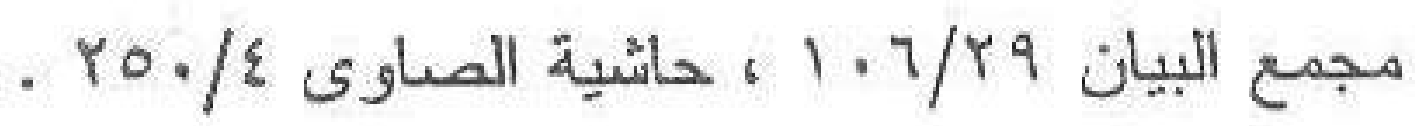




\section{3ى رهابع الابيان القرآتى}

وفى لنسان العبر : يقال : فلان طاهز الثياب إذا وصـفوه بطهـارة النفس و البر اءة من العيب ، وفالن نس الثياب إذا كان خبيث الفعل و المذهب

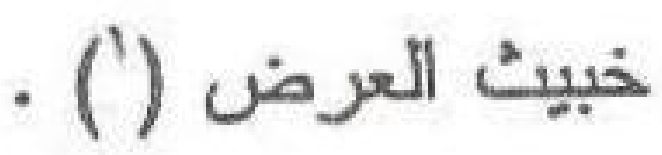

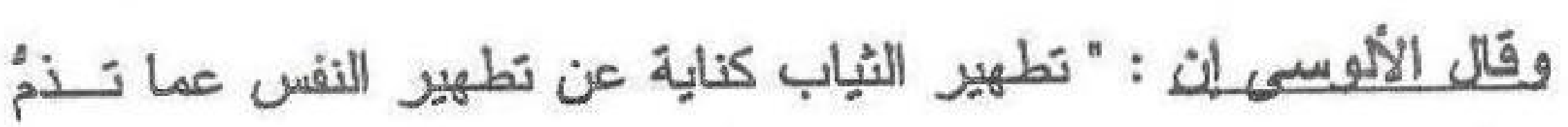

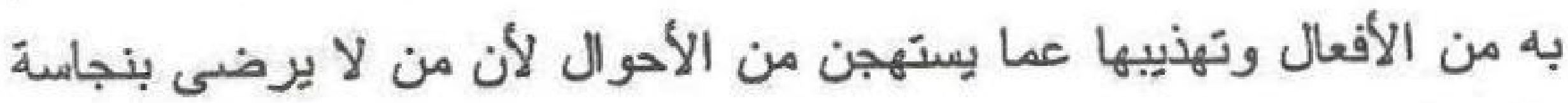

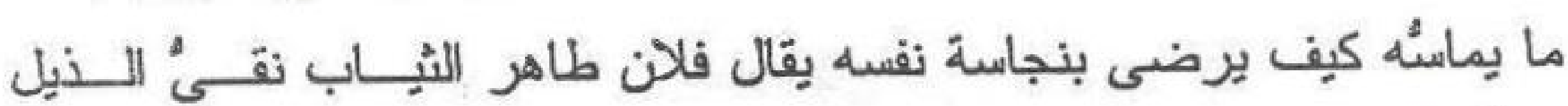
والأردان إذا وصف بالثقاء من المعايب ومدانس الأخلاق .

ويقال فلان دنس الثياب وكذا سم الثياب للغادر ولمن قبح فعله (")

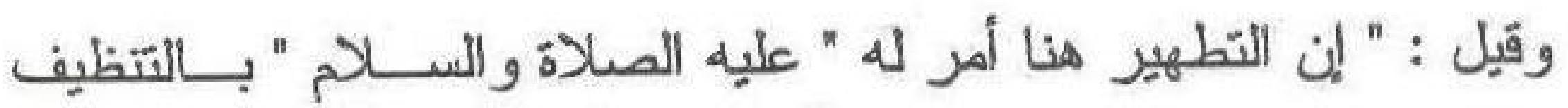

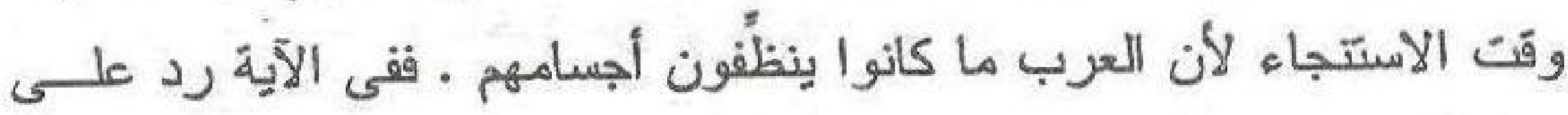

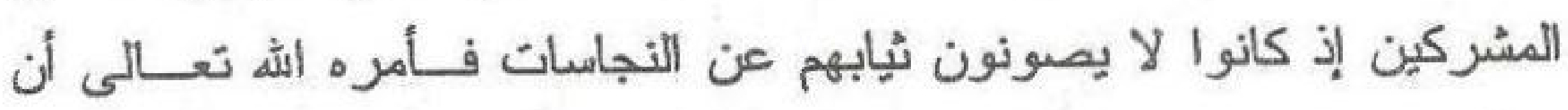
يخالفهم فى ذلك ، بل كان كثير منهم يبول على عقدئ. ومن العلماء من يرى أن الستعمال التطهير هنا مراد به ثقصير الثياب

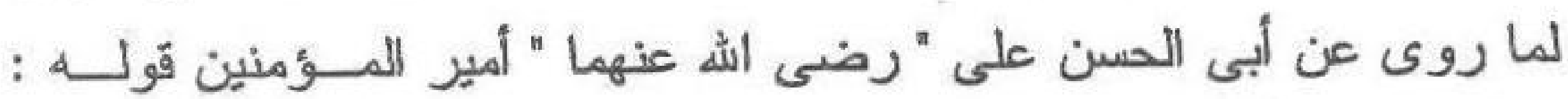

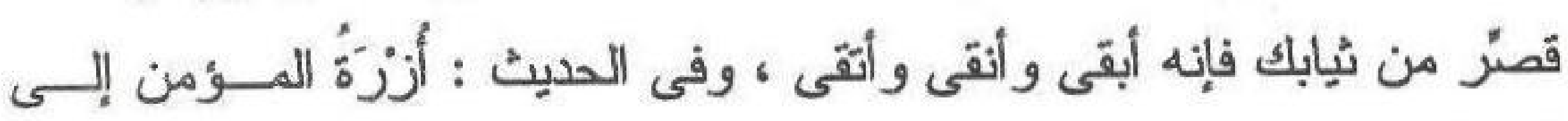

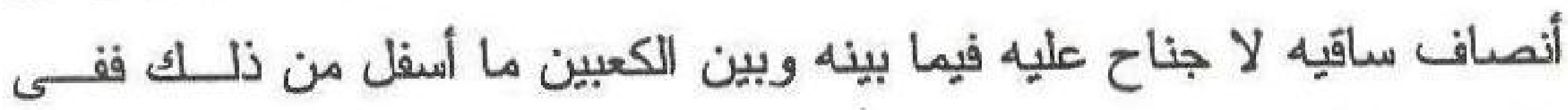

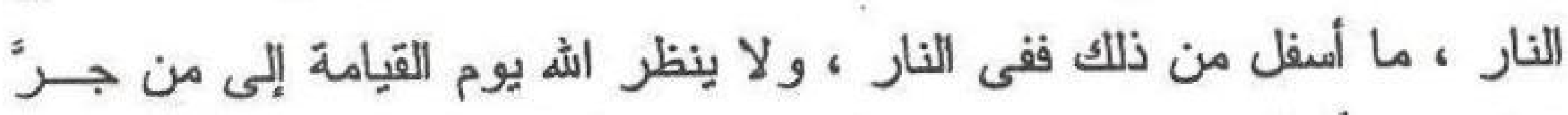

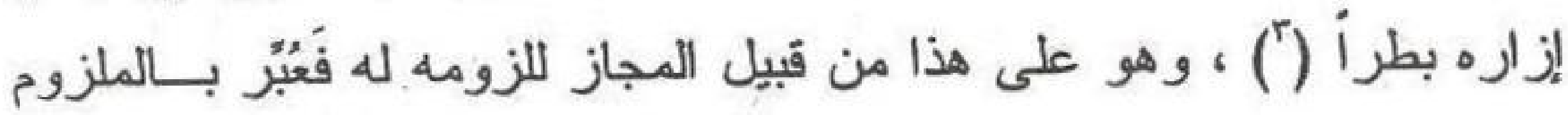

$$
\begin{aligned}
& \text { (1) اللسان مادة ثوب . }
\end{aligned}
$$

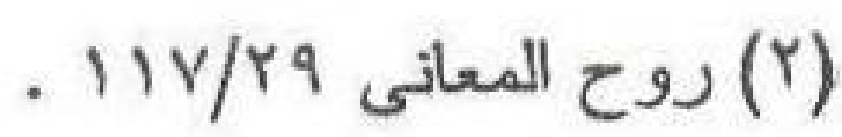

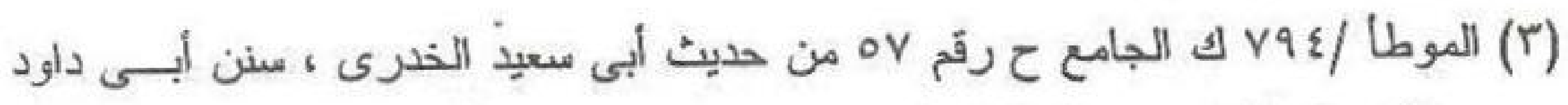

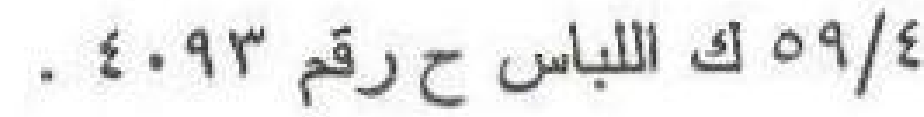




\section{جلح (لكلغة لالعربي2}

عن اللززم إذ تقصير الثياب مطلوب لأنه كثير أ ما يُفض تطويلها إلـى جـر" ذيولها على القاذورات ، ومن العلماء من يرى جواز الجمع بــين الحقيقــة والمجاز حبث حمل التطهير على حقيقته ومجازه أعنى التقصير ، ومنهم من ئن

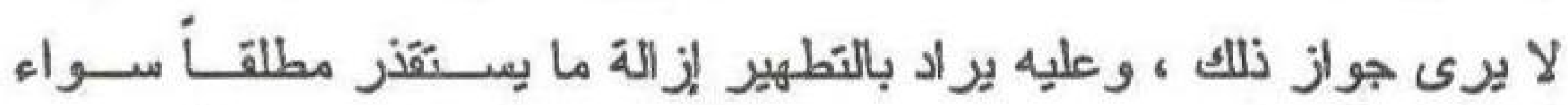

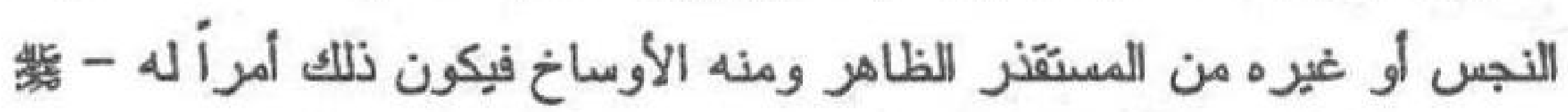
- بتتظيف ثيابه و إزالة ما يكون فيها من وستخ وغيره من كل يسنقذر فإنــهـ منفر لا يليق بمقام البعثة ، ويسيلزم هذا بالأولى تنظيف البدن من ذلك ، ولذا

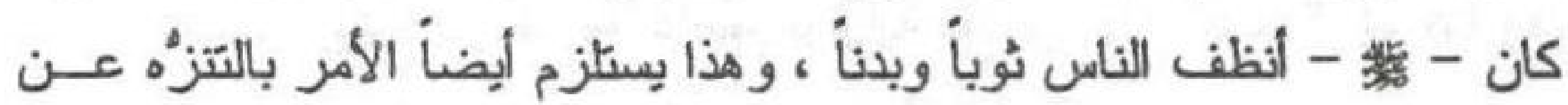

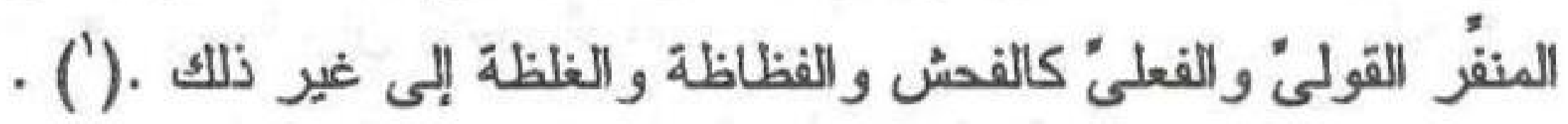

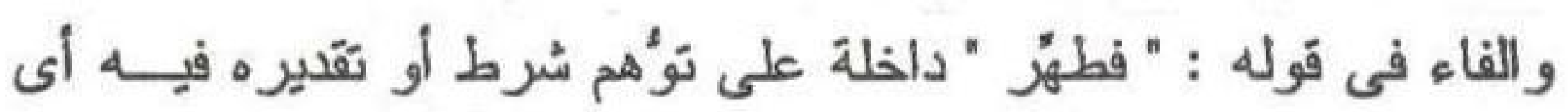

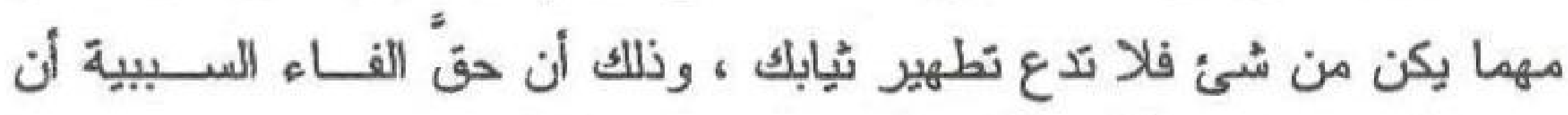
يكون ما بعدها مسبياً لازماً قبلها فلما لم يذكر قبلها شئ يترنب علئ عليه ما بعدها

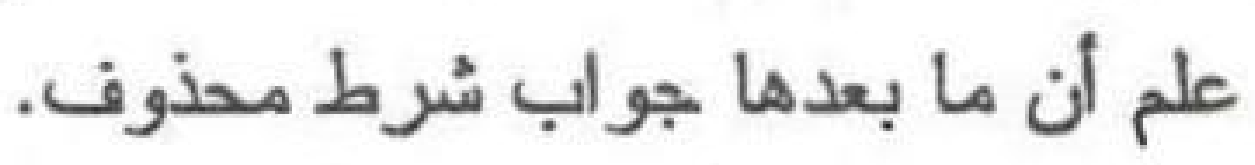
وأن المعنى : وما يكن فطهر ثيابك أى أى شئ يكن فلا تذع تطهيــر ثيابك و هذا آكد فى إفادة الاختصاص بالنسبة إلى مجرد تقديم المفعــول مــن

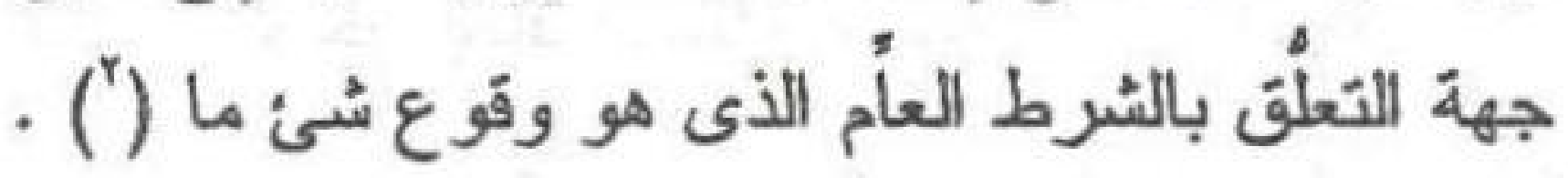

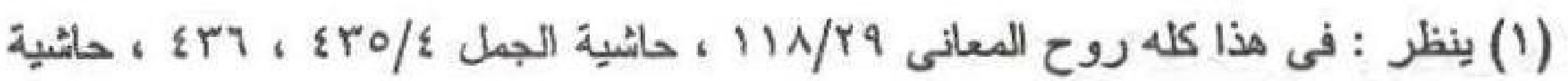

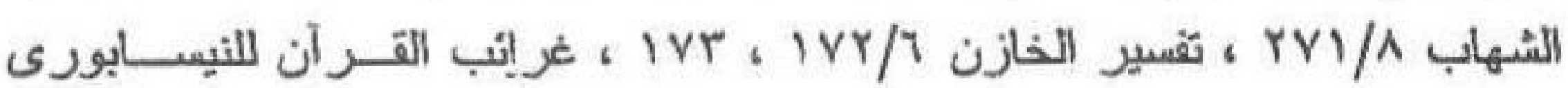

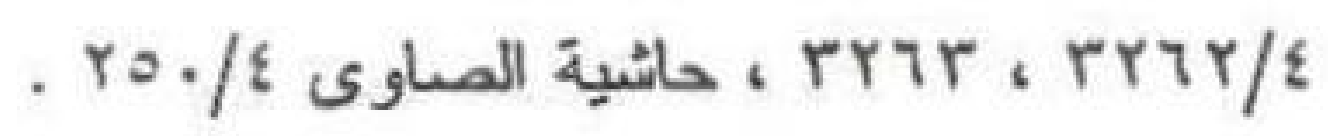

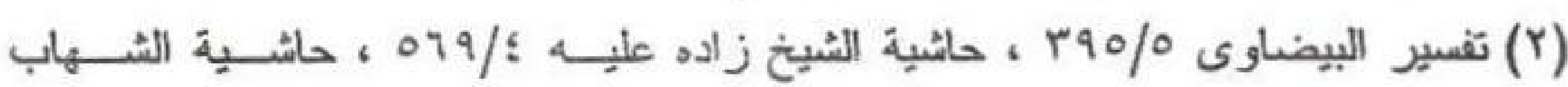

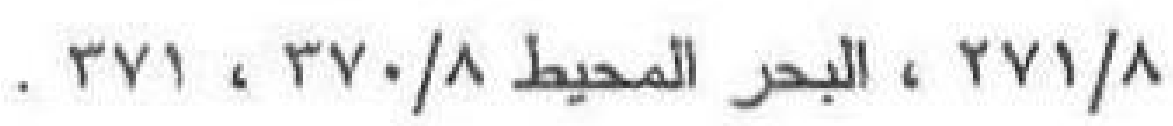




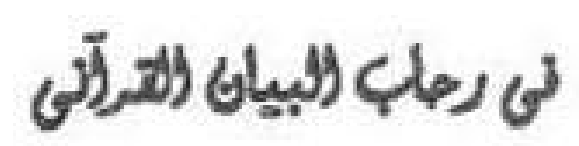

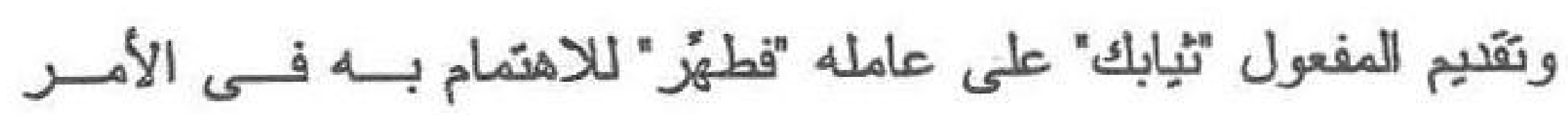

بالنطهير ، وللعناية به لمناسبته لمقام النبوة .

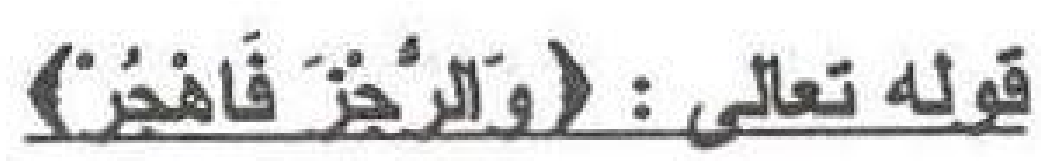

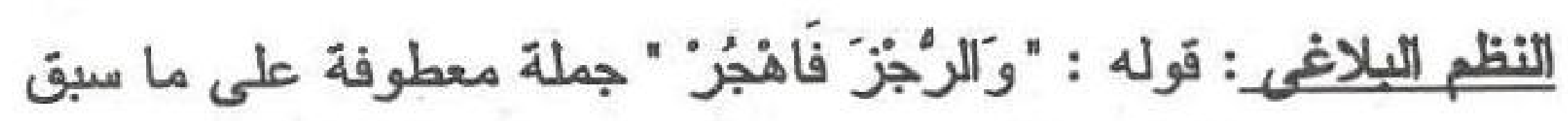

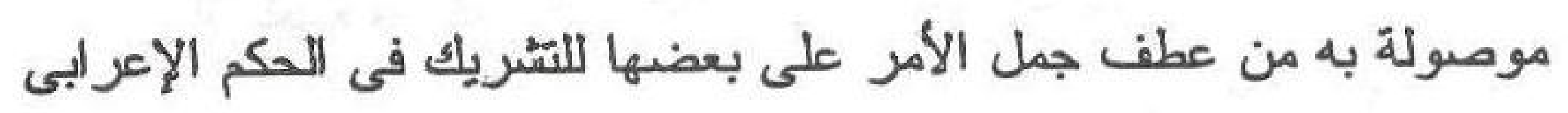
ول ولآتفاق فى الخبر والإنشاء.

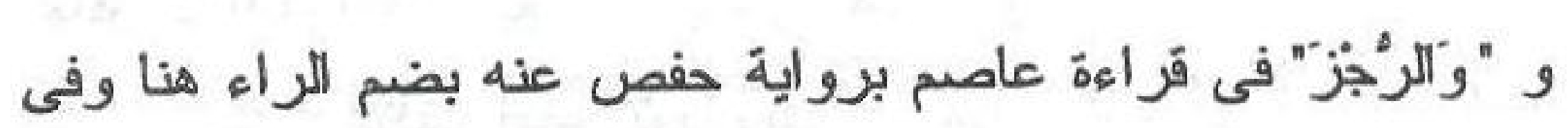

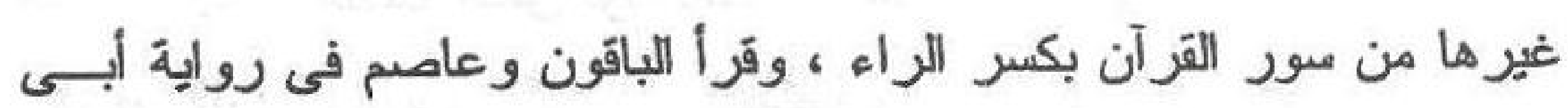

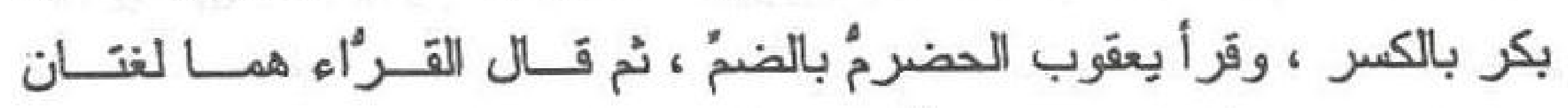

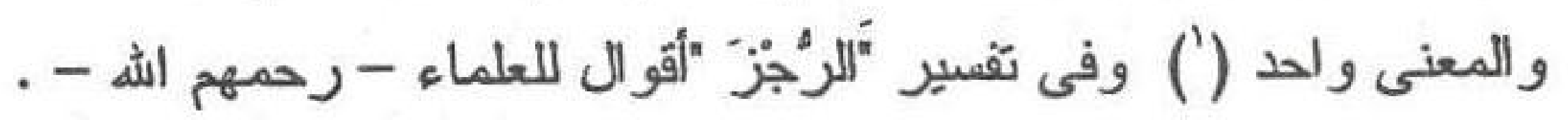

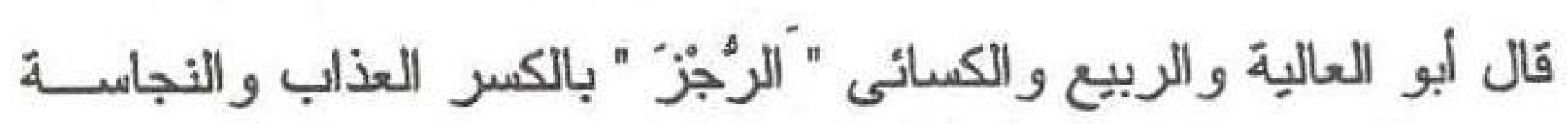

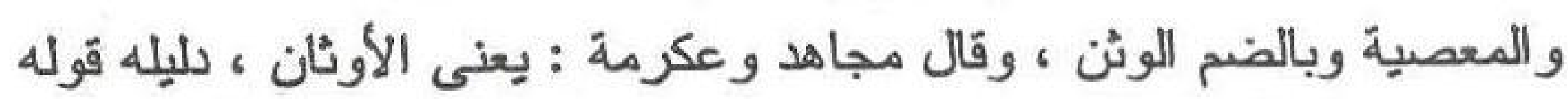

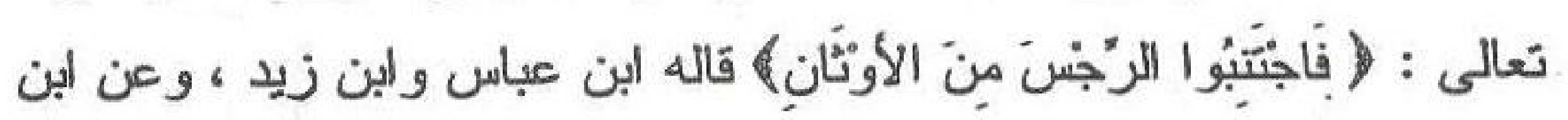

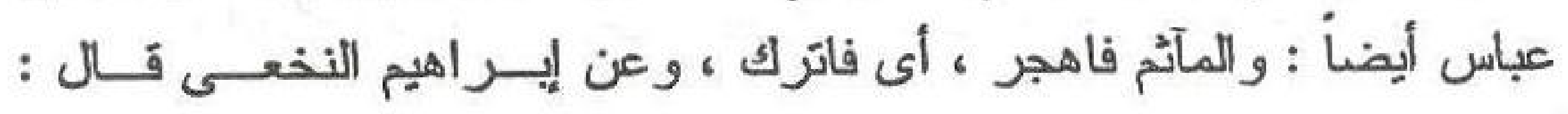

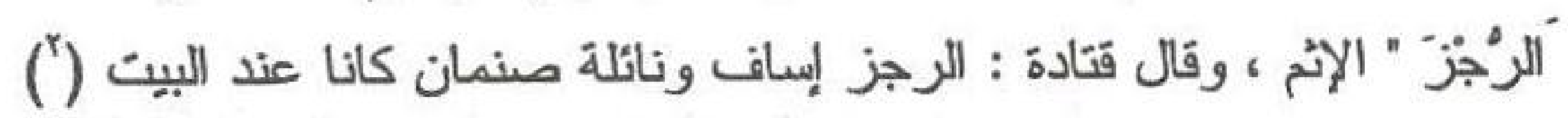

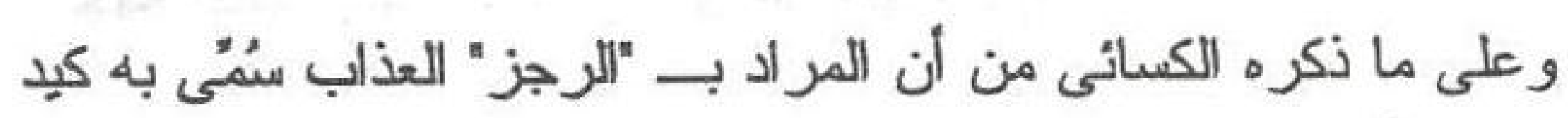

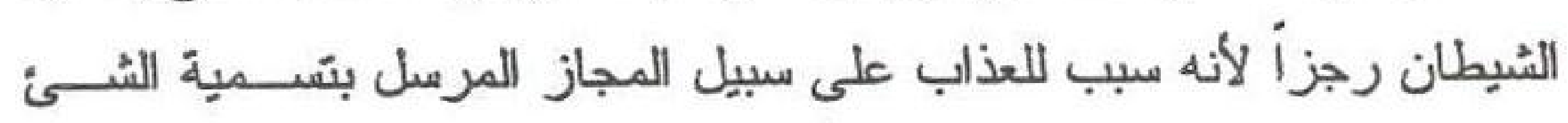

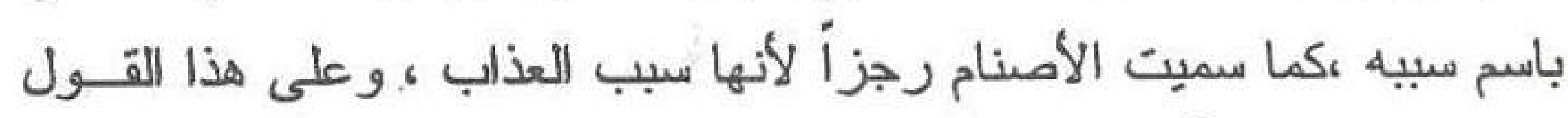

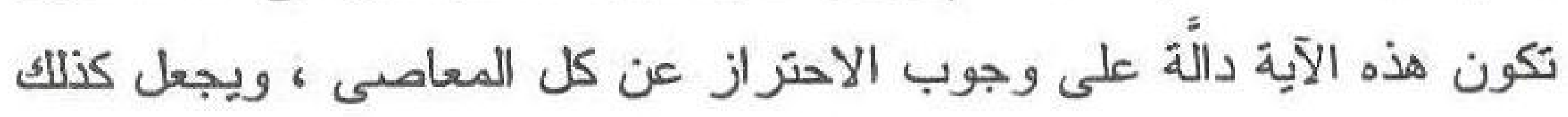

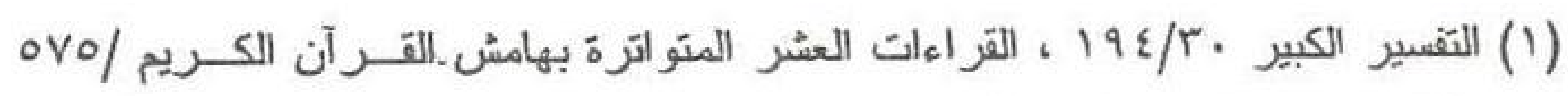

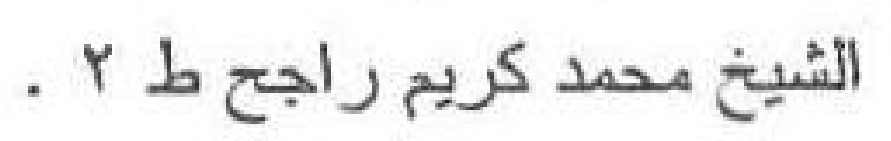

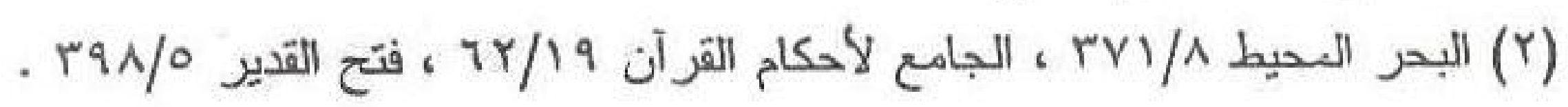


"الرجز" على ما يشمل الأوثان وغيرها من أكل المينـــة والـــدم ، إذ أصـلـ العذاب الاضطر اب فى الأعمال و المعتقدات ، ومن هنا أقيم سبيه المؤدى إلِيه من المآثم فكأنه قيل أهجر المآثم والمعاصى المؤدية إلـى العــذاب ، أو أن الكلام هنا على حذف مضاف أى أسباب الرجز ، أو ذا الرجز فاهجر أى ذا العذاب ، أو أن الكلام من باب المجاز المرسل لعلاقة المجاوزة بأن سُمّى ما

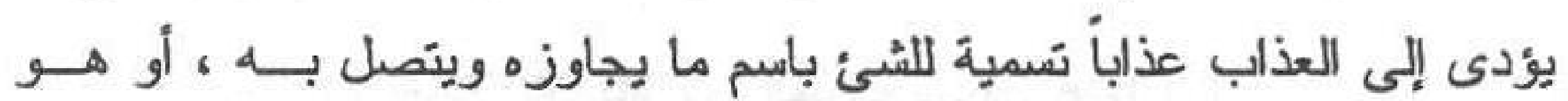

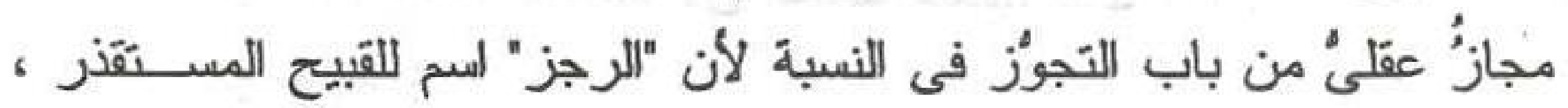
و هو معنى الرجس وهو سبب مؤد إلى العذاب ، فجاء قوله تعالى "و الرجـز فاهجر" كلاما جامعاً فى مكارم الأخلاق كأنه قيل له اهجر الجفاء و السفه وكل (') شئ قبيح ، و لا تتخلت بأخلاق هؤلاء المشركين المستعملين للرجزئ وتقديم المفعول "الرجز" على عاملة "اهجر" للاهنمام فى مهيع الأمــر بتركه ، ودخول الفاء على الفعل "قاهجر" لتوهم شرط مقدر أى مهما يكن من اهن

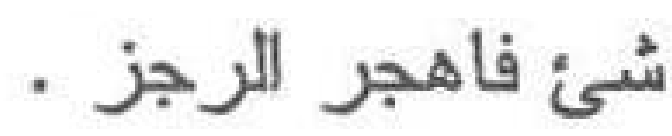
و الهجر المأمور به هنا مراد به " ترك المخالطة وعدم الاقتراب مـن الشئ وجاء الهجر كناية - هنا - عن ترك التلبس بالأحو ال الخاصة بـأنواع الرجز لكل نوع بما يناسبه فى عرف الناس() و الأمر بهجر الرجز يســلتزم أن لا يعبد الأصنام وأن ينفى عنها الإلهية.

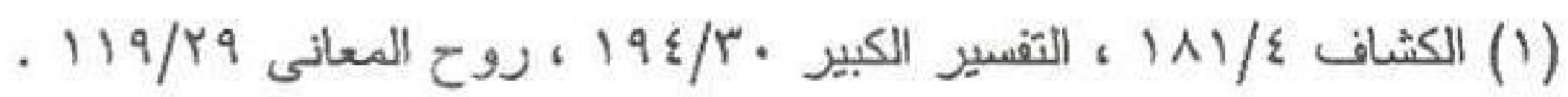

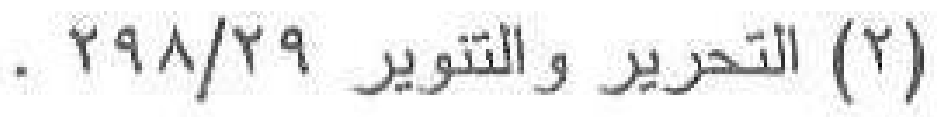




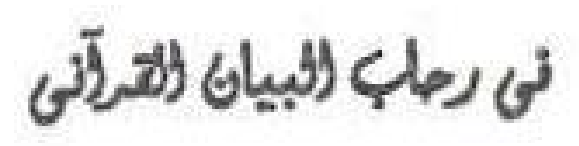

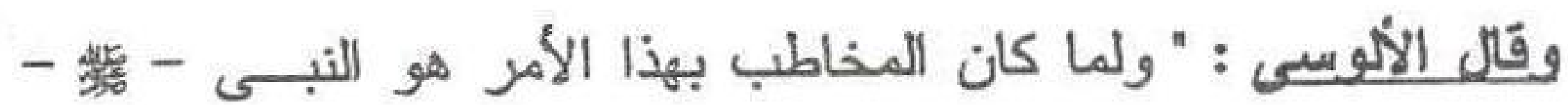

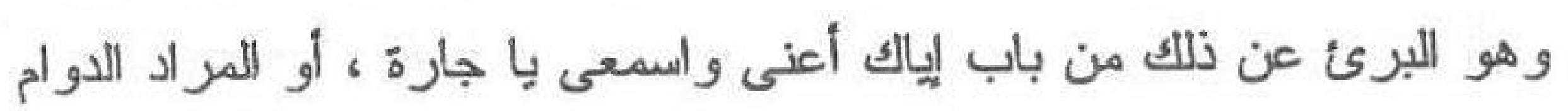

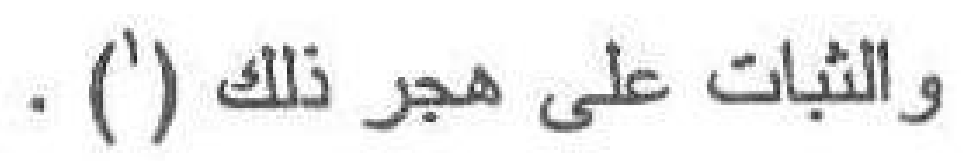

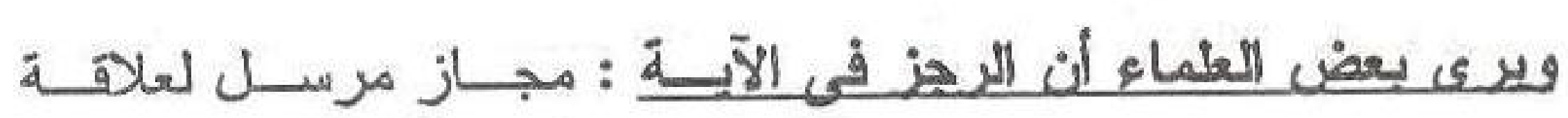

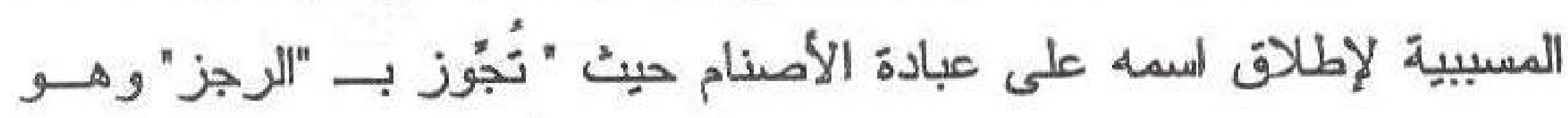

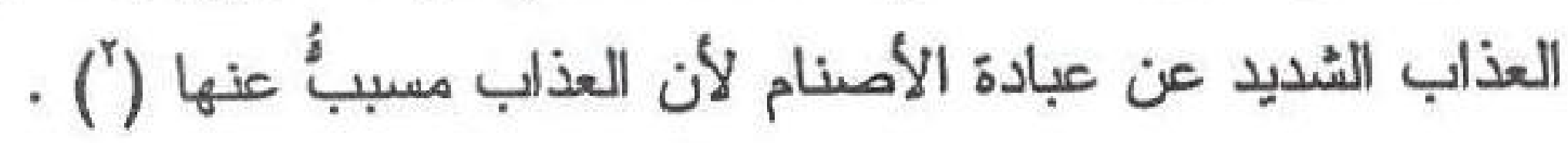
وخلاصة القول: في هجر "الرجز" أن المر اد منه الثبات على هجـــره لأنه - كائ - كان بريئاً منه.

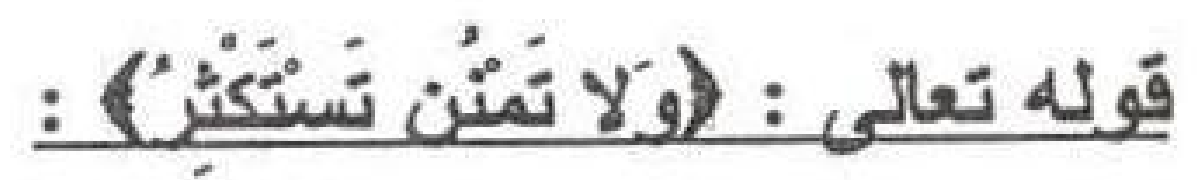

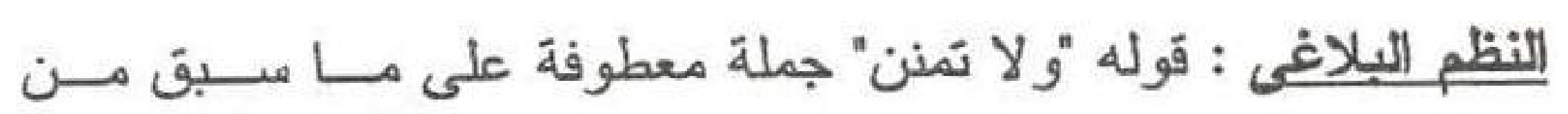

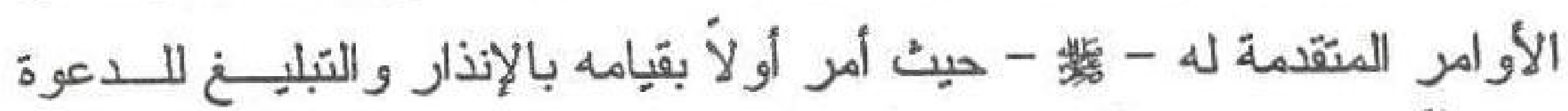

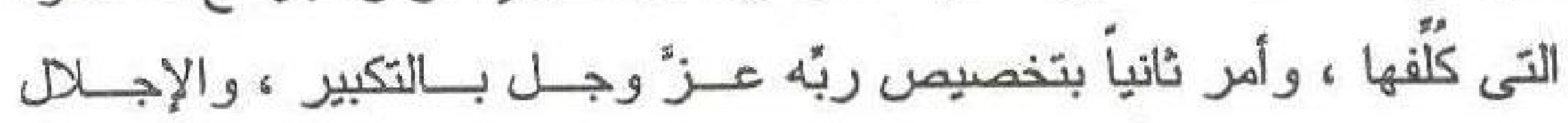

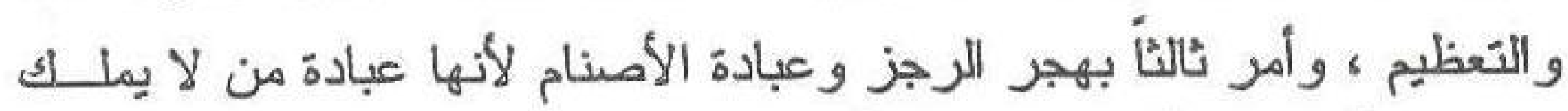

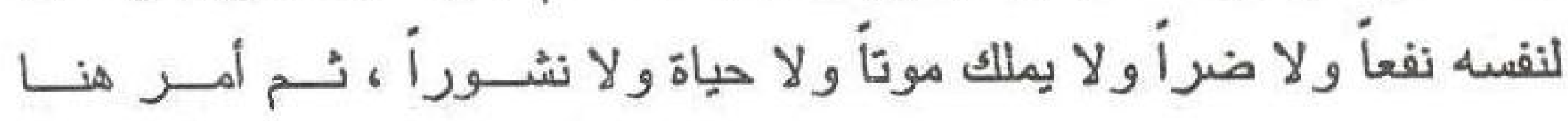

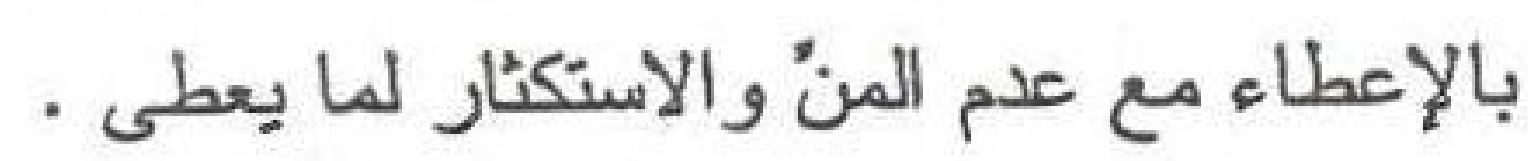

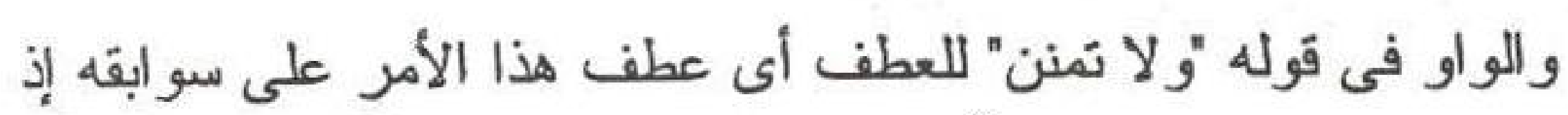

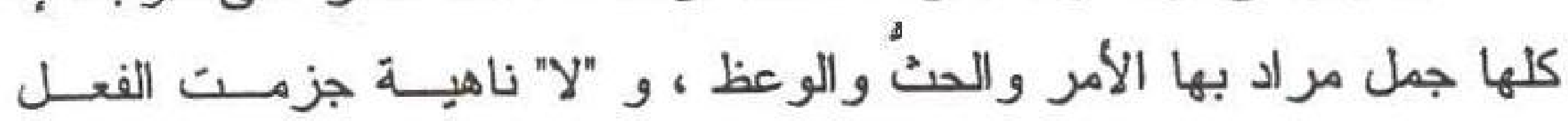

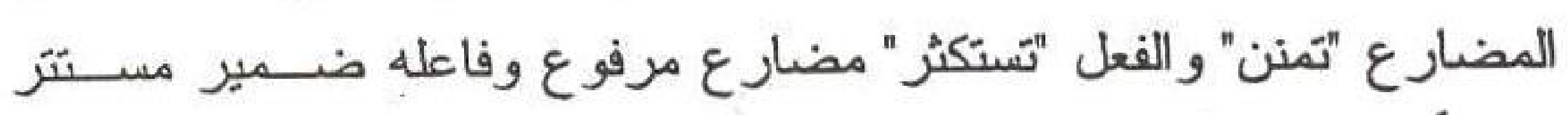

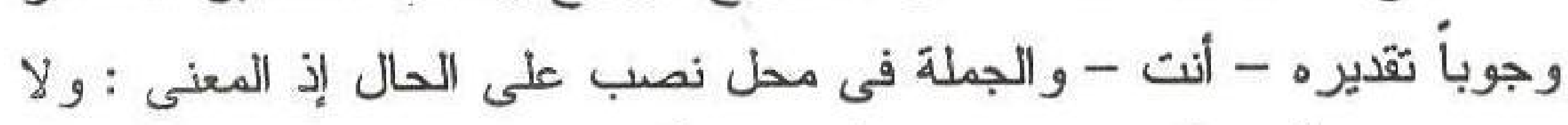

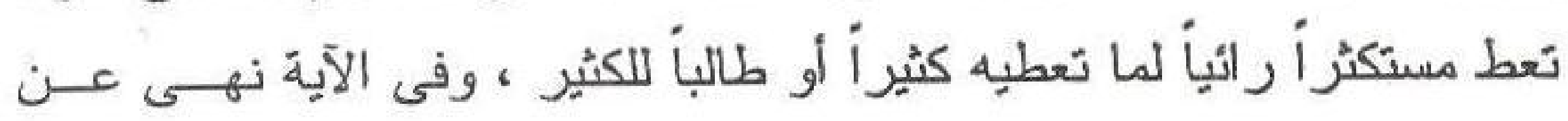


الاستخزار والمر اد به : أن يهب شيئاً وهو يطمع أن بيتعوّض من الموهوب له أكثر من الموهوب وهذا جائز .

قَال العلأمة اللزمشُرى : " فيه - أى فى النهى - وجهان : أحدهما :

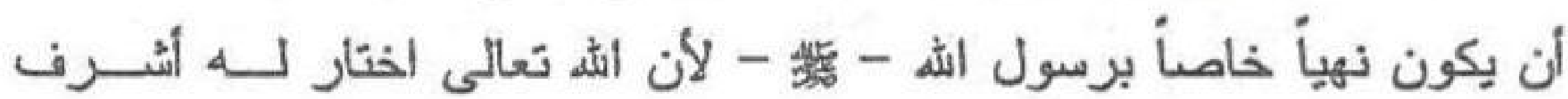

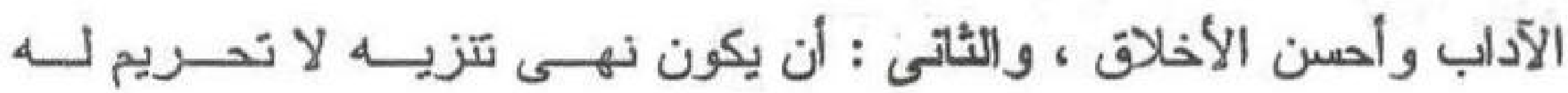
ولأمته|(') ، ولما كان الله تعالى قد اختار لرسول الله - مئد - أكمل الصفات، و أشرف الأخلاق فامتتع عليه أن بِهب لعوض أكثر ، و العين فــى الفعـل " تستكثر" للوجدان لا للطلب أى لوجود طلب الكثير من وراء العطية ، و النهى عن ذلك لأنه نوع إعجاب وفيه بخل خفى .

وقد تعددت كلمة العلماء - رحمهم الله تعالى - فعن الحسن و الربيع :

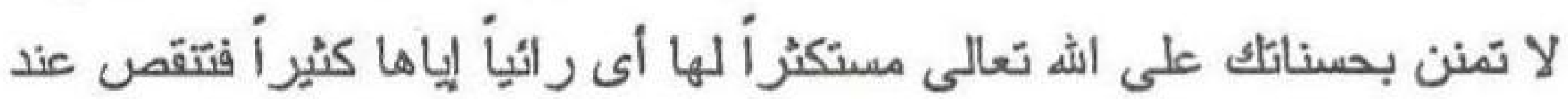
الله عز وجل ، وعن ابن زيد : لا تمنن بما أعطاك الله تعـالى مــن النبــوة

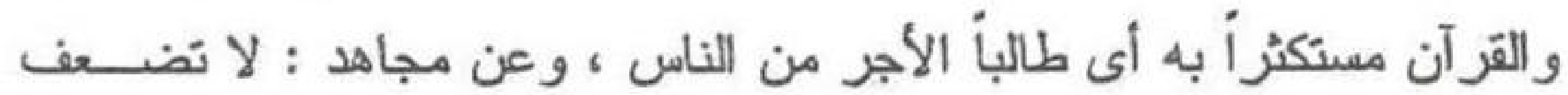

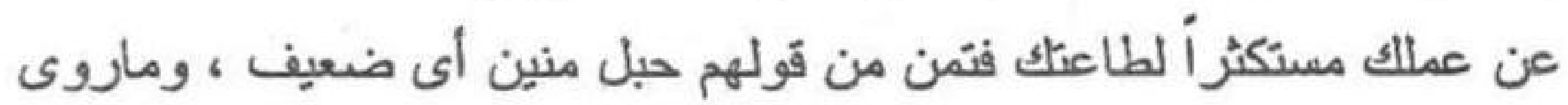
عن ابن عباس - رضى الله عنهما - أنه قال أى لا تقل قد دعونهم فلم يقبل

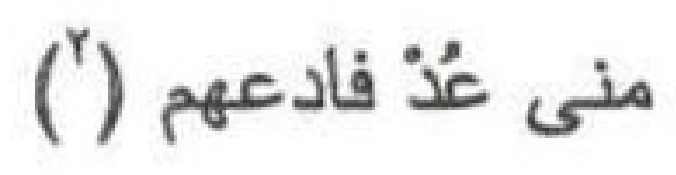

و المن المذكور فى الآية مر اد به العطــاء علـى ســبيل الاســتعارة

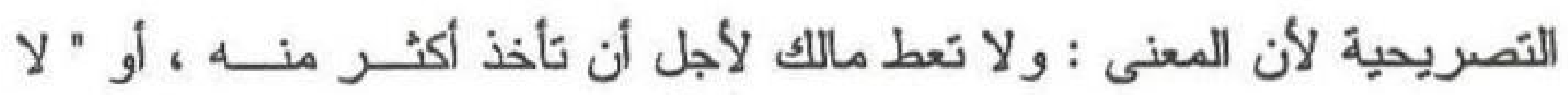
تعط الناس عطاء وتستكثر لأن الكريم يستقلُ ما بعطى وإن كان كثير أ " ( ("). 


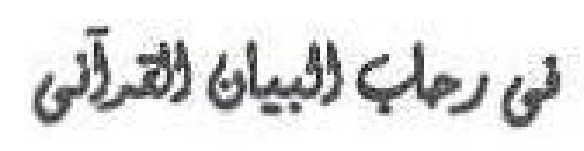

$[\varepsilon \curlyvee]$

وسر" النهى فى الآية أن يكون العطاء خالياً عن الثظظار العوض تعفةــأ

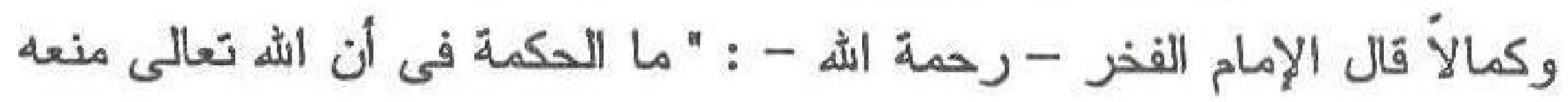

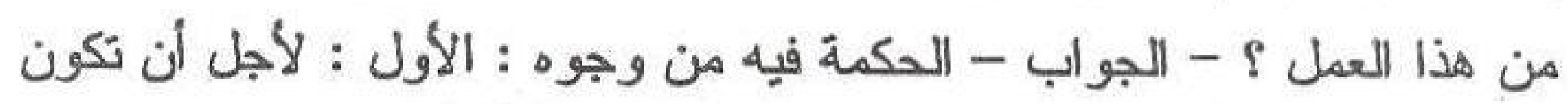
عطاياه لأجل اله لا لأجل طلب الدنيا ، فإنه نهى عن طلب الدنيا فى قولـهـ :

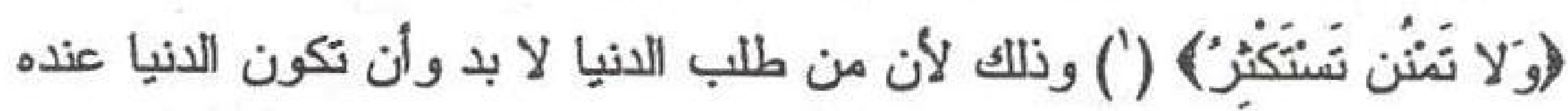

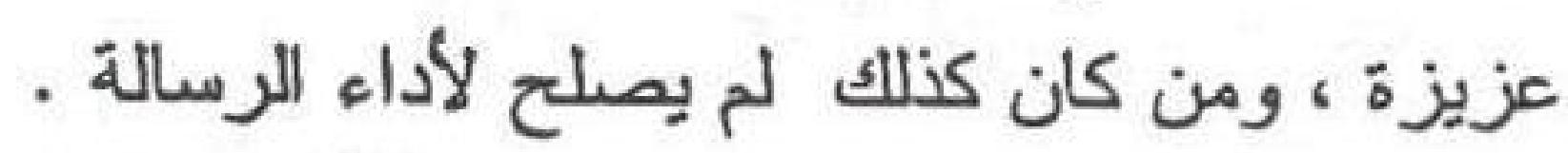

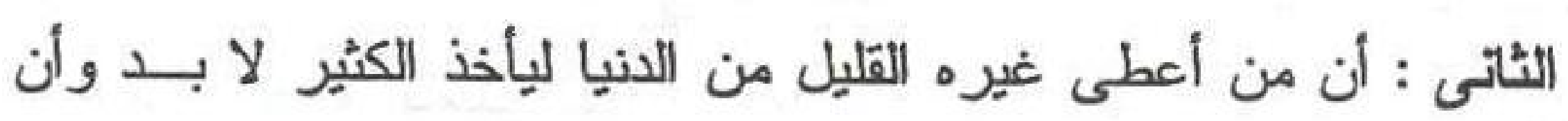

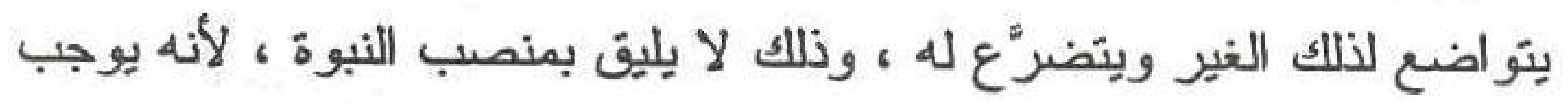

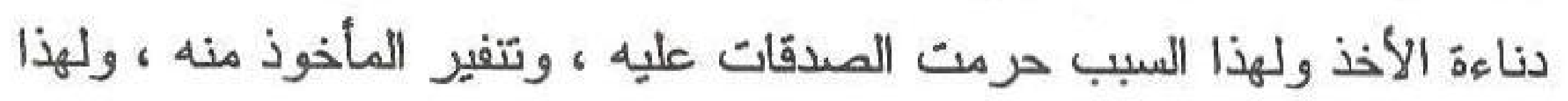

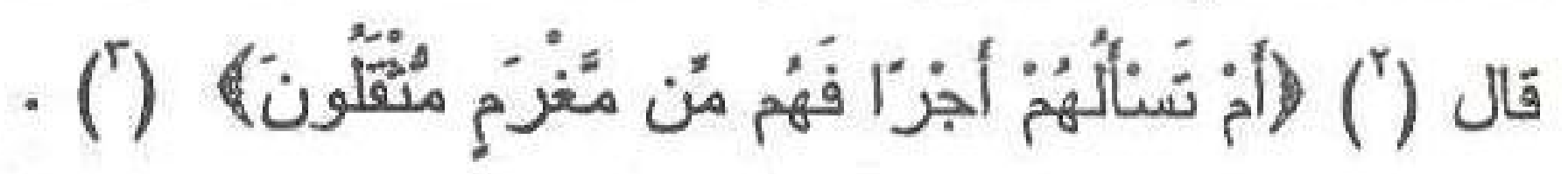

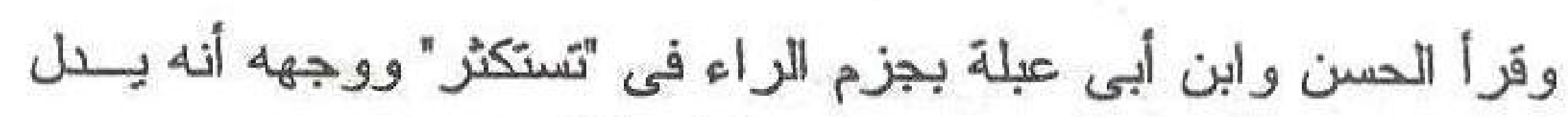

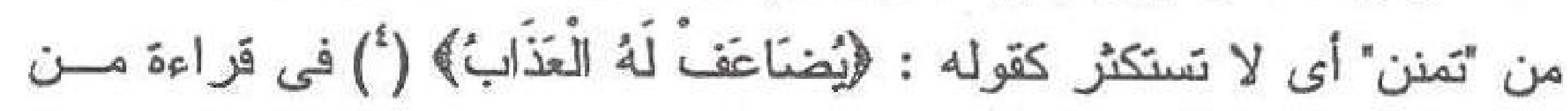

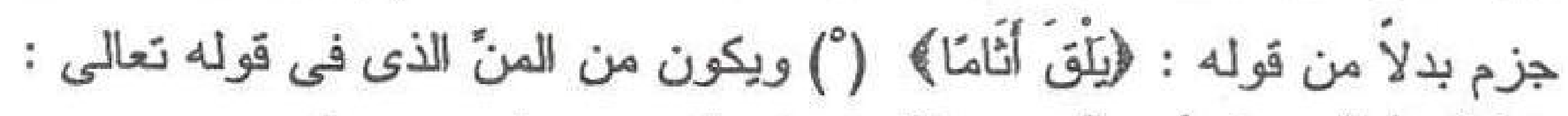

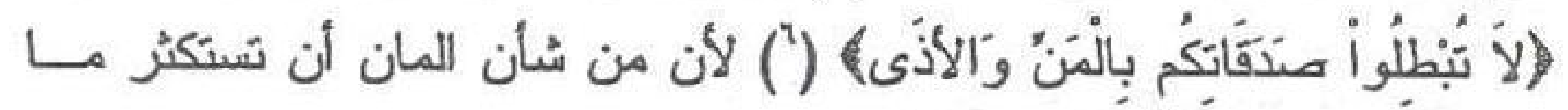

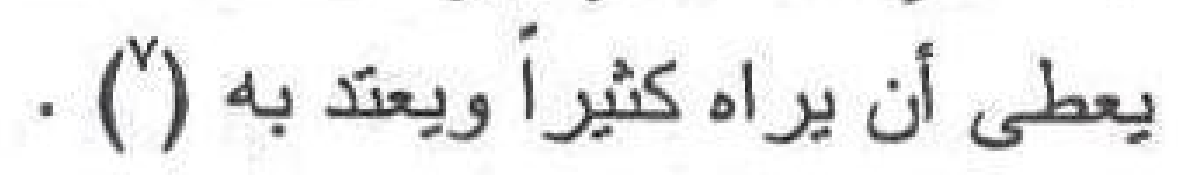

$$
\begin{aligned}
& \overline{.1 r y / \alpha(1)} \\
& \text {. }
\end{aligned}
$$

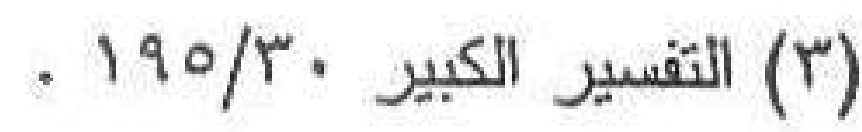

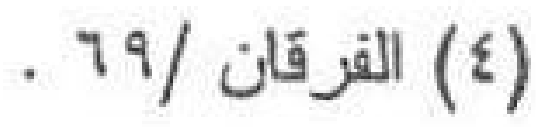

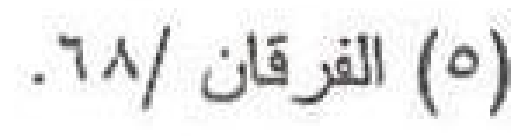

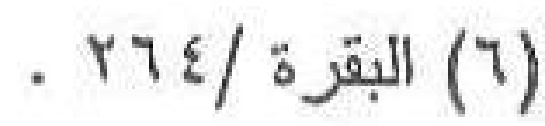

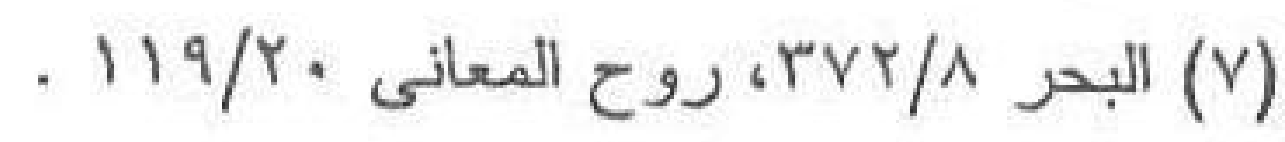




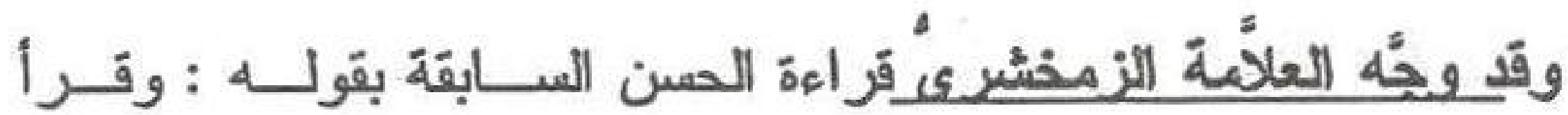

الحسن - تستكثر - بالسكون ، وفيه ثلاثة أوجه : الإبدال من "تــنـ" كأنــهـ

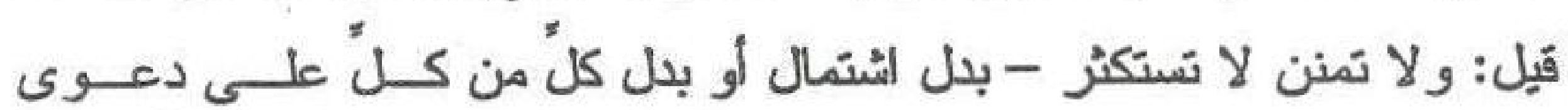

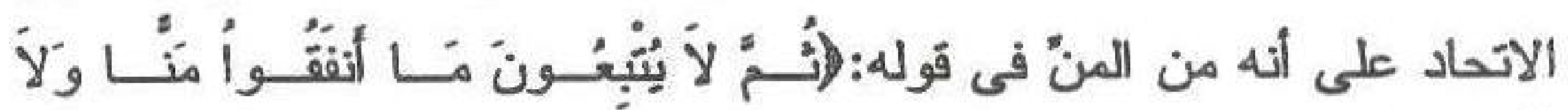

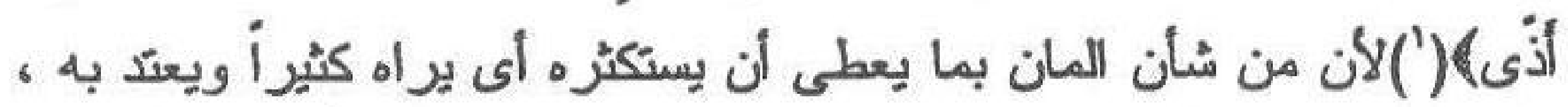

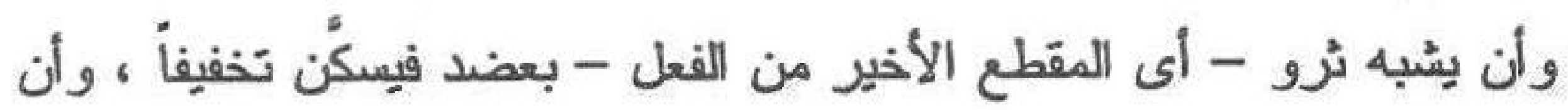

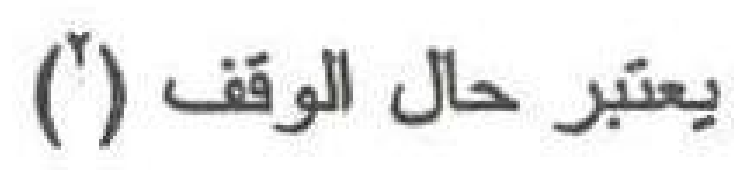

وقد اعترض الثبيخ أبو حيان على الوجهين الأخيرين مسن نوجيسـ

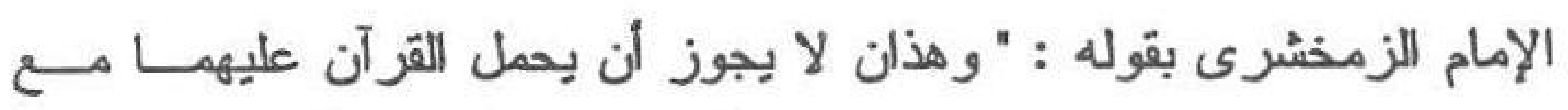

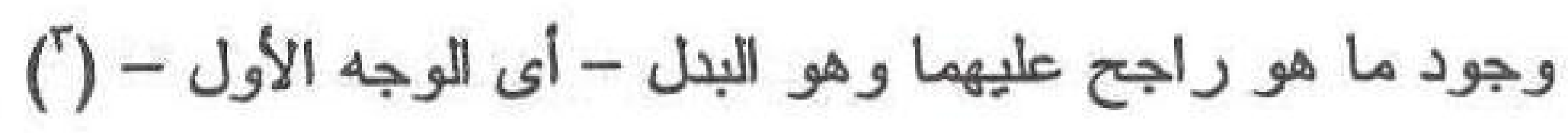

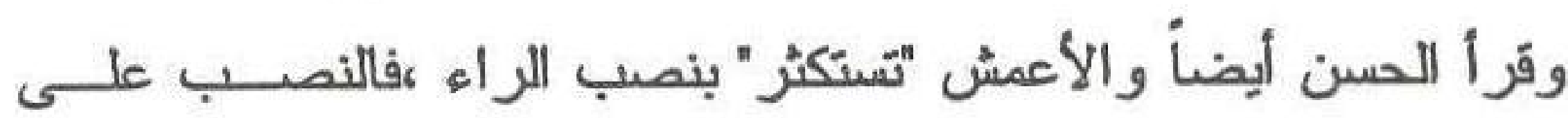

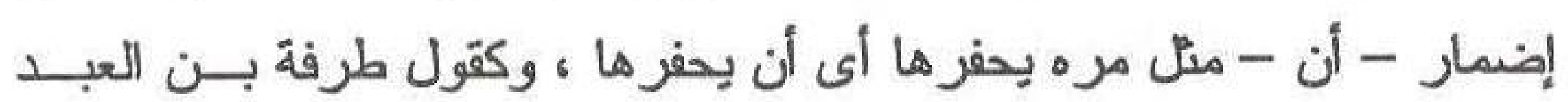

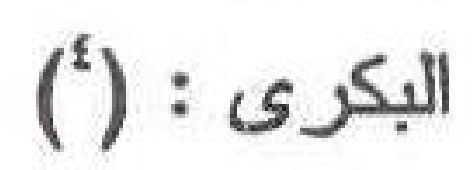

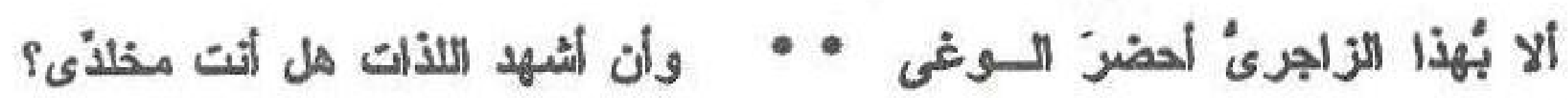
فى رواية من نصب "أحضر" أى : أن أحضر ، ويؤيد هـــه القـــراعة

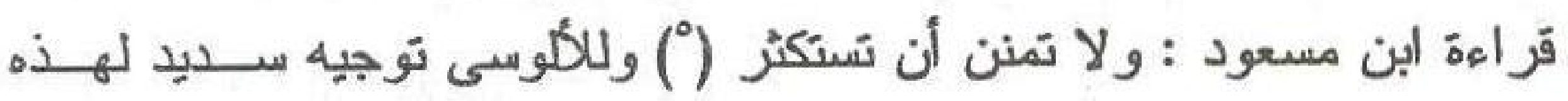
القر اعة فى قوله : " وقرأ ابن مسعود بإظهار - أن - فالمن بُ بمعنى الإعطــاء

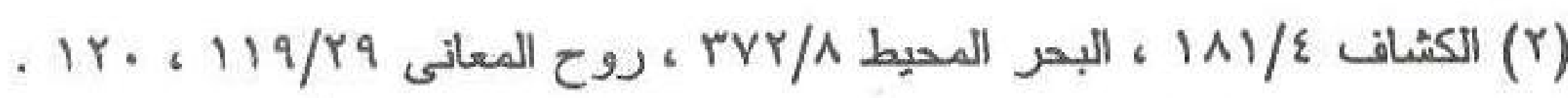

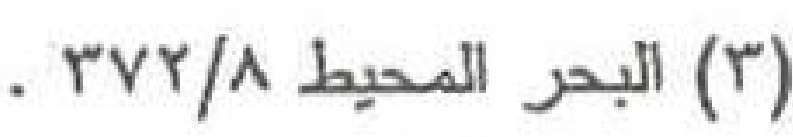

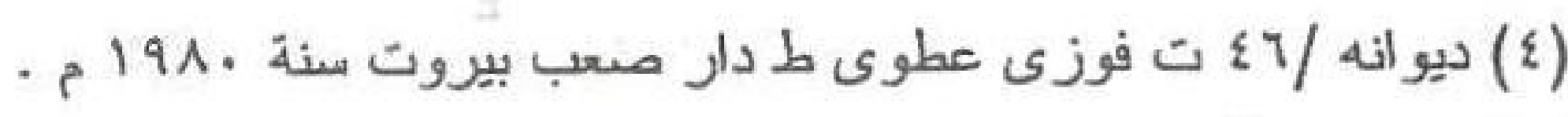

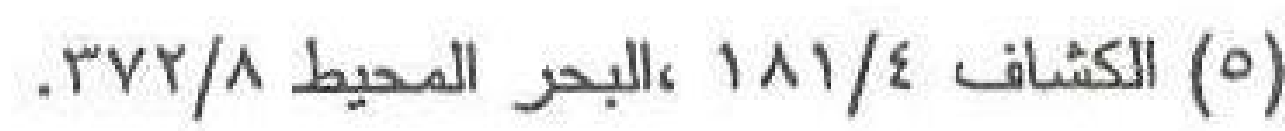


و الكلام على إرادة التعليل أى و لا تعط لأجل أن تستكثر أى تطلـب الكئـرز

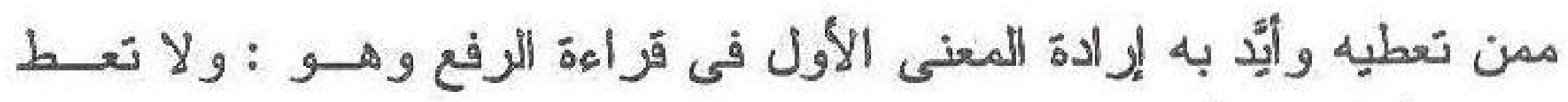

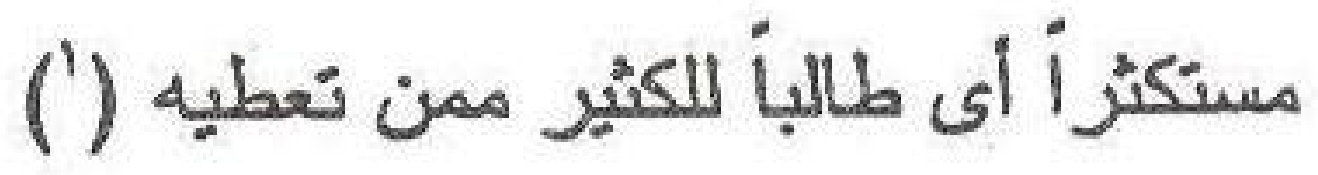
ومناسبة هذه الآية "ولا تمنن تستكثر" وعطفها علـى الأمــر بهجـر

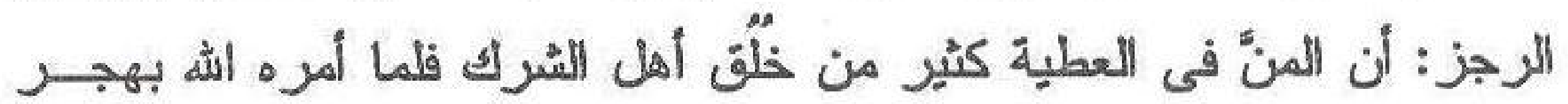

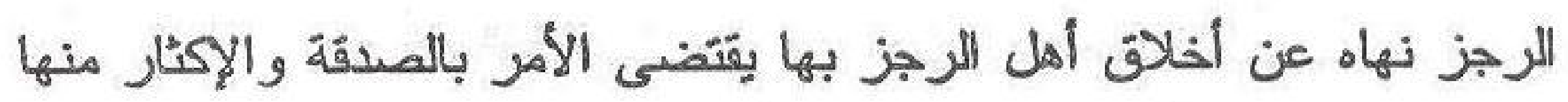

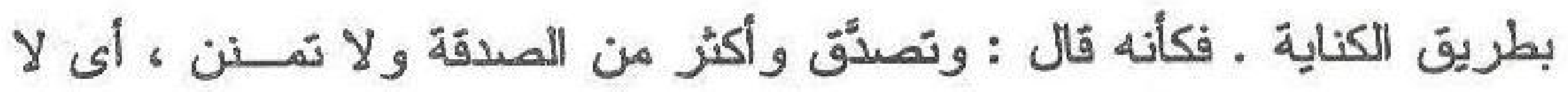

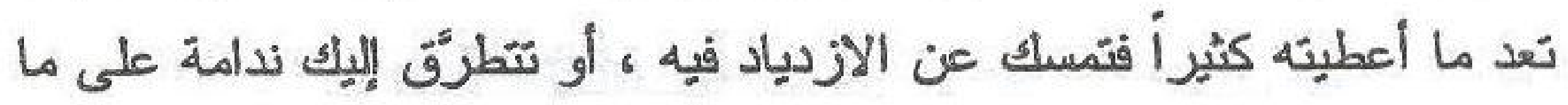

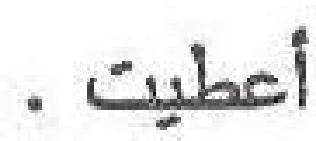

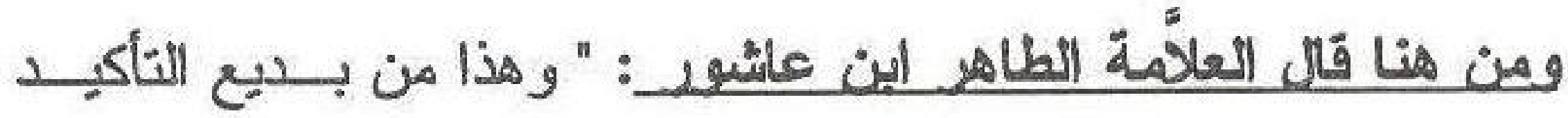

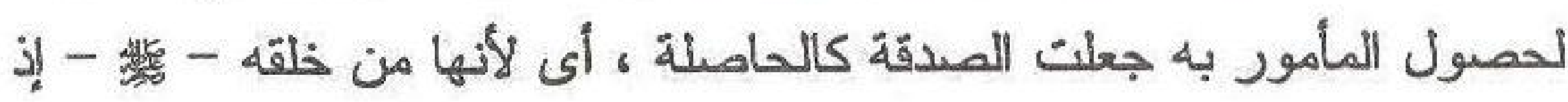

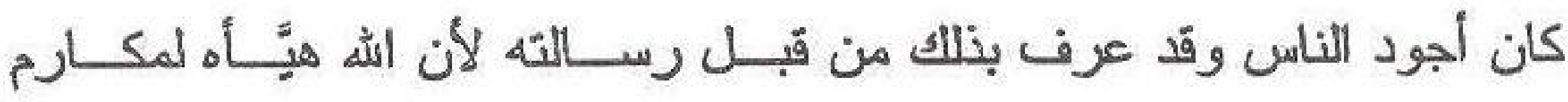

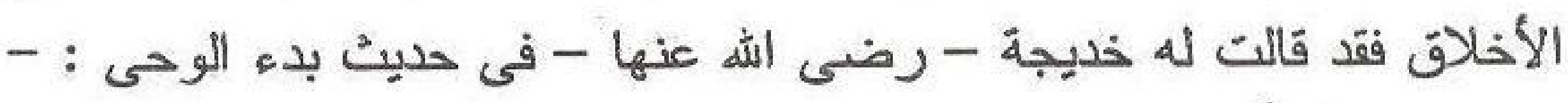

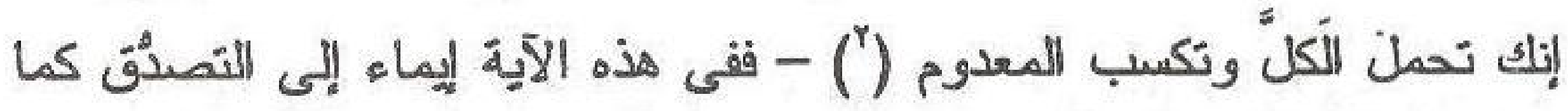
كان فيها إيماء إلى الصلاة ، ومن عادة القرآن الجمع بين الصلاة والزكاة(َ) ).

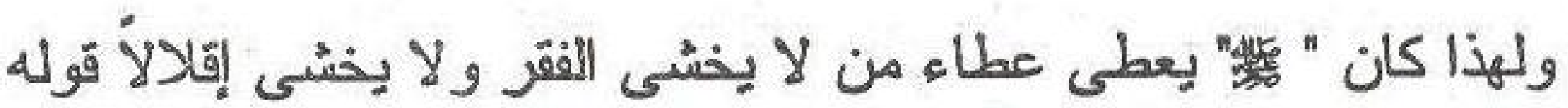

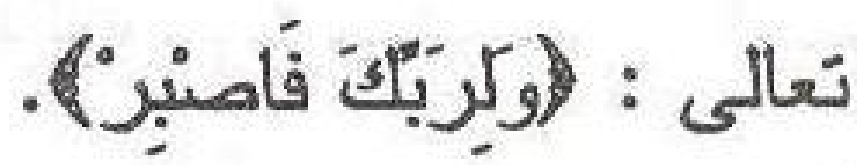

$$
\text { (1) (1) (1) روح المعانى }
$$

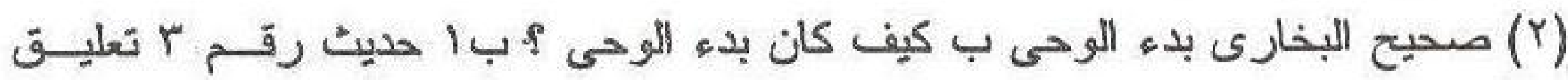

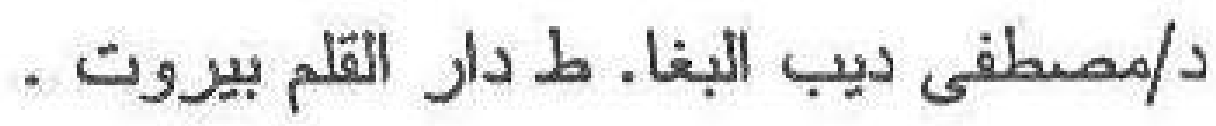

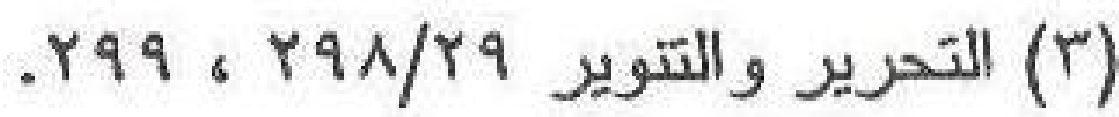




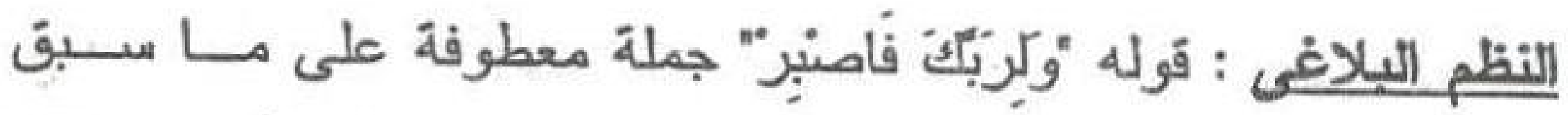

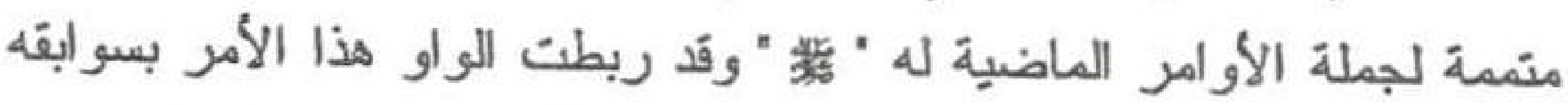
لأنه لما أمر " علية الصلاة والملام " بفضائل الأخلاق ومحاسنها تمّم الشه له له هذه الأو امر بأعلاها شاناً و أشرفها قراً وهو تحمل المشاقٍ . فجاء هذا الأهر

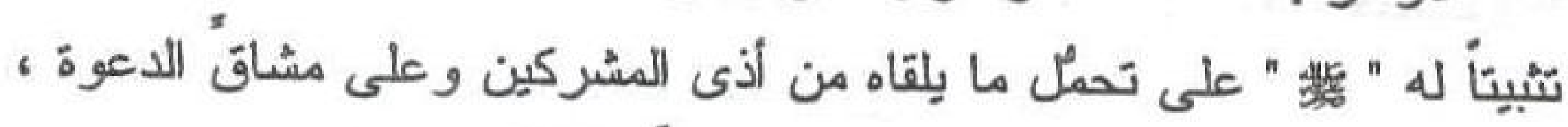

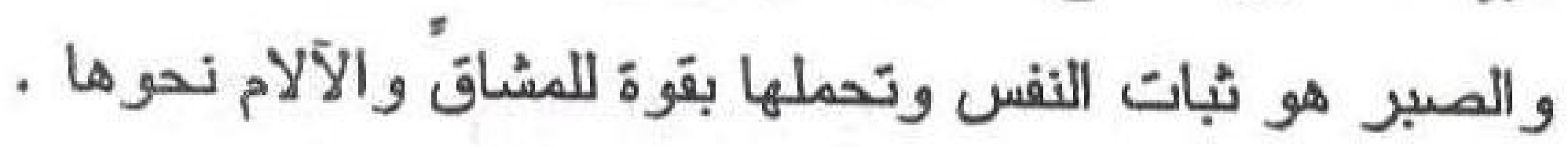
و التقديم فى "ولربكّ" من نقديم متعلقَّات الفعل عليـه للاختصــاص أو

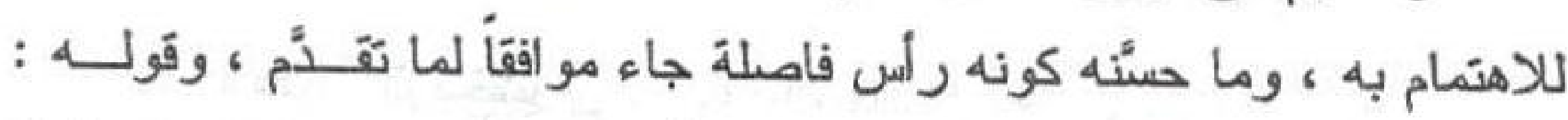
"ولربئك" يجوز - كما قيل - فيه وجهان : أحدهما : أن نكون اللحم لام العلة أى لوجه ربك فاصبر على أذى الكفار ، و على عبادة ربك ، وعن كل مـالا

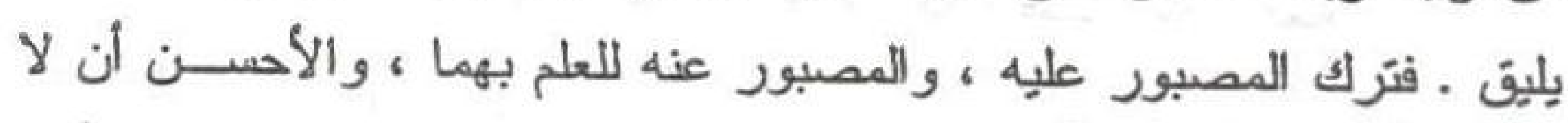

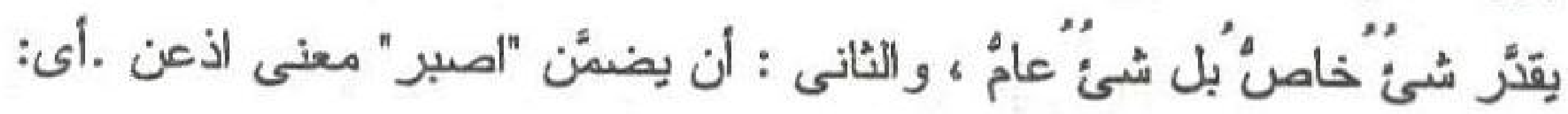

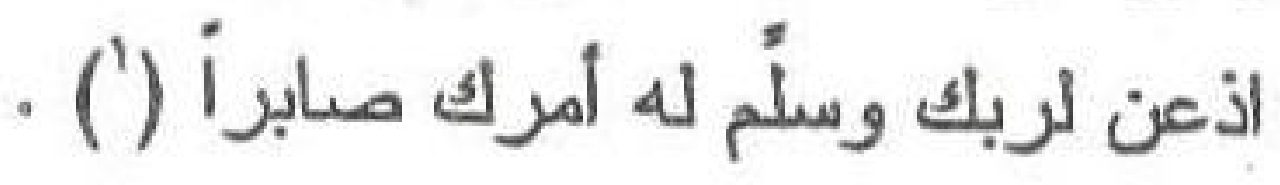

يقول الإمام الفخر - رحمة الله - : إنا أمرناك فى أول هذه السـورة بأشياء ونهيناك عن شئ فاشتغل بتلك الأفعال والتروك لأجل أمر ربك ، فكأن

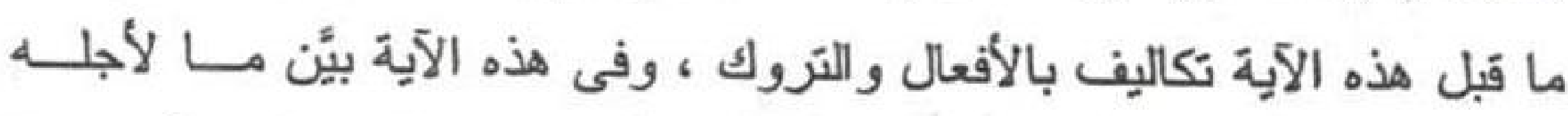

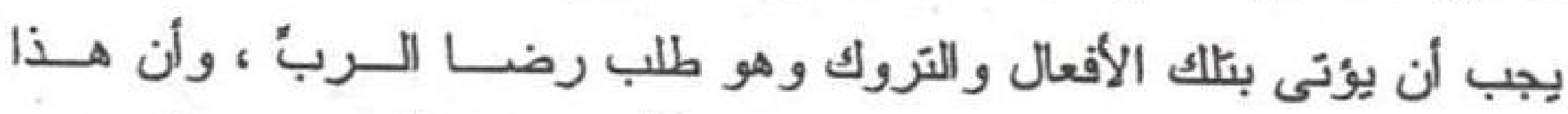

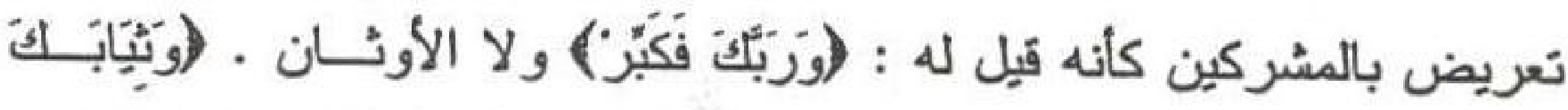

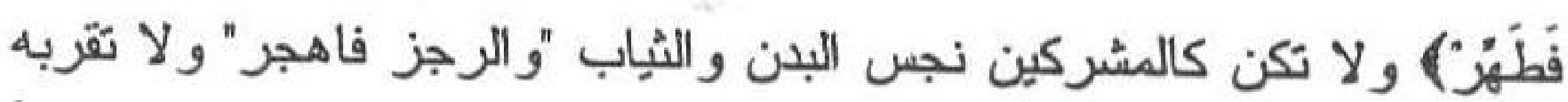

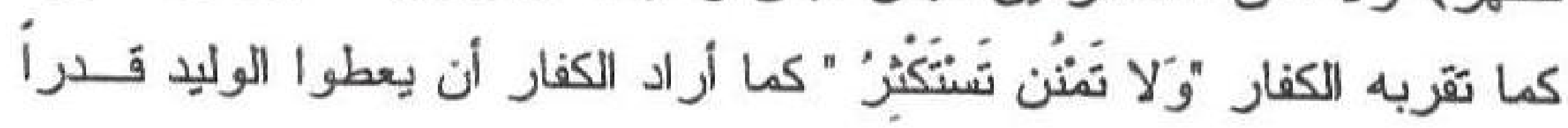




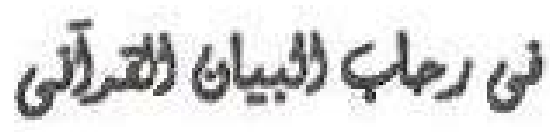

من المال وكانوا يستكثرون ذلك القليل " ولربكّك فاصبر " على هذه الطاعات

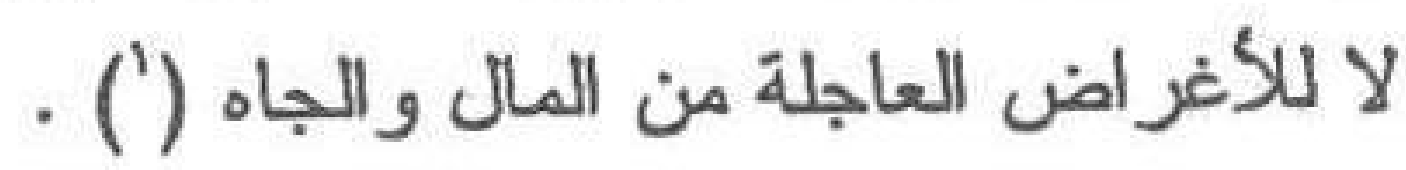

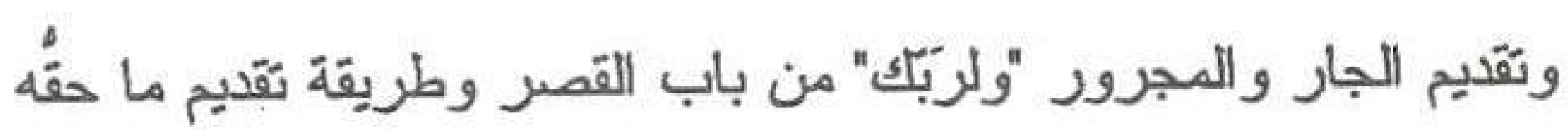

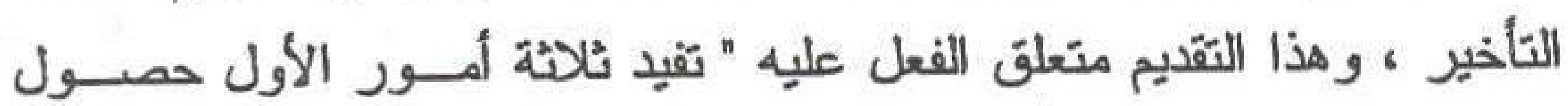

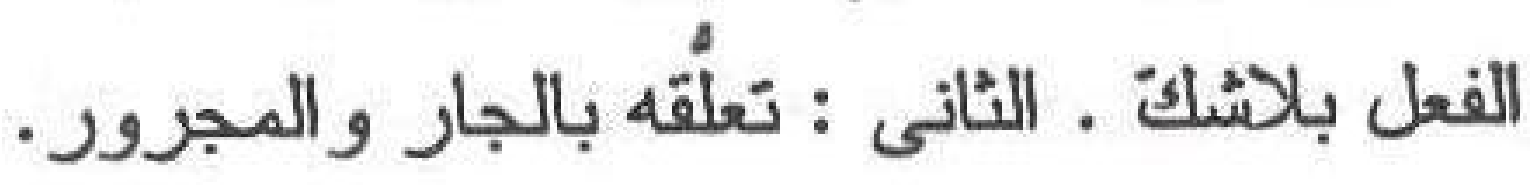

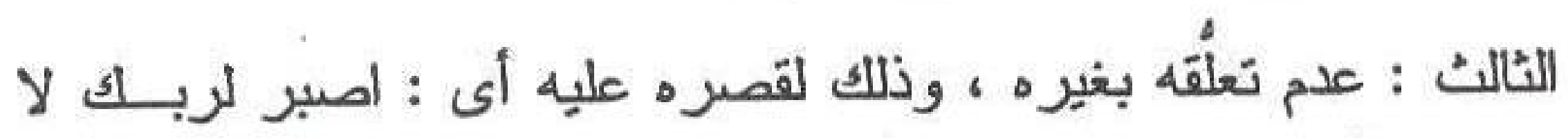

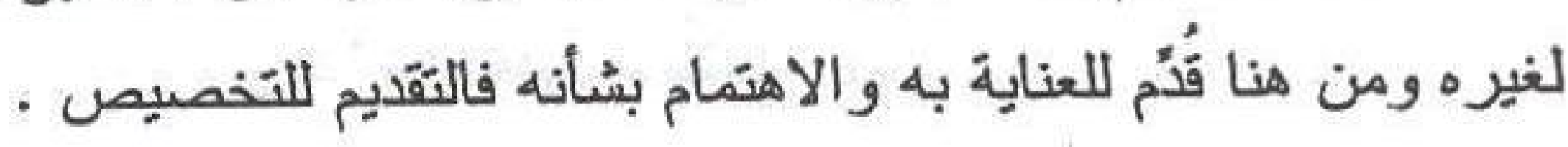

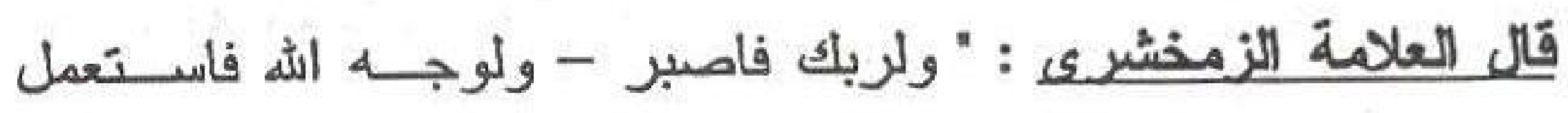

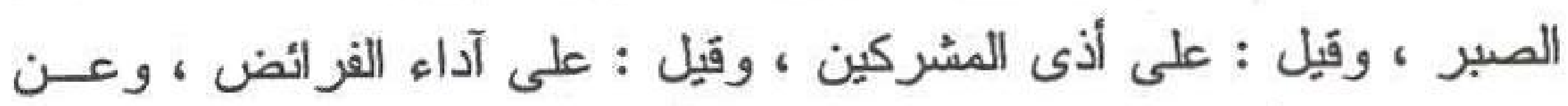

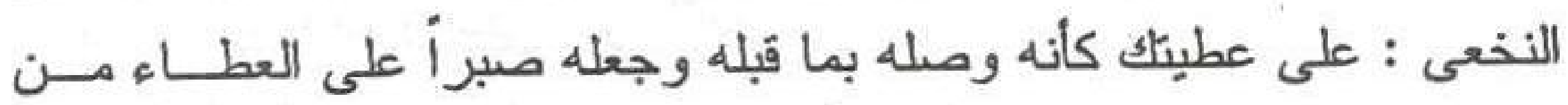

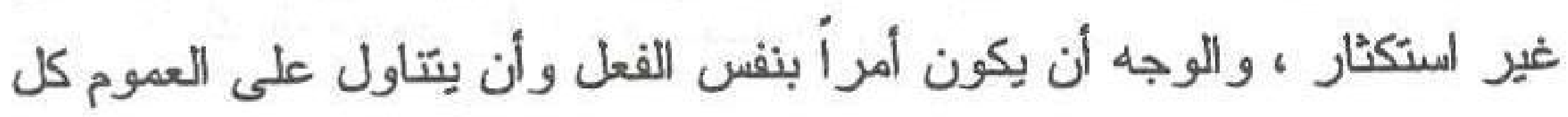

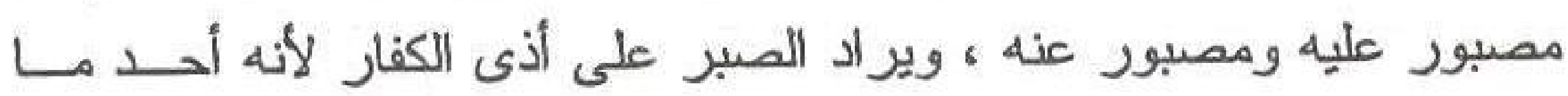

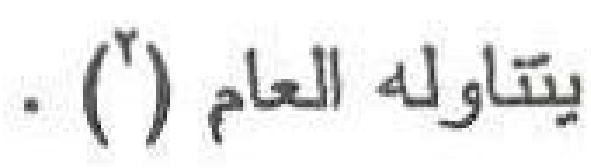

وقد وضنَح الشيخ ز ادة - رحمه الله - مر اد الزمخشرى · فى استعمال

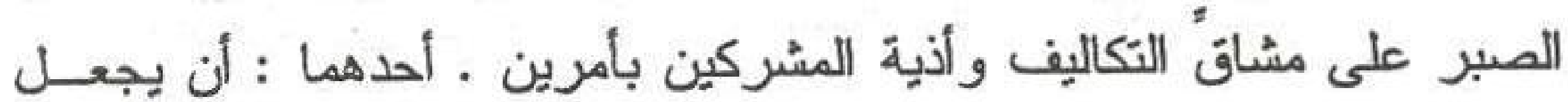

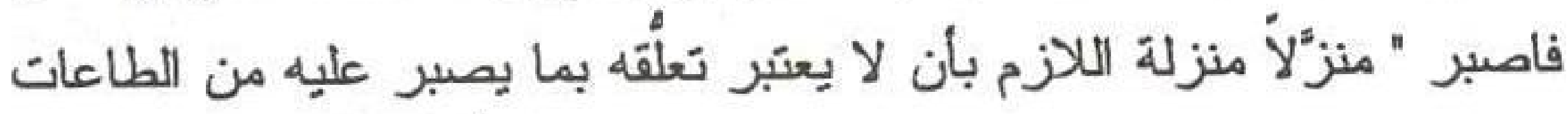

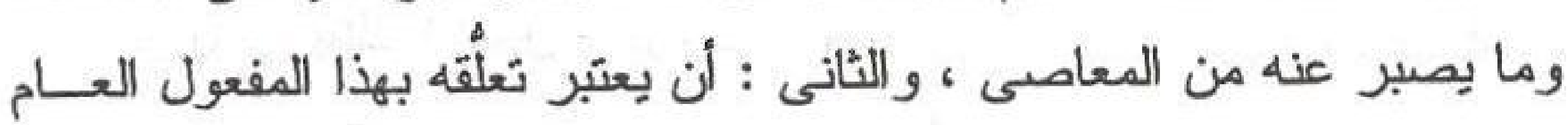

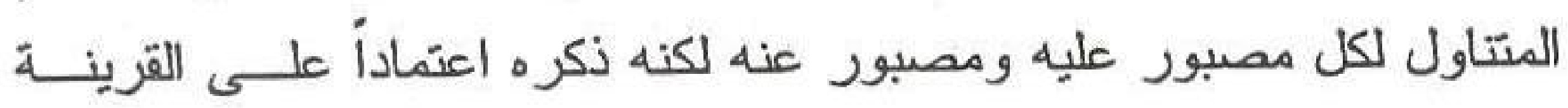


لقصد التحميم هع الاختصسار كأنه قيل إذإ سمعت هذه الأكأليف مــن الأفعـال و التزوك فاصبر عليها لأجل أمر ربك أو لوجهه الكريم (') ويُعدَّى فعل الصبر إلى اسم الذى يتحمله الصنابر بحرف " على " ومن

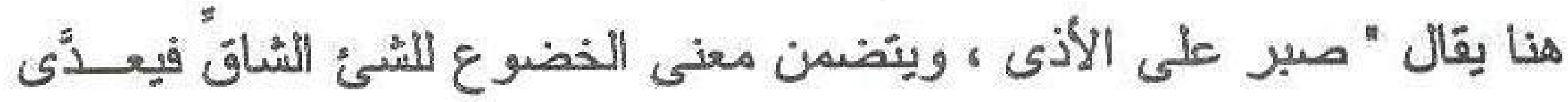

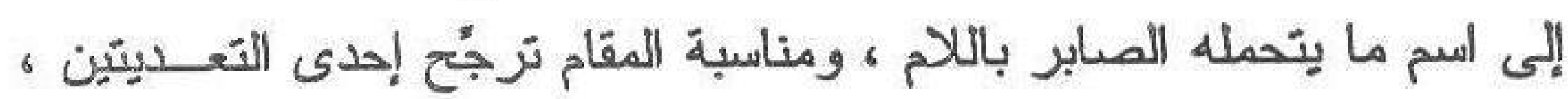

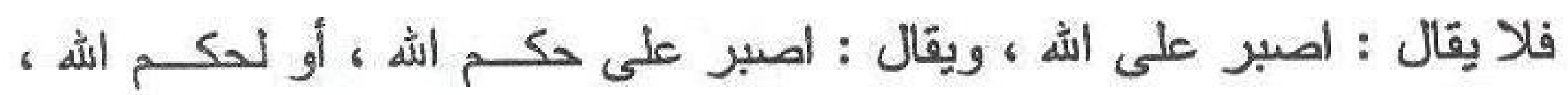

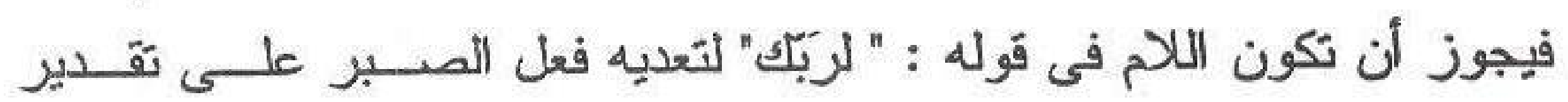

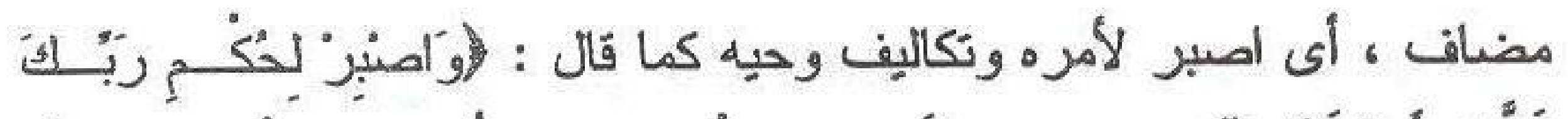

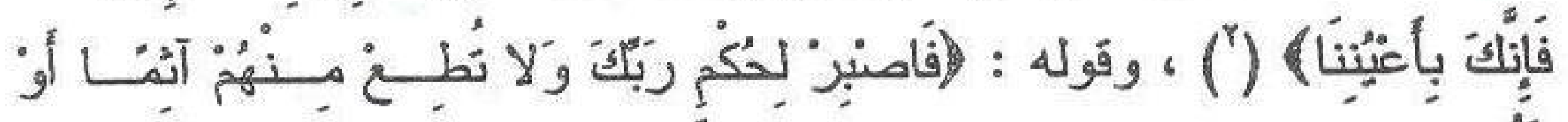

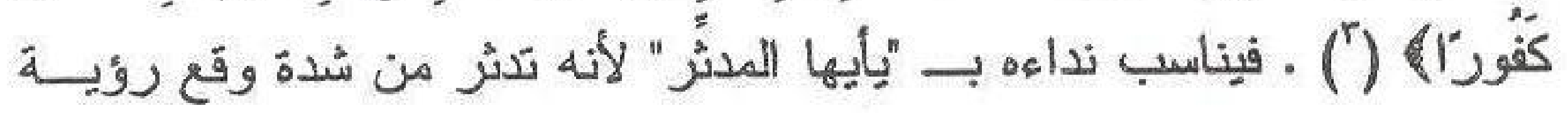
الملك، ونزك ذكر المضاف لتذهب النفس إلى كل ما هو من شأن المضــاف

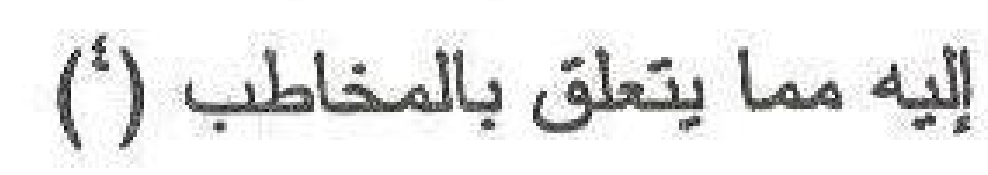
و التعبير عن الله تعالىى بصفة الربوبية فى قوله : "لربك" إيماء إلى أن

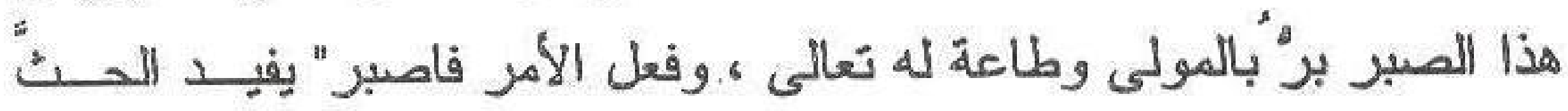

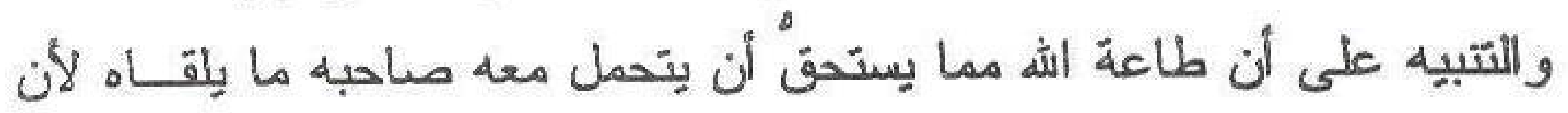
الجز اء عنده تعالى مكفول مضاعف . قِال الألوبسى : "وعن ابن عباس - رضى اله عنهما - الصبر فـى

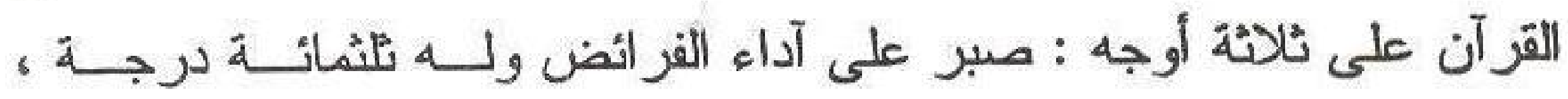

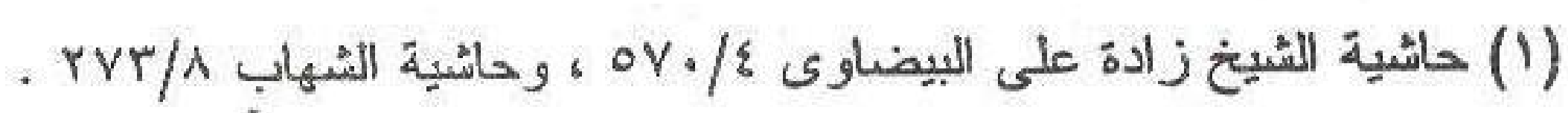
. ¿N/ الطور (Y) . Yع/ الانسان (Y)

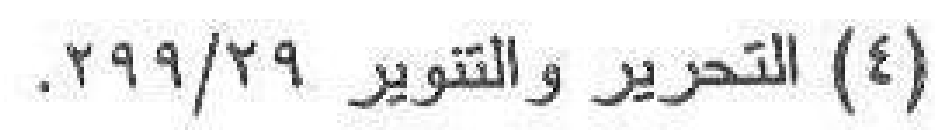


وصبر عن محارم الله تعالى وله ستمائة درجة ، وصبر على المصائب عند

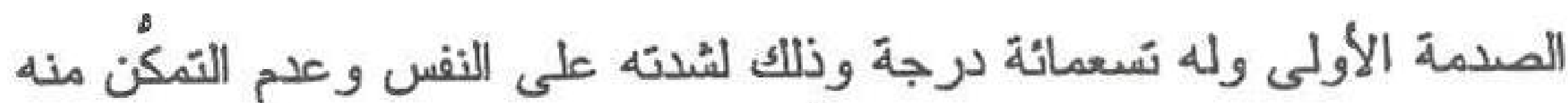

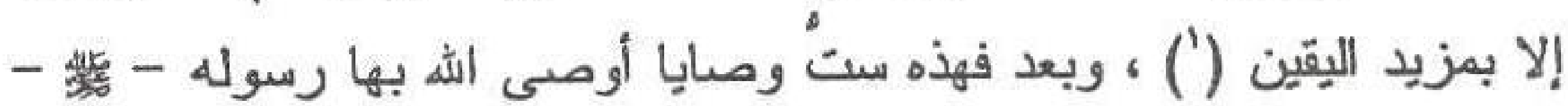

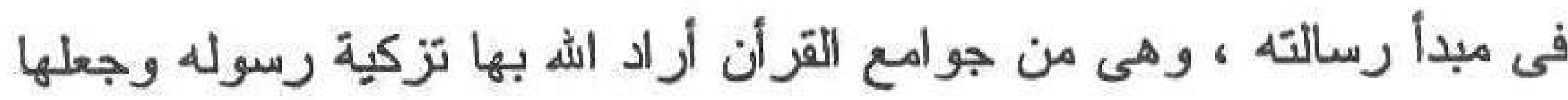

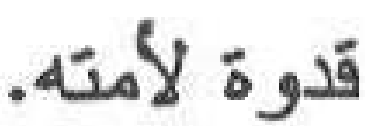

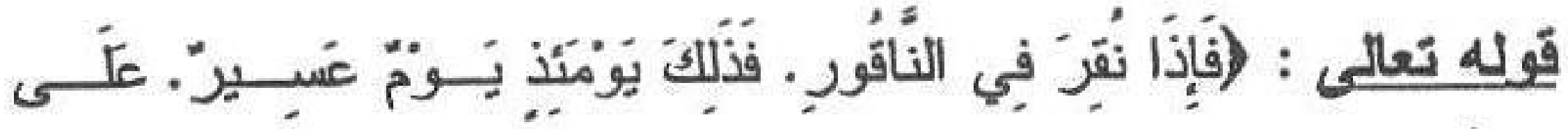

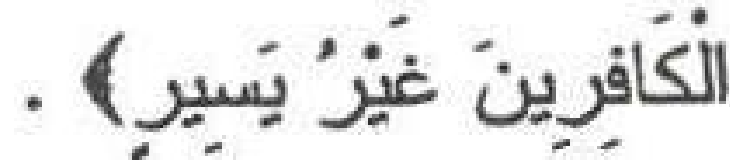

اللنظم البلاغى : الفاء فى قوله : "فإذا" للسببية أى تسبئ هذا الوعيـد

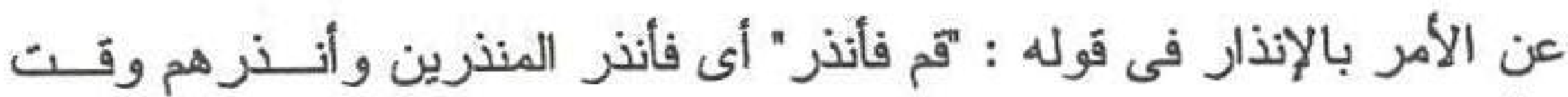

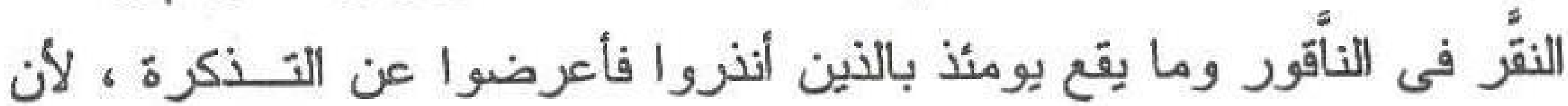

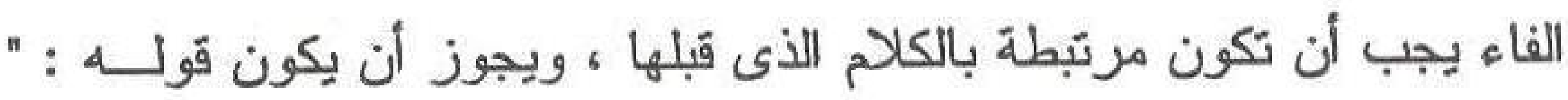

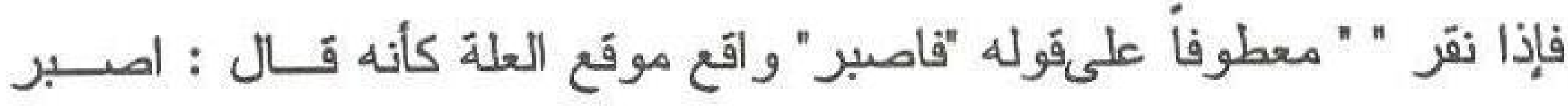

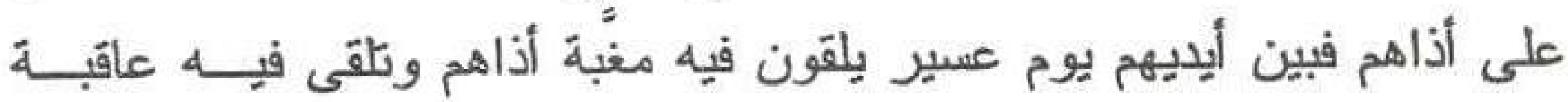

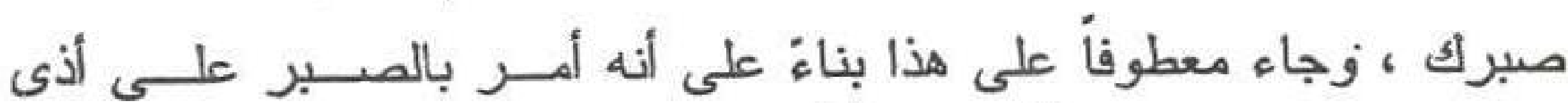

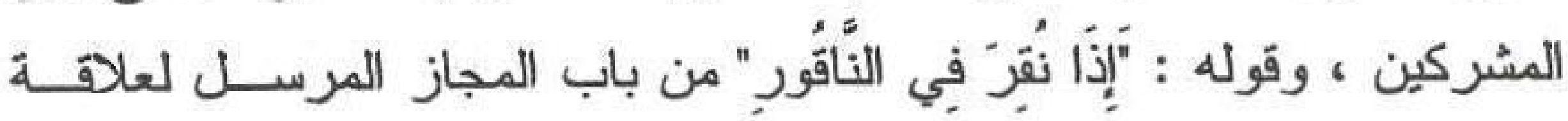

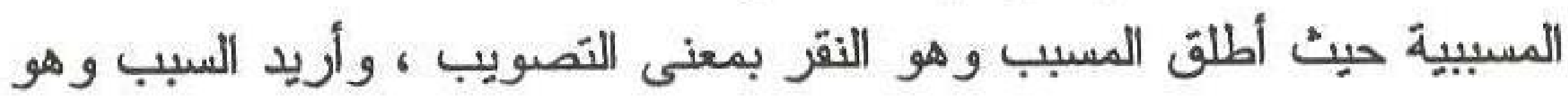

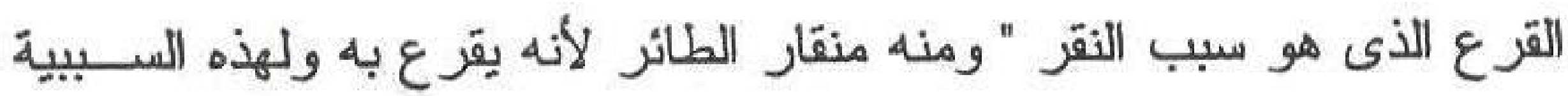

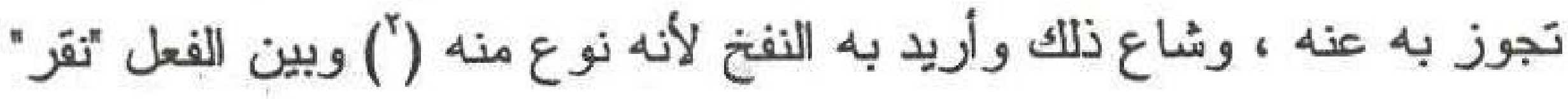
وبين الاسم "الناقور" جناس الشتقاق وهو ما يجمع فيه اللفظــان فـــ أصــل

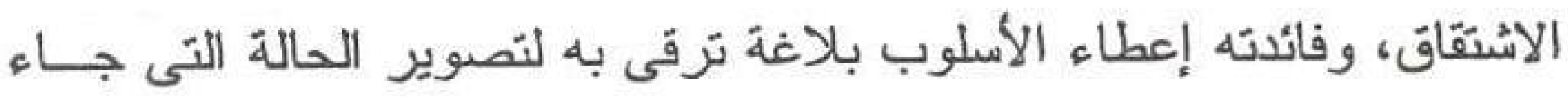

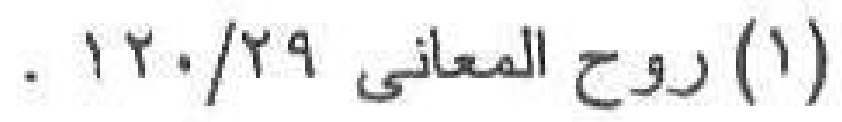

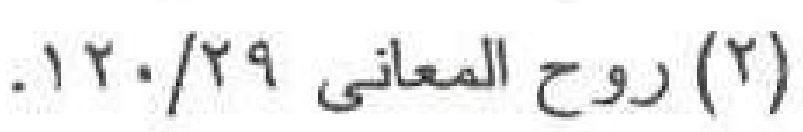




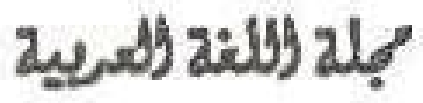

هن أجلها مع مطابقته لمقتضى هذه الحال ، وهو أدعى إلى تأكيده وتتبيته فى

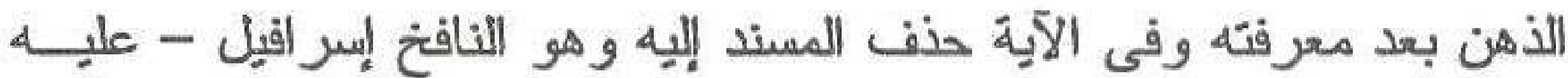
السلام - وسر حذفه توجيه المخاطب لنفس الحثث ، وذلك لأن الذى يريــده القرآن أن يوجه الناس إلى هذا الحدث الجسيم دون أن يشغلوا بمن فعل هــذا لـون الفعل ، فليس هنآك كبير فائدة من ذكر المسند إلياه . و "الناقور" فاعول من النقر بمعنى التصويت ، و "النَّاقور " هو الصنور و الصنور قرن بنفخ فيه النفخة الأولى للفناء ، و الثانية للإنشــاء . (') . قــال الراغب : " هو - الصنور - مثل قرن ينفخ فيه فيجعل الله سبحانه ذلك سبياً

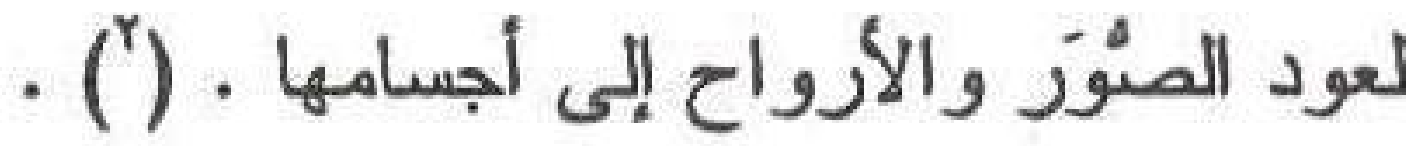
وفى الحديث : " عن عبد الله بن عمر - رضى الله عنهما - قال قال أعرابى يا رسول الله : ما الصنور ؟ قال قرن ينفخ فيه (")، ومنه أيضاً قوله سمعه ينتظر أن يؤمر أن ينفخ فينفخ قال المسلمون فكيف نقول يا رسول اله قال قولوا حسبنا الله ونعم الوكيل توكلنا على الله ربنا ،وربما قال سفيان على اله توكلنا (أ)

وقد " اختلف فى أن المر اد بذلك الوقت يوم النفخـــة الأولـــى أو بـــوم

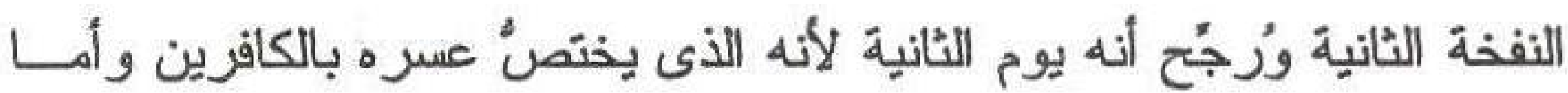

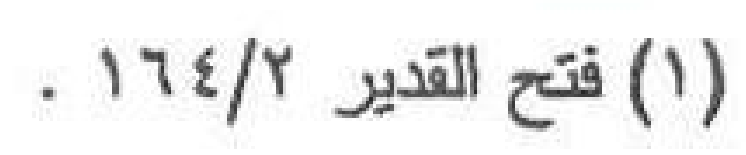

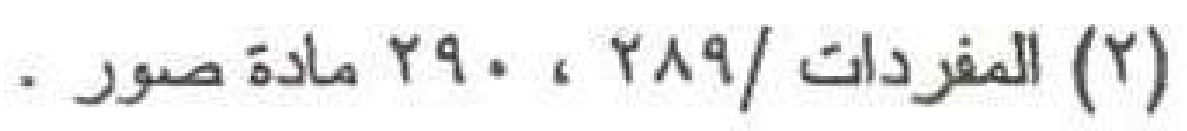

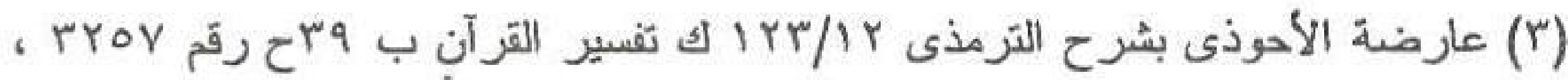

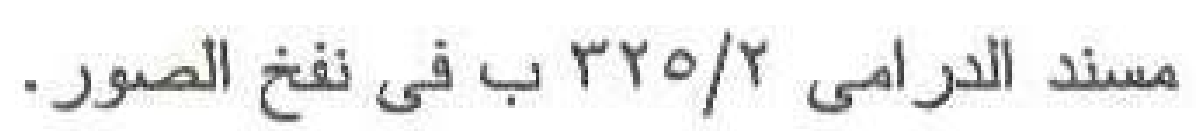


وقت الذفذة الأولى فحكمه الذى هو الإصعاق يعم البرَّ والفاجر وهــو علىى

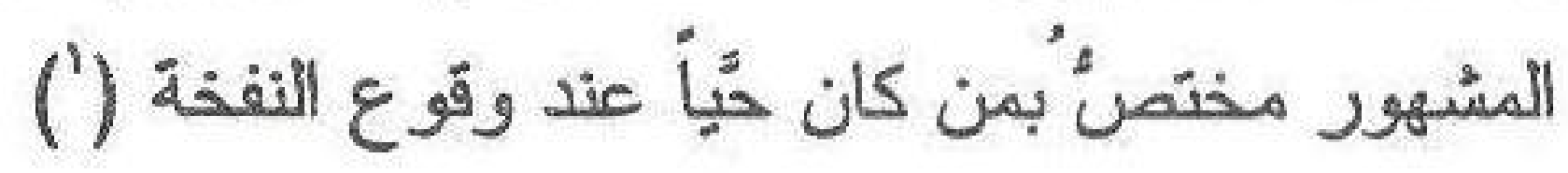

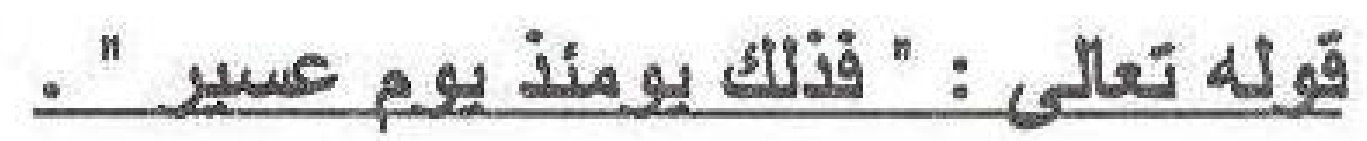
المنظم البلاغعى : الفاء فى قوله " فذلك " رابطة لجو إب - إذا - وذللك -

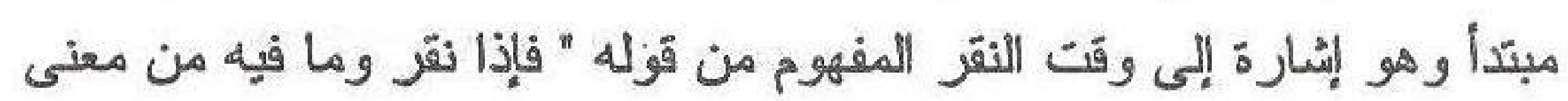

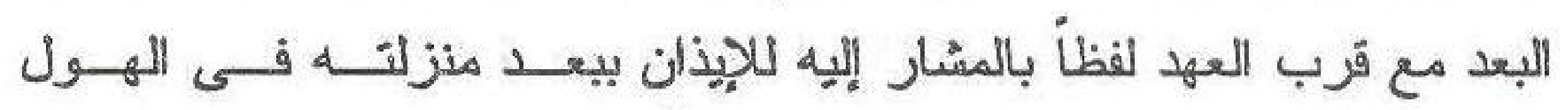

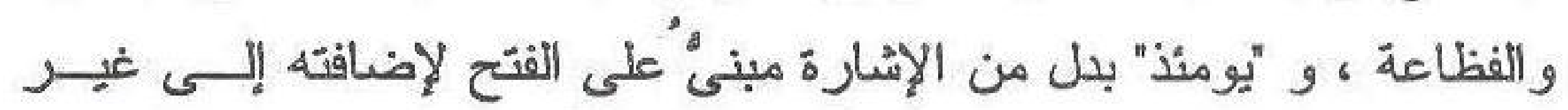

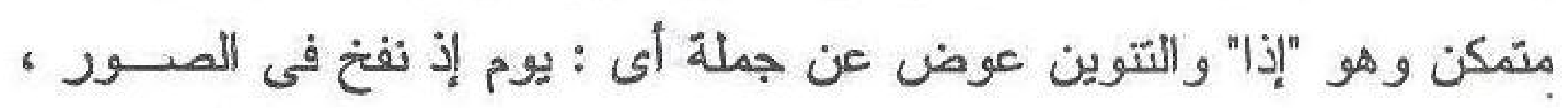

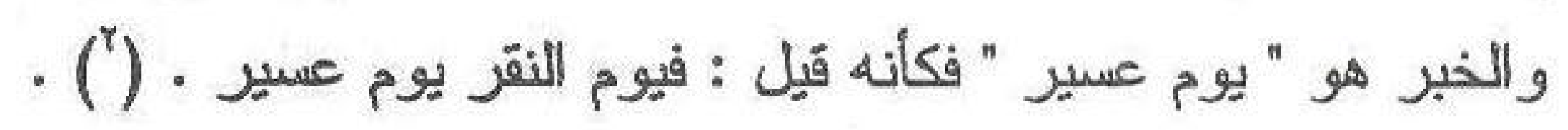

والمراد بالإشارة بيان شدة هذا اليوم فهو يوم " شديد هائل بشتذهُ فيــــ

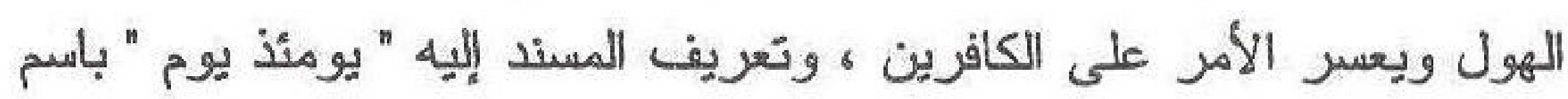

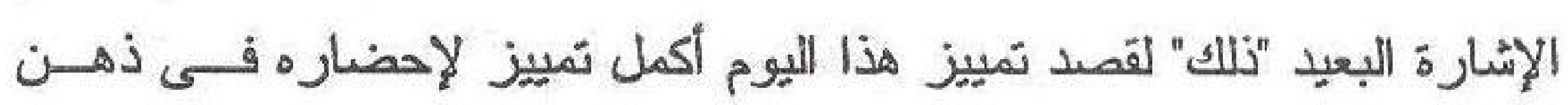
السامع ، فيكون أكثر تصور لله ، بحيث لا يغيب عنه شئ مسنـ أوصــافه ،

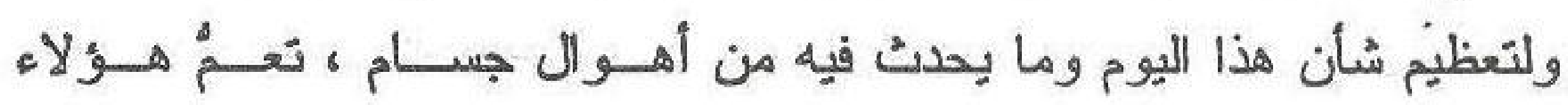

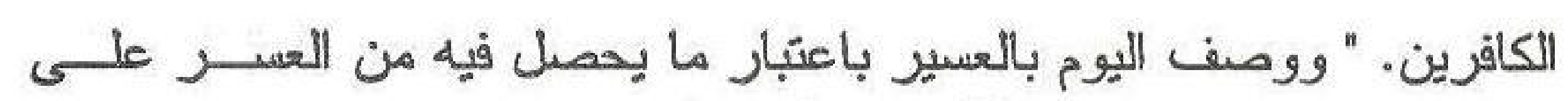

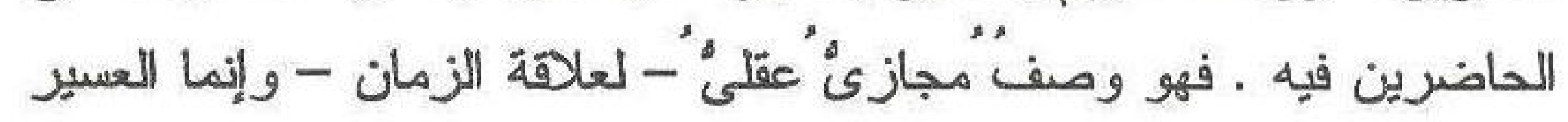

$$
\text { ما يقع فيه من الأحداث (r) }
$$

$$
\begin{aligned}
& \text { (1) (1) נوح المعانى (1) (1) }
\end{aligned}
$$

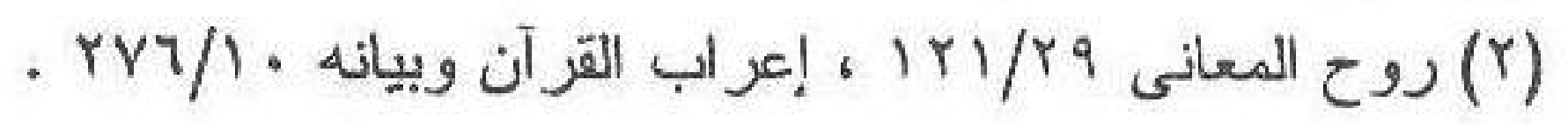

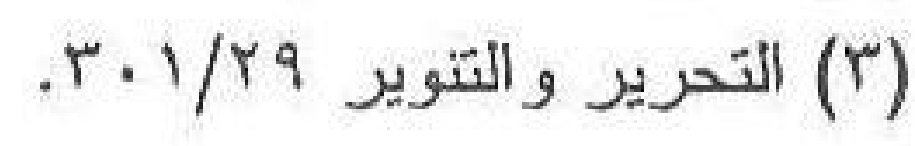


وقوله : " على الكافرين " جار ومجرور منعلق بقوله "عسير" وقيل :

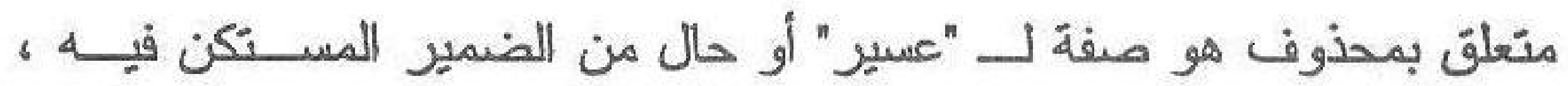

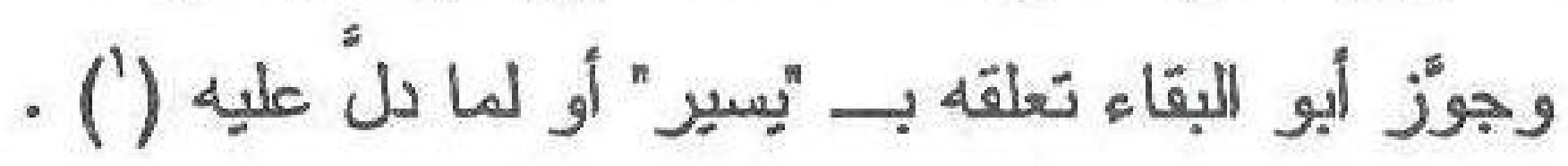
وقوله " على الكافرين " هن باب القصر . قصر صفة الشُدة و العسـر على الموصوف وهم الكاقرون ، وقد أفاد هذا القصر اختصاصهم بهذه الشدة دون غير هم ، وهو قصرُ 'إضافى قُ قصر تعيين ، فهذه الشدة و العسر خـاصُ بهم لا ينعدًاهم إلى غير هم و هم المعنيون به دون سواهم ، فهو عسبر عليهم

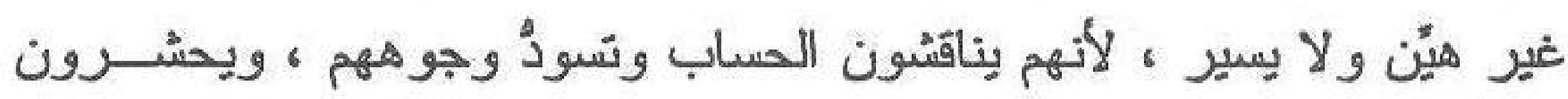

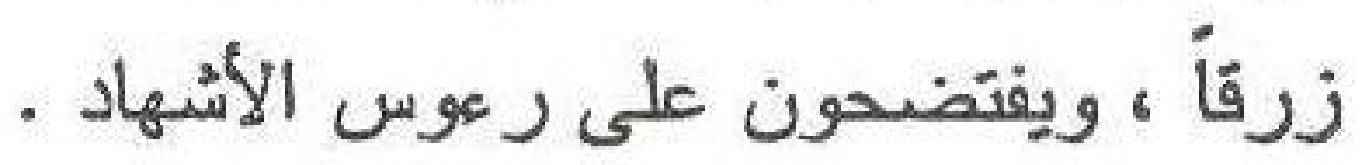
وقوله : " غير يسيز " تأكيد لمعنى "عسير" بمر ادفه ، وهو من غر ائب

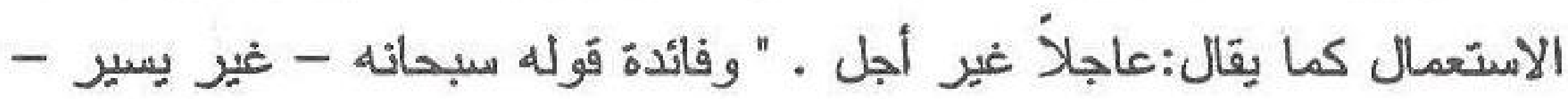
أى سهل بعد قوله نعالى - عسير - تأكيد عسره على الكاقرين فهو يمنع أن

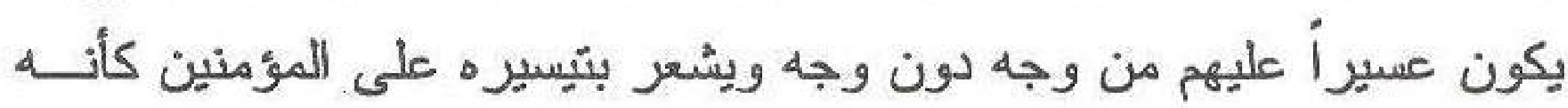
قيل عسير على الكافرين غير يسير عليهم كما هو يســير علـى أضــدادهم - (المؤمنين (1)

وقد بيَّن العلأمة الزمخشُرى : فائدة هذا التأكيد الوارد فى قوله : "غير يسير" بقوله "فإن قلت : فما فائدة قوله - غير يسير - و - عسير - مغـن عنه ؟ " قلت : لما قال :- على الكافرين - فقصر العسر عليهم قال : - غير يسير - ليؤذن بأنه لا بكون عليهم كما يكون على المؤمنين يسيرأ هيناً ليجمع

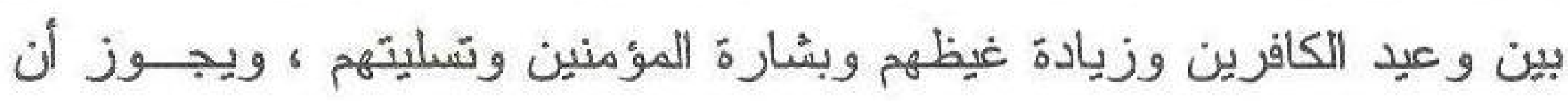


يراد أنه عسير لا يرجى أن برجع يسيراً كما يرجى تيسر العسير من أمسور

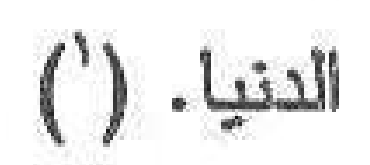

وعلى هذا فإن الكافرين ينقطع رجاؤهم مسن جميـع الوجـوه التـى

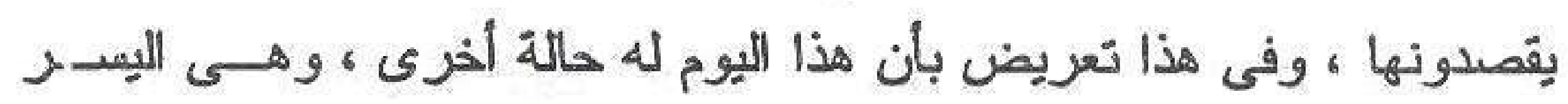
على المؤمنين ليجمع بين إغاظة الكافرين ووعيــهم ، وبئــارة المـؤمنين

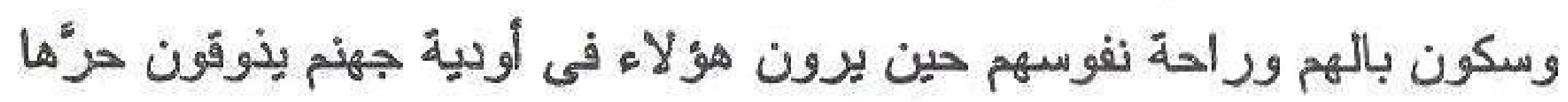

وسعير ها ويعانون قسوتها وزفيز ها وزقومها وغسلينها . 


$$
\text { المبهي (لأثانى) }
$$

المريك عبك الأشقى الأناجر

$$
\text { الاولير بنك (المغيرة }
$$




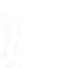


جلة للثنة الكمبية

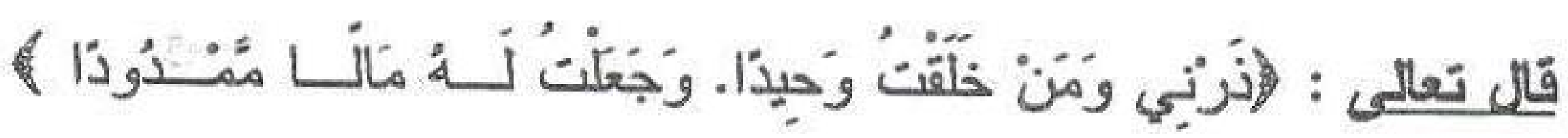
الآيات.

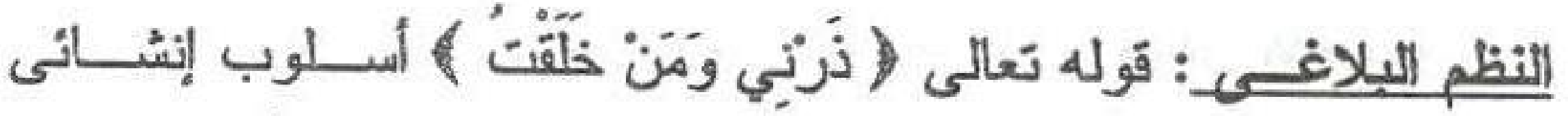
طريقة الأمر مر اد به التهديد وهو جملة استئنافية مؤذنة بأن حدثًا وقع كــان سبياً فى نزول هذه الآية عقيب الآيات المشتملة على عدة أو امر لرســول الهـ

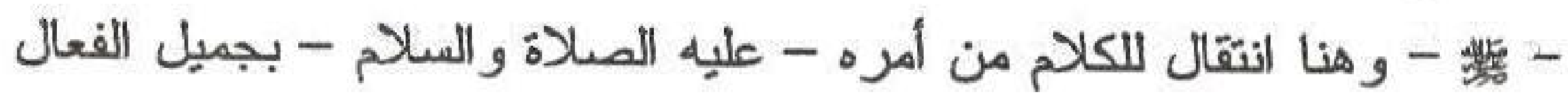
وكريم الخصال بأسلوب دقيق على الحديث عن زعيم من زعماء الكـافرين ومدبر مطاعنهم فى القرآن الكريم ودعوة الرسول - - - . ذكر المفسرون : أن الآية نزلت فى الوليد بن المغيرة . كان من أكابر قريش ، لذلك لقب الوحيد وريحانة قريش ، وقد أنعم الله عليه بنعم الدنيا فى كي المال و البنين ،وأغدق عليه الرزق فكان ماله كالنهر الدفاق ، وكان له بستان

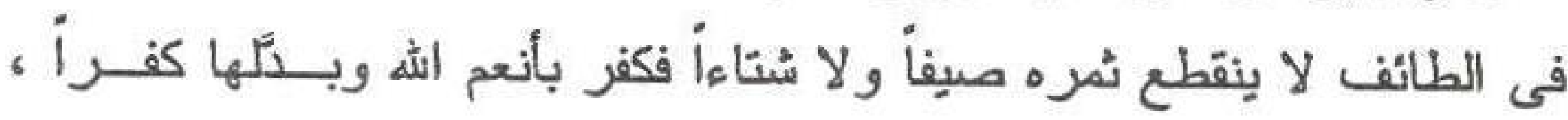
وقابلها بالجحود و النكر ان لآيات الله تعالى و الاقتر اء على رسوله. قالر أبو عبد الله القرطبى: عن سبب نزولها فى الوليد : " وإن كـان

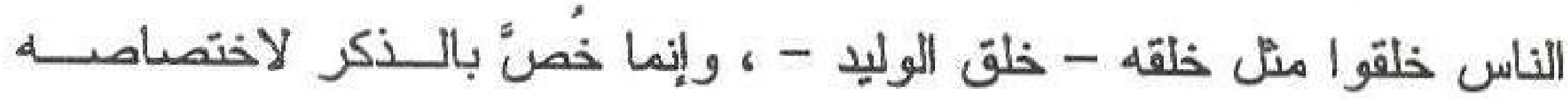

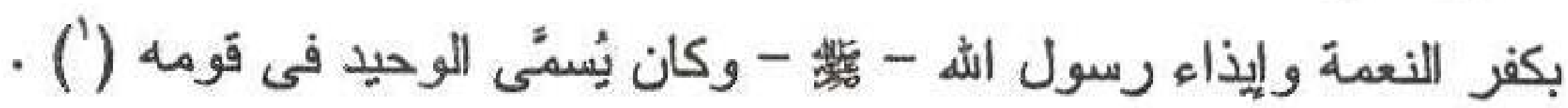
فقوله : "ذرنى" أسلوب بليغ فى التهديد والوعيد ، وتصدير الجملة بفعل

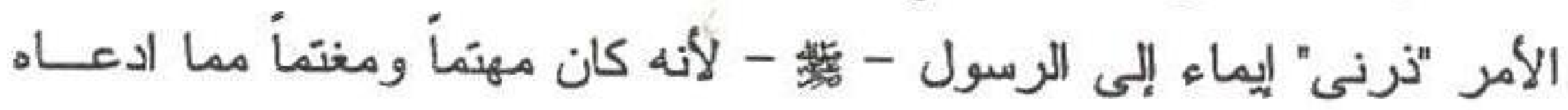

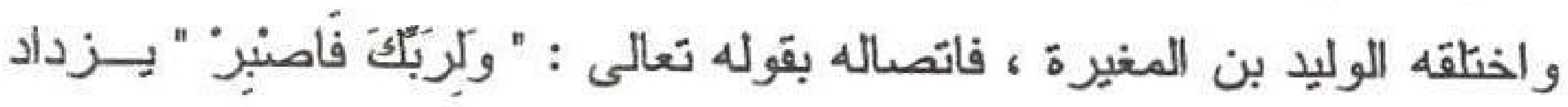
وضوحاً

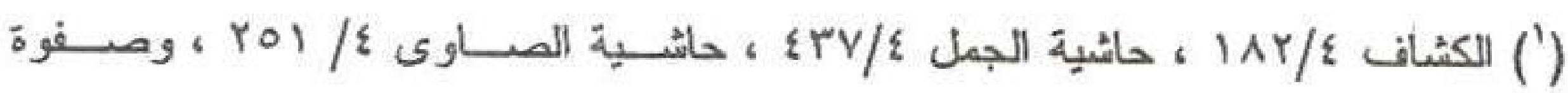
التفاسير 


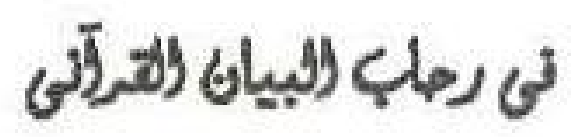

قالر الشبخ الطاهي ابن عاشتح : و أياماً كلن فقد وقع الاتفاق علـى أن

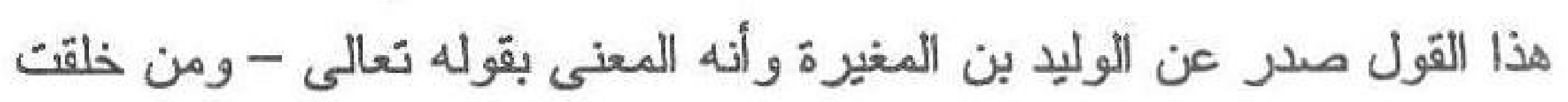

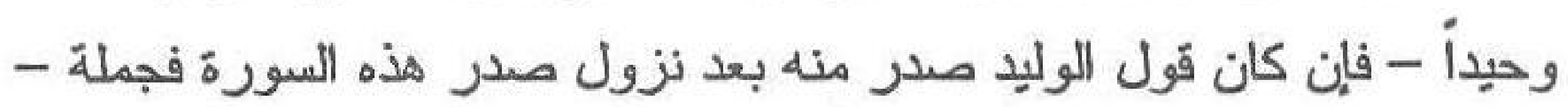

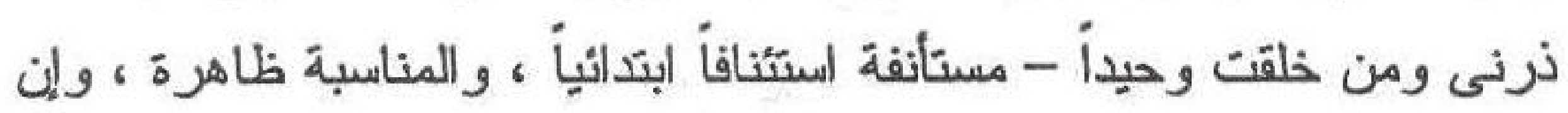

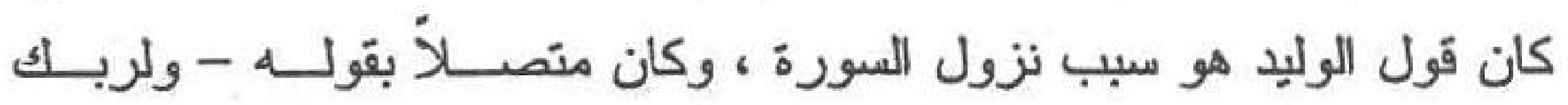

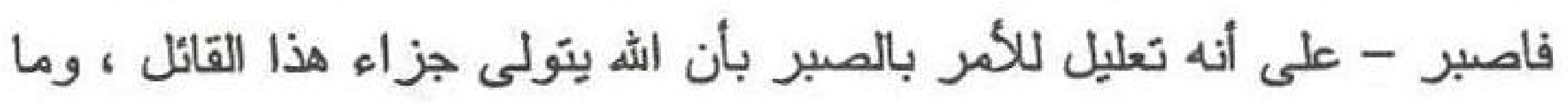

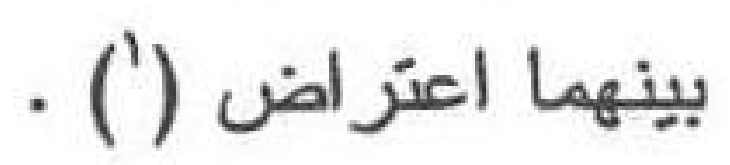

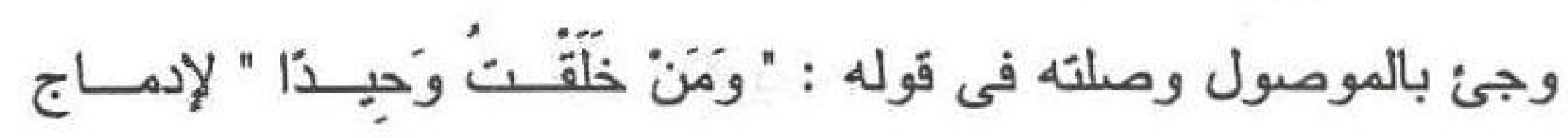
تسجيل كفران الوليد النعمة فى الوعيد و التهديد .

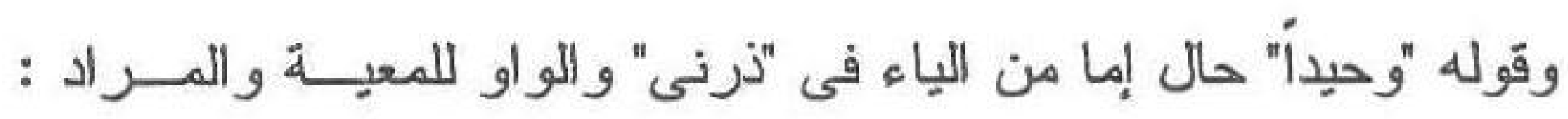

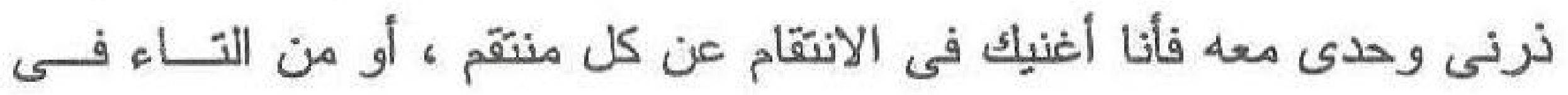

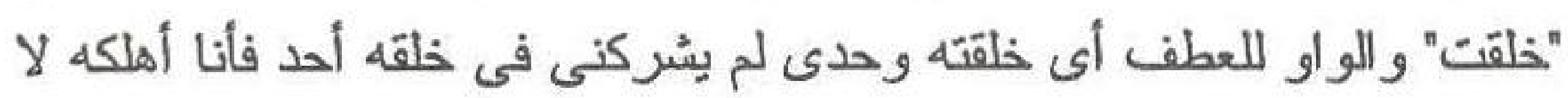

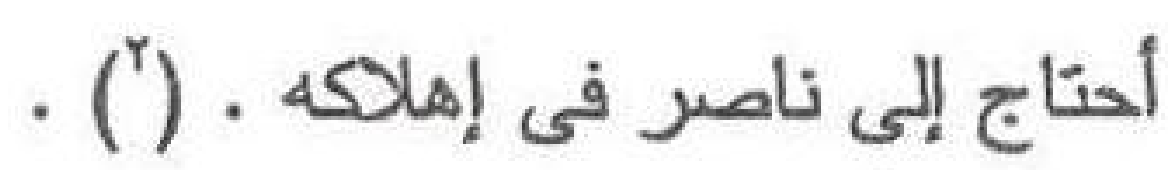

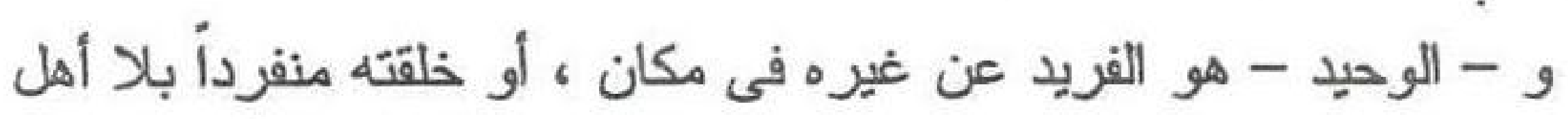

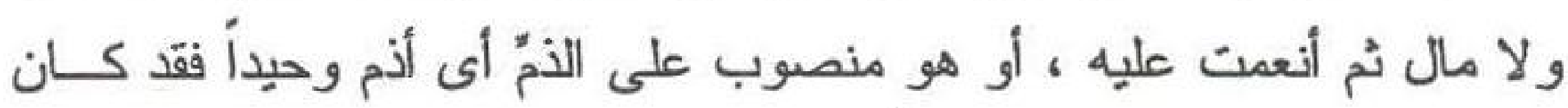

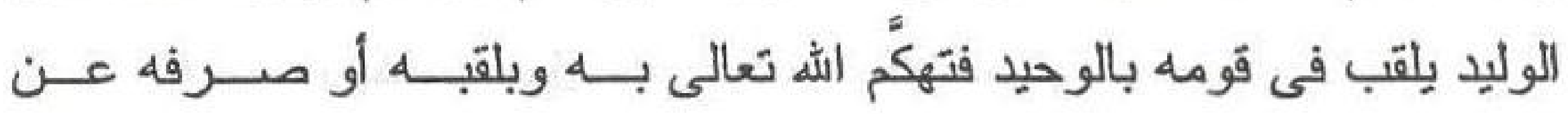

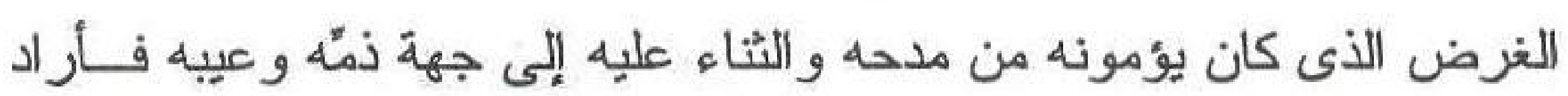

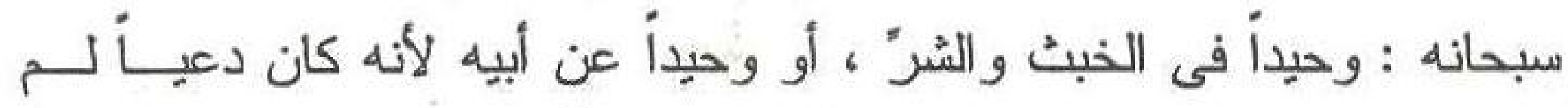

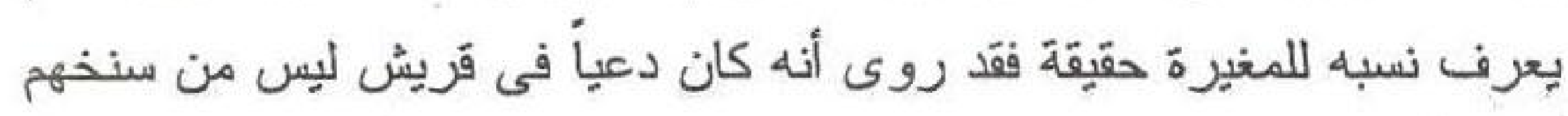

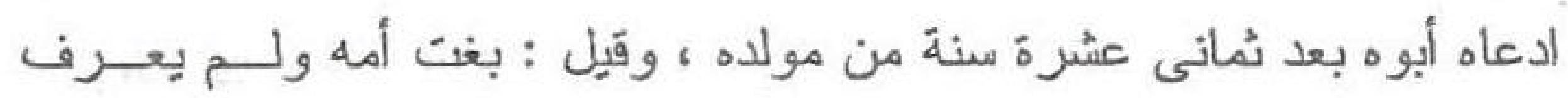




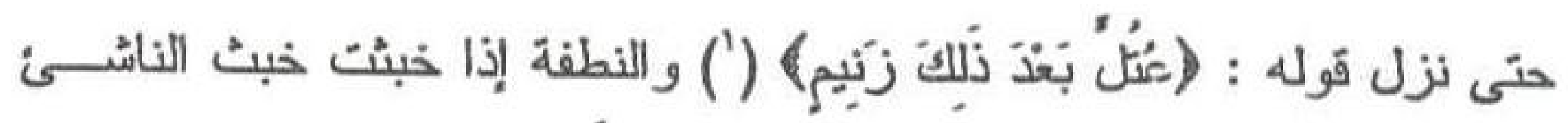
منها ، روى أنه دخل على أمه وقال : إن محمدأ وصــفنى بعشــر صــفــات

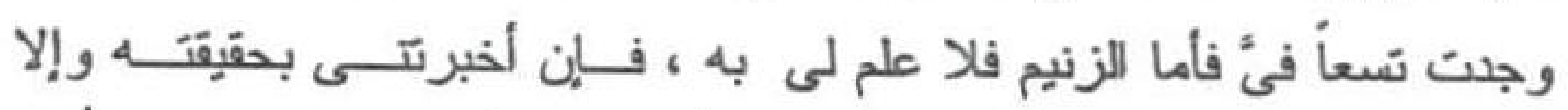

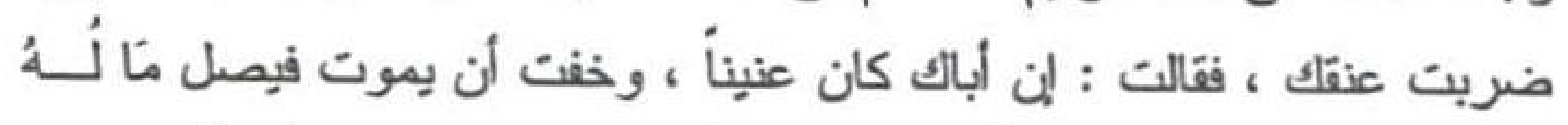

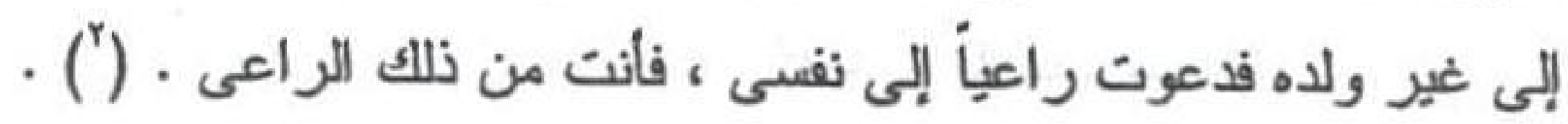
ويرى الشبيخ الصاوى : أن قوله تعالى : "نرنى ومن خلقت وحيــداً "

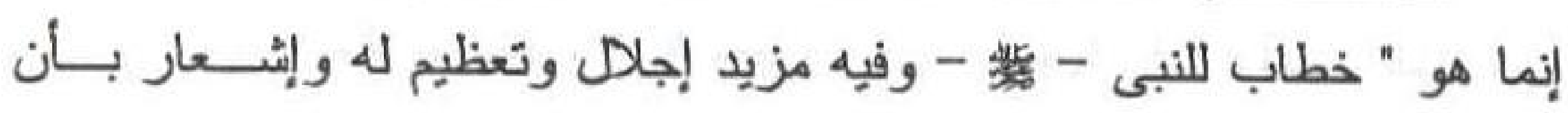

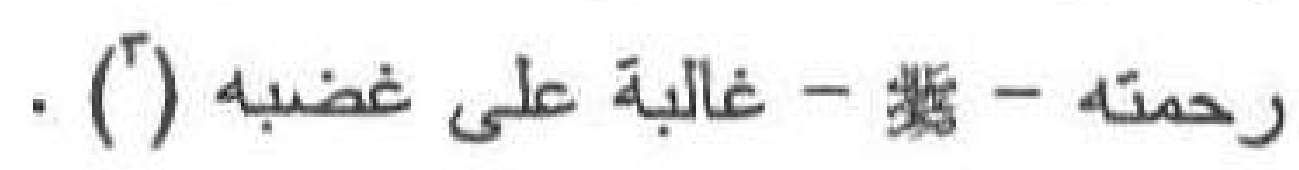

ولم أر أحدأ من المفسنين: ذكر هذا الرأى ، بل أجمعت كلمتهم على

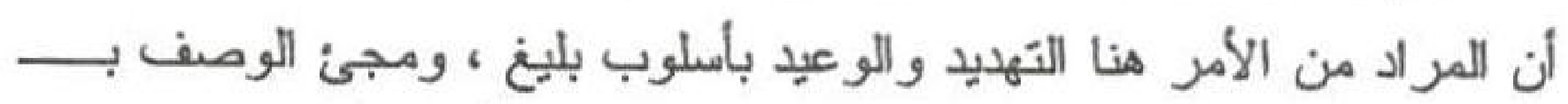
"وحيداً" بعد الفعل "خلقت" ليصرف هذا عما كان مرادأ به فينصرف إلى مــا يصلح لأن يقارن فعل "خلقت" أى أوجلته وحيداً عن المال و اللبنين والبعطة ،

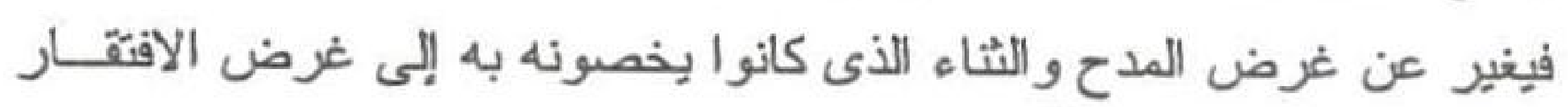

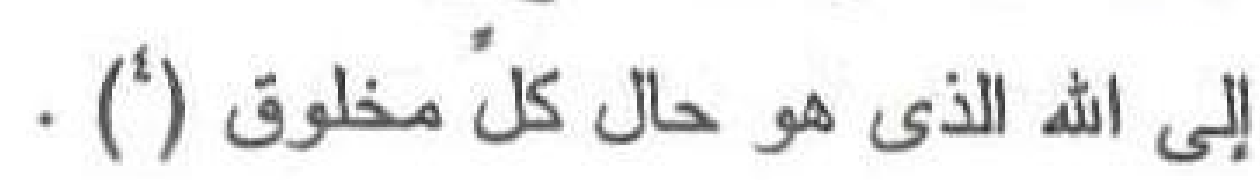

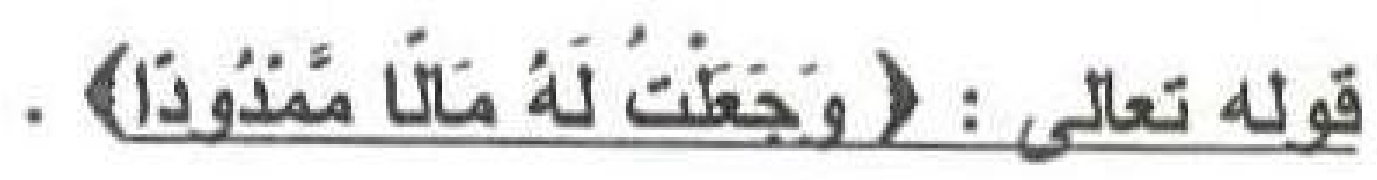

(النظم البلاغى : قوله : "وجعلت له" معطوف على قوله : "ذرنى ومن خلقت وحيداً " من عطف الخاصن" على العامٍ ، و هذه الجملة موصولة بسابقتها

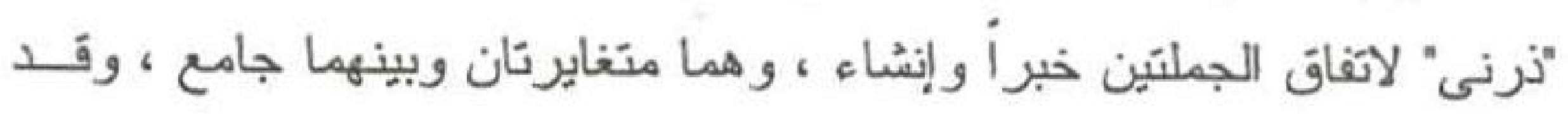

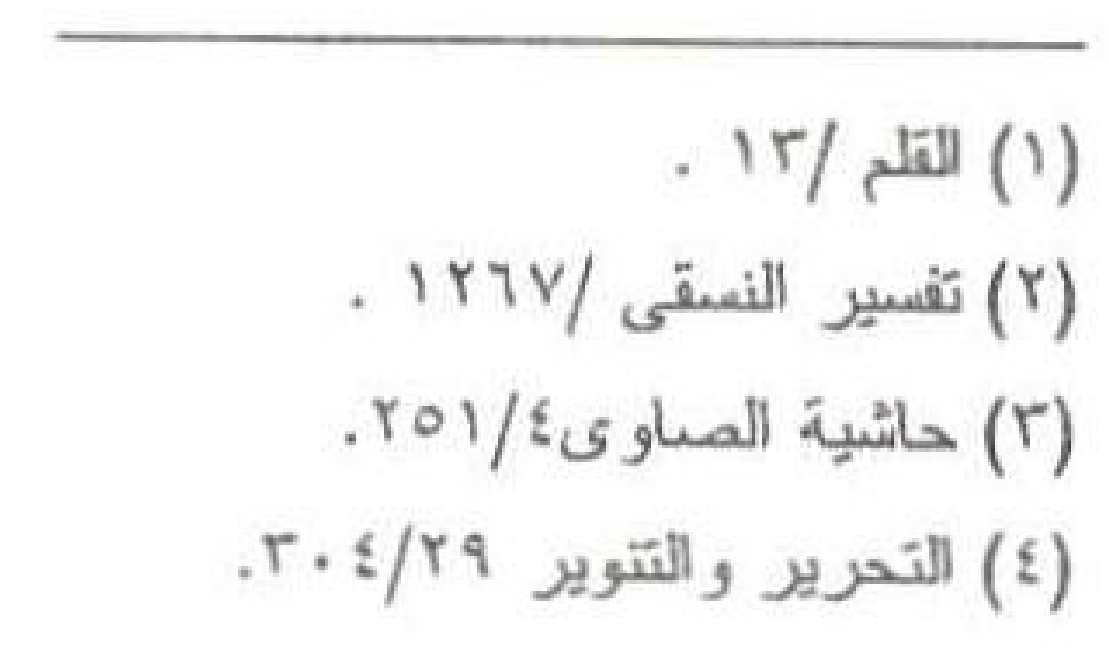




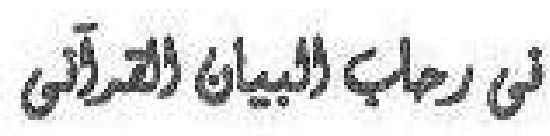

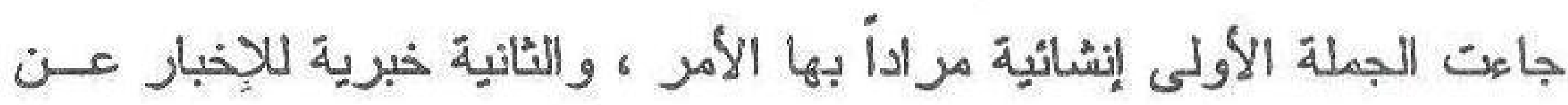

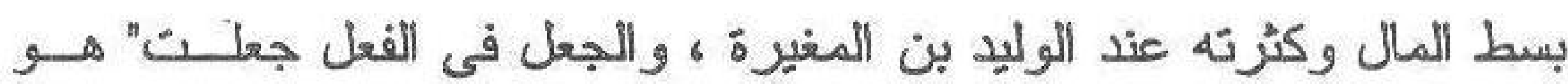

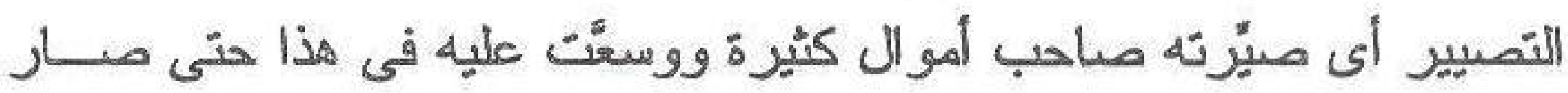

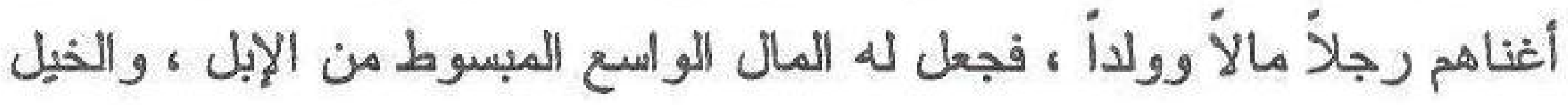
والغنم ، والبساتين النضرة ، أو المال المدود بالنماء ،، وقيل : كــان لــــ

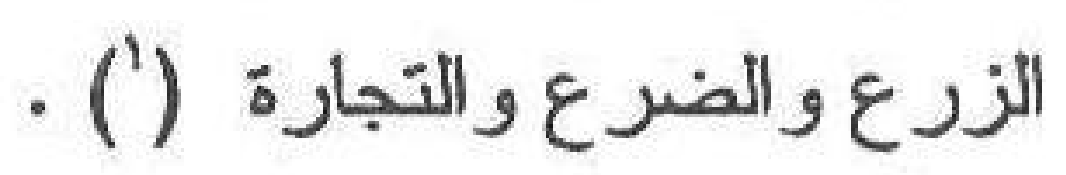

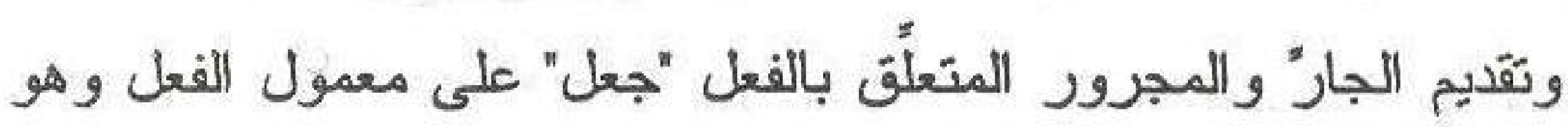
المفعول من باب القصر للاختصاص أى هذه التوسعة و البسط والمدُ و الكثرة

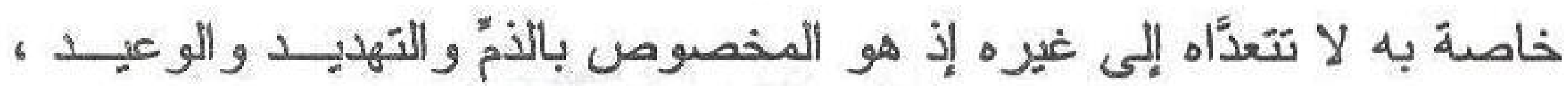

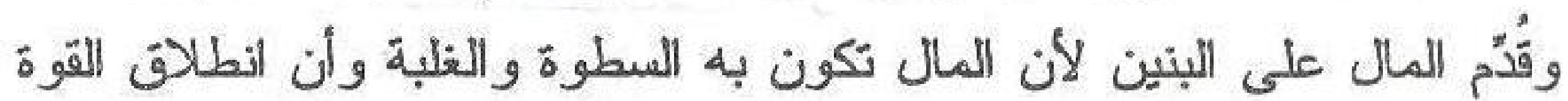

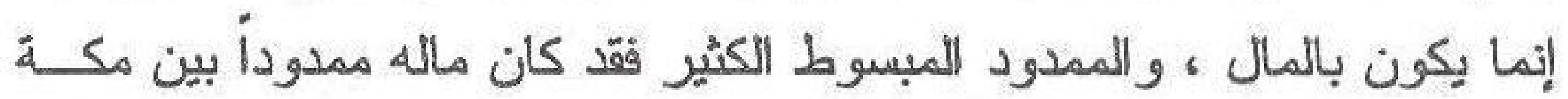

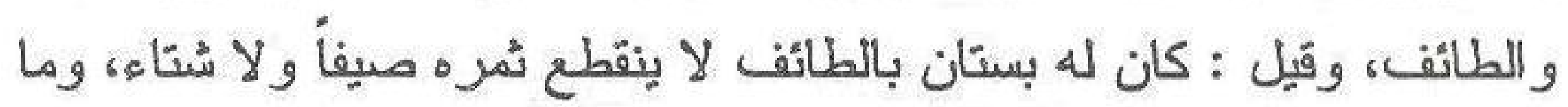
كان له من الإبل و النعم والجنان و العبيد بين مكة والطائف وقيــل : المــال

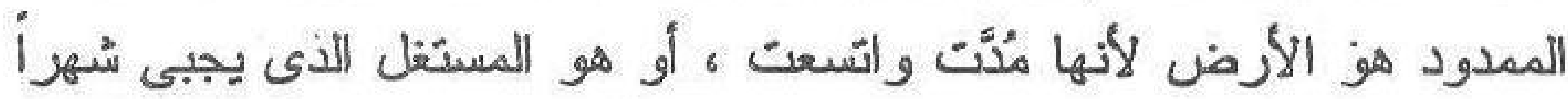

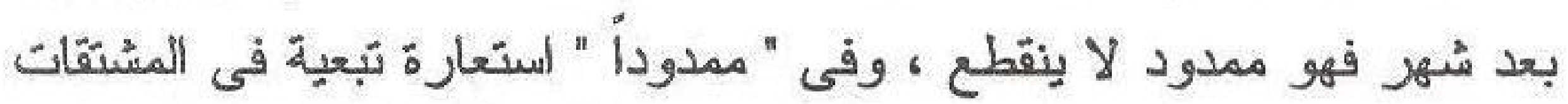

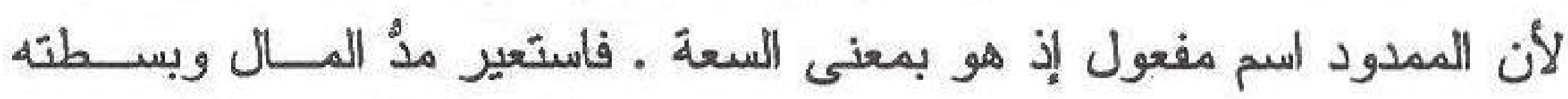
لكثرته وسعته كمدً الماء بين الوديان ، فقد تشعَّب مال الوليد وكثر بين مكـــة

$$
\text { والطائف. }
$$

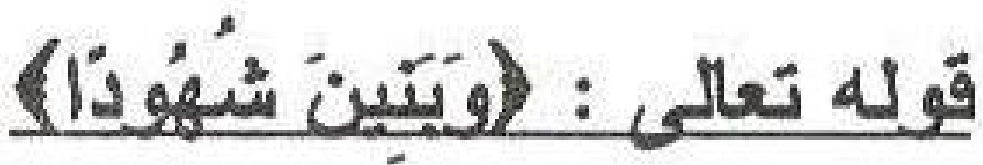

الإنظم البلاغى : قوله : "وبنين" جملة معطوفة على سابقتها موصولة بها لا تفاقهما فى الخبرية ، فلما ذكر سبحانه أنه قد أعطاه المال ، امــنَّ الشه 


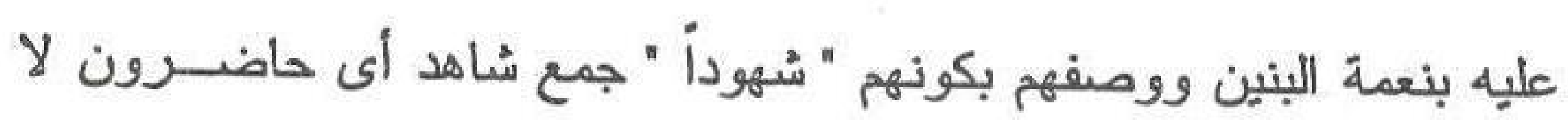

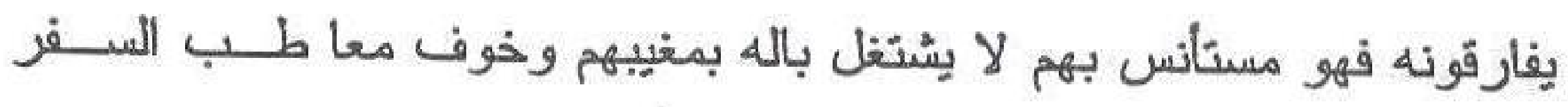

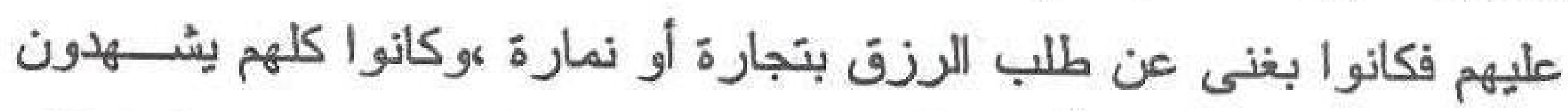

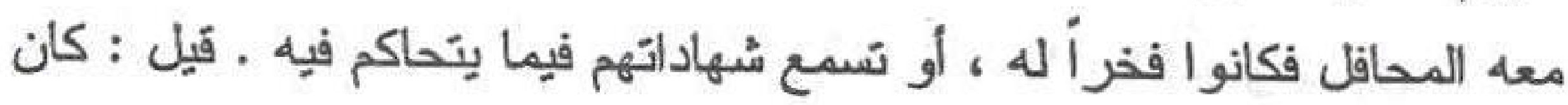

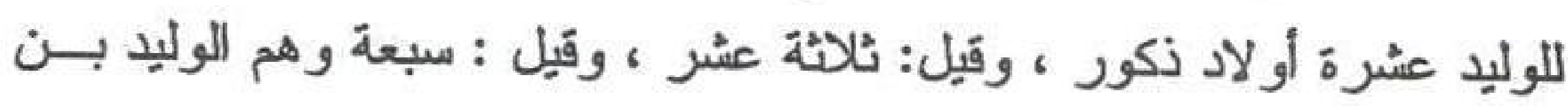

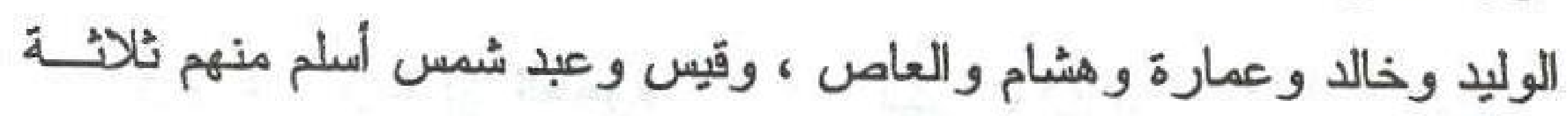
خالد و هشام و الوليد .

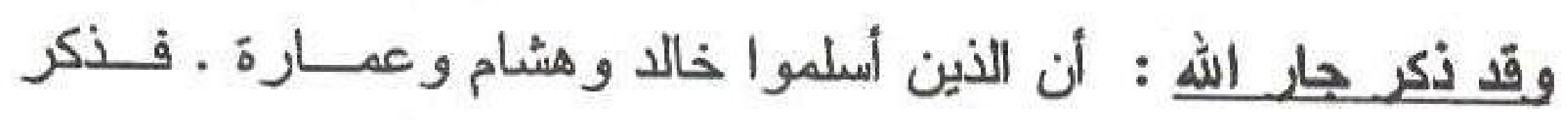

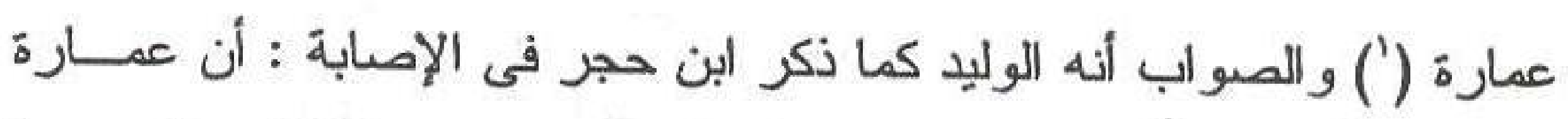

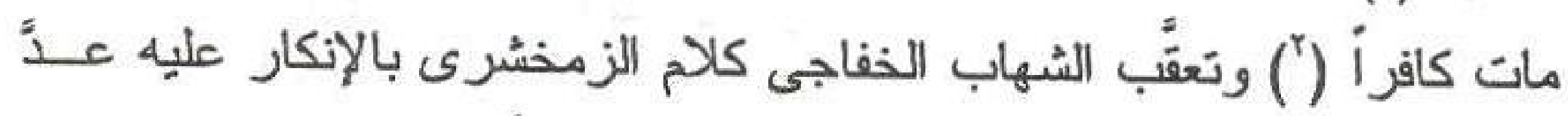

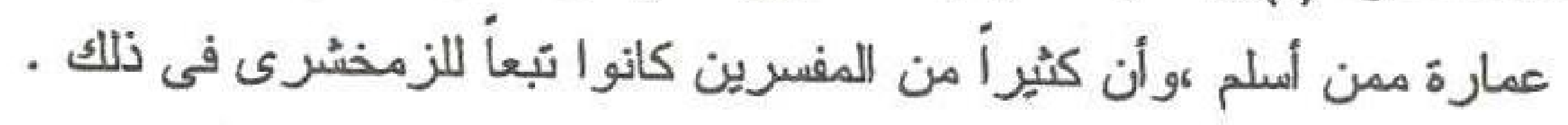

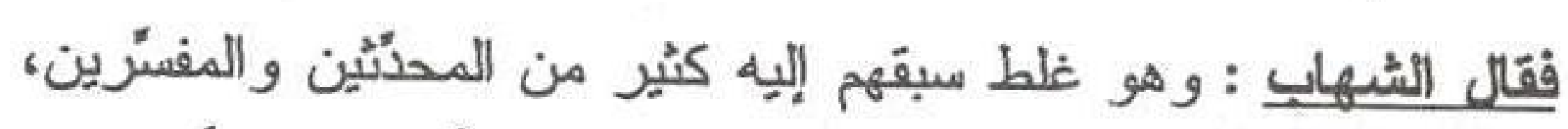

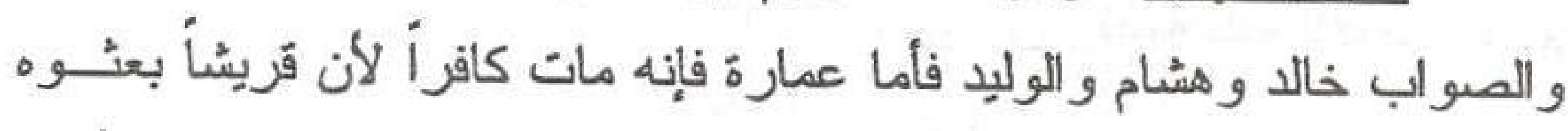

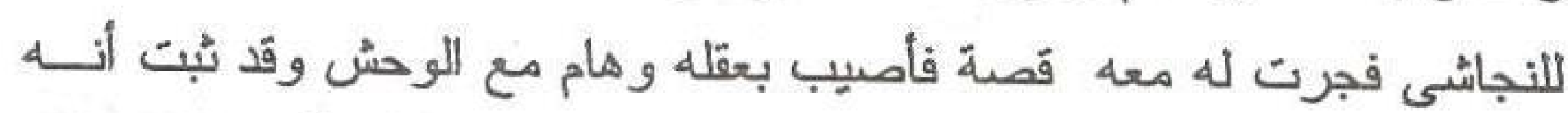

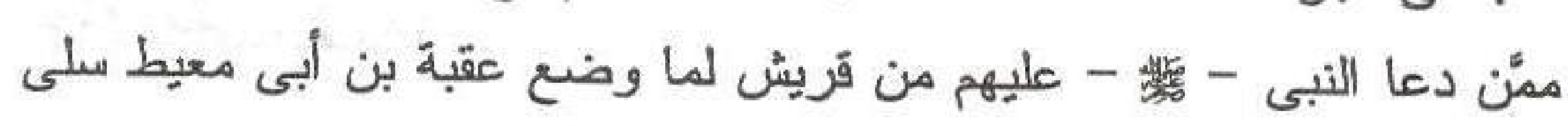
الجزور على ظهره وهو يصلى (").

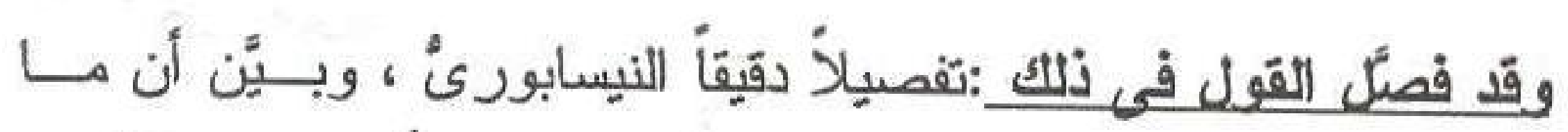

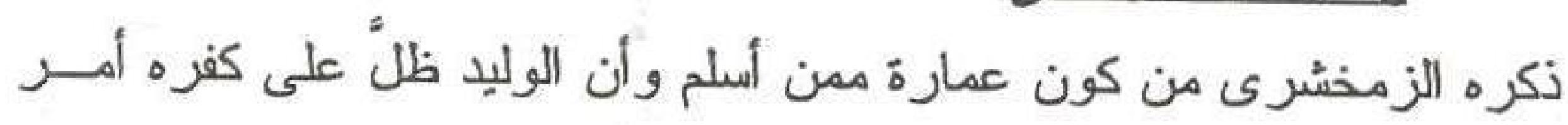

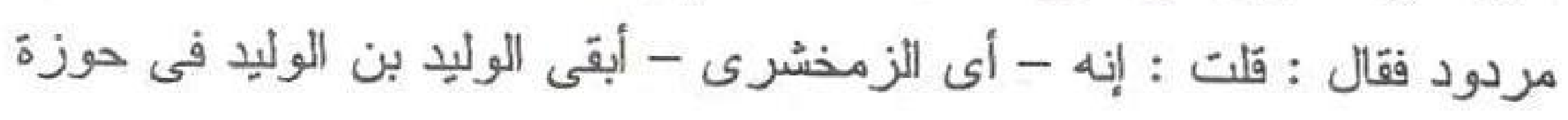




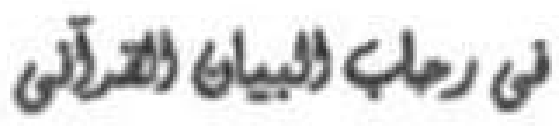

الكفرة ، وهو مصلم حسن الإسلام مغهور الصدبة كما ذكره رثــيد الــدين الوطو اط فى رسالته وصاحب سر العلف سيد الحفاظ أبو القاســم ـ فيـهـ أن

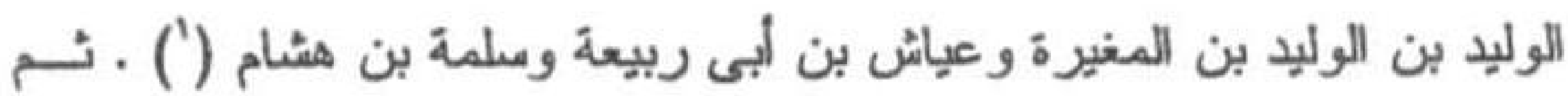

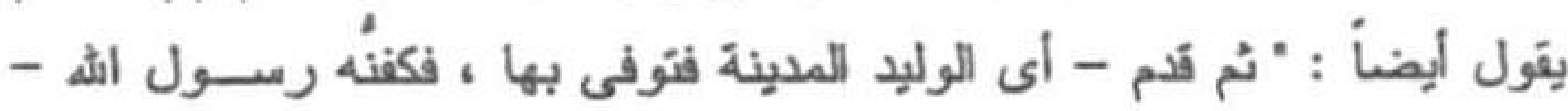

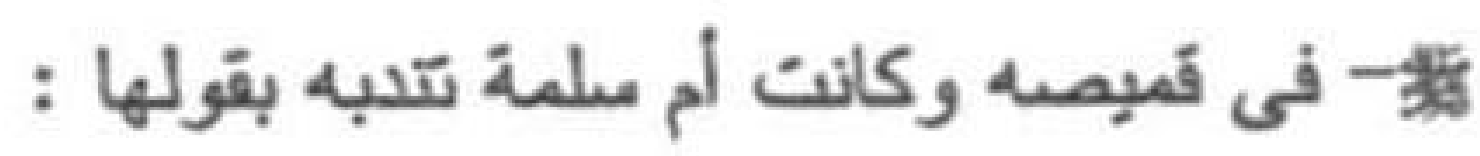

أبكى الوليد بن الوليد بن المغيرة لبكى الوليد بن الوليد أخا العطيرة

والعجب من - جار اله - أنه ذكر فى سورة الزمر فى تقسير قوله :

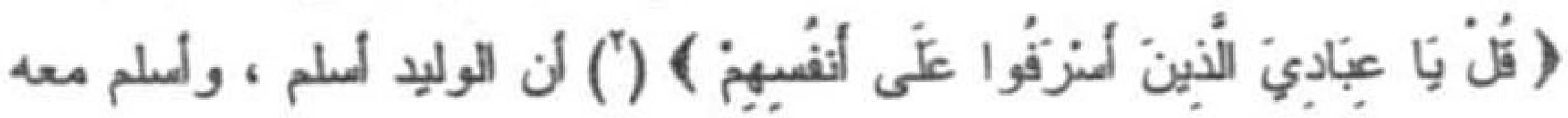

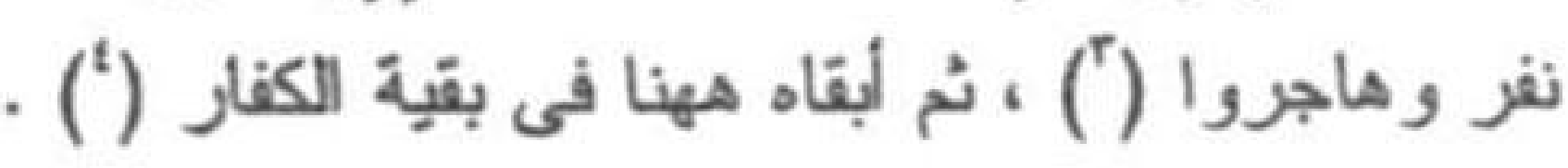

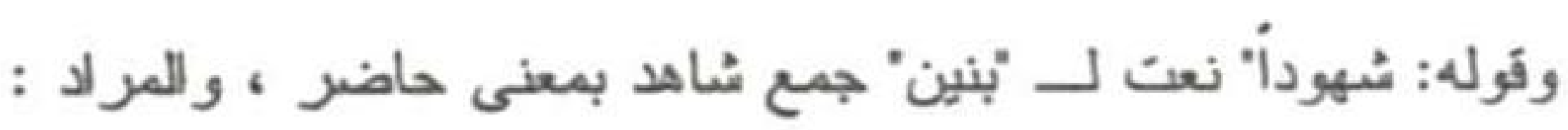

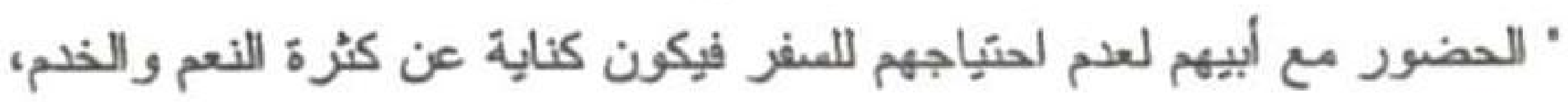

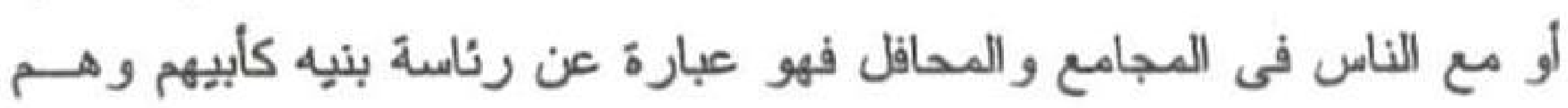

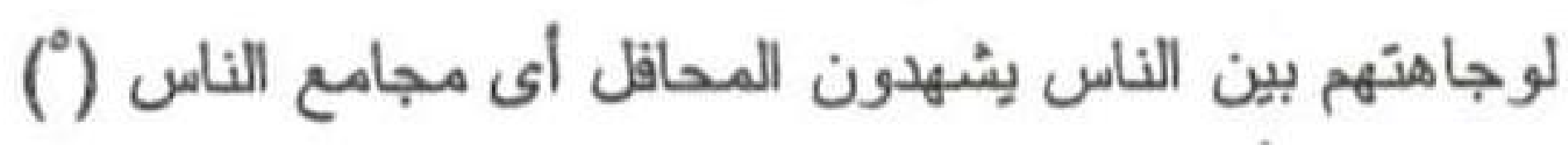
قوله تعلالم : (ومهيت له تمهيدا) .

اللنظم البلاغىـ: قوله : "ومهدت" معطوف على ما سبق من عطـــ

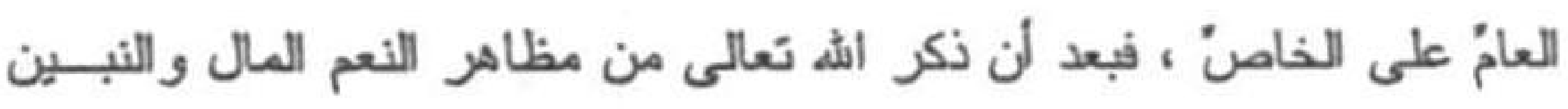

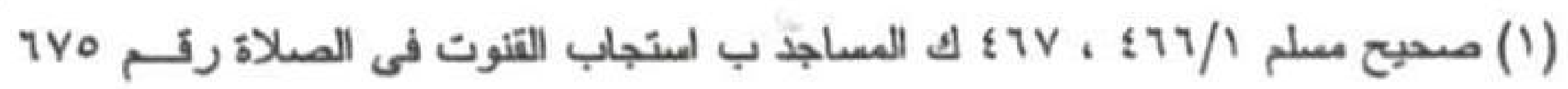

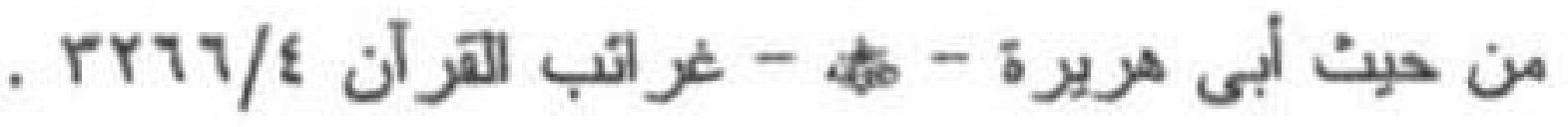

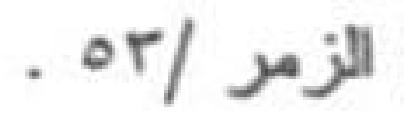

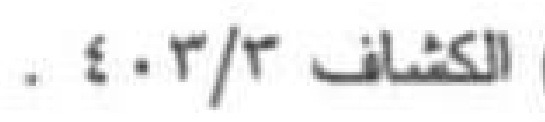

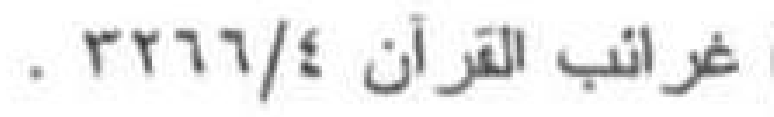

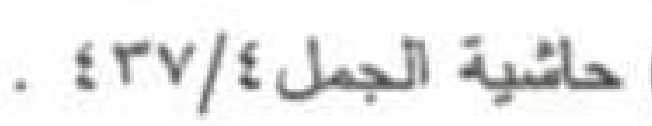


عاد هنا فعمُ الخيرات الدنيوية التى أنعم بها عليه فقال تعالى : " ومهُخت له

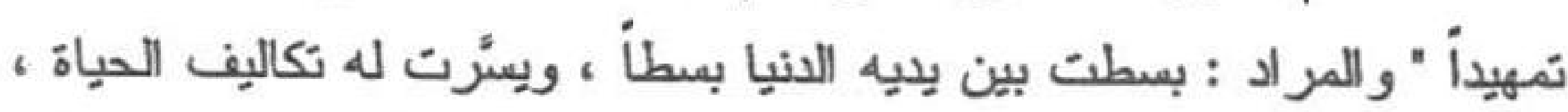

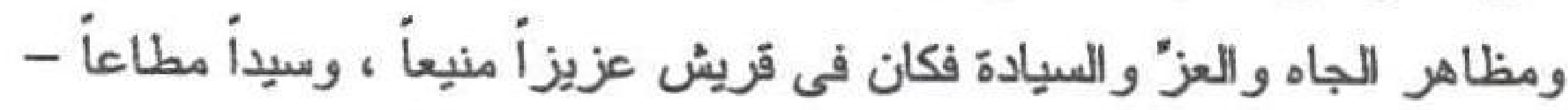
و المراد من الآية : بسطت له الرياسة والجاه العريض فأتممت عليه نعمنـى ولى

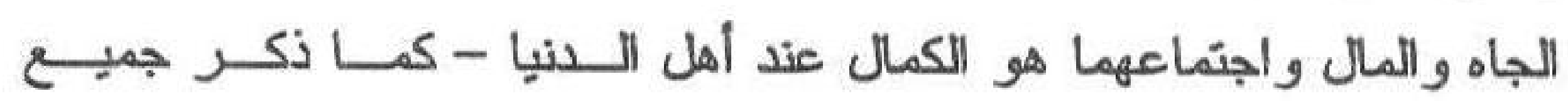
المفسرّين - حتى جعل الناس ذلك دعاء الخير فيما بينهم ، قـائلين: أدام الله تأيبدك وتمهيدك ، ولذللك كانوا بلقبونه بالوحيد وريحانة قريش لان الريحــان

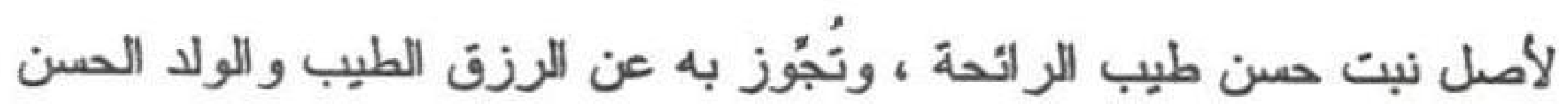

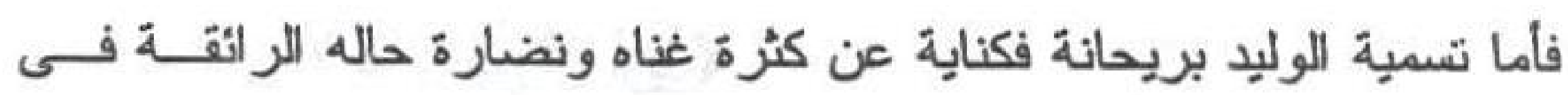

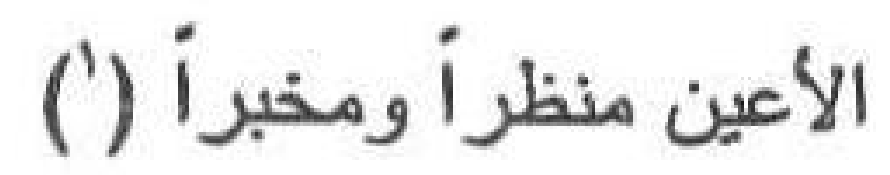

والتمهيد : مصدر مهُّ بالتشّديد فى الهاء ، وهو دالُ على قوة المهد ، و المهد هو تسوية الأرض وإز اللة ما يقضن جنب المضطجع عليها ، ومنه مهد

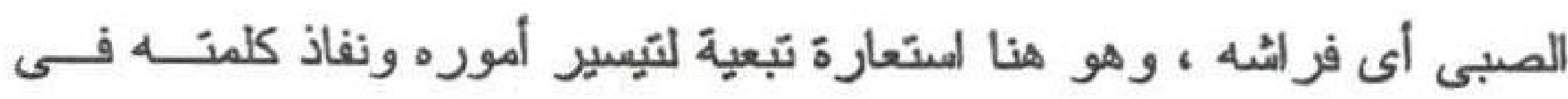
قومه بحيث لا يعسر عليه مطلب ولا بِتعصى عليه أمر ، فهو مسنعار من مهاد الأرض وفرام الصبى لتيسيز الأمور وبسطة الجاه والمــال و الولــده،

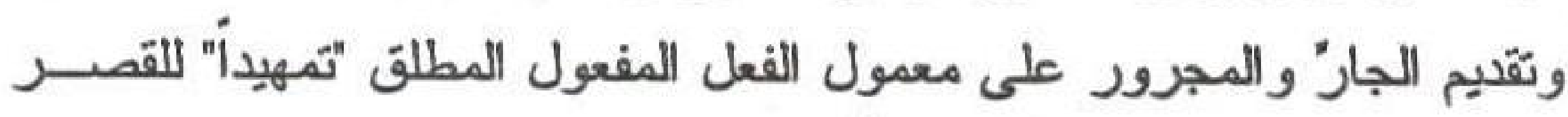

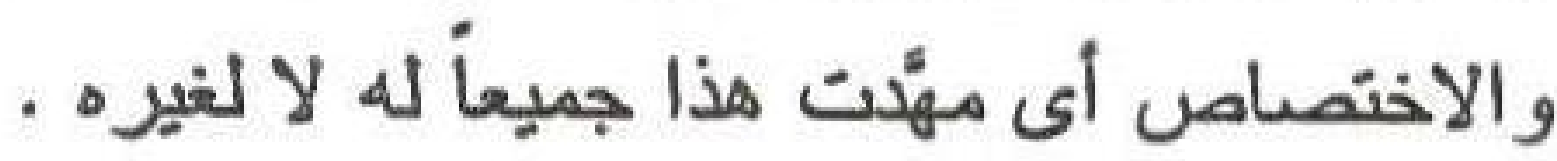
وجاء الفعل "مهًّدت" مؤكدأ بمصدره على المفعولية المطلقة ليتوسـل بتكيره لاافادة تعظيم ذلك التمهيد ، وليس يطرد أن يكون التأكيد لرفع احتمال - 1المجاز 


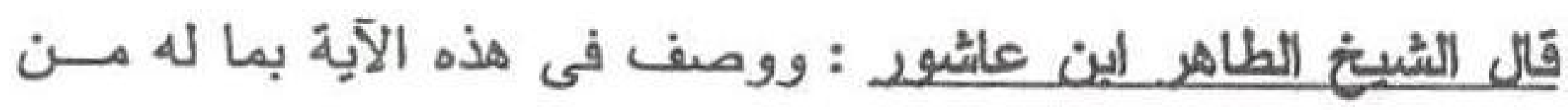

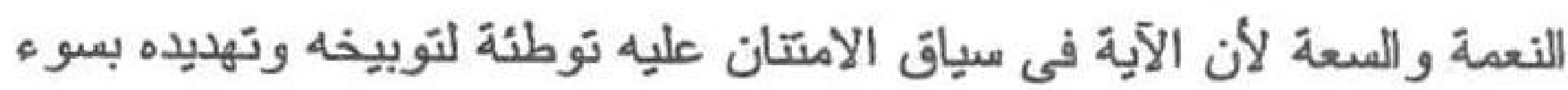

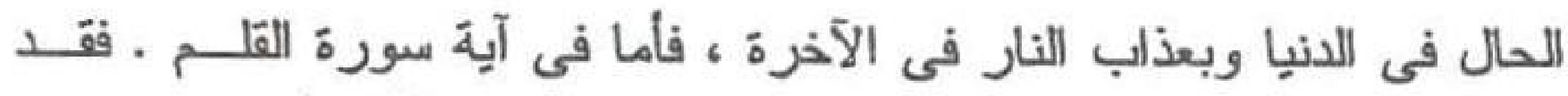

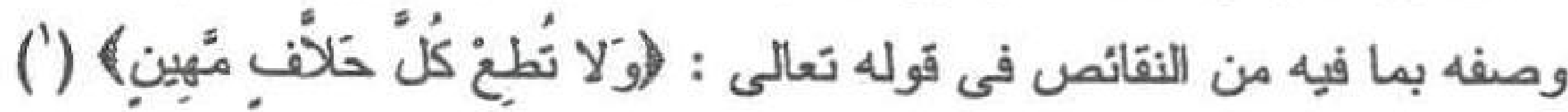

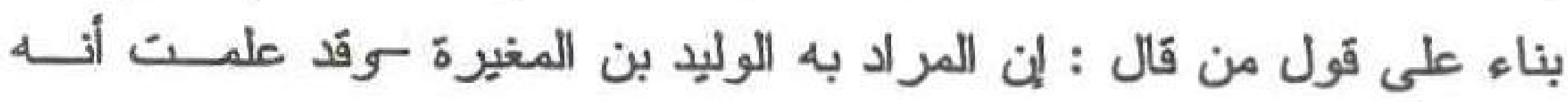

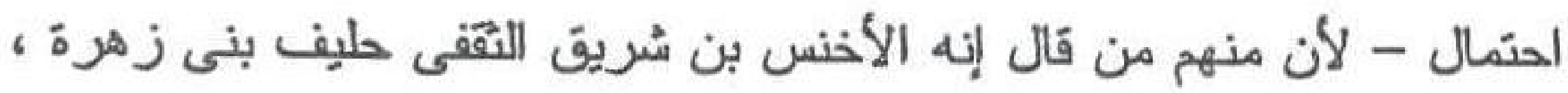
أو الأسود بن عبد يغوث الزهرى - لأن تلك الآية فى مقام التحذير من شره

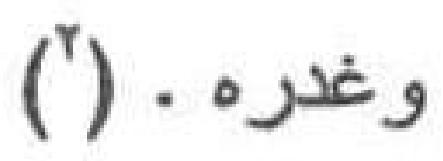

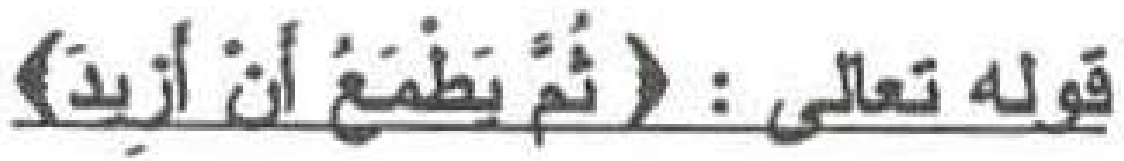

إلنظم البلاغى : قوله : "ثم يطمع " جملة معطوفة على ما سـبق ،

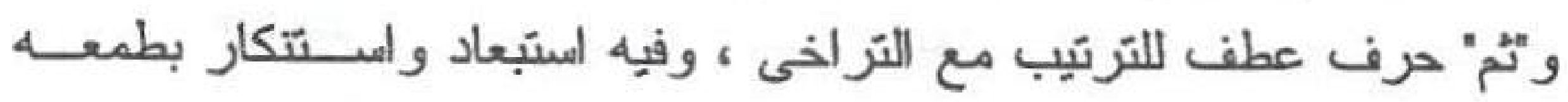
وحرصنه وتهالكه على زيادة المال و النعمة .

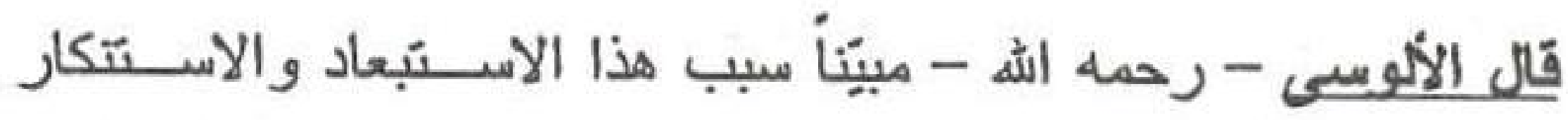

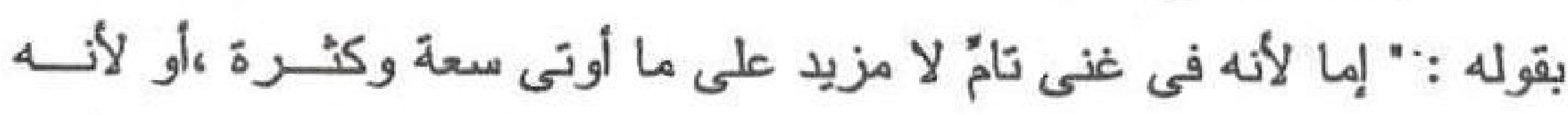

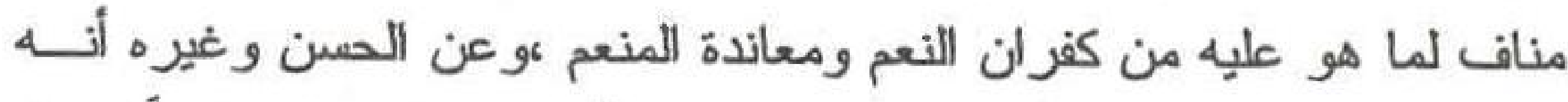

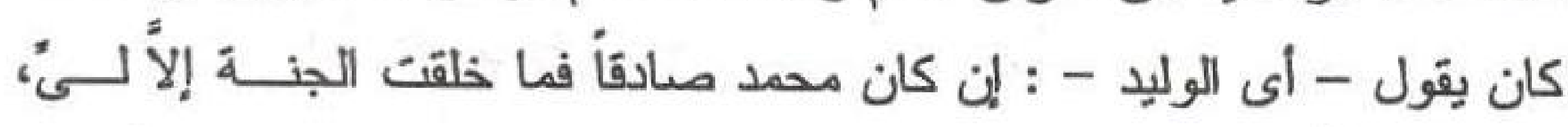

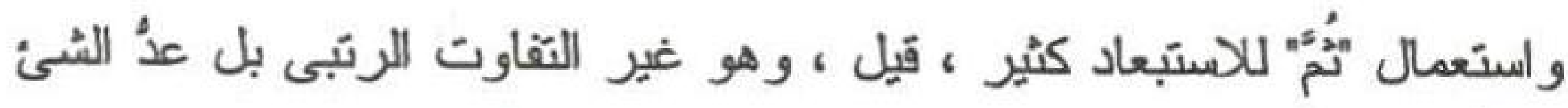

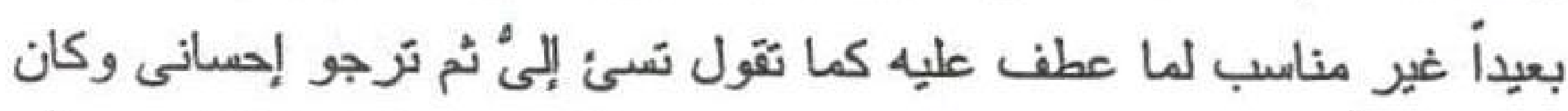

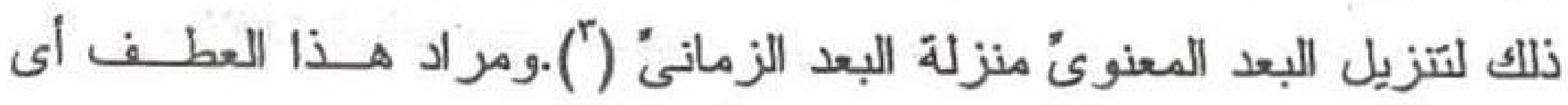


و أعظم من ذللك أنه يطمع فى الزيادة من تلك النعم ، وذلك بما بعــرف مــن يسر أموره ، و هذا مشعر باسنبعاد حصول المطموع فيه وقد صرح به فيه فئى

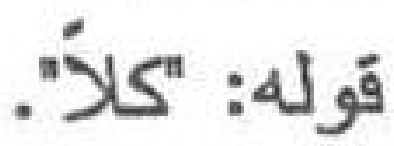

و - الطمع - كما يقول المشيخ الطاهر ابن عاشور هو : " طلب الشئ

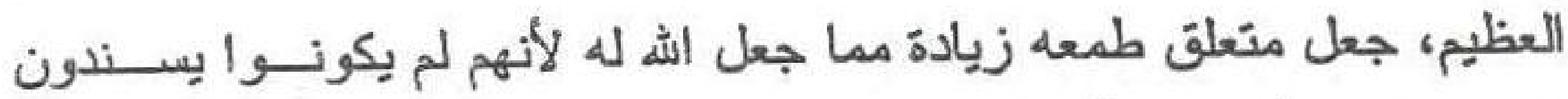

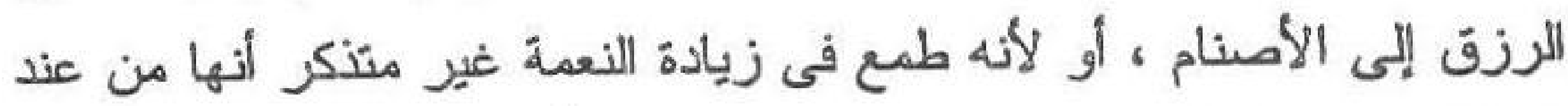

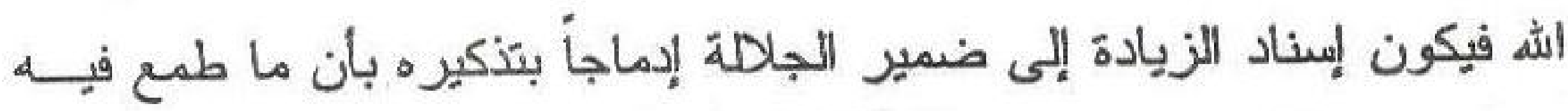
هو من عند الذى كفر هو بنعمته فأشرك بـ غيره فى العبادة ، ولهذه النكتــة

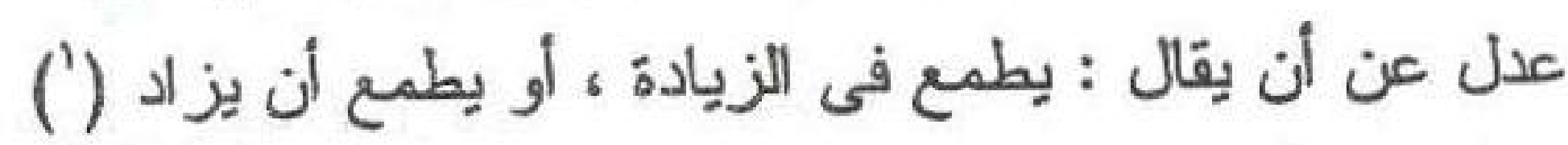
ومجئ الفعلين "بطمع" و "أزيد" مضار عين دلالة على تجدد واستمر ار هاتين الخصلتين منه ونكرار ذلك منه فهو طالب منهوم لا ينقطع طلبه وشُدة طمعه فى الزيادة أو الاستز ادة من المال و الولا و الجاه . وقد جعل الإمام الفخر الرازى : العطف بــ "ثم" للإنكار و التعجــب فيقول : " لفظ - ثم ههنا معناه التعجب كما تقول لصاحبك : أنزلت لك دارى

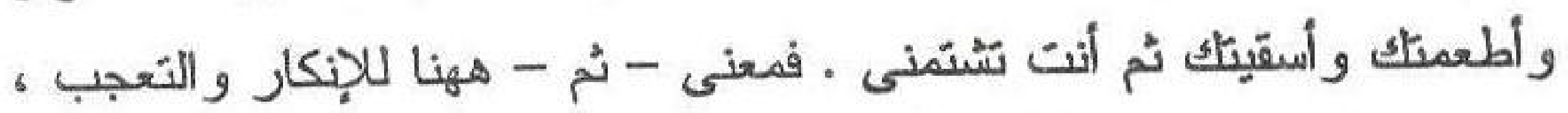
ثُم تلك الزيادة التى كان يطمع فيها هل هي زيادة فى الدنيا أو فى الآخــرة ؟

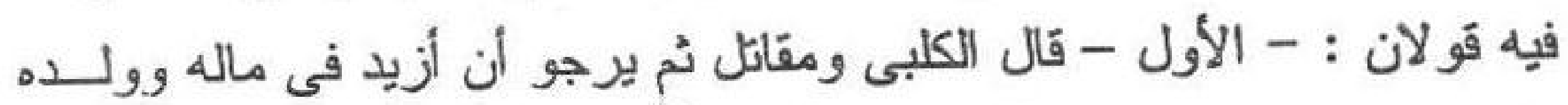
وقد كفر بى ، - الثانى - أن ثلأك الزيادة فى الآخرة قيل : إنه كان بقول إنى

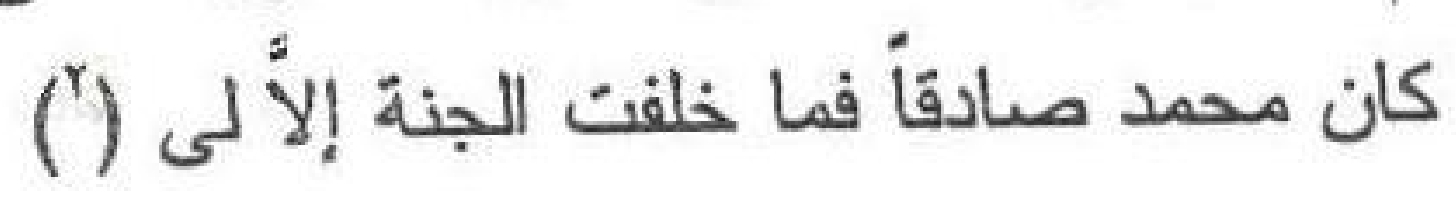


نى رهابع البيان (لاتركآى

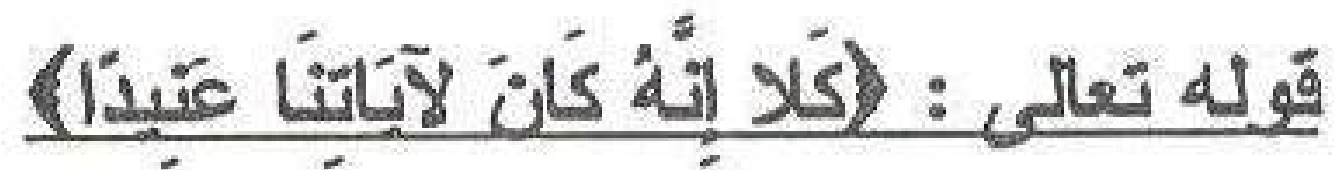

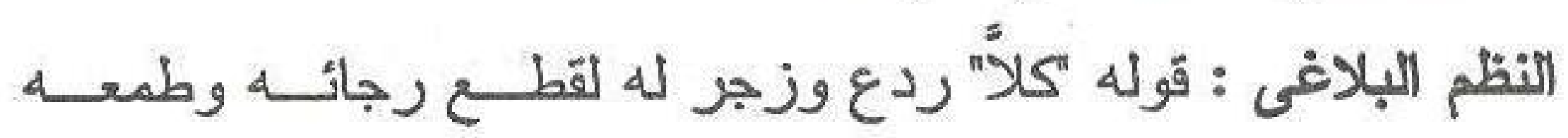

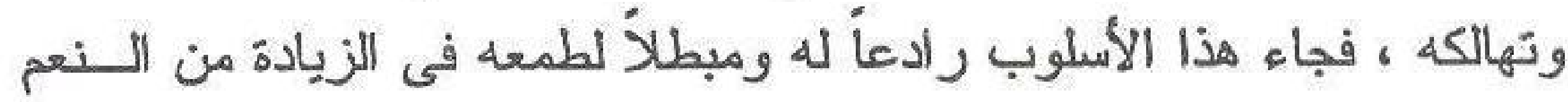

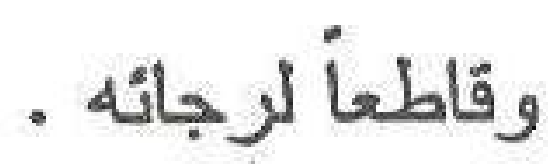

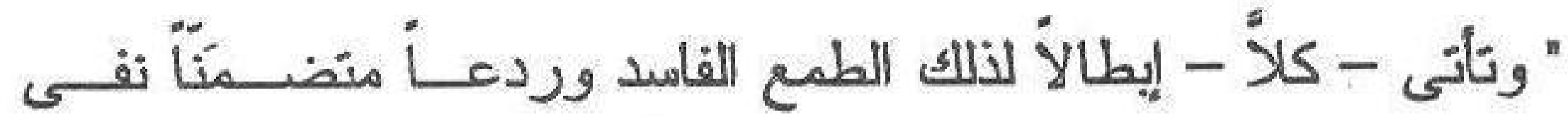

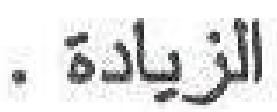

- يقول المفسرّون - : ولم يزل الوليد فى نقصان بعد قوله - كلاًّ -

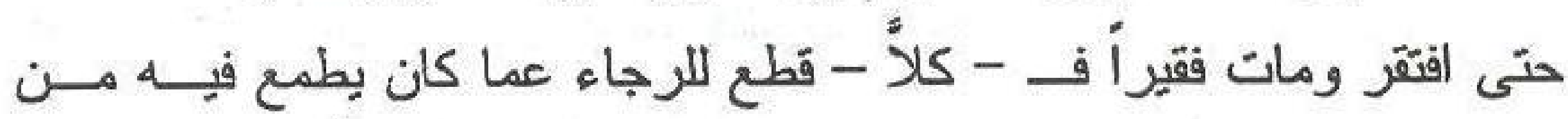

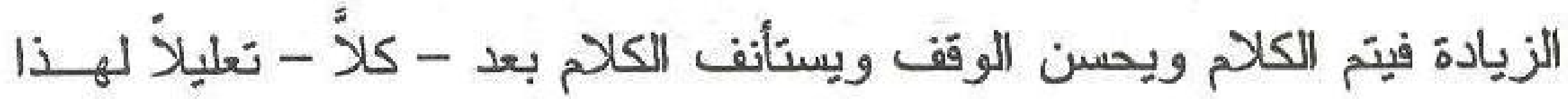

الردع المتضّمن النفى بقوله : - إنه كان لآياتتا عنيداً - كأن قائلأ قال : " لم لم

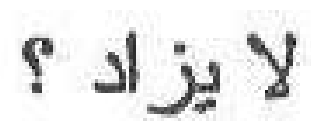

فقيل : إنه عاند آيات المنعم وكفر بذلك نحمثنه ، والكافر لا يســتحقُ

(') (المزيد (2)

وقد لمح الشيخ الطاهر ابن عاشور فى أسلوب الردع هذا ملمحاً دقيقاً

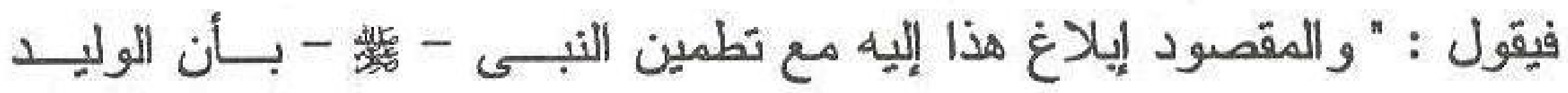

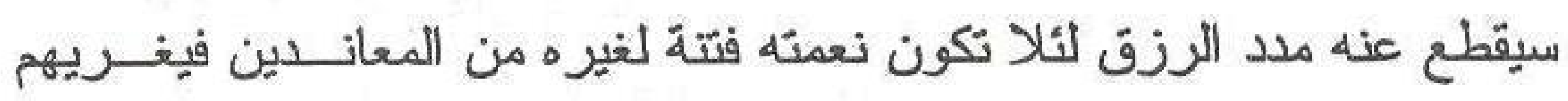

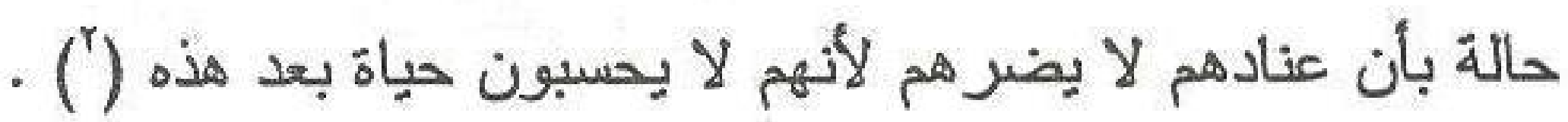

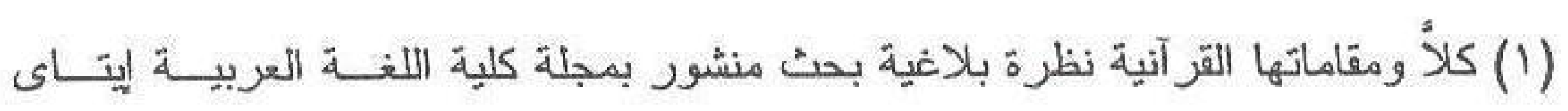

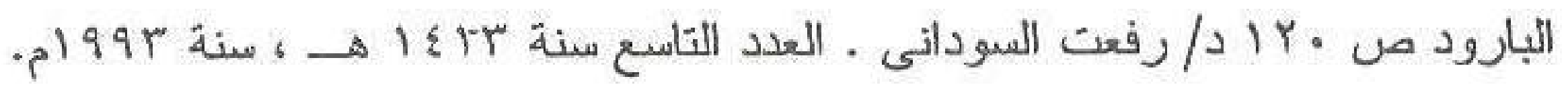

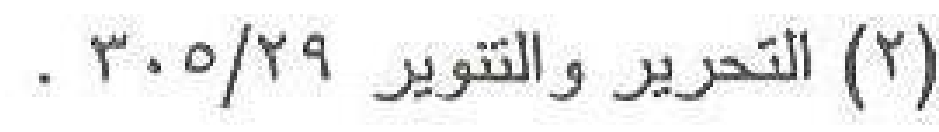




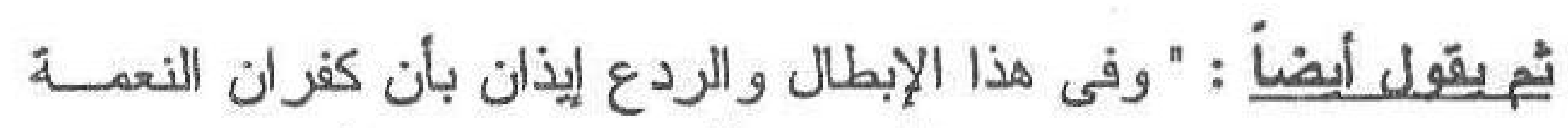

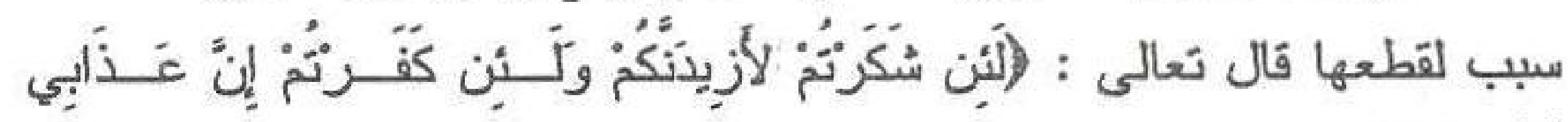

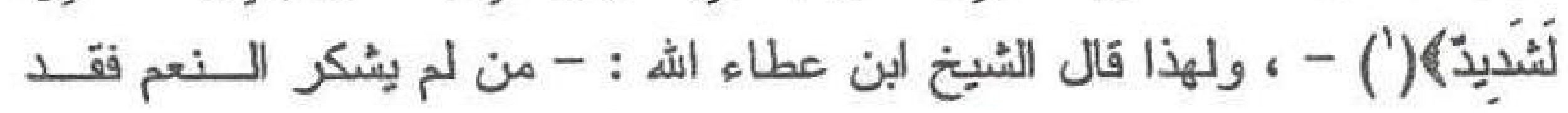

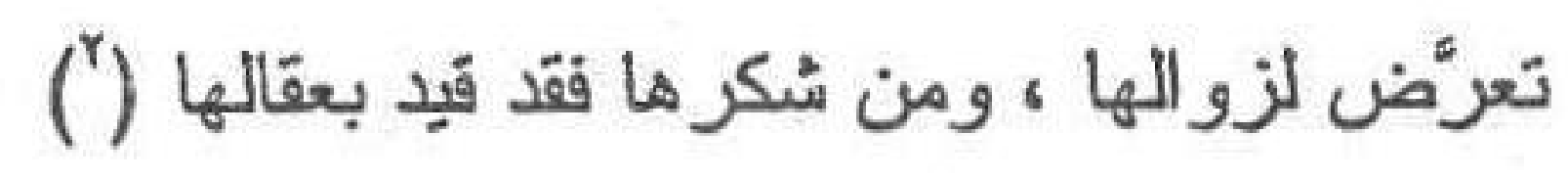

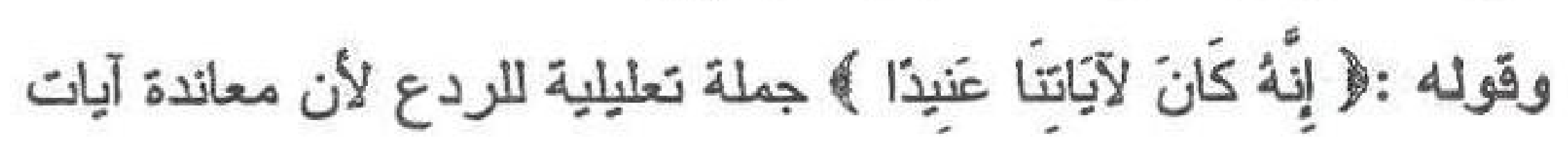

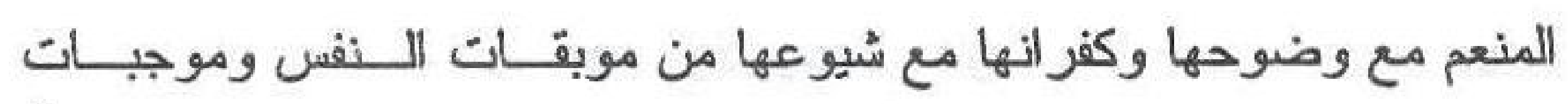

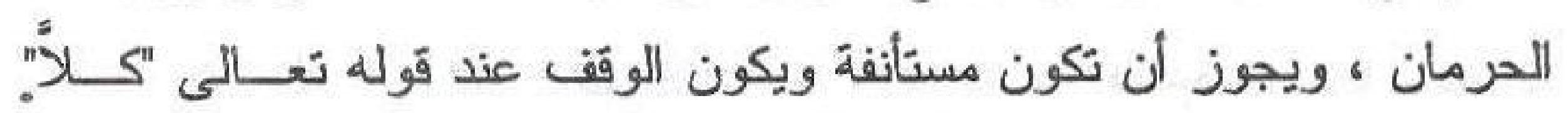

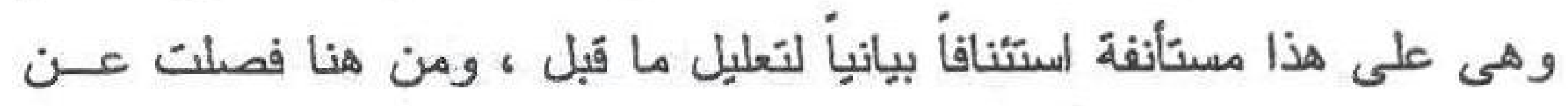

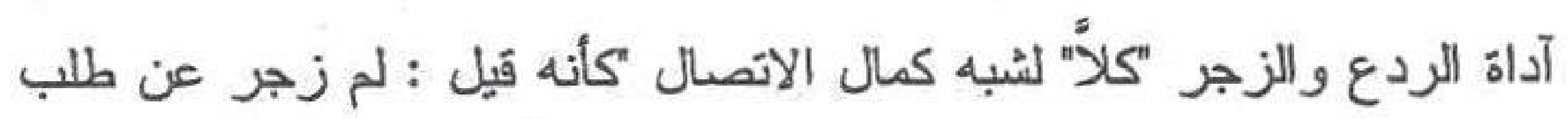

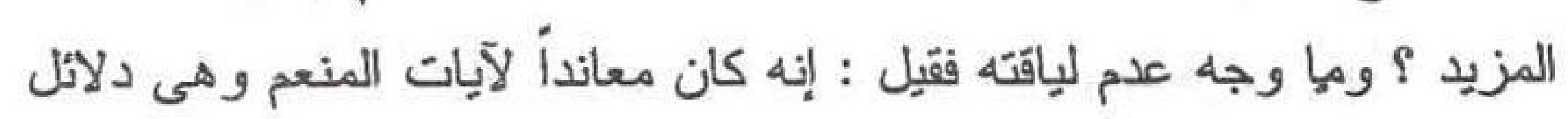

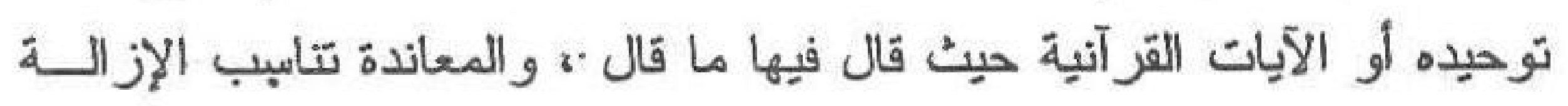

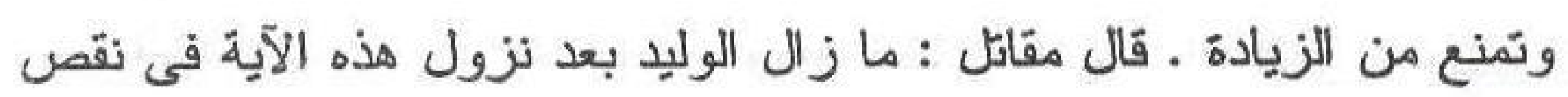

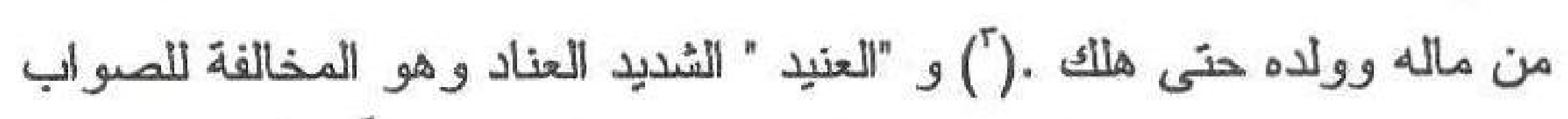

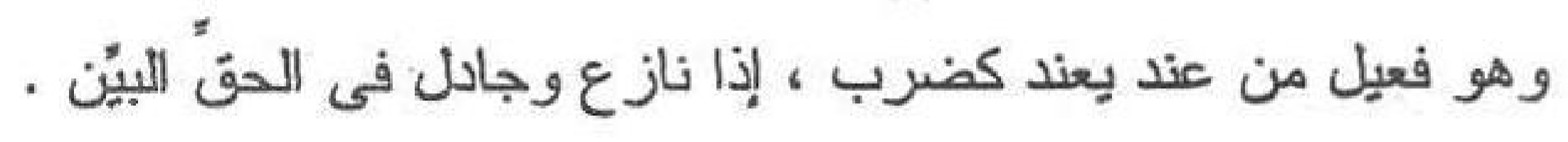

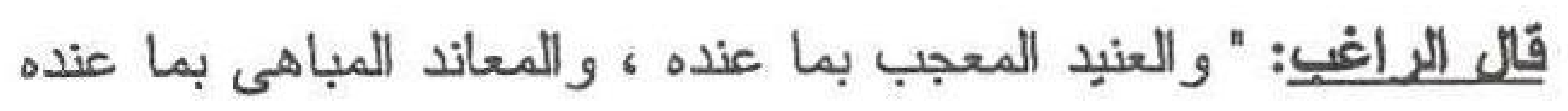

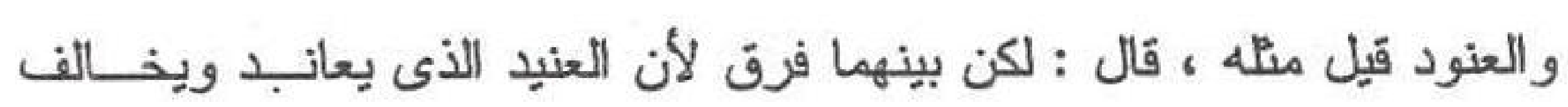

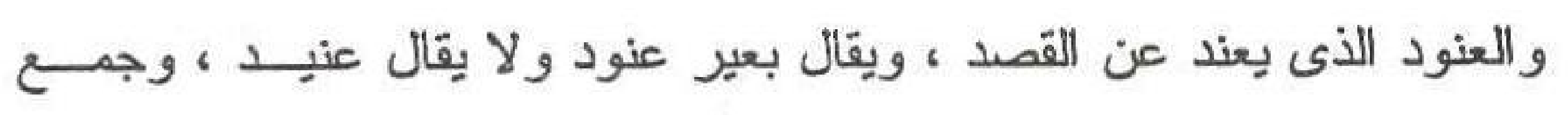

$$
\begin{aligned}
& \text { (1) (1) إير اهيم / (1) }
\end{aligned}
$$

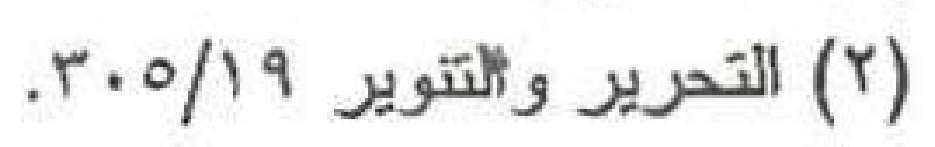

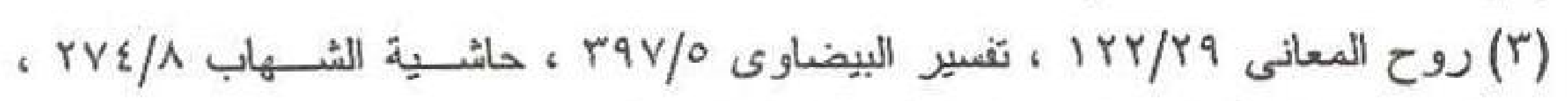

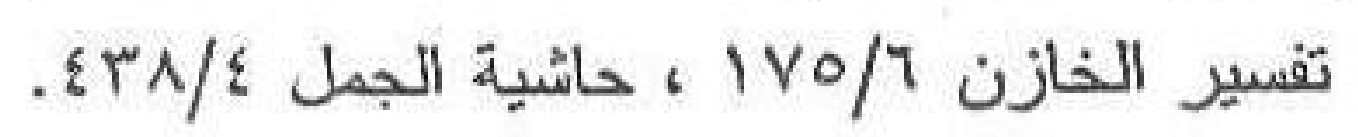


العنيد عند ، والعنيد العادل عن الطريق فى الحكم ، وعند عن الطريق علل (') عنه ولما كان اللوليد بن المغيرة بهده المنزلة من العناد والكفر والجحـود

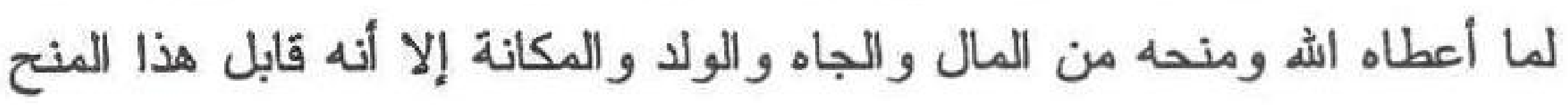
و العطاء والتمهيد بالجحود ، فلما كان كذلك فلا مزيد له لأنه كافر .

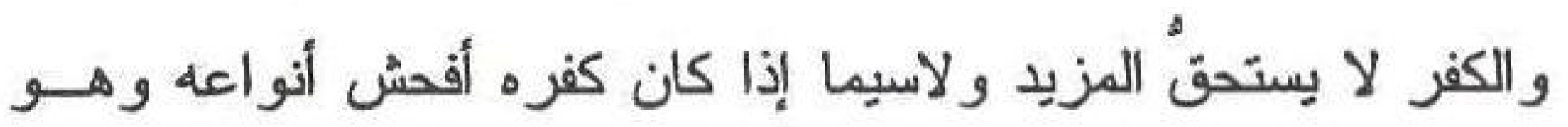
كفر العناد و العنيد : هو الذى كان العناد خلقه وديدنه فلثدة عناده وصفه الله

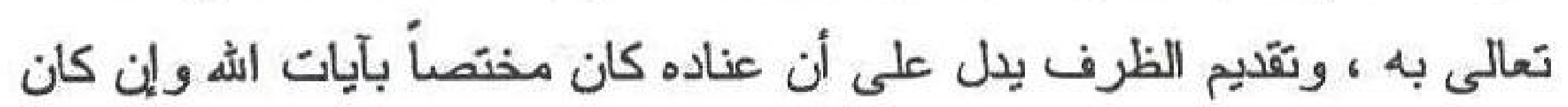

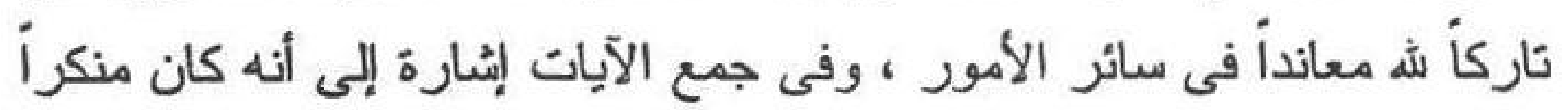

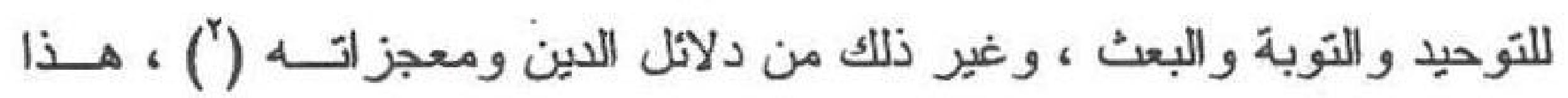

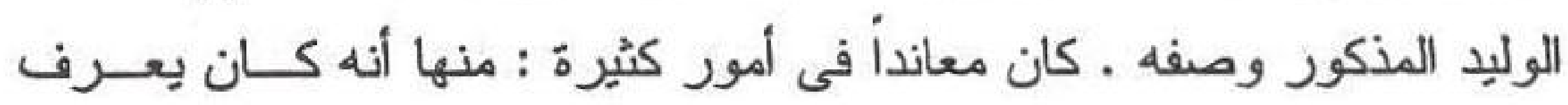

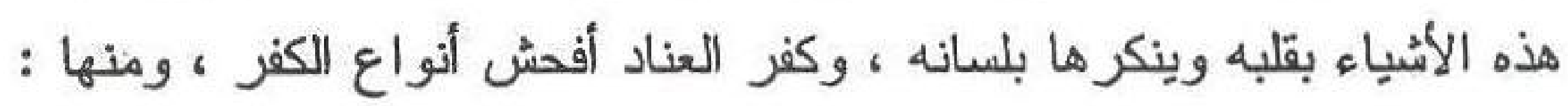

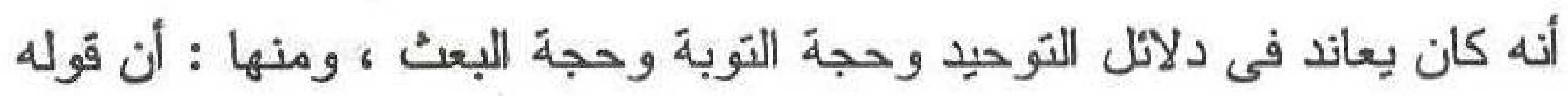

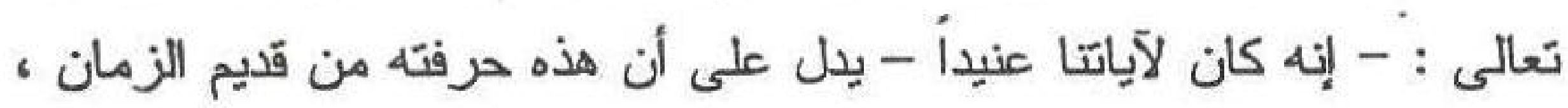

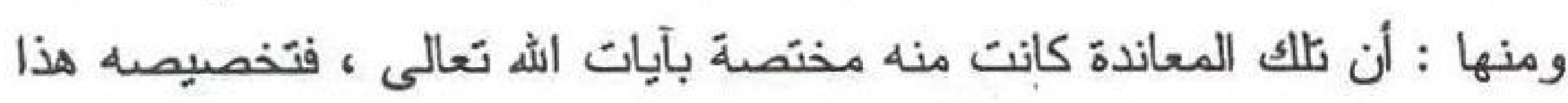

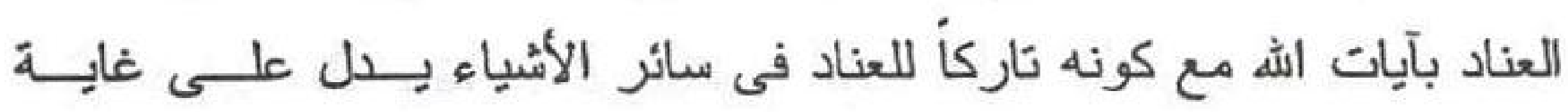

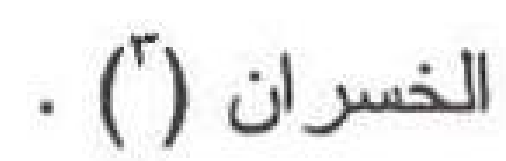

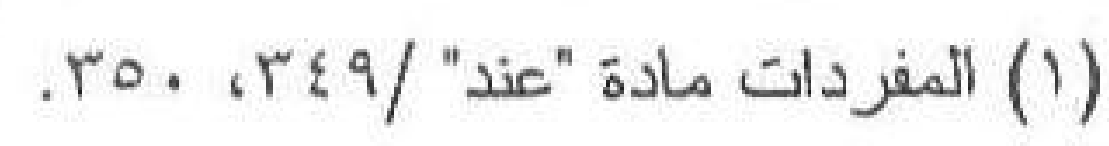

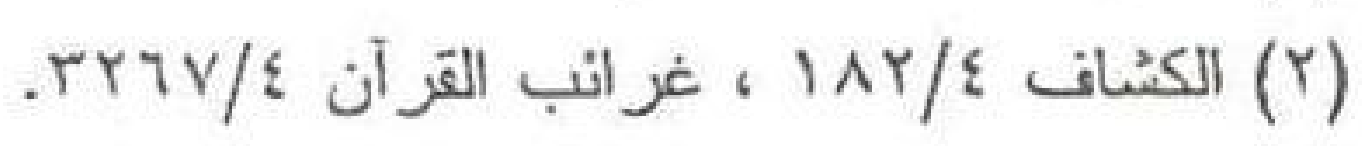

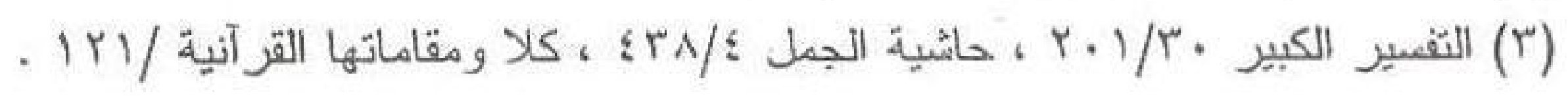




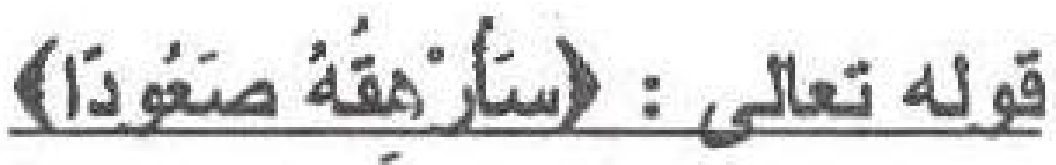

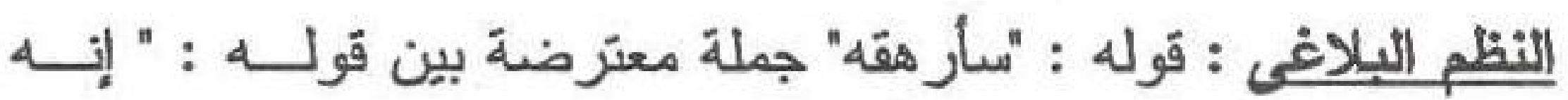

كان لآياتتا عنيداً :وبين قوله : "إنه فكرّ وقدًّ " وفصد بهذا الاعتر اض تعجيل

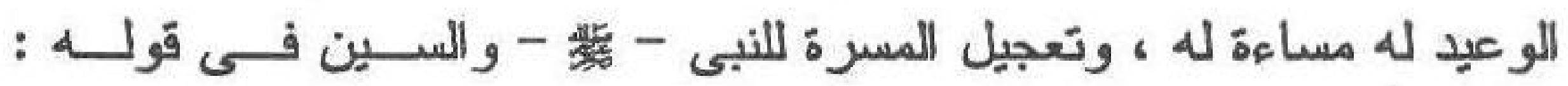

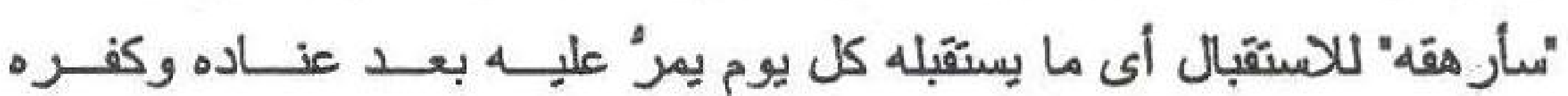
الشديدين لآيات الله ، والإرهات : الإتعاب وتحميل مالا بطات يقال : " رهقه

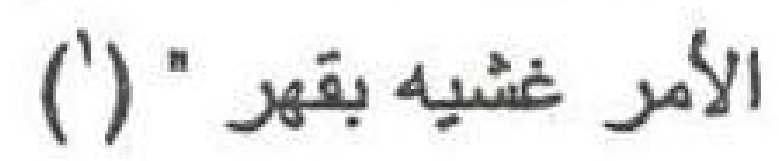

و المراد من هذا الفعل مأغشيه عقبة شاقة المصعد ، وهذا من قبيـلـل

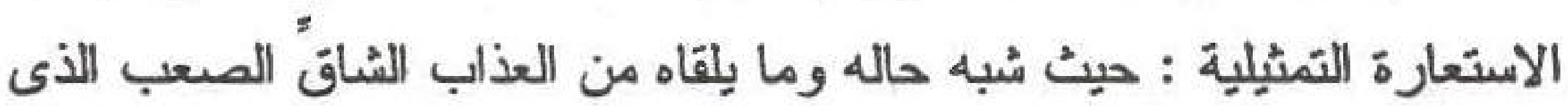

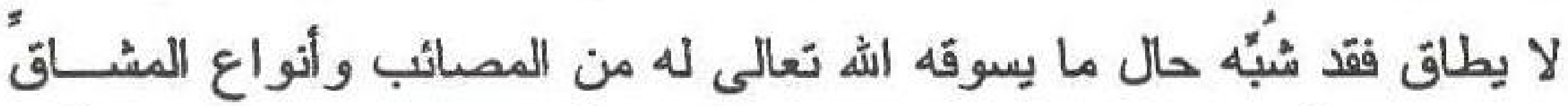

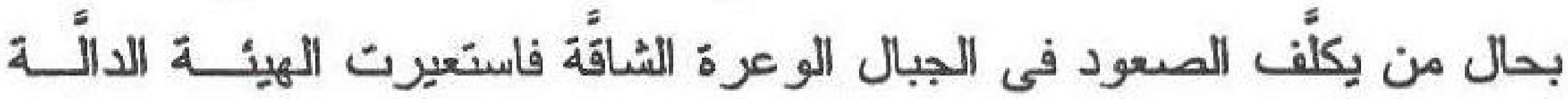
على المشَّه به للهيئة الدالَّة على المشّبّه على سبيل الاستعارة التمثيليــة ، أو أنه " سينقلب حاله من حال راحة وتتعُم وتمهيد وبسطة المال و الجاه إلى حالة سوأى فى الدنيا ثم إلى العذاب الأليم فى الآخرة ، وكل ذلك إرهات له (r) . فاستعيرت حالة العذاب و الشُقاء لضد الحالــة العــابقة مــن النعـيم و الراحة وفاعل "سأرهقه" وهو المسند إليِه حذف لأنه معلوم لدى السـامعين

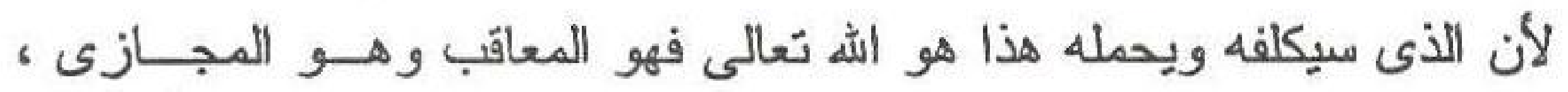

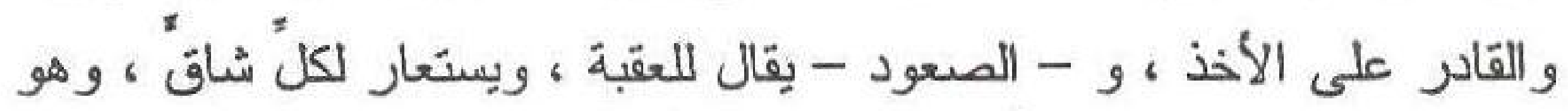

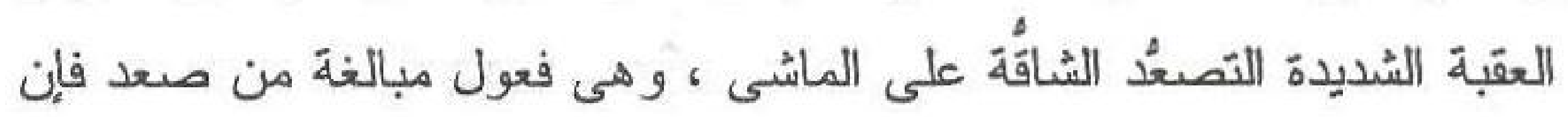

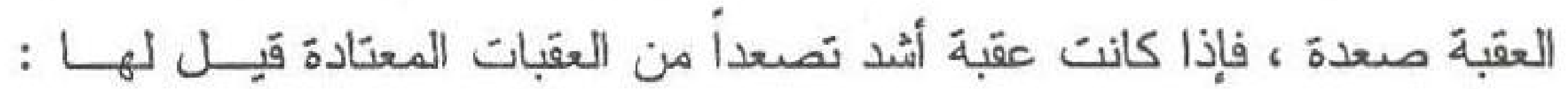

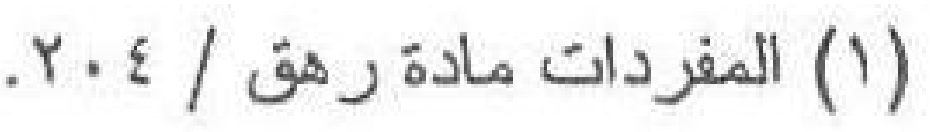

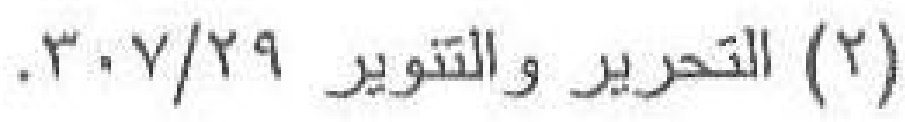


صعود ، وكان أصل هذا الوصف أن العقبة وصفت بأنها صاعدة على طريق

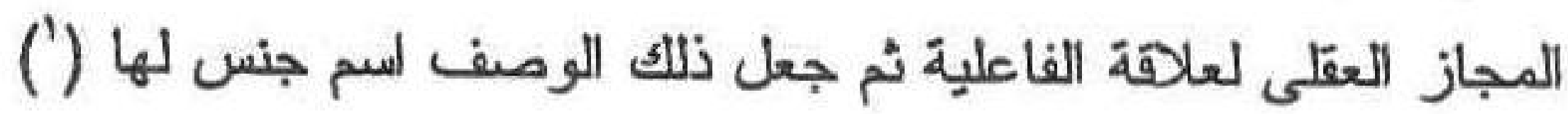

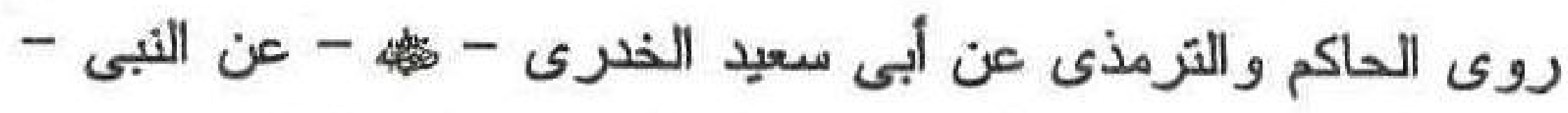

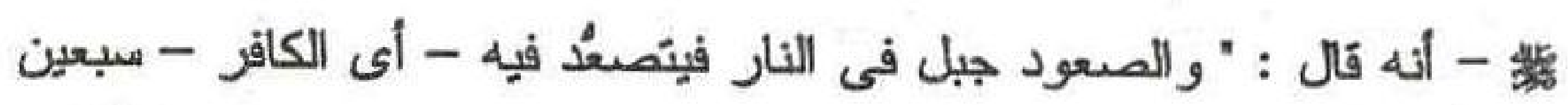

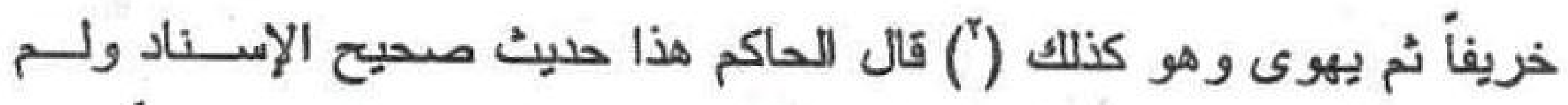

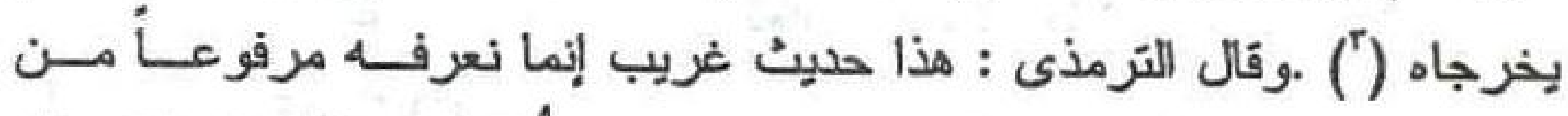

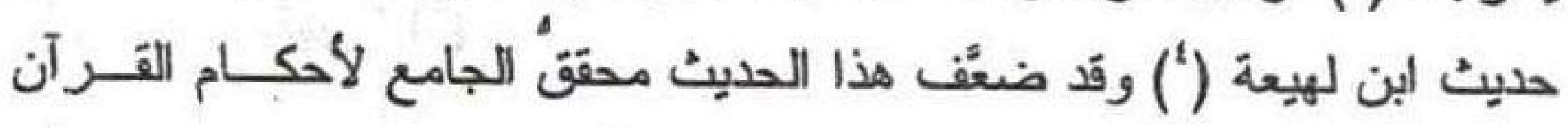

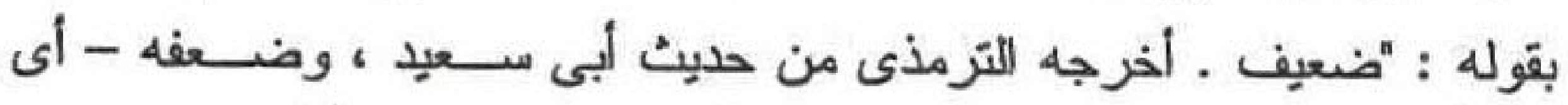

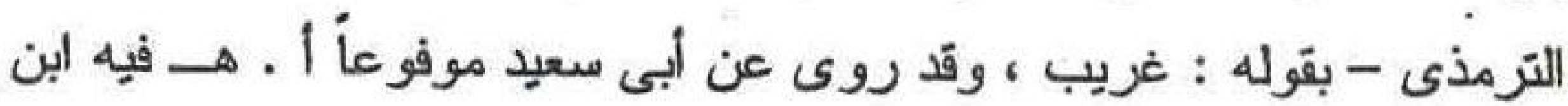

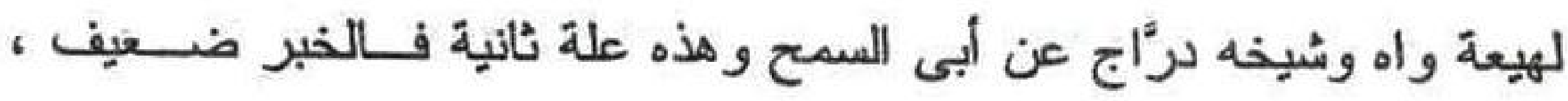

والراجح وقفه " ( )

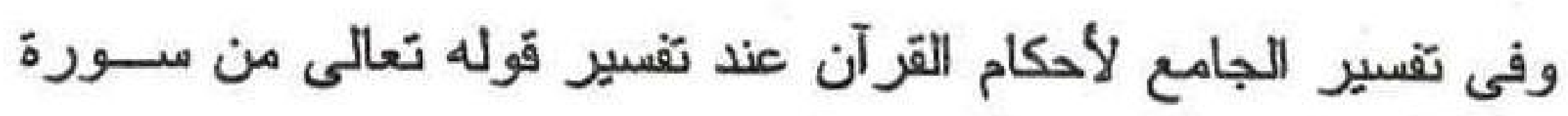

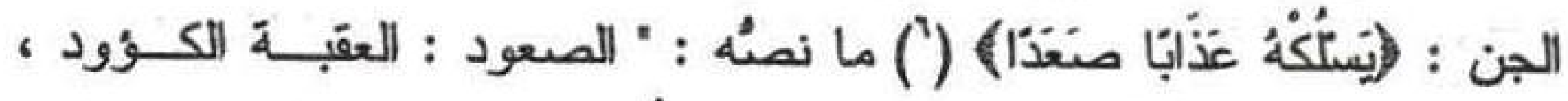

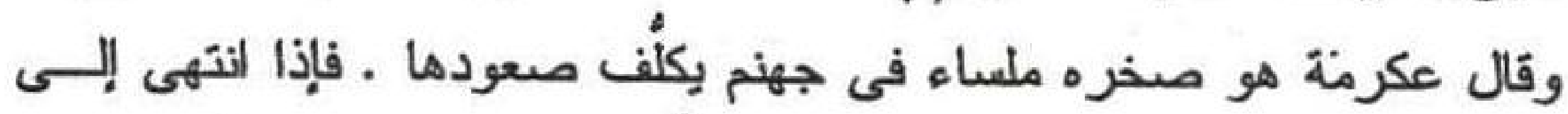

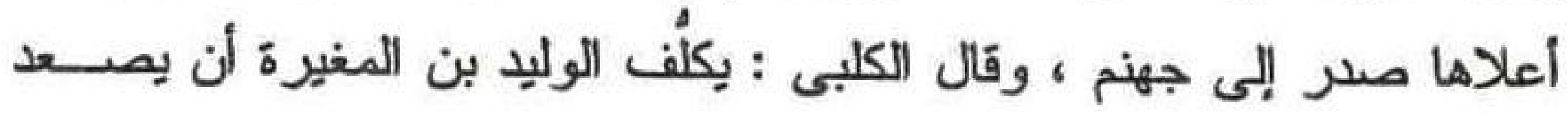

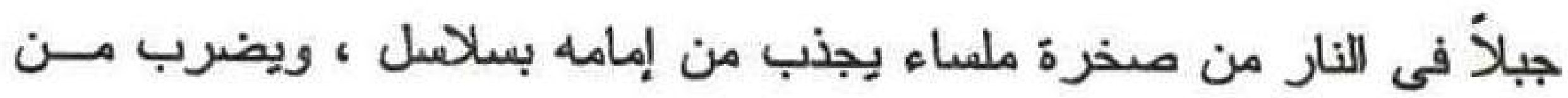

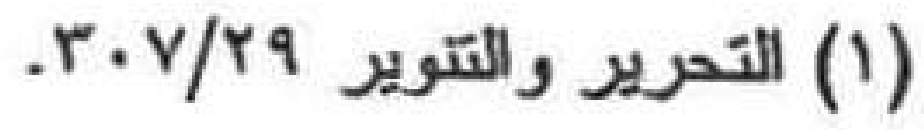

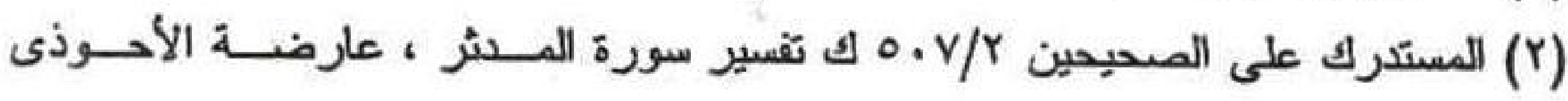

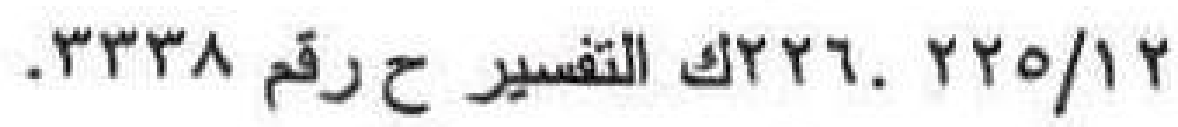

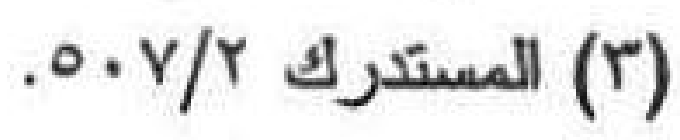

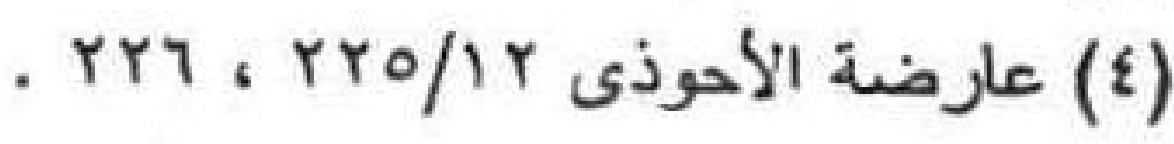

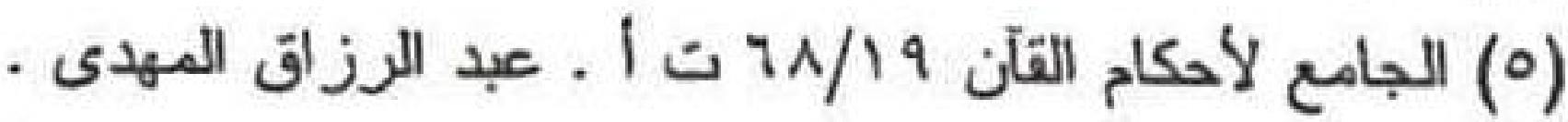


خلفه بمقامع حتى يبلغ أعلاها ولا يبلغ في أربعين سنة ، فإذا بلـــغ أعلاهـــا

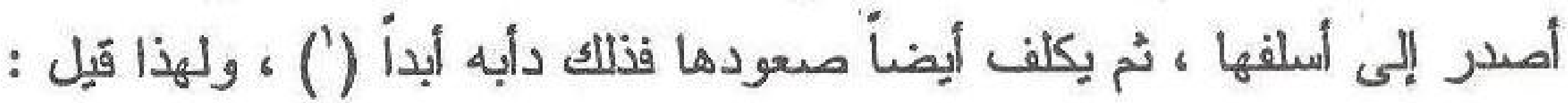
إنه طال به الفزع فكانت تتصاعد نفسه ثُ لا يموت ، وقد جعل له من عذاب النار ما أسفر عنه عذاب الدنيا .

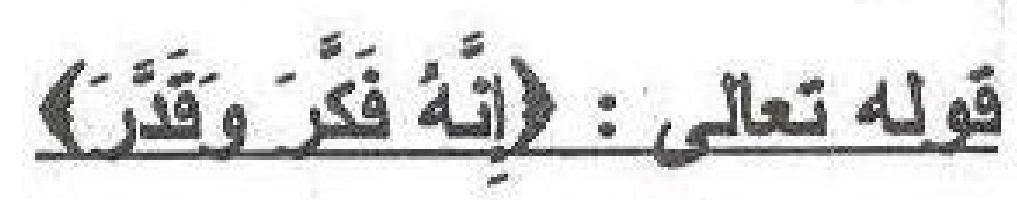

النظم البلاغى : قوله : "إنه فكر " تعليل لاستحقاقه هذا الوعيد الأنف

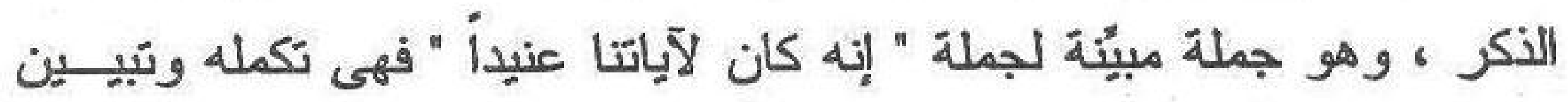
لها، ومن هنا فصلت هذه الجملة " إنه فكرّ وقدَّ " عن جملة " إنه كان لآياتنا

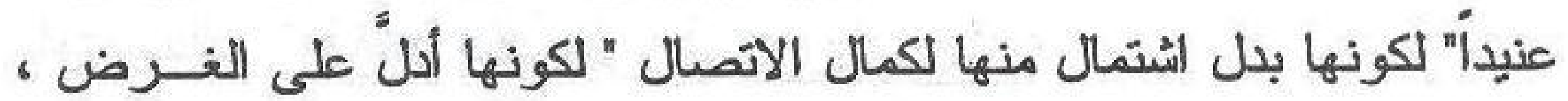

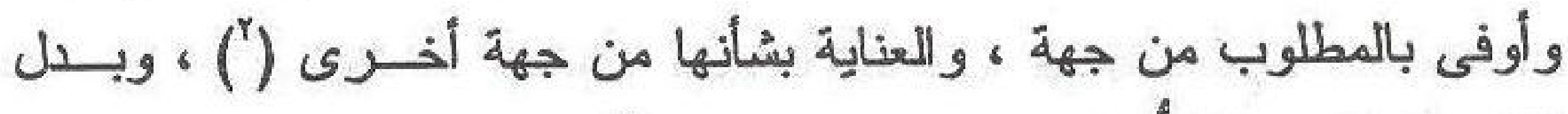

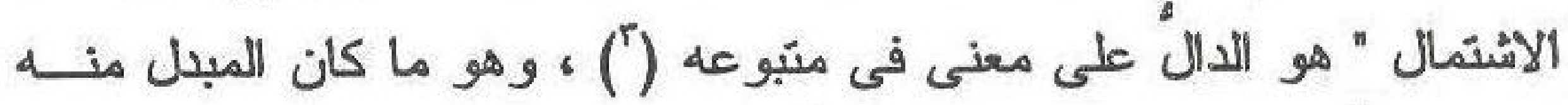

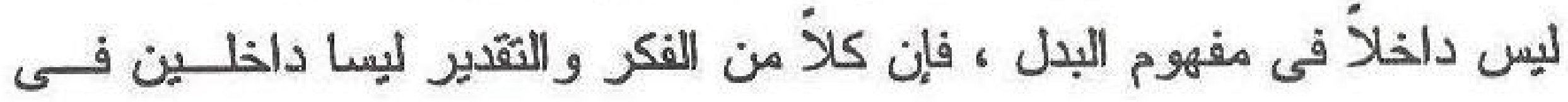

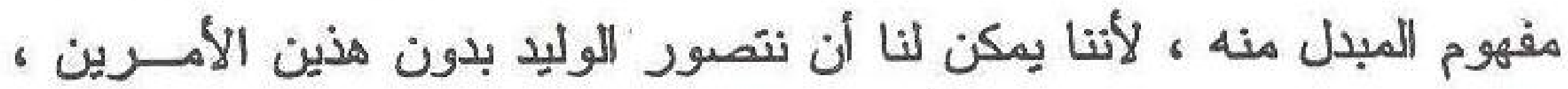

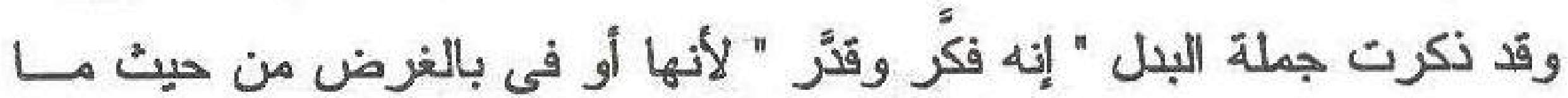

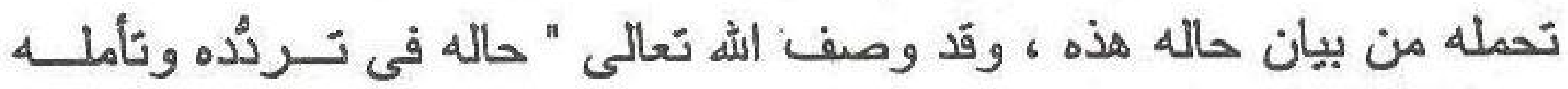
بأبلغ وصف ، فابتذئ بذكر تفكيره في الرأى الذى سيصدر عنه وتق ديزه ،

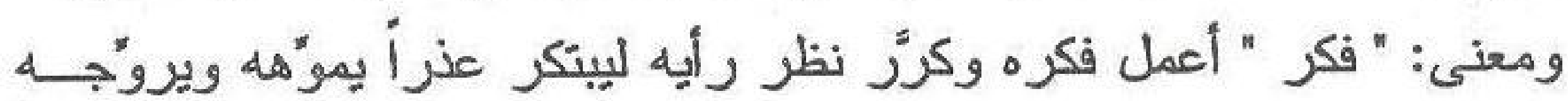

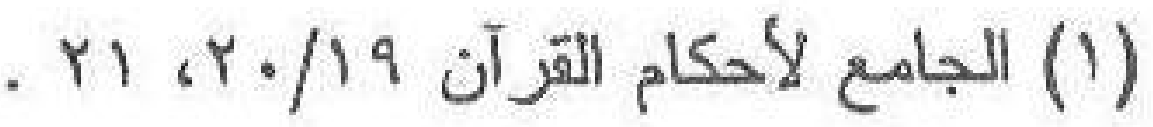

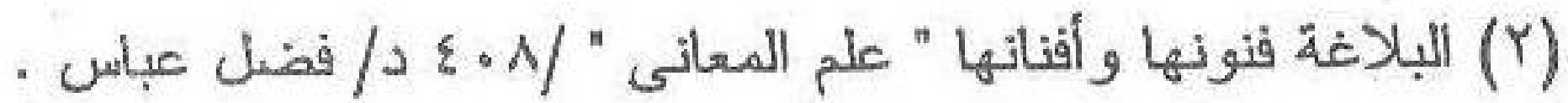
. MrN/Y شرح ابن عقيل 
على الدهماء فى وصف القرآن بوصف كلام الناس ليزيل عنهم اعتقاد أنـا أوحى به إلى النبى - (1) (1)

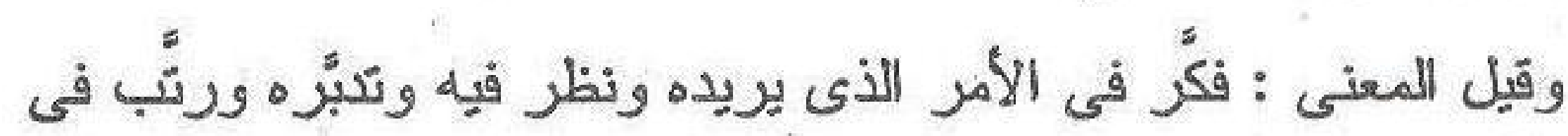

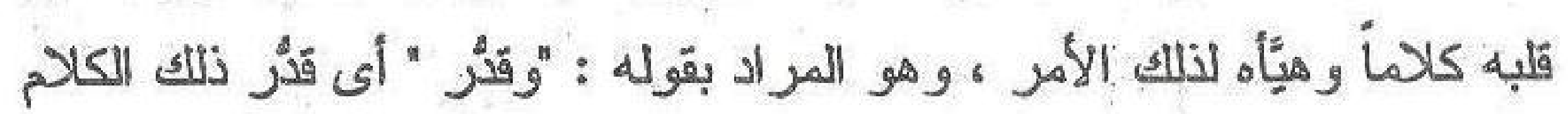

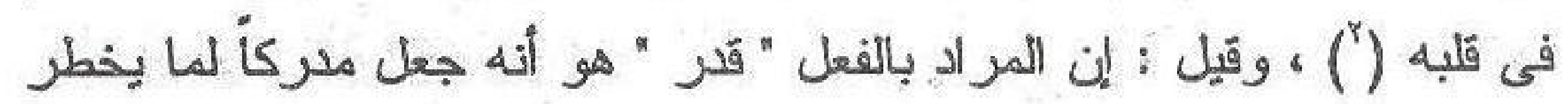

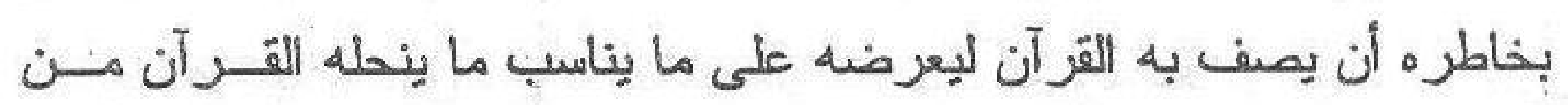

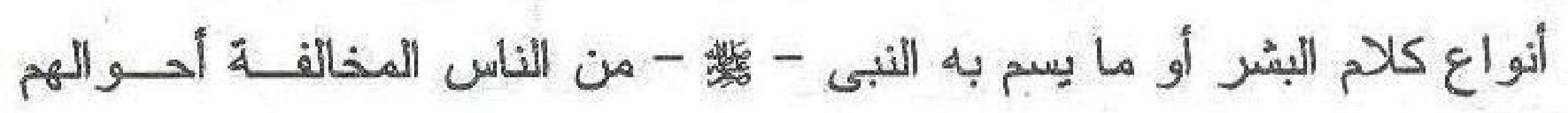

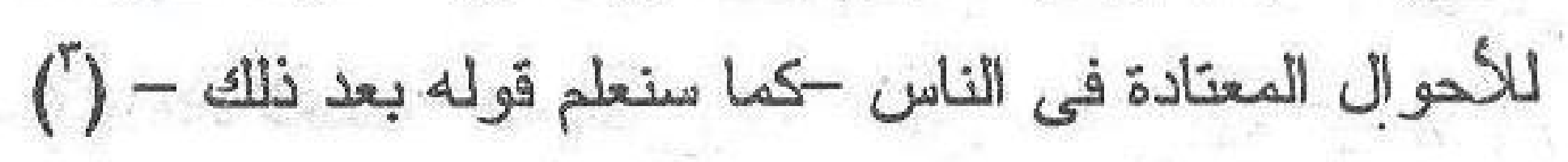

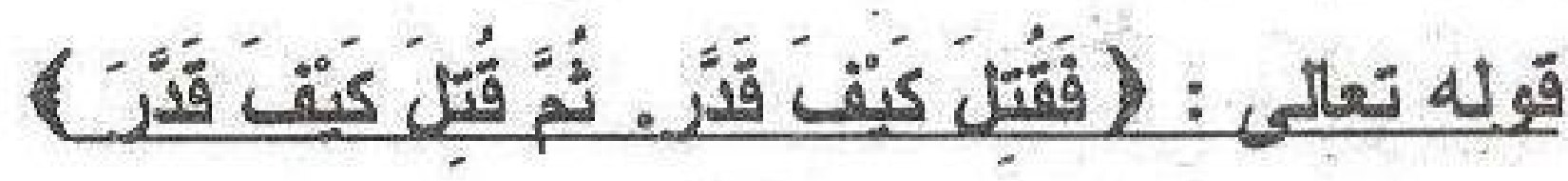

النظل البلاغى : قوله : "فقتل" تفريع لذمّه عن سيئ فعله ، و هى جملة

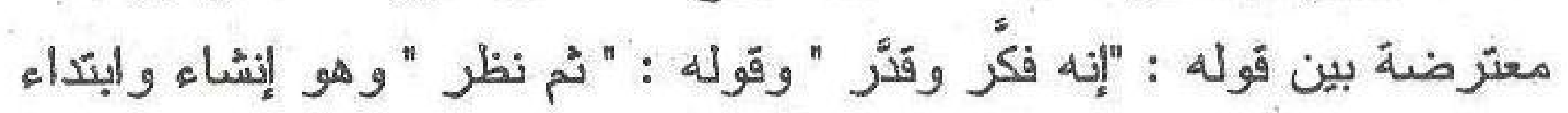

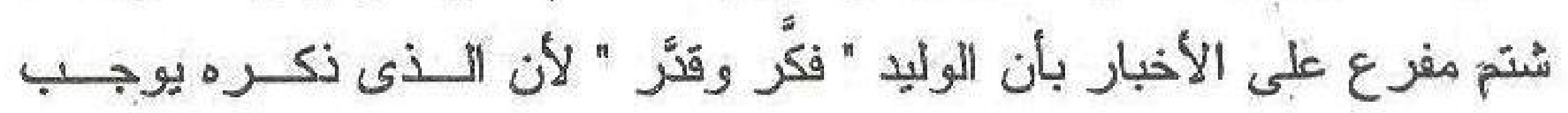
الغضب عليه .

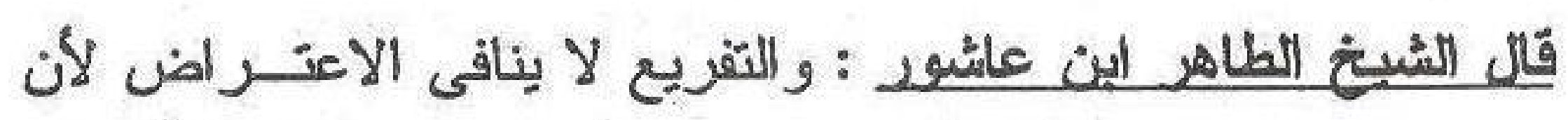

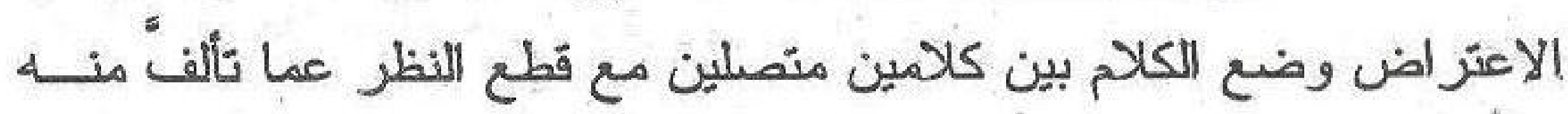

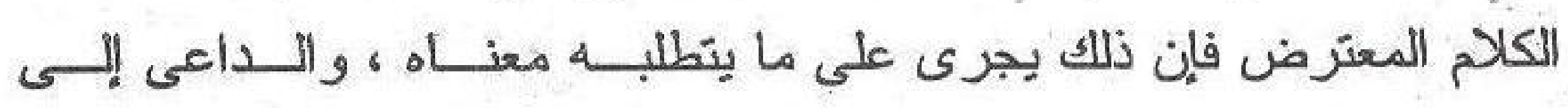

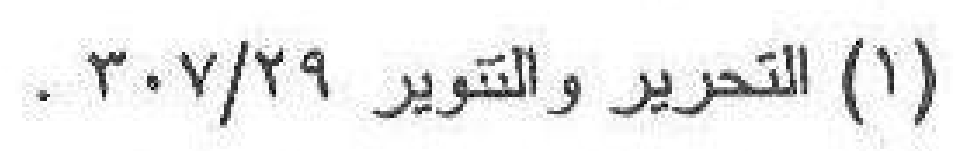

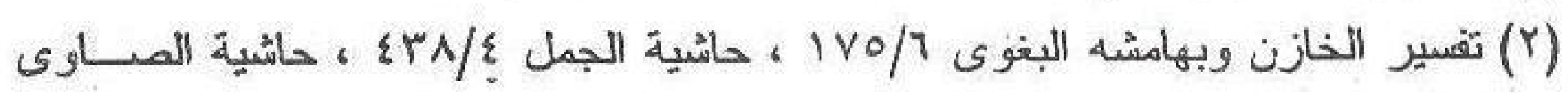


الاعتر اض هو التعجيل بفائدة الكلام للاهنمام بها(') ، ثــم يقــول : " وهــنـ ز عموا أن الاعتز اض لا يكون بالفاء فقد توهموا (') . و الفعل " قَتل " بمعنى لعن و عذب فى الدنيا ، و هو دعاء عليـهـ بــان يقتله قاتل ، أى أنه دعاء علِيه بتعجيل موته وذلك لأن حياته حياة مرذولــة كونة

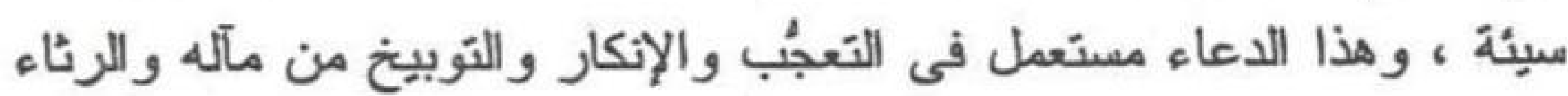
له ، و هو مشهور في كلام العرب .

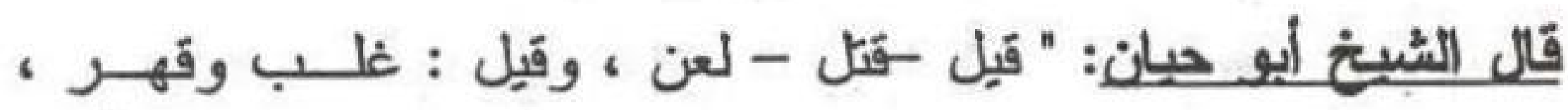
وذلك من قوله - (") أى قول امرىئ القيس سبسميك في أعشار قلب مقتل . أى مذلّل مقهور بالحب فلعن دعاء عليه بالطرد و الإبعاد و غلب وذلك إخبـار بقهره وذلتنه ، وقيل : دعاء مقتضاه الاستحسان و التعجب فقيل ذلك لمنزعـهـ الأول فى مدحه القرآن ، وفى نفيه الشعر و الكهانة والجنون عنه ، وقيل ذلك

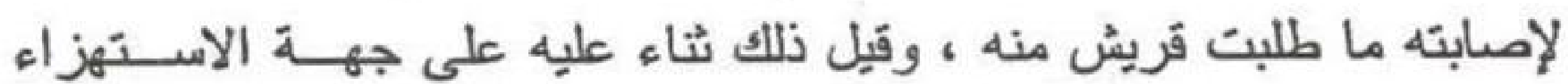

ثم يقول أيضاً : " قولهم - قاتلهم الله () مشهور فى كلام العرب أنه يقال عند السنعظام الأمر والتعجب منه ومعناه أنه بلغ المبلغ الذى يحسد عليه

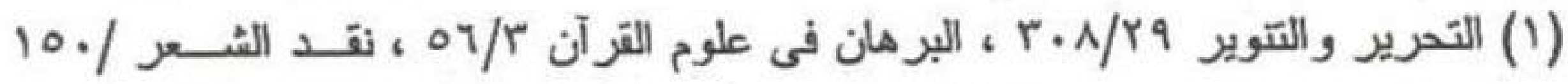

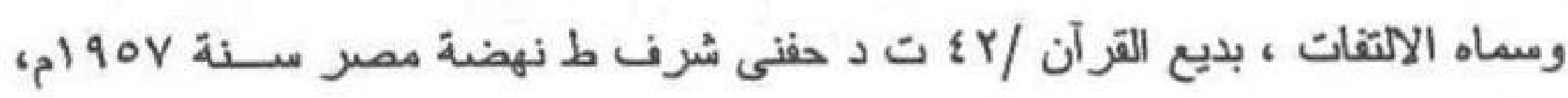

$$
\begin{aligned}
& \text { الإيضاح r/ع أب الكال } \\
& \text { (r) التحريز والتتوير } 9 \text { (r. }
\end{aligned}
$$

(r) شرح القصائد العشر / آr ، صدره :وما ذرفت عيناك إلا لتضربى بسهميك و القصيدة من بحر الطويل شرح التبريزى . 


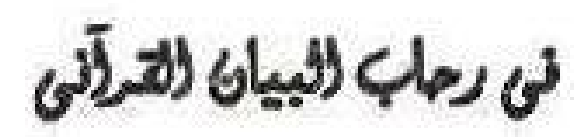

ويدعى عليه من حساده ، والاستقهام فى - كيف قدر - فى معنى ما أعجب

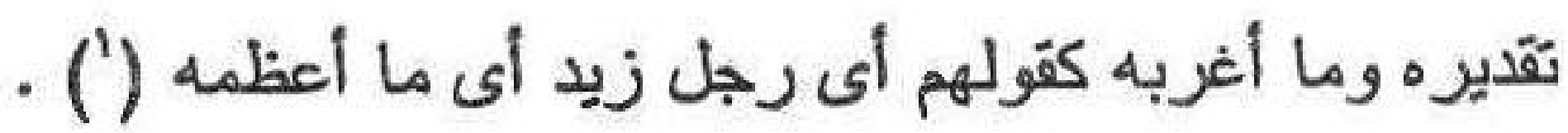
ومثل هذا القول قد يستعمل فى التعجيب من حسن الحال ألا تراهم -

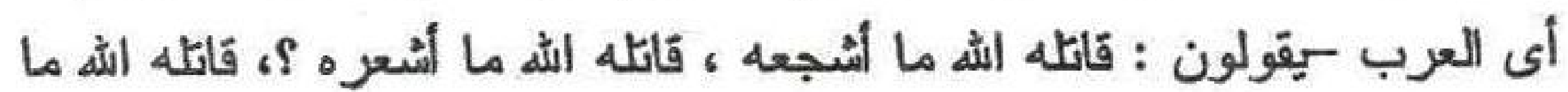

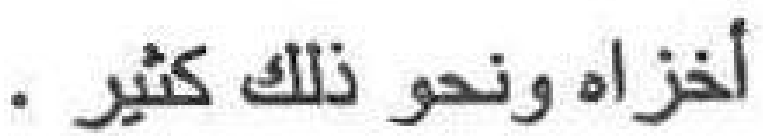

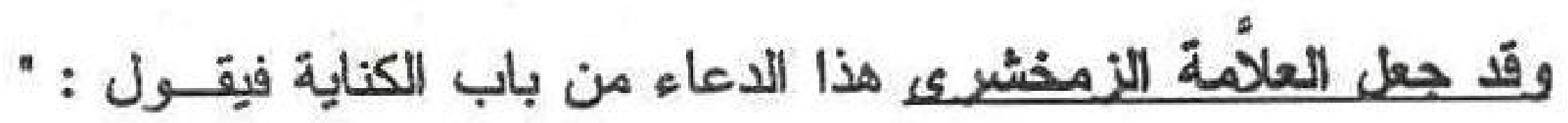
فقتل كيف قَدّر - تعجيب من تقديره وإصابته فيه المحزّ ورميه الغرض الذى كان تنتحيه قريش ،أو ثناء عليه على طريق الاستهزاء به ، أو هى حكاية لما

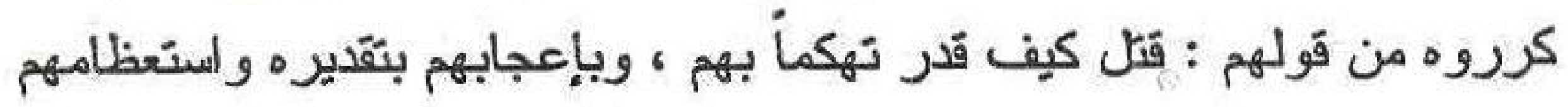

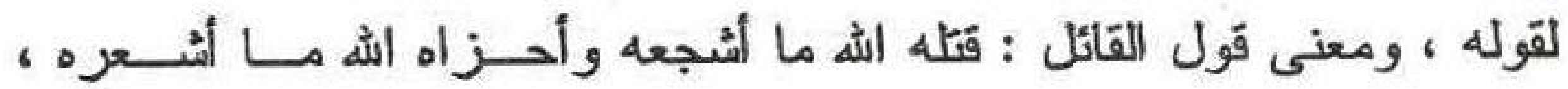

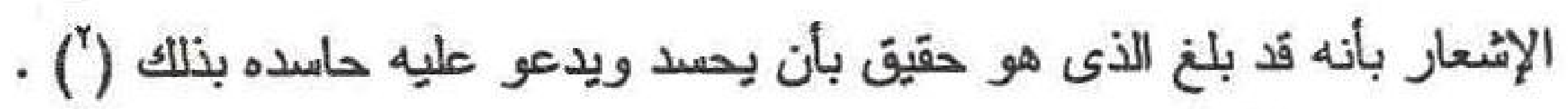

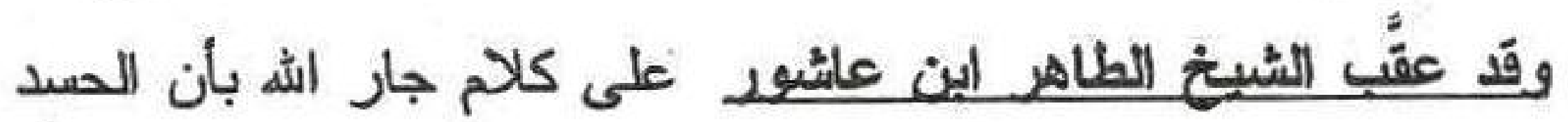
هنا غير مقصود و لا ملحوظ ، وأن المر اد بالكناية هنا بيان سوء حاله فيقول:

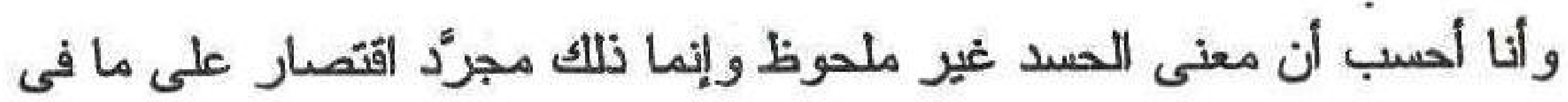
تلك الكلمة من التعجب أو التعجيب لأنها صارت في في ذلك كالأمثال ، والمقام

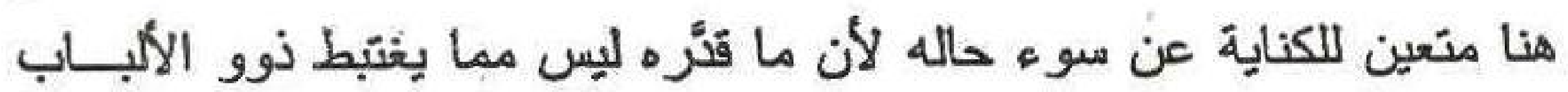

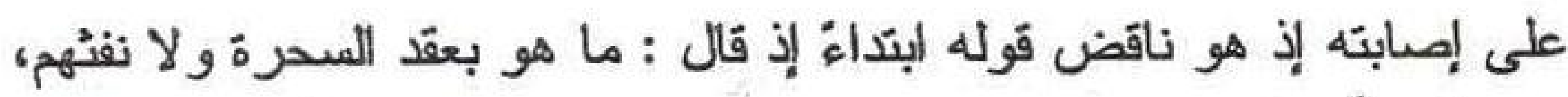

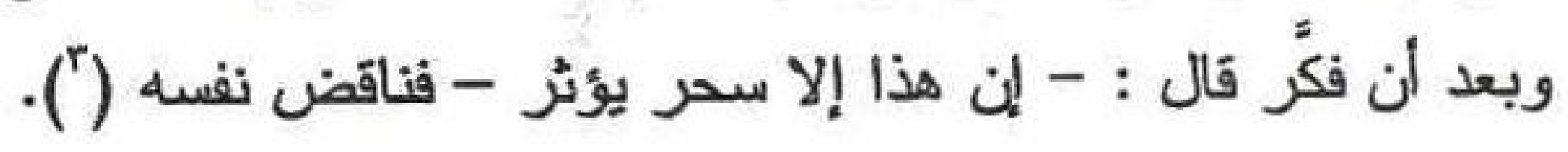

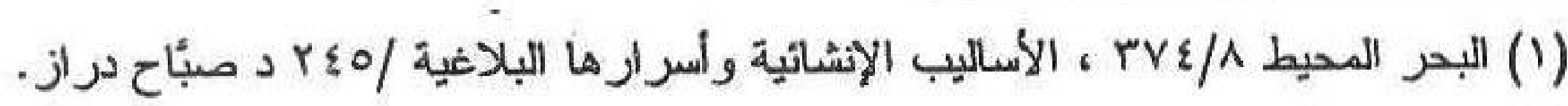

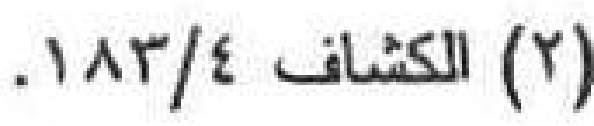

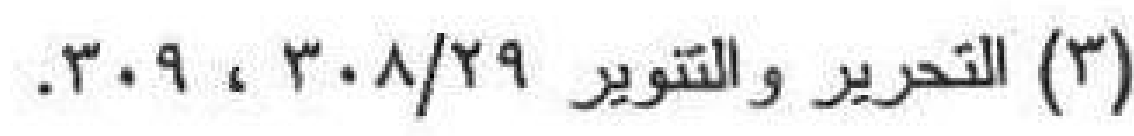


روى الحاكم من حديث ابن عباس - رضى الله عنهما - : أن الوليد

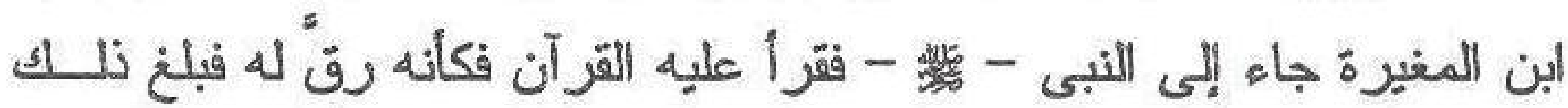

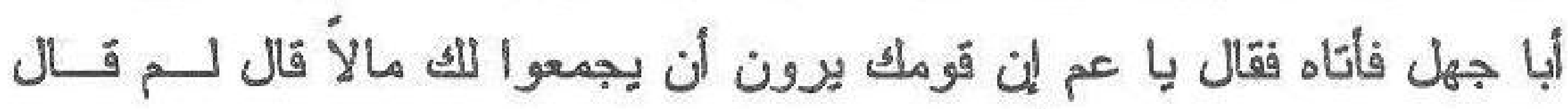

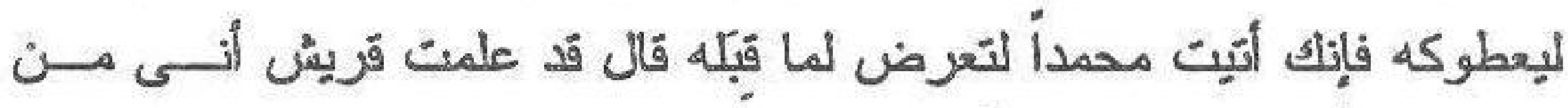

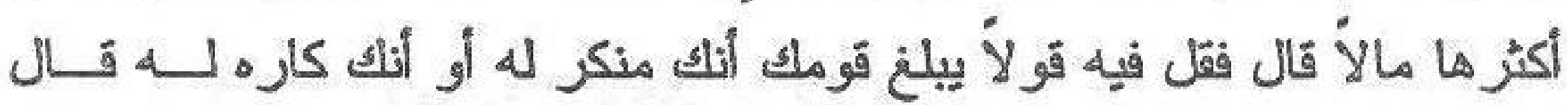

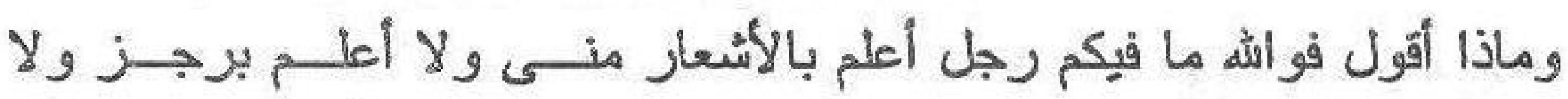

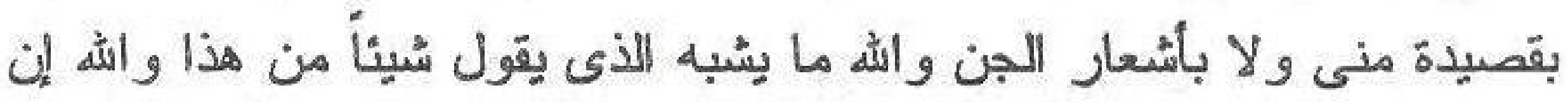

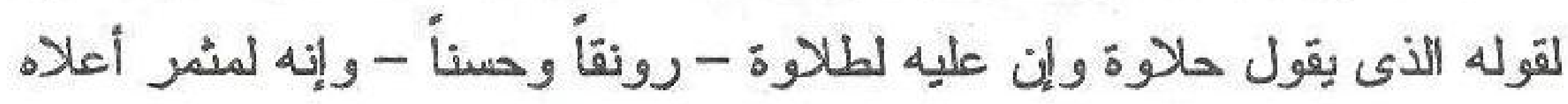

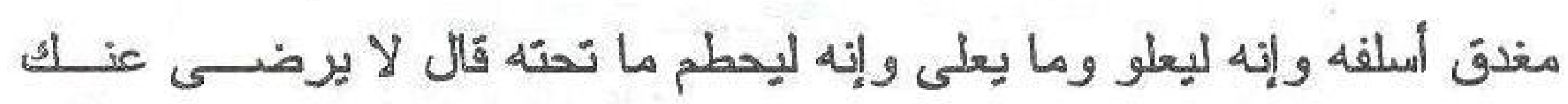

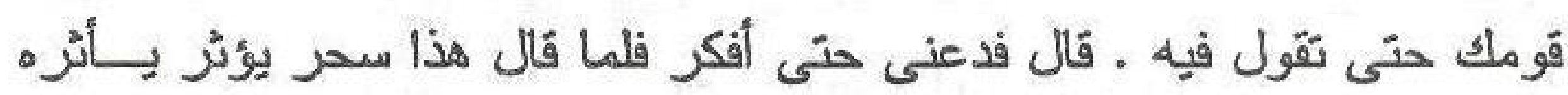

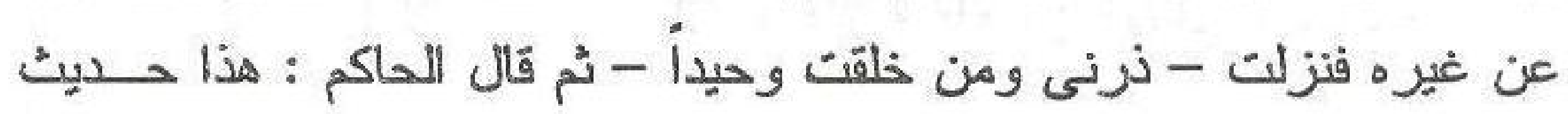

$$
\text { صحيح الإسناد على شرط البخارى ولم يذرجاه (') }
$$

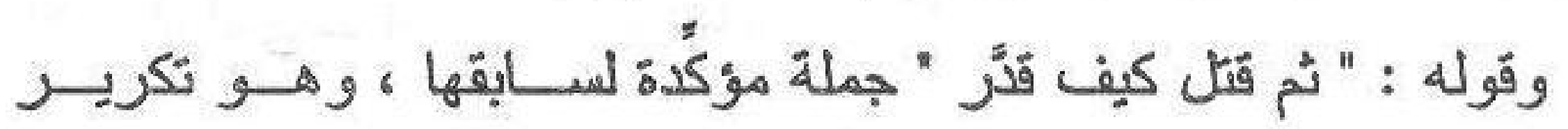

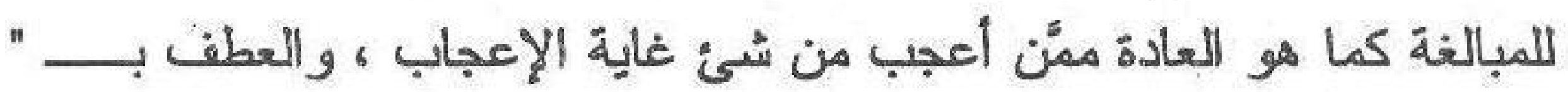

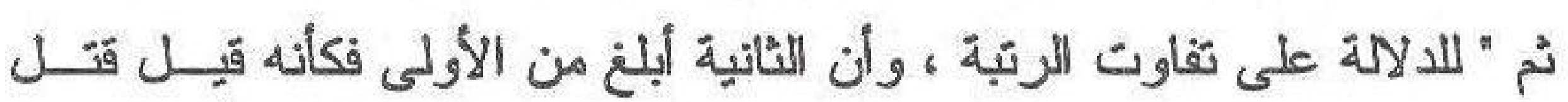
بنوع ما من القتل بل قتل بأسده وأُشده ، ولهذا ساغ القعطف فيه مع أنه تأكيد، لأنه إذا كان المعطوف بها عين المعطوف عليه أفادت أن معنى المعطــوف

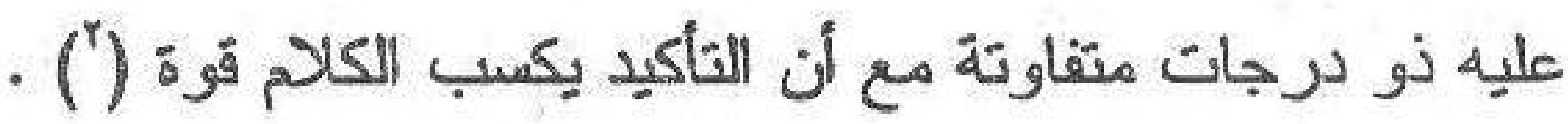

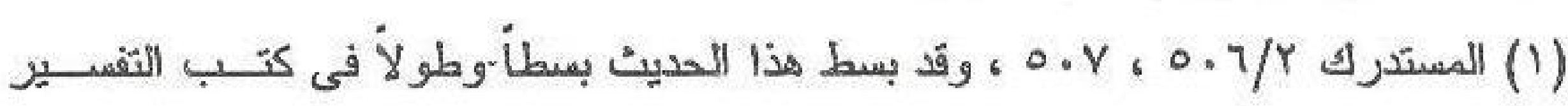

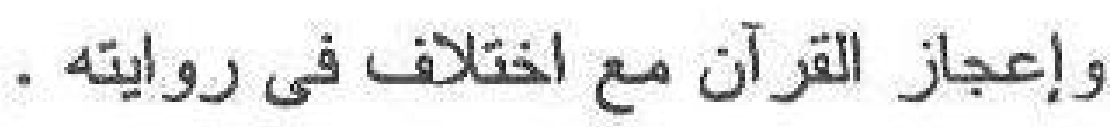




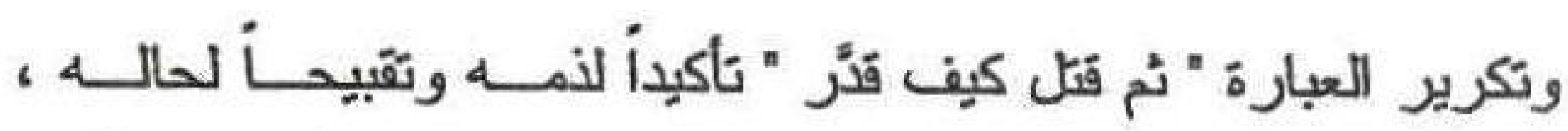

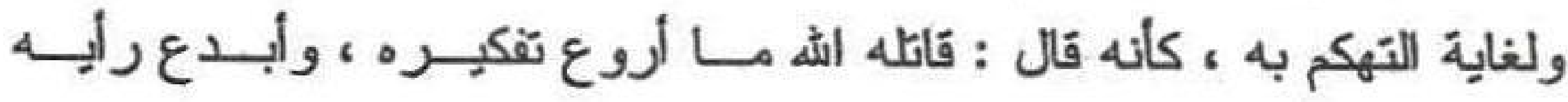

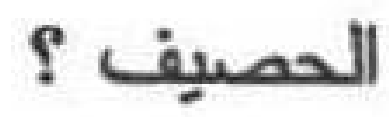

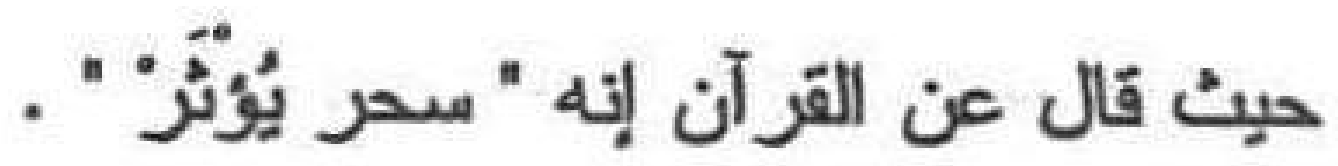

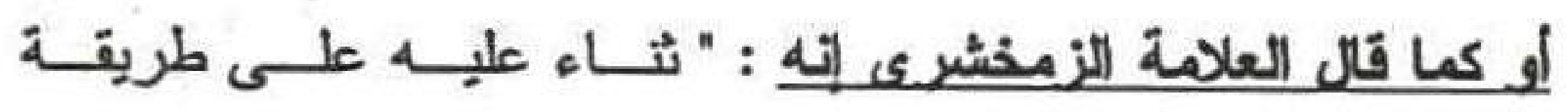

الاستهزاء به أو هى حكاية لما كرروه من قولهم : - قتل كيف قدر - تهكما

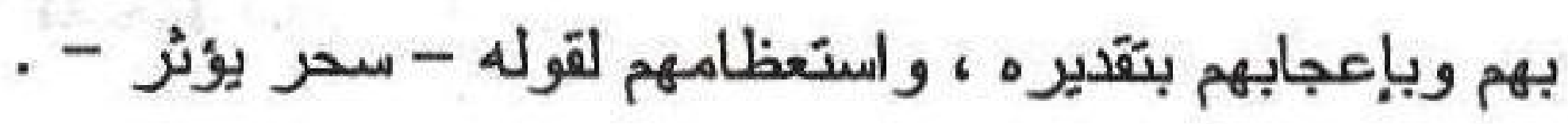

وقد بئن - رحمه الله - سبر" العطف بـ "تم" دون الفاء كما فى قوله :

" فقتل كيف قدر" بقوله : فإن قلت : ما معنى - ثم - الداخلــة فـى نكريــر

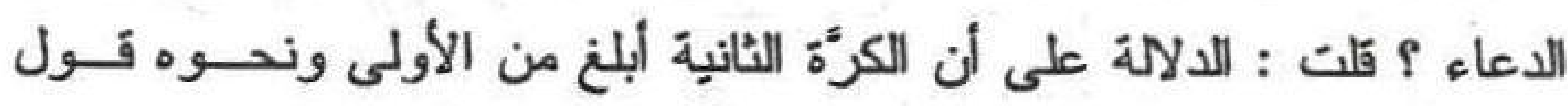

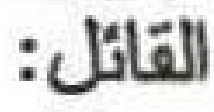

ألا يا اسلمى ثم اسلمى ثُمت لسلمى · (') - (')

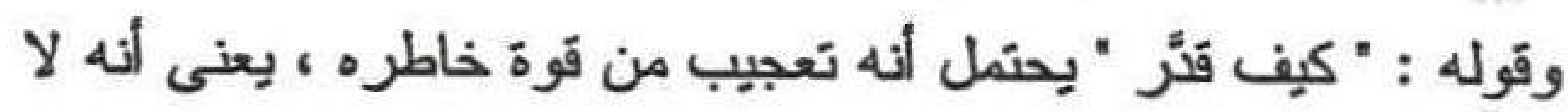

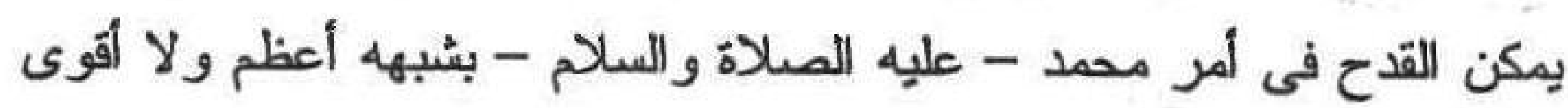

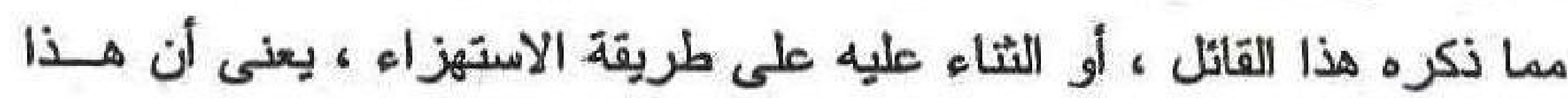

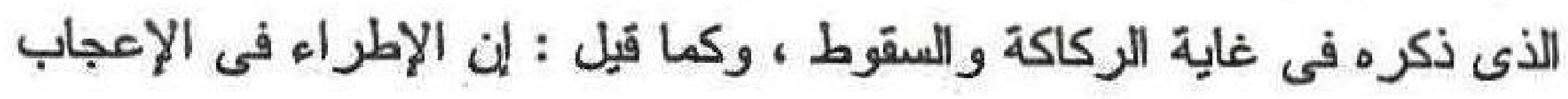

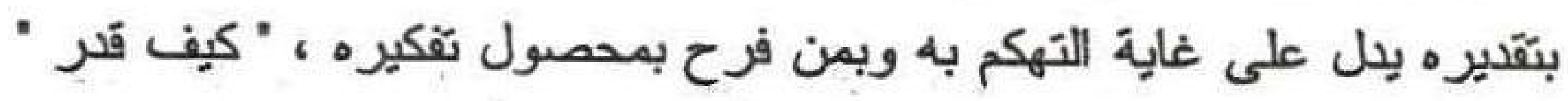

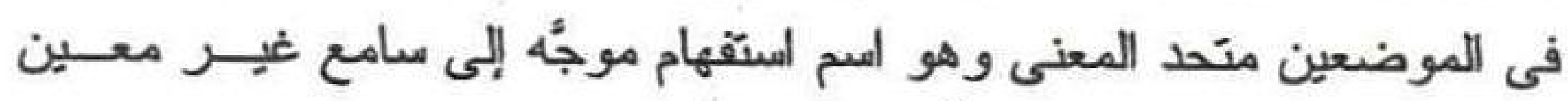

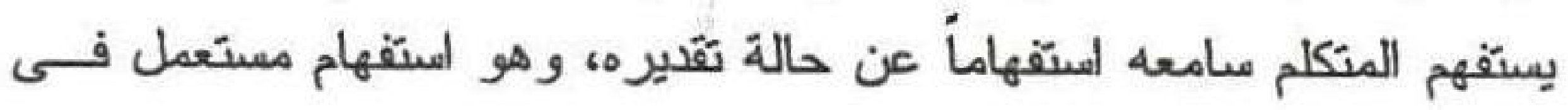
التعجيب المشوب بالانكار على وجه المجاز المرسل بعلاقة الإطلاق و التقبيد

(1) العابق نفسه ، صدر بيت عجزه : ثلاثث تحيات وإن لم تكلهى ـ ديـوان الحماسـة 
و " كيف " فى محل نحسب على الحال مقَّمة على صاحبها لأن لها الصدر ،

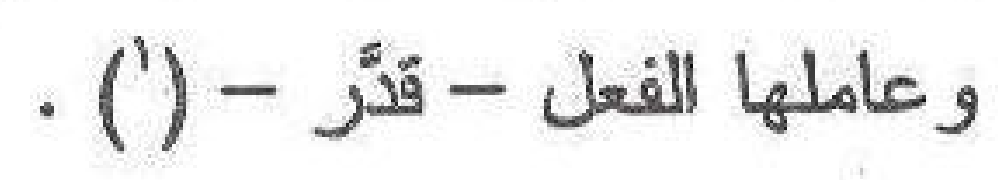

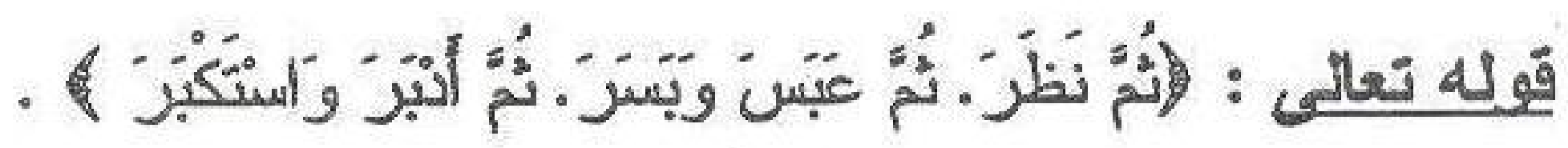

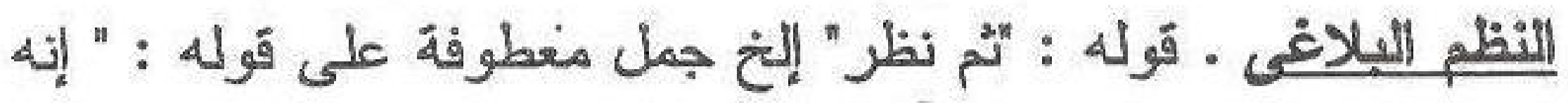

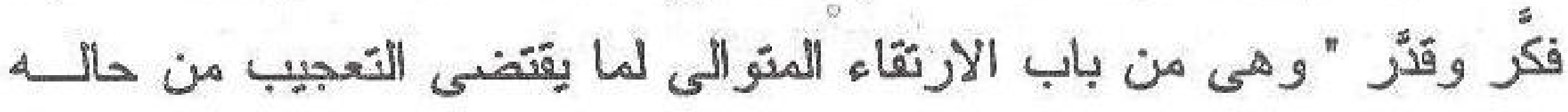
والإنكار عليه ، فالتز اخى هنا تز اخى رنبة لا نزاخى زمن ، وذلك أن نظره و عبوسه وبسر ه وإدباره و استكبار ه مقارنة لتفكيره وتقديره ، وقيل : نظر فيى

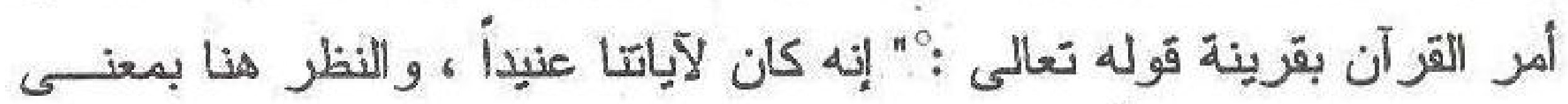

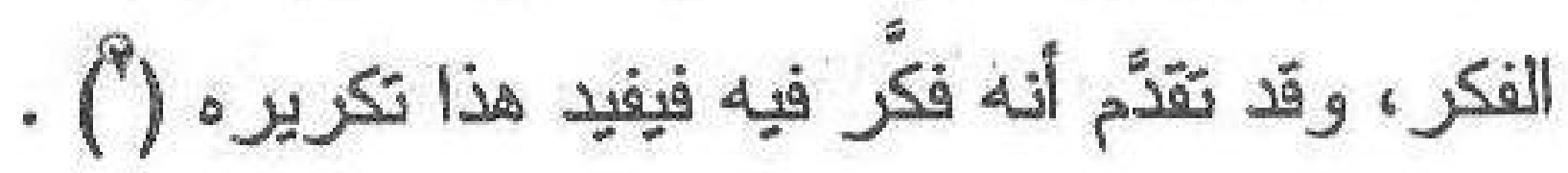

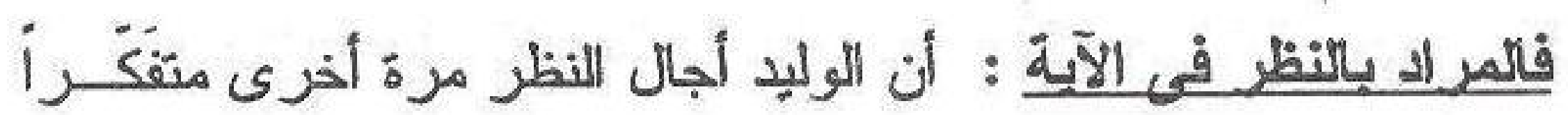

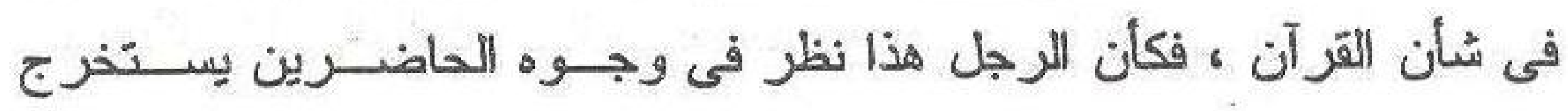

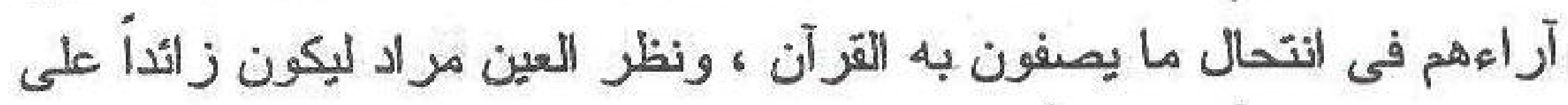

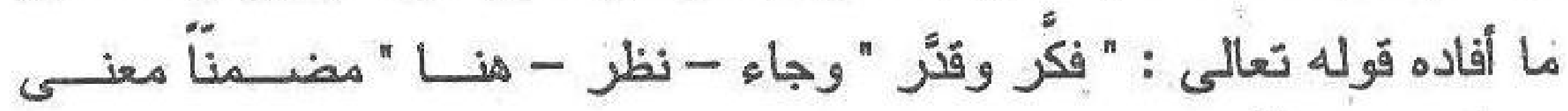

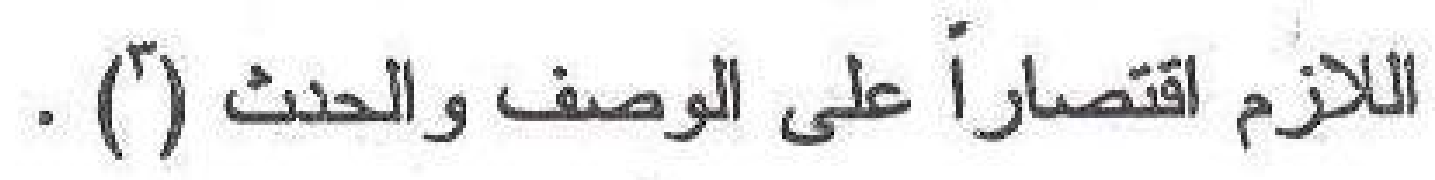

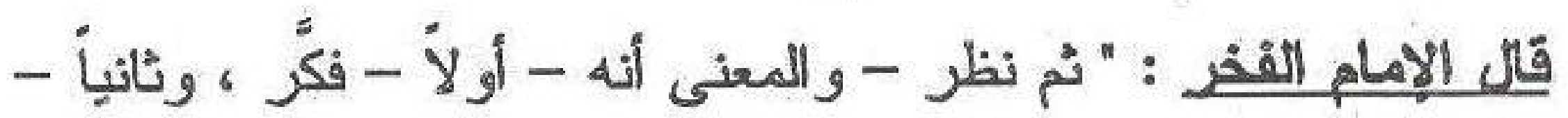

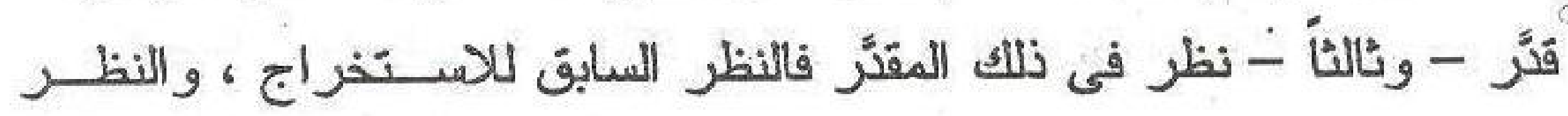

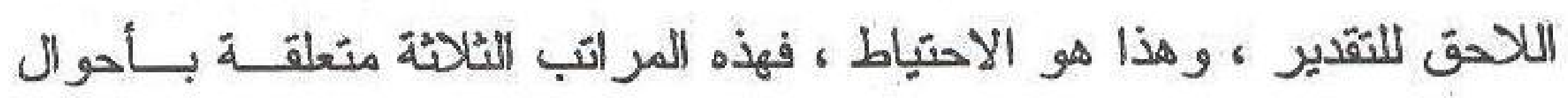

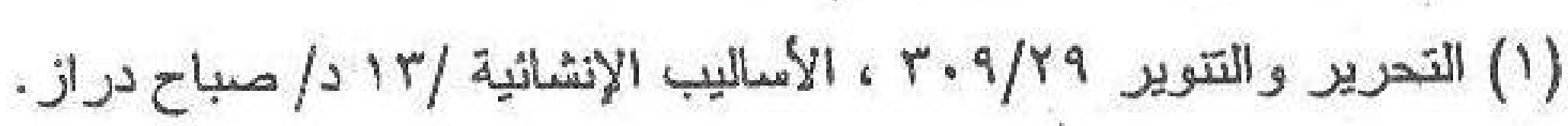
r r (Y)/A حاشية الشهاب

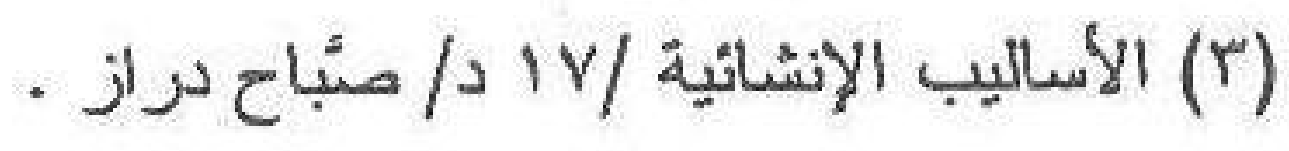

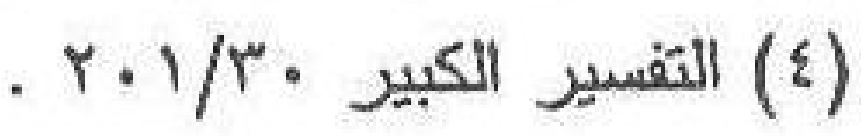


وقوله : " ثم عبس " معطوف على الفعل " نظر" و المراد قطب وجهه

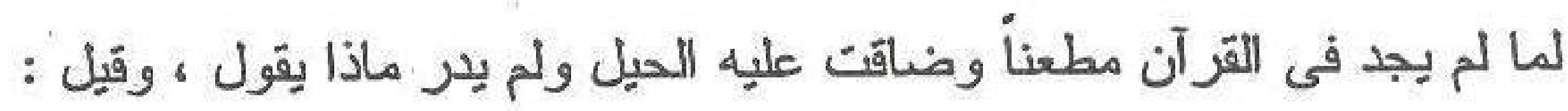

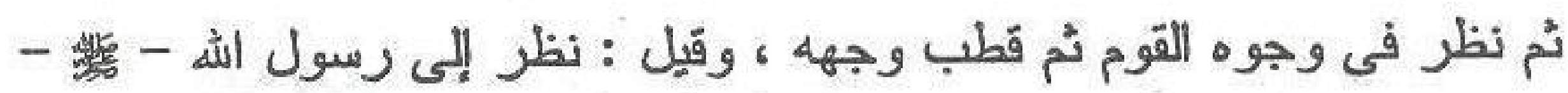

"مُم قَطب فى وجهه " عليه الصلاة و السلام " .

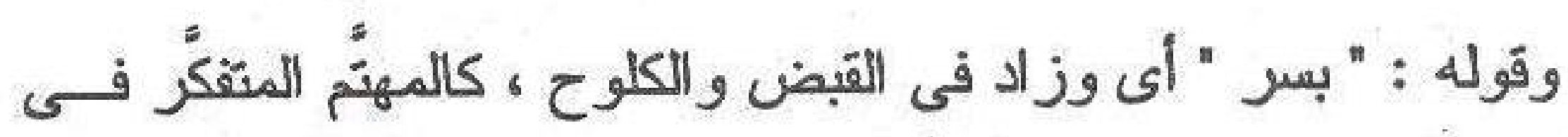

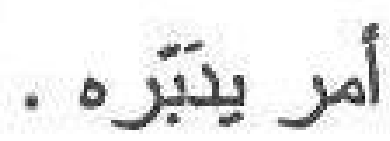

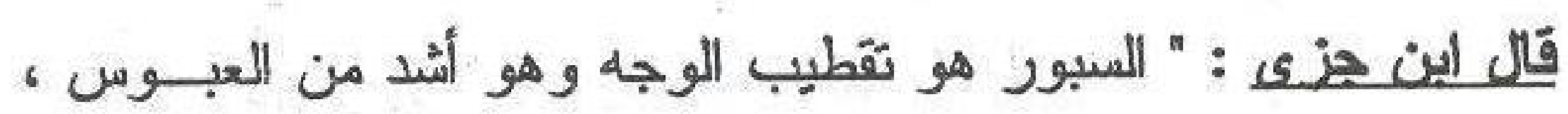

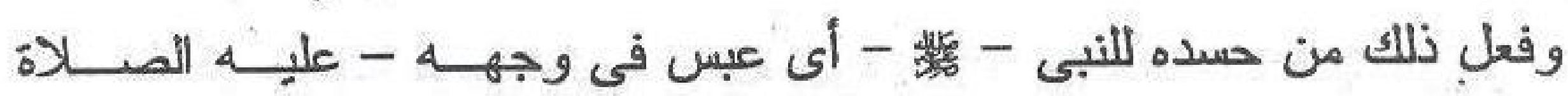

و السلام - أو عبس لما ضاقت عليه الحيل ولم يدر ما يقول (') . (') .

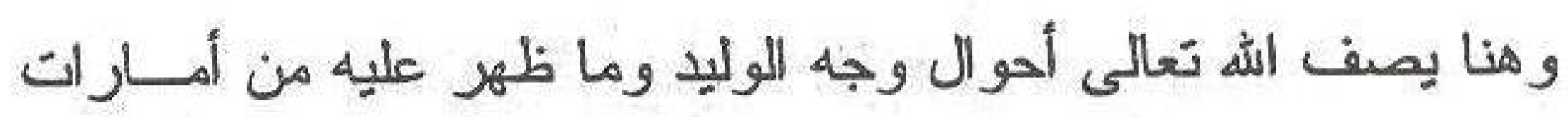

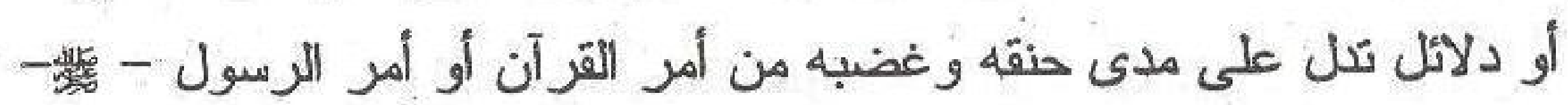

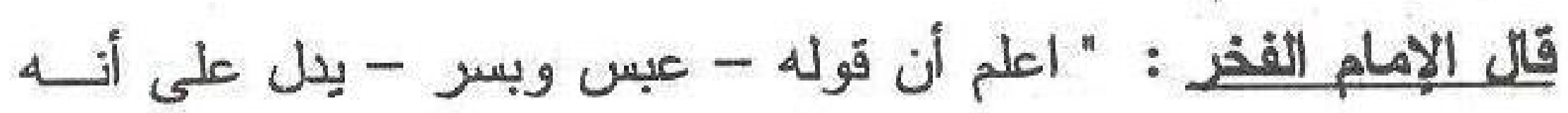

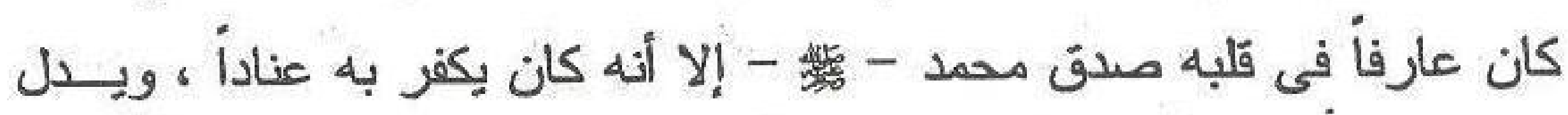

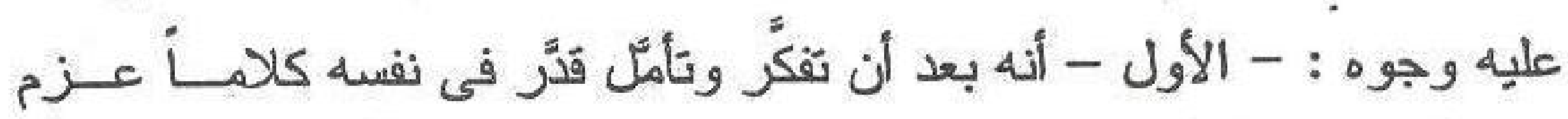
على أنه يظهره ظهرت العبوسة فى وجهه ولو كان معتقداً صحة ذلك الكاول الكلام

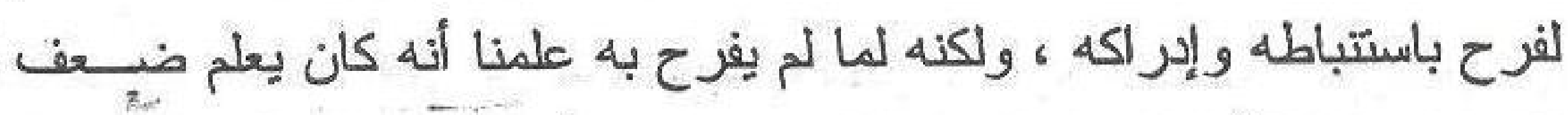

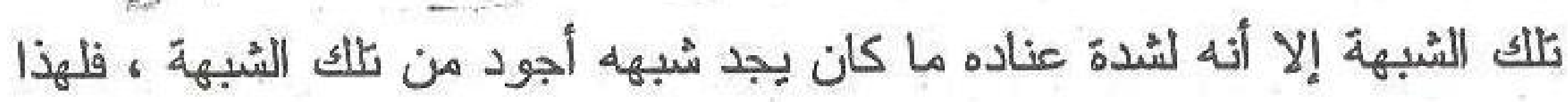

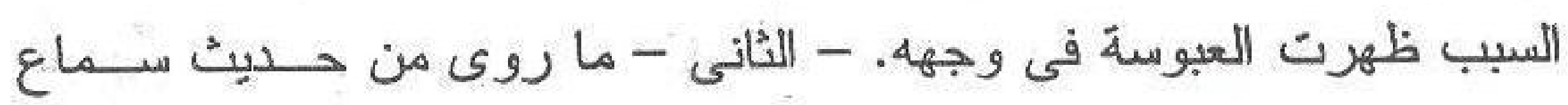
الوليد سورة فصلّت من الرسول - على - وما جرى بينه وبينه - عليه الصلاة 


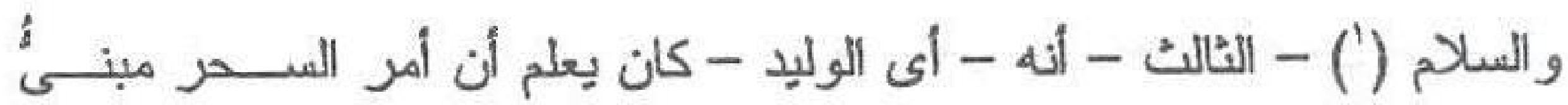

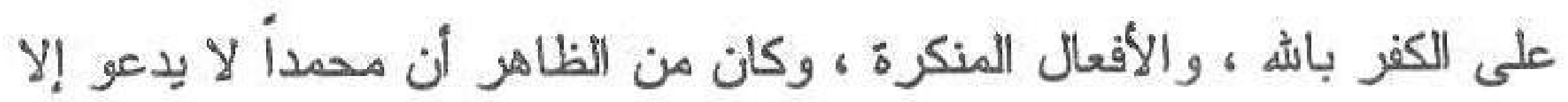

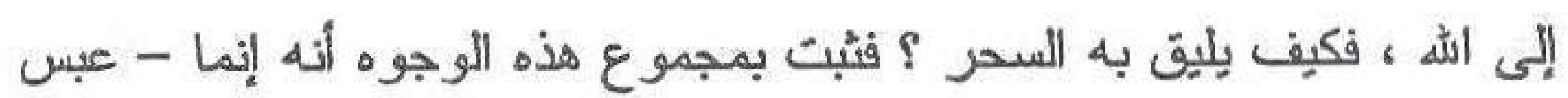

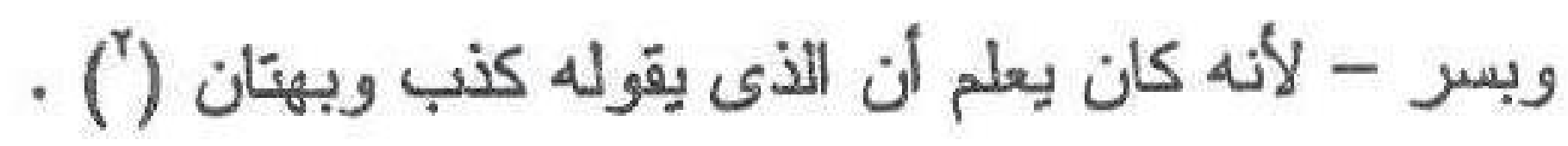
وقد وضنّح الر اغب - رحمه الله - معنى الفعل " بسر" توضيحاً دقيقاً، وذلك بقوله : " البسر الاستعجال بالمئ قبل أوانه نحو بسر الرجل الحاجــة طلبها فى غير أو انها ، وبسر الفحل الناقة ضربها قبل الطلب ، وماء بسـر متناول من غيره قَبل سكونه ، وقيل للقرح الذى ينكا قبل النضب بسر ، ومنه قيل لما لم يدرك من التمر بسر ، وقوله عز وجل : - ثم عبس وبسر - أى ولى

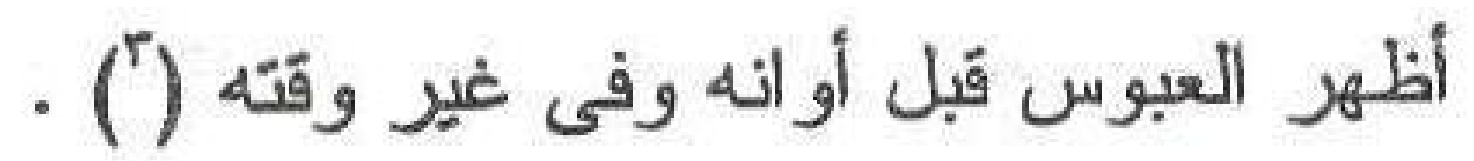
وقد تمّ العطف في هذه الجمل بعروف مختلفة ، ولكل منها مناسبة أما ما عطف بـ "ثم" فلأن بين الأفعال مهلة وتأنياً ، لأن بين النظر و العبوس ، وبين العبوس والإدبار تزاخياً .

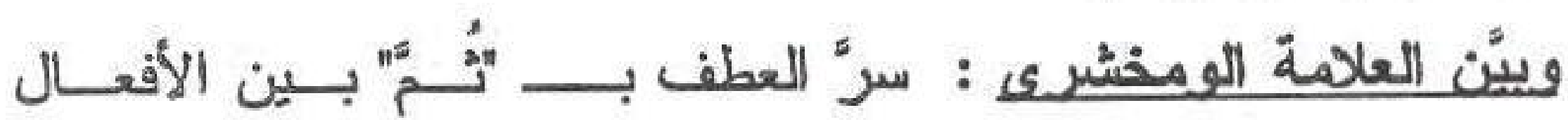
المذكورة فقال : " فإن قلت ما معنى المتوسطة - أى ثم - بين الأفعال التـى بعدها قلت : الدلالة على أنه قد تأنىً فى التأمل وتمهئل ، وكان بين الأفعـال

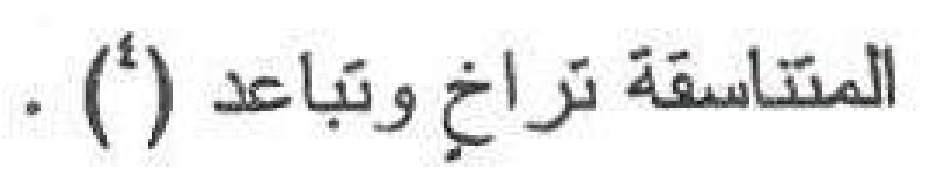

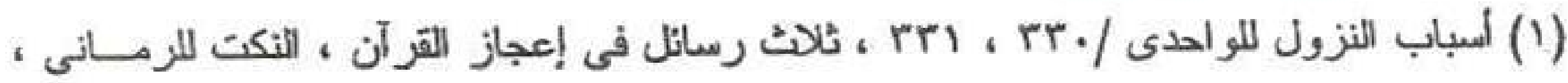

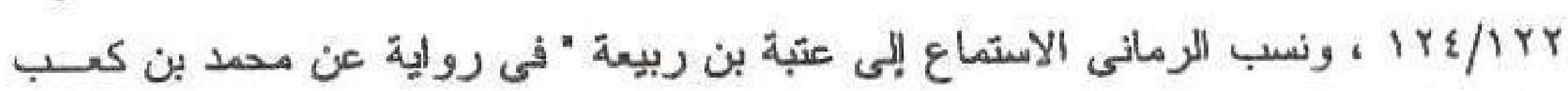


فى رهابع (البيان الآترآنى

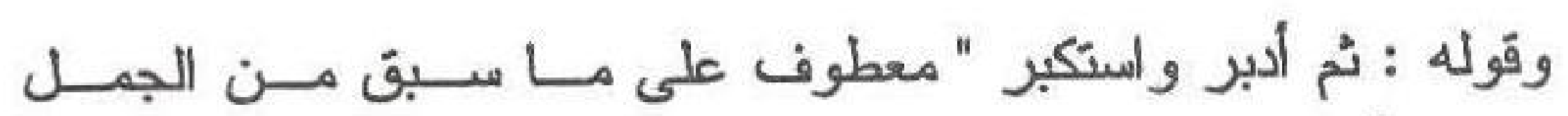

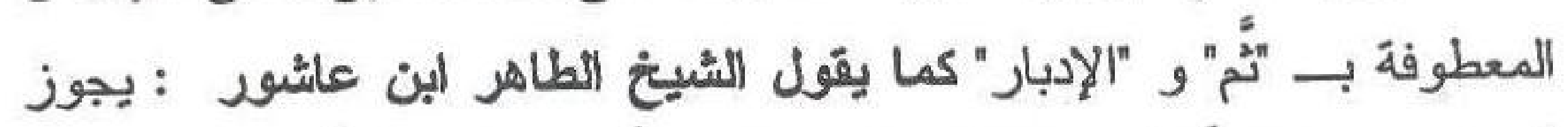

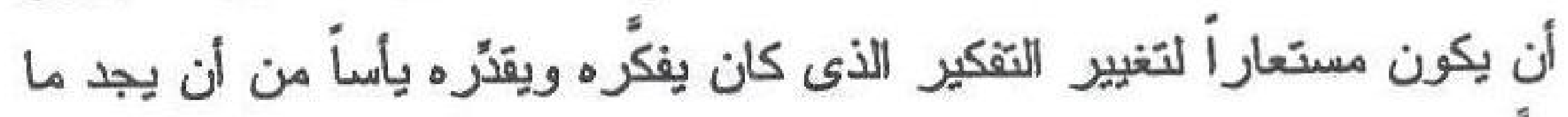

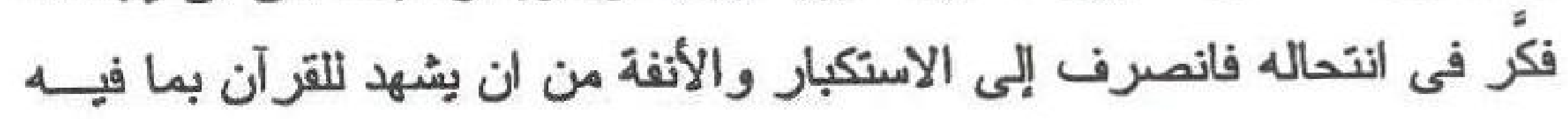

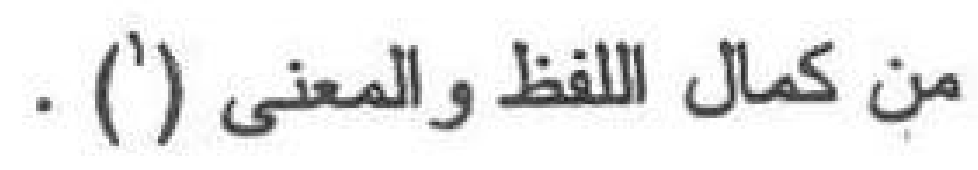

وعلى هذا فالفعل "أدبر" استعارة تبعية استعير لتغيير الرأى و الفكر . .

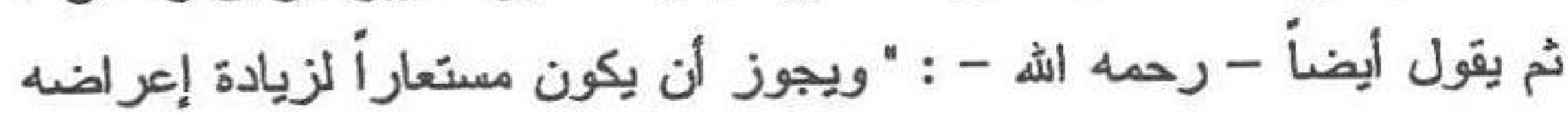

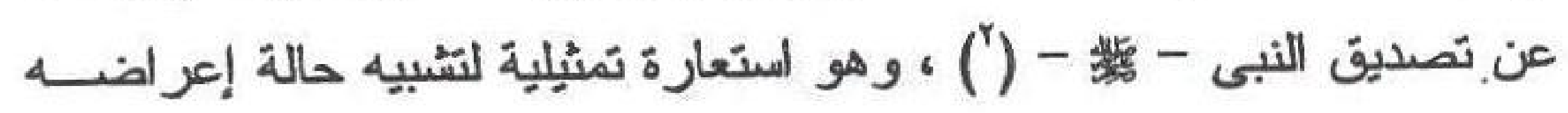

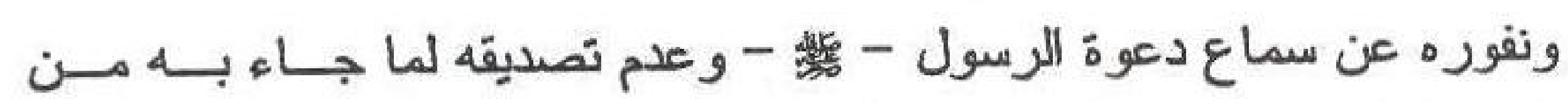

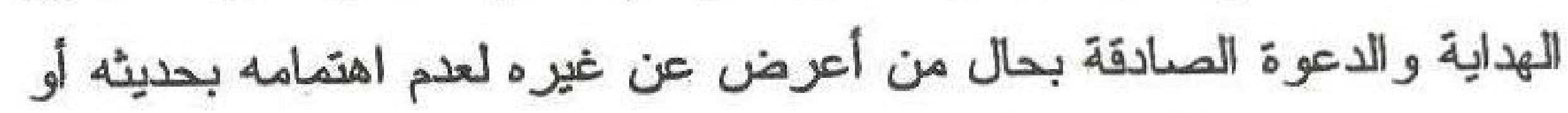

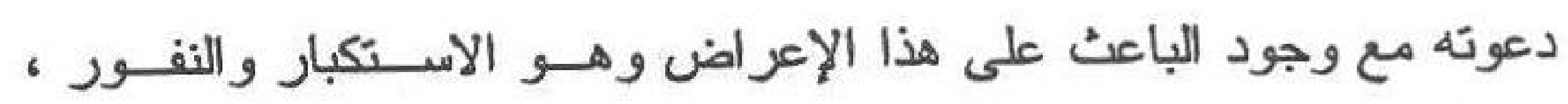

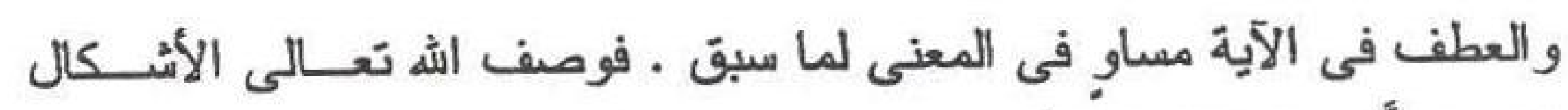

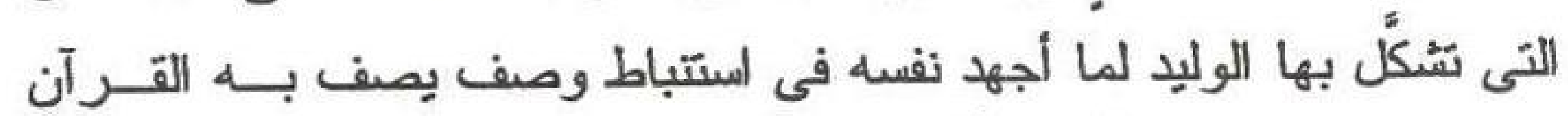

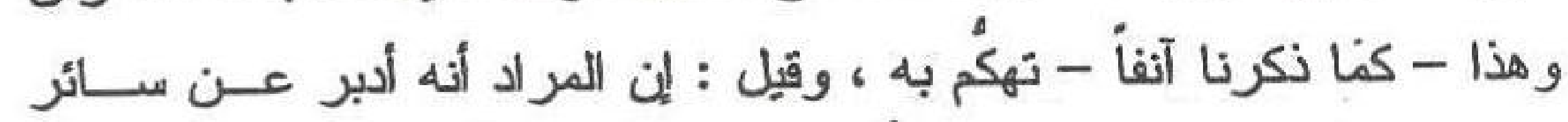

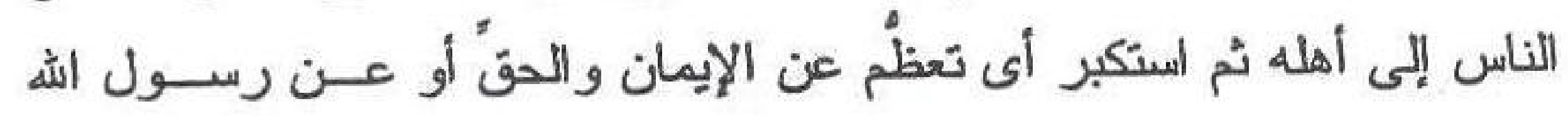
. - 紫-

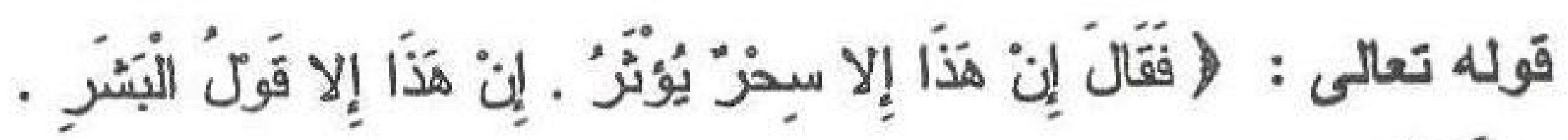

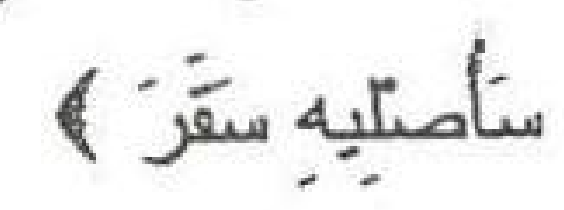

النظم البلاغى : " فقال " إلخ معطوف على ما سبق لبيان ما أنتجته

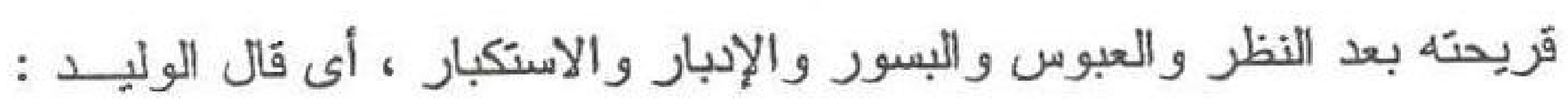

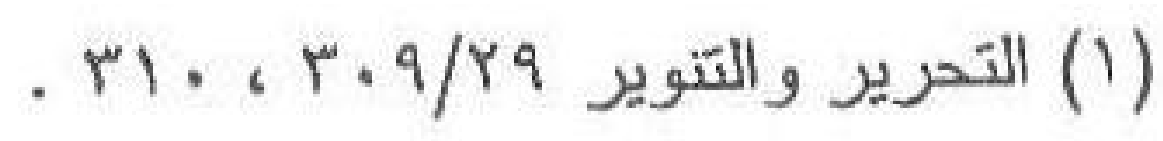
(r) (r) ( السابق نفسه. 
إن ما يقوله محمد - عليه الصلاة و السلام - ويرويه ويتعلًّه من سحرة بابل وغير هم : " ويؤره من صاحب اليمامة مسليمة الكذاب ، ويقال : معناه مــا هذا الذى يقول إلا سحر يزويه عن جابر ويسار أو عن أهل بابل (') . وجاء الفعل هنا معطوفاً بالفاء دون ما سبق . لأنه كما يقول - جـار الله - لان الكلمة - سحر - لما خطرت بباله بعد التطلب لم ينمالك أن نطق مأن بها من غير تلبث (") ) . فقد استخدم الوليد حرف الفاء اللدلالة على أنــه لمــا خطر بباله وجرى على عقله كون القرآن تمويهاً وتخِيلاً يسحر بـهـ محمــد

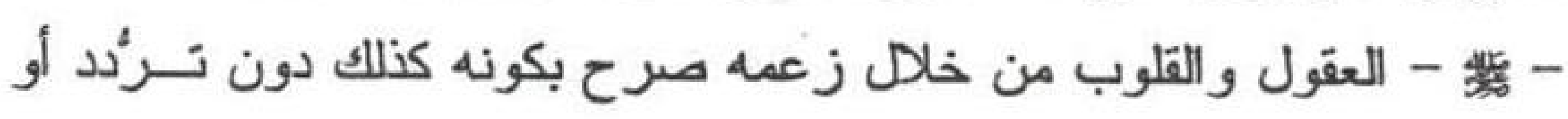
تفكير . فالفاء هنا للتعقيب من غير مهلة ، وعلى هذا فلا مخالفة فيها مع ما

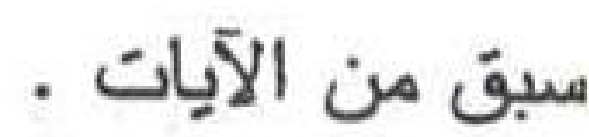

وقوله : " إن هذا إلا سحر يؤثر " أســلوب قصــر طريقــه النفـىى

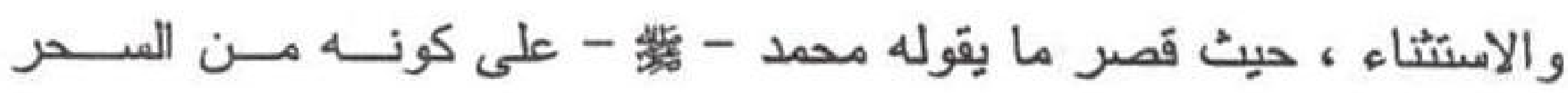
و التخيِيل ، من قصر الموصوف على الصفةَ قصراً إضافياً قصر تعيين . وجملة "يؤثر" صفة لقوله : "سحر" والمراد أنه منقول عن السحرة ، وقوله هذا مذكور بفاء التعقيب ليعلم أنه لمًّا ولَّى واستكبر . ذكر هذه الشّبهة ونطق بها ، فكان نطقه بها حقيقاً بأن يعطف بحرف التعقبب - الفاء -. يقول الإمام الفخر - رحمه الله - - وفى قوله - يؤثر - وجهـان -

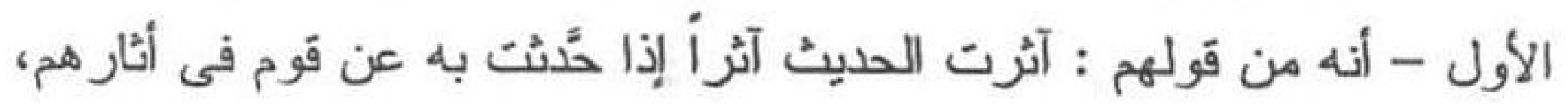

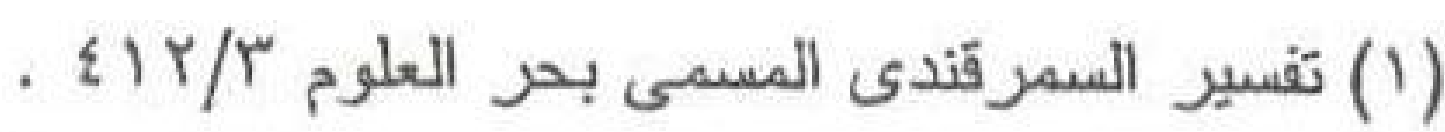

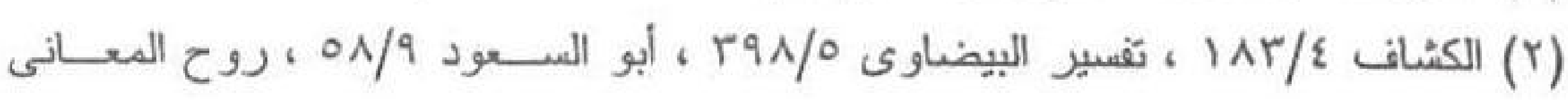


أى بعد ما ماتوا هذا هو الأصل ، ثم صار بمعنى الروايسـة عمـن كــان - الثانى- يؤُر على جميع السحر ، وعلى هذا يكون هو من الإيثار (') .

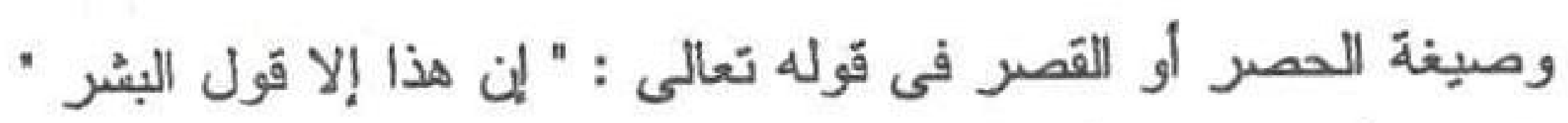

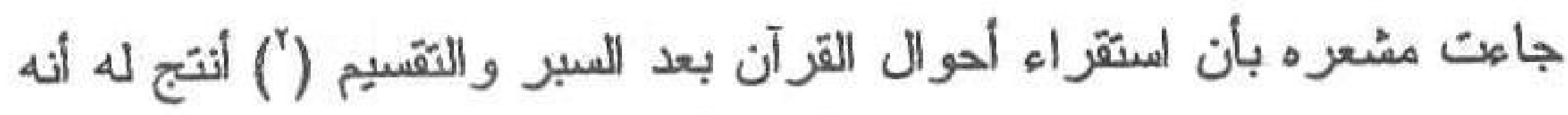

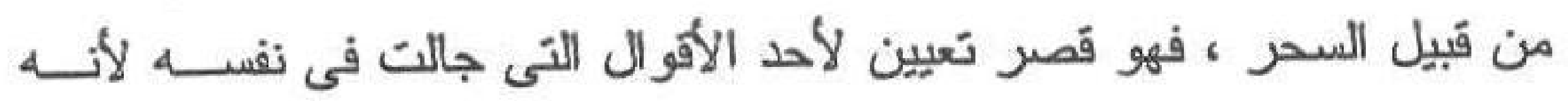

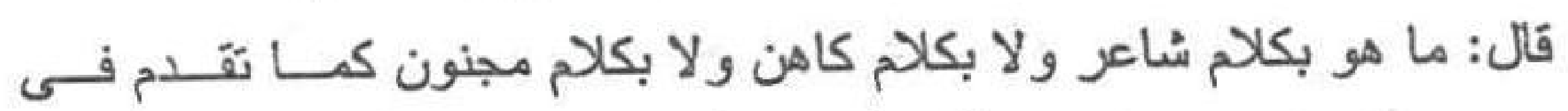

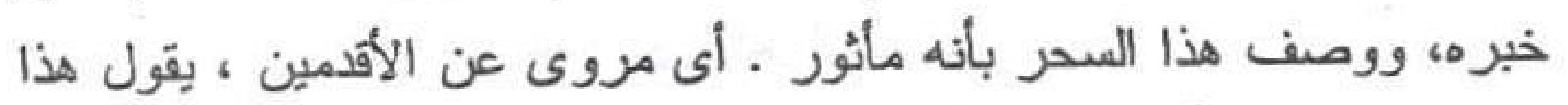

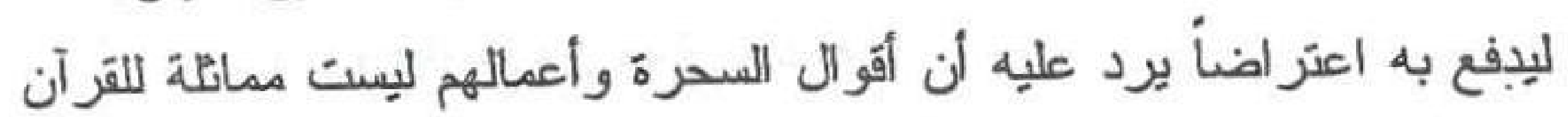

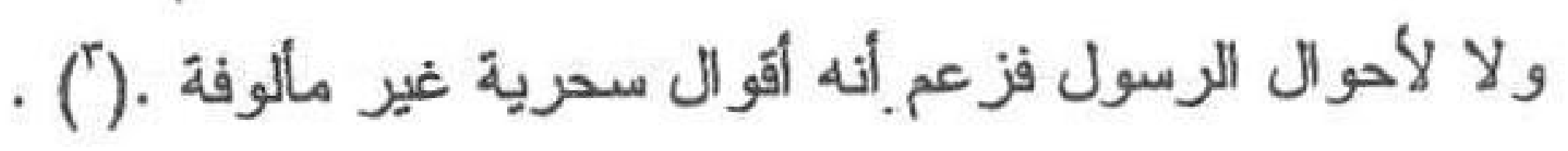

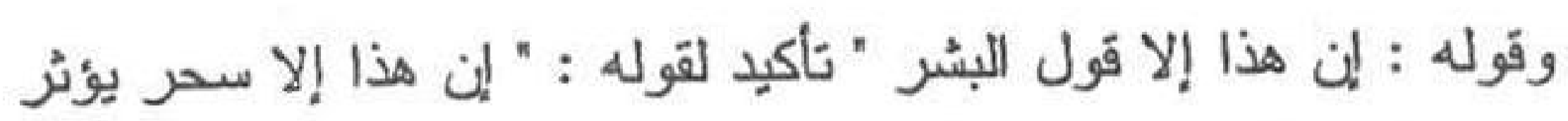

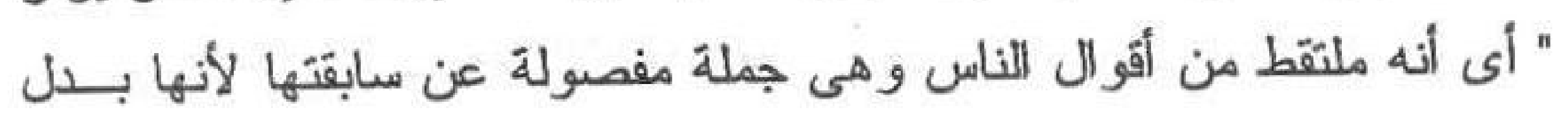

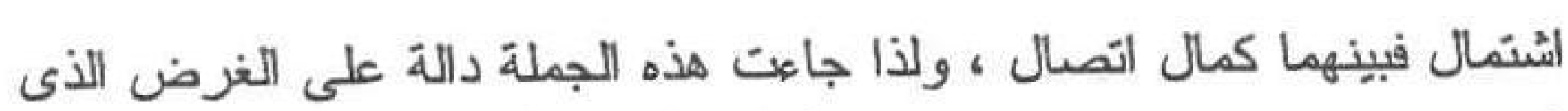

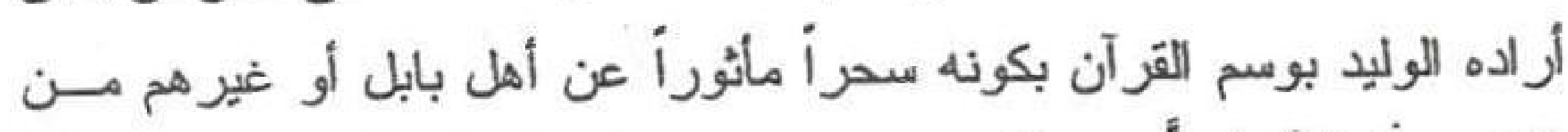

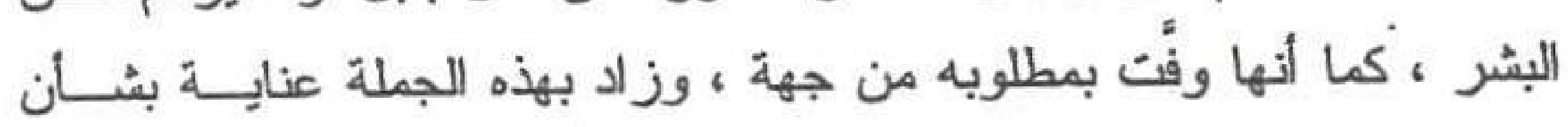

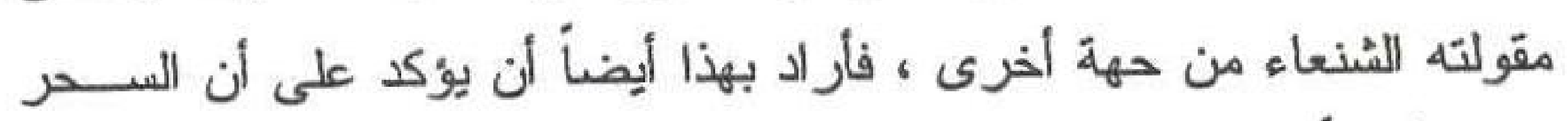

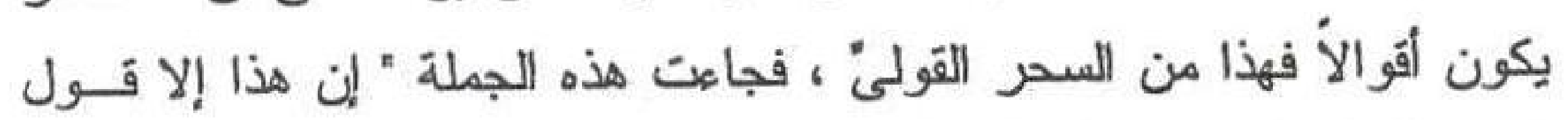

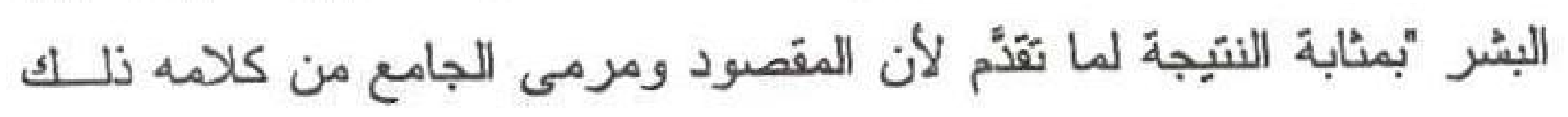

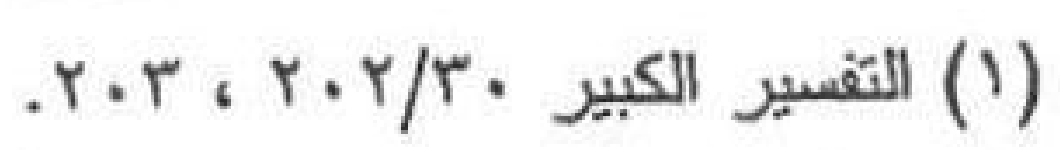

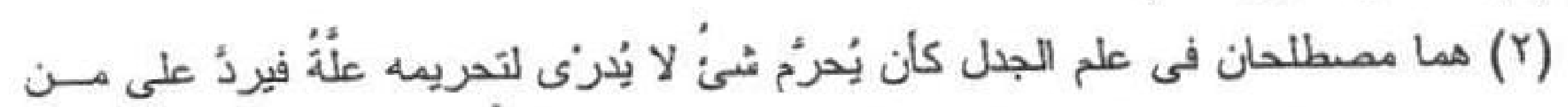

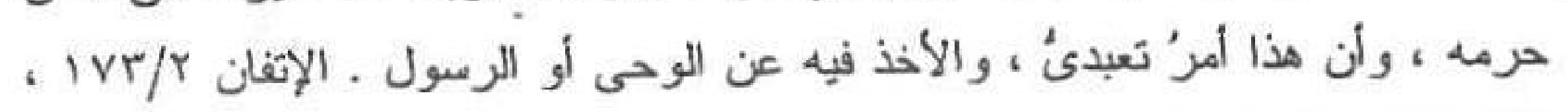

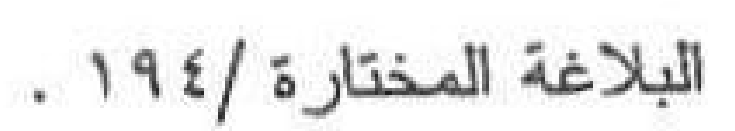

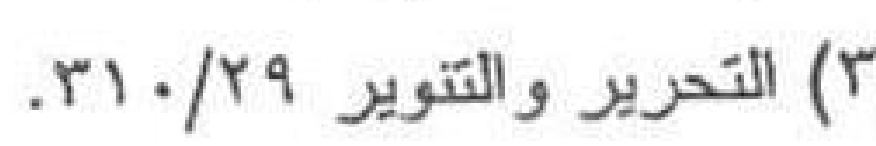


كله أن القرآن ليس وحياً من الله ثم جاء بهذه الجملة أيضاً بأسلوب القصـر عن طريق النفى والاستثناء الذى يفيد أن الوليد بخاطب هؤلاء القوم الــذين

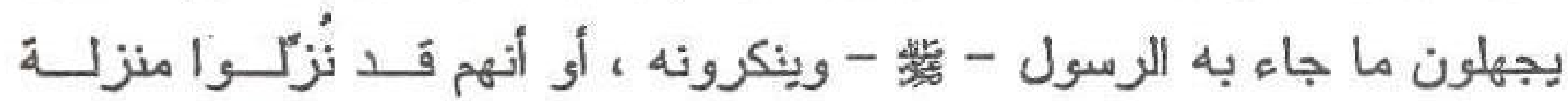

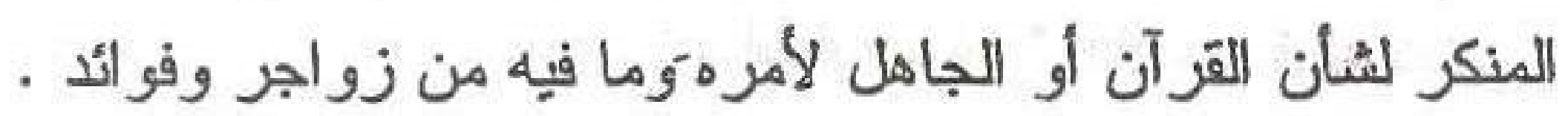

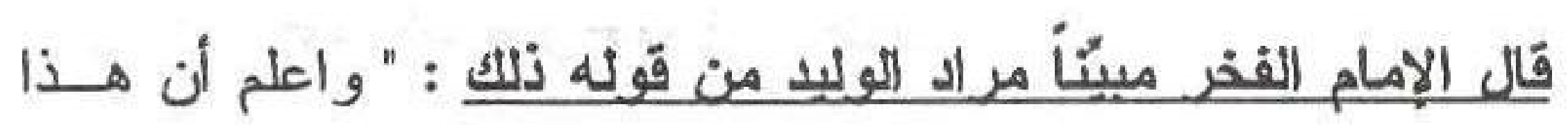

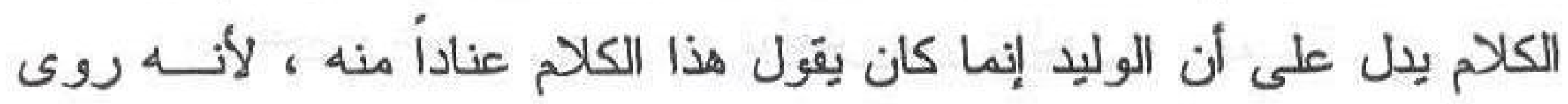

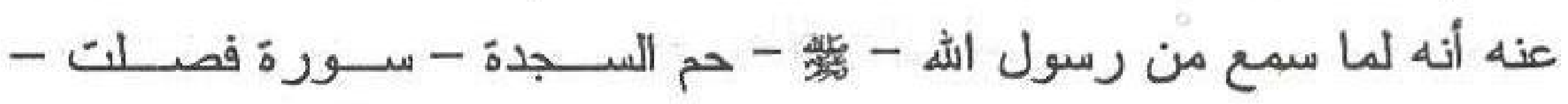

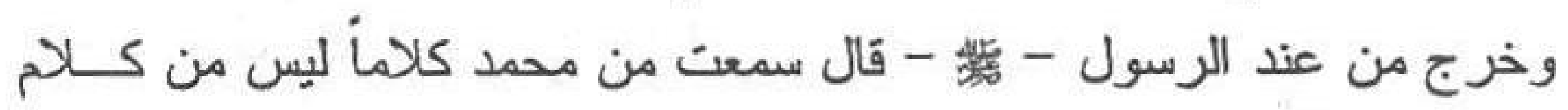
الإنس ولا من كلام الجن ، وإن له لحلاوة و إن عليه لطلاوة و أنه بعلــو ولا

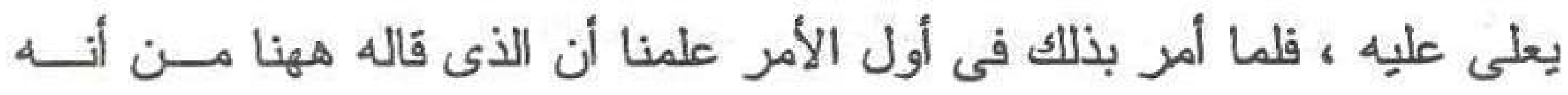
قول البشر ، إنما ذكره على سبيل العناد والتمرد لا على سبيل الاعتقاد (') . وقد فصلت جملة " إن هذا إلا قول البشر " عن جملــة " إن هــذا إلا سحر يؤثر "ولم ينّم الوصل بينهما لأنه كما يقول العلاًّة الزمخشرى : "فإن فئ قلت : فَمْم لَمْ يوستّط حرف العطف بين الجملتين ؟ قلت : لأن الأخرى جرت من الأولى مجرى اللوكيد من المؤكد (") . أى أن ذلك من مسورغات الفصل بين الجمل وهو التأكيد لكمال الاتصال .

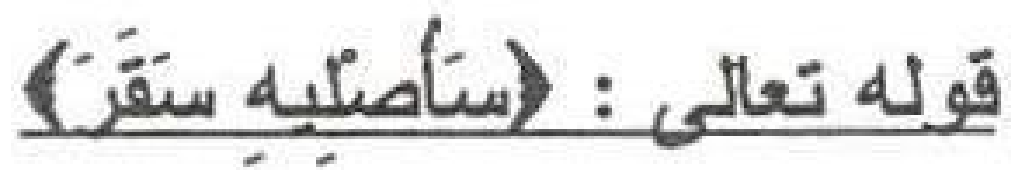

النظم البلاغى : قوله : "سأصليه "جملة مستأنفةً امتثنافاً بيانياً ناشــئاً عن قوله تعالى : " إنه فكرّ وقدرّ " إلى آخر الآيات فذكر وعِيـده وبعـذاب

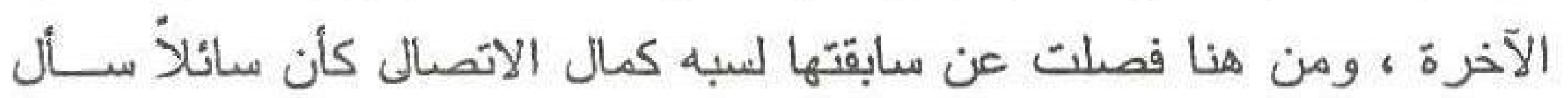




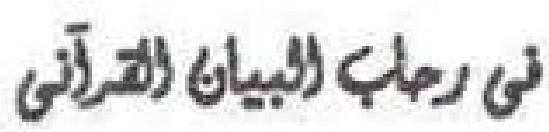

[^r]

فما جزاء الوليد بن المغيرة بعدما قال ما قال فى شأن القرآن والرسول -

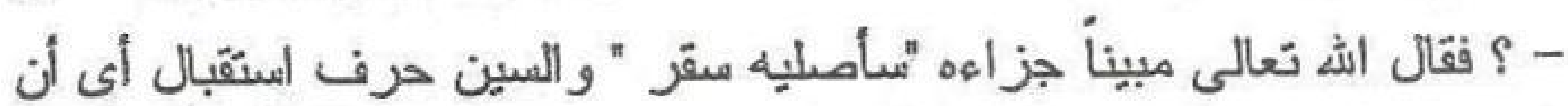
الجزاء اللى ينتظره فى الآخرة جهنم وما أدرالك ما جهنم ؟ ويجوز أن يكون قوله تعالى : " سأصليه سقر " بدلاً من قوله تعالى "

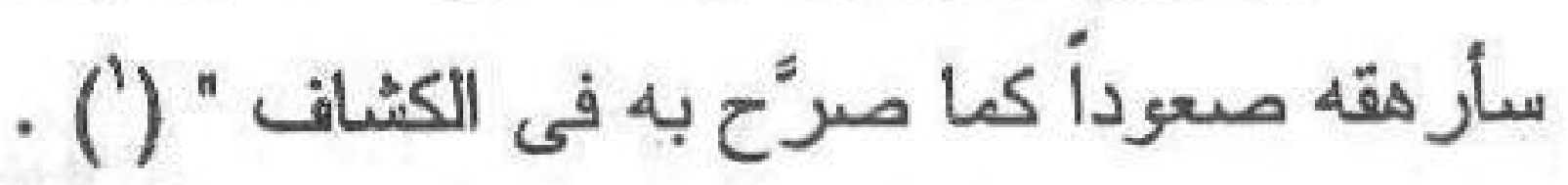

والإصلاء كما بقول الشيخ الطاهر ابن عاشتو : جعل الثئ صالياً،

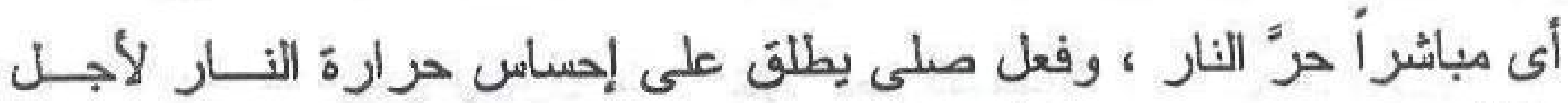

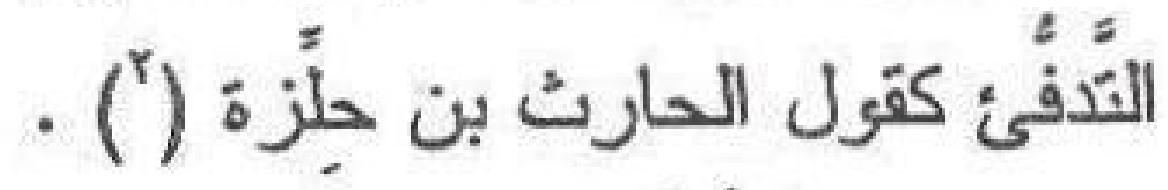

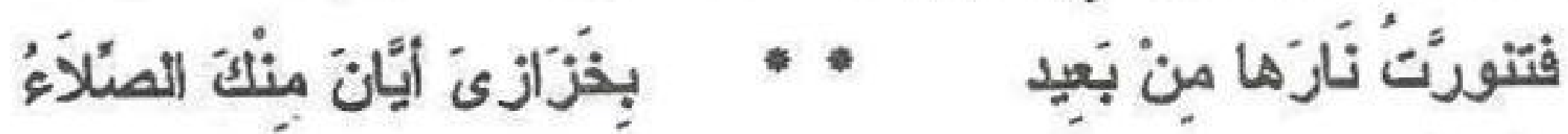

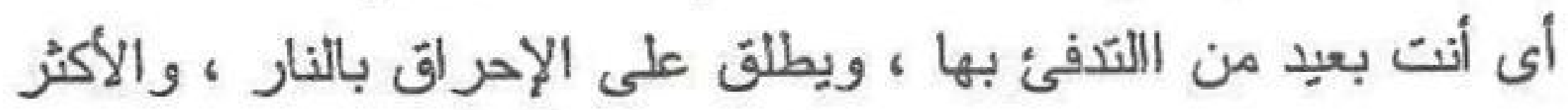
إذا ذكر لفعل هذه المادة مفعول ثان من أسماء النار أن يكون الفعل بمعنى الأسى

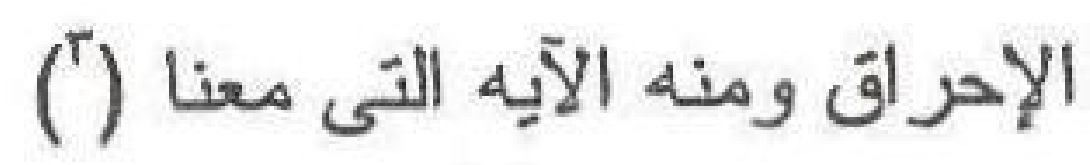

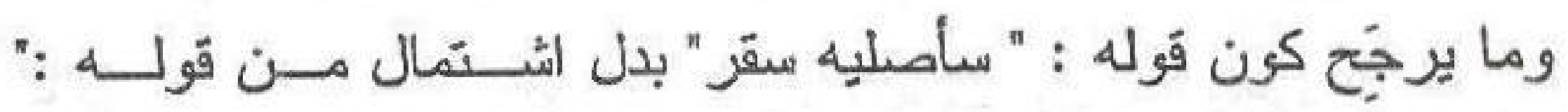

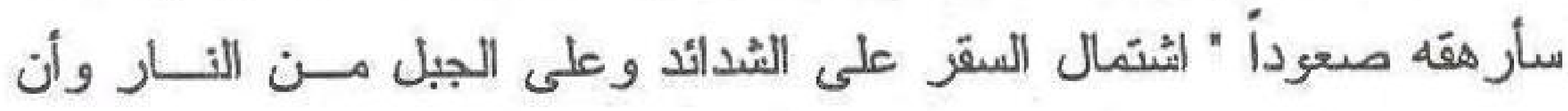
الوصف الآتى لـ " سقر " لا ينافى الإبدال على إرادة الجبل بناءٔ على ألى أن

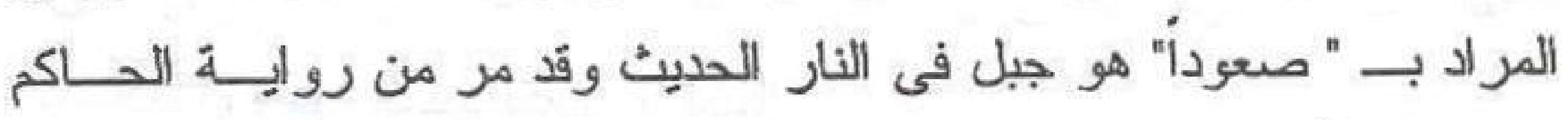

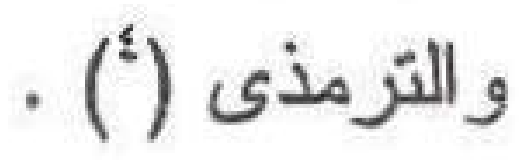

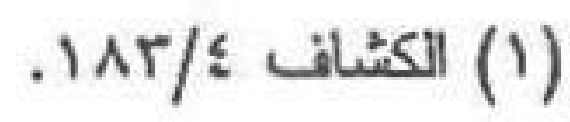

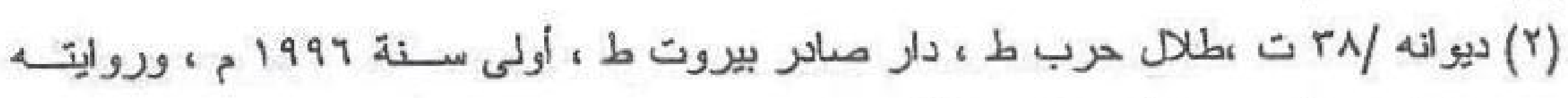

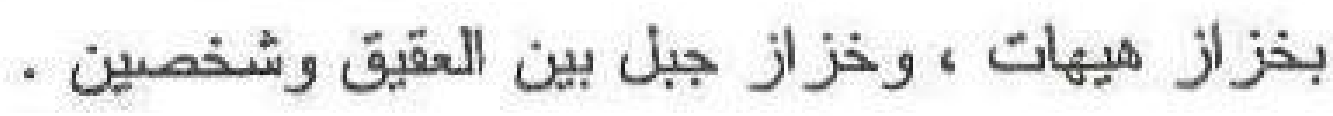

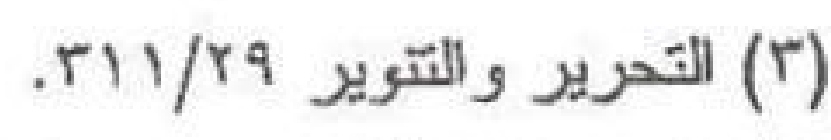

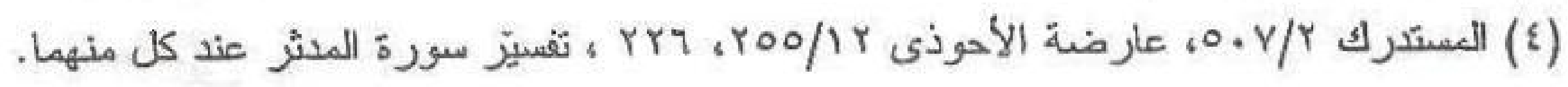




\section{ملح الكلن2 لكعبية}

قِال الشبخ أيو حيلن : ويظهر أنهما - الآيتان - جملتان اعتقبت كل و احدة منهما فتوعد على عبيل التوعد العصبان الأى قبل كل واحدة منهمـــا فتو عد على كونه عنيداً لآيات اله بارهات صعود و على قوله بأن القر آن سحر ميؤثر بإصلائه سقر (') وسقر " السم علم لجهنم ، أو اسم من أسماء النار ، ومن دركات جهنم وجاء فحى تفسير " روح البيلن " للبروسوى ما نصنه : " وقــال ابـنـ عباس - رضى الله عنهما - : - سقر - اسم للطبقة السادسة من جهنم يقال

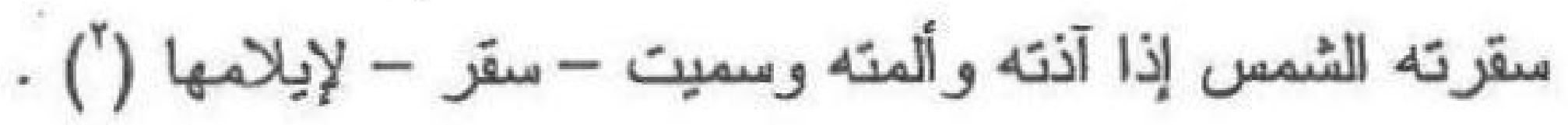
وكنلك برى ابن عطية - رحمه الله - أنهيا : الدرك المــادس مسن جهنم (") و وعلى ما ذكر فهو السم ممنوع من الصرف للعلمبـــة و التأنيــث،

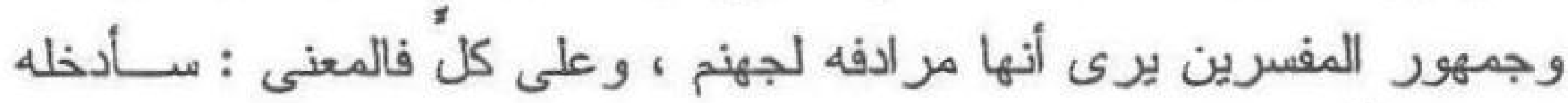

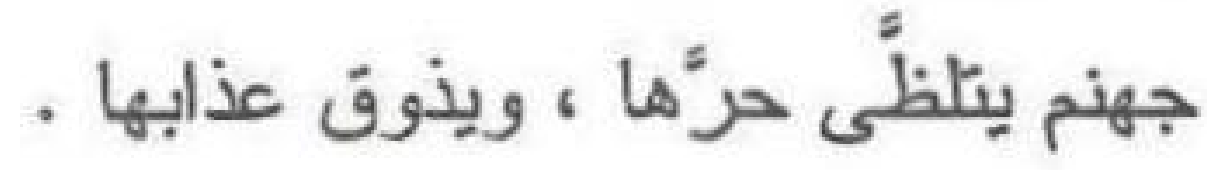

وذكر الإمام السبوطى : أن كلمة "سقر" معرئب دون أن يذكر الكلمة

المعرَّبة ولا من أى لغة هى ، و إنما نقل ذلك عـن الجــو اليقى أنـــه اســم

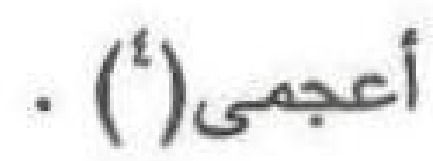

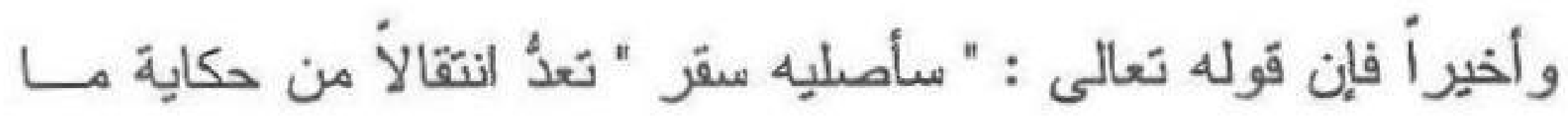
قاله الوليد بن المغيرة إلى بيان الجزاء الذى ينتظره فى الآخرة ، وهذا جز اهلى

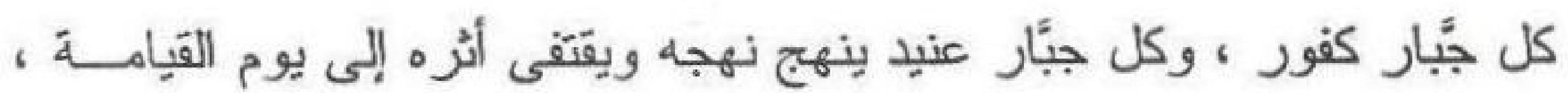

$$
\begin{aligned}
& \text { (1) البحر المحيط A/ro/r. . }
\end{aligned}
$$

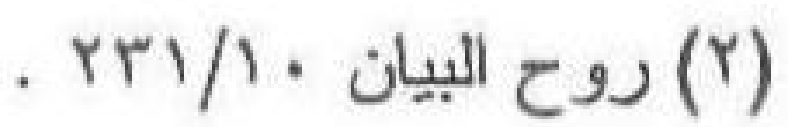

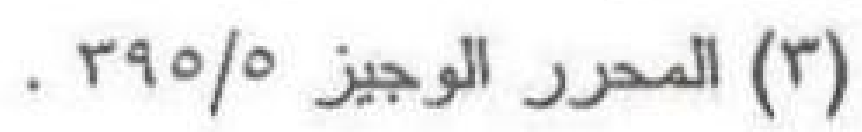

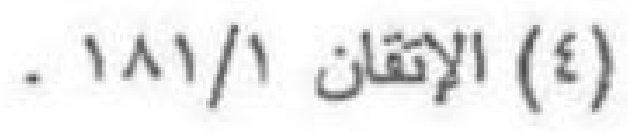




\section{فم رهاب الوبيان لآقرلتى}

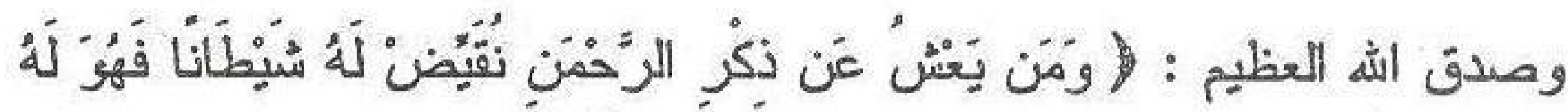

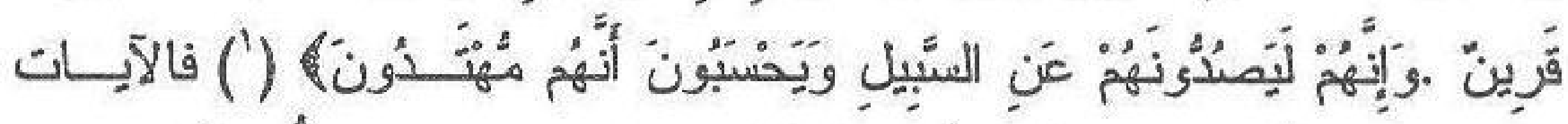

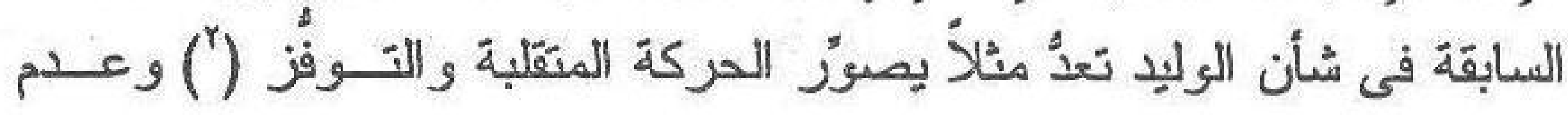

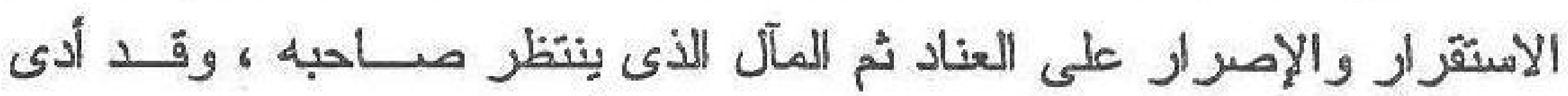

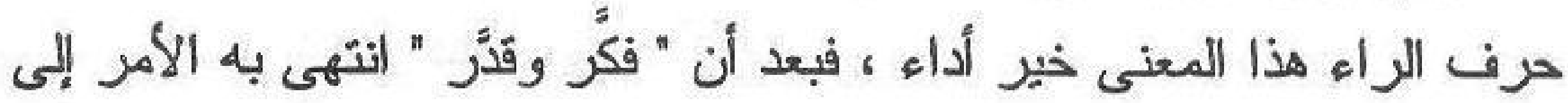

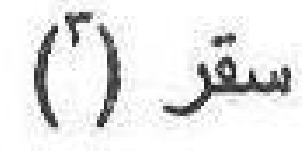

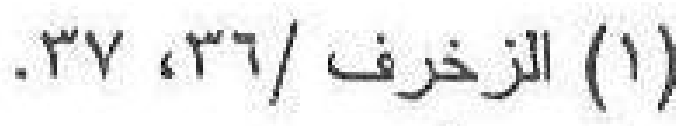

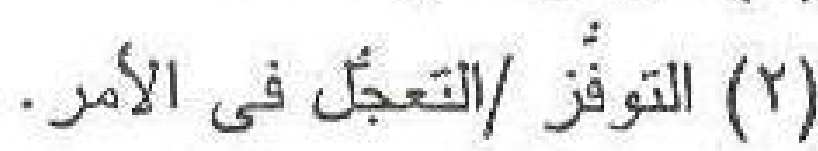

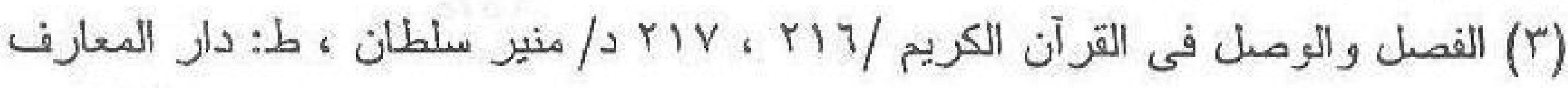

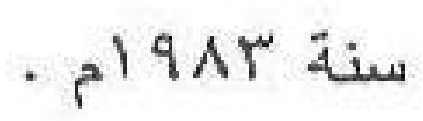




\section{المبهي (لأثاله}

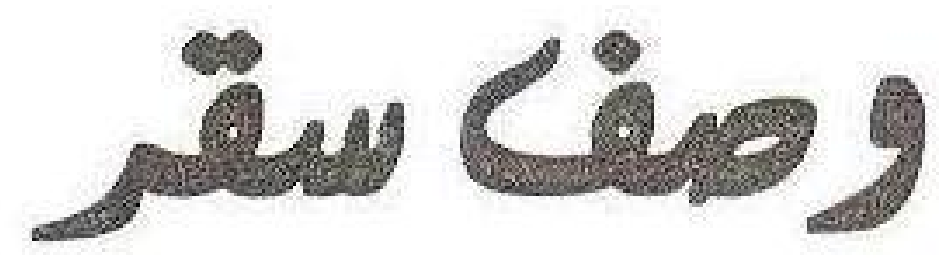

وبياك مرو هُزنة جهنم 



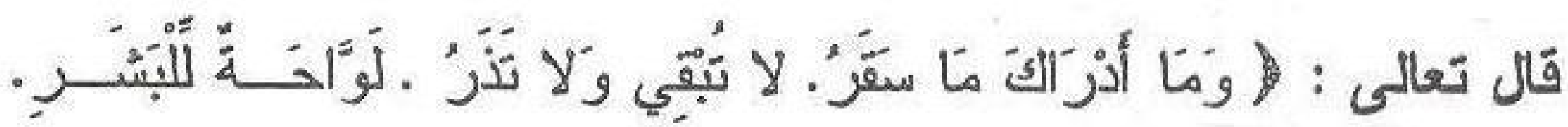

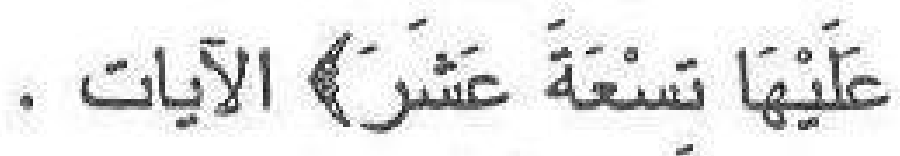

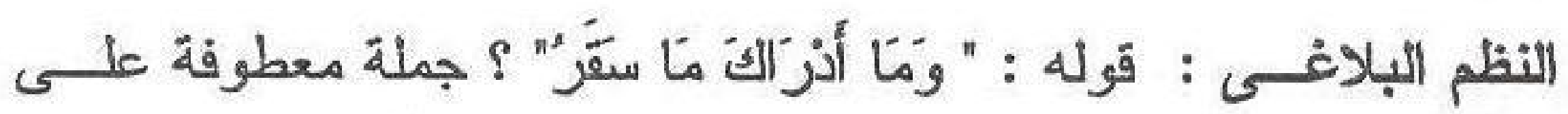

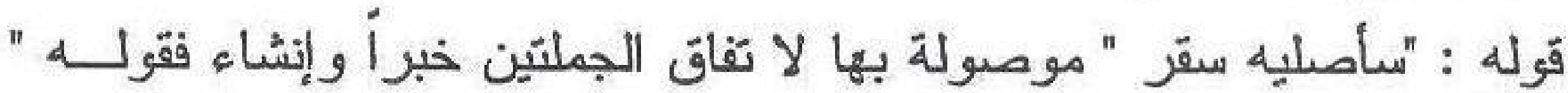

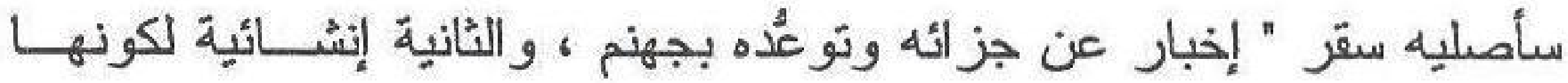
الستفهامية أو مبنية على الاستفهام ، " والواو عاطفة ، و و - ما - اسم استفهام فى محل رفع مبندأ ، و - أدر الك - فعل ماض و الفاعل مستتر تقديره هـــ ك. و الكاف حرف خطاب مفعول به أول ، والجملة خبر - ما و المعنى : أى شئ أعلمك ؟ و - ما الثانية اسم استفهام مبتدأ ، ، و - سقر - خبره ، و الجملـة

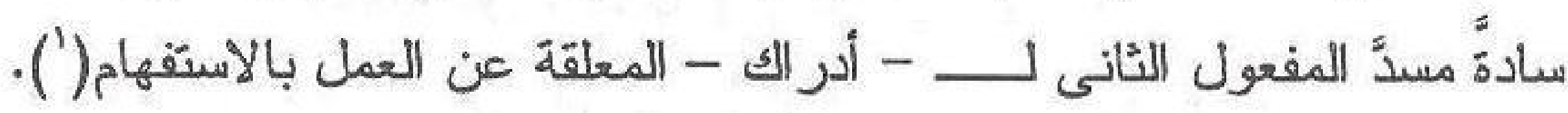
و الاستهام مر اد به التهويل و التفظبع أى وما أعلمك أى شئ هى سقر ؟

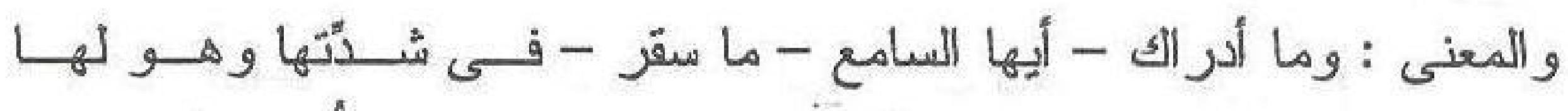

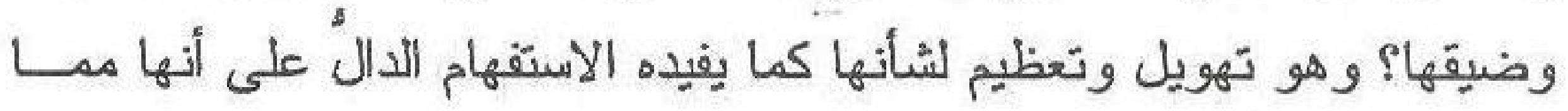

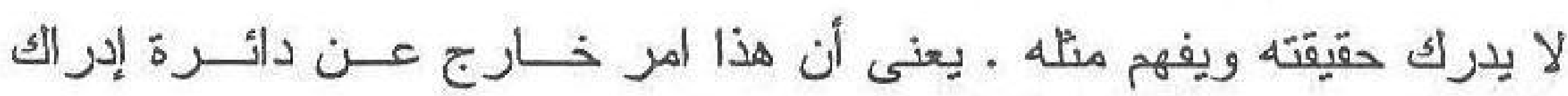

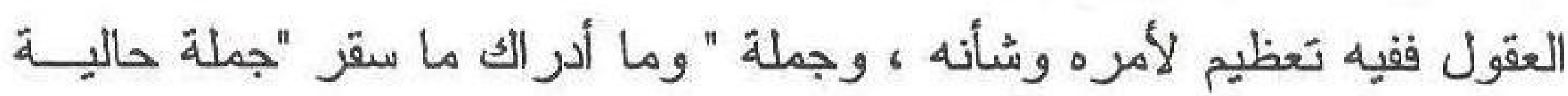

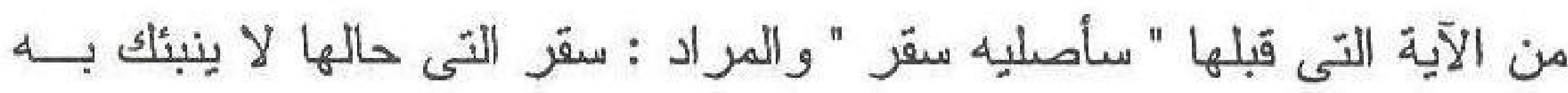
منبئ ، و هذا بيان لفظاعتها وشدة هولها وتغيظها على أهلها .

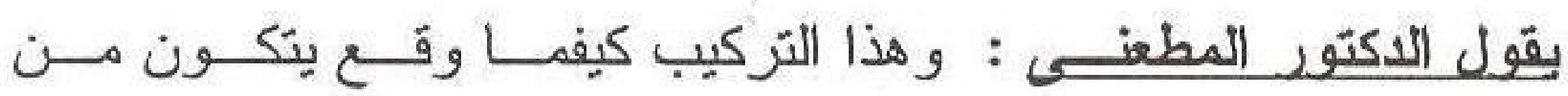
استفهامين لا استفهام واحد ـ الأول - هنا - قوله تعالى : " ومــا أدر الك " ؟ و أما الثانى - هنا كذللك - فهو قوله تعالى : " وما ســر " ؟ و المــر اد دــن 
الاستفهام الأول هو اللفى أى الإنكار ـ أما المراد من الاستفهام الكـانى فهـو

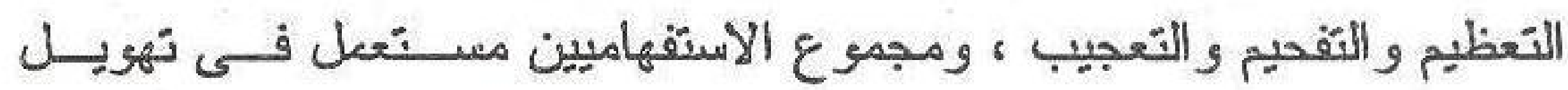

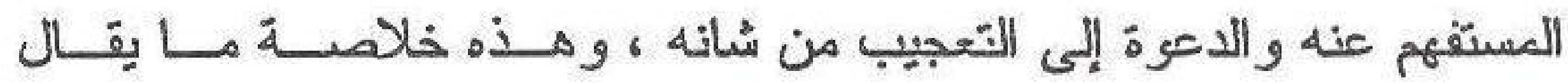

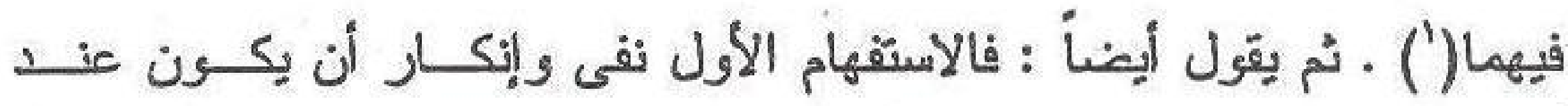

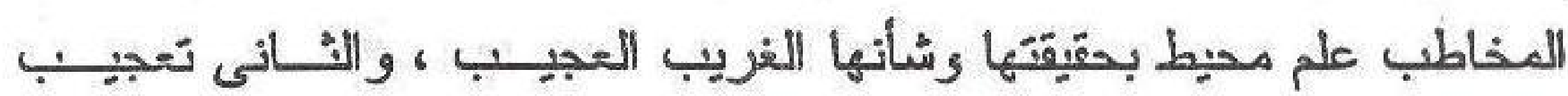

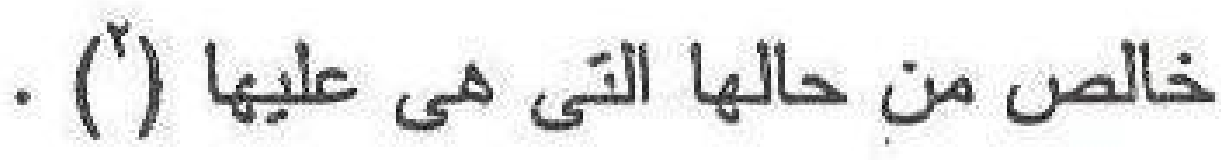

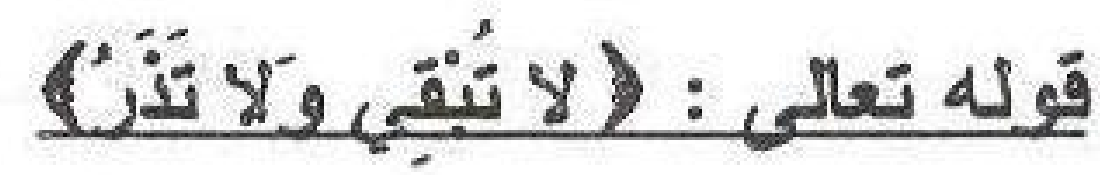

النظم البلاغى : قوله : " لا تبقى " بدل اشتمال من التهويل الذى أفادته

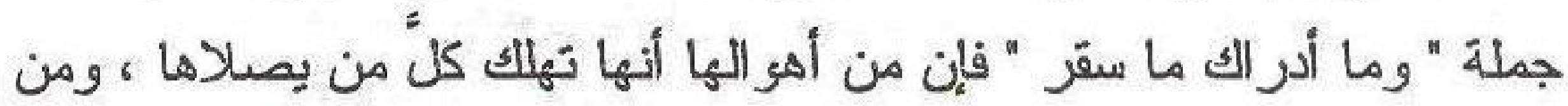
هنا فصلت هذه الجملة عن سابقتها لأن بين الجملتين كمال اتصال ، فجملة "

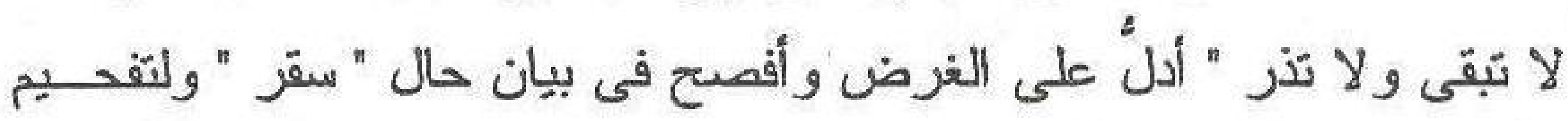

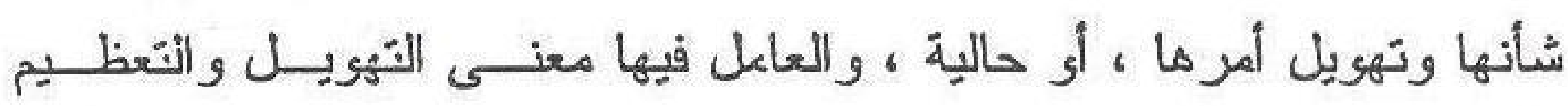
لأمر ها ، وذلك لأن الاستفهام بقوله تعالى : " ما سقر " للتعظــيم فــالمعنى:

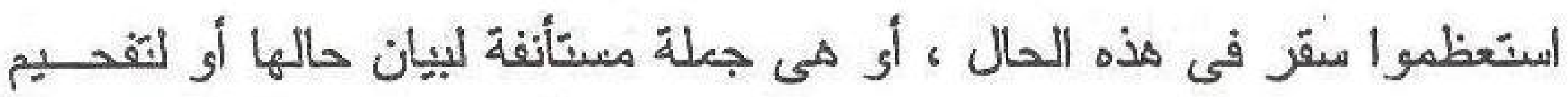

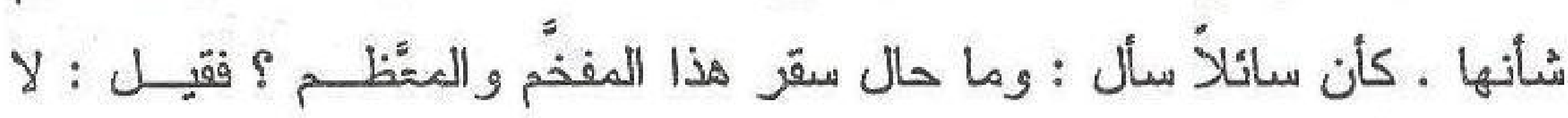

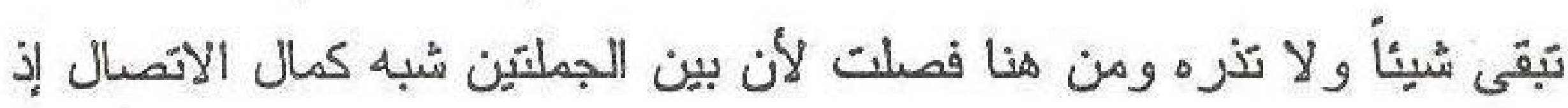

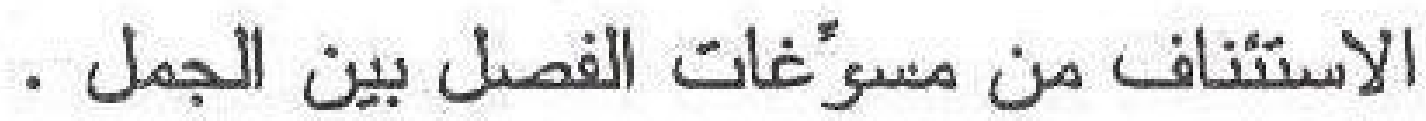

ويرى بعض المحثثين : إلحاق شبه كمال الاتصال بضــرب كمـال الاتصال وذلك إذا وقعت الجملة الثانية من الأولى موقع الجواب عن سـؤئال 
صريح أو مقدر (') ومستنده فى ذلك كلام الإمام عبد القاهر - رحمه الله إذ يقول : "فتزك العطف يكون إما للاتصال إلى الغاية ، أو الاثفصال إلــى ملى الغاية (†) ويقصد بالاتصال كمال الاتصال ، و إدخال شبه كمال الاتصال فى هذا الضرب دخولاً أولياً، وكذلك مراده بالانفصال كمال الانقطاع مع دخول شبه كمال الانقطاع فى هذا الضرب ويعدُ كلن واحد من الشبهين صورة مسن ولن صور كمال الاتصال أو كمال الانقطاع.

وحذف مفعول " تبقى " لقصد العموم ، و المعنى لا تبقى منهم أحداً أولاً

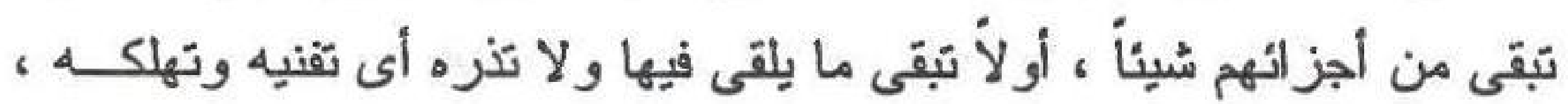
وقوله : " ولا تذر " معطوف على قوله : " لا تبقى " فهى فى معنى الحال ، أى "ولا تبقى لهم لحماً إلا أكلته و لا تذرهم إذا أعيدوا خلقاً جديدأ إلا أكا تهنه وهذا أبدأ وهى لا تقنع بمجرد التعذيب بنوع من أنواع العذاب بل تبالغ فى لَّى تعذيبه إلى أن تهلكه ()

وقوله تعللم : " لا تبقىى ولا تذر " قيل : إنهما لفظان متر ادفان بمعنى

واحد ، وقيل : إنهما متغايران ، ولتوضيح ذلانك نتأمل ما ذكره الإمام الفذر رحمة الله -

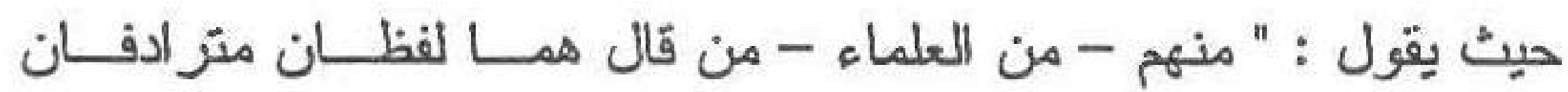

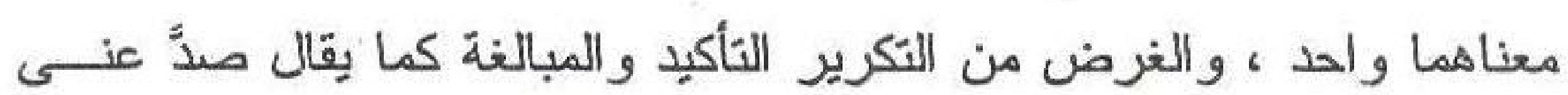

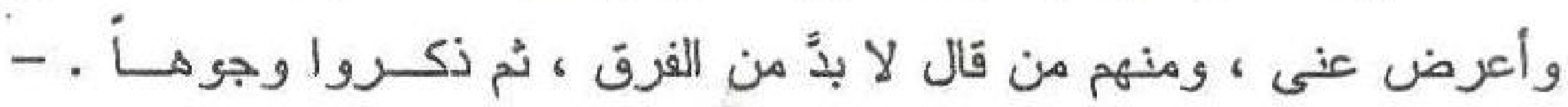

(1) دراسات فى علم المعانى /97 19 د/ حسن مخيمر ط :الأمانة مصر ط : أولـى ســة

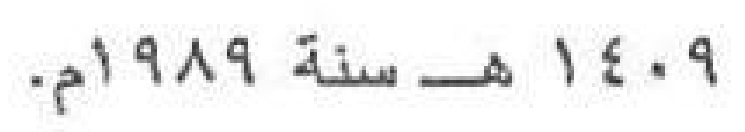

(r) دلائل الاعجاز / (r)

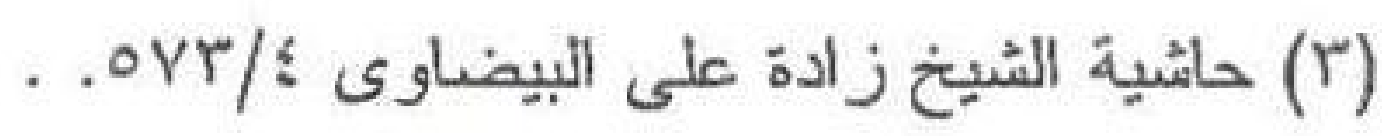




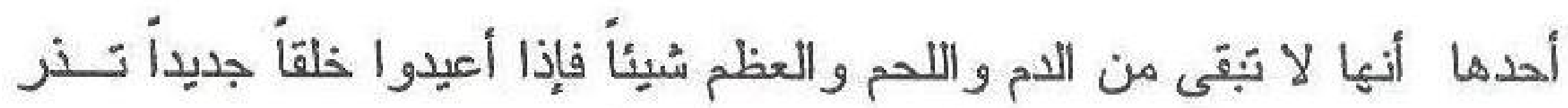

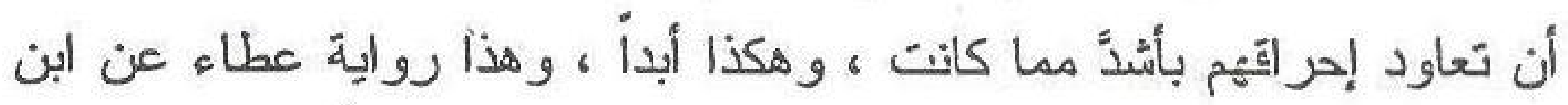

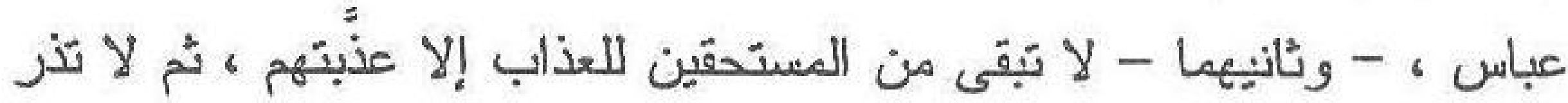

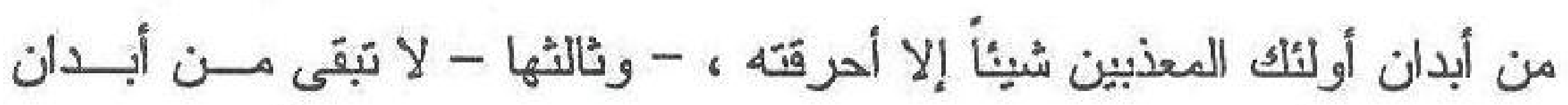

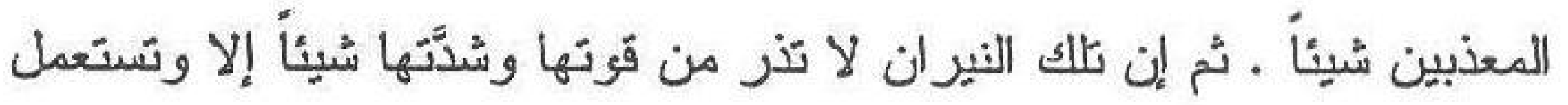

تلك القوة و الثُدة فى تعذيبهم (')

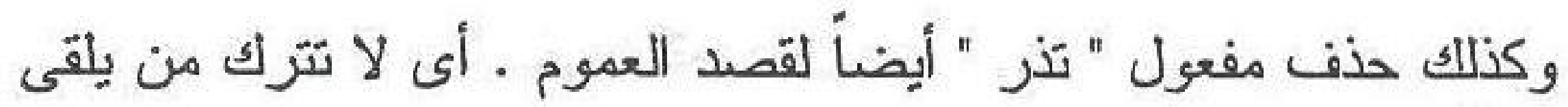

فيها ، أى لا تركه غير مصلى بعذابها ، و هذه كناية عن إعادة حياته بعـد

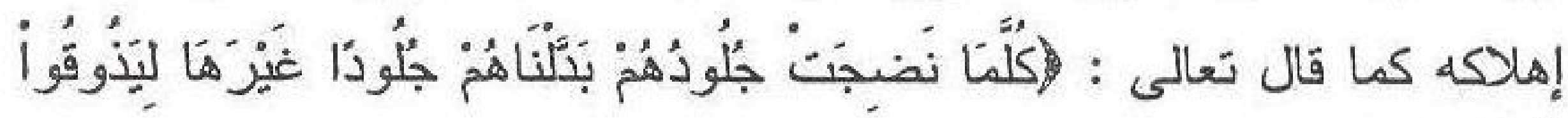

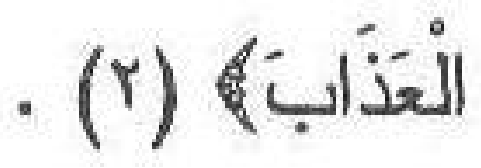

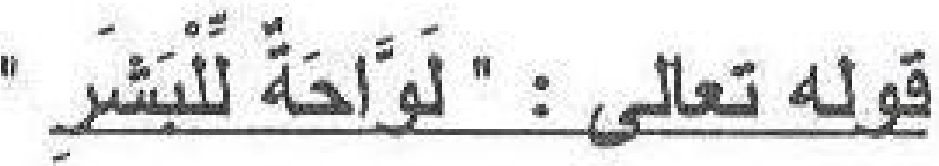

النظم البلاغى : قوله : " لوًَاحة " خبر لمبتدأ محذوف وهو المسند إليه

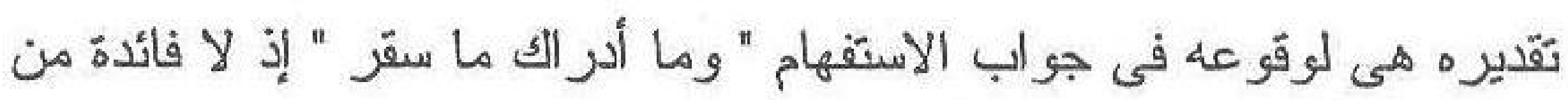

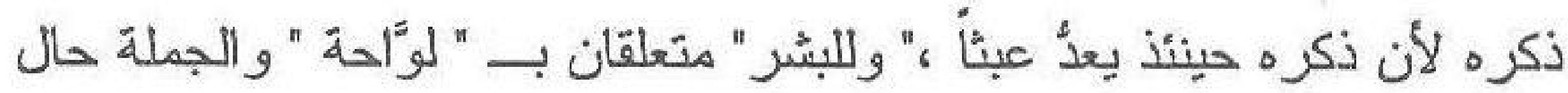
ثانية أو السثنافية . مكره

قال الثبيخ الجمل: قوله - لوَّاحة للبشر - قرأ العامة بالرفع خبر مبتدأ

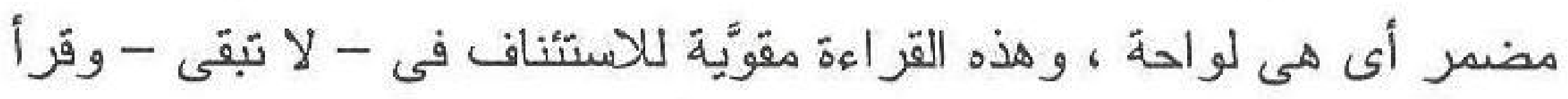
الحسن وابن أبى عبلة وزيد بن على وعطية العوفى بنصبها على الحسال ،

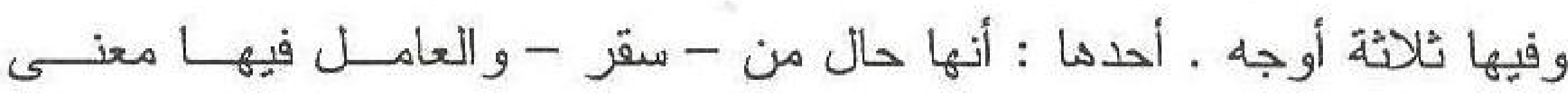
التعظيم كما تقدّم ، والثانى : أنها حال من - لا تبقى - ، و الثالث : من - لا لان 
تذر - وجعل الزمخشرى نصبها على الاختصاص للتهويل ، وجعله الشيخ -

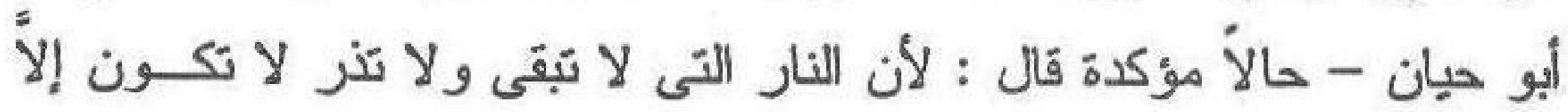

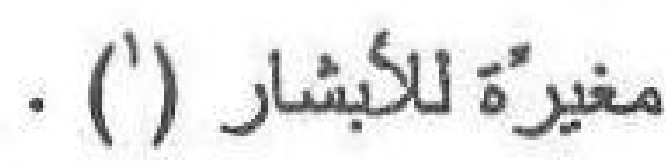
و الثانى : وإليه ذهب الجمهور أنها من لوَّحه أى غيَّره وسوَّده ، وهو ما ذهب إليه ابن عباس ومجاهد وقتادة وَأبو رزين () . وقيل : "اللوح " شُدة العطش يقال : لاحه العطش ولوَّحه غيَّره أو غيَّ خلقته ، و عليه قول القائل . (") .

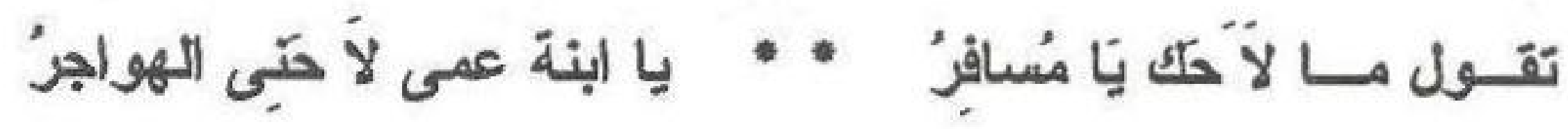
و "اللؤوحبالضمٌ : الهواء بين السماء والأرض (أ) . و " البشر " إما جمع بشرة أى مغيرّة للجلود ، و إما أن يكون المراد به

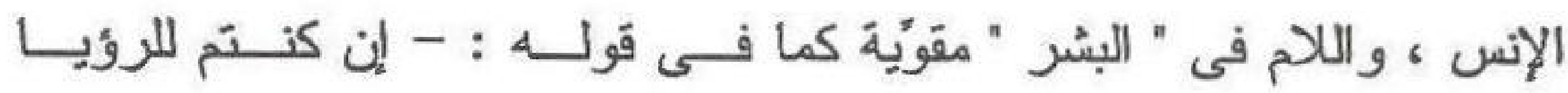

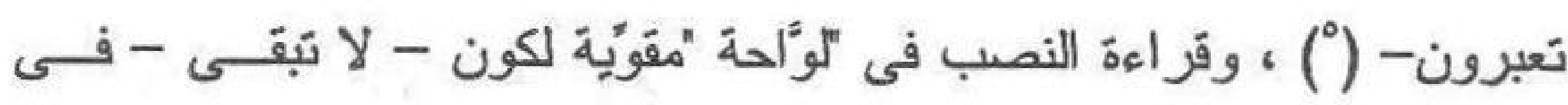

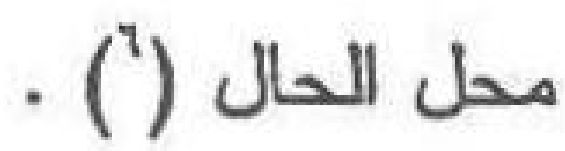
اعتراضنُوردُه : وملخص هذا الاعتر اض أنه لا يصحُ وصف " سقر

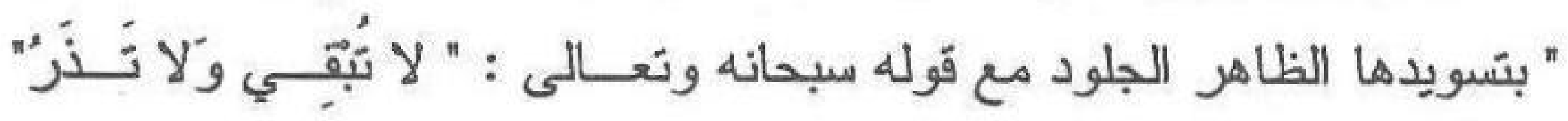

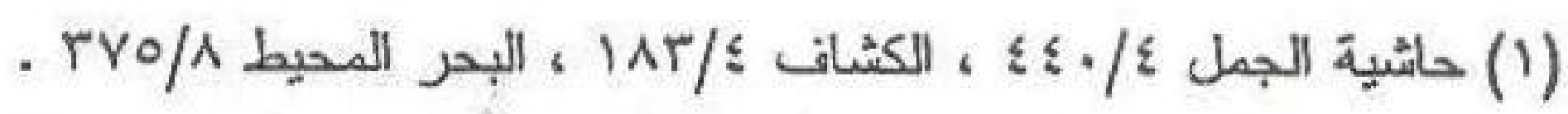

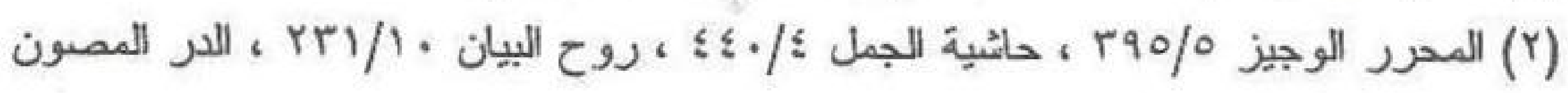
. $\varepsilon 1 V / r$

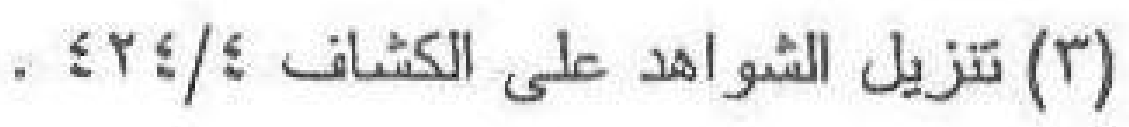

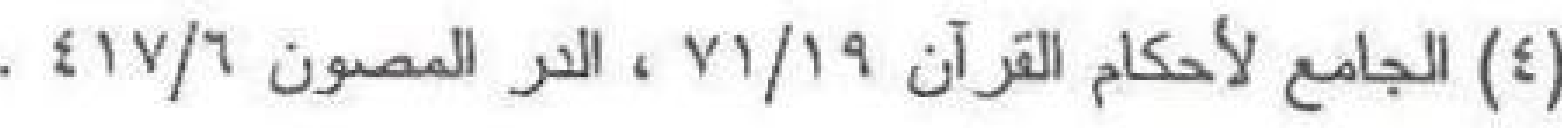




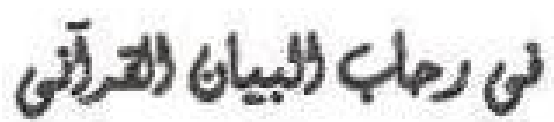

الصريح فى الإحراق والجواب عن هذا الاعتر اض : أنها فى أول الملهــاة

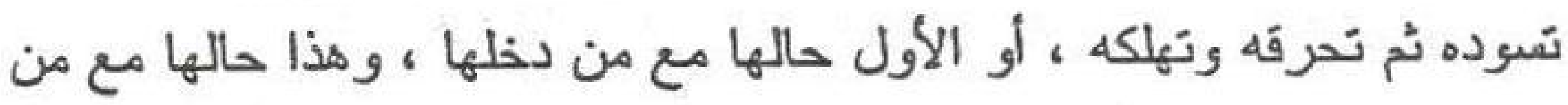

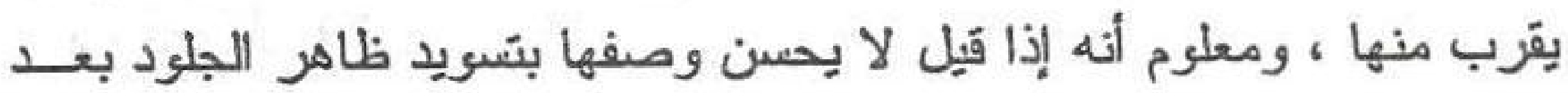

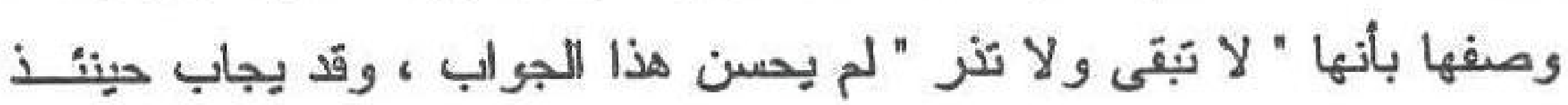

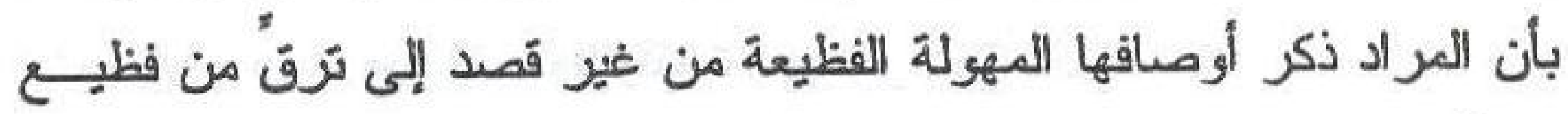

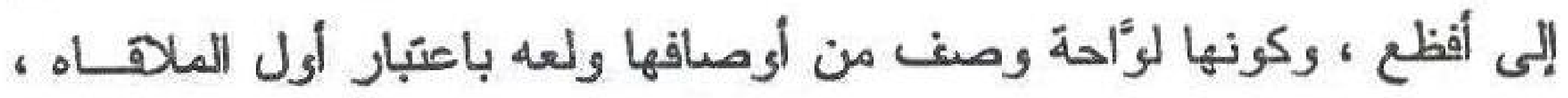

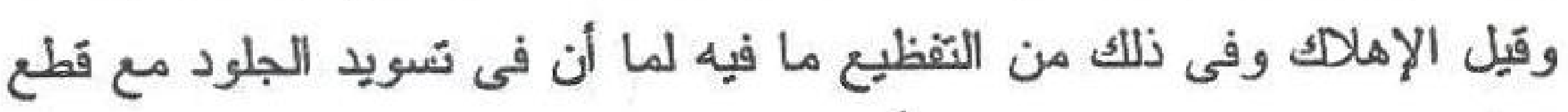

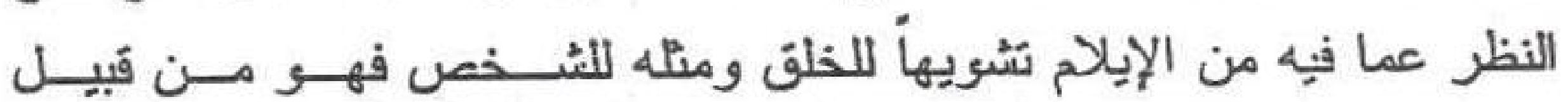
التتميم)(')

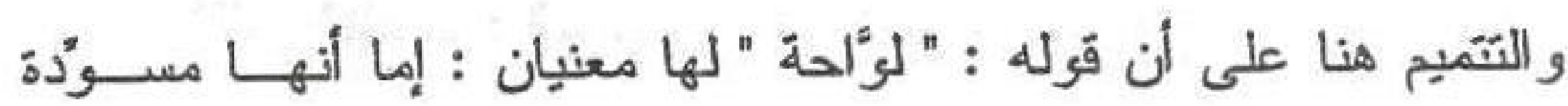

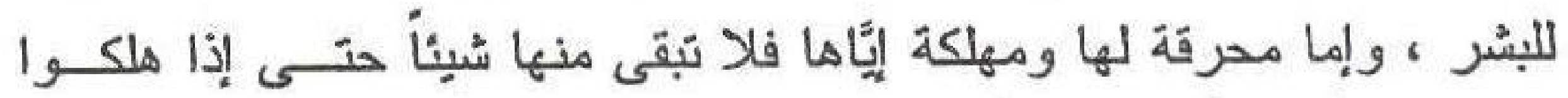
أعيدو اخلقاً جديدأ وهكنا أبداً .

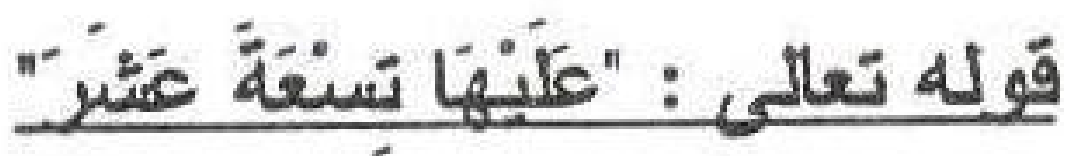
اللنظم الثلاغى : قوله : " عليها " الآية خبر رابع عن " سقر " من قوله

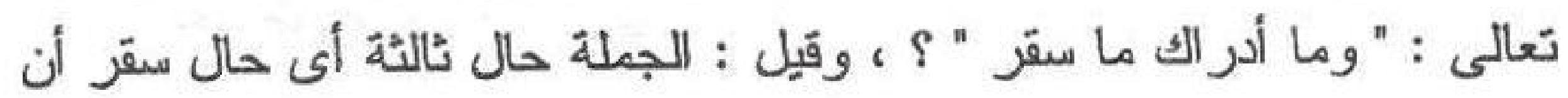

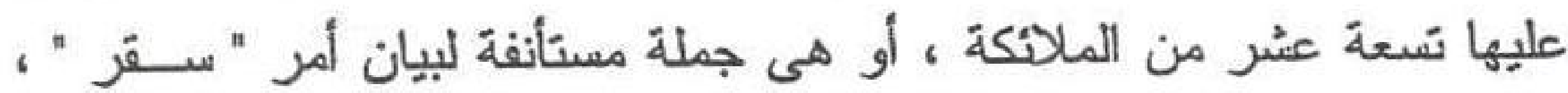
و هى جملة مفصولة عما سبق ، و " عليها " خبر مقدم من باب تقديم المسند

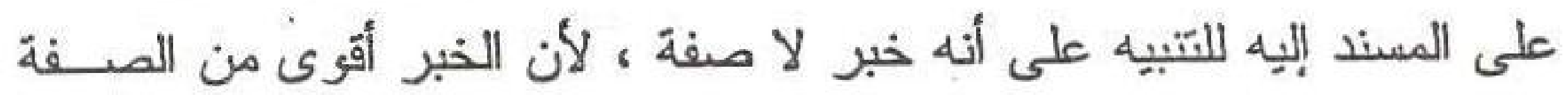

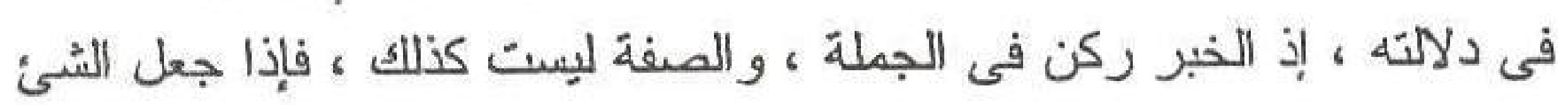

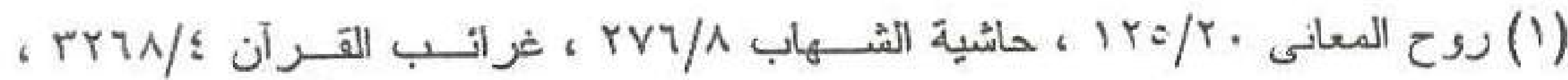

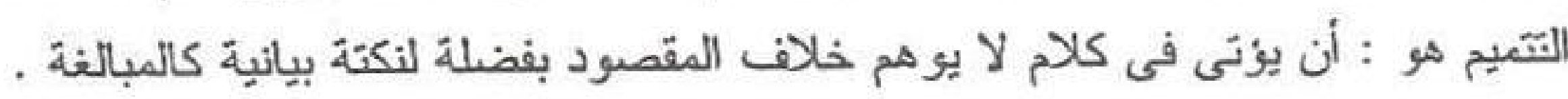

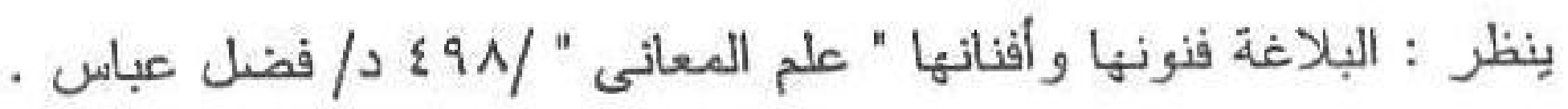




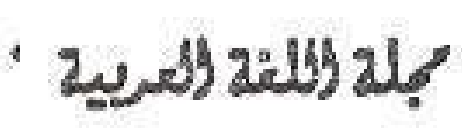

خبر أ كان دالأ على شأنه وخطره أكثر من كونه صفة من الصفات ، ولهــذا

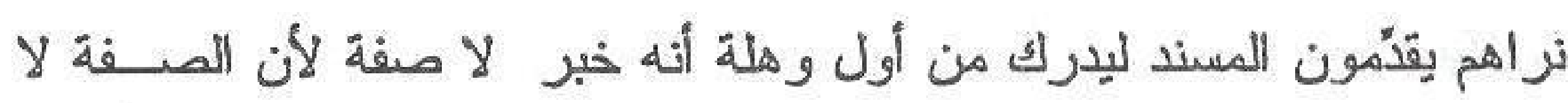
تثقدّم على الموصوف ، ولكن الخبر قد يقدَّم على المبتدأ ، و إذا كان خبرأ كان أقوى فى الألالة على ما يريدون ، ثُ إن فى ثقديم المسند على المسند إليــــا

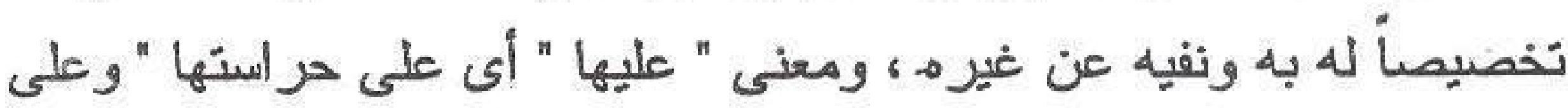
"هنا استعارة تبعية فى الحروف لأن الاستعلاء هنا استعلاء مجازى بتسّـبيه

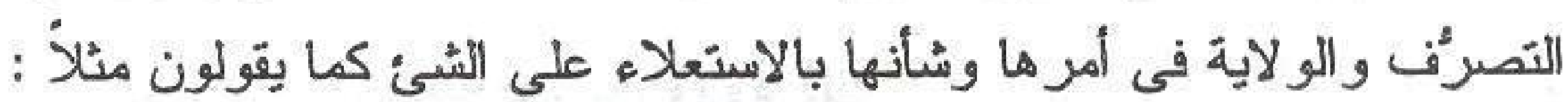

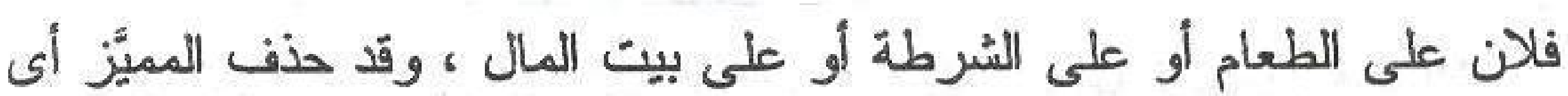

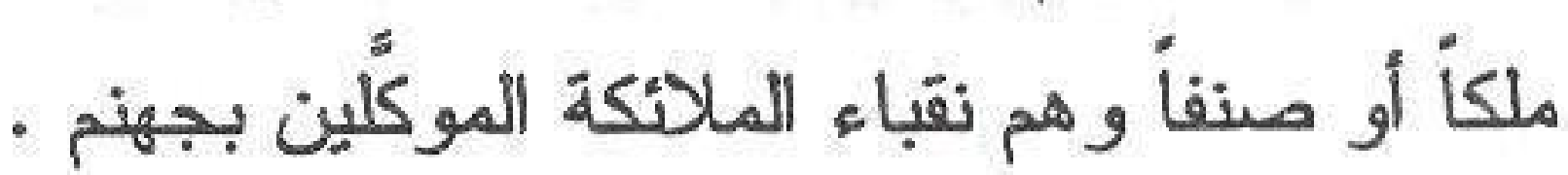

قال الشبخ أبو هيلن : التمييز محذوف والمتبادر إلى الذهن أنه ملك ألا تزى العرب وهم الفحصاء كيف فهموا منه أن المر اد ملك حين سمعو ا ذلك ،

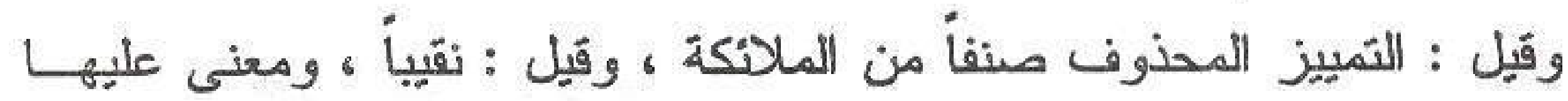

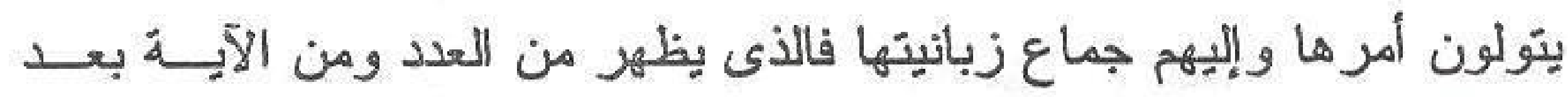
ذلك، ومن الحديث أن هوُ لاء هم الأقباء ألا نزى إلى قوله نعالى : - وما يعلم جنود ربك إلا هو • وقوله - عليه الصلاة و السلام - يؤتى بجهنم يومئذ لها

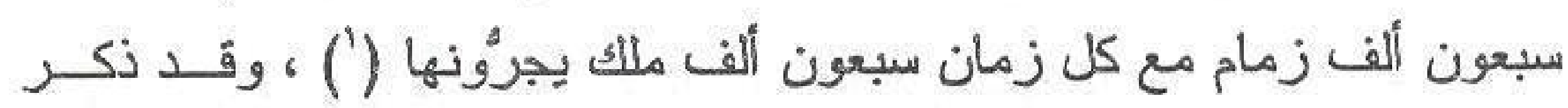

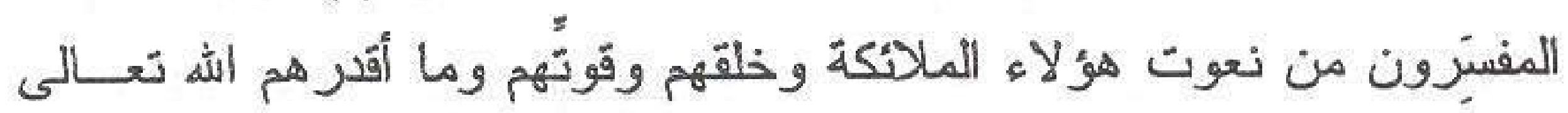
عليه من الأفعال ما الله أعلم بصحته (i). وقد وضع الأستاذ محى الأدين الدرويش : هذه الأية تحت ما يُسمَّى فنَ" الإبهام : "وهو أن يقول المنكلم كلاماً يحتمل محنيين منتسايرين لا بتميـز

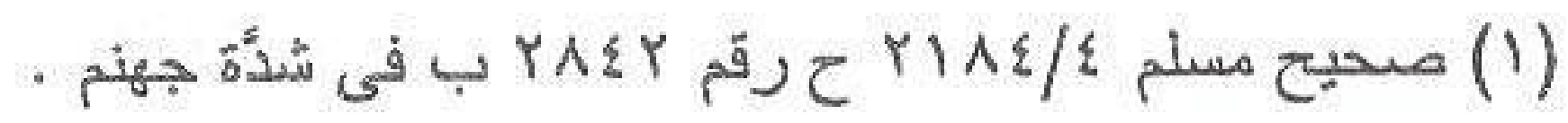

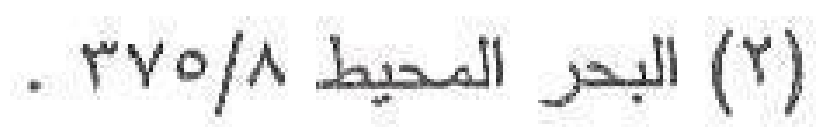


أحدهما عن الآخر والفرق بينه وبين الآشر الك المعيب أن الاشترالك لا يصح

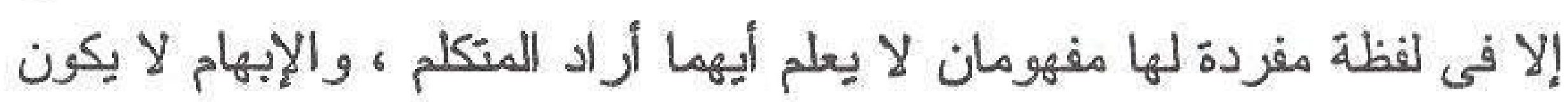

إلا فى الجمل المؤتلفة المفيدة (')

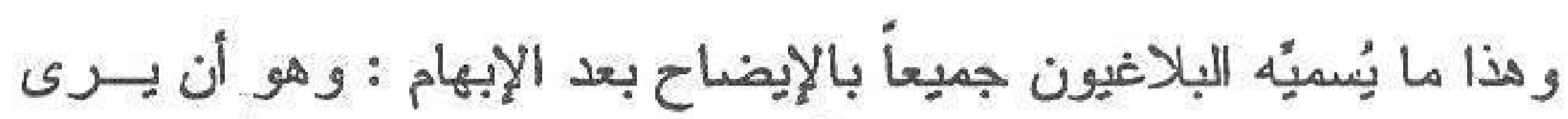

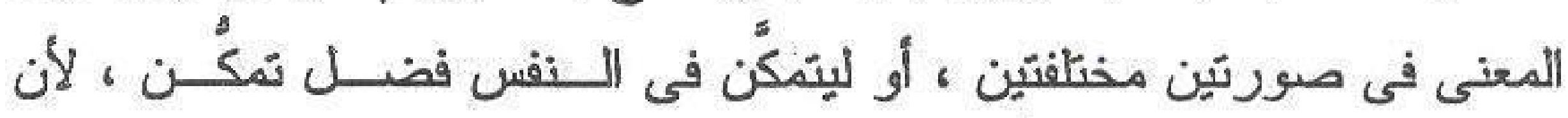

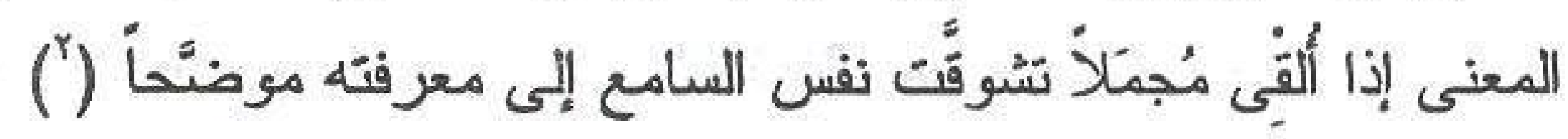

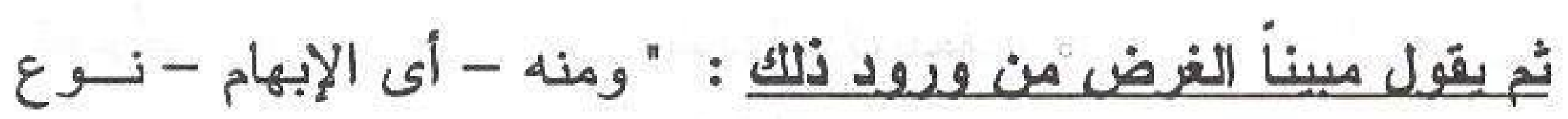
آخر يقع لأحد أمرين : أما لامتحان جودة الخاطر وإما لامتحان قوة الإيمان وضعفه وهذه الآية التى نحن بصددها من هذا النوع أمَ لأى امتحان قودة الإيمان

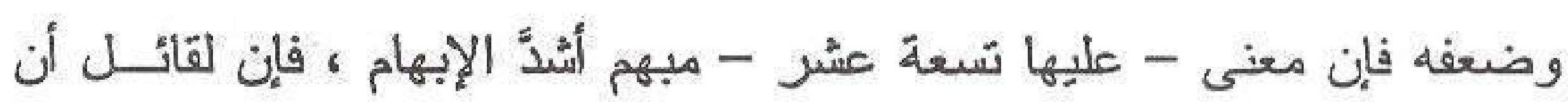
يقول : ما النكتة فى ذكر هذا العدد ؟(")

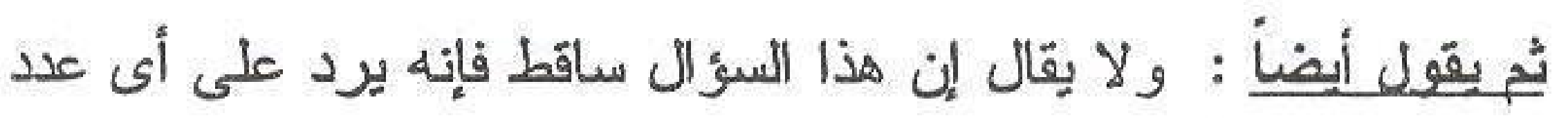

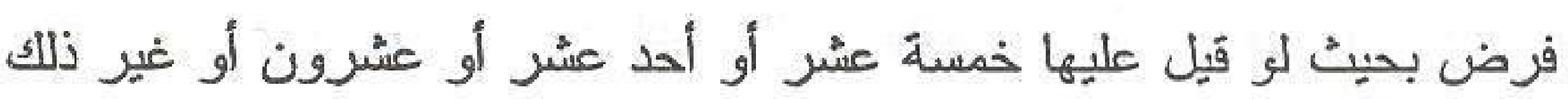

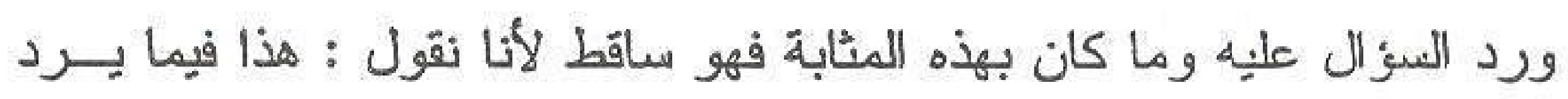

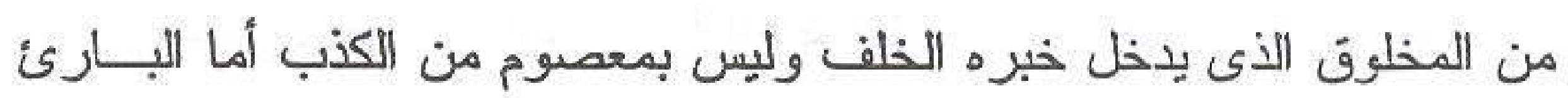

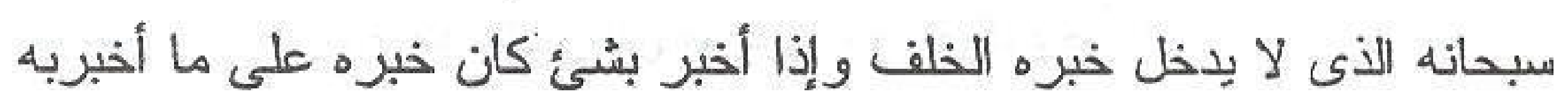

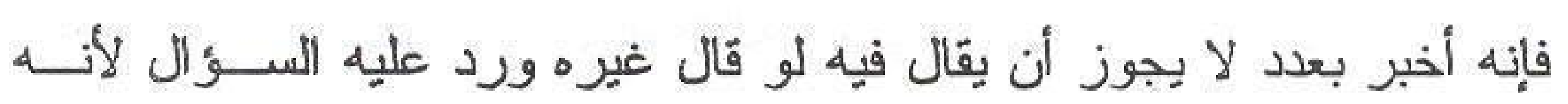

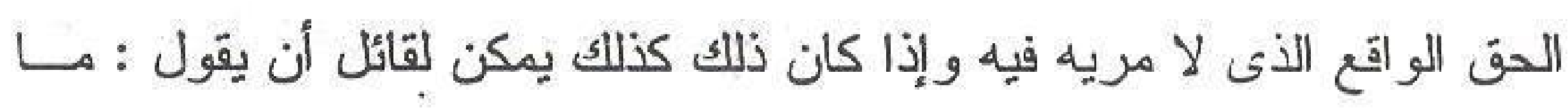

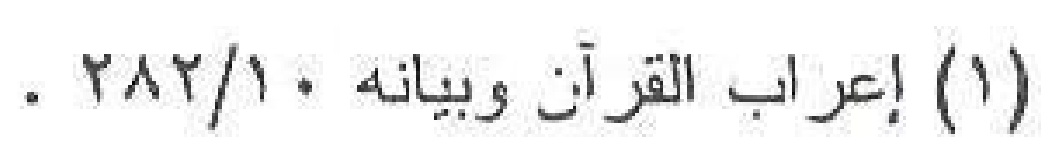

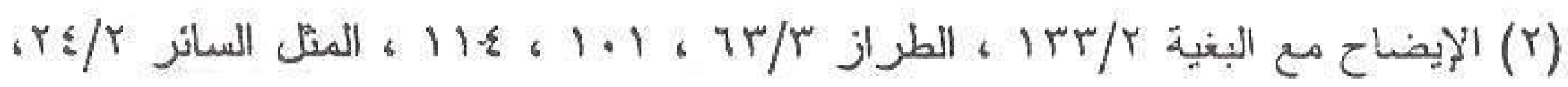

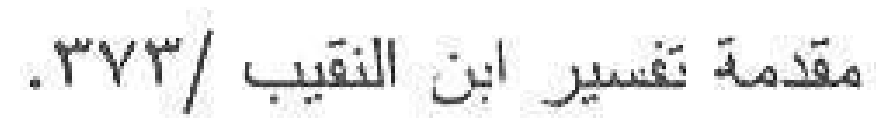

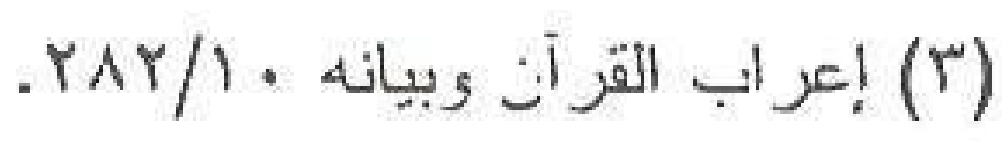


الحكمة فى جمل ملائكة العذاب على هذه العدة ؟ فيكين السؤ الل وارداً مستحقاً

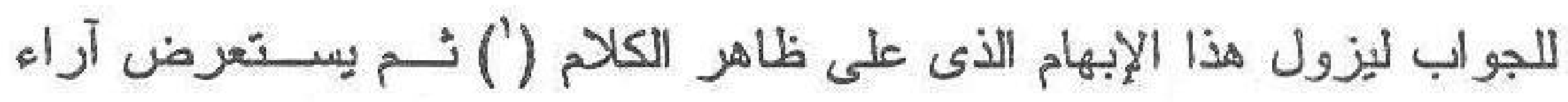
- المفسرين فى ذلك () مدون

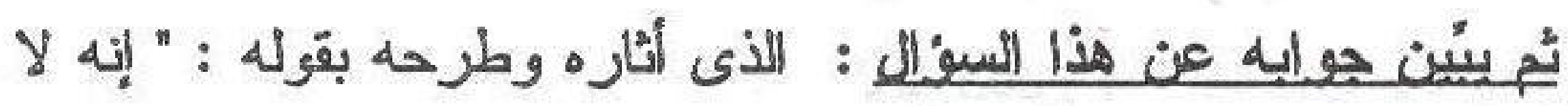

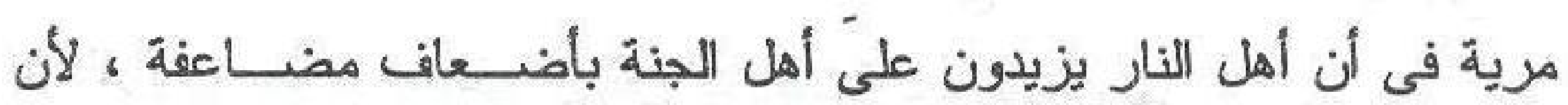

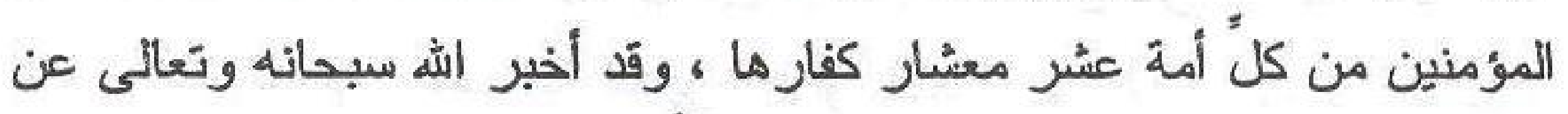

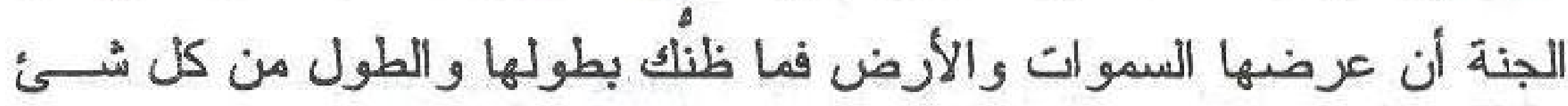
فى معترف العادة أكثر من العرض فأهلها على هذا لا يحصــيهم العــدُ ولا

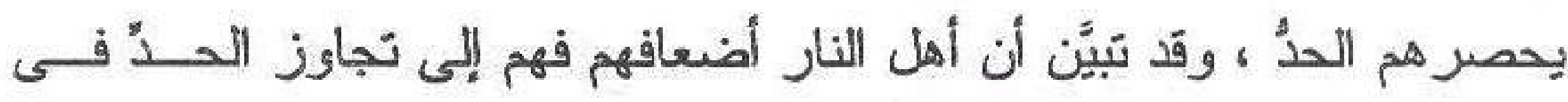

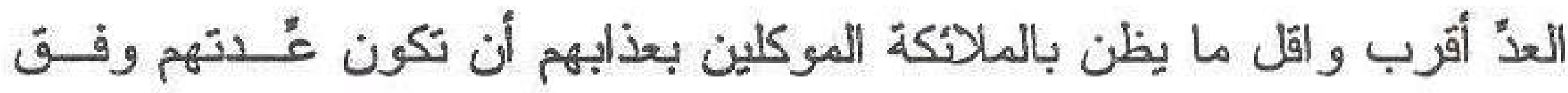

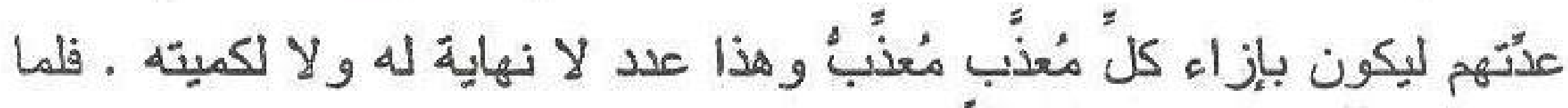

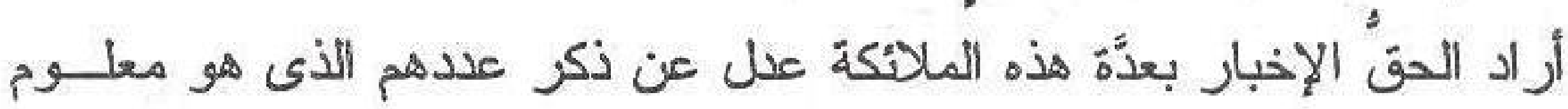

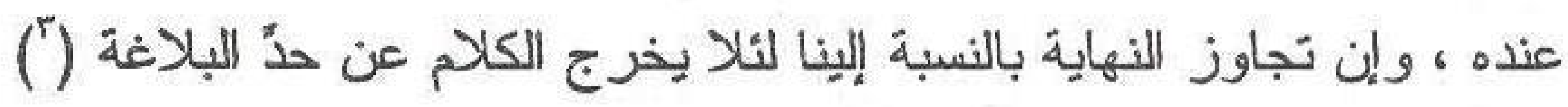

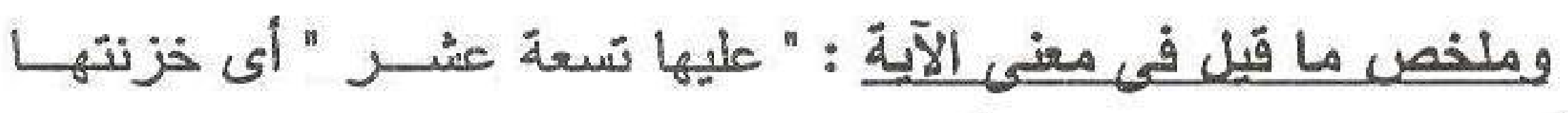

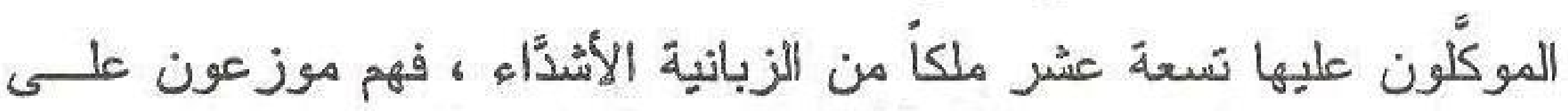
دركات سقر أو جهنم

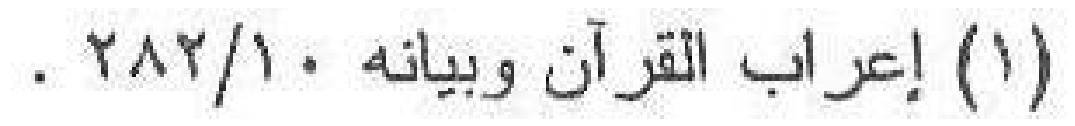

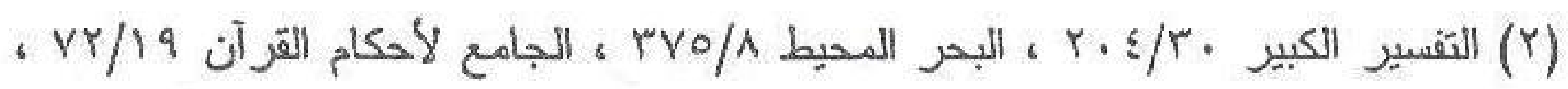
النيسابورى / الن /

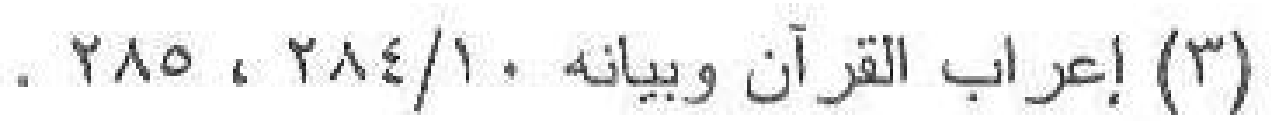




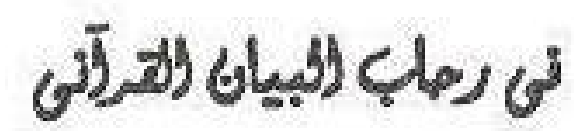

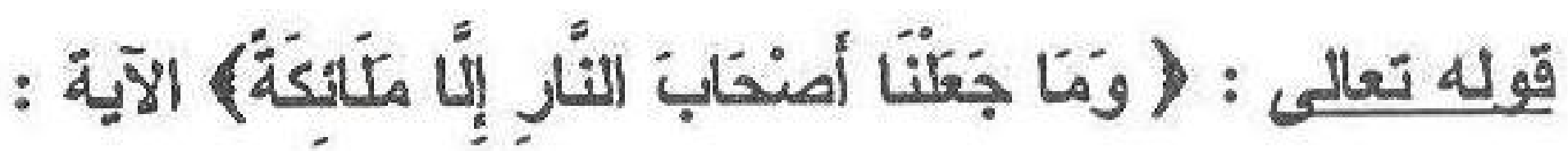

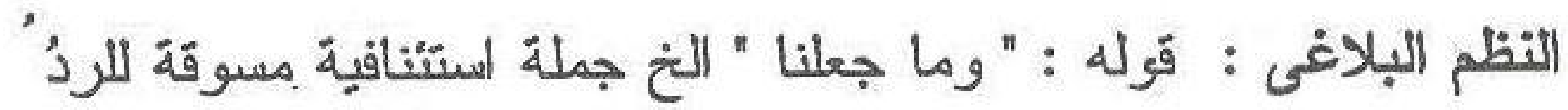

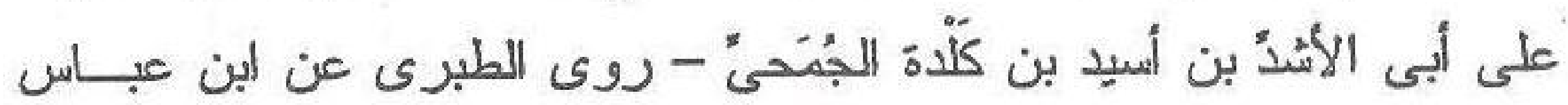

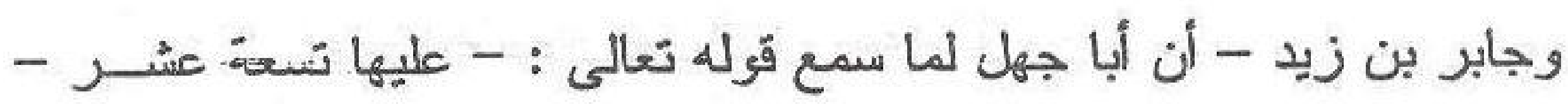

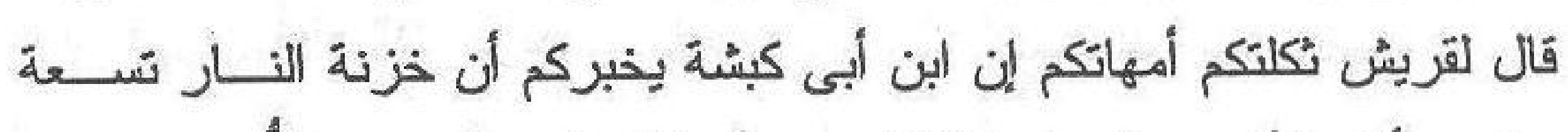

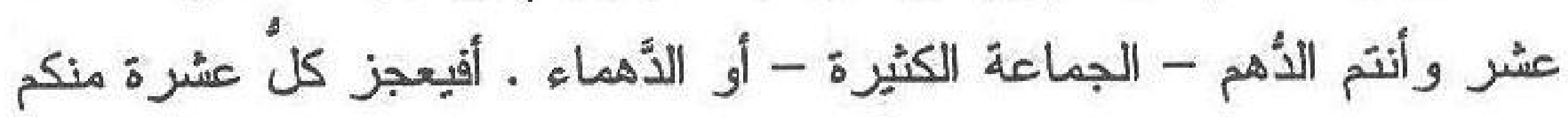

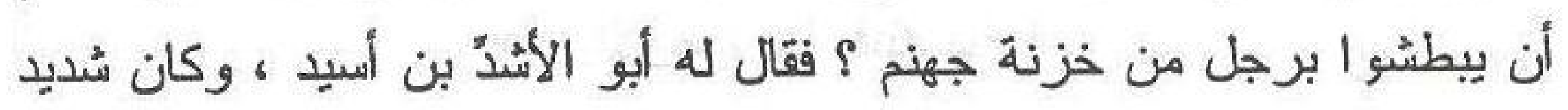

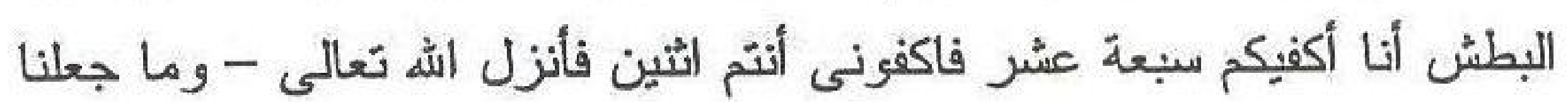

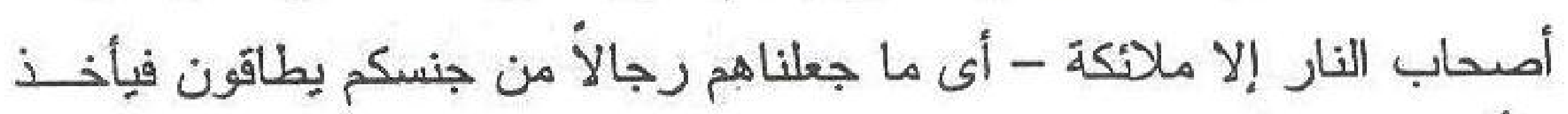
كلُ رجل رجلاً فمن ذا يغلب الملائكة (') .

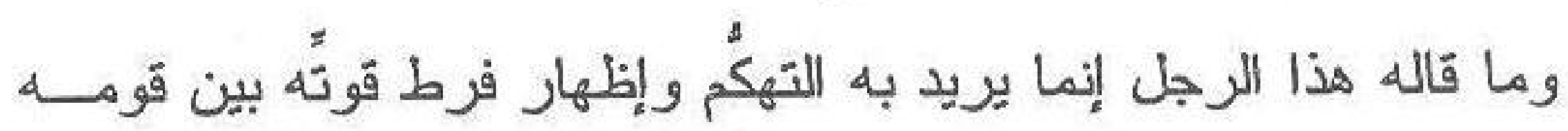

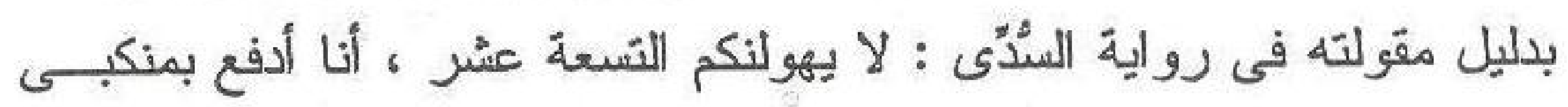

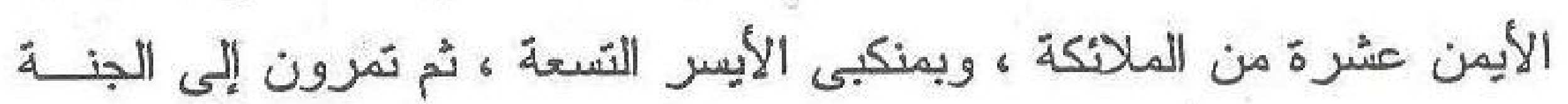

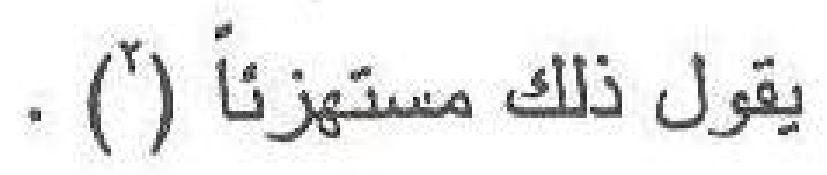
و المر اد بـ " أصحاب النار " هم تسعة عشر ، وفى هذا وضع الظاهر

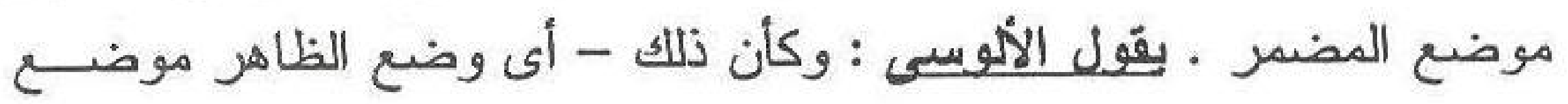

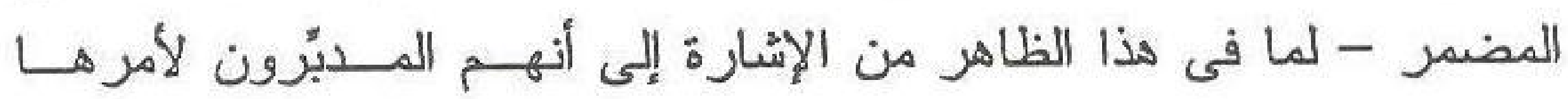

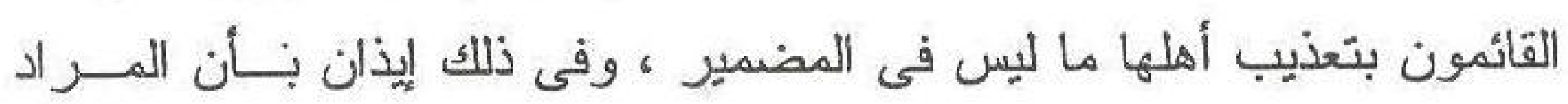

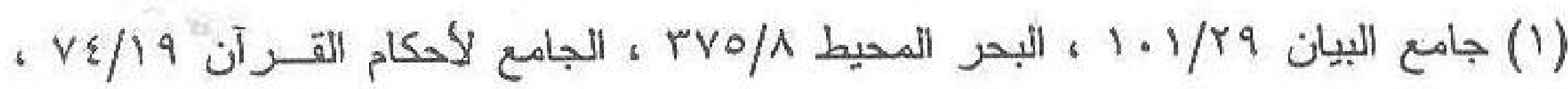

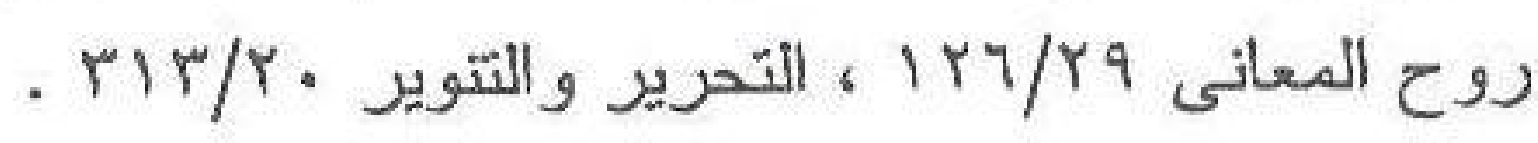




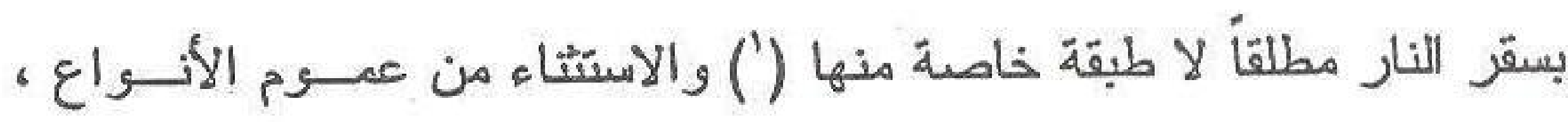
و المعنى : وما جعلنا خزنة النار من نوع إلا من نوع الملأكة ليخالفوا جنس

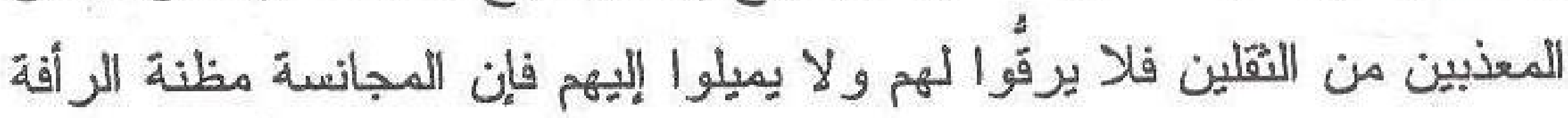
ولذا بعث الرسول من جنسنا لبرحم بنا ولأنهم أقوى الخلق وأقومهم بحقٍ الشه

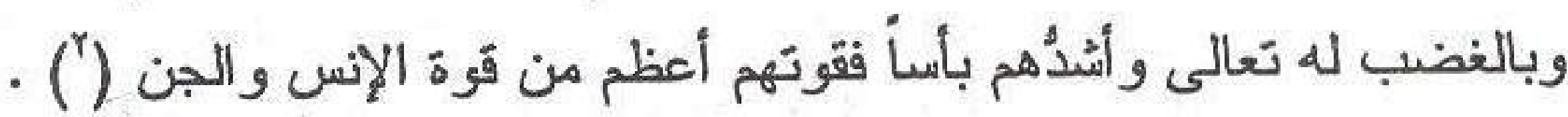

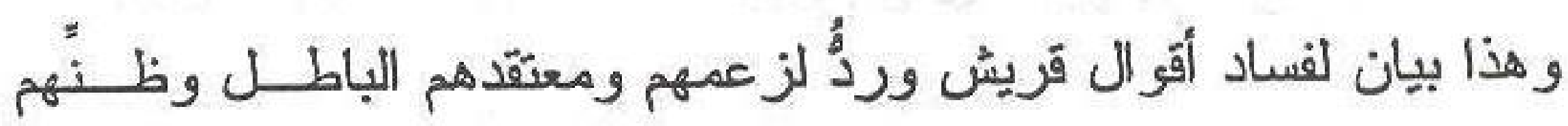

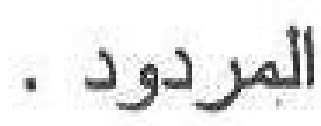

وفى قوله تعالى : " وما جعلنا أصحاب النار إلا ملأككة " أسلوب قصر

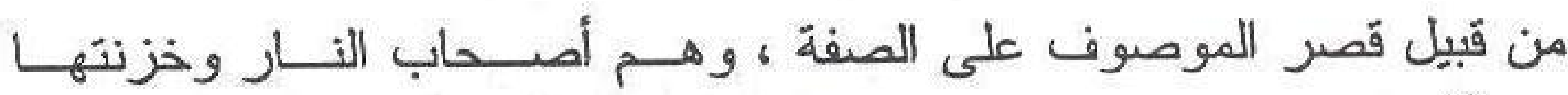

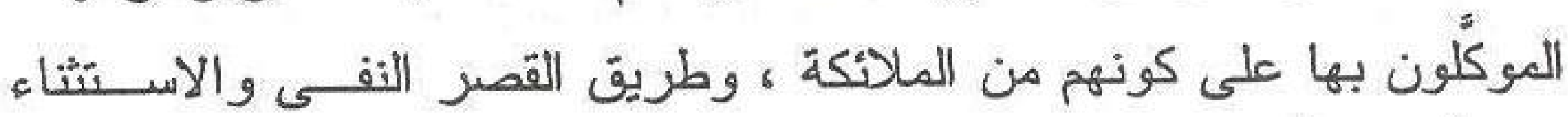
قصراً إضافياً فمع كونهم ملأككة إلا أن لهم صفات أخرى كالقيام بأمر جهنم أو تذبير شأنها أو الآخذ أو كونهم غلانظاً شداداً لا يعصون اله ما أســرهم ،

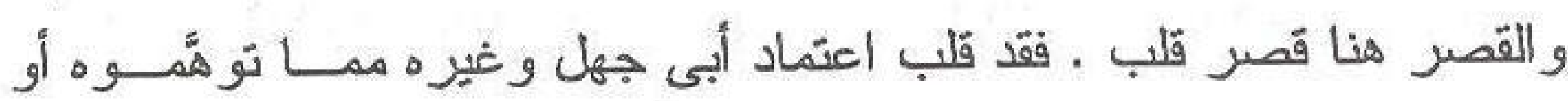

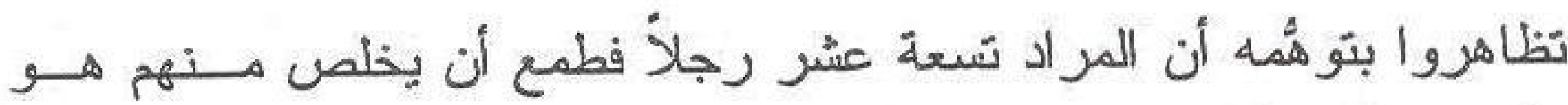

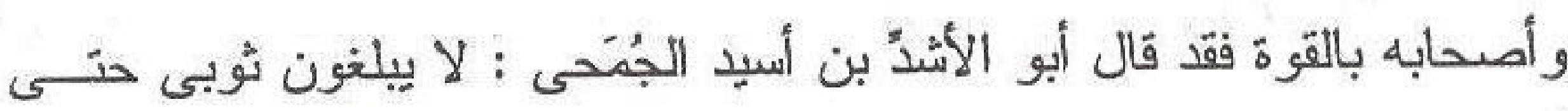

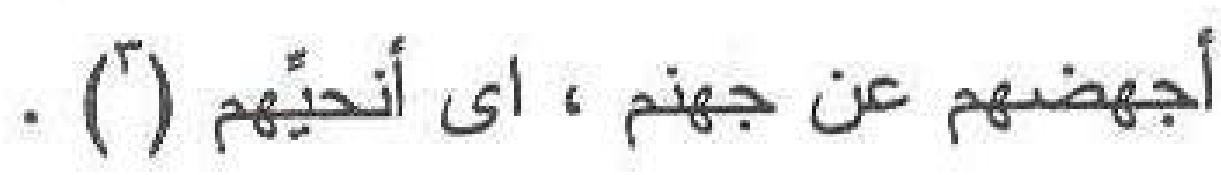

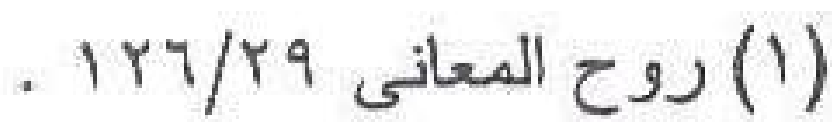

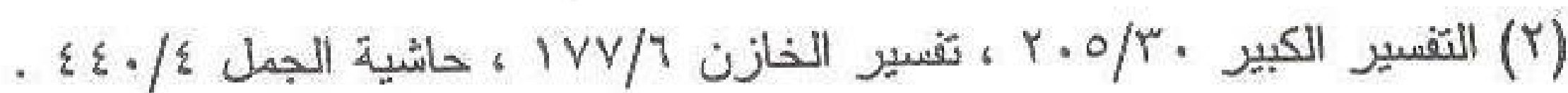

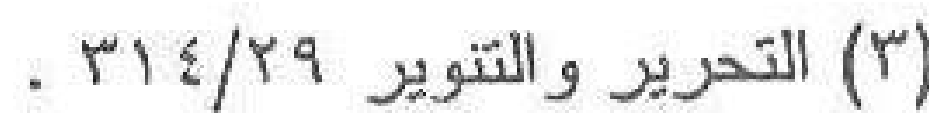




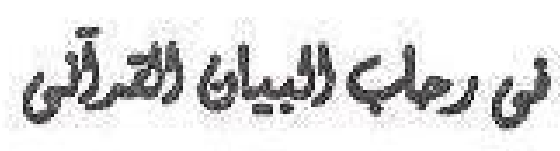

[91]

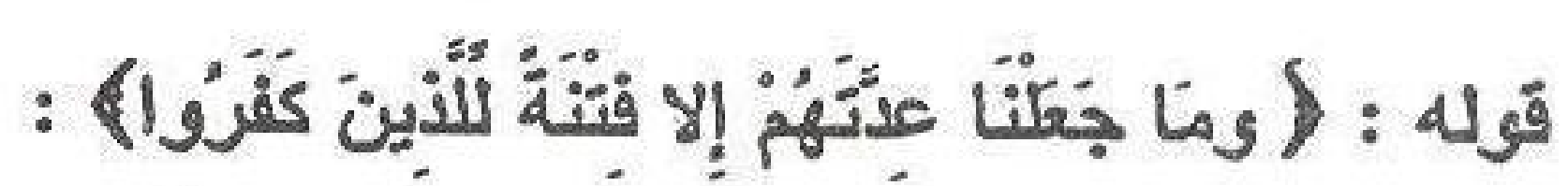

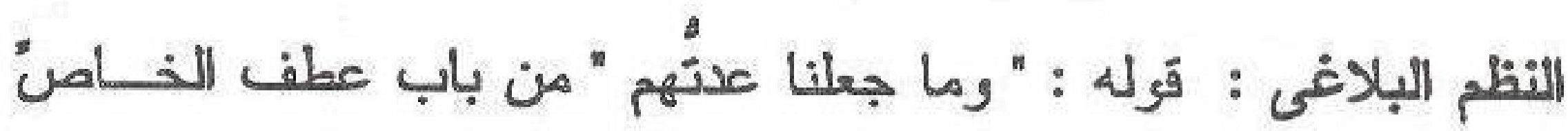

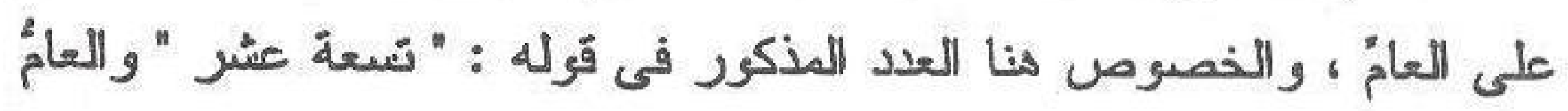

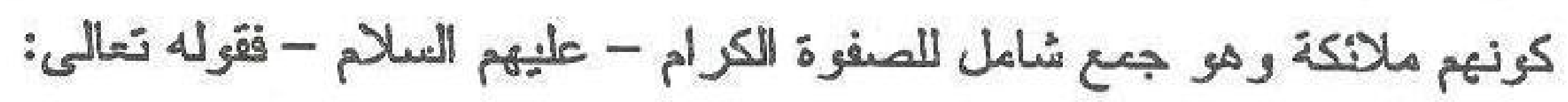

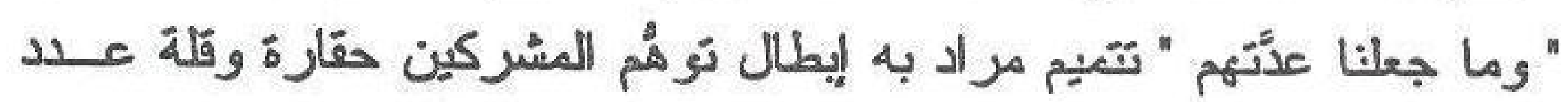

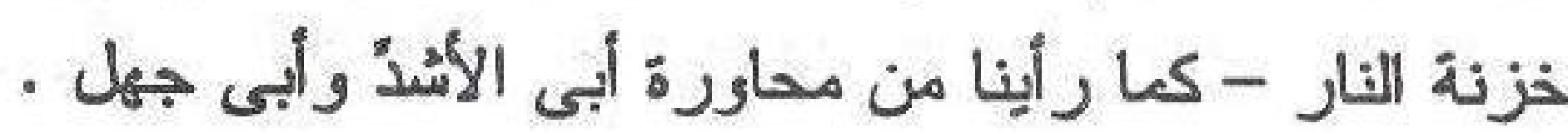

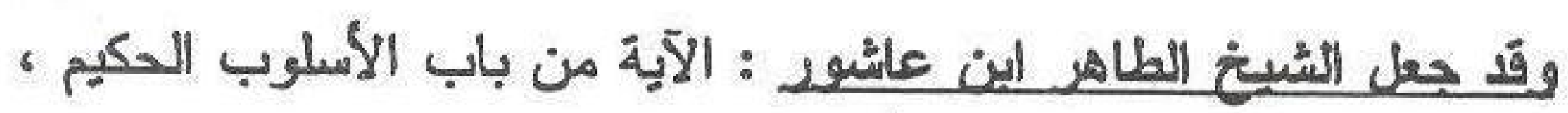

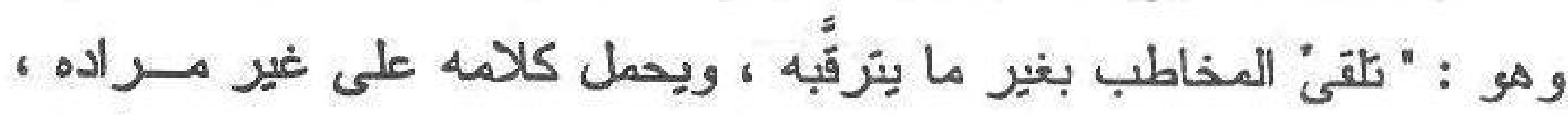

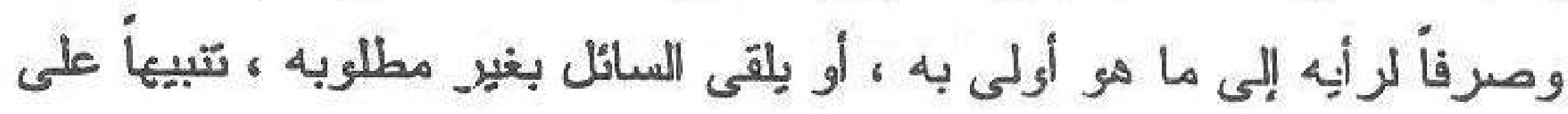

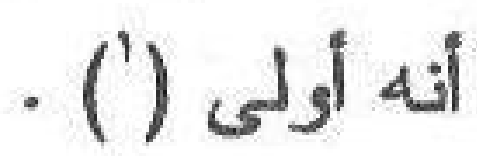

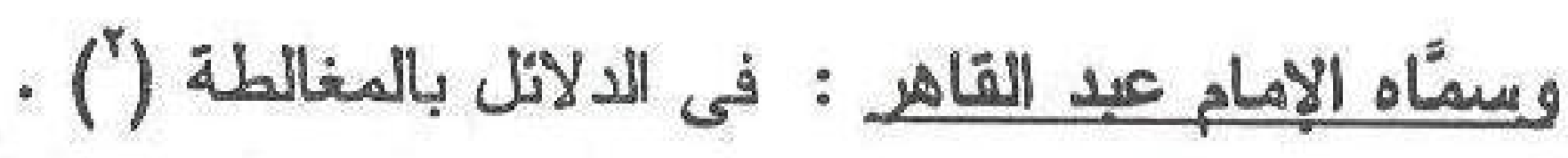
ويرى الدكتور محمد أبو موسى : أن هذا الأسلوب - الحكيم - جدير

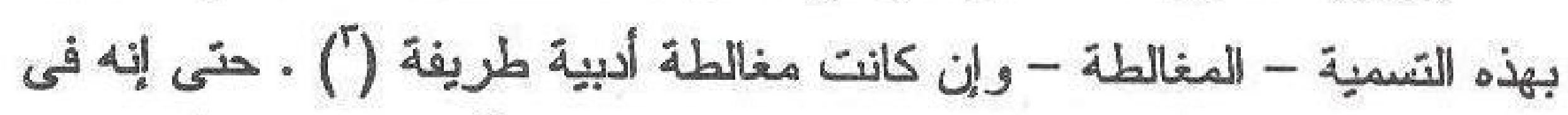

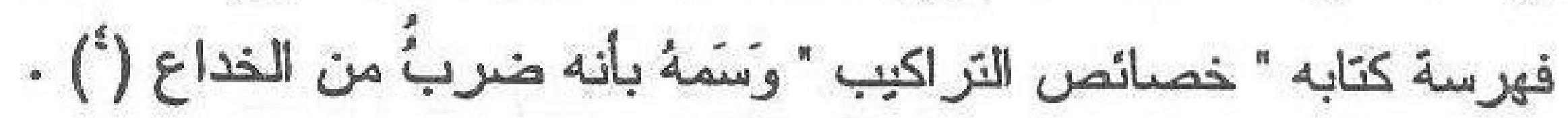

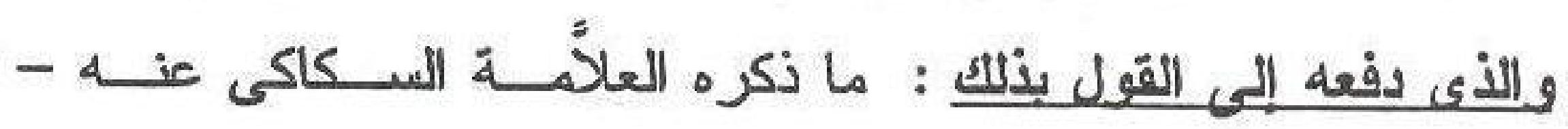

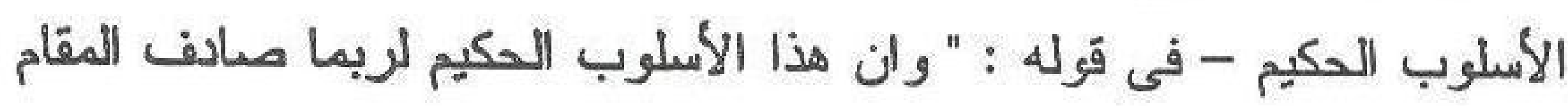

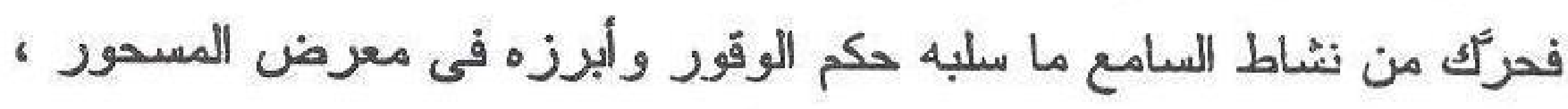

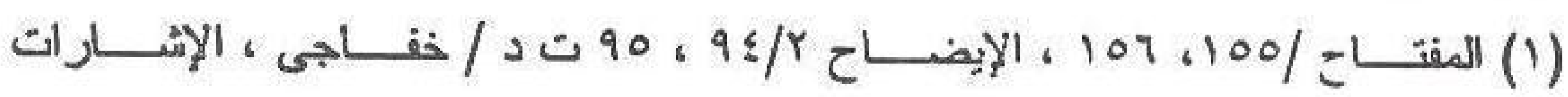

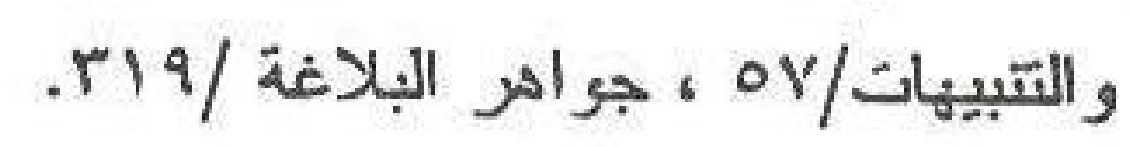

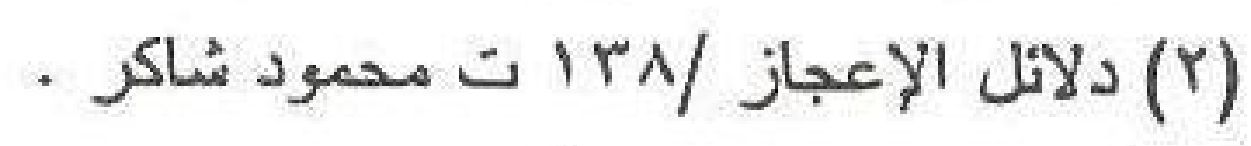

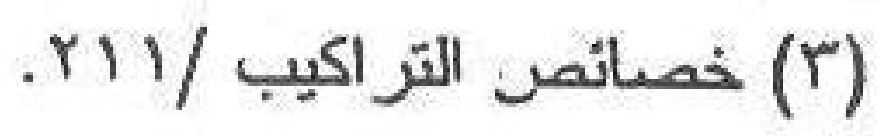

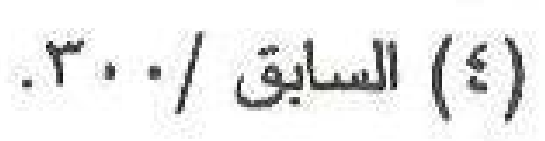




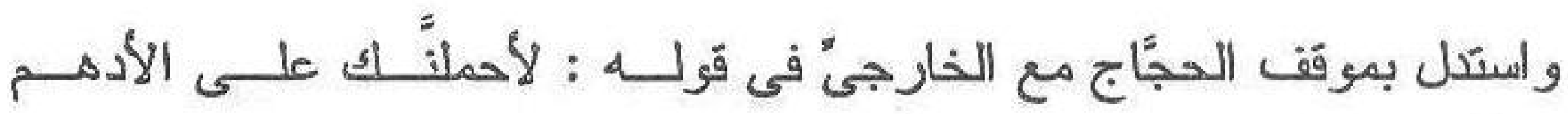
( ) (الأشهب (1)

أما بالنسبة لإجر اء الأسلوب الحكيم فى الآيِة : فإن الكلام قد أثار فـى

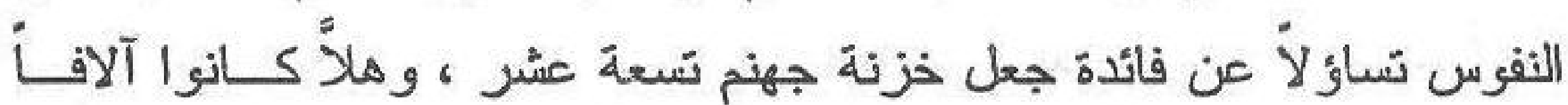

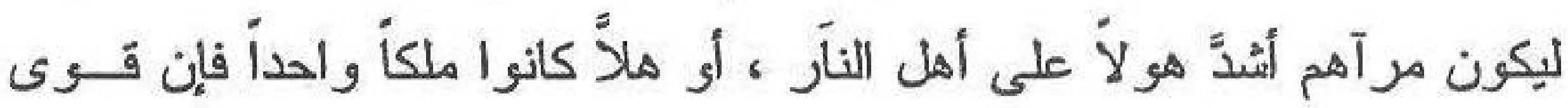

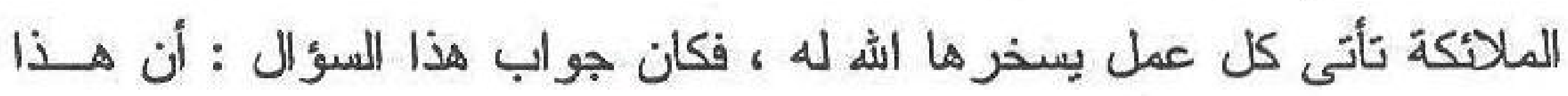
العدد قد أظهر لأصناف الناس مبلغ فهم الكفار اللقرآن ، و إنما حصلت الفتنة من ذكر عددهم فى الآية السابقة "تسعة عشر " فقوله : " وما جعلنا عـدتَّهم"

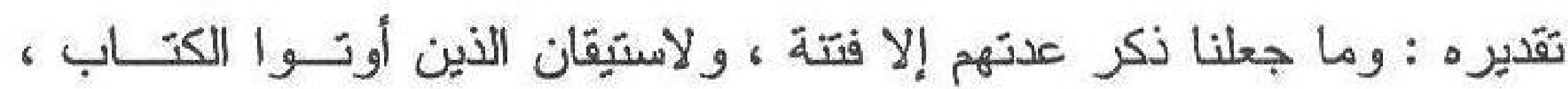

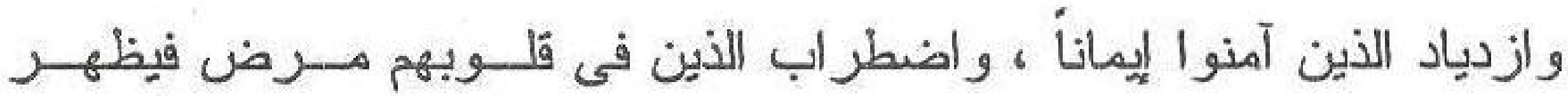
ضلال الضالين و اهنداء المهتدين ، فاله جعل عدة خزنة النار تسعة عشــر

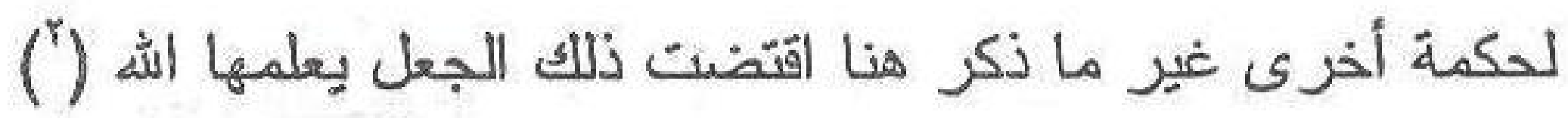
وقوله : "وما جعلنا عدَّتهم إلا فنتـة للذين كفروا " أسلوب قصر طريقــهـ النفى و الاستثناء ، و هو قصرُ إضافى من باب قصر الموصوف على الصفةة، و هو عدد الملأئكة على كون هذا العدد فتنة يفتن الله بها الكافرين ، و أسلوب وني

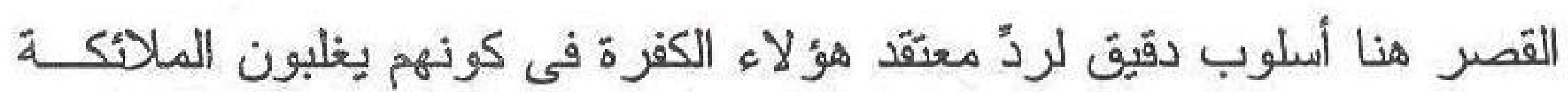
أو بعجزونهم ، وذلك أن طريقه وهو النفى والاستثاء لا يقال إلا فى الشـئ سئ الذى يجهله المخاطب وينكره فلما كان هؤلاء ينكرون قوة الملائكة وقدرتهم

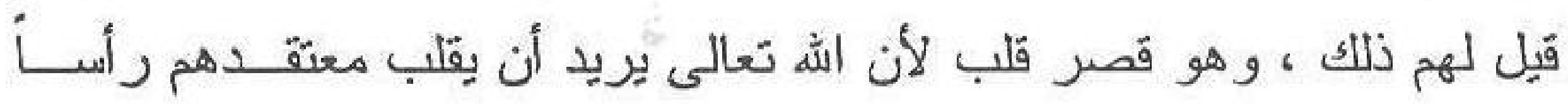
على عقب ويردَّ وهمهم . 


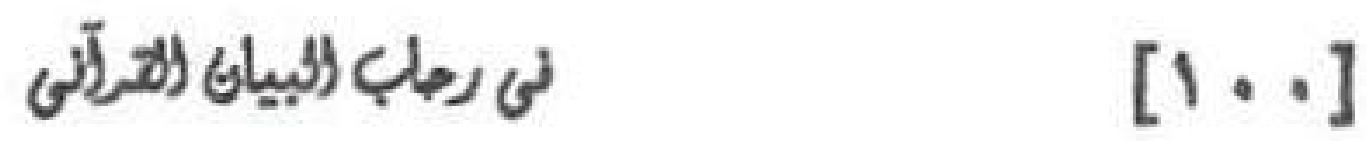

والاستناء مفرَّغ (') لعفعول ثان لفعل " جعلنا " تقَديره : جعلنا عدتهم

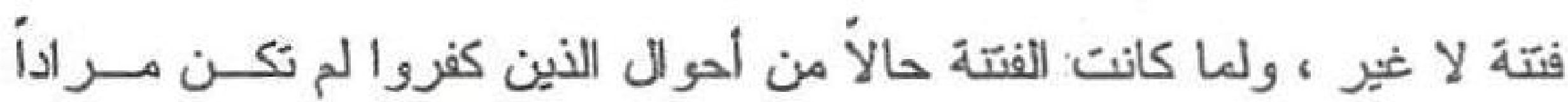

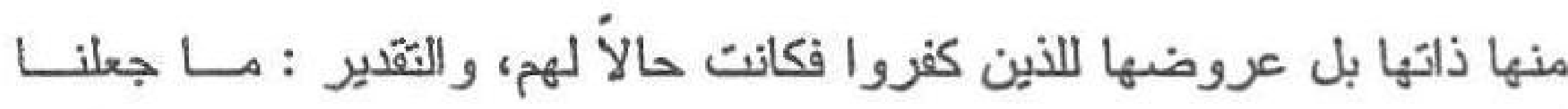
ذكر عدتهم لعلة وغرض إلا لغرض فتتة الذين ، فانتصب "فتتة " على أنسه

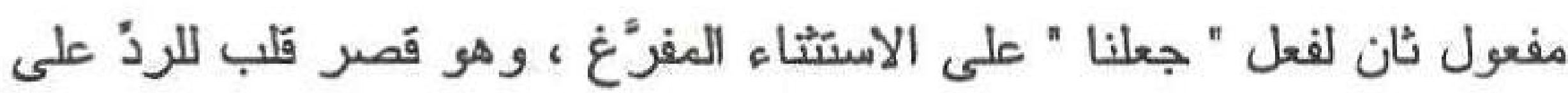

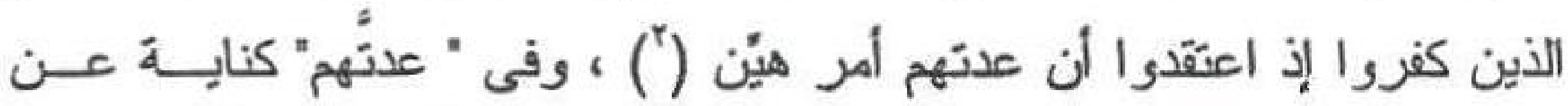

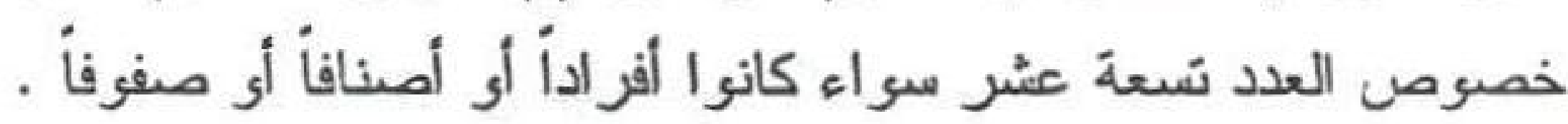

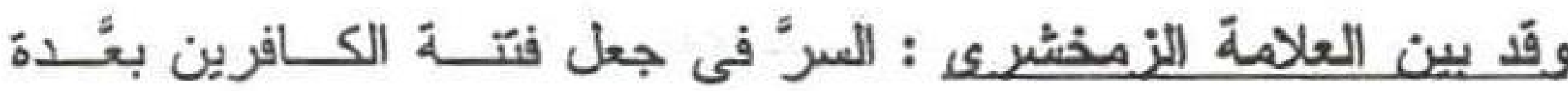

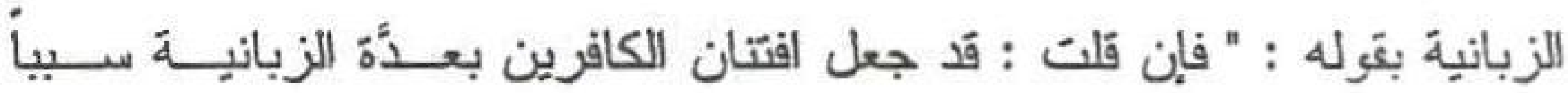

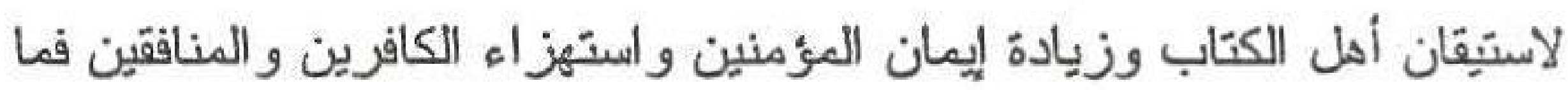
وجه صدة ذلك ؟ الأل

قَلت : ما جعل افتتانهم بالعدةً سبباً بالعدة سبياً لذلك و إنما العدةَ نفســها

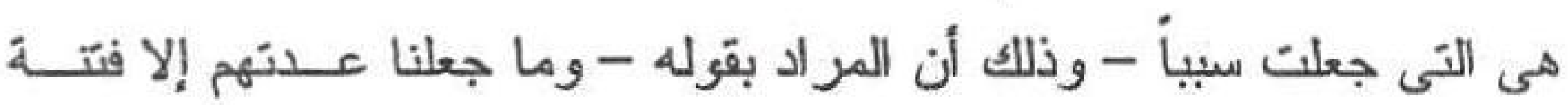
للانين كفزوا - وما جعلنا عدَّهم إلا تسعة عشر ـ فوضع - فتتة للذنين كفروا

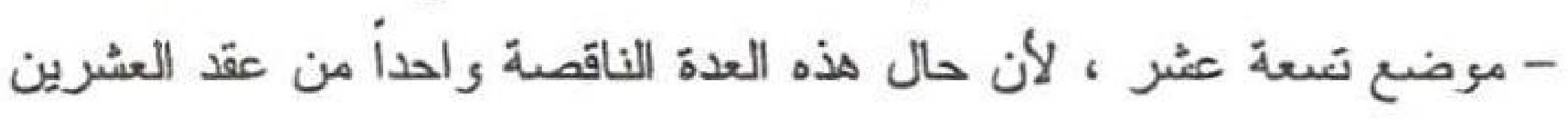
أن يفستن بها من لا يُومن بالله وبحكمته ويعترض ويستهزئ و لا يذعن إذعان العؤهن وإن خفى عليه وجه الحكمة ؟، كأنه قيل : ولقد جعلنا عدتهم عدةَ من

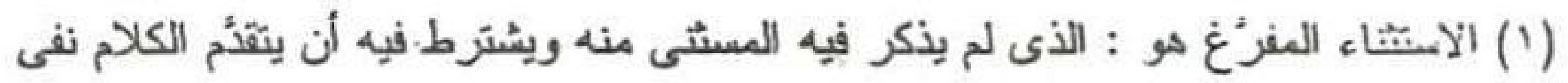

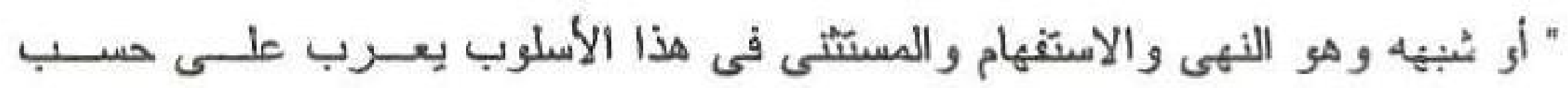
العو امل السابقة عليه"

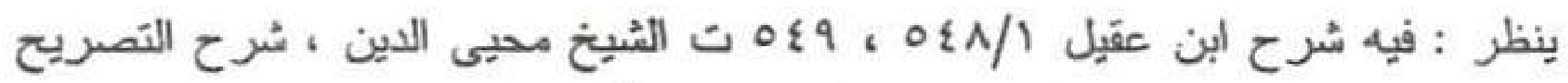

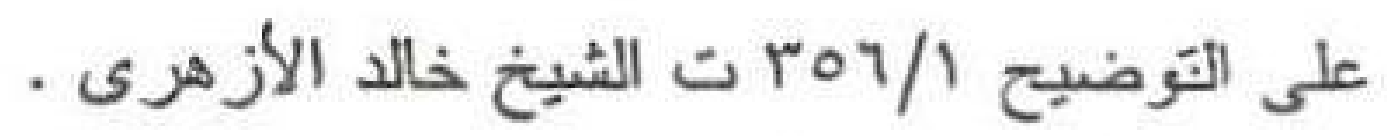

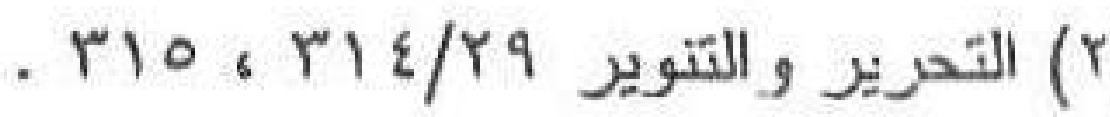


شأنها أن يفتتن بها لأجل استيقان المؤمنين وحيرة الكافرين واســـيقان أهـلـل الكتاب لأن عدتهم تسعة عشر فى الكتابين ،فإذا سمعوا بمثلها فــى القـــرآن

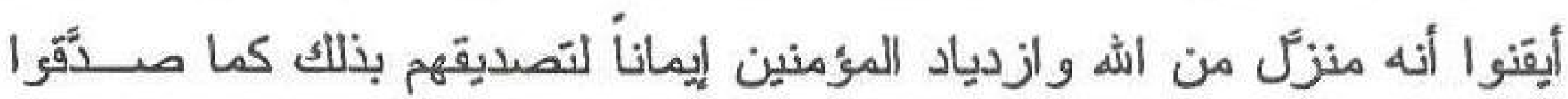

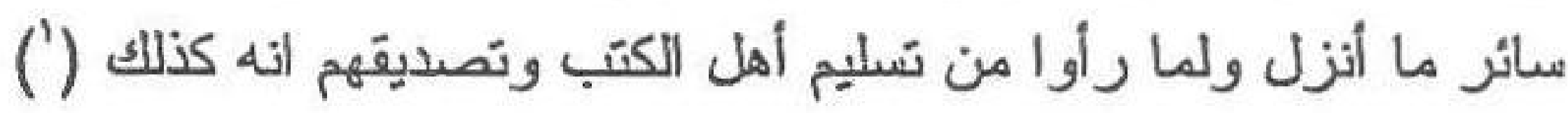

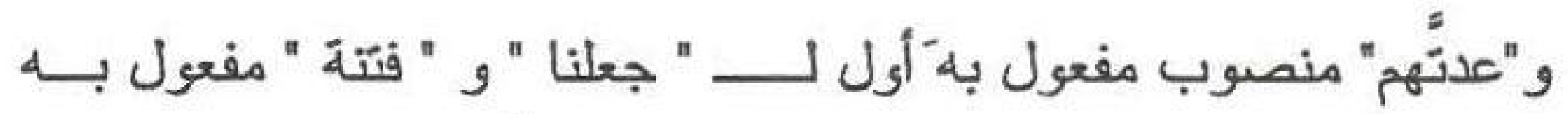
ثان على حذف مضاف أى سبب فتتة ، وليست مفعولاً لأجله و " الذين " جار ومجرور متعلقان بـ " فتتة " وجملة " كفروا " صلة الموصول . ومن المفسرّرين من جعل قوله : وما جعلنا عدتَّهم إلا فتتة " مــن بـاب

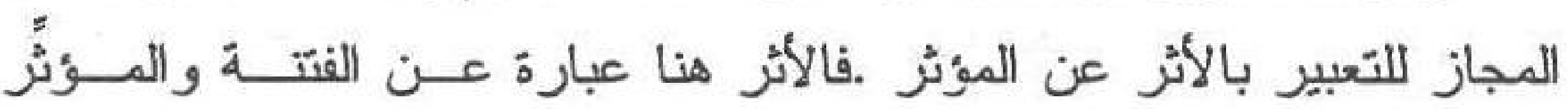

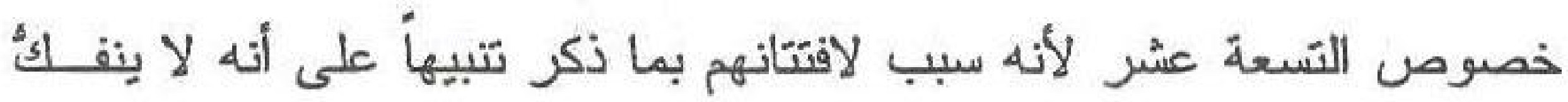

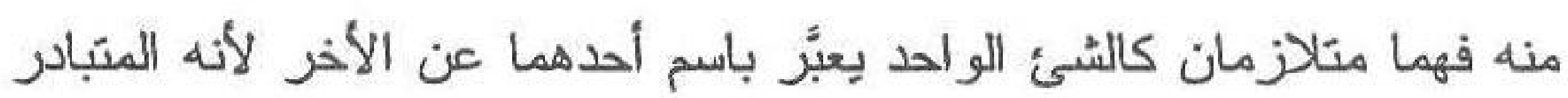
منه ( (T) · و هذا ما يُسمّى بإطلاق السبب و إر ادة المسبًّب عنه فى باب المجاز المرسل ، و اللام فى " للذين كفروا " للاختصاص لأن الذين كفروا هم الذين سخروا من هذا العدد ولم يدركوا - لجهلهم وعنادهم - هغزى الحكمة الإلهية فيه . بل نراهم يفسرّون الجعل فى الآية بالقول . يقول الشبخ زلدة - رحمه الله - : قوله - أى البيضـاوى - ولعـل المراد تفسير الجعل بالقول - جواب عما بقال : كيف يصحُ جعلهم فى نفس الأمر على هذا القدر معللخ لاستيقان أهل الكتاب وازدياد المــؤهنين إيمانــان

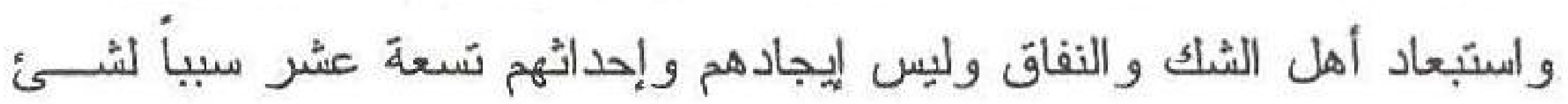

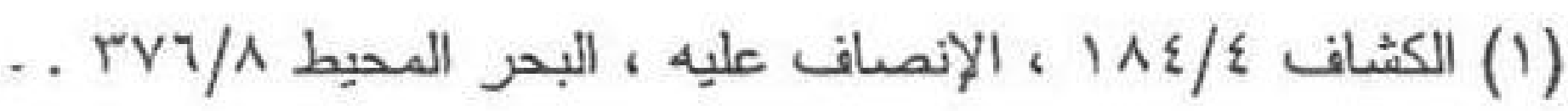

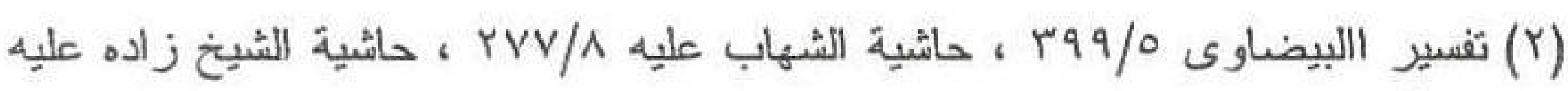
أيضiأ 


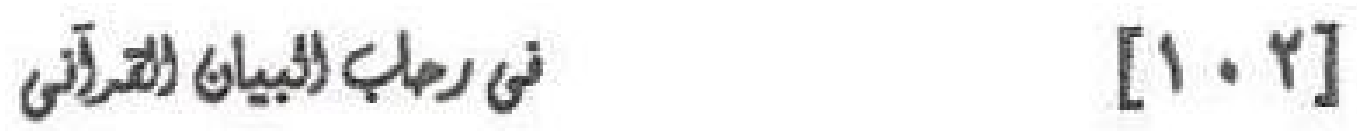

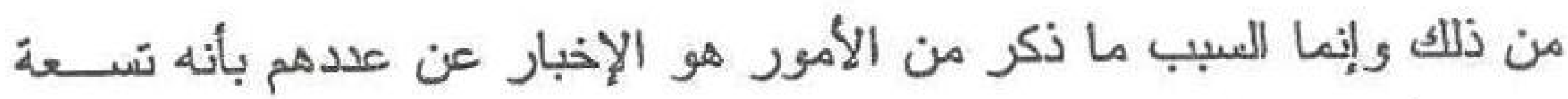

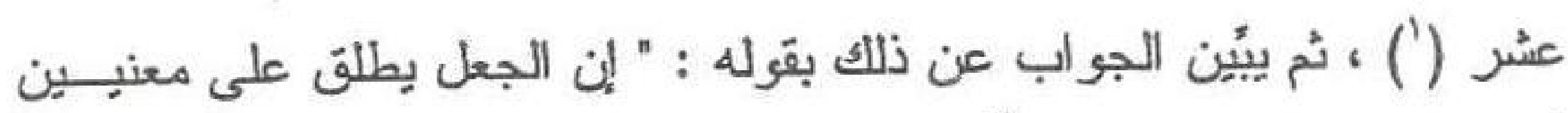

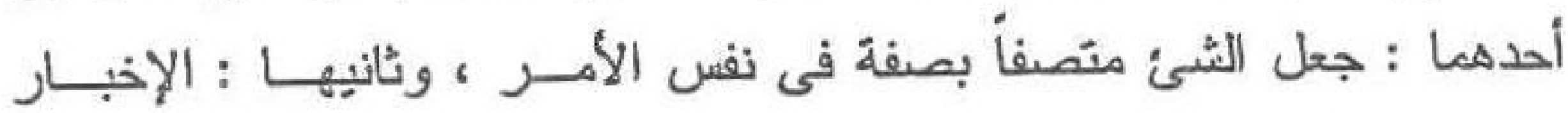

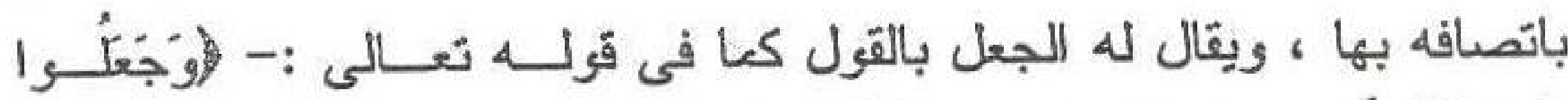

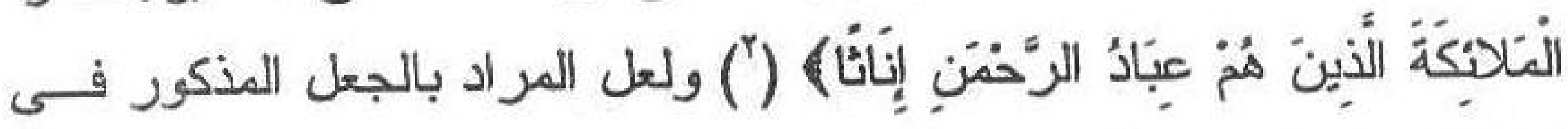

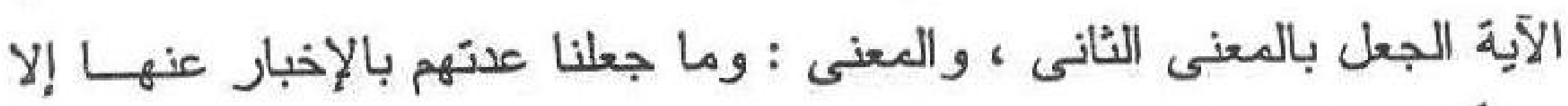

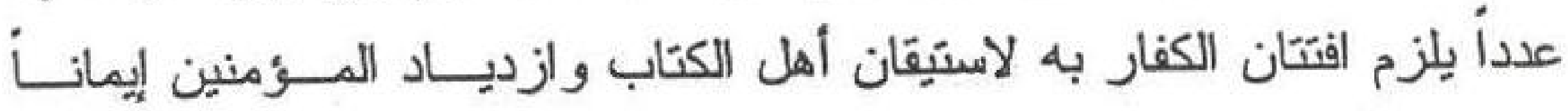

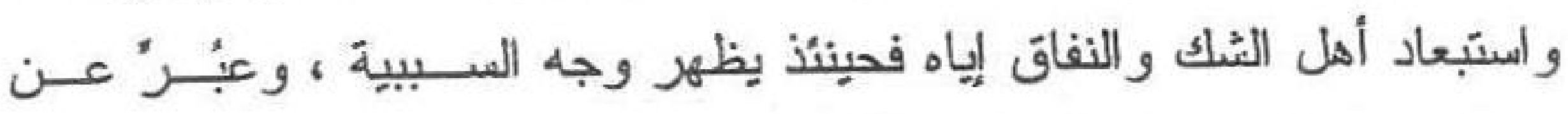

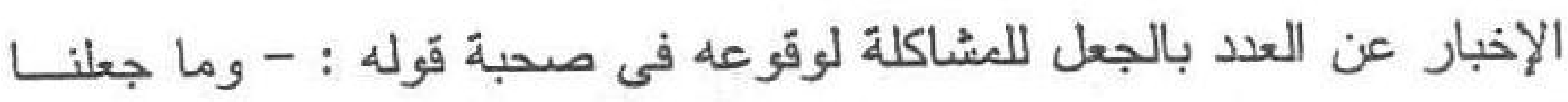

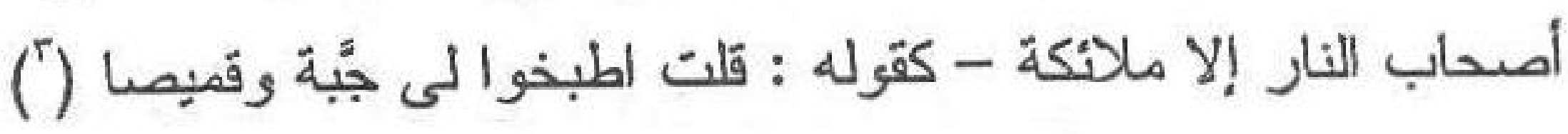

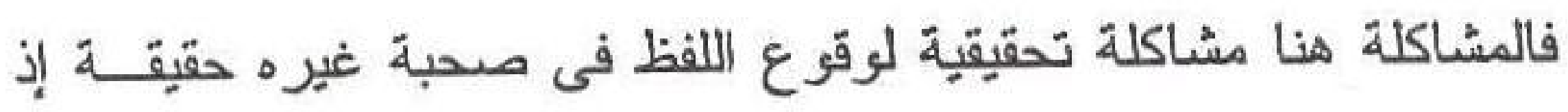

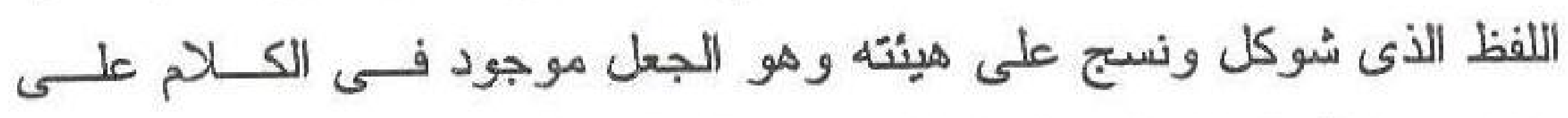
حقيقته، و إطلاق الجعل على القول من قَبيل الاستعارة .

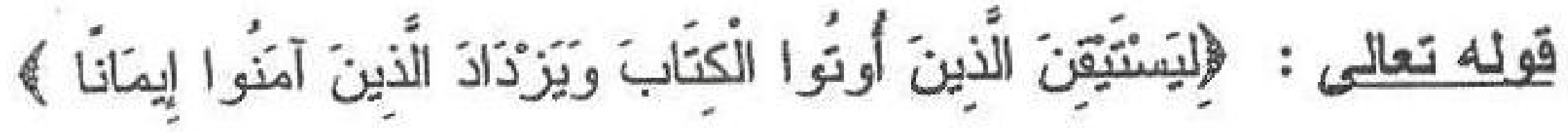

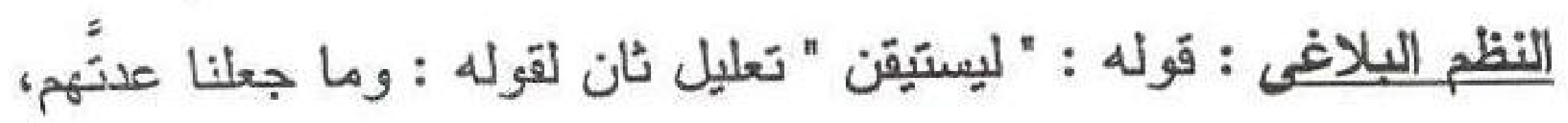

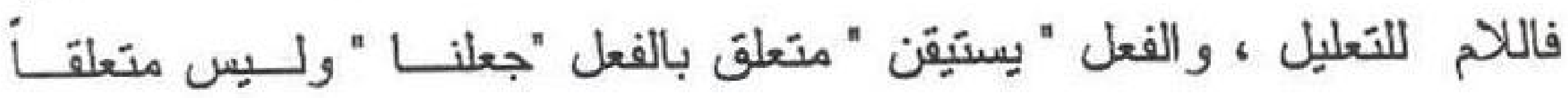

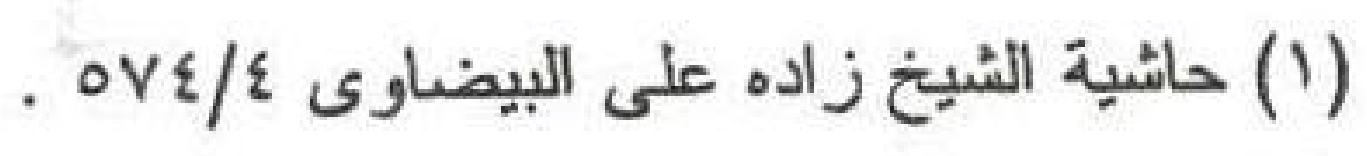

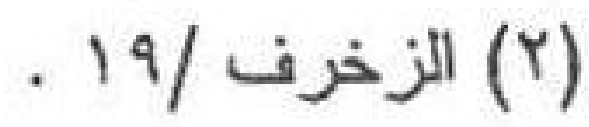

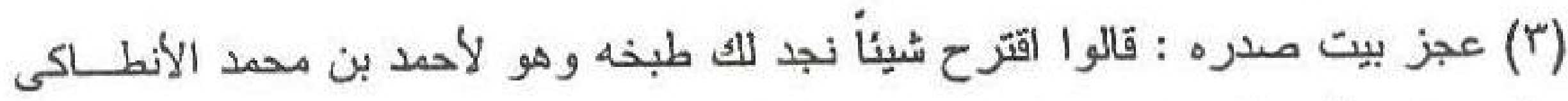

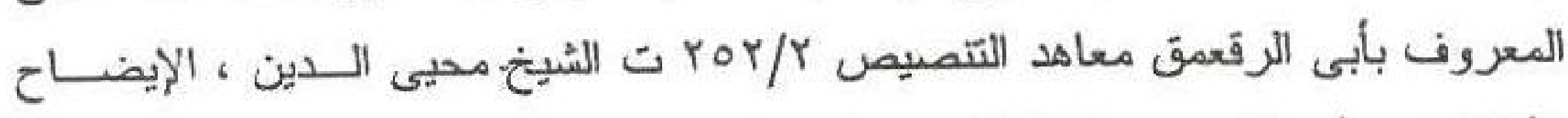

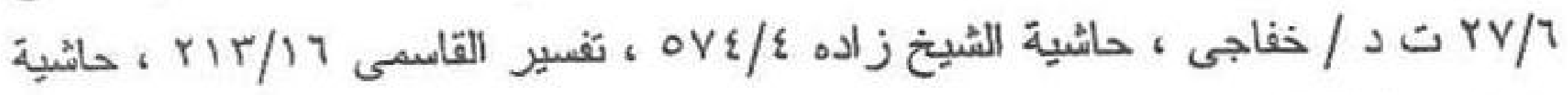
الثهاب rVY/A 


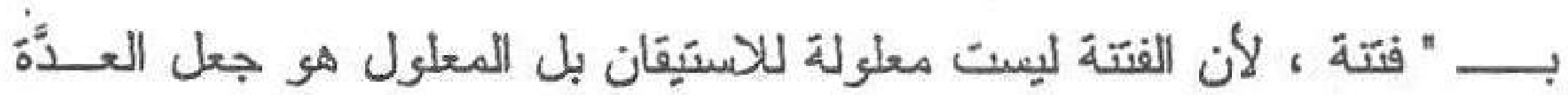

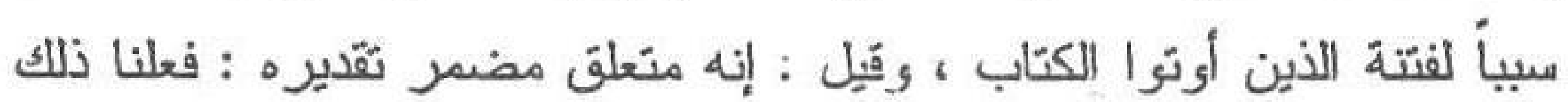
ليستيقن الذين أوتىا الكتاب .

وتعريف العسند إليهه باسم الموصول "الذين " لزيادة تقريــر الغــرض

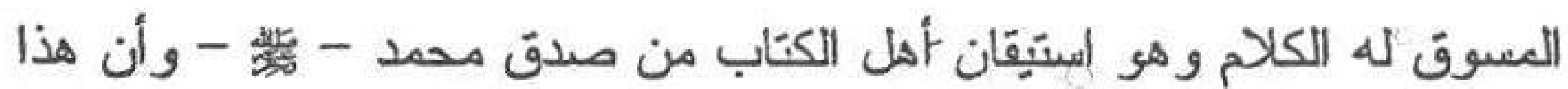
القرآن من عند الله ، إذ يجدين هذا العدد فى كتبهم المنزّكة . ويرى الشيخ ابن المنير أن : الاستيقان راجع إلى ما قبل الاستثناء وأن هذا الرأى - من وجهة نظره - أفضل من رأى الزمخشرى فيقول : ويجوز

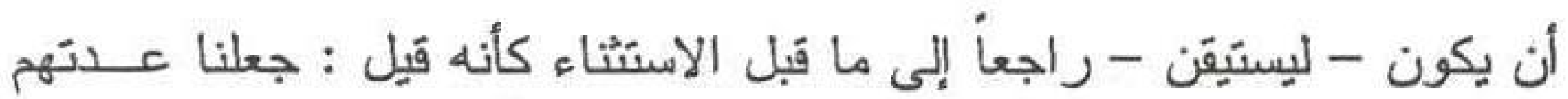

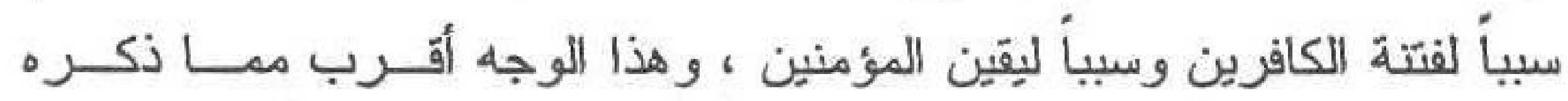

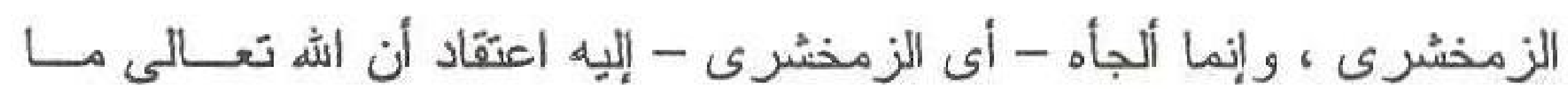

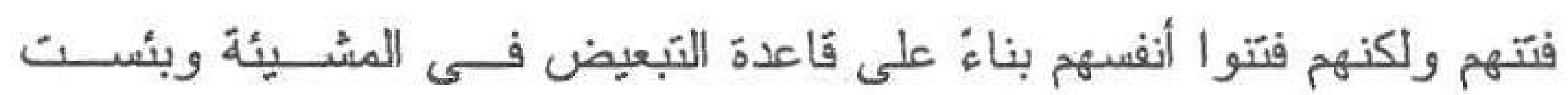

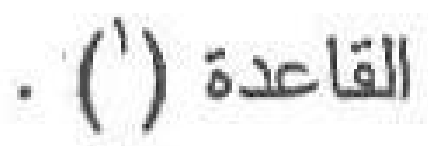

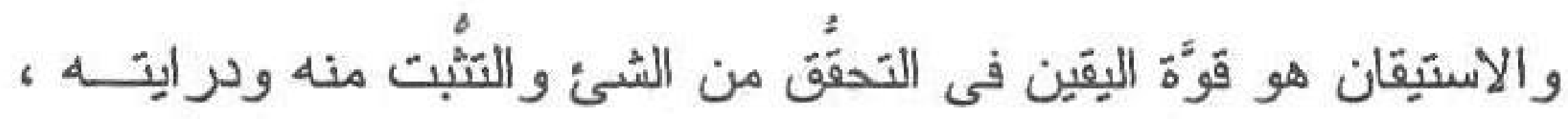

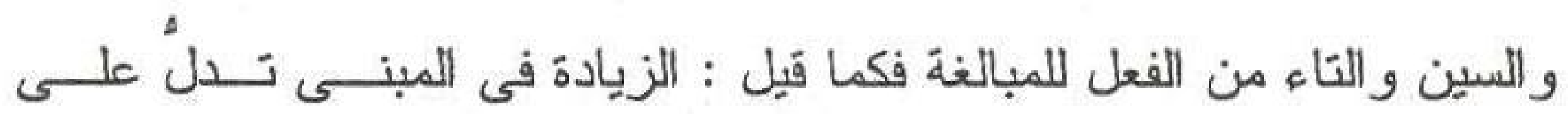

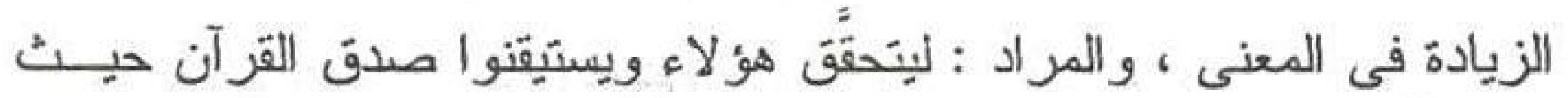

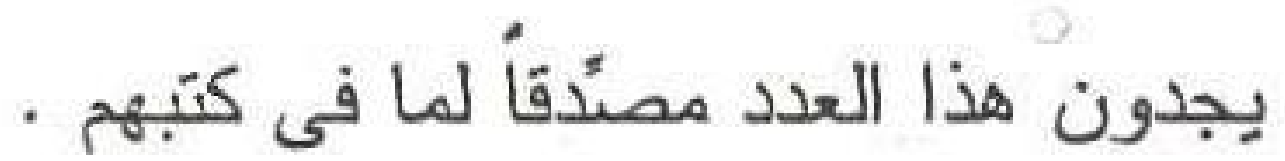

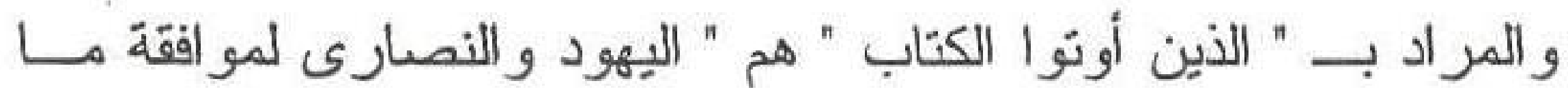

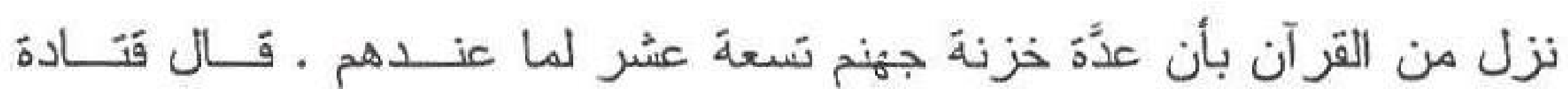
و الضحَّاك ومجاهد و غيرهم ، و المعنى : أن الله جعل عذدّة الخزنة هذه العــدَّة 


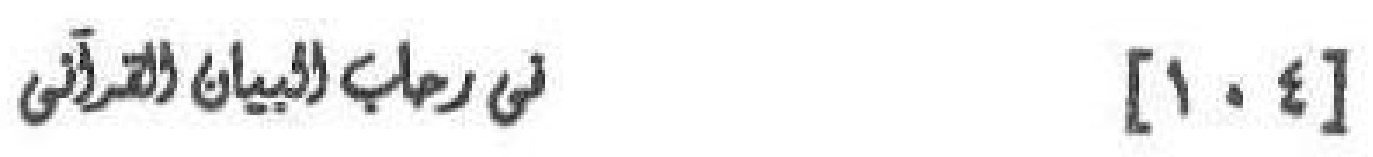

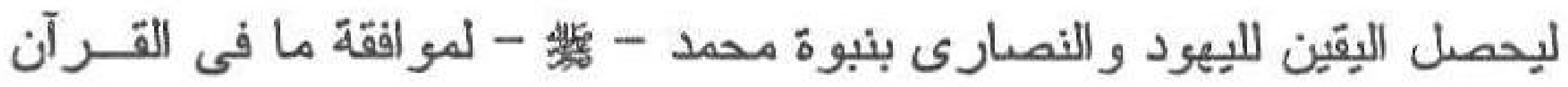

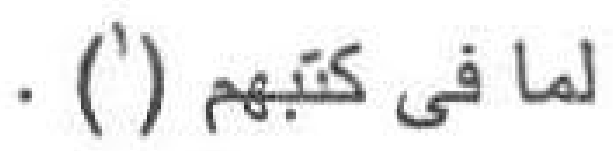

والاستيقان كما يقول الثبيخ الطاهي الين عاشور : من شأنه أن يعقبه

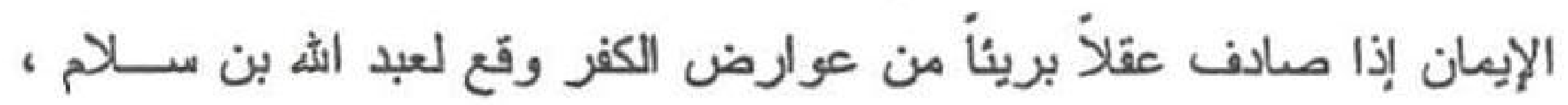
وقد لا يعقبه الإيمان لمكابرة أو حسد أو إئفاق من فوات جاه أو مان مال كما كان

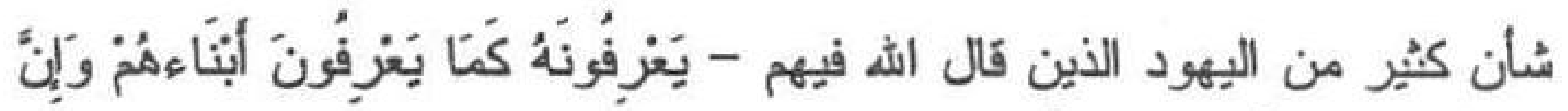

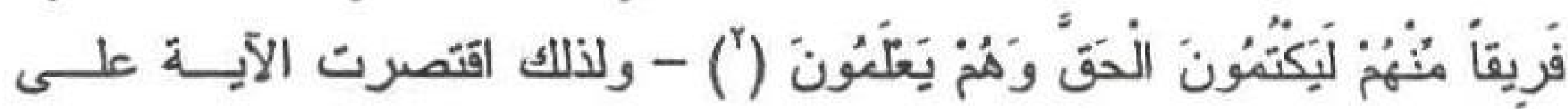

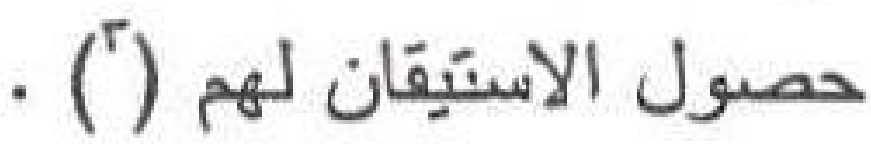

وفى قوله : " الذين أوتوا الكتاب " كناية عن موصــوف هــم اليهــود

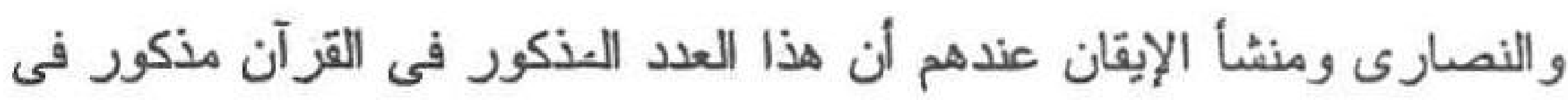
التور اذ و الإنجيل - قَبل التحريف - فوروده فى القر آن يحدث عندهم اليقــين بأن القر آن وحى من عند الله لمطابقة معناه معانى كتبهم (أ) .

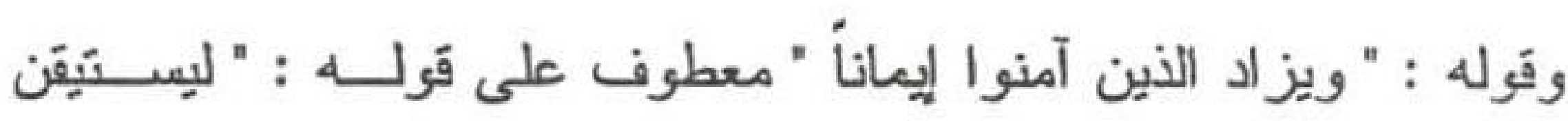
الذين أوتوا الكتاب " موصول به لا تفاقهما فى الخبرية ، وتعريف المعند إليه أيضاً بالاسم الموصول زيادة فى تقرير الغرض المسوق له الكلام وهو بيان

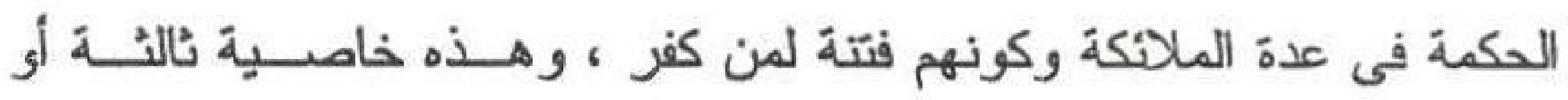

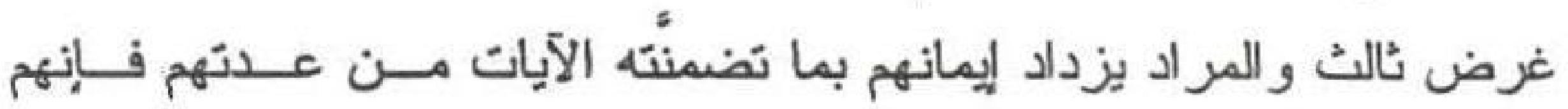

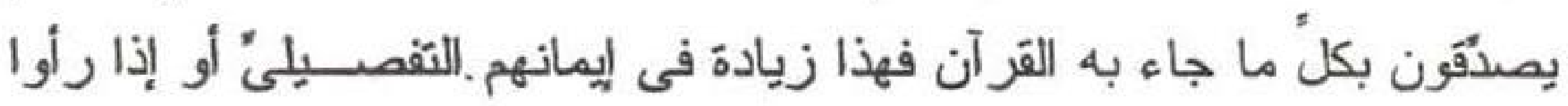

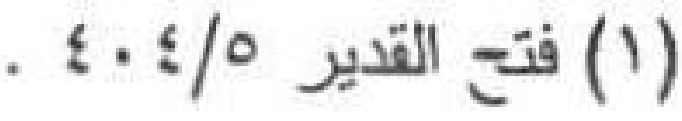

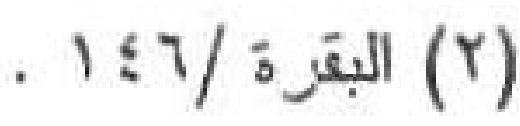

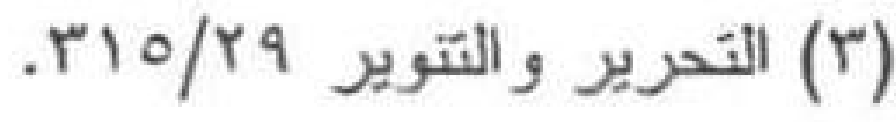

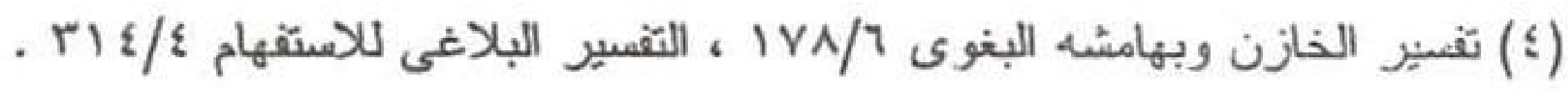


تصديق أهل الكتاب زاد إيمانهم ، ولذا قال المفسرّرون : هو فى الأول زيــادة فى الكم وفى هذا زيادة فى الكيف . " والازدياد بحسب الكمية لازدياد متعلقة فإن الإيمان قد كان يزداد به يوماً فيوماً فى زمان الوحى بحسب الودياد ازدياد مـــ

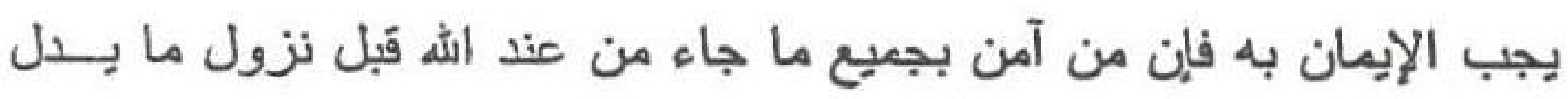

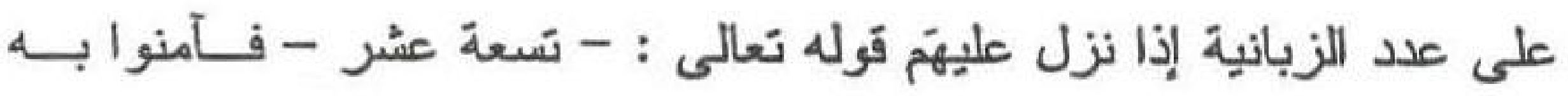
أيضاً فلا شكَّ أنه يزداد إيمانهم بحسب الكمية لازدياد متعلقه - و على الثانى: يكون المراد بالازدياد ازدياد يقينهم قوة بتصديق أهل الكتاب بــهـه وبمو افقــة

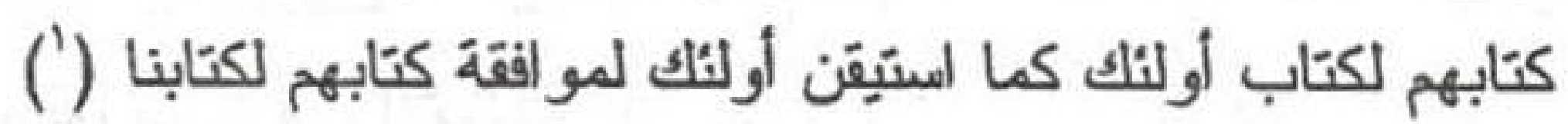

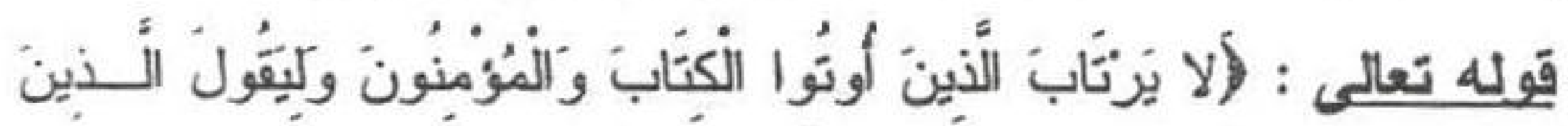

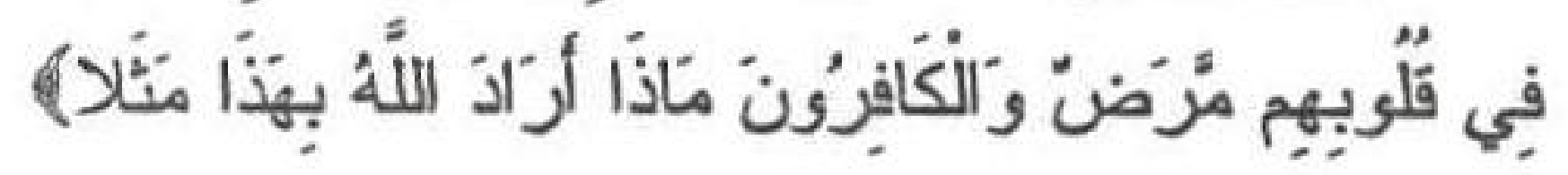

النظم البلاغى : قوله : " ولا يرتاب معطوف على ما سبق ، و هو تأكيد

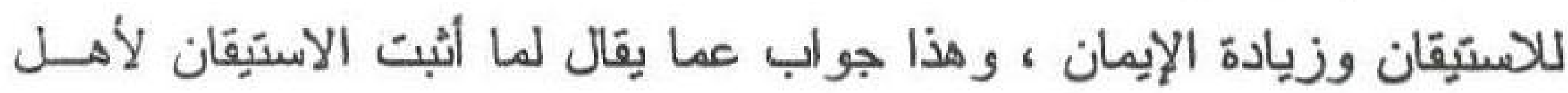

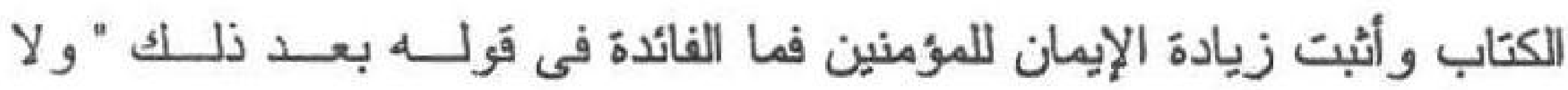
يرتاب الذين أوتوا الكتاب و المؤمنون " ؟ وتقدير الجواب الأول كونه تأكيداً ،

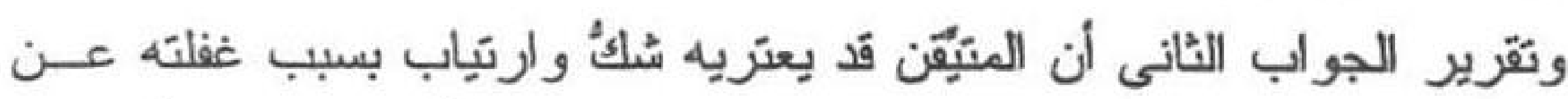

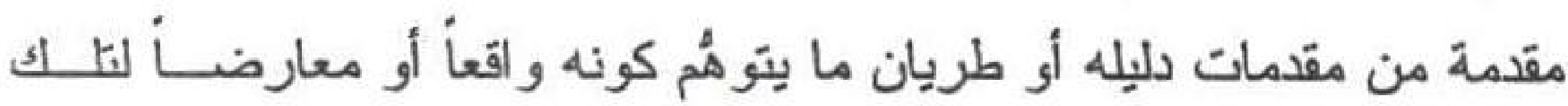

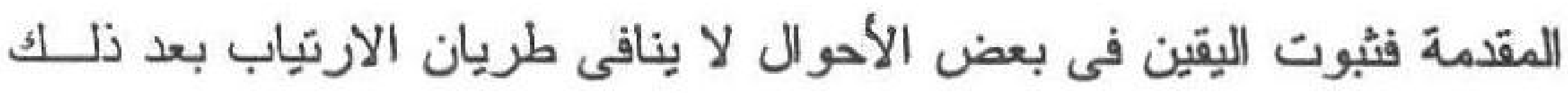
فالمقصود من ذكر هذا الكلام بعد ذلك بيان أن المراد من الاستيقان والازدياد المذكورين قبل أن يكونا بحيث لا يطر أ عليهما شكُ وارتياب أصلأ .

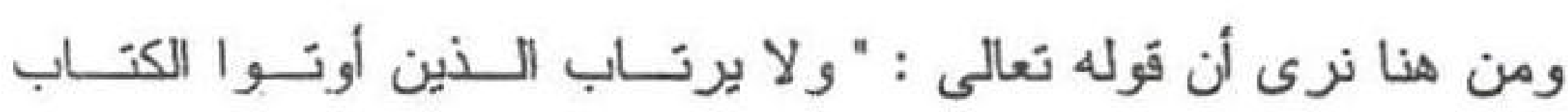

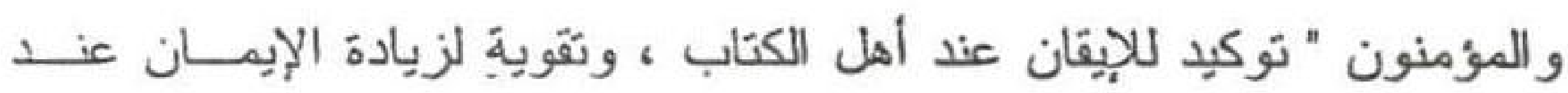




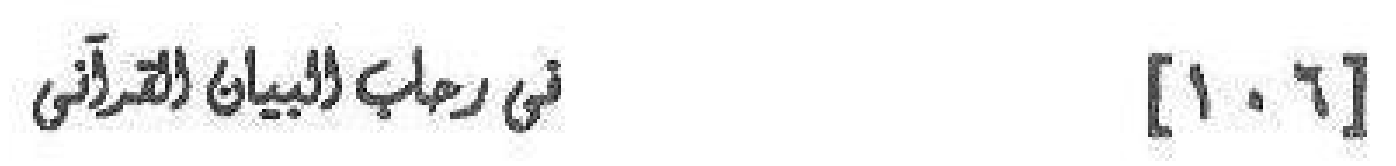

المؤمنين ، وهو توكيد معنى لا توكيد لفظ ، وأُخً نفى الارتياب على الإيقان

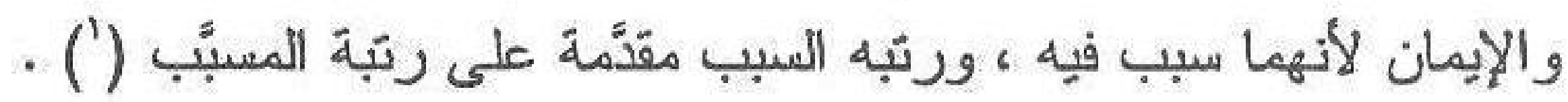

وجاء قوله :" ولا يرتاب " إلخ بعد ما ذكر لينتفى عـنهم الريــب فـلا

تعتريهم شبهة من بعد علمه لأن ذلك إيقان عن دليل ، وإن كان الفريقان فى كي

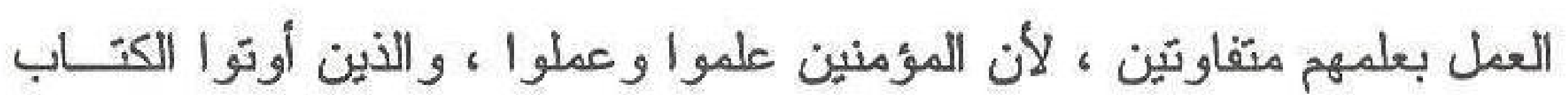
علموا وعاندوا فكان علمهم حجّة علئهم وحسرة فى نفوسهم .

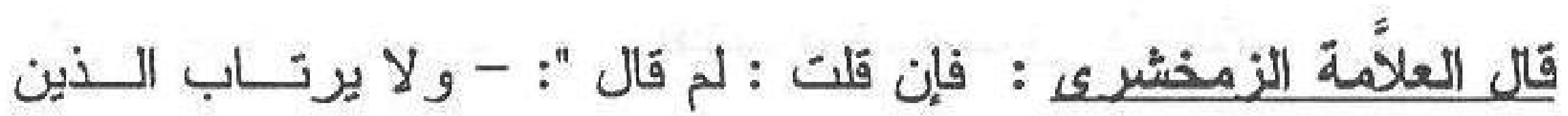

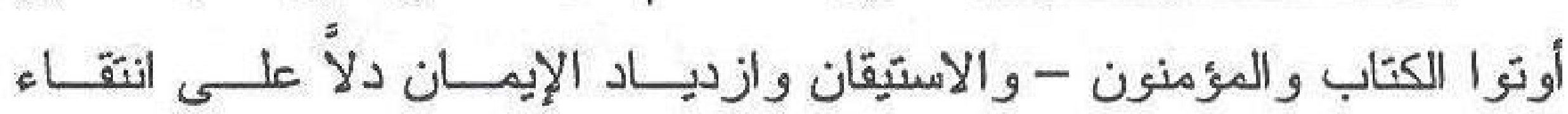

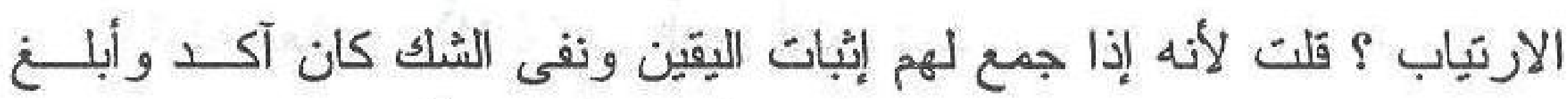

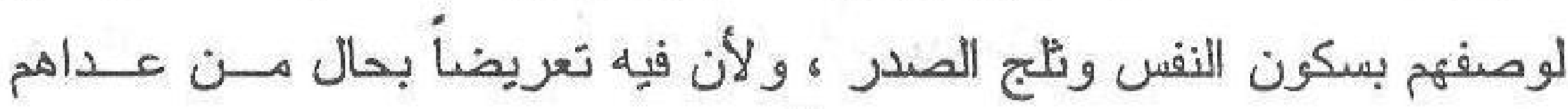

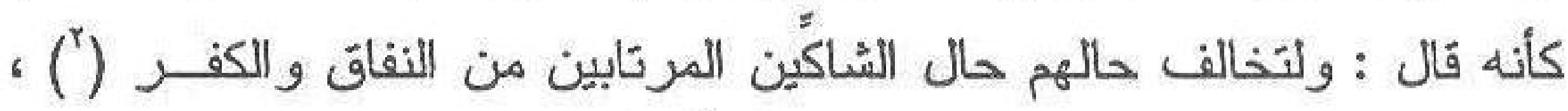

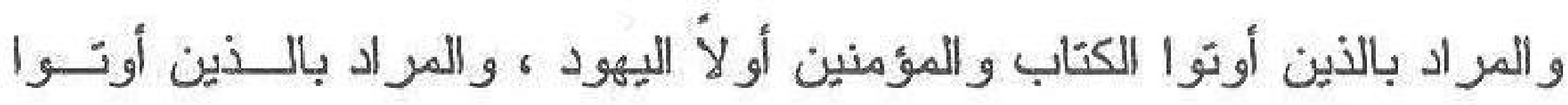

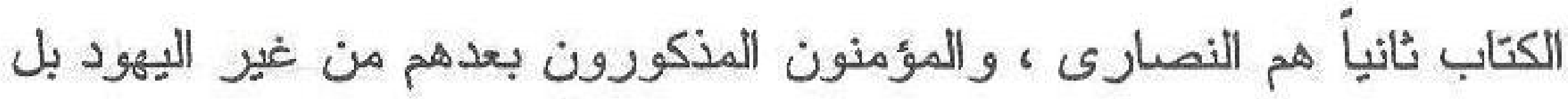

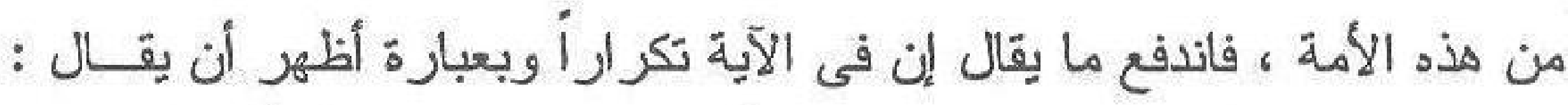

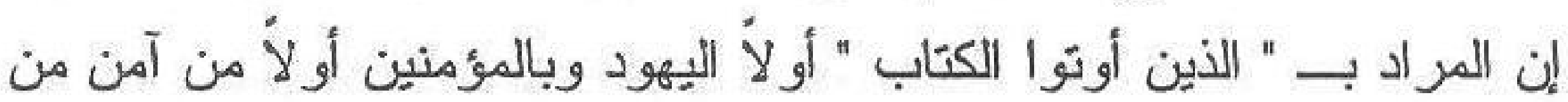

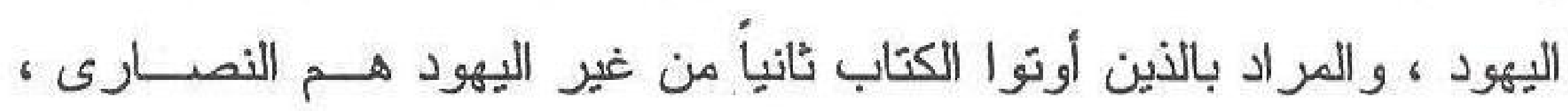

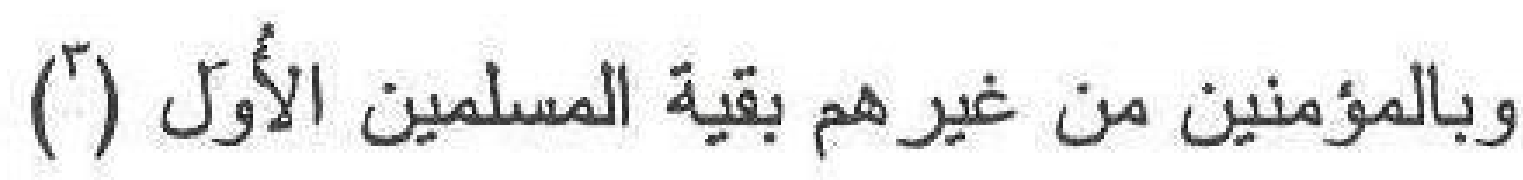

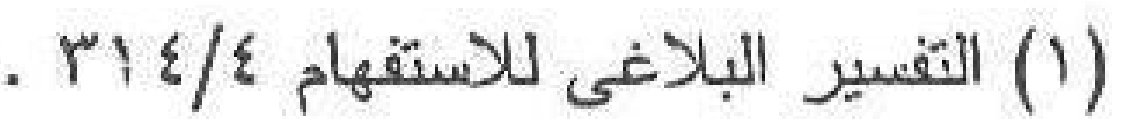

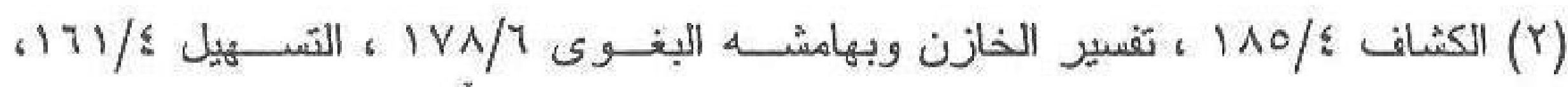

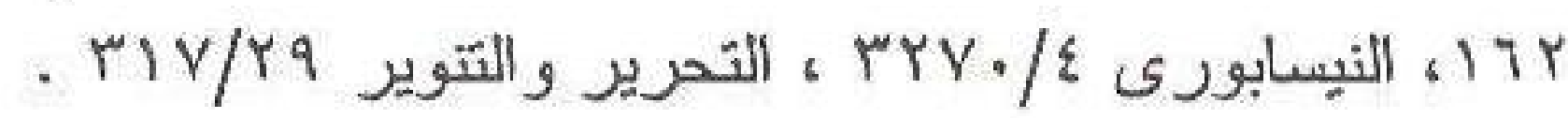

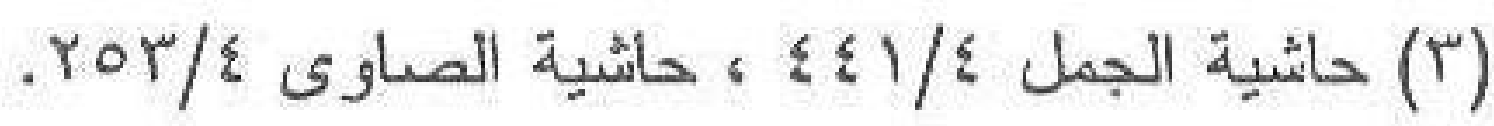


و التعبيز عن الذين آمنوا في قوله : " و المؤمنون " باسم الفاعـل بعـد

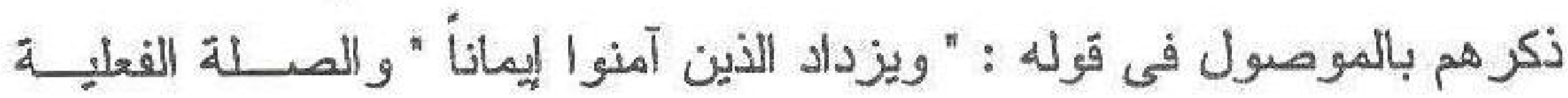
المنبيُة عن الحدوث للإيذان بئباتهم على الإيمان بعد ازدياده ورسوخهم فـى ذلك ومداومتهم عليه فلا يفارقونه بشُكُّ أو ارتياب . قاله الألموسـى : " و إنما لم ينظم المؤمنون فى سلأك أهل الكتاب فى نفى الارتياب حيث لم يقل : ولا يرتابوا للتتبيه على تباين النفيين حالاً فإن انتقاء الارتياب من أهل الكتاب مقارن لما ينافيه من الجحود ومن المؤمنين مقارن لما يقتضيه من الإيمان وكم بينهما ، وقيل :: إنما لم يقل : ولا برتابو ا بـل قيل ولا يرتاب إلخ . للتصبيص على تأكيد الأمرين لاحتمال عود الضمير فى لي لئ (') ذلك على المئمنين فقط

وقوله : "وليقول الأين فى قلوبهم مرض و الكافزون " معطوف على ها سبق وهو الغرض الخامس من الأغر اض التى سيقت لبيان عدة الملائكة فى كونهم " تسعة عشر " بعد نفى الارنياب ، وهو تعليل لهذا العدد . و " الذين فى قَلوبهم مرض " كناية عن موصوف وهم المنافقون الذين وجدوا بعد ذلك فى المدينة ، ويككن هذا من باب الإخبار بالغيوب معجزة له -

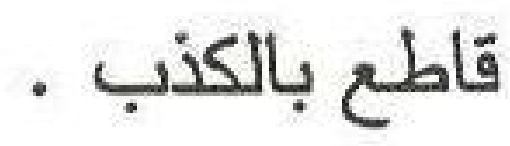

قالل ابن الجعزى : " وفيه ثلاثة أقوال : أحدها : أنه النفاق . ذكــره الأكثرون ، و الثانى : أنه الثشك ـ قالته مقاتل ، وزعم أنهم بهود أهل المدينة ،

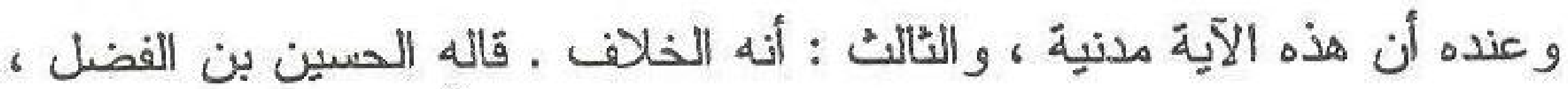
وقال : لم يكن بمكة نفاق وهذه مكية . فأمســـ " الكــافرون " فهــم مشــركو 


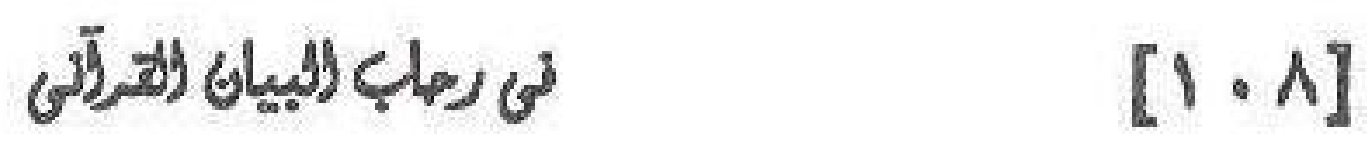

العرب(') ، والتعبير عن هؤلاء سواء كانوا المنافقين أو أهل مكــة بالاستم

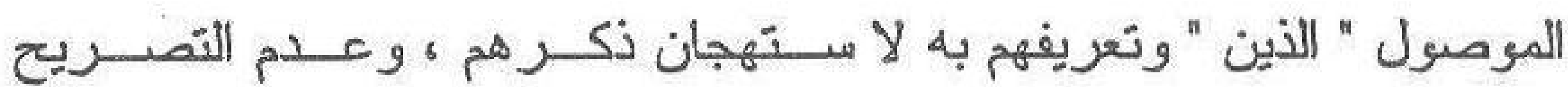

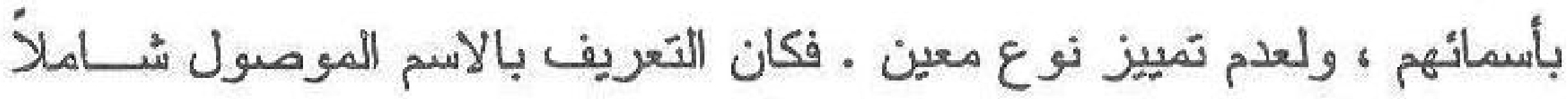

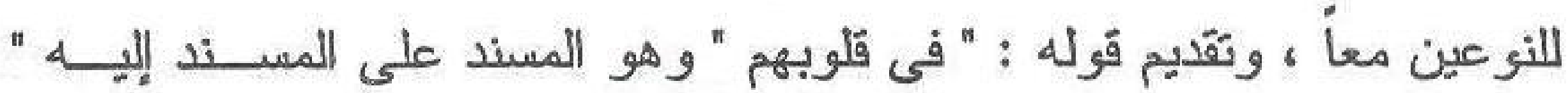

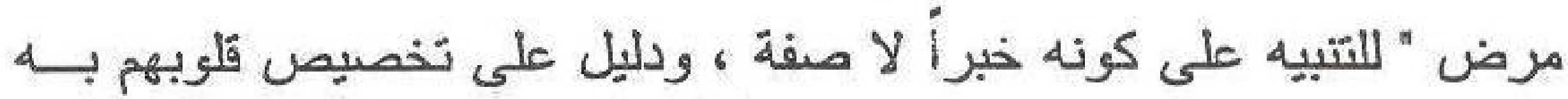
وهو دليل على فساد المعتقد لأنه إذا استقرّ" فى قلوبهم هكذا طبعت نفوســهم

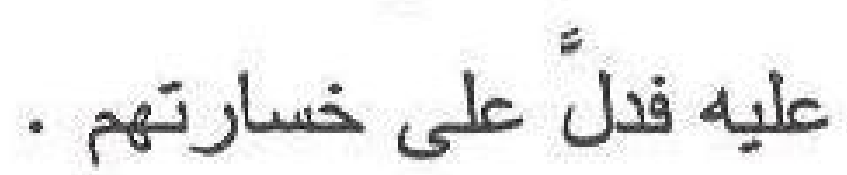

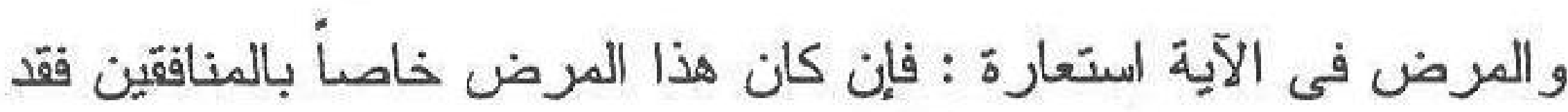

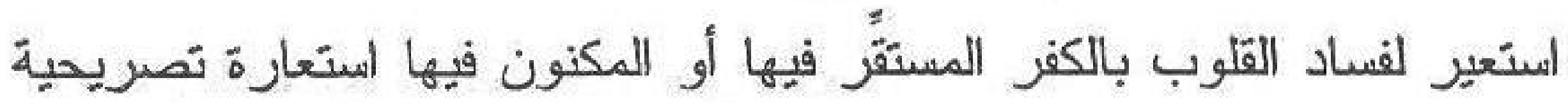

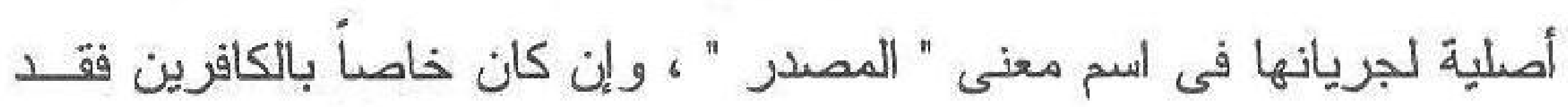

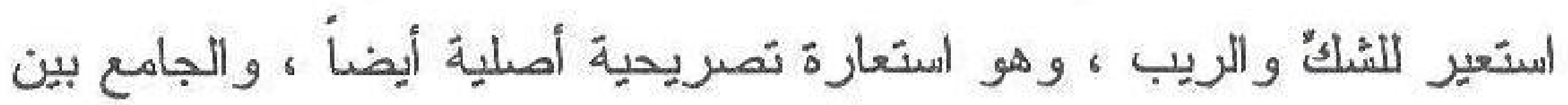

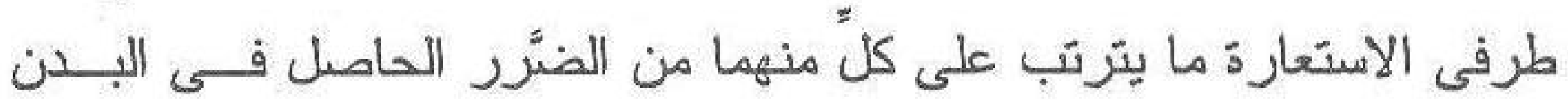
و الدين ـ فالمرض آفة حاصلة فى الإدراك كسوء الاعتقاد و الكفر ، أو هيئسة

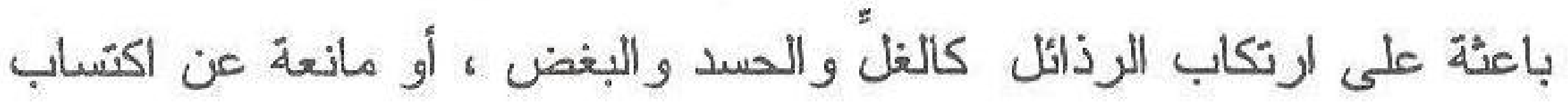
الفضائل كالضعف و الجبن والذور ، ومجئ " مرض " وهو المسند إليه نكرة للتحقيز و البشاعة ، و المقام يدل على ذلك - كما رأينا - . و هناك مزيد دقة فى عطف هذا الجزء من الآية على ما سبق وكونــهـ

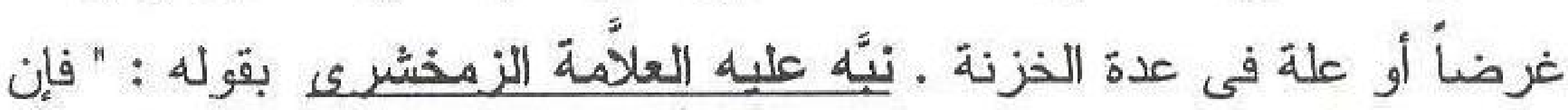

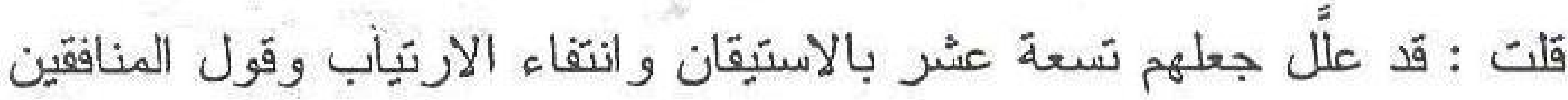

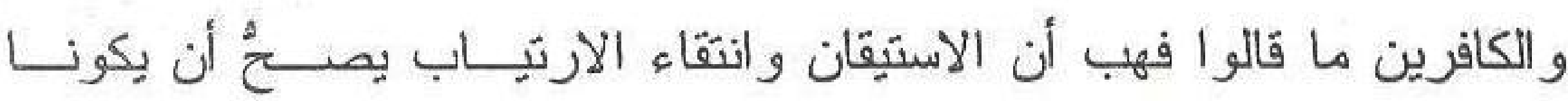

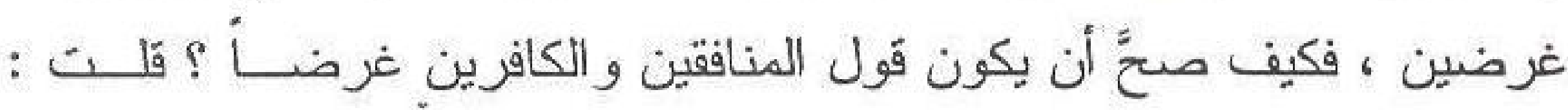


أفادت اللام معنى العلة والسبب ، ولا بيب في العلة أن تكون غرضــان ، ألا

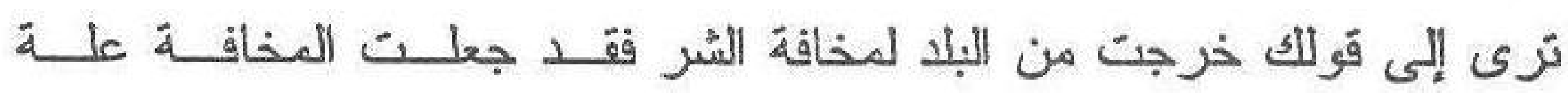
ل لخروجك وما هي بغرضك (') و " الكافرون " هم المصرُون على التكذيب و اللدد والجدل ، و التعريف

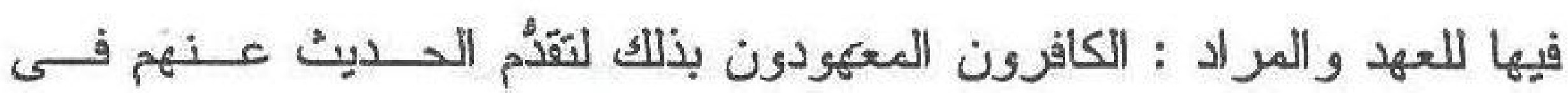
مجادلتهم و عنادهم وأنهم بقدرة على عجز الملائكة كما فى قصة أبى الأشــد

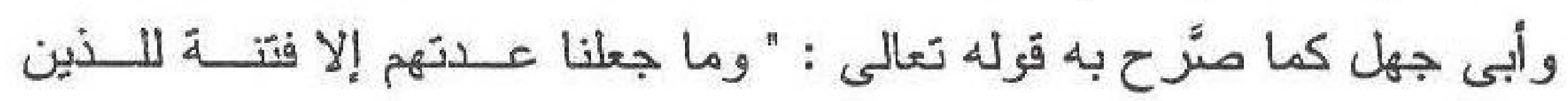

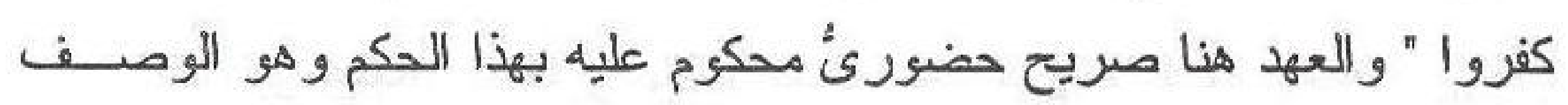
بالكفر لثقدمهه صر احة .

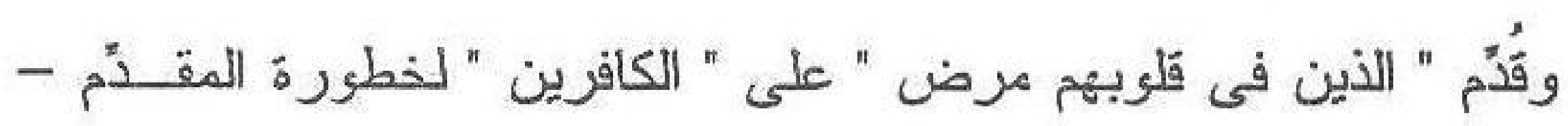
وهم المنافقون - إذ هم أمدذ خطر أ من الكافرين لعدم علم أحد بهخبر هم فهم

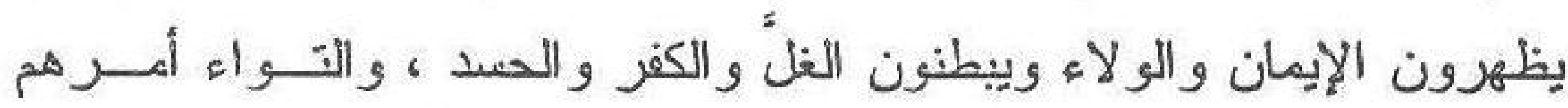

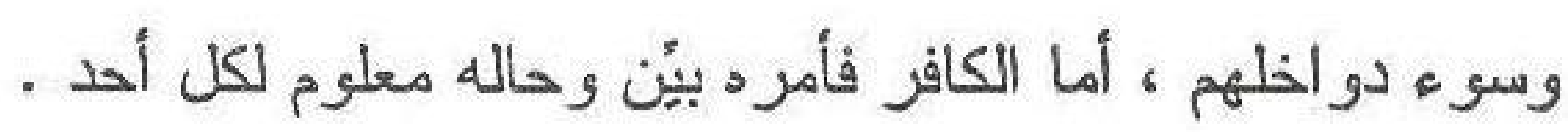

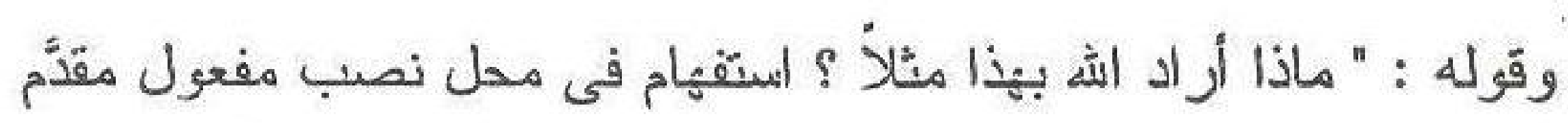

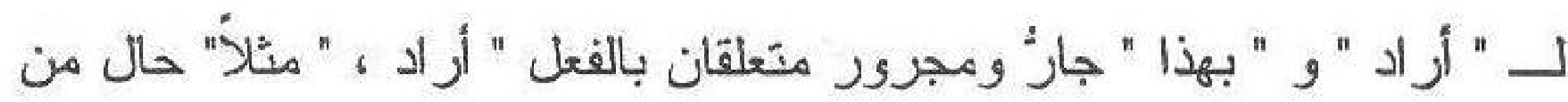

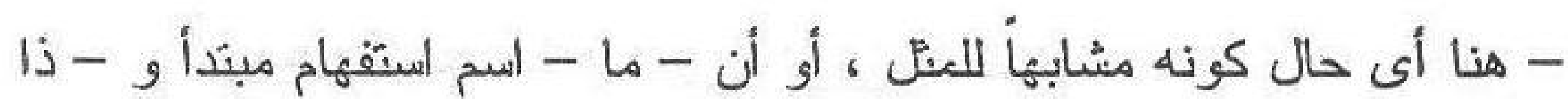

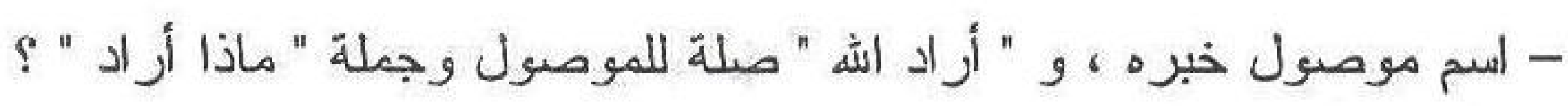

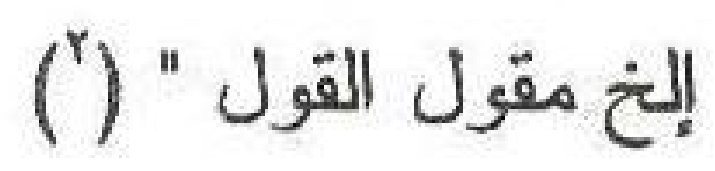
والاستفهام كما يقول المفنزون : للإنكار والاستغراب ، و هو لاستبعاد

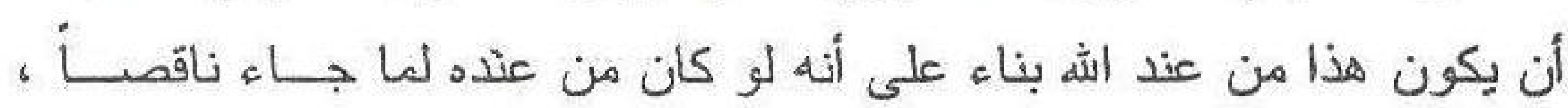


و إفر اد قولهم هذا بالتعليل مع كونه من باب فتتهم للإشعار باســنقالمه فـى الشناعة ." وأداة الاستقهام - ماذا - للمبالغة في الإنكار والاستغراب ، لذلك

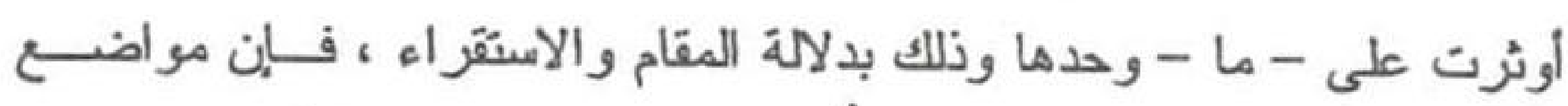

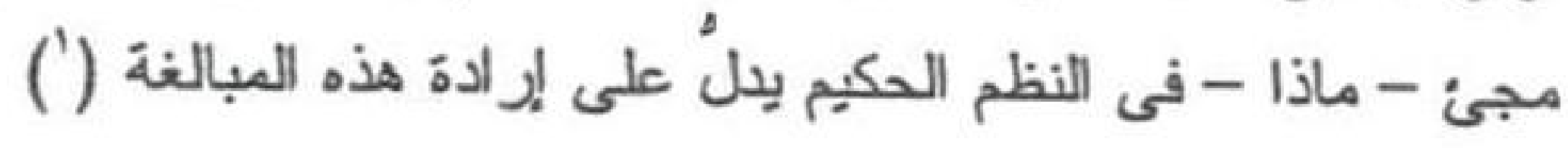
و المعنى المراد من قولهم ذلك بصيغة الاسنفهام : ما الذى أراده الله بها وهى عدّة الملائكة حال كونه مثلاً لا حقيقة لغرابته لان هذا العدد أمر غريب

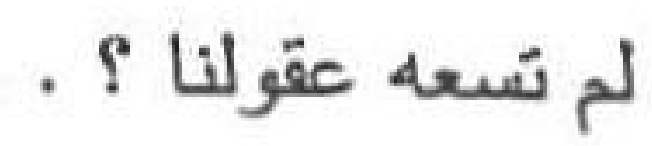
قِال البن عطية : " جاروا وضلَّ ا ولم يهتذوا لقصد الحق فجعلوا يستفهم

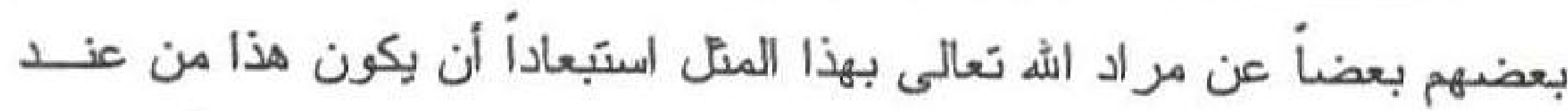
اله (†) ونسبهم ذلك إلى كونه مراد الله تعالى إما من باب الحكاية أى حكاية

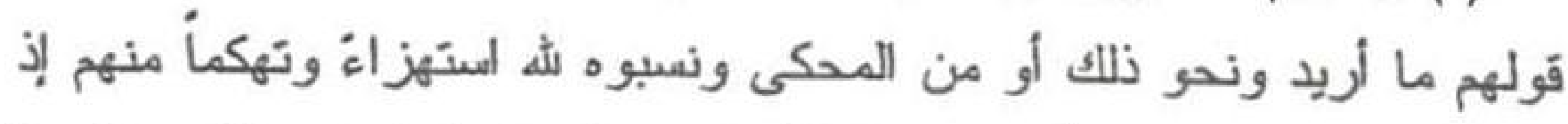

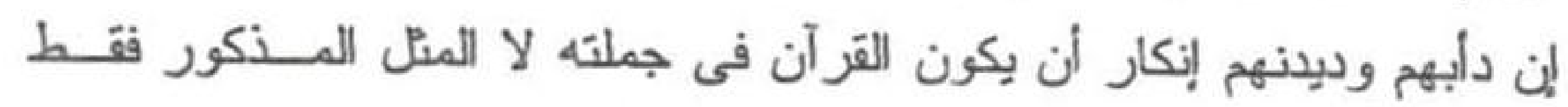
وحياً من عند الله تعالى ، و على هذا يكون نسبهم و إبنادهم ذلك إليه سبحانه وتعالى من باب المجاز العقلى حيث أسند فيه الفعل وهو " أر اد اله " إلى غير

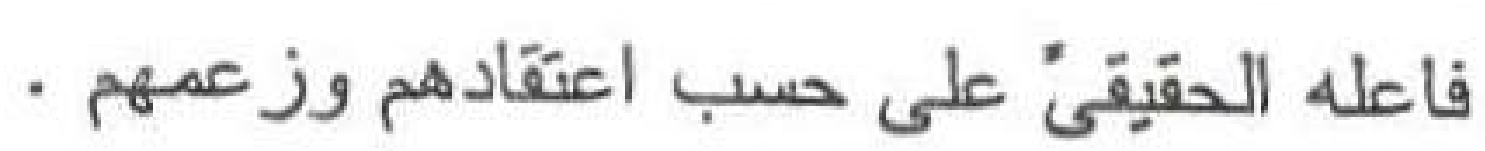
وقد جعل الشبيخ الطاهي ابن عاشور : هذا الاستفهام من باب الكنايــة بنفى إرادة الله تعالى العدد عن إنكار أن يكون الله تعالى قال ذللك فيقــول : " و الأمر الذى أراده اله بهذا الكلام فى حال أنه مثل ، و المعنى : لم يـرد الله

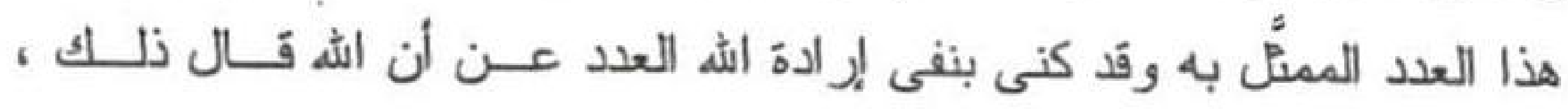

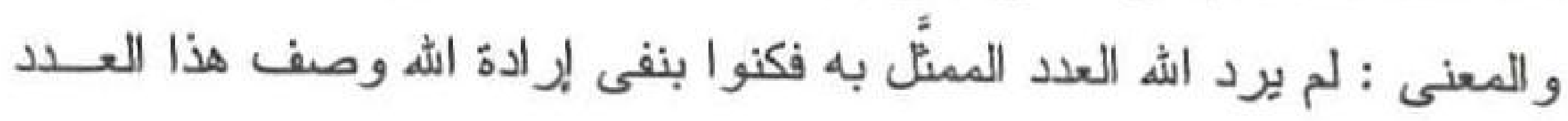

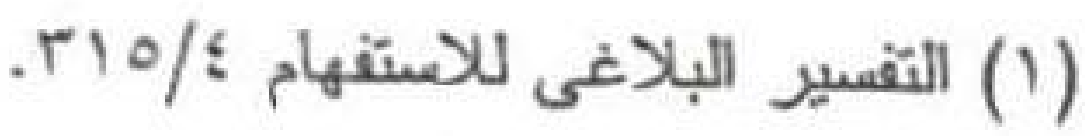

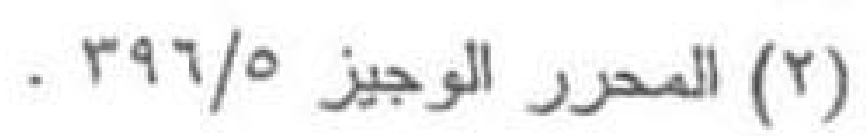


عن تكذيبه أن يكون هذا العدد موافقتاً للى اقع لأنهم ينفون فائنته وإنعا أر ادوا

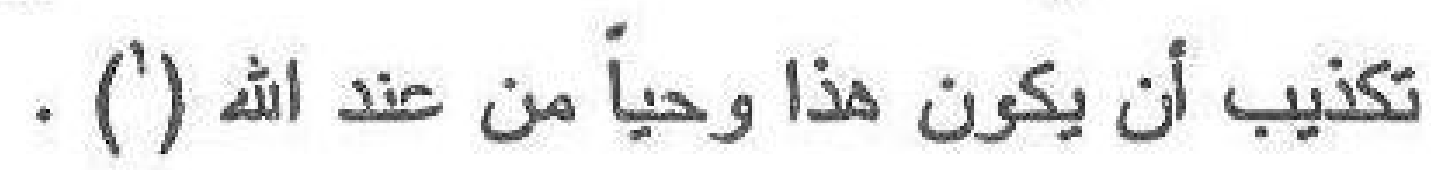

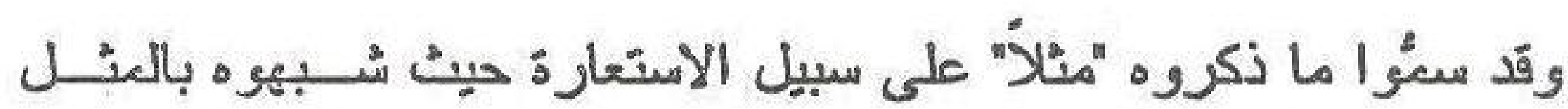

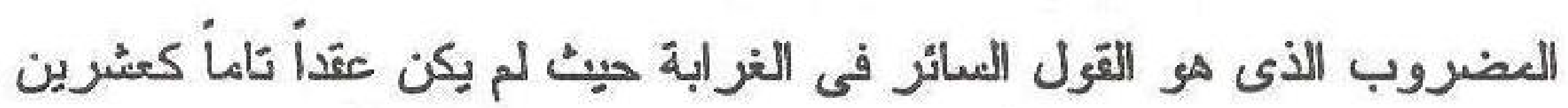

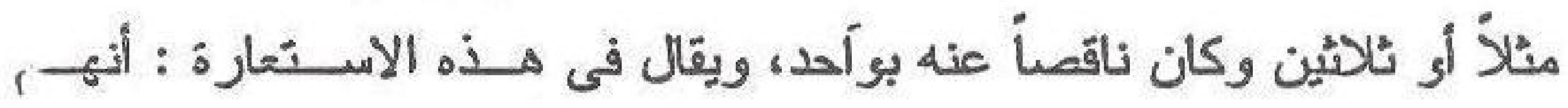

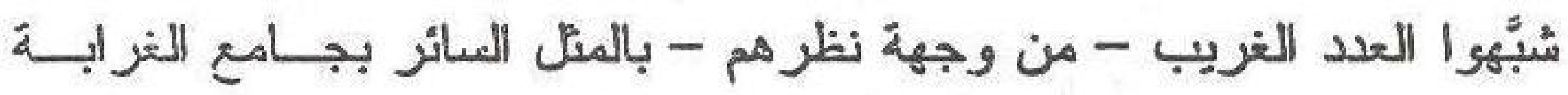

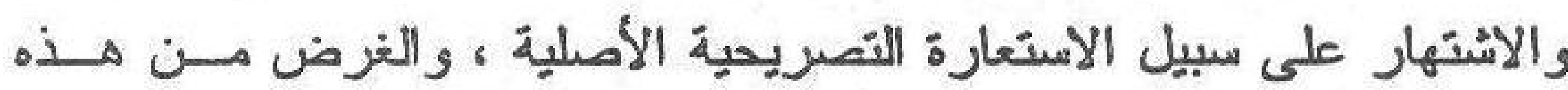

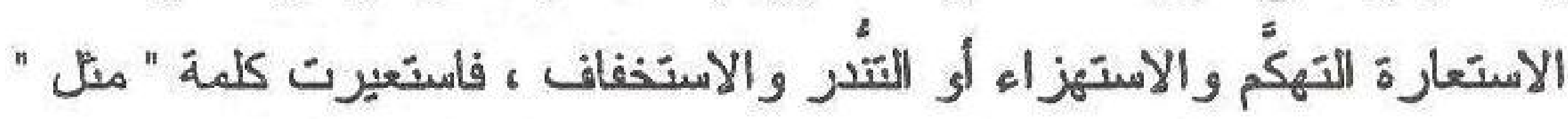

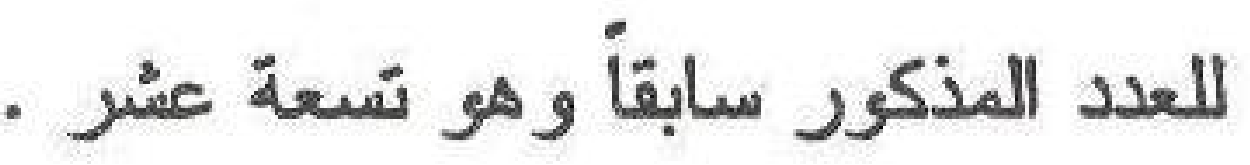

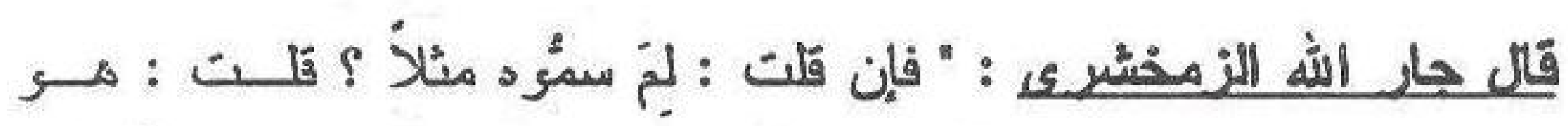
استعارة من المثل المضروب لأنه مما غرب من الكلام وبدع استغر اباً منهم

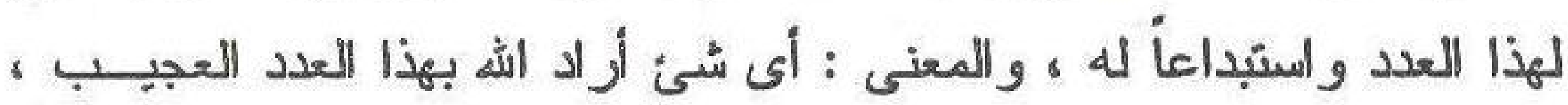

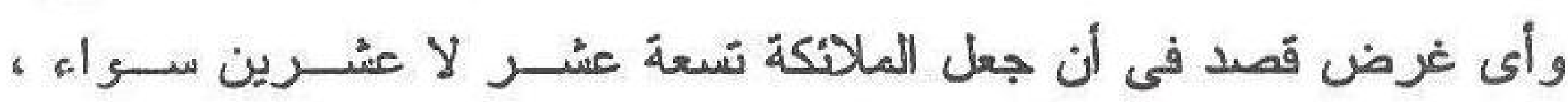

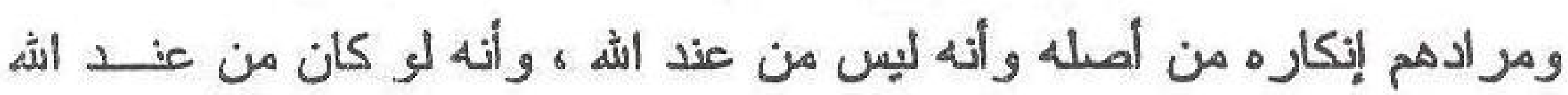

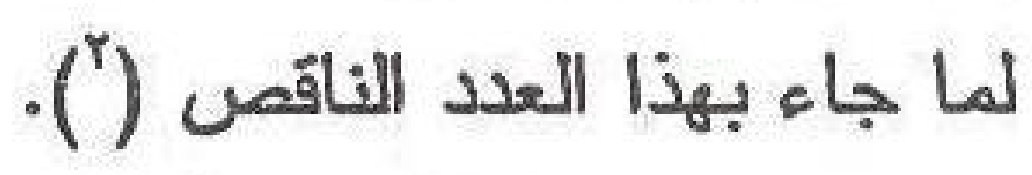

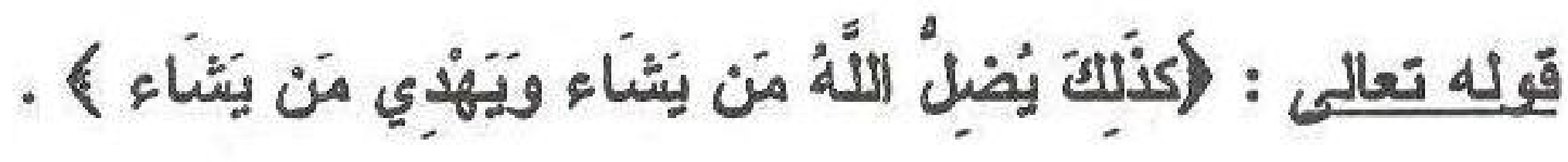

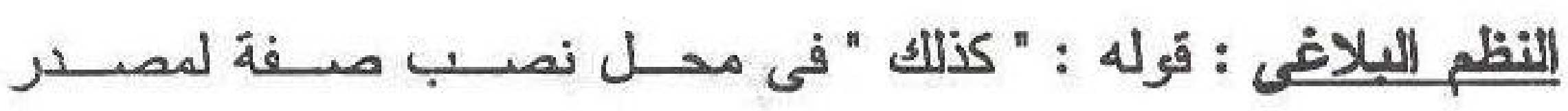

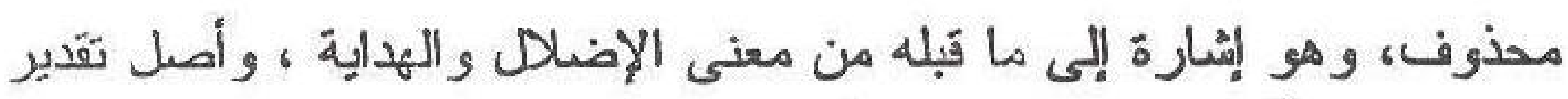

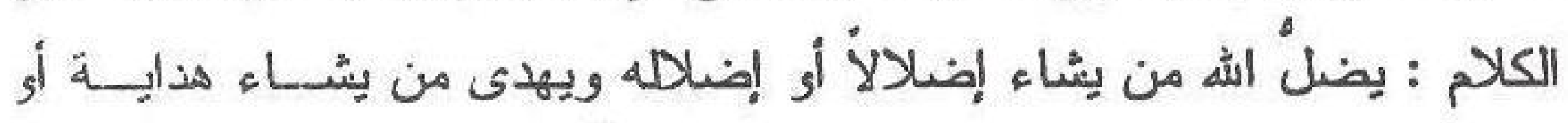

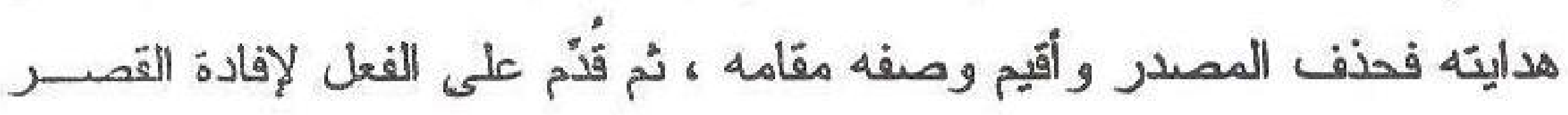




\section{تم رجاب البيان لالقرآتى}

\section{[IIY]}

فصلار النظم مثل ذلك الإضلال وتلك الهداية يضلُ الله تعـالى مسن بشـاء

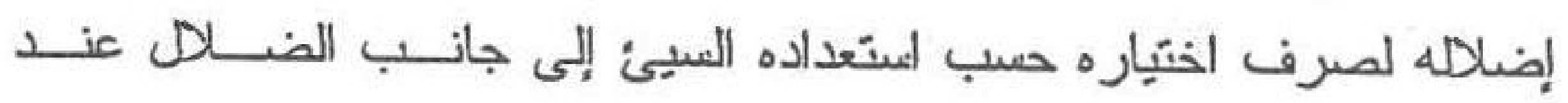

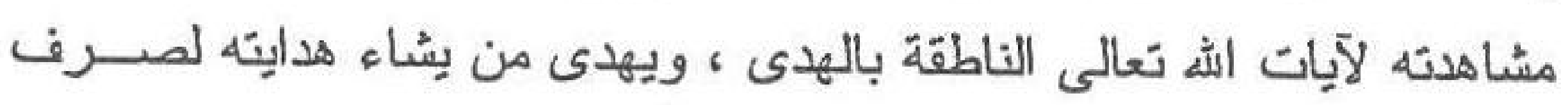

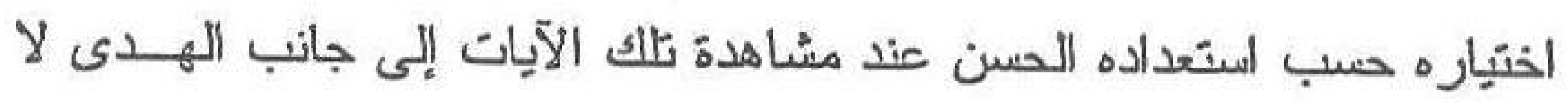

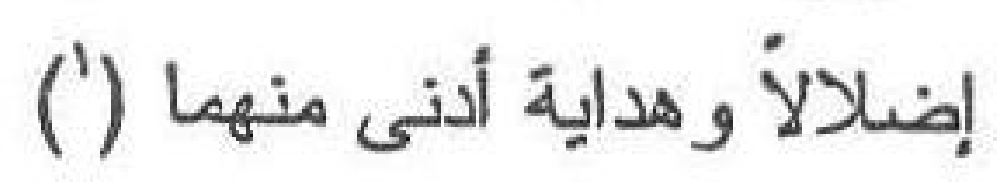

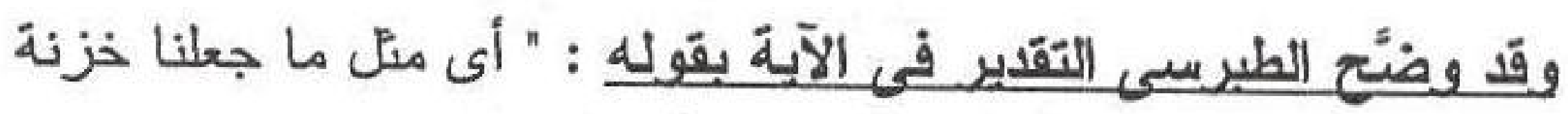

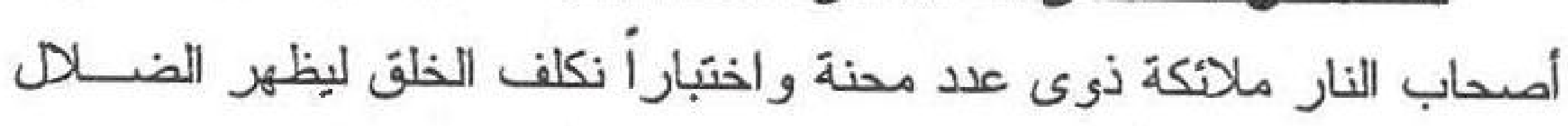

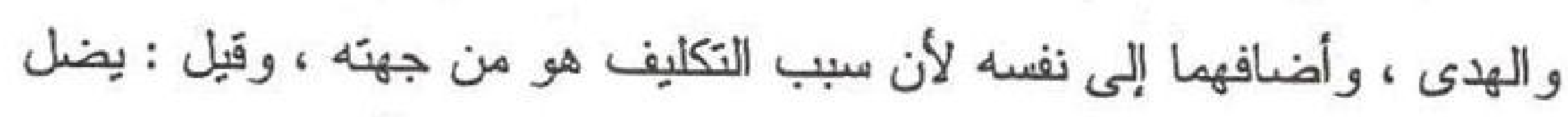

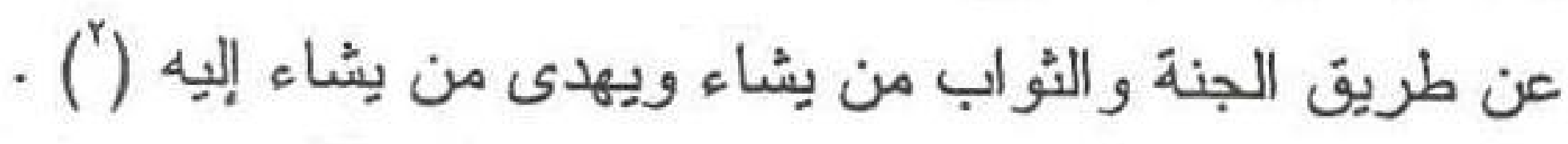

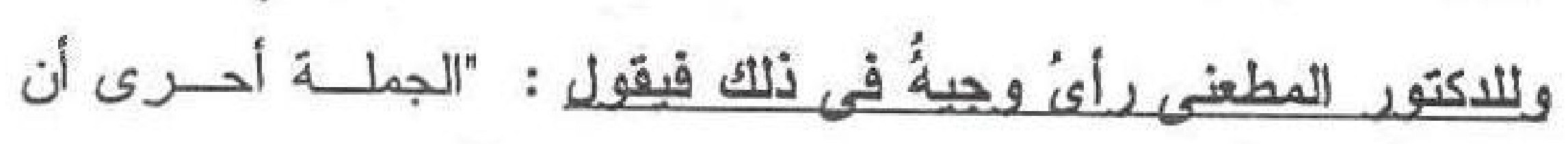

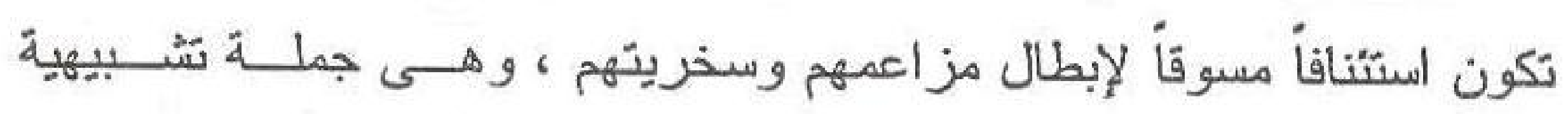

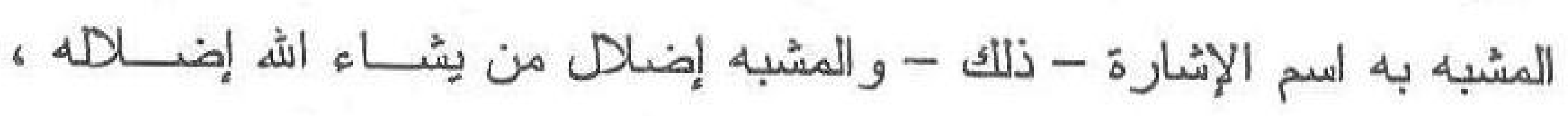

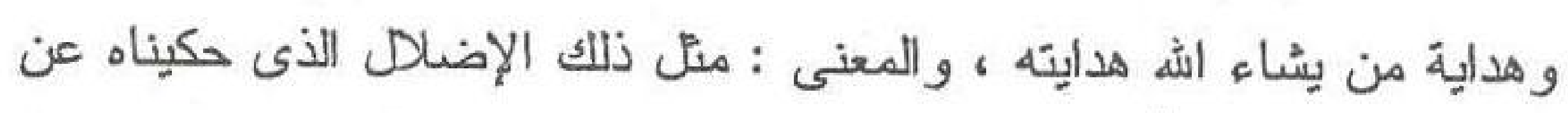

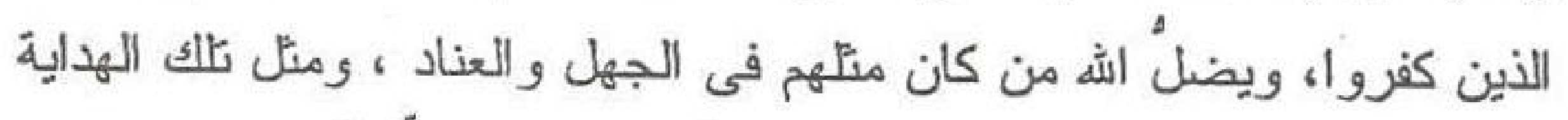

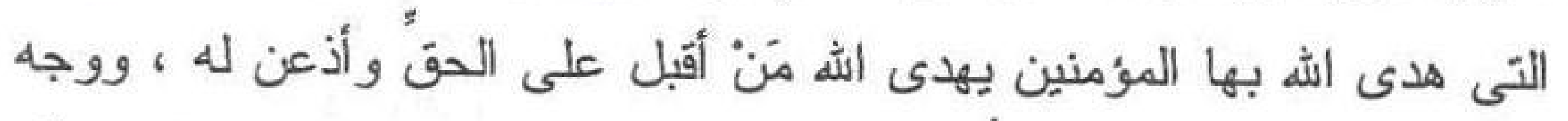

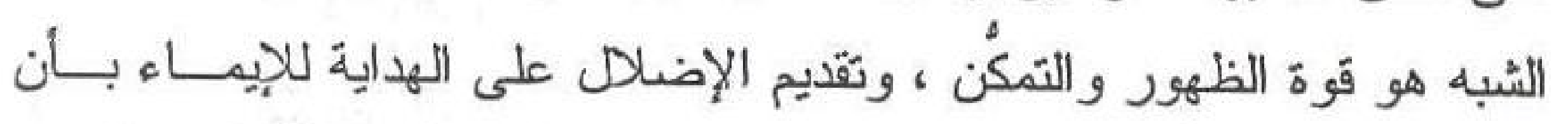

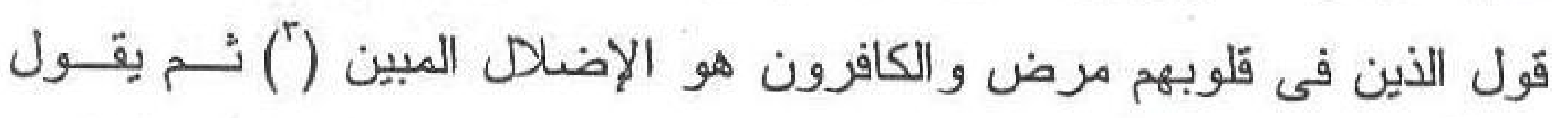

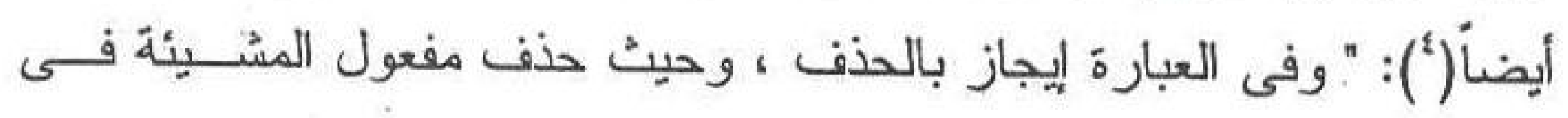

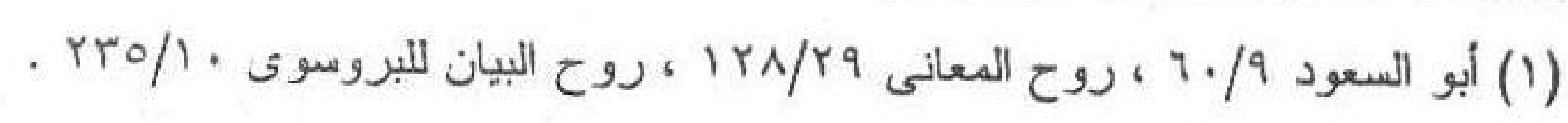

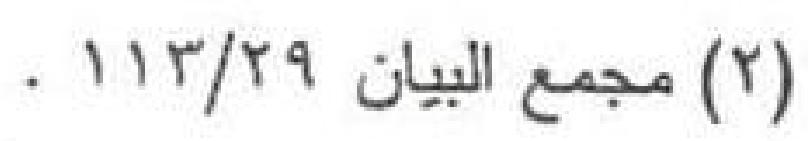

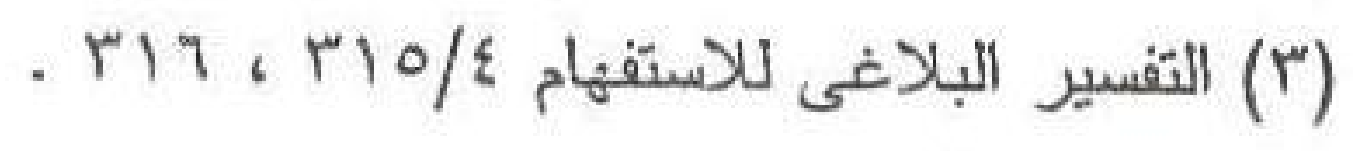

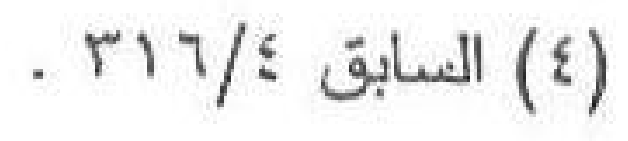




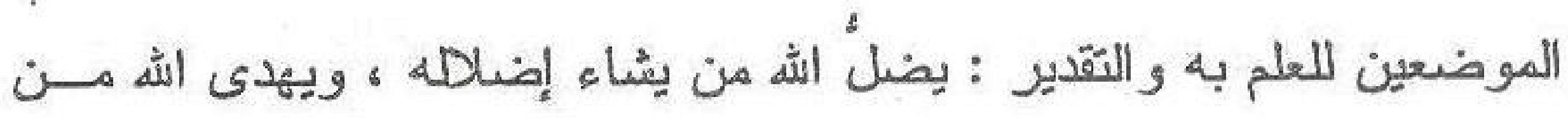
يشاء هدايته ، و هو حذف مطرد مع فعل المشيئة إلا إذا كان المفعول غريبـان وليس فى الكلام ما يدل عليه فيجب ذكره كقول الشاعر .

ولـو شئت أن أبكى دمأ لبكيته عليه ، ولكن ساحة الصبر أوسىع و هذا البيت كما قال محقًّ الإيضاح : " الشاهد فيه ذكر المفعول - أن

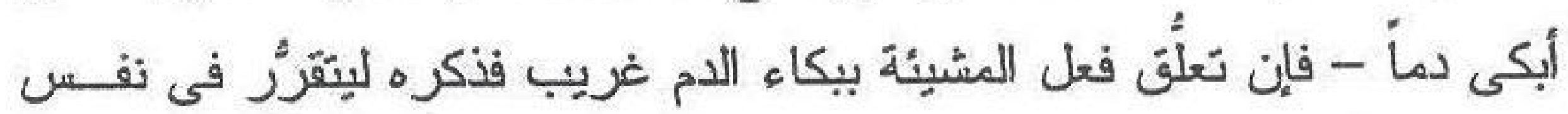

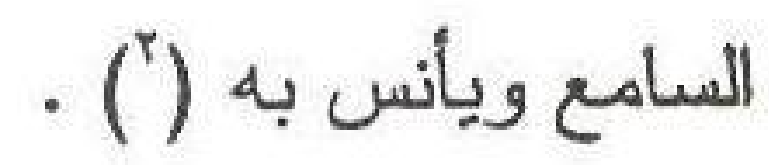

وقد بيَّن سماحة الثشيخ الطادر ابن عاشتح : الغرض من التشبيه فى

الآية بقوله : " و الغرض من هذا التشبيه تقريب المعنى المعقىل وهو تصرُف من

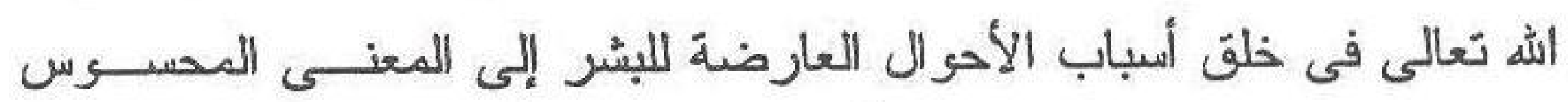

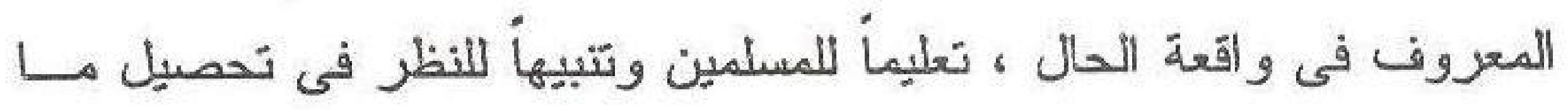
ينفع نفوسهم ، ووجه الشبه هو السببية فى اهنداء من يهتدى وضــلال مسن

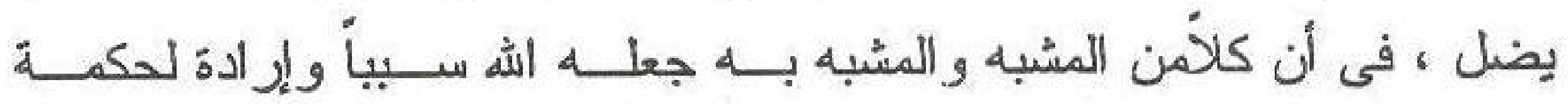
اقتضاها علمه تعالى فتقاوت الناس فى مدى إفهامهم فيه من مهند ومرتساب

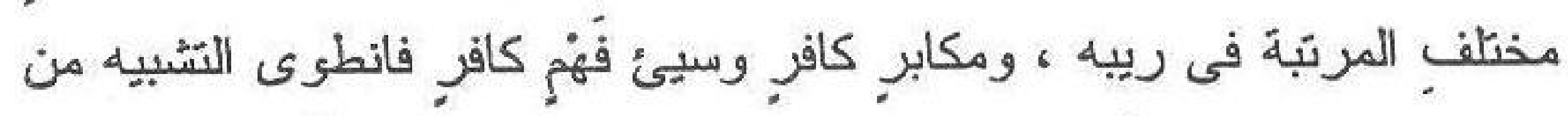
قوله - كذلاك - على أحوال وصور كثيرة تظهر فى الخارج (")

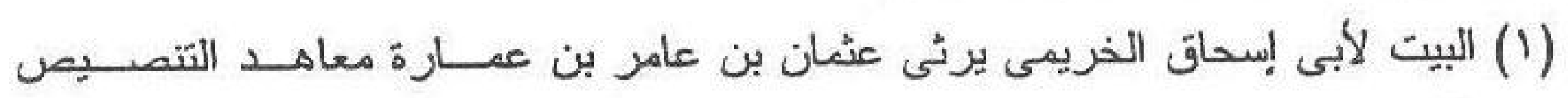

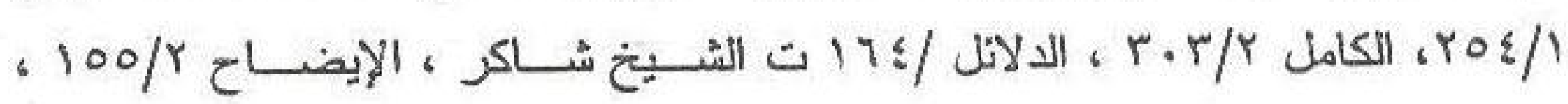

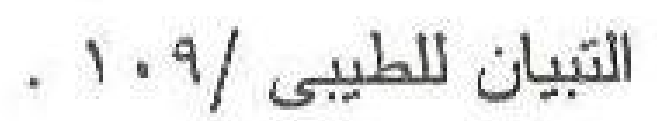
. الإيضاح r)

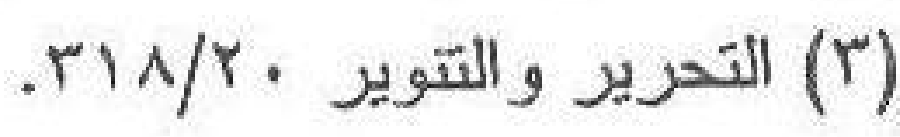




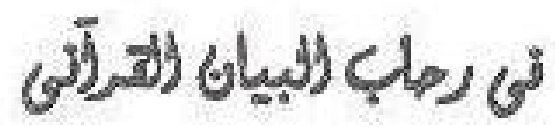

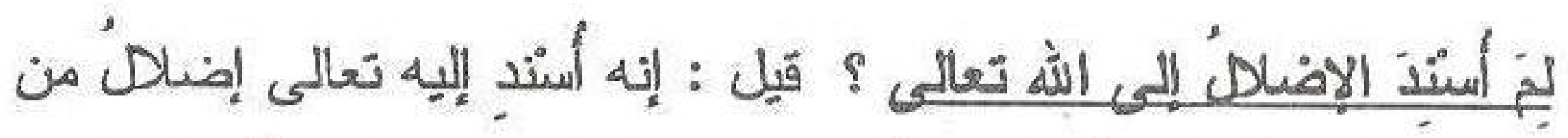

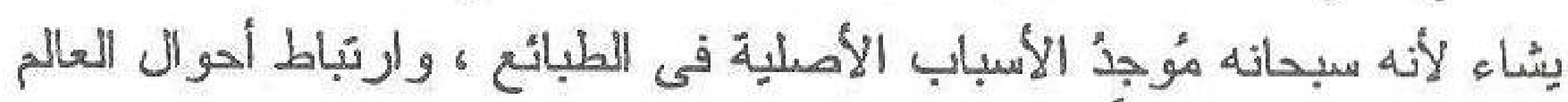

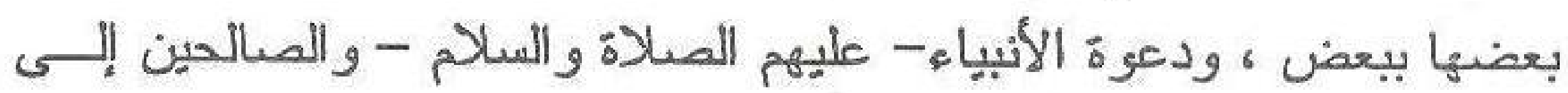
الخير التىى أدتَ بالضًّالين إلى ضلالهم وبالمهتدين إلى هداهم ، وكل من خلق

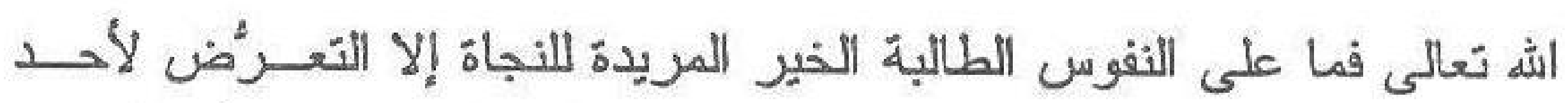

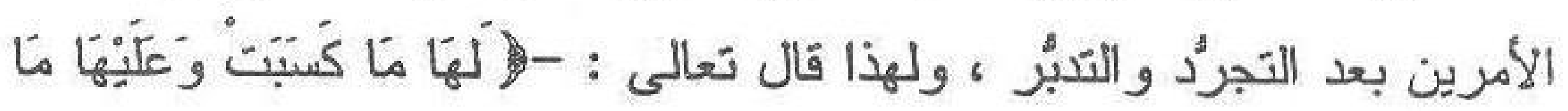

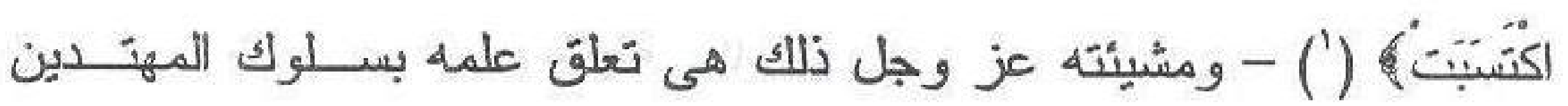

$$
\text { و الضَّالين }
$$

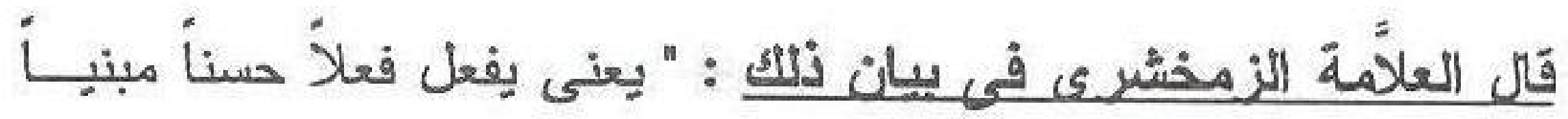

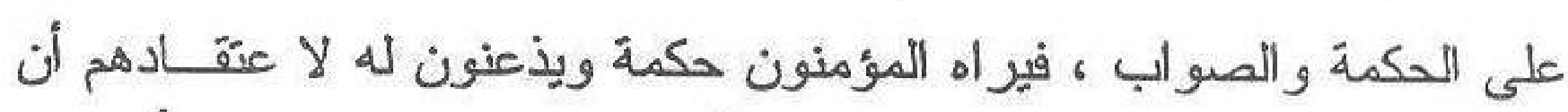

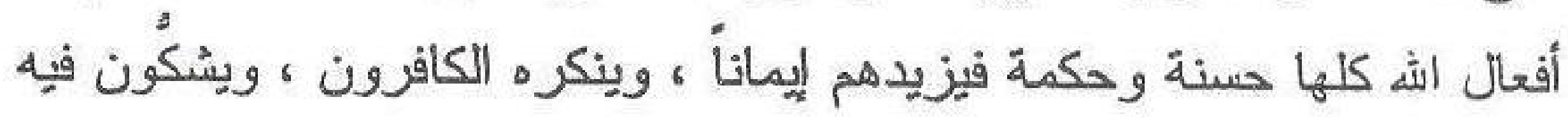

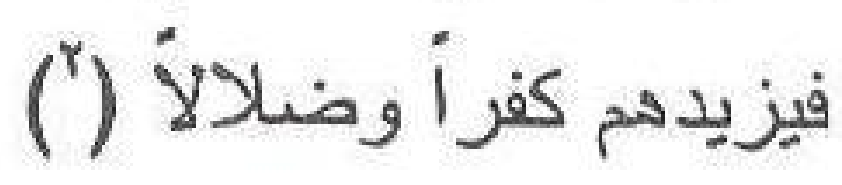

وما أحسن بيلن ما ذكرنا ها فسرّ به الإمام النسفقى ذلك بقوليه : " بعنى

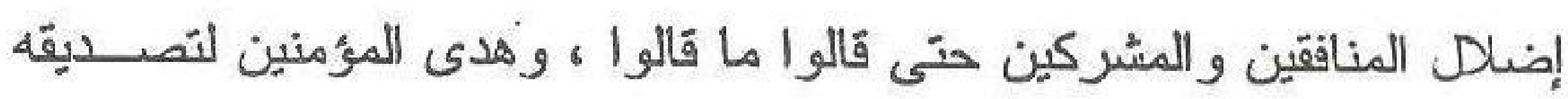

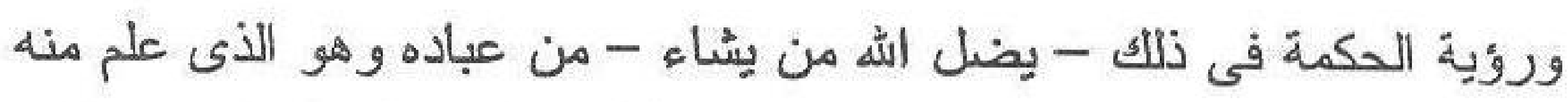

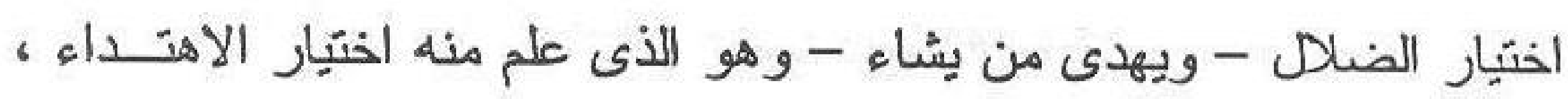

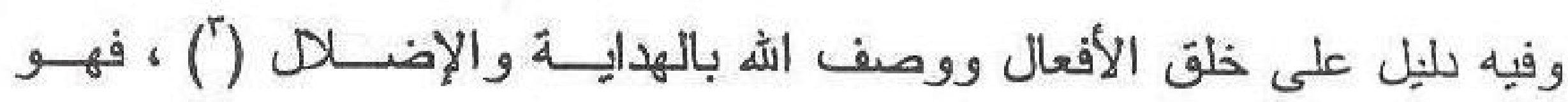

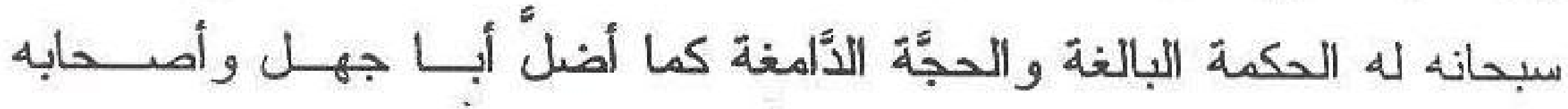
و أبقاهم على ضلالهم ، و هدى المؤمنين ونفع بهم كعمر وخالد وعمرو إلخ .

$$
\begin{aligned}
& \text { (1) (البقزة (1) } \\
& \text {. 1110/5 الكثاف }
\end{aligned}
$$

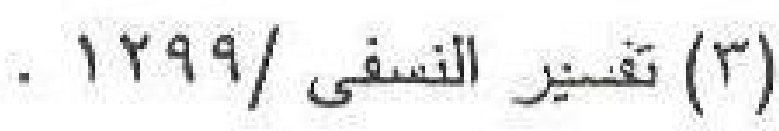




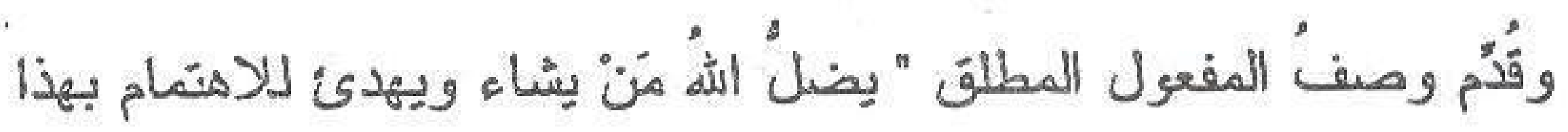
التشبيبه لما يرشد إليه من تفصيل عند التكبرُ فيه ، وحصل من تقديمه محسنّ

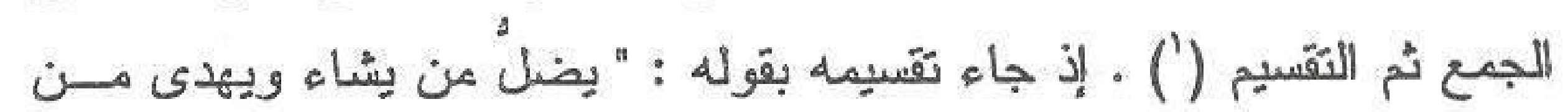

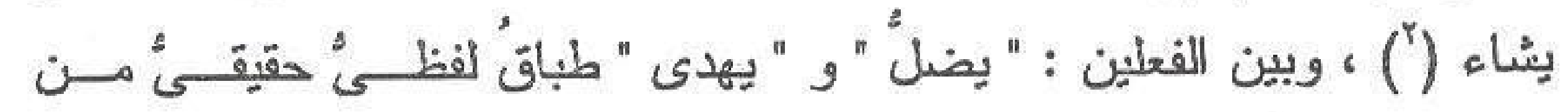

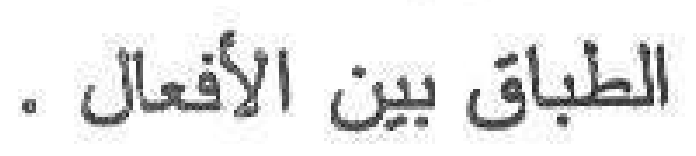

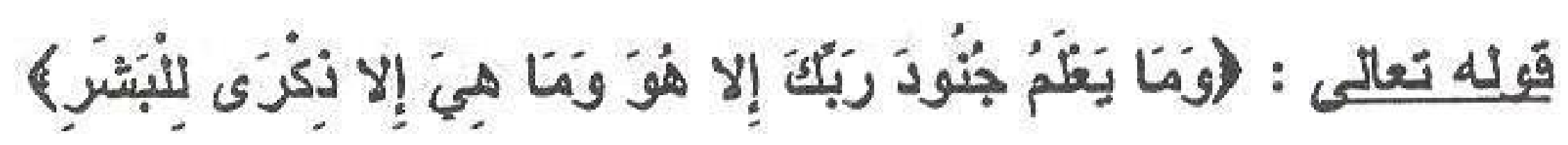
النظم البلاغى : قوله : " وما بعلم " جملة مستأنفة جاءت جوابـان وردًاً على أبى جهل لتهكُمه واستهزائه فى قوله : أما لربٍ محمد أعوانُ إلا تسعة

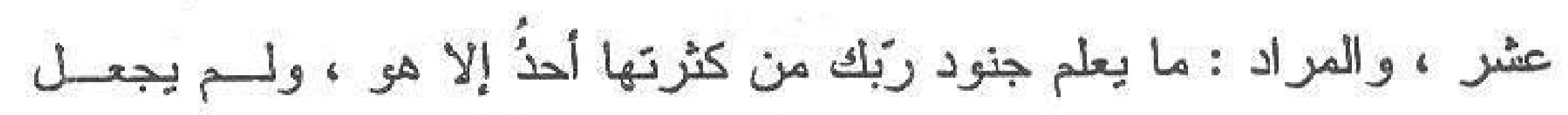

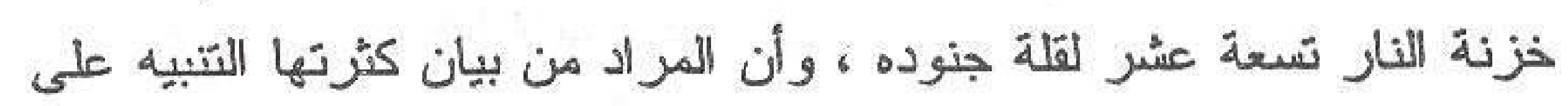

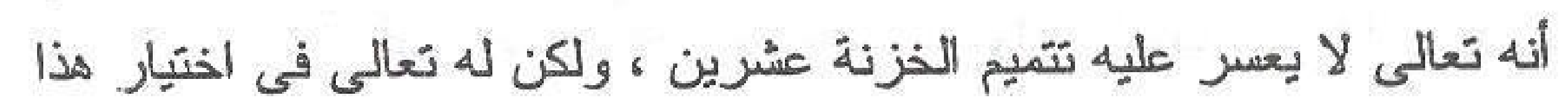

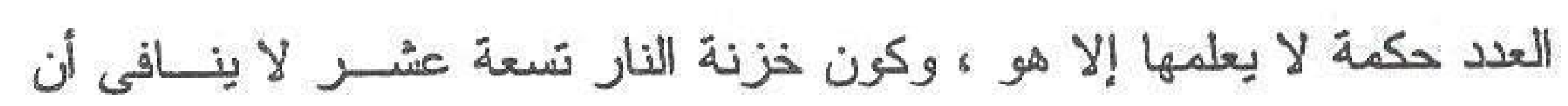

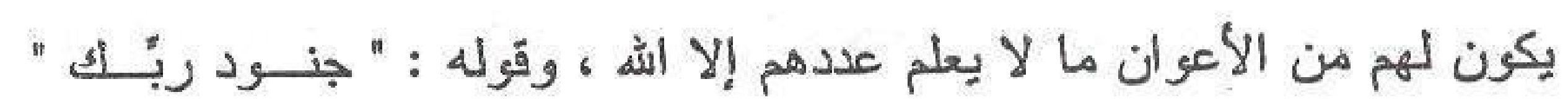
مفعول مقدّم واجب التقديم لحصر الفاعل وقصره عليه ، وتخصيصه بــهـ ، و هذه الجزئية من الآية تأخذ حكم التذييل المتّمّم لردّد نعالى على المسنهزئين

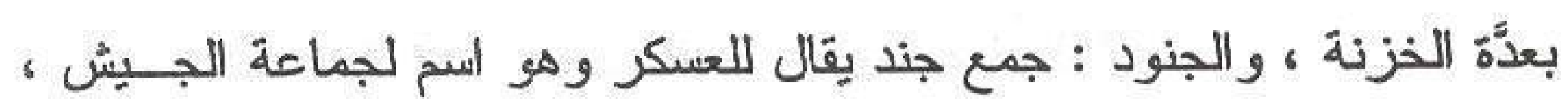
وهو هنا استعارة تصريحية استعير لجماعات الملائكة التى خلقها اله تعـالى

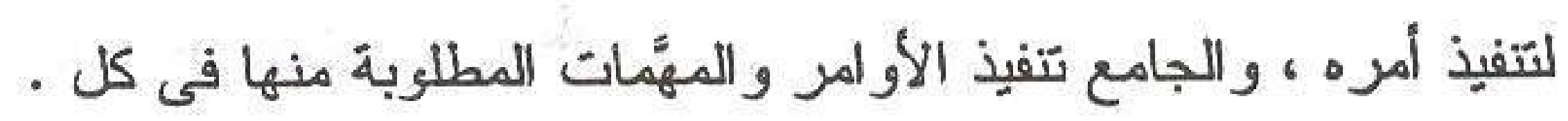

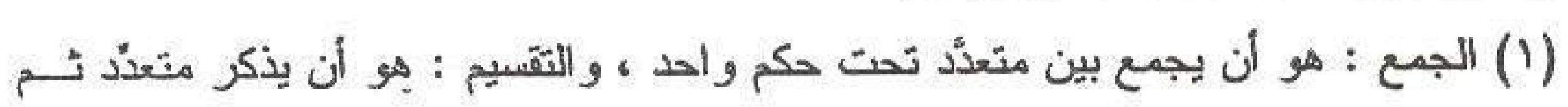

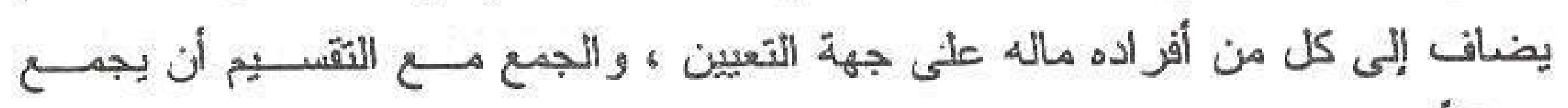

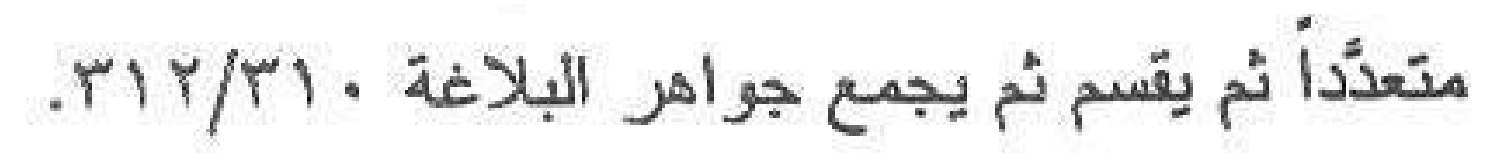

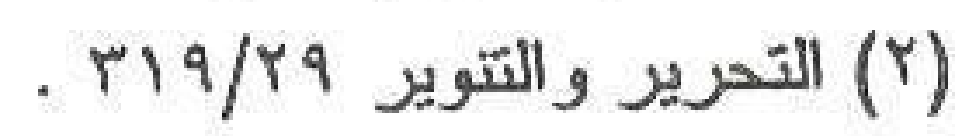




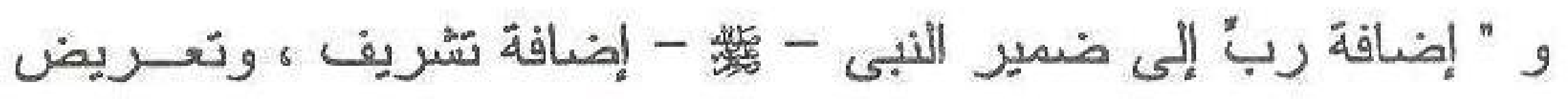

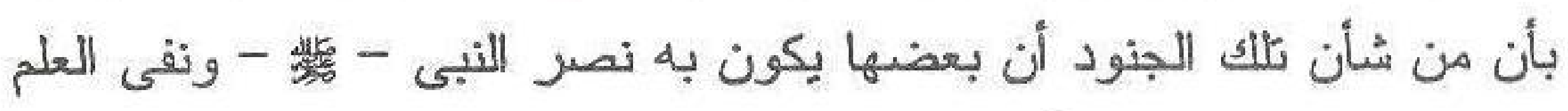
هنا نفى للعلم التقصيلى بأعدادها وصفاتها وخصائصها بقرينة المقام فإن العلم بعدد خزنة جهنم قد حصل للناس بإعلام من الله لكنهم لا يعلمون مسا وراء

(') ذل

وقوله : " وما يعلم جنود ربك إلاًّ هو " أسبلوب قصر من باب قصسر الصفةً على الموصوف ، وهى صفة علمه تعالى بملأكتها على ذاتثه سبحانه

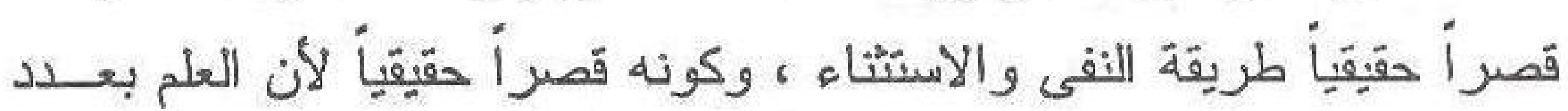

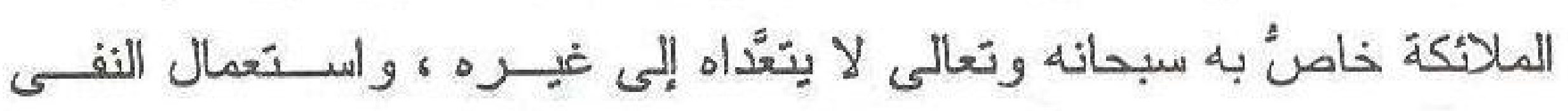

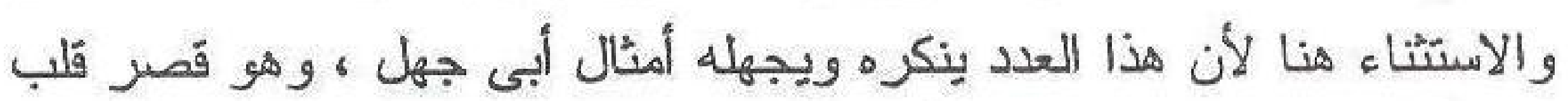

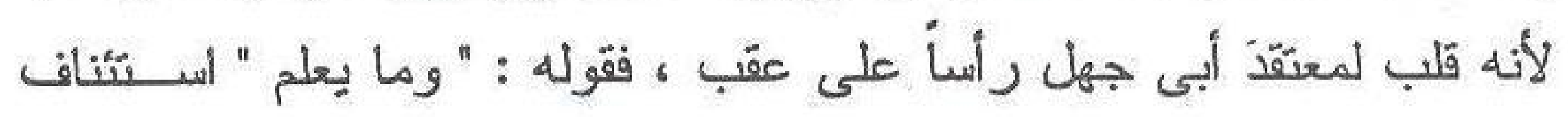
مبطل لاحنجاجهم على خصوص العدد المذكور " تسعة عشر "ولافع تَوهُم

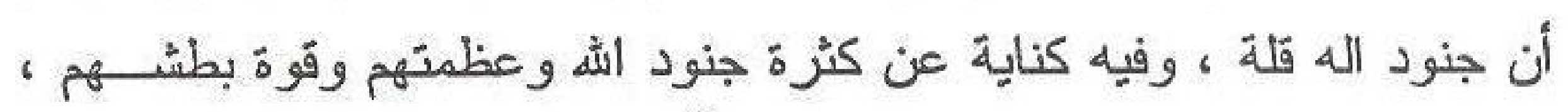

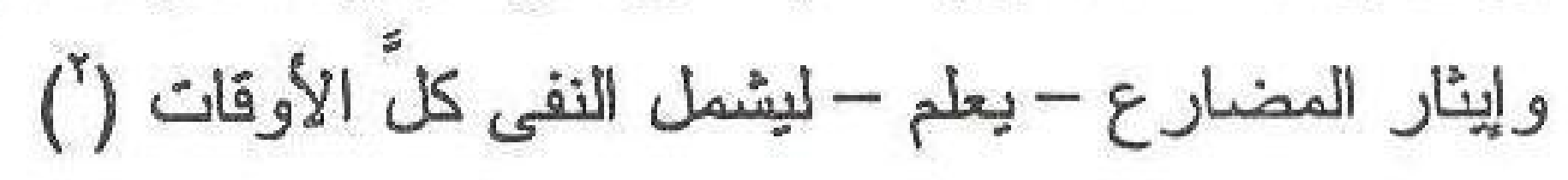

يقول القاسمى : " "يجوز أن تكون الجملة تأييداً لكون ما تقلَّم مــثلا .

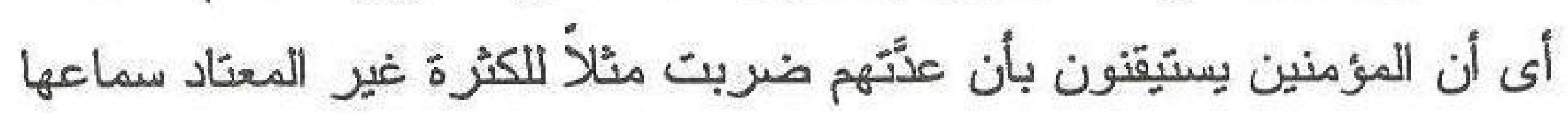
للكافرين ، ومن سنته تعالى ضرب الأمثال فى ثتزيله ، و إلا فلا بعلم جنوده إن

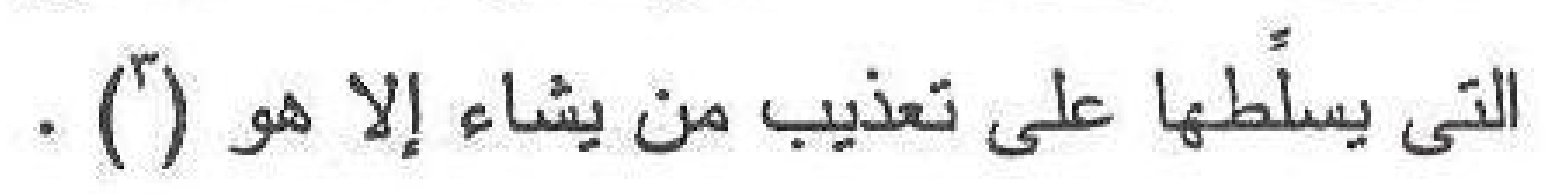

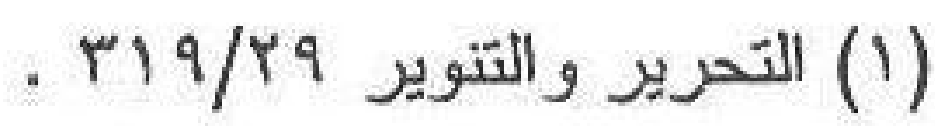

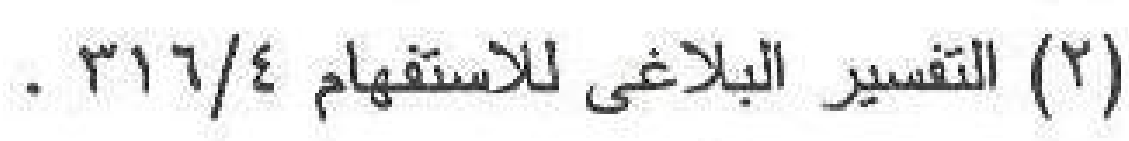

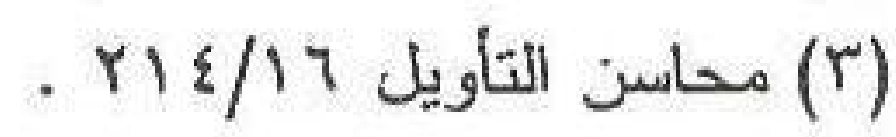


وقوله : "وما هى إلا ذكرى للبُشر " معطوف على ما ســبق ، وهـــا

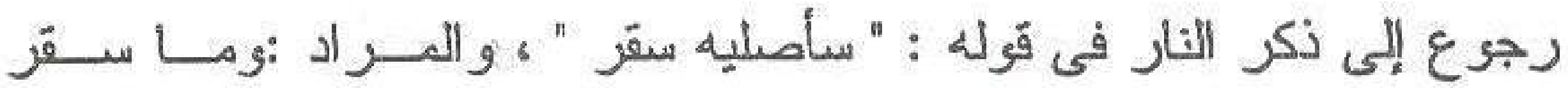
وصفتها إلا موعظة للناس ، وعُبر عنها بـ " ذكرى " لاعتبار التوعيد بهــا وذكر أهو الها ، و " العطف قيل : على قوله تعالى : - سأصليه سقر - ، ـ ـ ـ وما جعلنا أصحاب النار - إلى هنًا اعتر اض ، ووجهه أنه لما قيل: - عليها

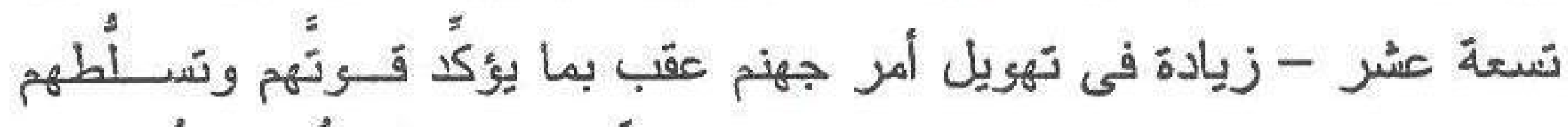

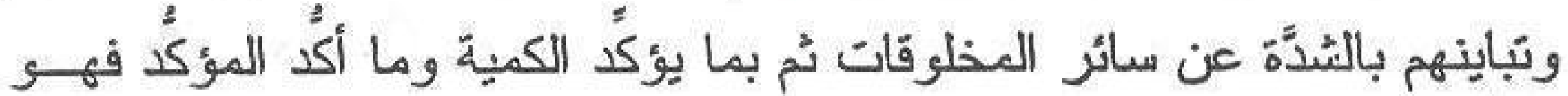

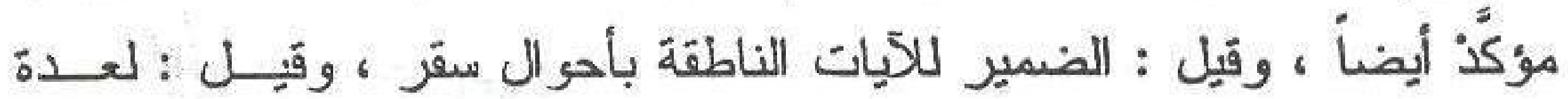
خزنتها و التذكير والعظة فيها من جهة أن فى خلقه تعالى ما هو فــى غايــة

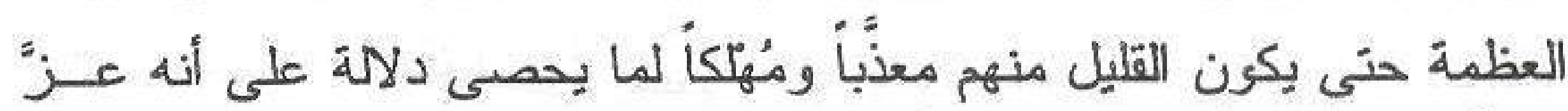
وجلَ" لا يقدر حق" قدره ولا توصف عظمته ولا نصل الأفكـار إلــى هــرم جلاله، وقيل : الضمير للجنود (')

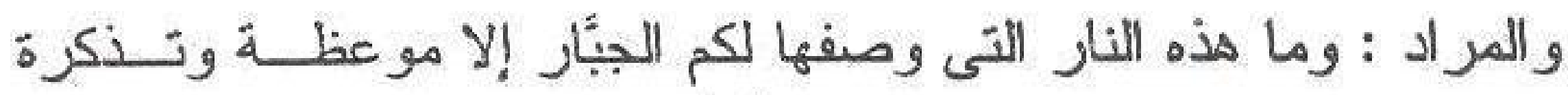

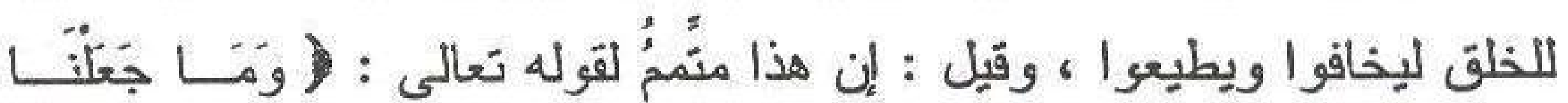

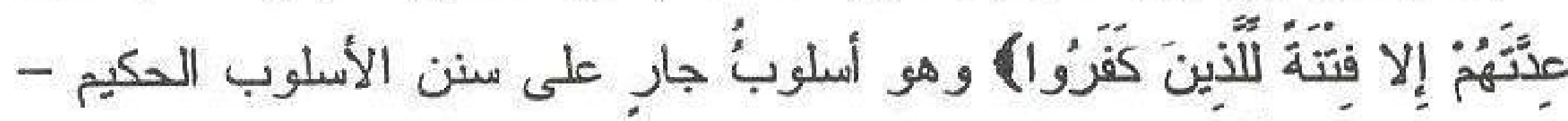

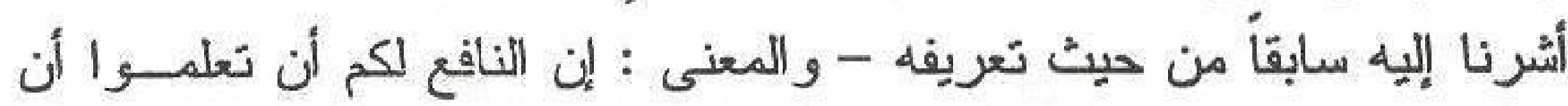

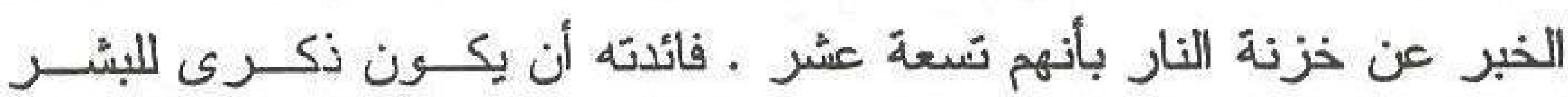

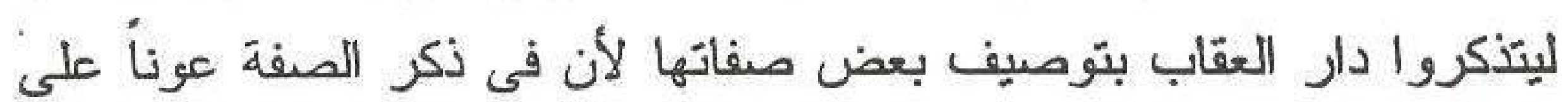
زيادة استحضار الموصوف ، فغرض القرآن الذكرى ، وقد اتخذه الضُّـالترن ومرضى القلوب لهوأ وسخرية ومر اء بالسؤ ال عن جعلهم تسعة عشر وَمْمَ لَمْ

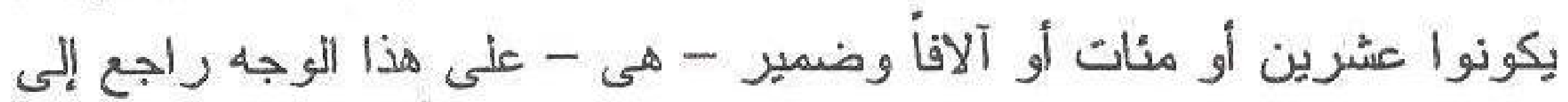


- عدَّته - (') وقوله : وما هى إلا ذكرى اللبشر " أسيلوب قصر من قصــر

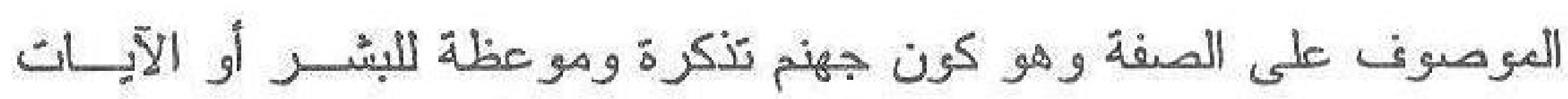

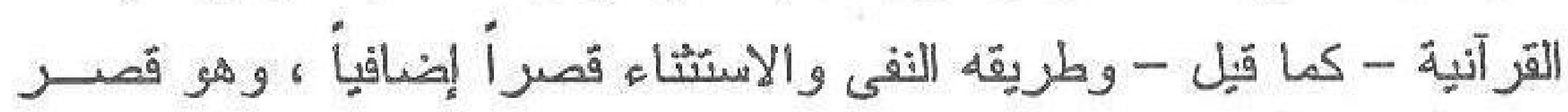

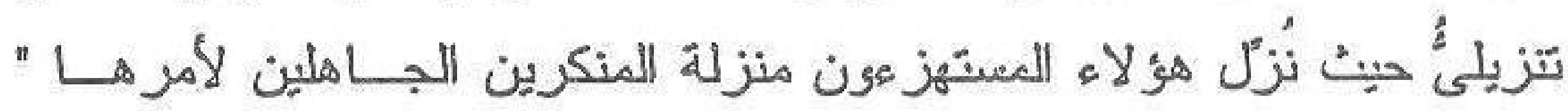

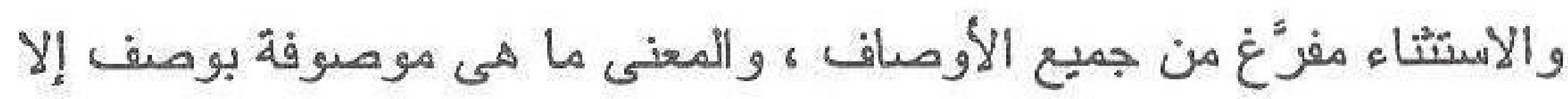
وصف ذكرى ، و اللام فى - للبشر - للاختصاص ، و الأكرى العظة والعبرة

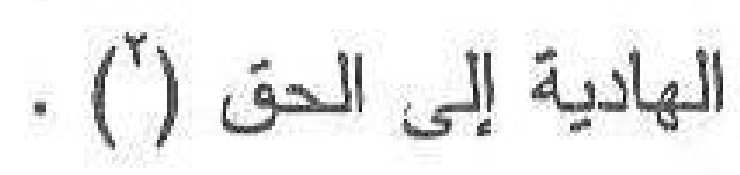

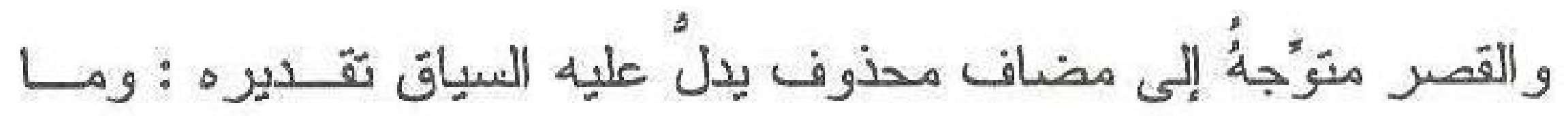
ذكرها أو وصفها أو نحو ذلك ، وبين قوله : " للبشر " هنا وقوله : "لوَّاحسة

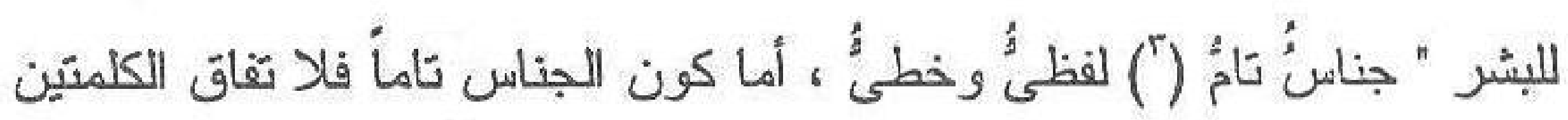

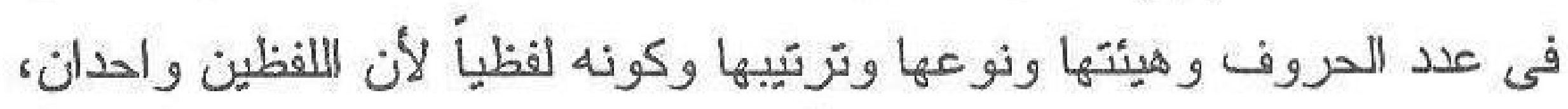

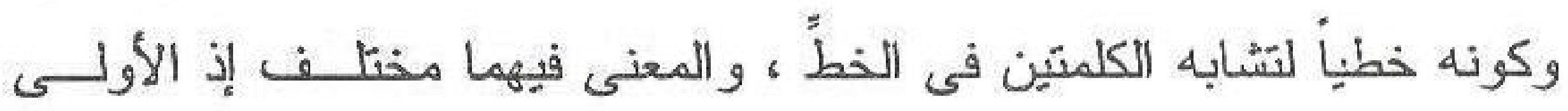
وهى التى فى قوله : " ذكرى اللبشر " بر اد بها الناس من الإنسس و الجــن ،

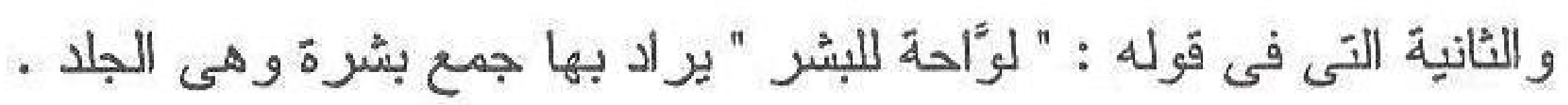

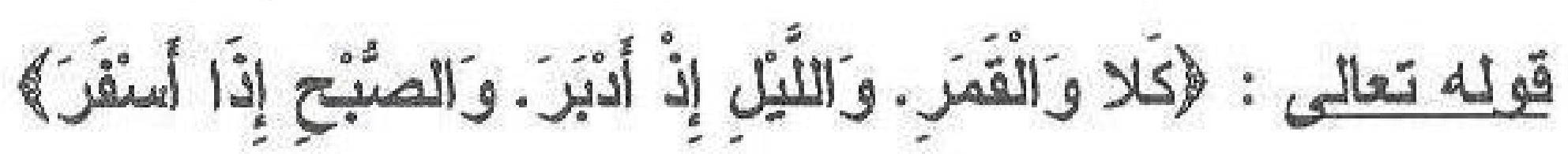

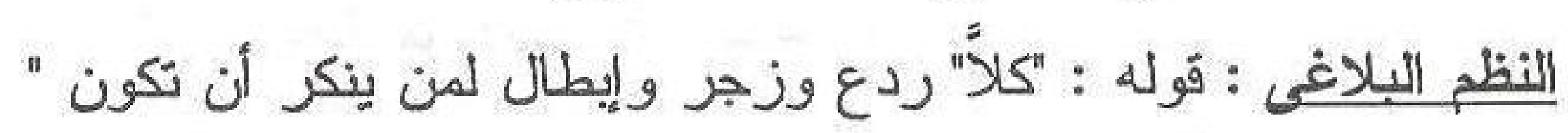

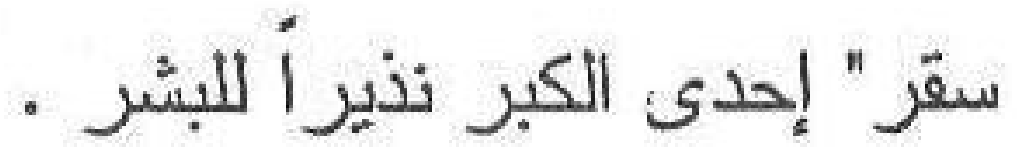

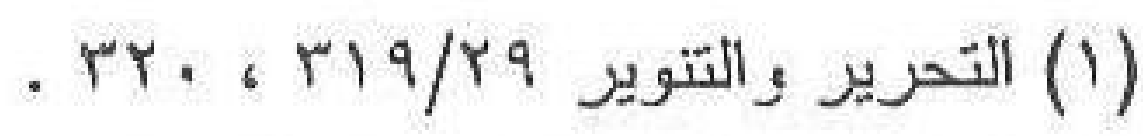

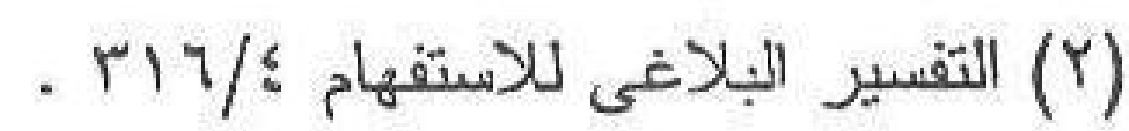

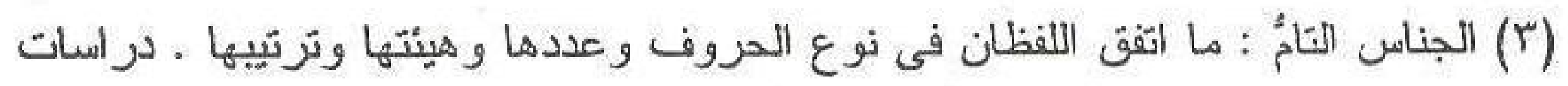

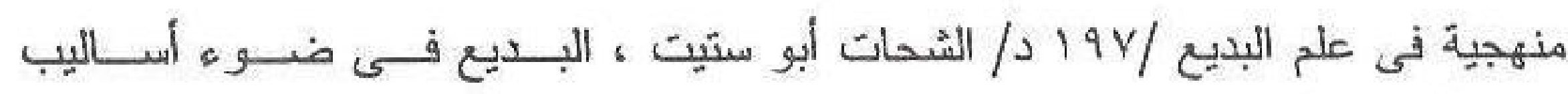

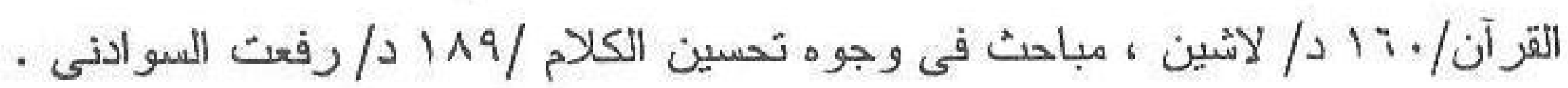




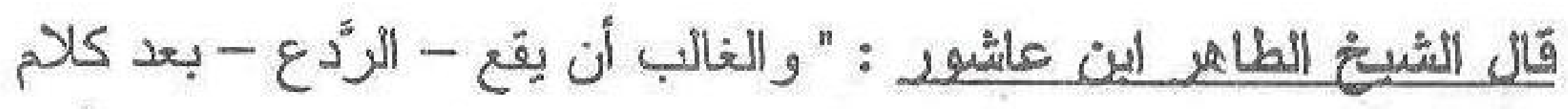
منكلم و احدأ ومن منكلم وسامع منل قوله تعالىى: - قال أصساب موسى إنّا

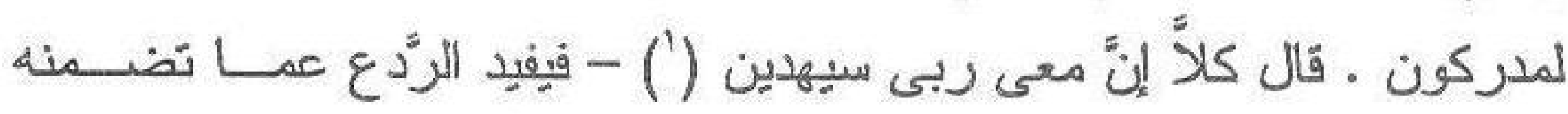

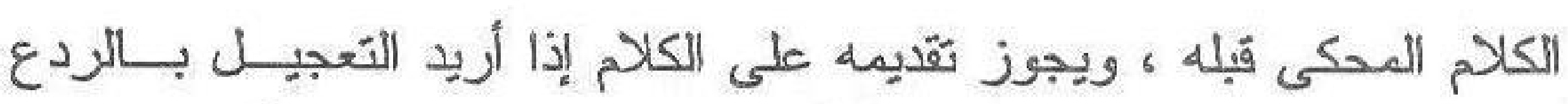
و التشويق إلى سماع ما بتده ، و هو هنا محتنل لأن يكون إيطالاً لما قبله هن قولهم : - ماذا أر اد الله بهذا مثلاً - فيكون ما بينها اعتر الضاً ، فيكون قوله:

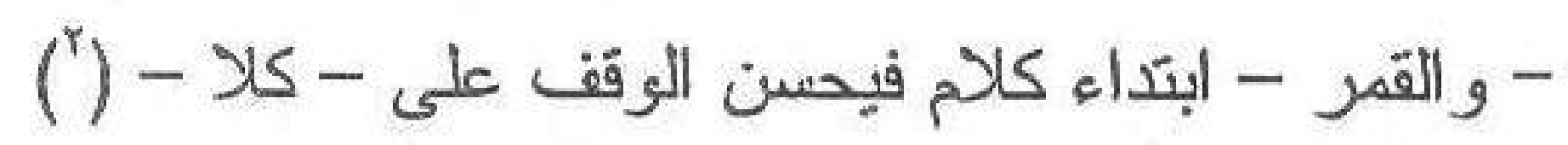

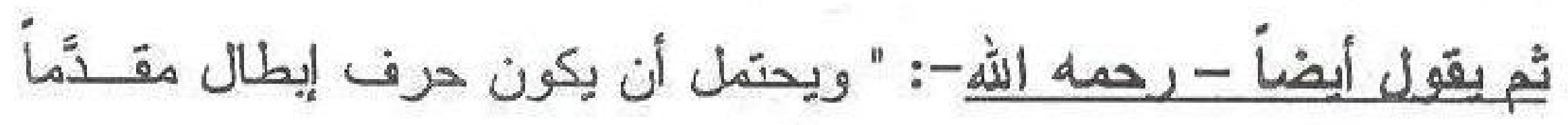
على الكلام الذى بعده من قوله : - نذير أ للبشر - تقديم لإبطال ما يجئ بعده

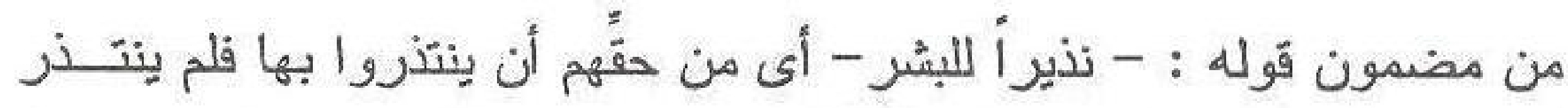

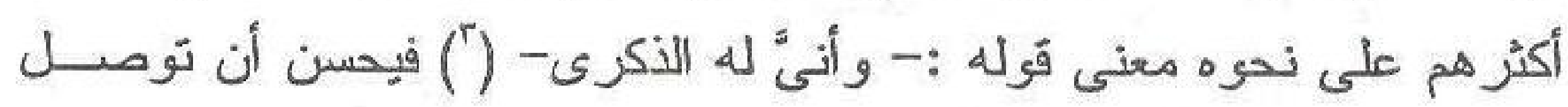

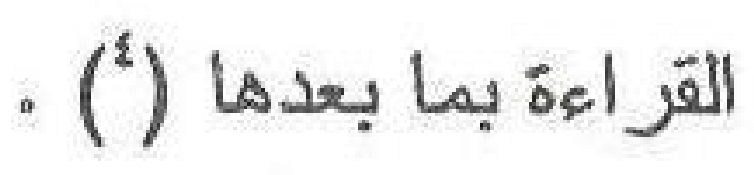

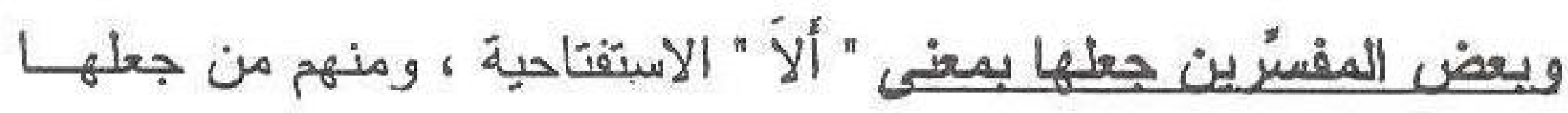

بمعنى - حقًا - فمن جعلها بمعنى "الألا " بفتح الهمزة ونخفيف الـلام كانــت

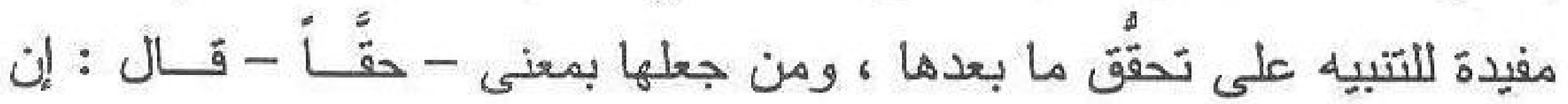

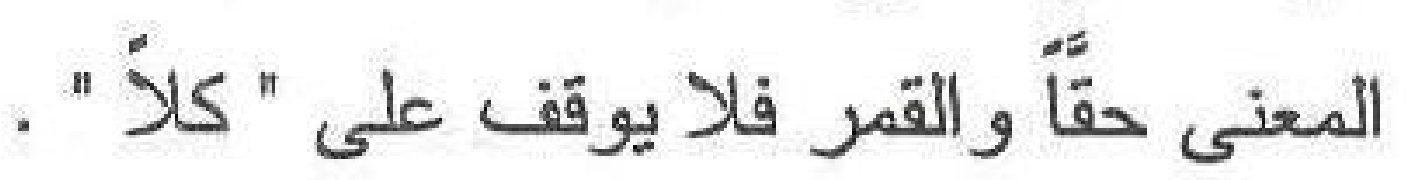

(1) الشعراء/ 11،74

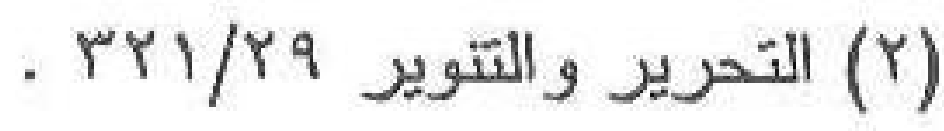

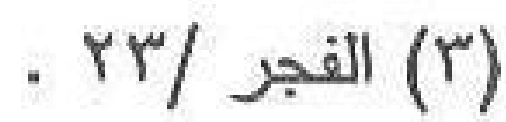

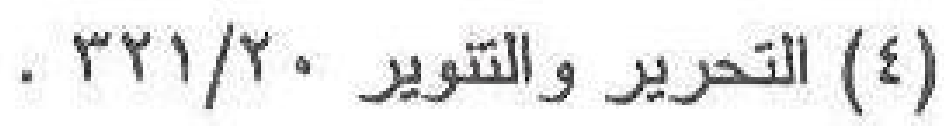




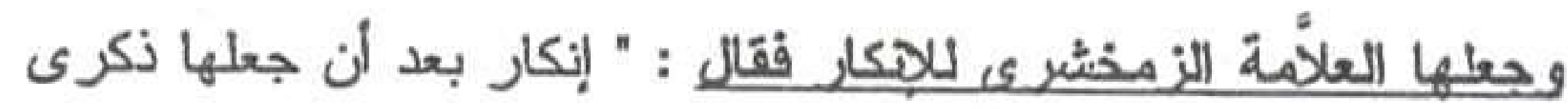

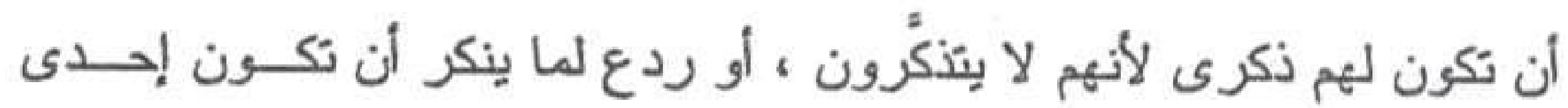

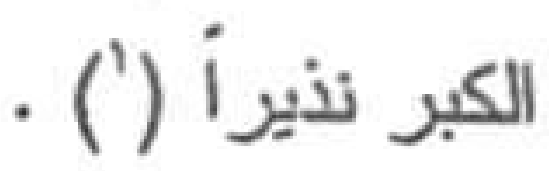

وقد تعقًب أبو حيًّان كلام الزمخشرى : منكراً عليه ما ذهــب إليـهـ -

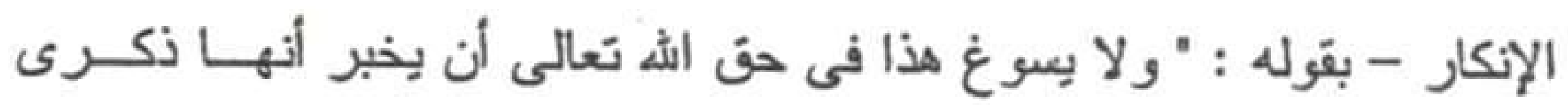

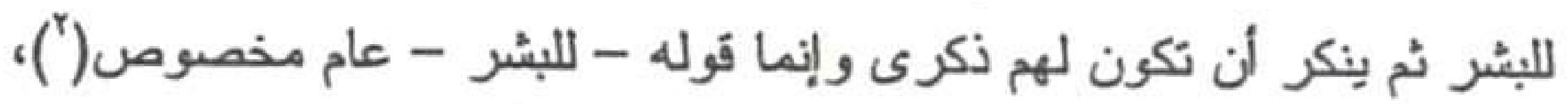

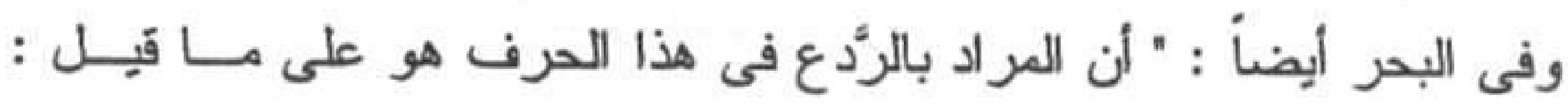

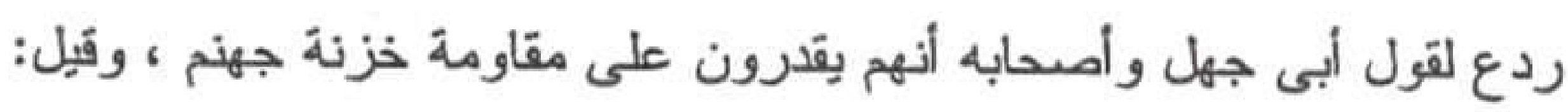

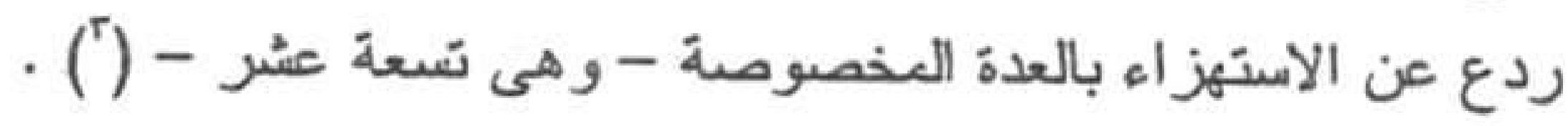

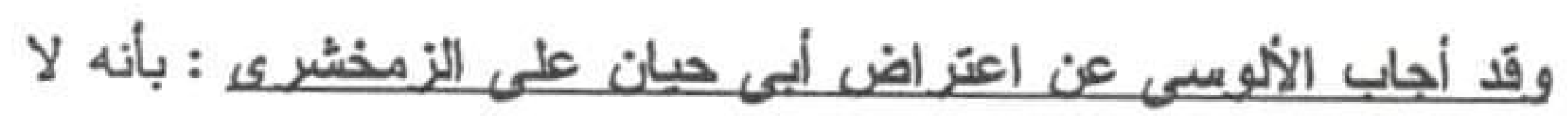

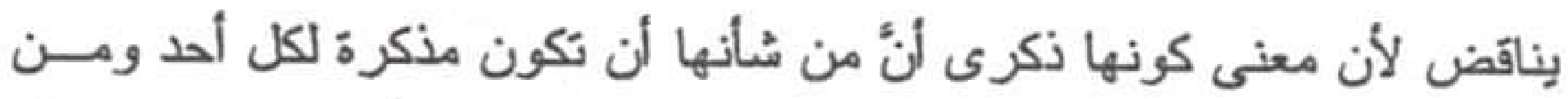

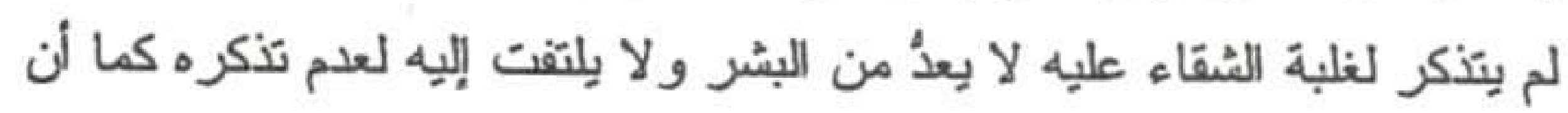

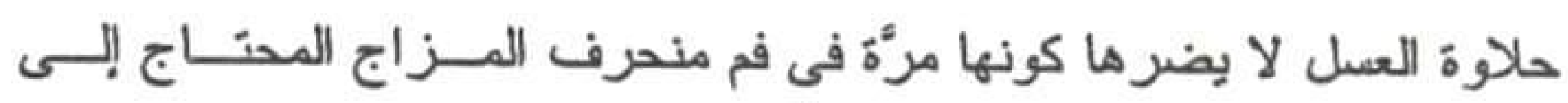

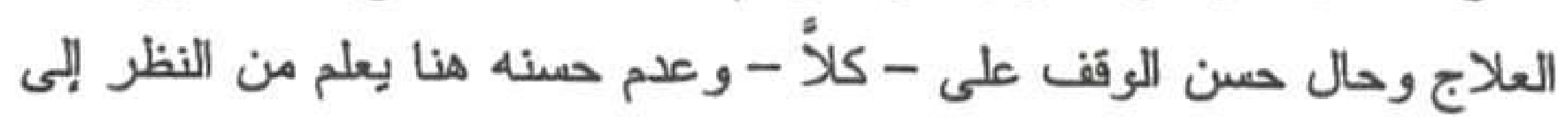

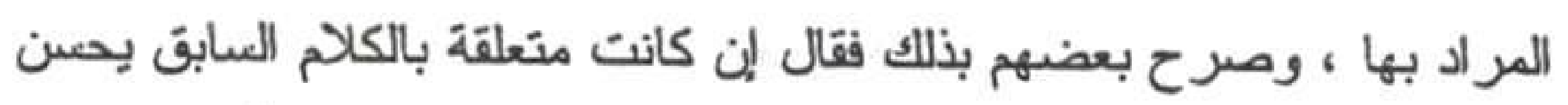

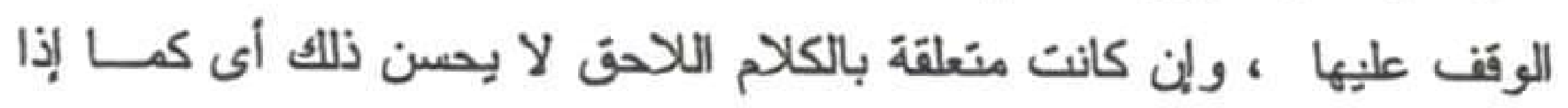

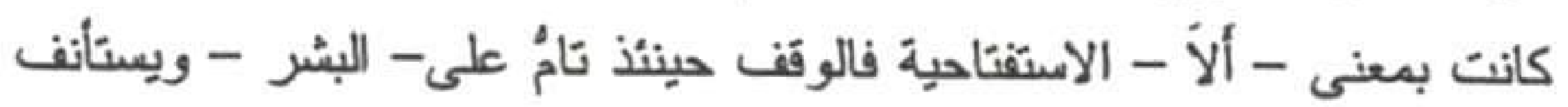

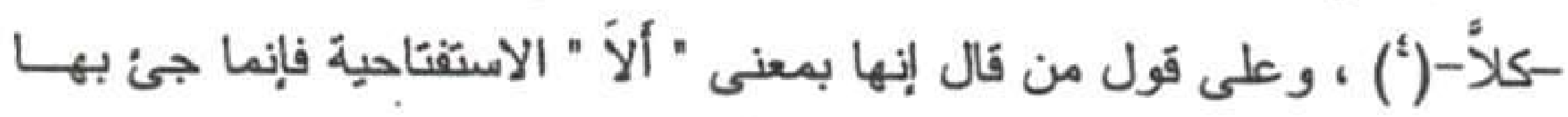

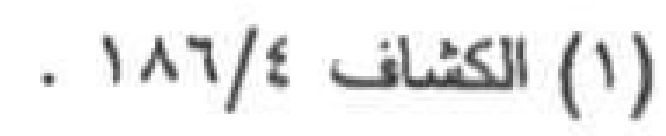

$$
\begin{aligned}
& \text { (Y) البحر المحيط rv/A (Y) }
\end{aligned}
$$

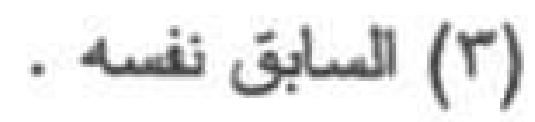

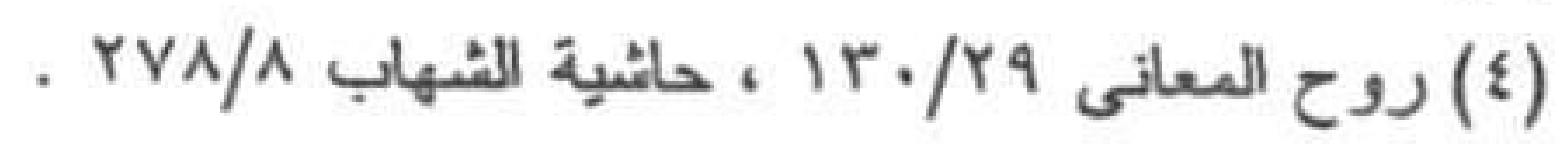


تعظيمأ للمقسم عليه ، وحينذذ فالوقف على ما قبلها "للبشر " ويبدأ الكلام بقرله " كلاً " و على قول من قال إنها بمعنى " حقاً " فقد جئ بها تأكيدأ للقسم بعده .

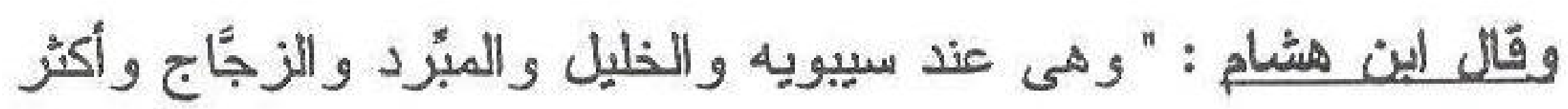
البصريين حرف معناه الردع والزجر لا معنى لها عندمم إلا ذلك حتى إنهم

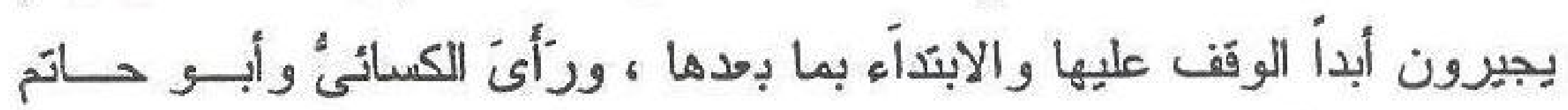

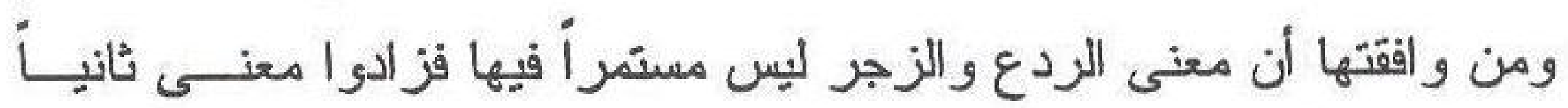

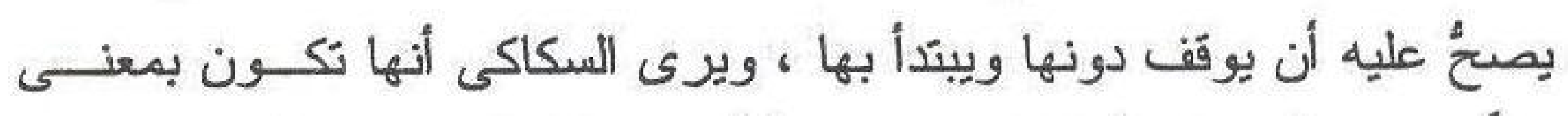

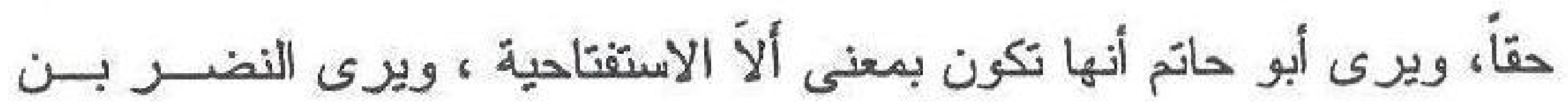
شميل و الفرًاء ومن و افقهما أنها تكون حرف جواب بعنزلة إى ونتم وحملوا عليه قوله : "كلاً و القعر " فقالو امعناه إى و القمر ، وهى جواب للتصديق(').

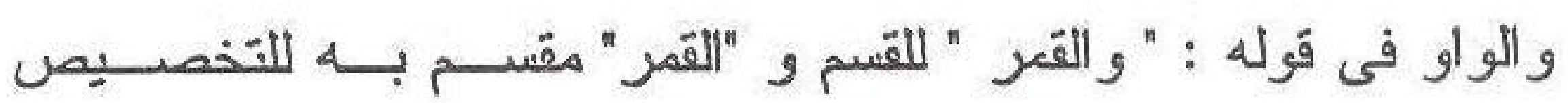

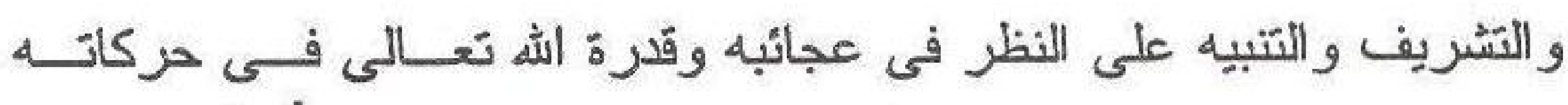

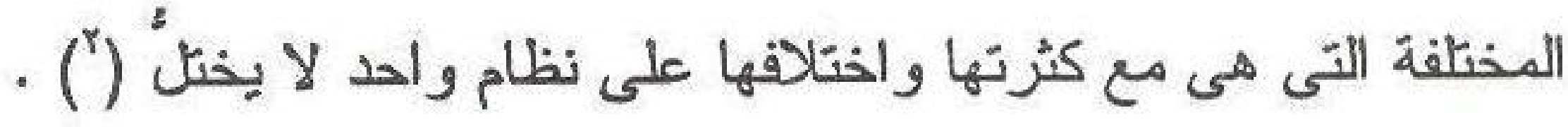
وقد أقسم القرآن بالقعر لما فيه من الآيات العجيبة في طلوعه وغروبه ومسيره وزيادته ونقصانه ومنازله التى ينزل فيها. " وهذا القسم يجوز أن يكون تذييلا لما قبله مؤكدّاً لما أفادته - كـلاًٌ من الإنكار والإبطال لمقالتهم فى شأن عدة خزنة النار ، فتكون جملة - إنها لإحدى الكبر - تعليلا للإنكار الذى أفادته - كلا - ويكىن ضـــمير إنهــا عائدأ إلىى - سقر - أى هى جديرة بأن ينذكُ بها فلذلك كان من لم يبذكرٌ بها

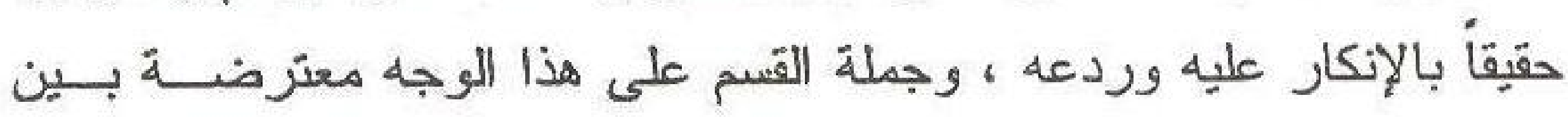




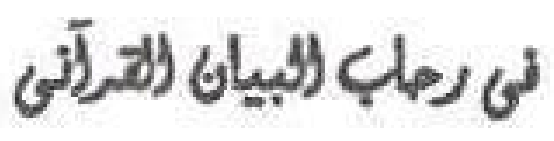

\section{$[1 Y Y]$}

الجملة وتعليلها ، ويحتمل أن يكون القسم صدرأ للكلام اللذى بعده ، وجملة -

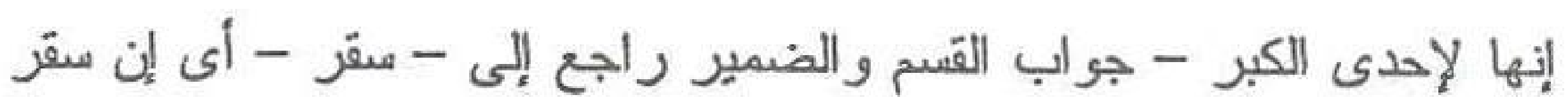

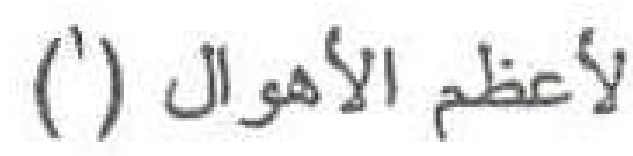

و المر اد من الآية الردع والزجر أى ليرتدع أولئك المستهزئون بالوحى التى

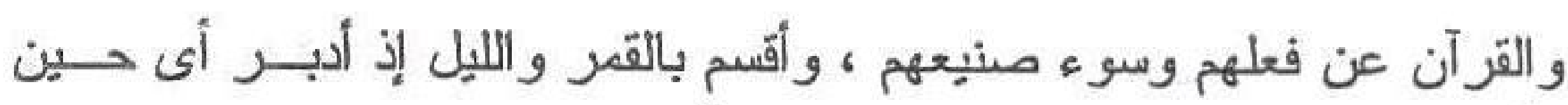

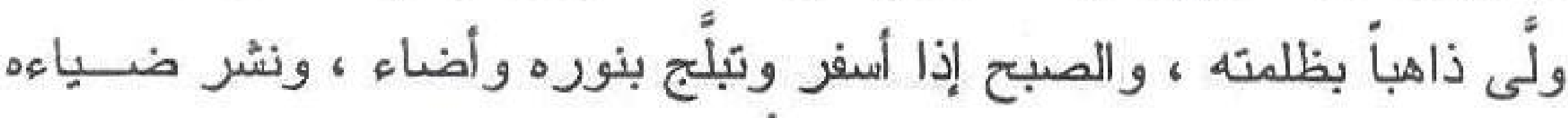

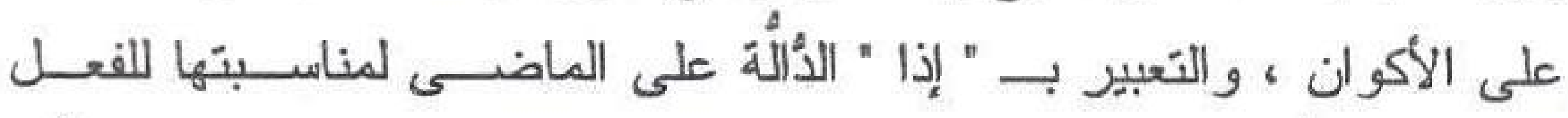

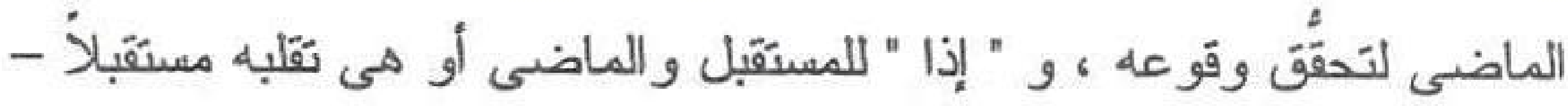

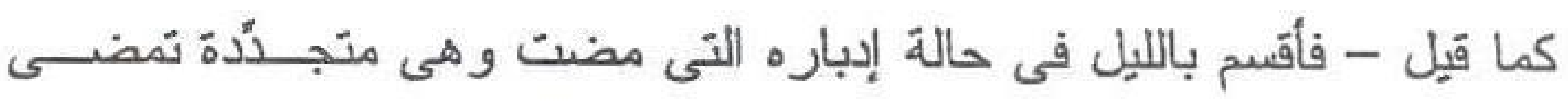

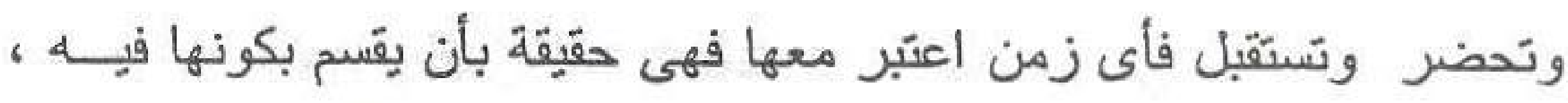

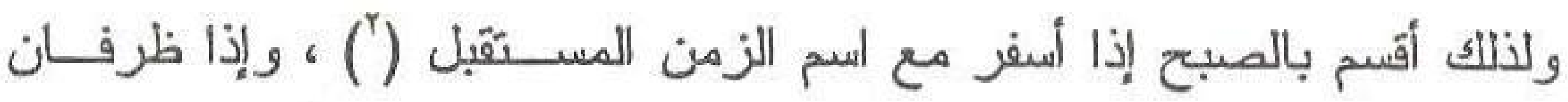

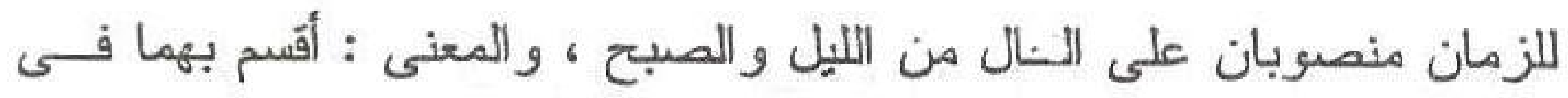
هذه الحالة العجيبة الدالة على النظام المحكم المشابه لمحو الله ظلمات الكفــر

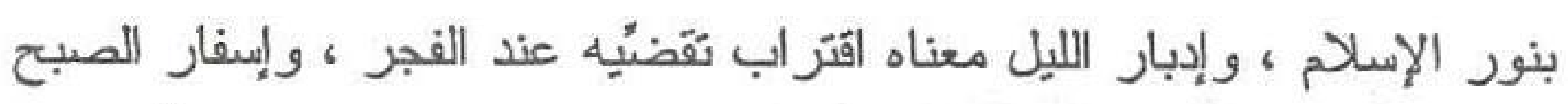

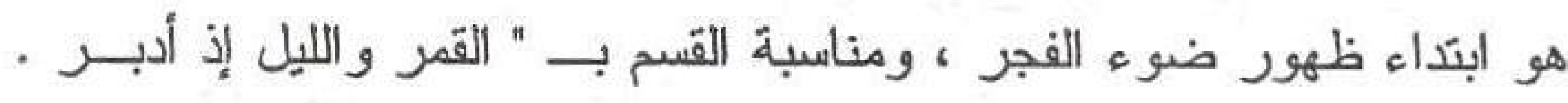

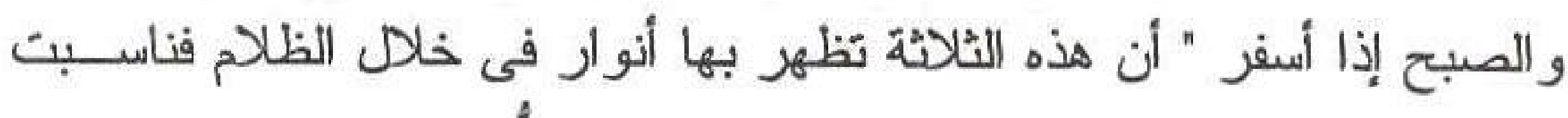

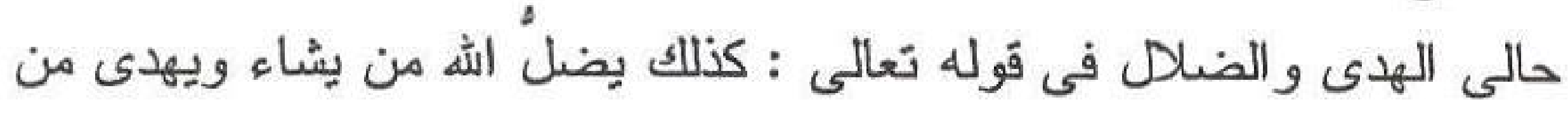

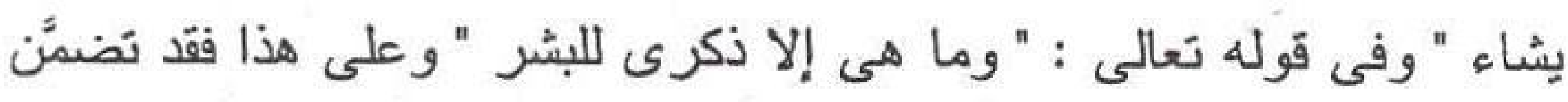

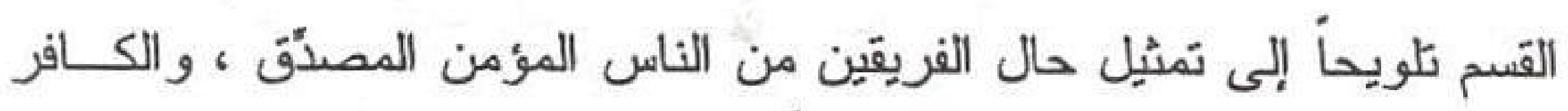

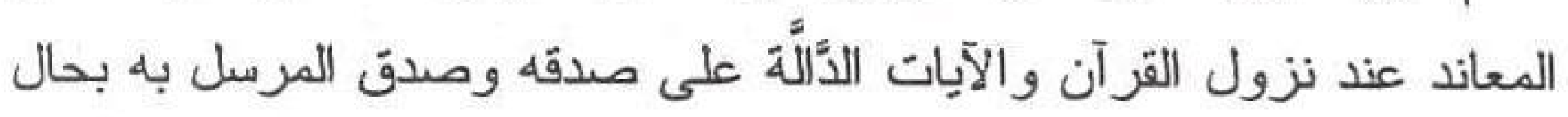




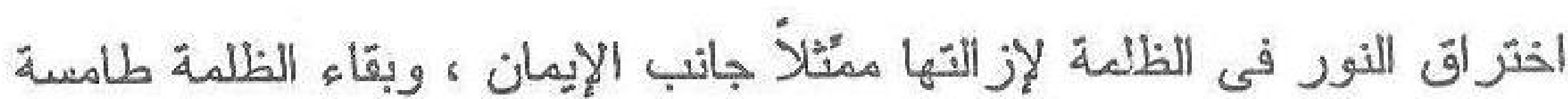

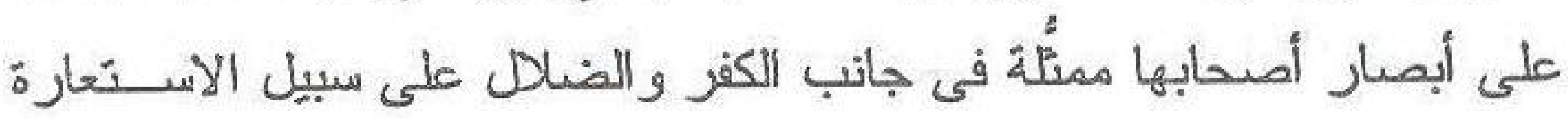

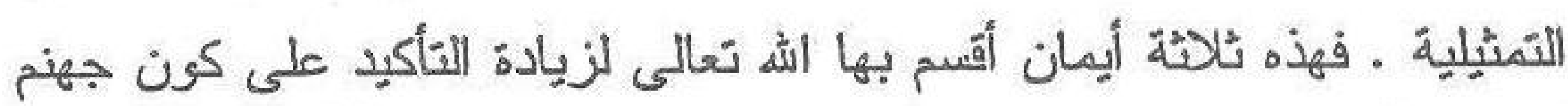

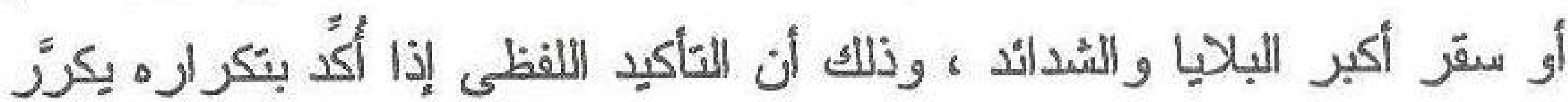

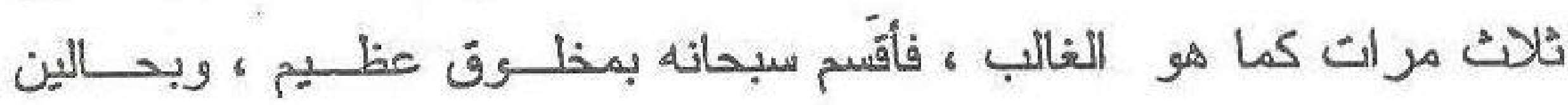
عظيمين : " والليل إذ أدبر و الصبح إذا أسفر " للالالة على آثار قدرته نعالى.

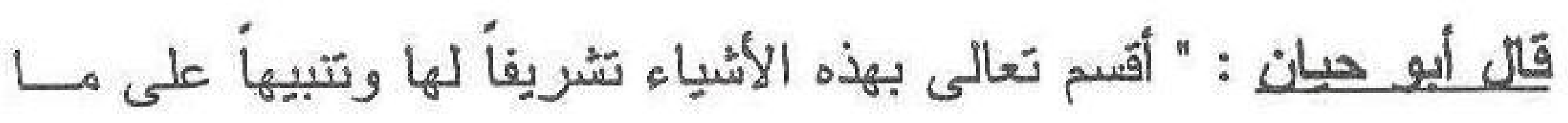
يظهر بها ، وقيها من عجائب الله وقدرته وقو ام الوجود بإيجادها ، أقسم على

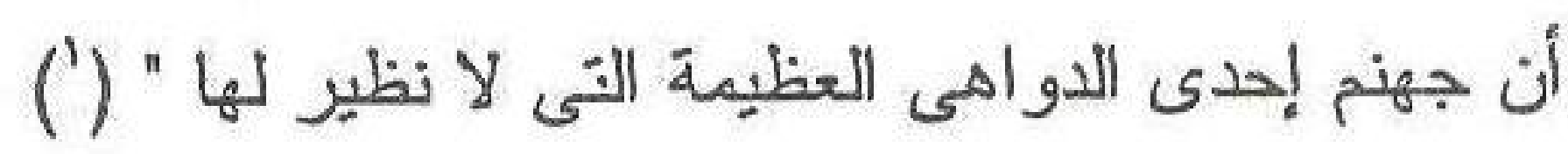

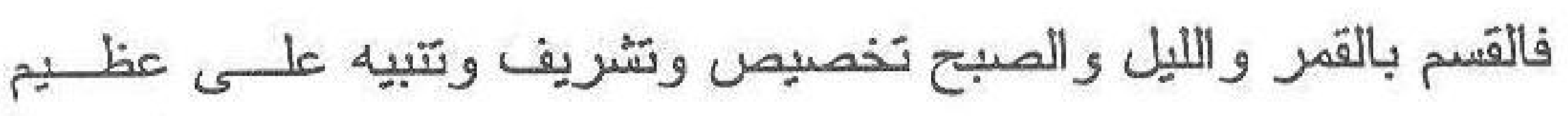

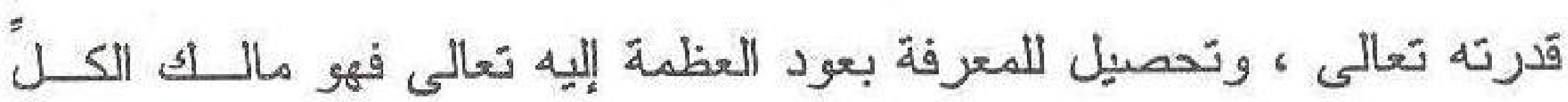
وقو ام الوجود به ونور السماءو الأرض لا إله إلا هو العزيز القهًّار.

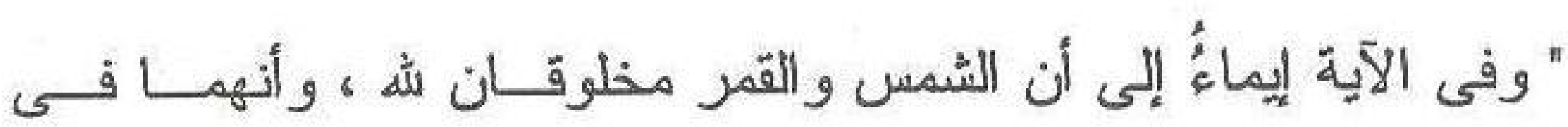

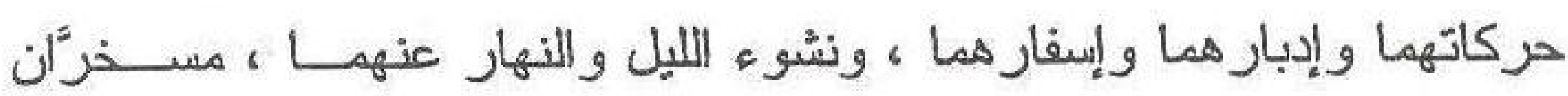

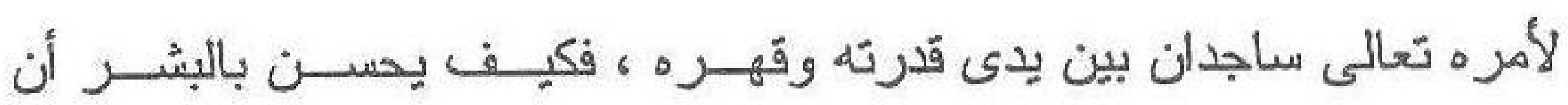

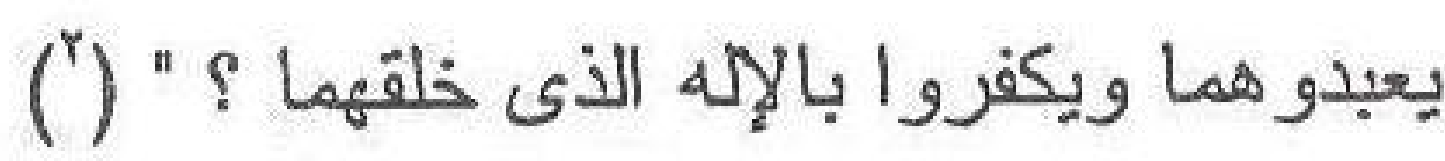

وفى قوله : " و الليل إذا أدبر " إبتعارة مكنية شبه الليل بإنسان يسـولَّى وجهه ويذهب ثم حذف المشبه به ودل عليه بشئ من لو ازمه وهو الإدبار . وقرئ " دبّر " بالتُلاتى وهى قراءة ابن كثير وابن عامر و أبى عمـرو

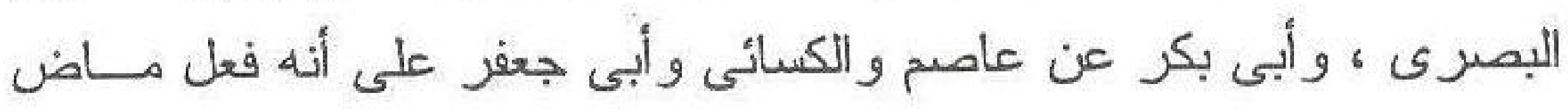




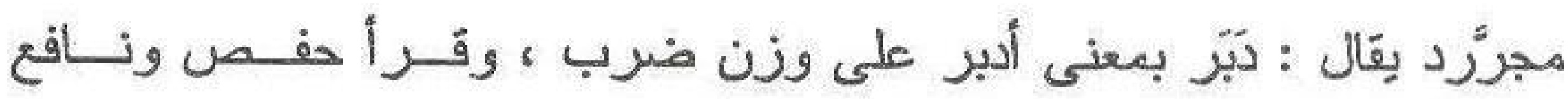

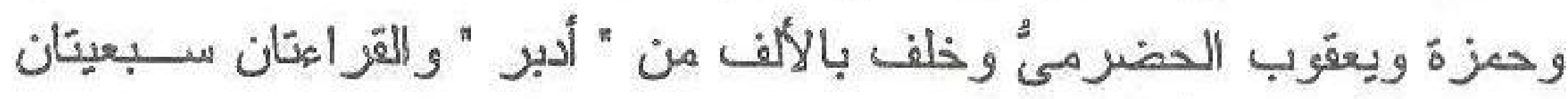

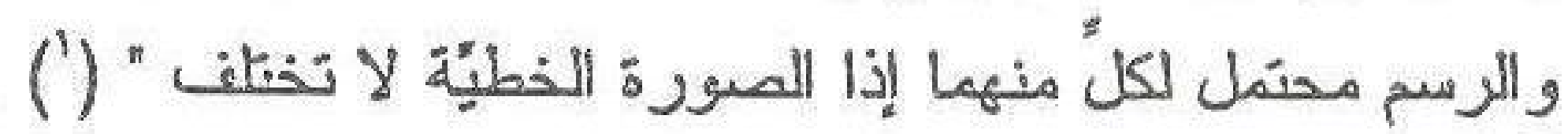

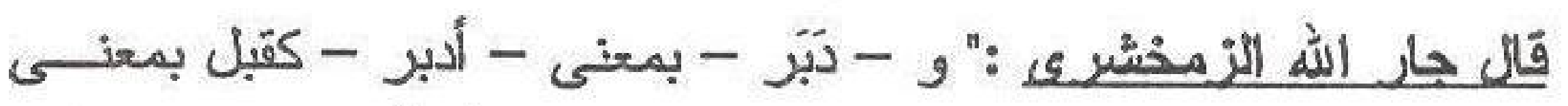

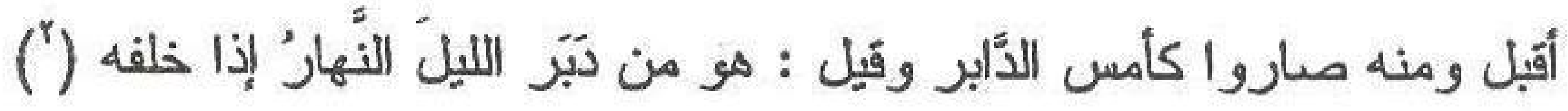

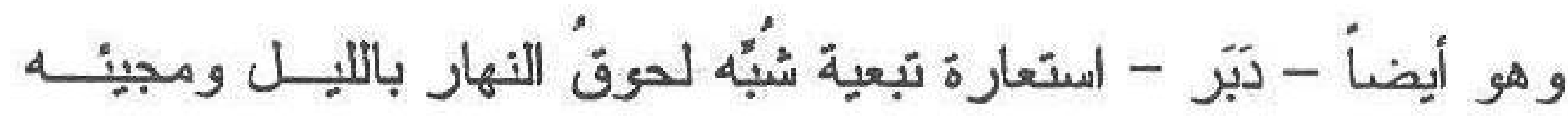

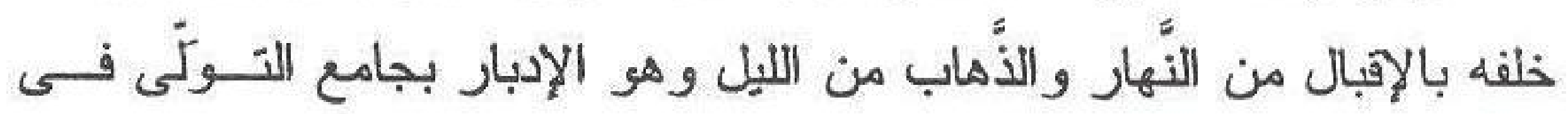

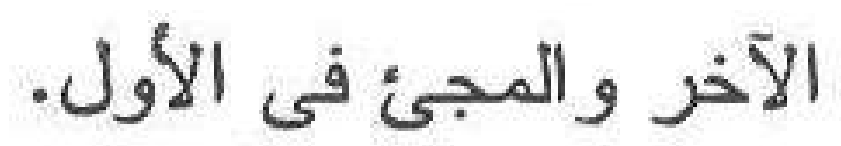

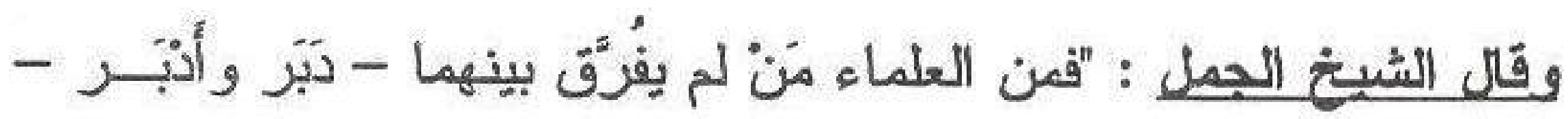
وأنهما بمعنى واحد - كما رأينا عند الزمخشرى وغيره - ومنهم من فـرَّق

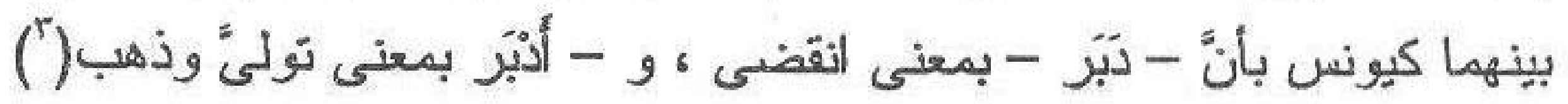

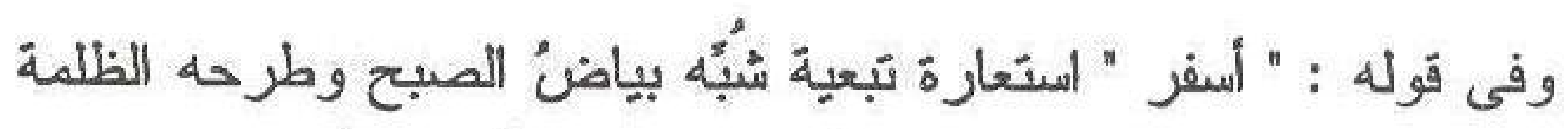
عن وجهه بالاسفر ار وهو ظهور شئ أبيض كان خافياً مسترّاً .

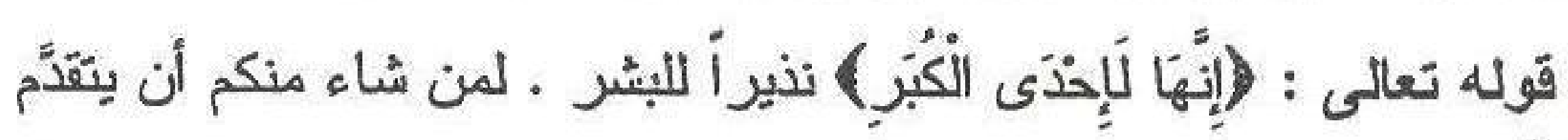

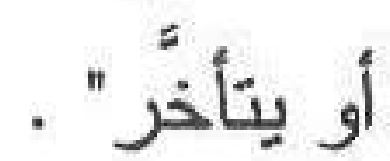

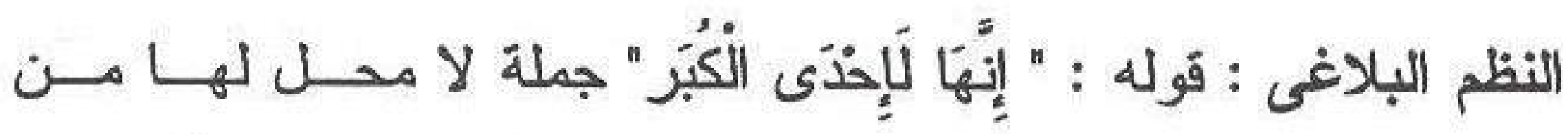

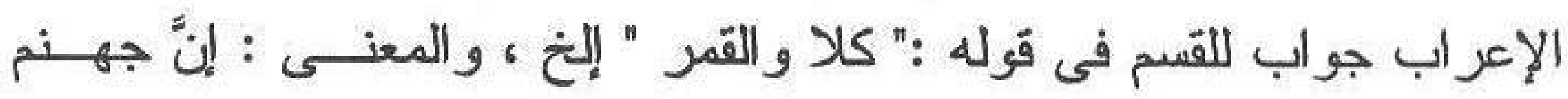

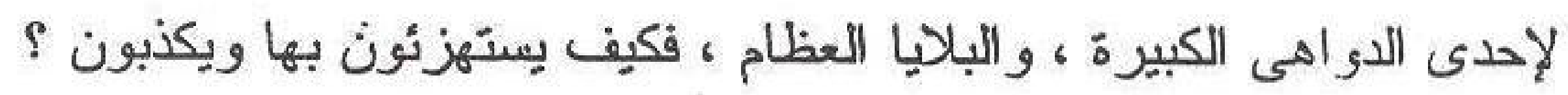




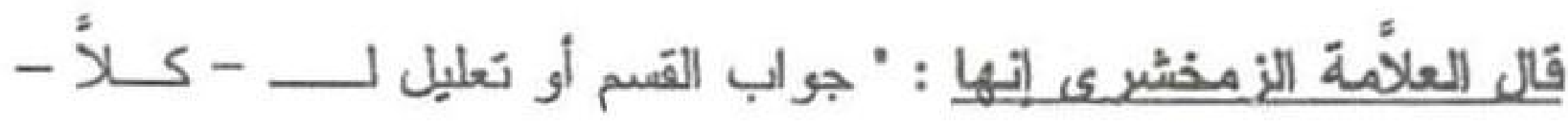
و القسم معترض للتوكيد ، و - الكبر - جمع الكبرى جعلت ألــف التأنيــث

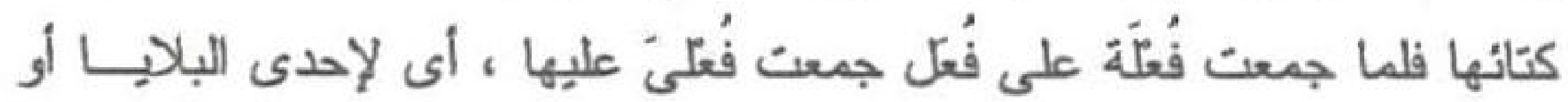
الدواهى الكبر ومعنى كونها إحداهن أنها من بينهن واحدة فى العظم لا نظيرة لها كما تقول هو أحد الرجال وهئ إحدى النساء (').

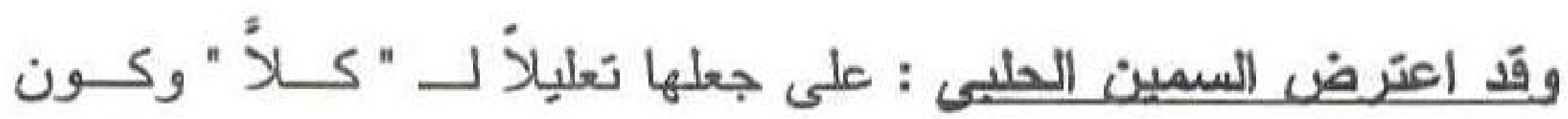

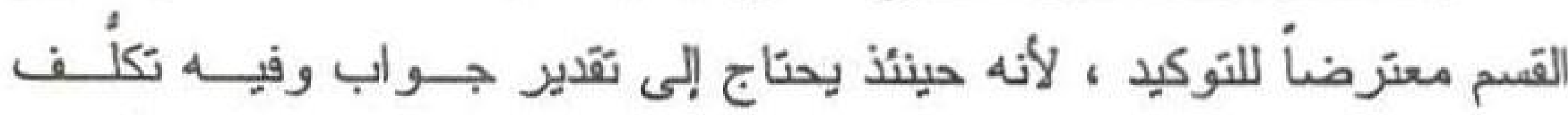

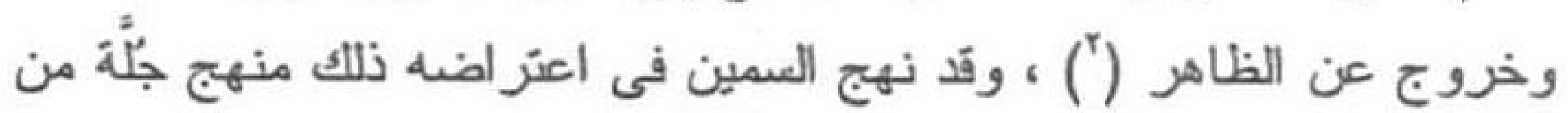

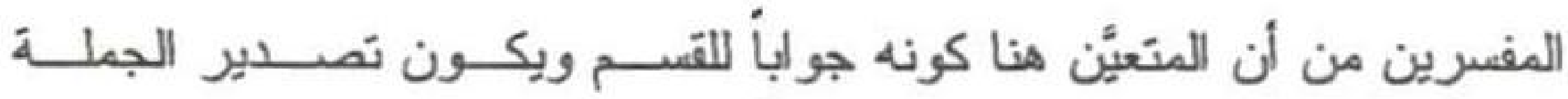

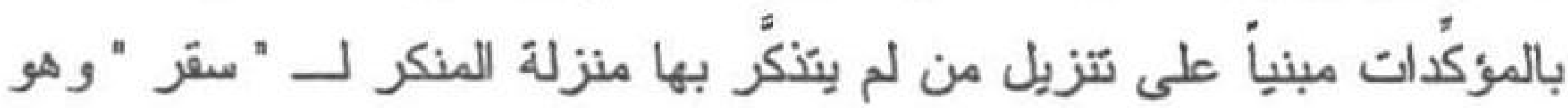

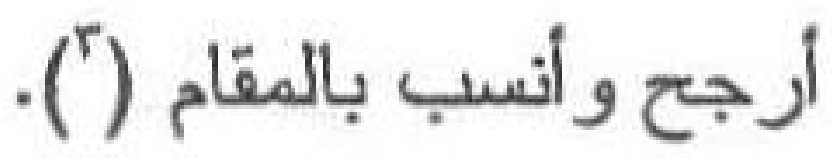

وقال المفسنرن : المراد من " الكُبز " دركات جهنم وهى سبع : جهنم، ولظى والحطمة وسعير وسقر و الجحيم و الهاوية ، فعلى هذا معنى كون سقر

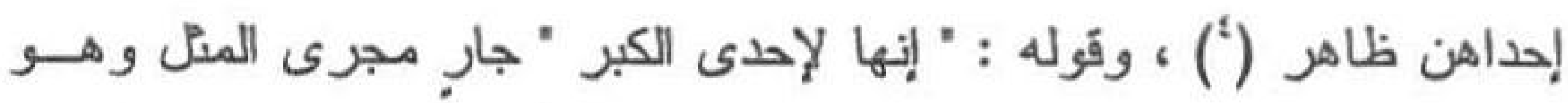

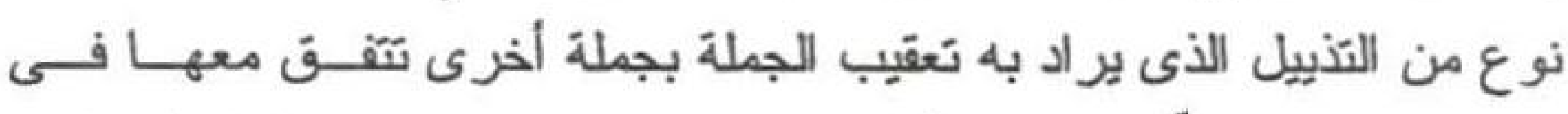

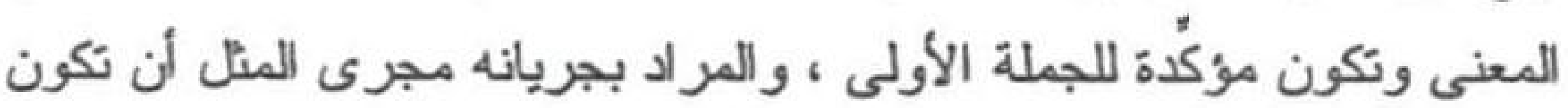

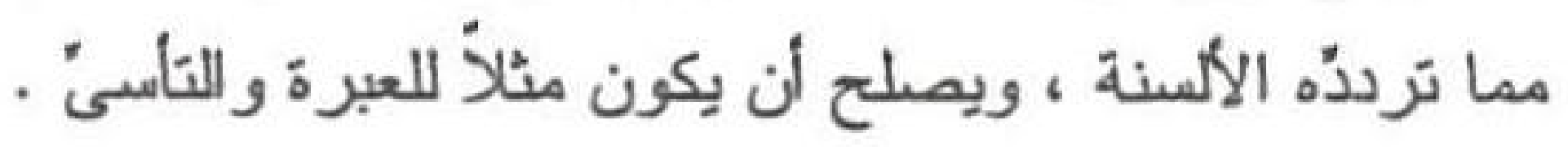

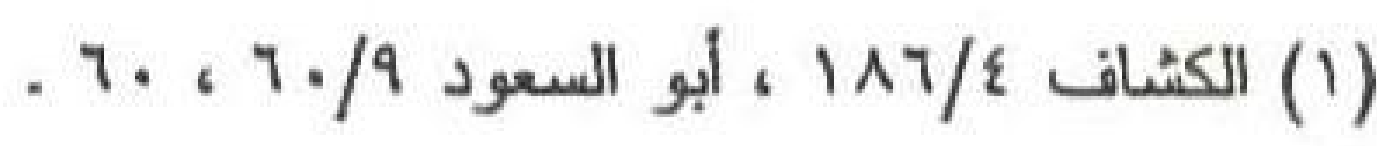

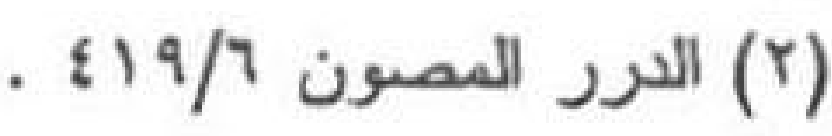

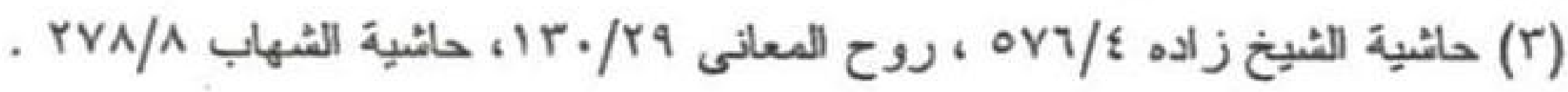

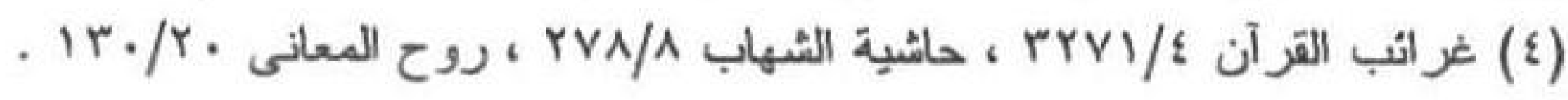




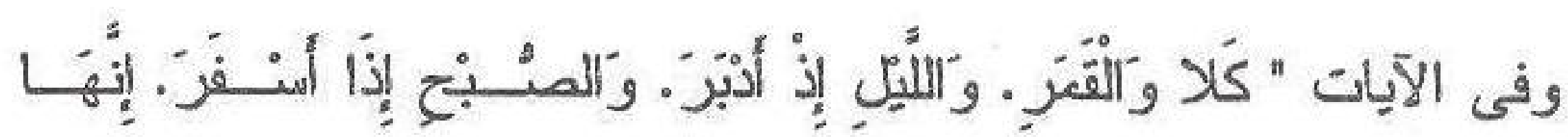

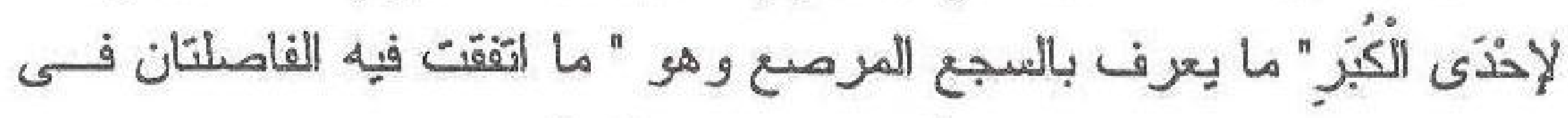

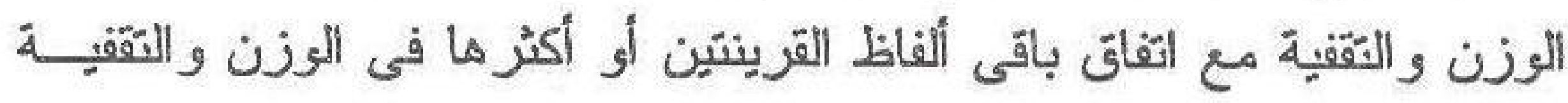
(') كذلك وهو إذا سلم من التكلف و التوالى والاسنكراه كان حسناً كما يقول أبـى

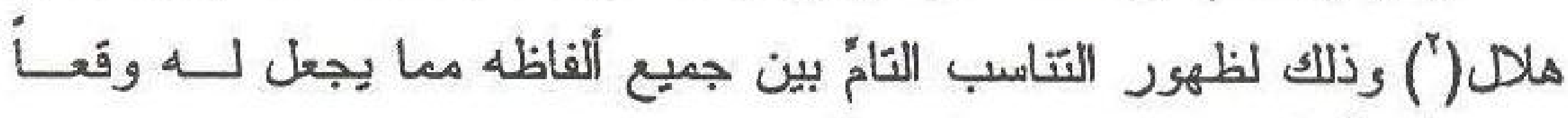

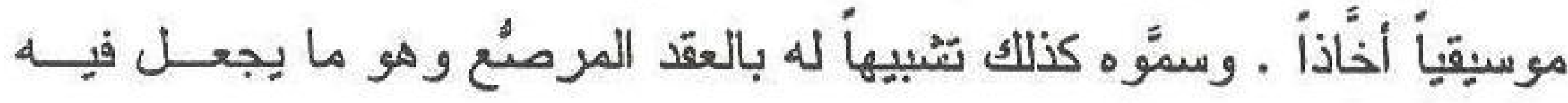

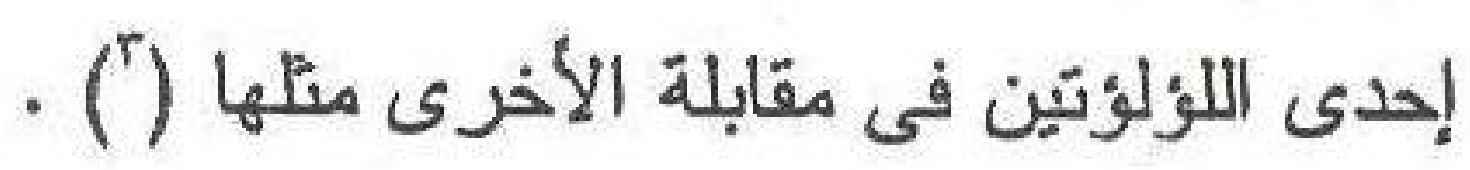

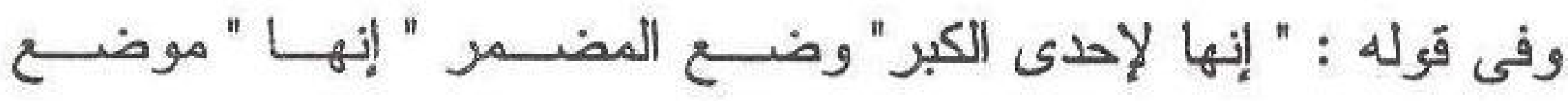

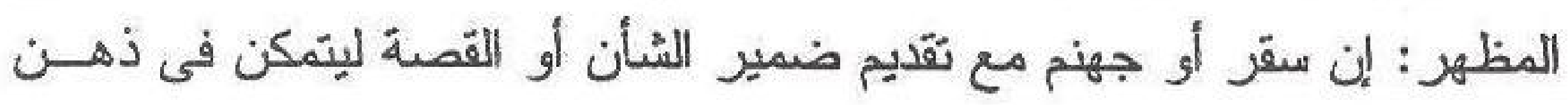

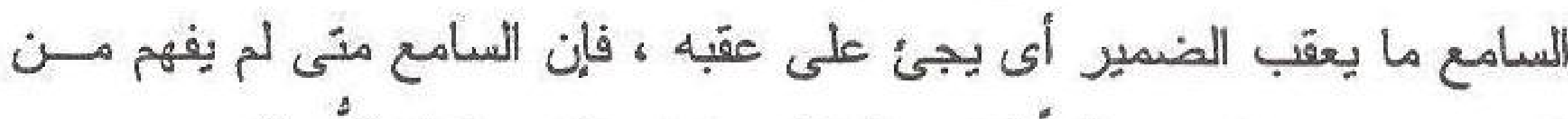

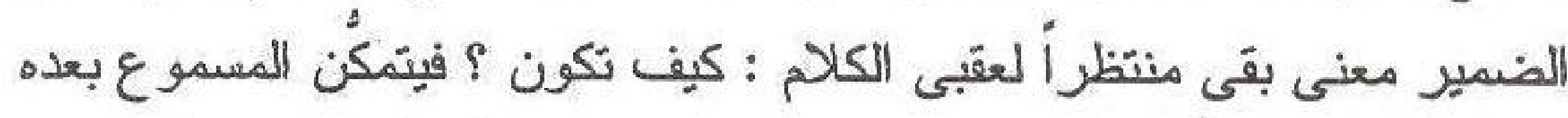

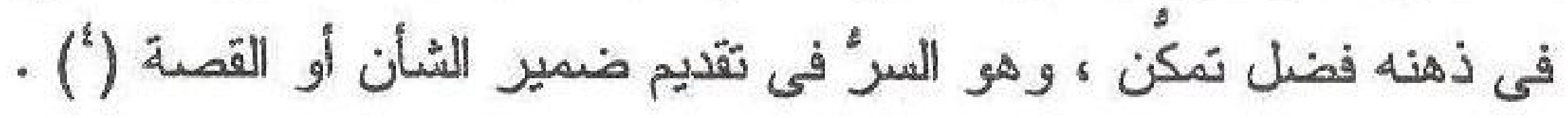

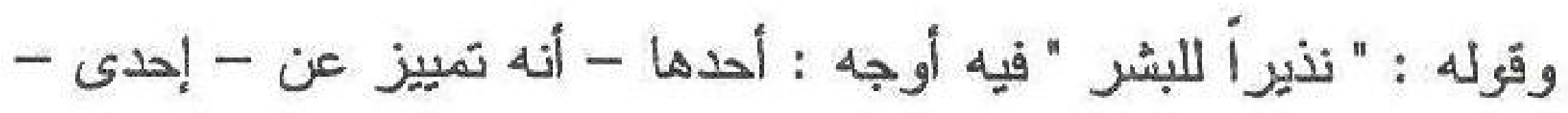

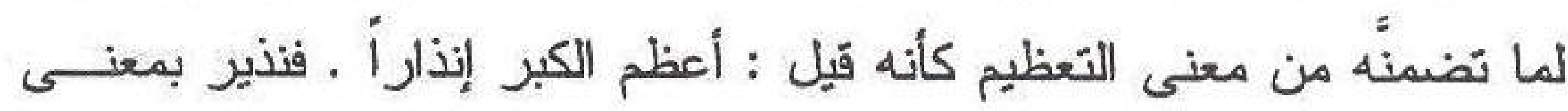

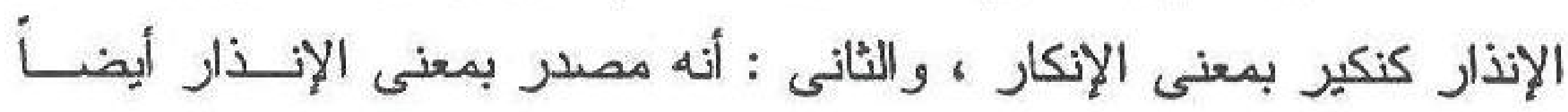

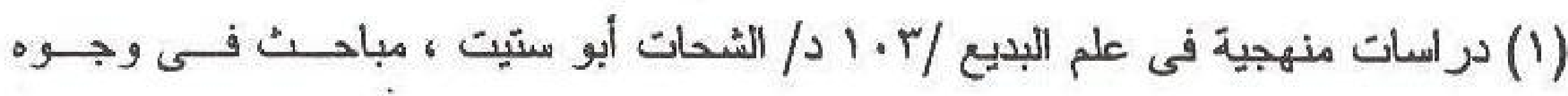

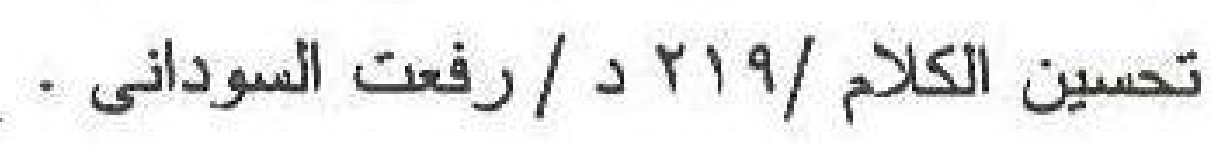

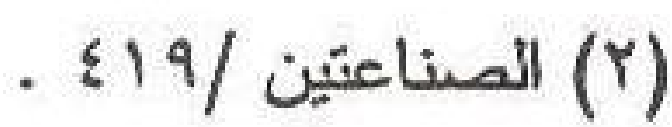

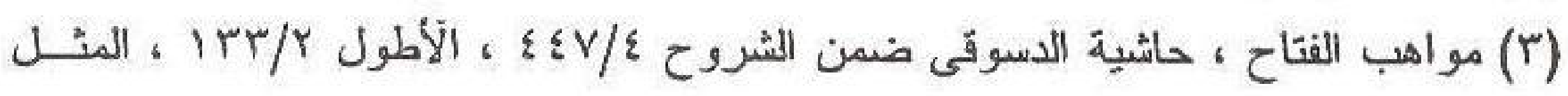

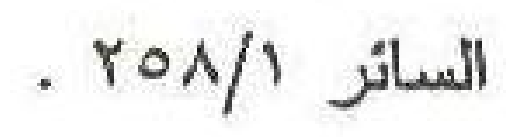

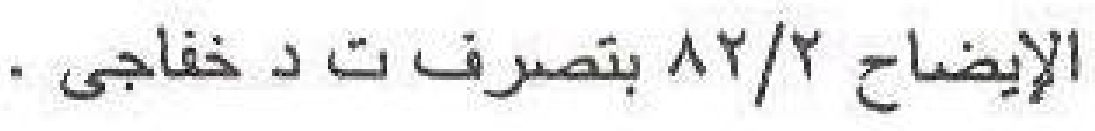


منصوب بفعل مقدَّر ، الثالث : أنه فعيل بمعنى مفعل وهو حال من الضمير ف - إنها - ، الر ابع : أنه حال هن الضمير فى - إحدى - لما تضـــنت مـن

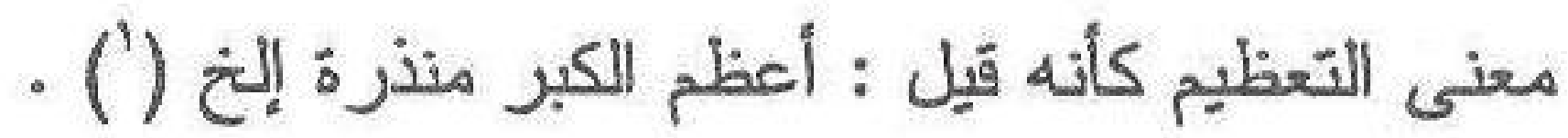

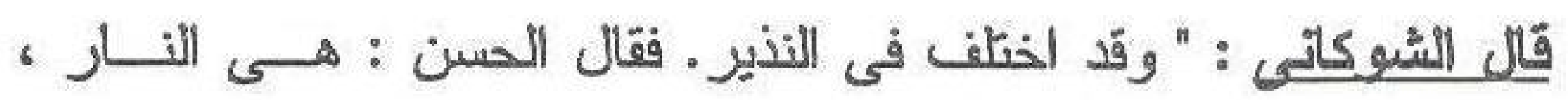

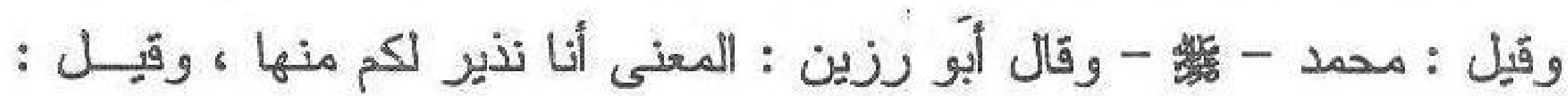

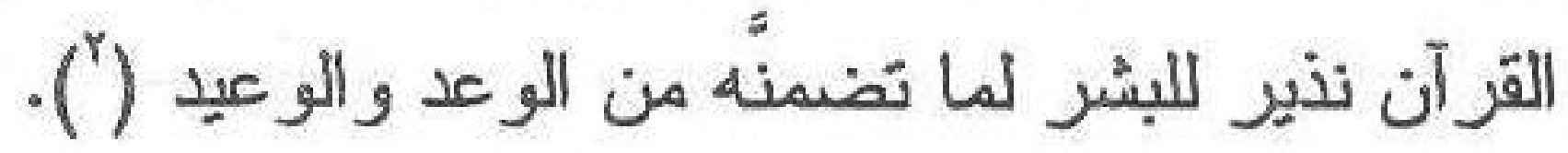
وكون " نذيراً" صفة للنار و المعنى : أن النار نذير للبشــر ورــذا قــان

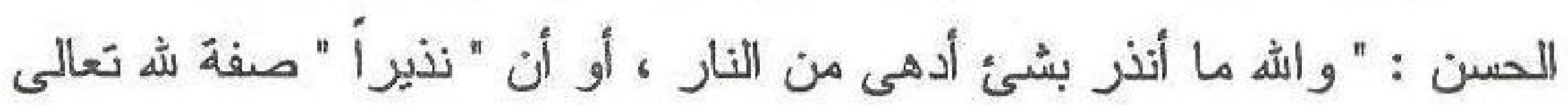

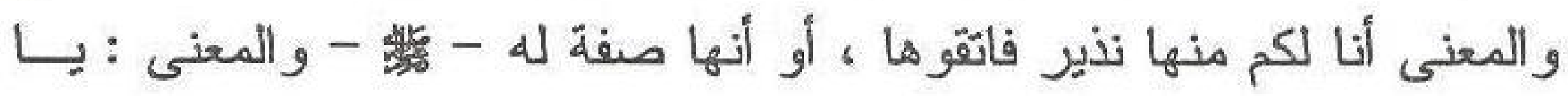
أيها المدثر قم نذيراً للبشر فأنذر - هكذا قال الخازن - (") و اللام فى " للبشر " مؤسسيّة لتقوية العامل ، و هذا إخبار منه تعالى عن جهنم في كونها " نذير أ للبشر " فهى إنذار للخلق ليتقوا ربيَهم .

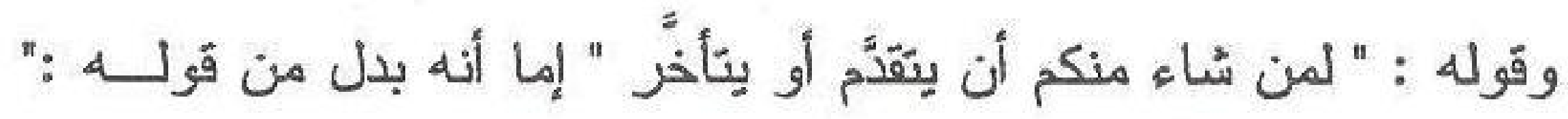

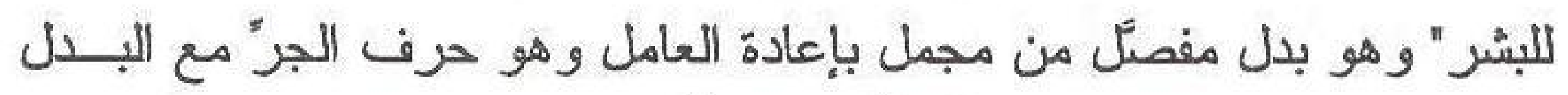

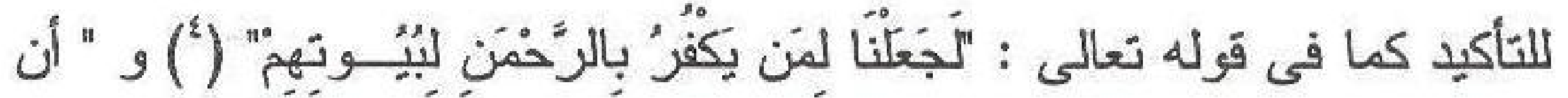
يبقدم " مفعول " شاء" و المراد : نذير أ لمن شاء الثقدُم أو الثأخير ، وقد ذيكـر مفعول " شاء" لوجود غرابة فيه ، إذ المعنى : إنها نذير لمن شاء أن يتّــدم إلى الإيمان والخير لينتز بها ، ولمن شاء أن يتأخر عن الإيمان و الخير فلا

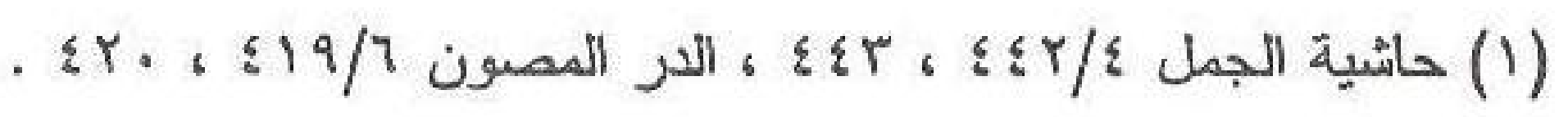

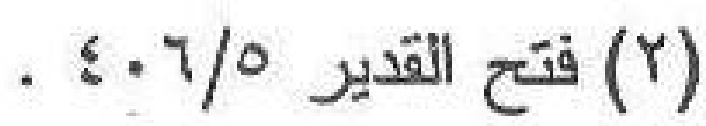

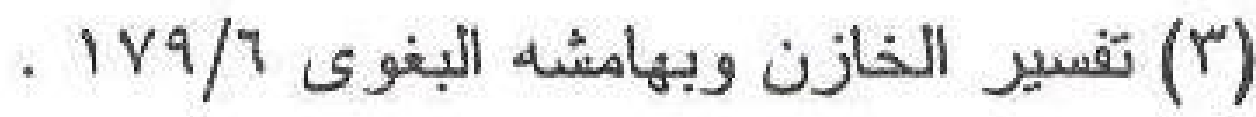

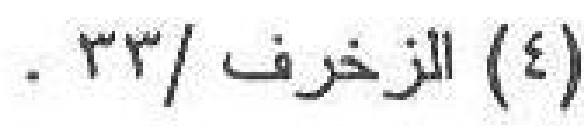




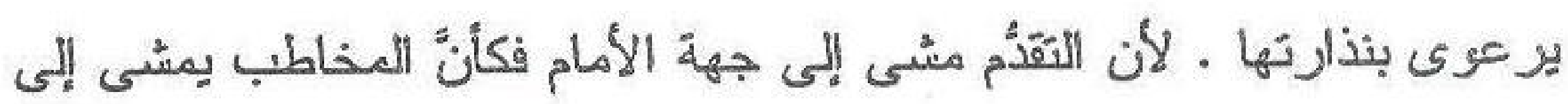

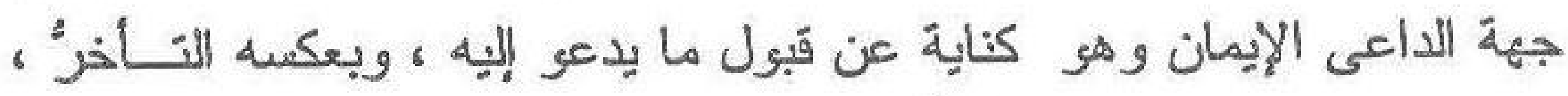

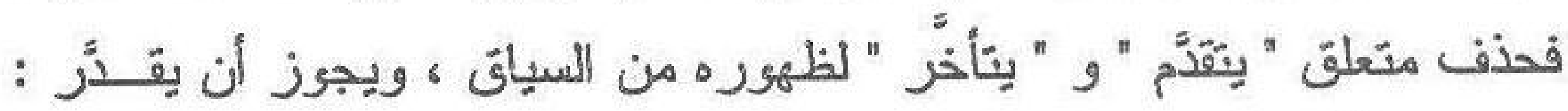

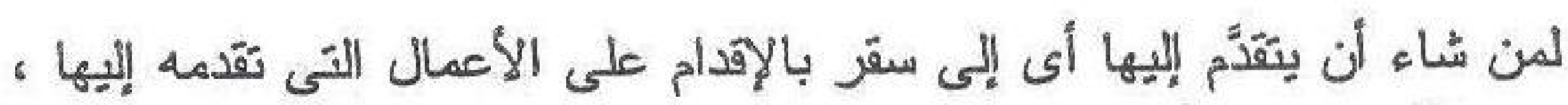

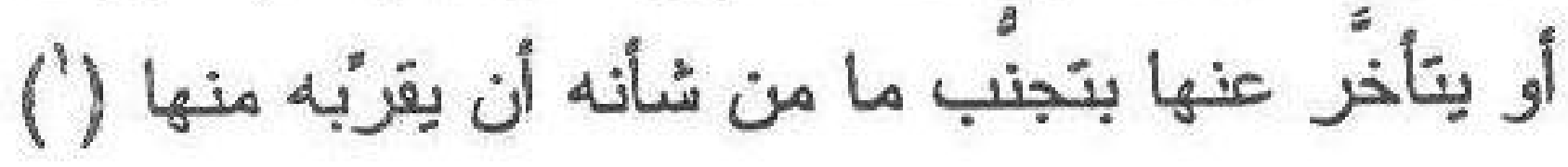

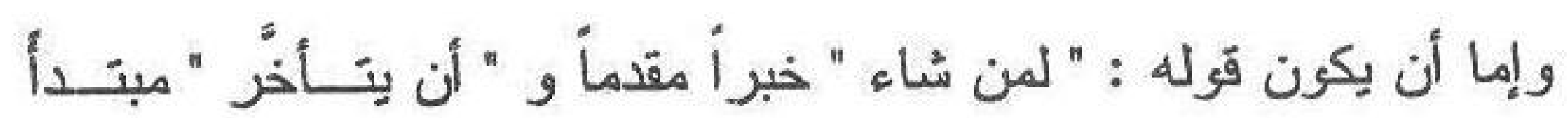

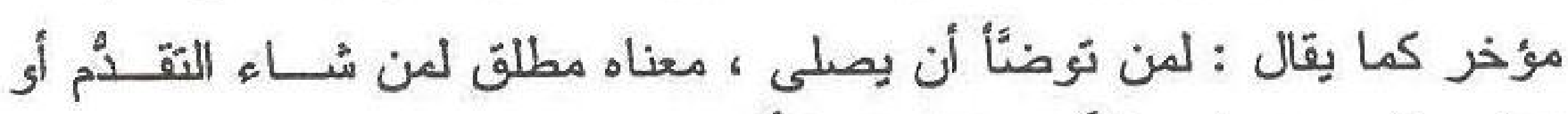

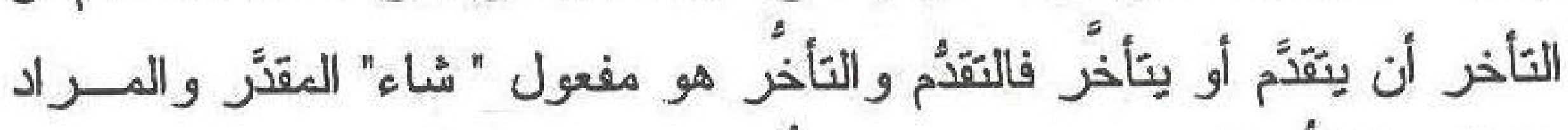

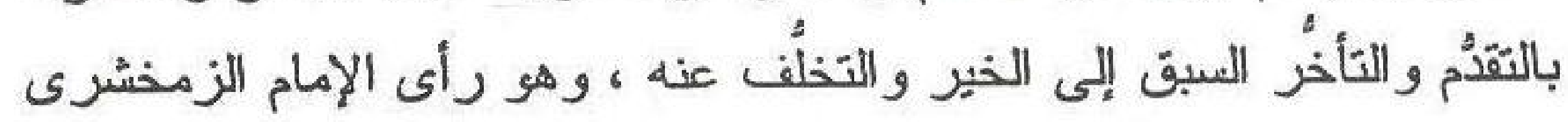

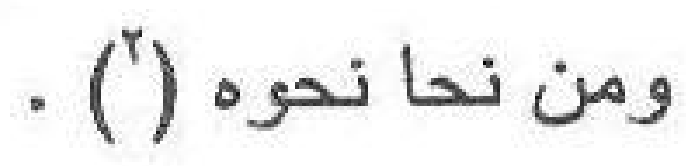

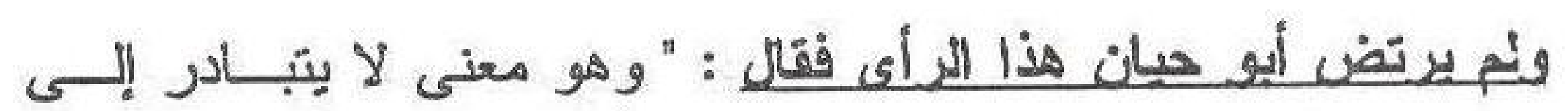

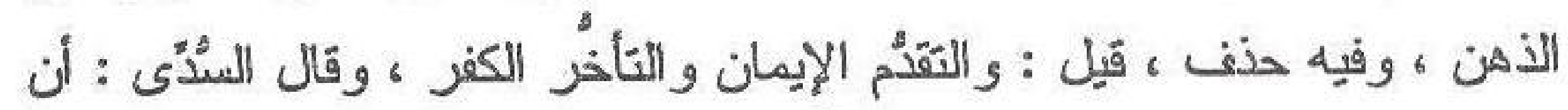

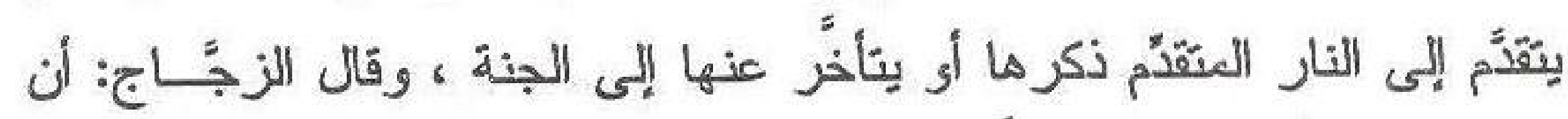

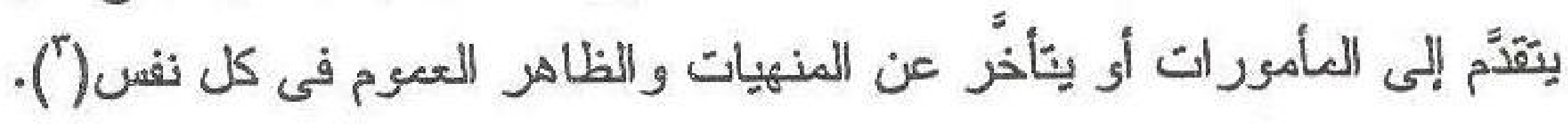
وفى ضنمير " منكم " التفات من الغيبة إلى الخطاب ـ إذ مقتضى الظاهر

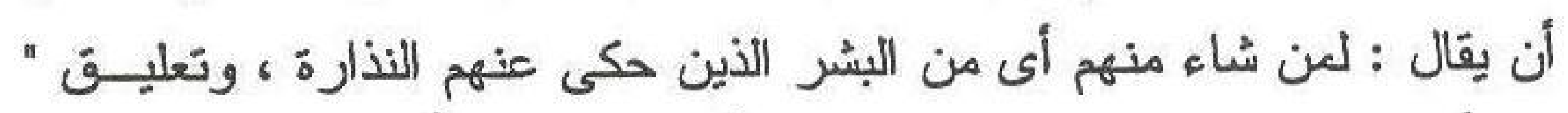

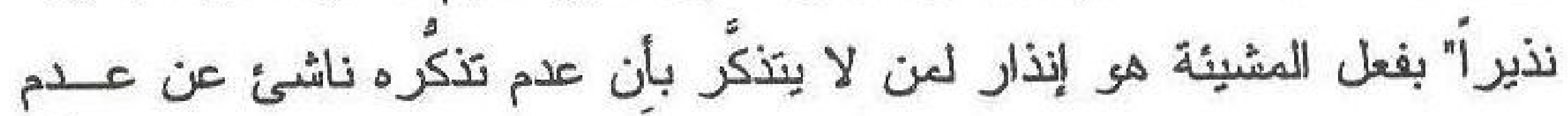

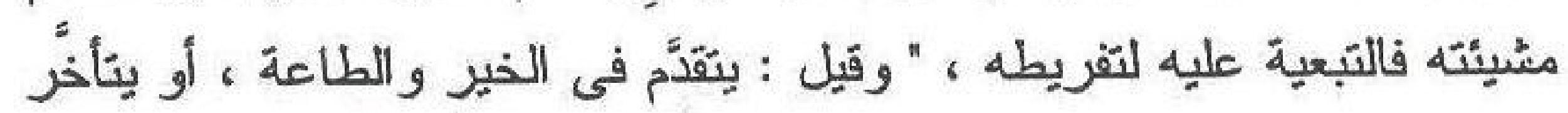

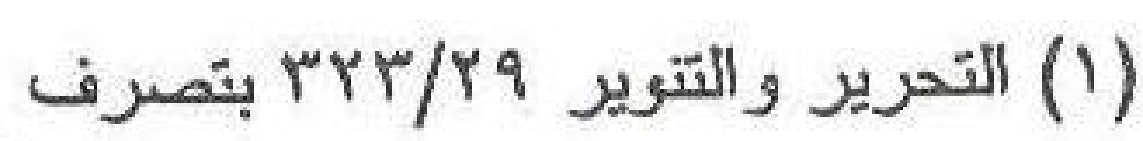

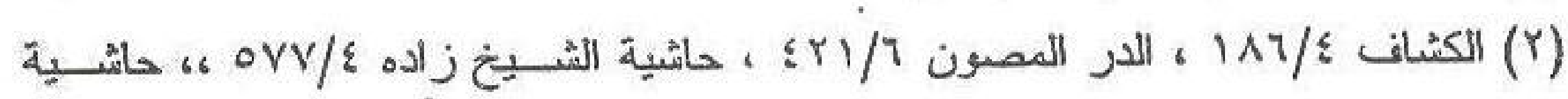

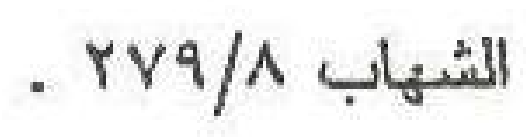
rVq/^ r r البحر المحيط 
عنهما فيقع فى الشُر" و المعصية ، و المعنى : أن الإنذار قد حصل لكل أحــــ ممن آمن أو كفر ، وقد تمستك بهذه الآيّة من يرى أن العبد غير مجبور على ولى ونى القعل و أنه متمكنّ من فعل نفسه ، و أجيب عنه بأن مشيئته تابعة لمشــيئة الله تعالى ، وقيل : إضافة المشيئة إلى المخاطبين على سبيل التهديد (') . قالر اللطبرى : قال ابن عباس : من شاء اتبع طلاعة اله ، ومسـن شـاء

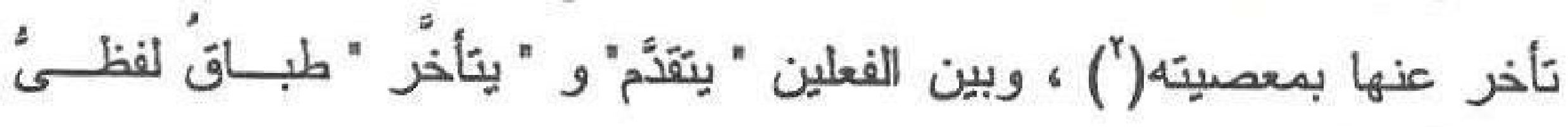

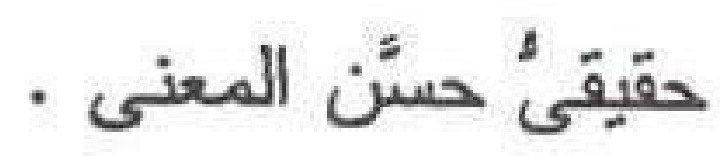



المبيهى (لارليع

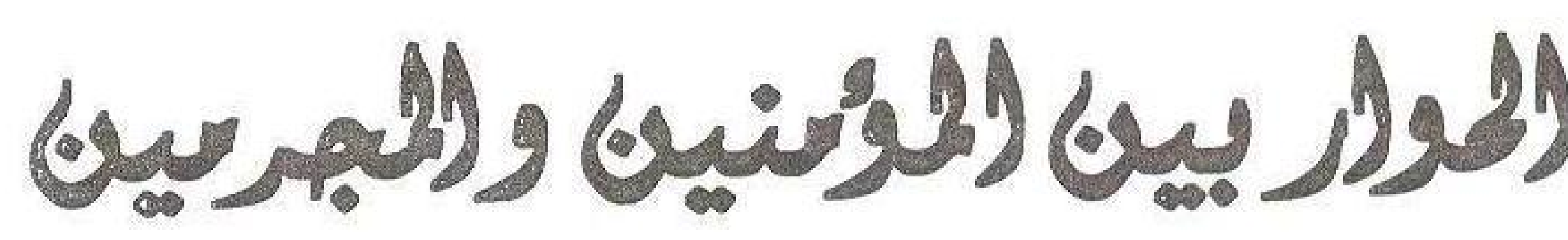

$$
\text { في الوأخرة }
$$




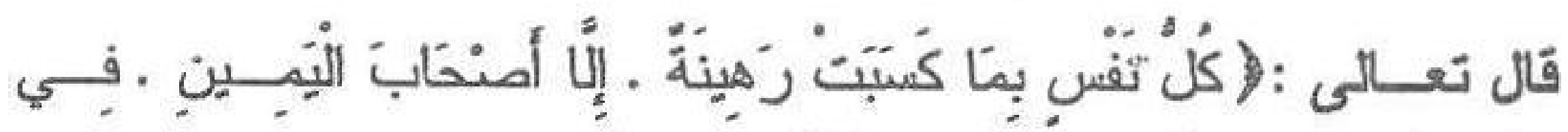

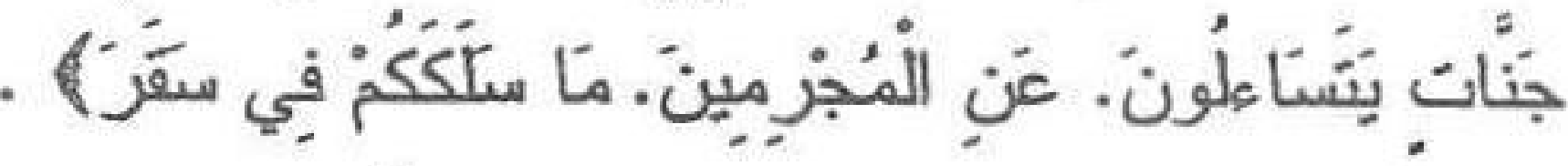

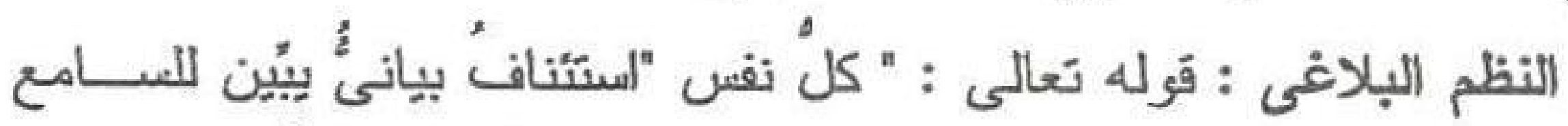

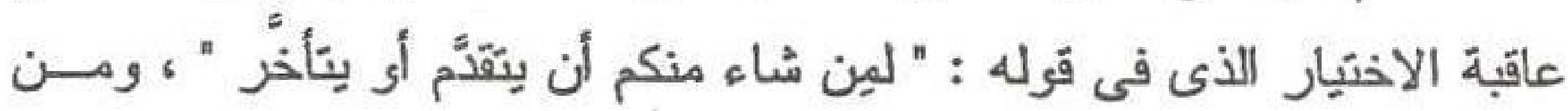

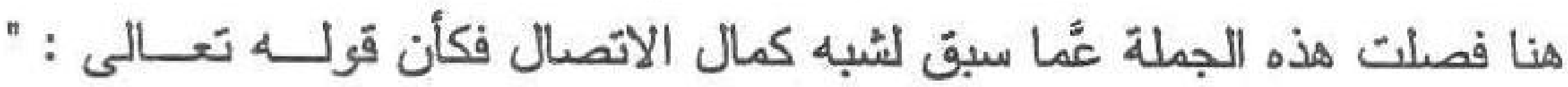

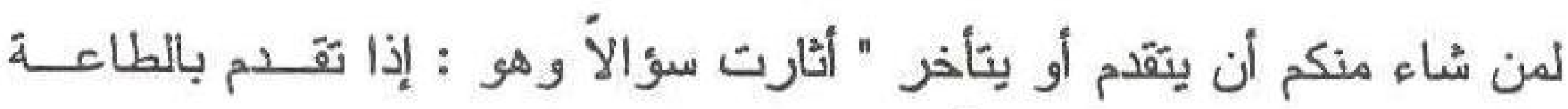
وتأخر بالمعصية ما الذى يترتَّب على ذلك ؟ فقيل برتهن بععله ويما كسـبـ

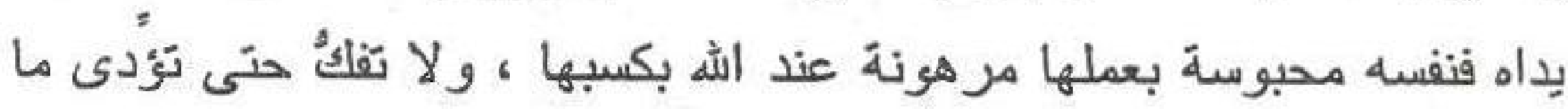
عليها من الحقوت والعقوبات فهو على نفسه بصرة ليكسب ما بقضى به إلى

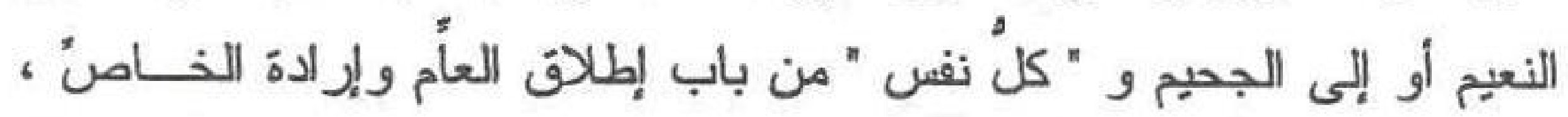

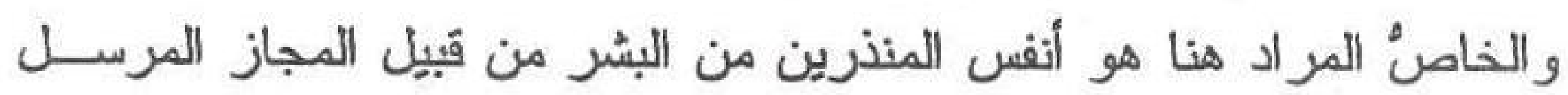
و علاقته الخصوص ، و القرينة هى ما تقيده مادة " رهينة " من معنى الحبس • والأسر

و الباء فى قوله " بما " للمصاحبة أى مصحوبة بكسبها ، وليست للسبيبة

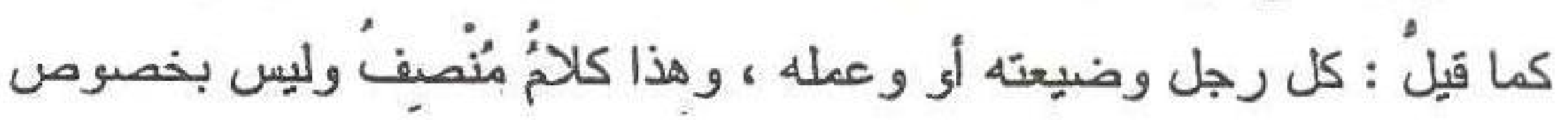
تهديد أهل الشر" وقوله : " رهينة " فيه ثلاثة أوجه : الأول : أن "رهينة " بمعنى رهن

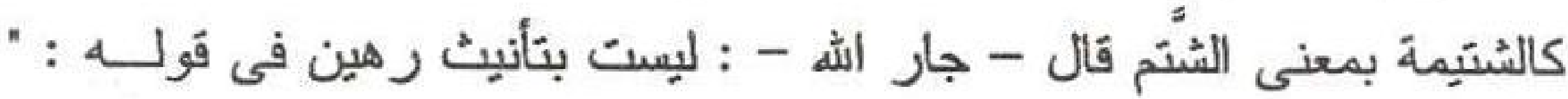

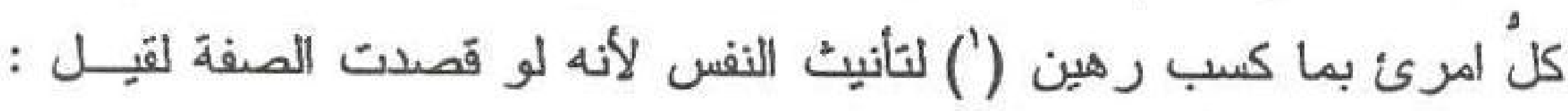

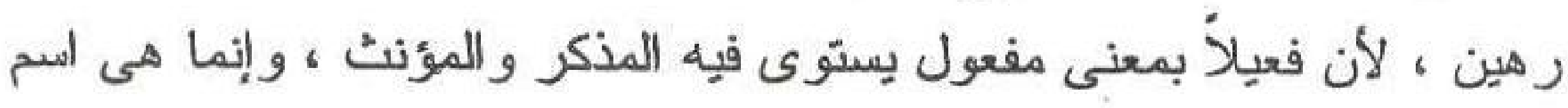


بمعنى الرهن كالشتيمة بمعنى الشتنم كأنه قَيل : كل نفس بما كسبت رهـين ،

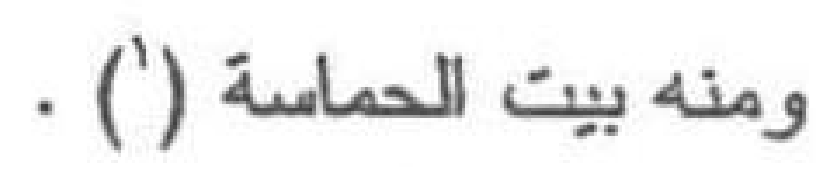

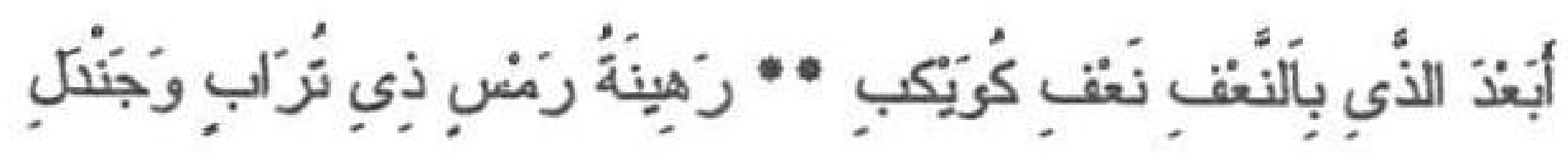
كأنه قال : رهن رمس ، و المعنى : كل نفس رهن بكسبها عند الل غير

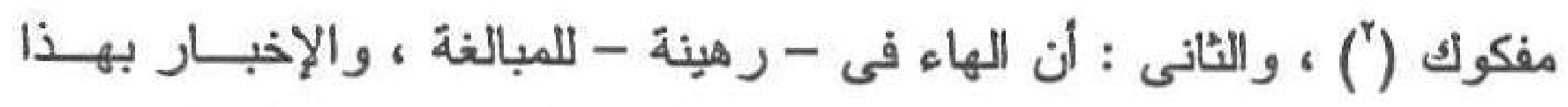

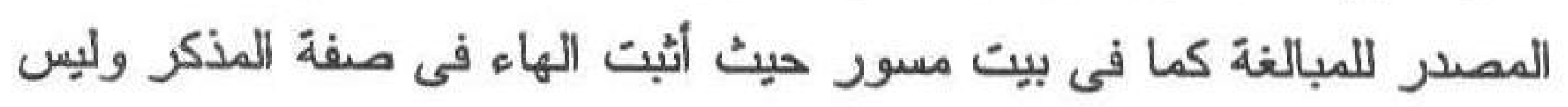

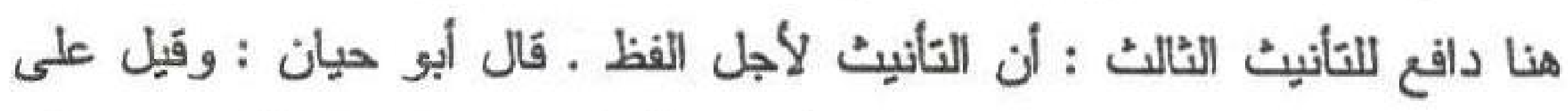

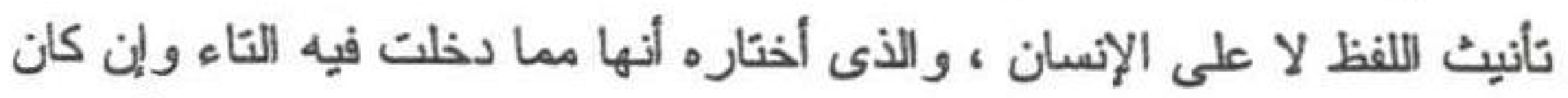

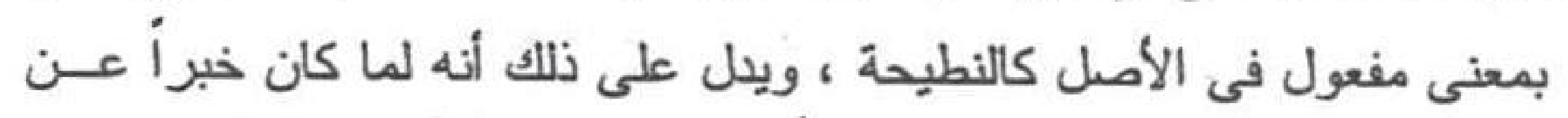

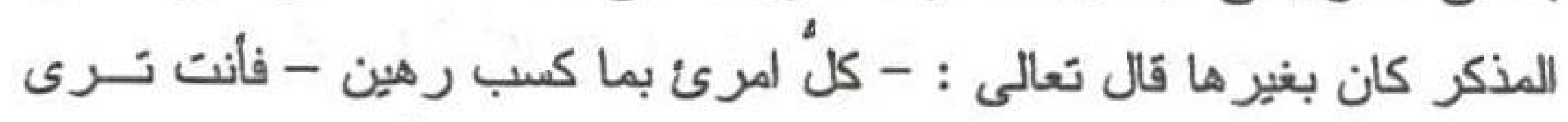

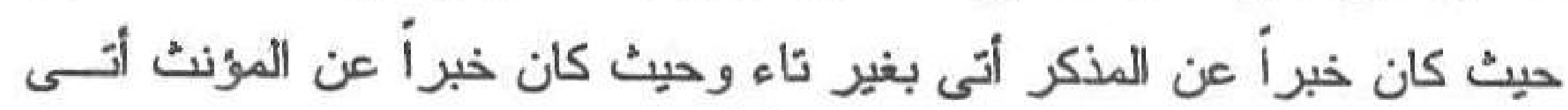

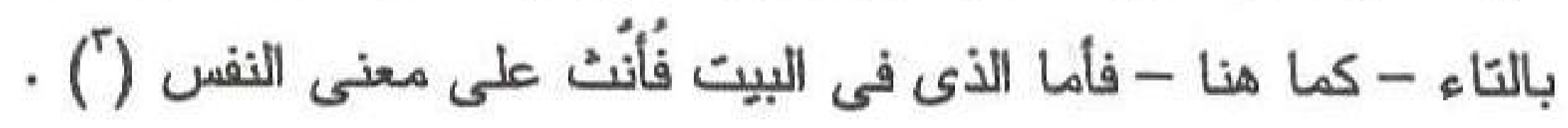

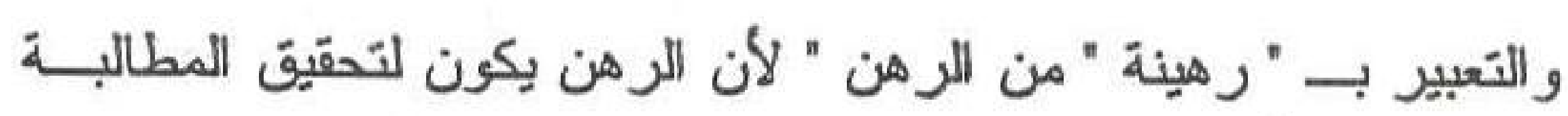

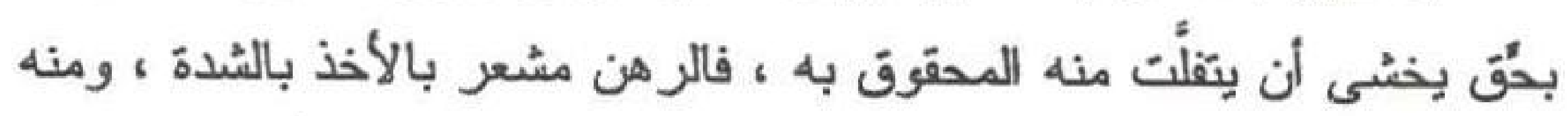

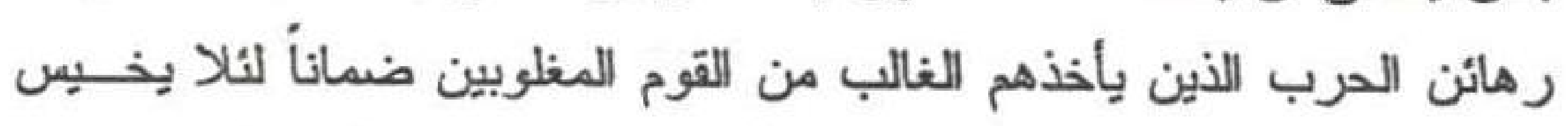

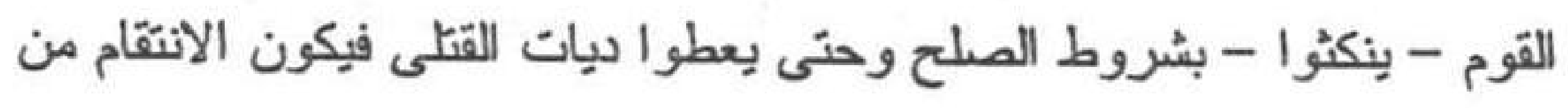

(1) ديوان الحماسة / /9 9 ، والبيت لمسور بن زيادة الحارثى وقيل لعبد الرحمن بن زيد،

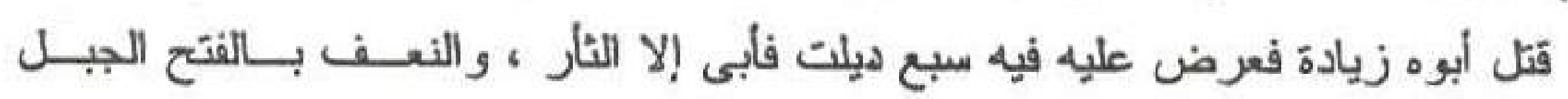

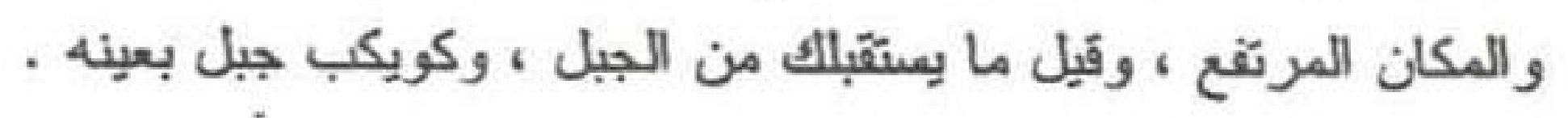


الرهائن (') قوله : " إلا أصحاب اليمين " الستثناء منصل لأن اله تعالى جعل

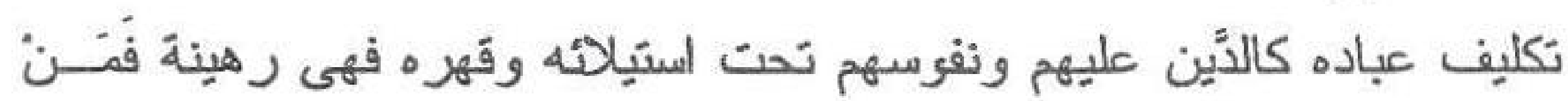

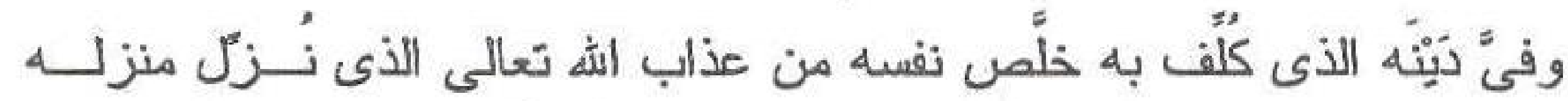

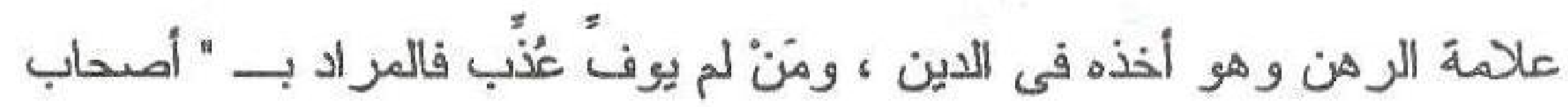
اليعبين " على الاستثاء المنصل المسلمون المخلصون ليسوا بمرتهنين لأنهــم أدَّوا ما كان عليهه ، وقَيل : إن الاستخناء منقطع و المراد بهم على هذا أطفال المسلمين لأنهم لا أعمال لهم يرتهنون بها ، وقيل : هم الملأكية ، و المعنى : لكن أصحاب اليمين فى جنات ، وقيل : بجوز الاتصال والانقطاع بناء على لإنى أن الكسب مطلق العمل أو ما هو تكليف (") و التعبيز بـ " أصحاب " دلالة على مصاحبتهم لهذه الجهة من حيـث أخذ كتبهم أو غيرها ، والتعبيز بالاسم " أصحاب " دلالة أيضنأ على ثبــوت هذه الصفة لهم ودو امها لحالهم ، و التعبيز بـ " اليمين " لأن اليمين هو جهة وله أهل الكرامة فى الاعتبار كجهة يمين العرش أو يمين مكان القدس يوم الحقّر وأخذ السعداء كتبهم بيمينهم وغير ذلك مما لا يحيط بها الوصف ، و التعبيـر باليمين مشهور فى الخير و النفع كما فى قوله - - مئمة - يمين الله ملأى سحًاء

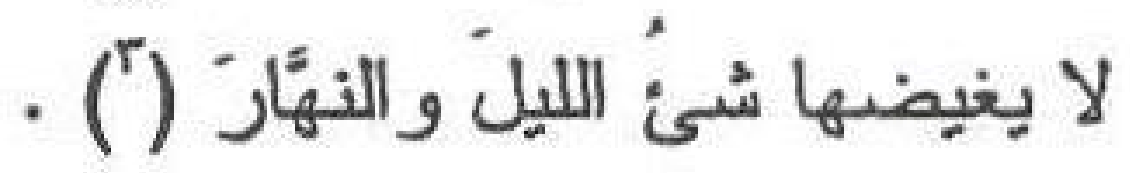

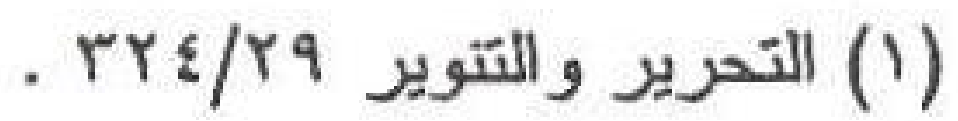

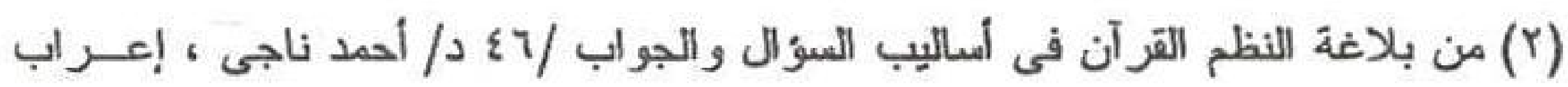

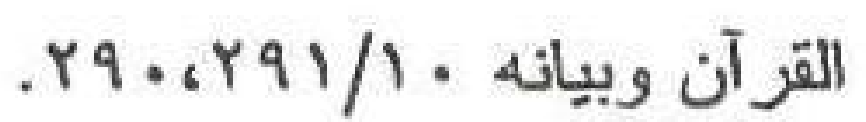

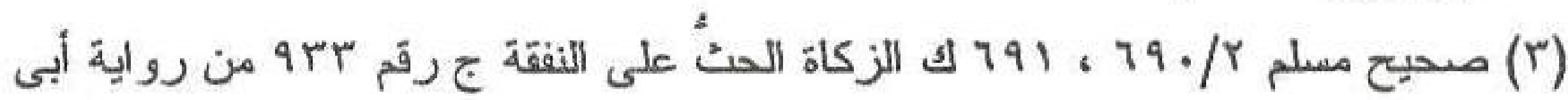


فى رهاب كلبيان الترآنى

وكقول الشُمًاخ بن ضرار فى عَرَابة الأوسى (') .

إلىى الخيرات مُنْفَعْ القرين

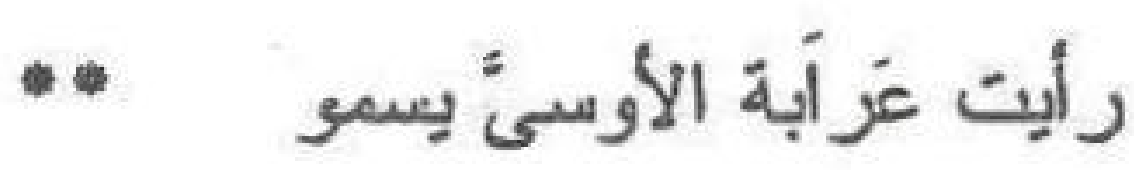

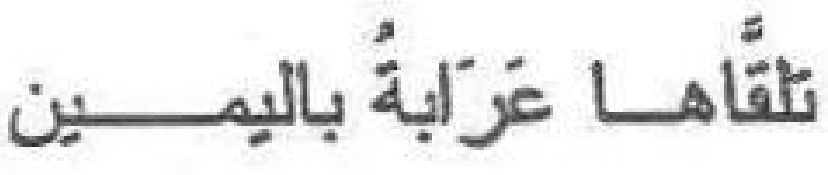

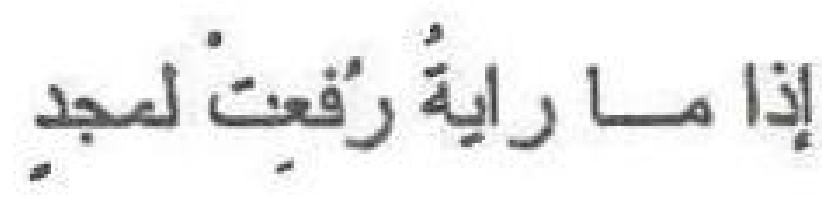

إذ اليمين مضروبة فى القوة و الشدة كما يقول أصداب المعانى ، كـــ

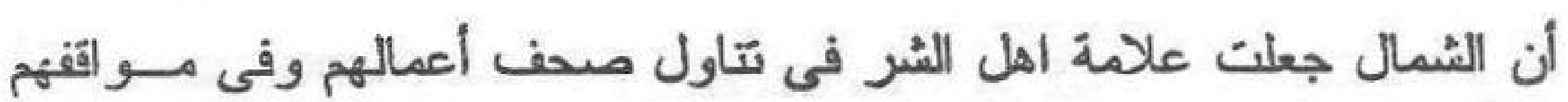
وغير ذلك كما حكى القرآن عنهم ذلك كثير آ.

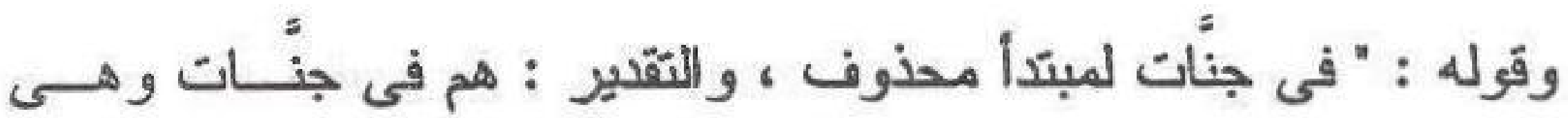

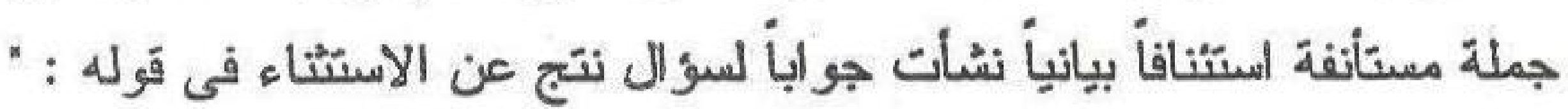

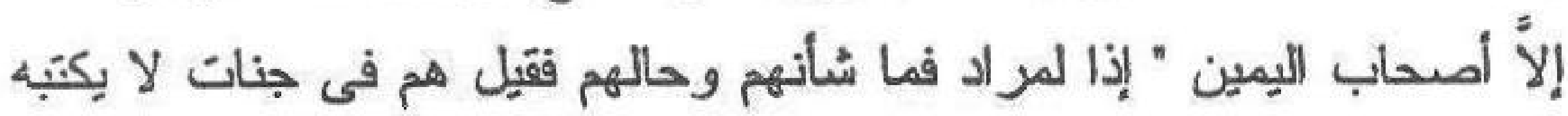
كنها ولا يدرك وصفها ، والتتوين للتعظيم ، ويجوز أن يكون منعلقاً بقوله :

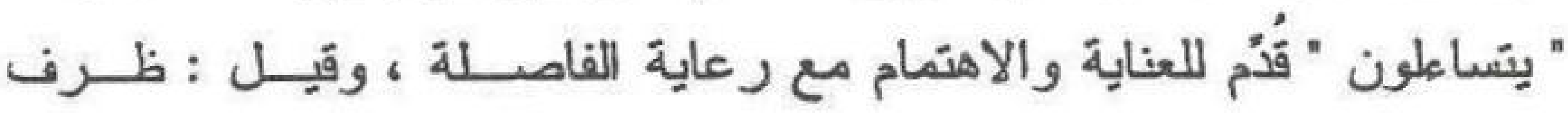

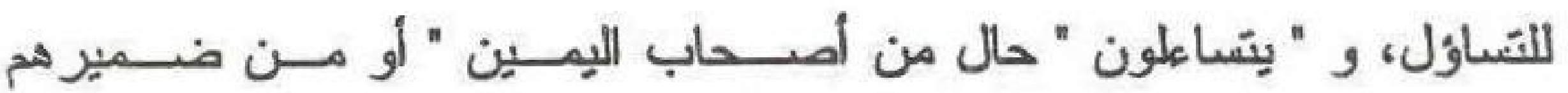
المحذوف ، ومن هنا استخدم لأجل الاستثاء المنقطع - كما قيل - .

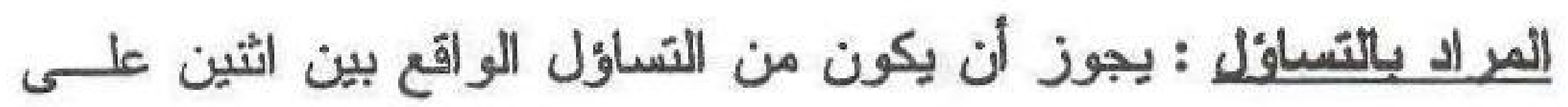

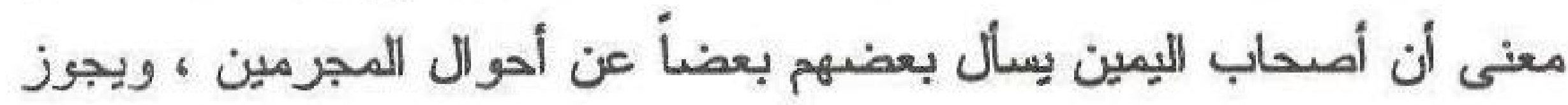

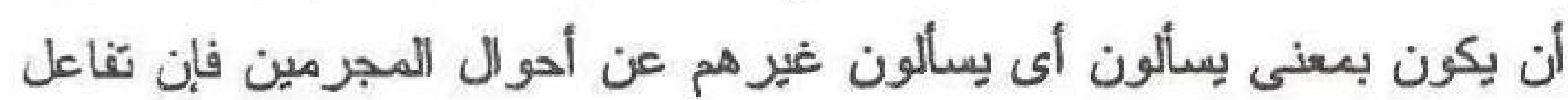

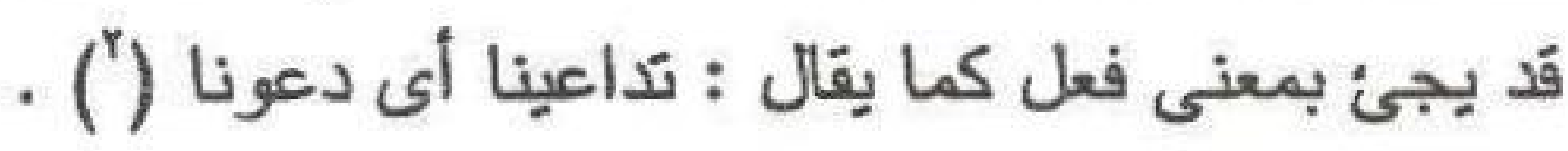

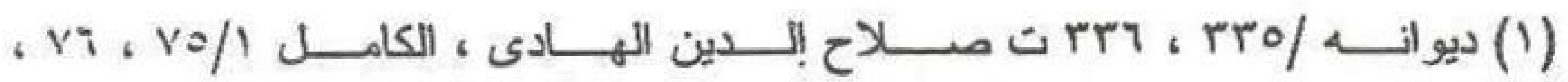

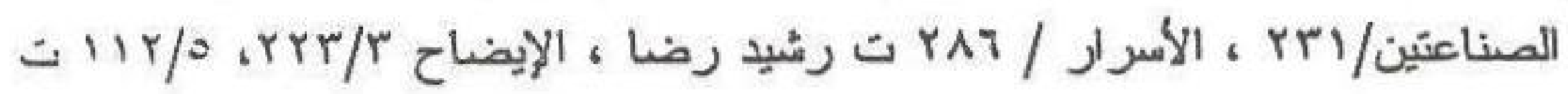

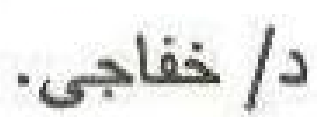

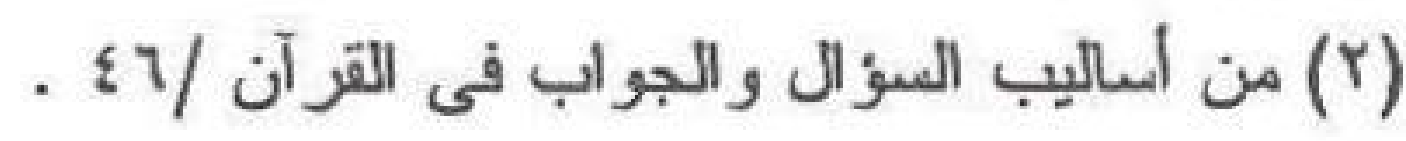


قالل الألويسى : " وليث المراد بتساؤلهم أن يسأل بعضهم بعضاً على ئى أن يكون كلُ واحد منهم سائلاً ومسئولاً معأ بل وقو ع السؤ ال منهم مجــرَّاً عن وقوعه عليهم فإن صيغة التفاعل والن وضعت فى الأصل للإلالة علىى صدور الفعل عن المعندى ووقو عه عليه معأ بحيث يصير كل واحد من ذلك

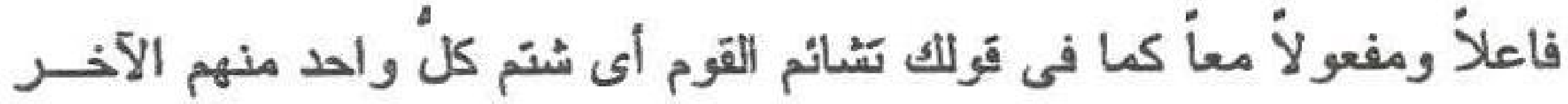
لكنها قد تجرئد عن المعنى الثقانى ويقصد بها الدلالة على الأول فقط ويكــون

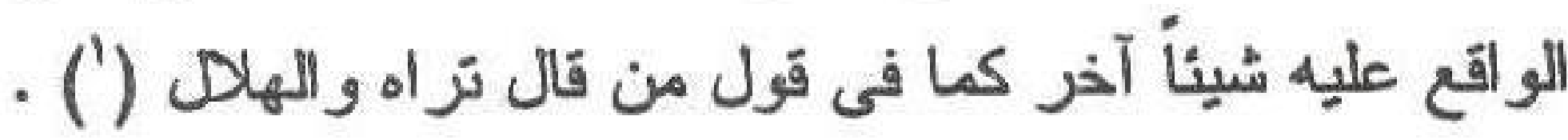

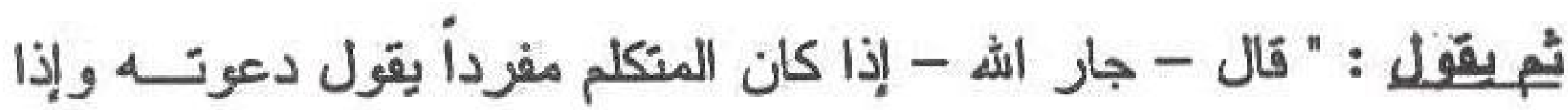
كان جماعة يقول تداعيناه ونظيزه رميته وتر اميناه ور أيت الهلال وتراعينـاه ولا يكون هذا التفاعل من الجانبين وعلى هذا فالمســؤول محــذوف أعنـى المجرمين والثقدير : يتساعلون المجرمين عنهم أى يسألون المجرمين عـن

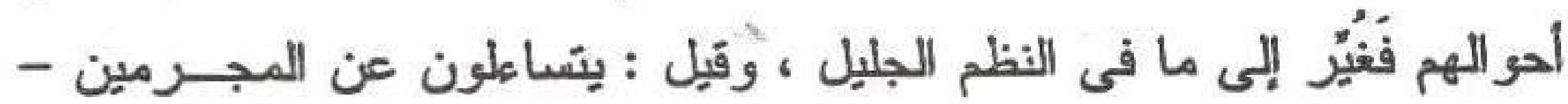
و المعنى على ذللك ، وحذف المسئول لكونه غير المسؤول عنه (") .

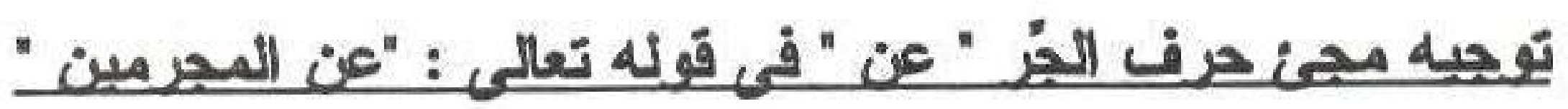
على التقديرين السابقين فى بيان التساول : ليس المجرمــون مســؤلا عنهم بل هم المسئول منهم فلا بدًّ من توجيه " عن " فإن قوله : " ما ســاككم فى سقر " ؟ؤال للمجرمين ، وقوله : " يتساعلون عن المجرمين " ســؤال عنهم فلا ينطابقان ، و إنما ينطايقان لو قيل : يسألون المجرمين ما سلككم فى في سقر ؟ وبوجيه الكلام أن قوله : " ما سلككم فى سقر " مع جو ابه حكاية مسن مـن

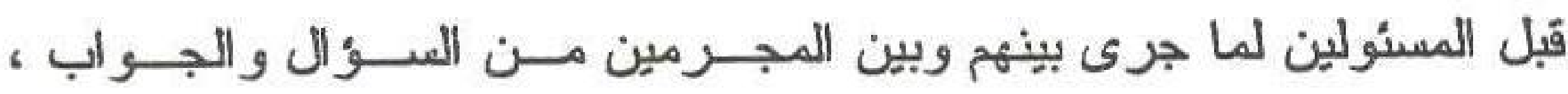

$$
\begin{aligned}
& \text { (1) (1) روح المعانى }
\end{aligned}
$$

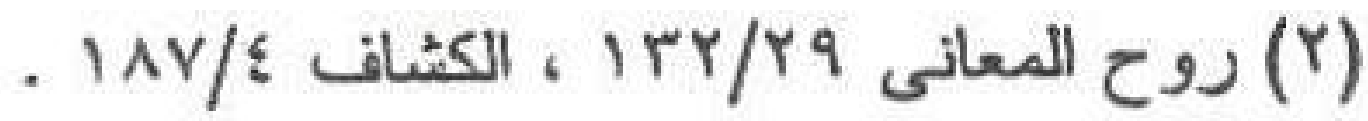


و المعنى : أن أصحاب اليمين لما تساعلو ا بعضهم بعضاً أى بأن سألوا غيرهم

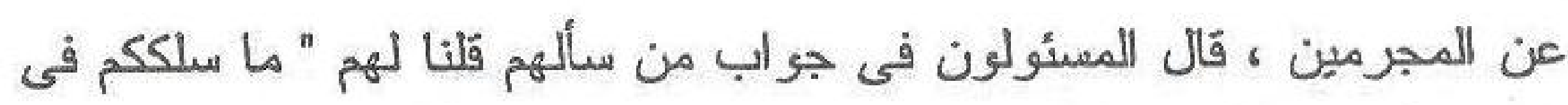

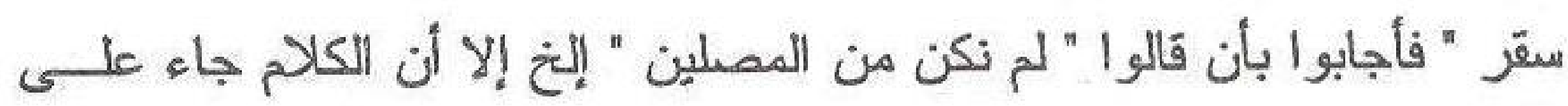

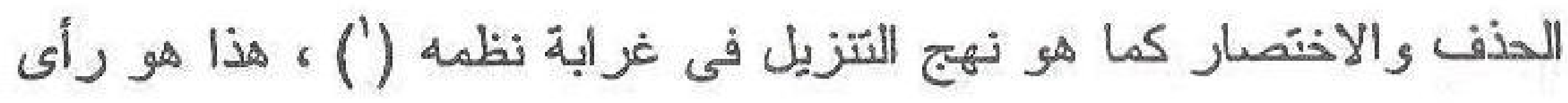

\section{الزمخشرى زمن نهج ، وفيه تعسف .}

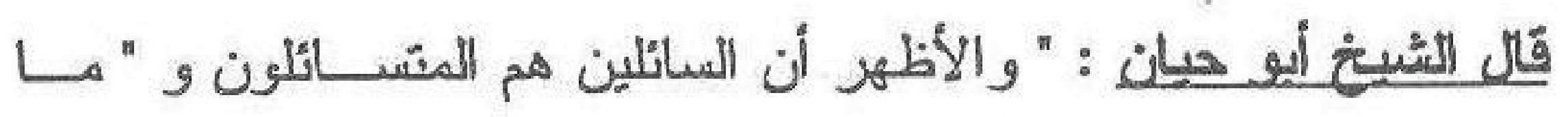

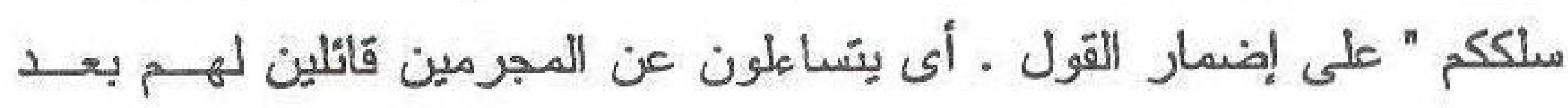

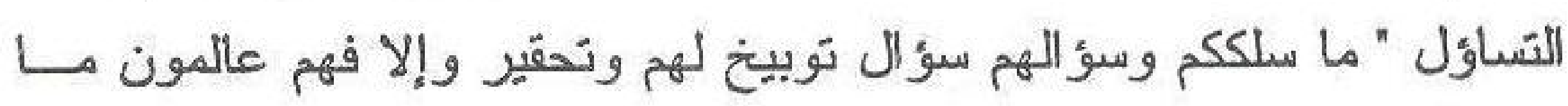

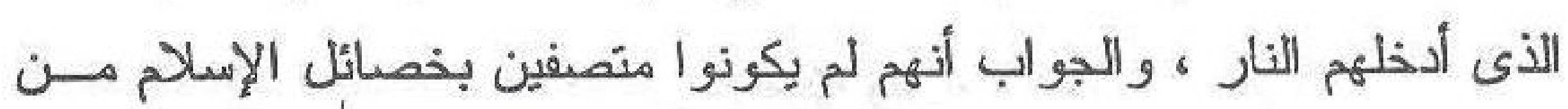

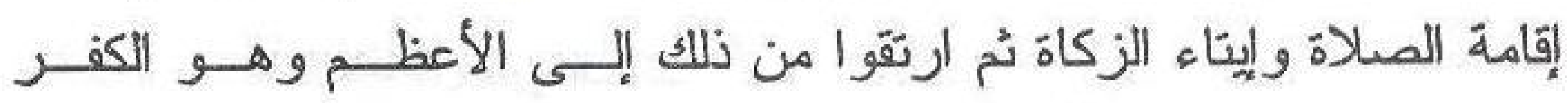

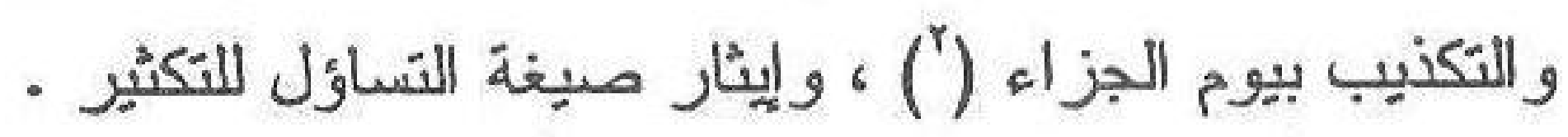

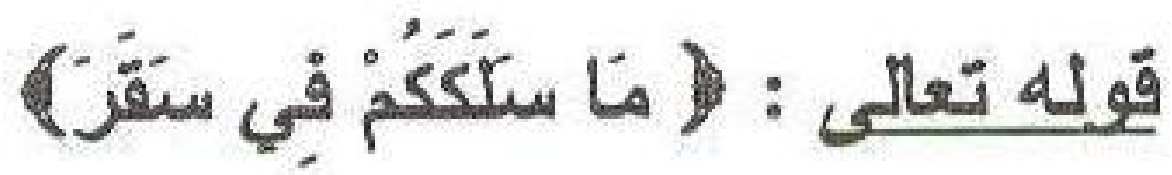

الإنظم البلاغى : "ما سلكمم "بيان للتساؤل من غير حاجة إلى إضــمار

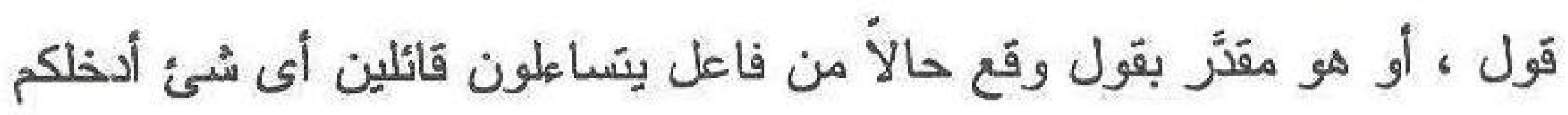

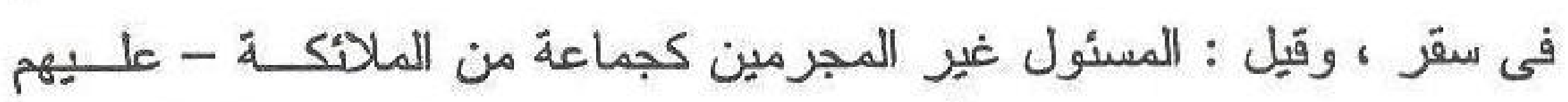

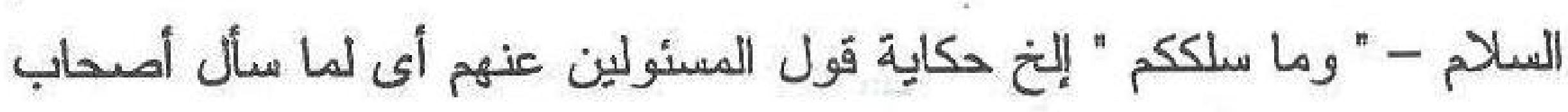

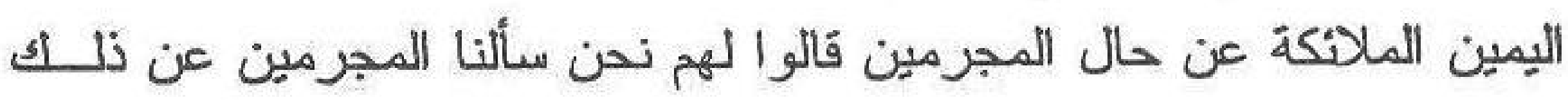

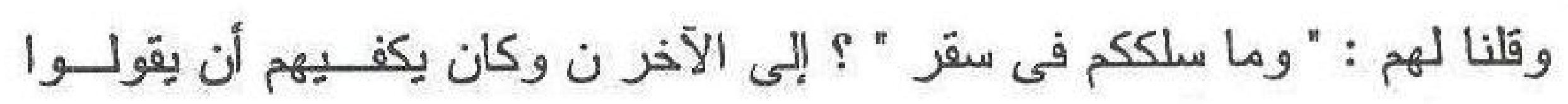

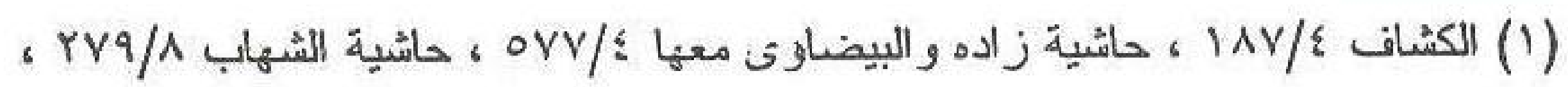

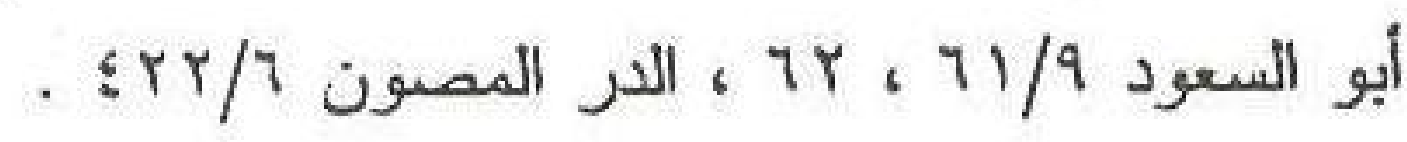

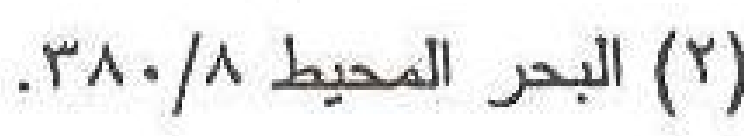




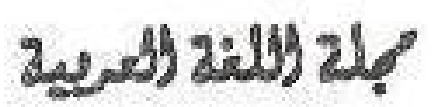

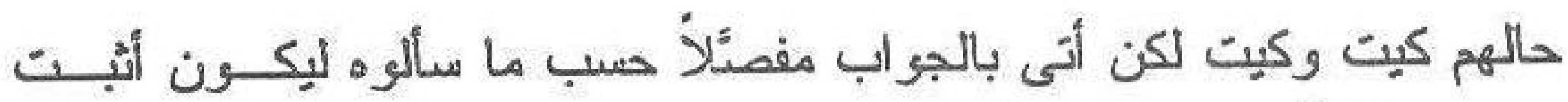

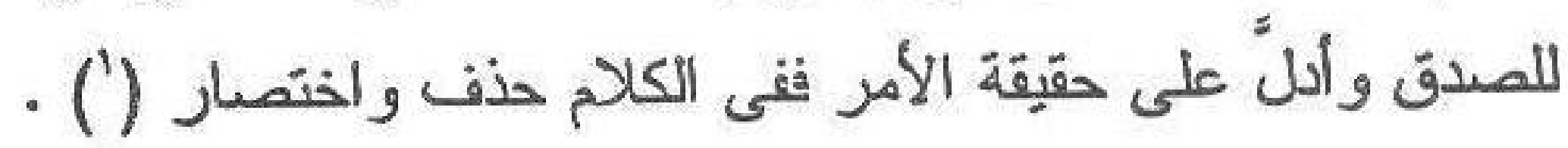
و " ما " فى قرله : " ما سلككم " استفهامية ، والمر اد بالاستفهام التوبيخ

والتعجيب من حالهم وإلا فالمؤمنون عالمون بسبب دخولهم اللنار . و " سلككم " من السلاك بعنى الإدخال فى الشئ كإدخال الخيط فى سمّ

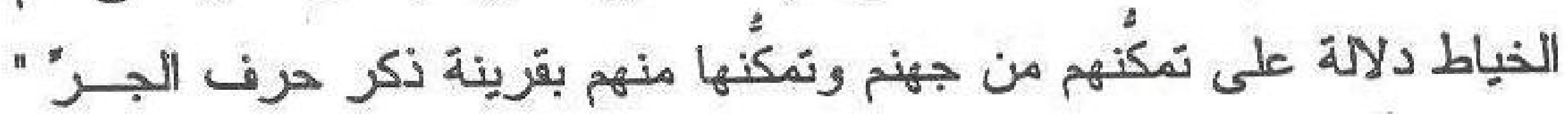

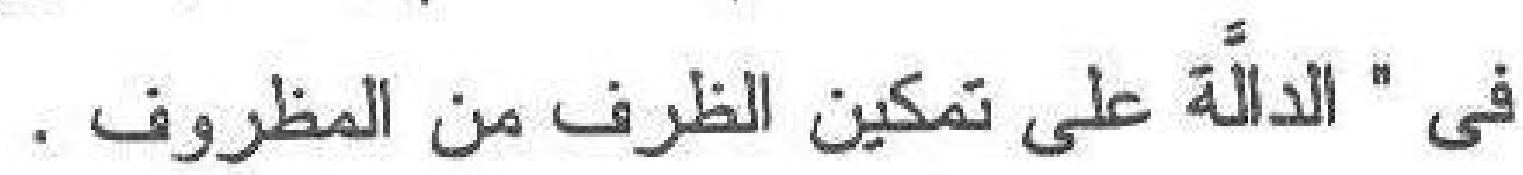
وقد تناول هذه الآيخة الاكتور المطعنى : تتاولاً دقيقاً من الواجـب أن

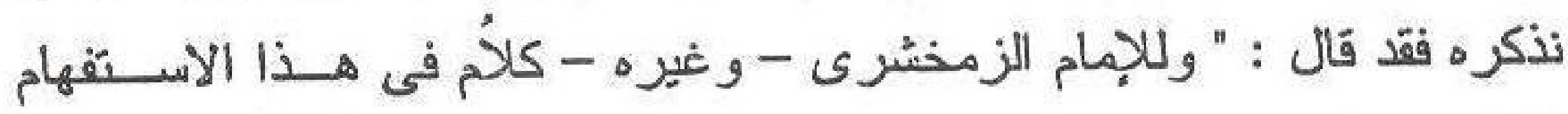
نتفق معه فى بعضه ونختلف معه فى بعض آخز ، وأما الذى نتفق معه فِيسـا

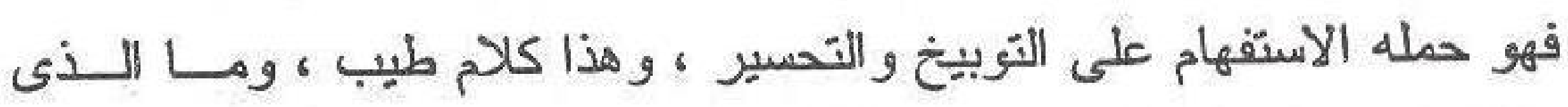
نختلف معه فيه ـ " ما سلككم فى سقر " ؟ هذا السؤال موجَّه فى ظاهر النظم

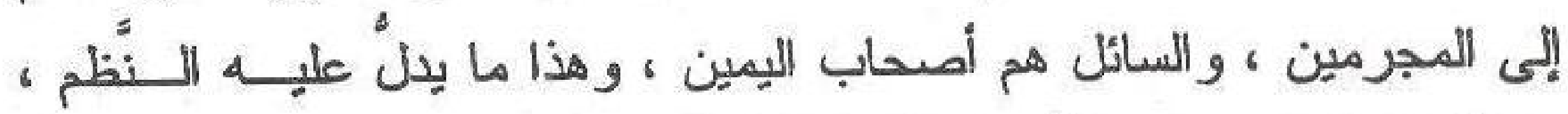

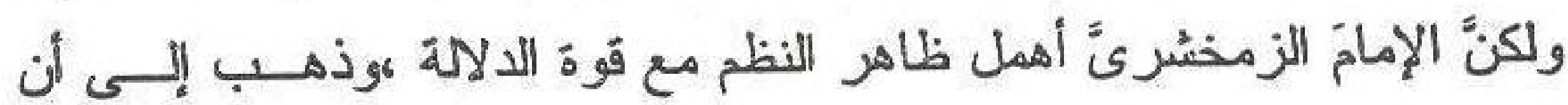

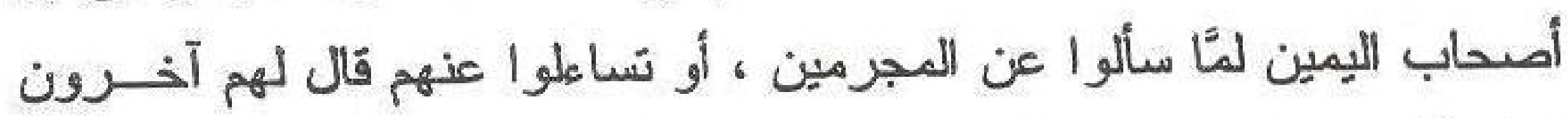

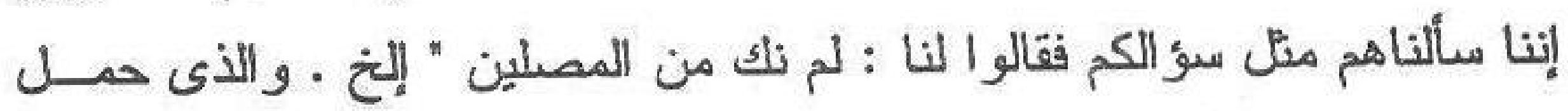
الإمامً الزمخشرىً على هذا ادعاؤه أن النظم غير مطابق للجواب لأن القرآن حكى أن أصحاب اليمين يتساعلون عن المجرمين ، أى يسأل بعضهم بعضاً أو يسألون غير هم ، فكيف يصحُ أن يكون جواب المجرمين لأصحاب اليمين؟ 


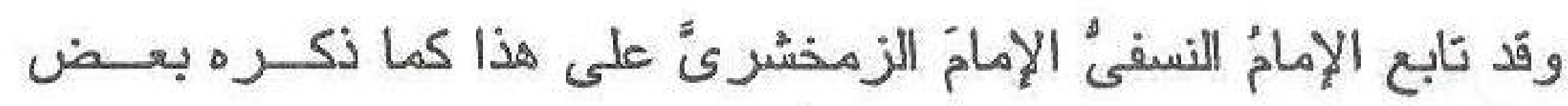

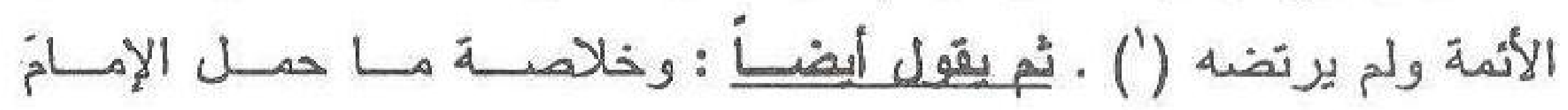

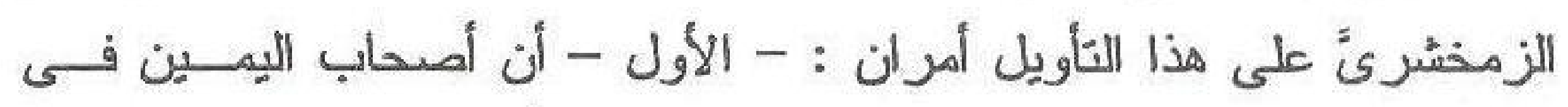

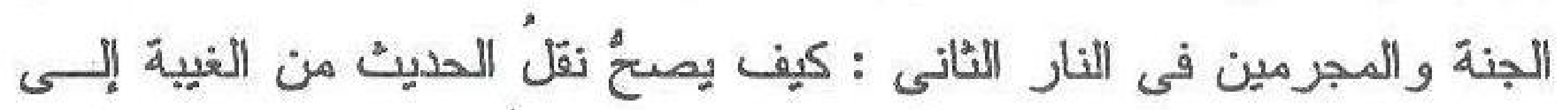

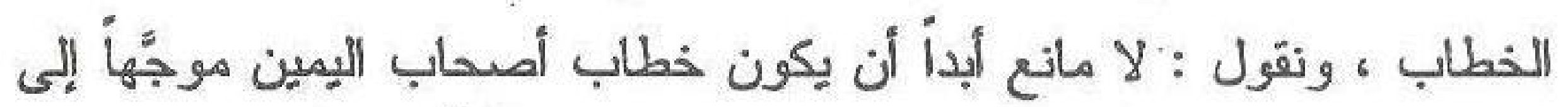

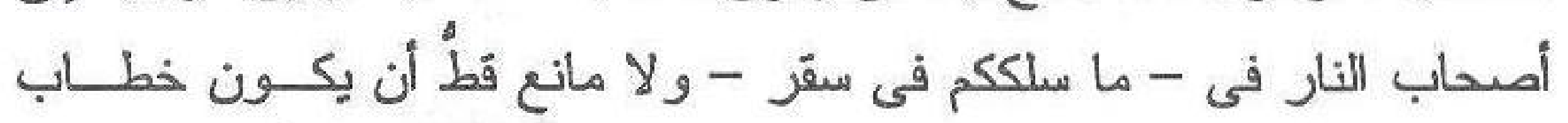

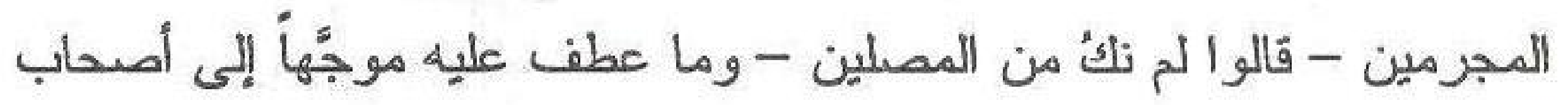

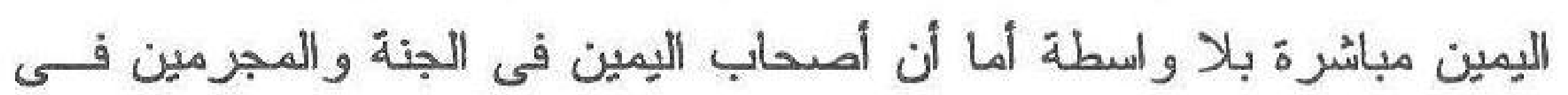
النار فقد ورد فى سورة الأعراف الحوار الطويل المباشر بين أصحاب الجنة

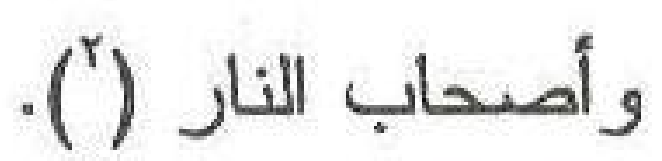

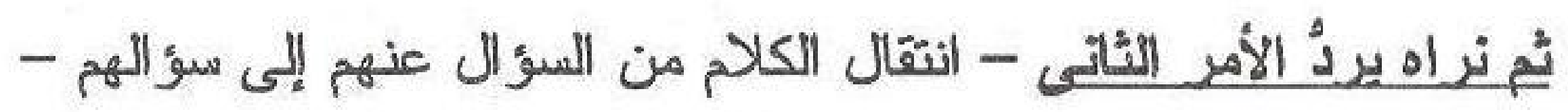

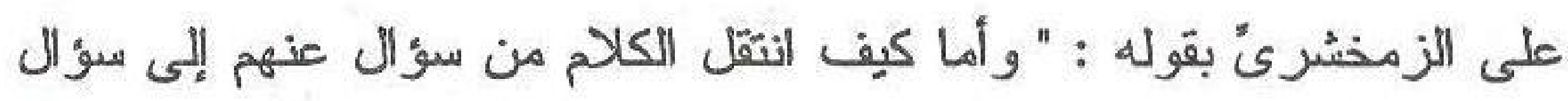

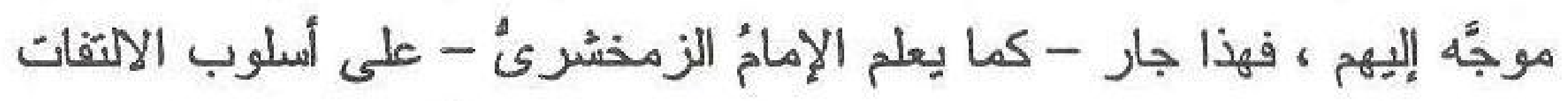

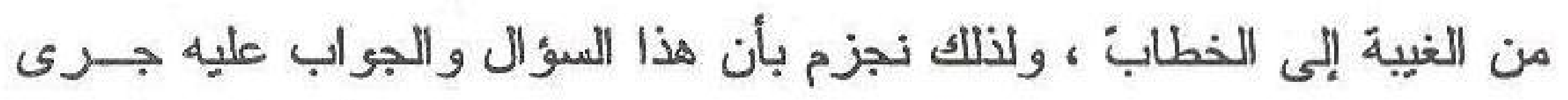

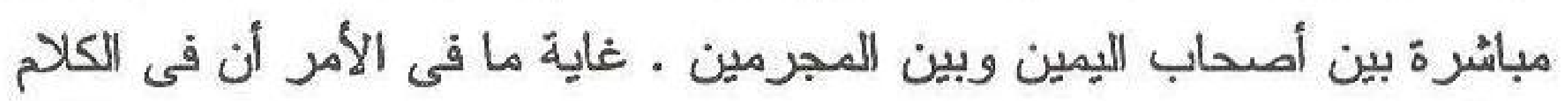

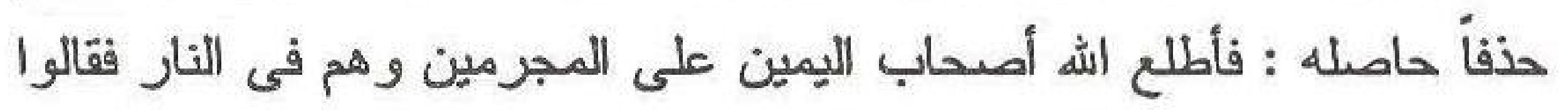

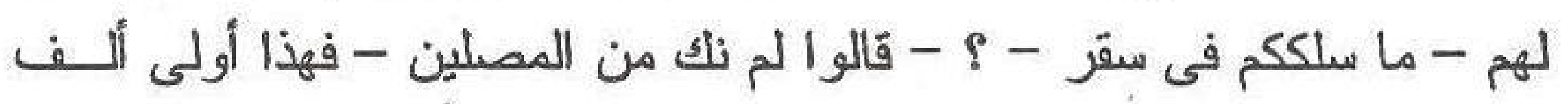

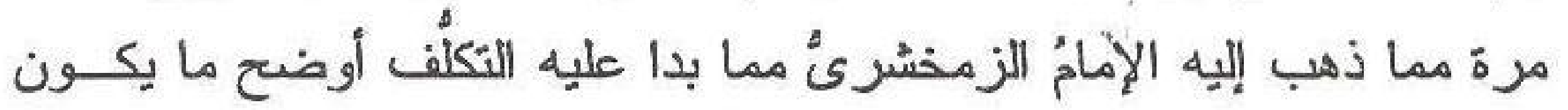

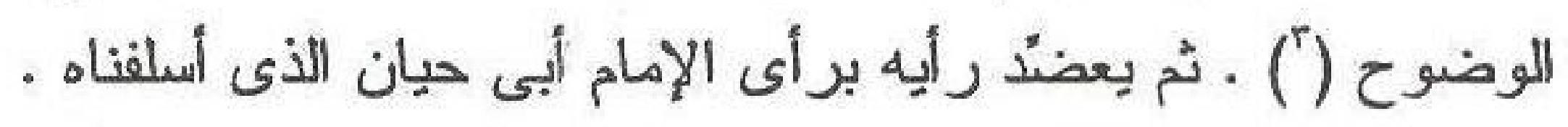

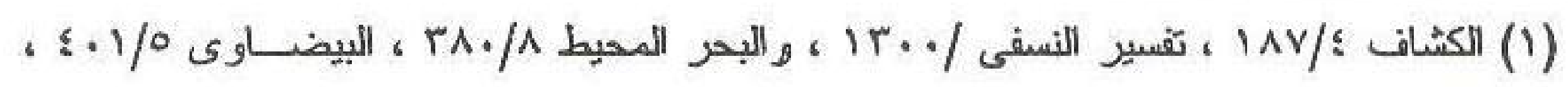

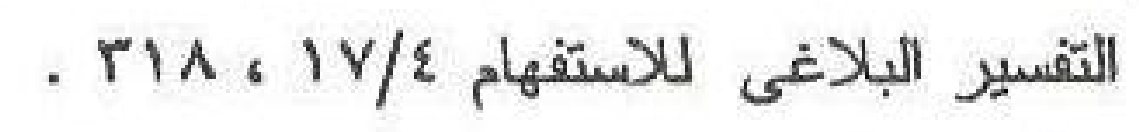

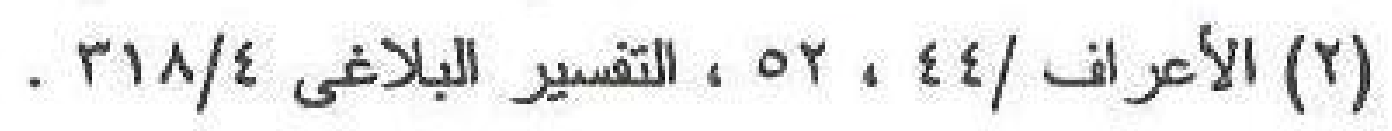

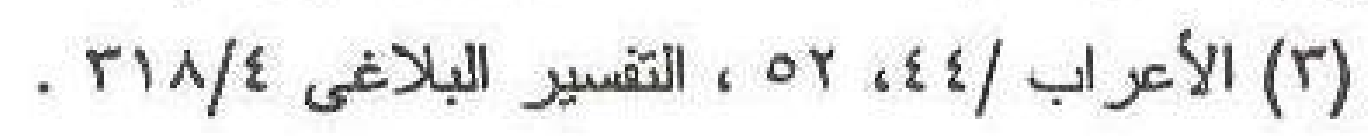




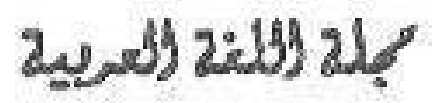

وقوله : " ما سلككم " سؤال عن السبب ، وهو حرئٌ أن يكون من الفنّ" البديعى" المستّى بـ " تجاهل العارف " وهو - كما يقول البلاغيون - : سوق

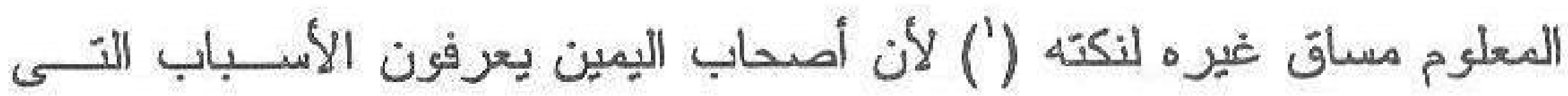

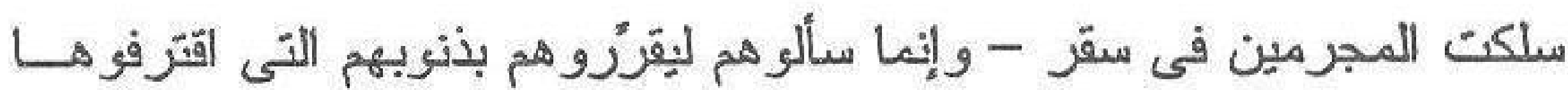

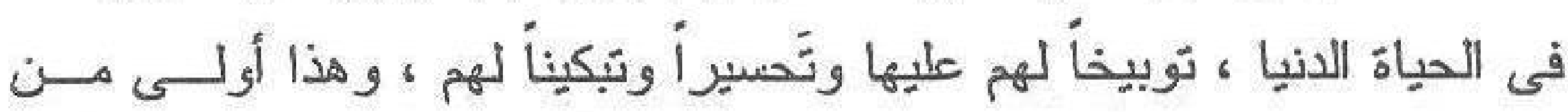
حمل الاستفهام على حقيقته ، ثم التماس العذر لأصحاب اليمين كيف يسألون المجرمين عن أسباب دخولهم النار وهم يعرفونها ؟ الذاهب إلى هذا الــرأى لـى لإئ

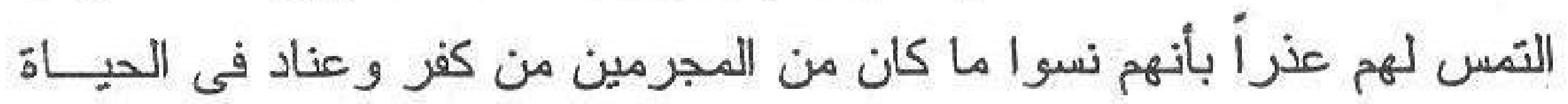

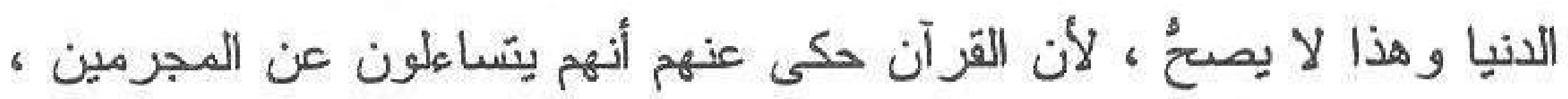

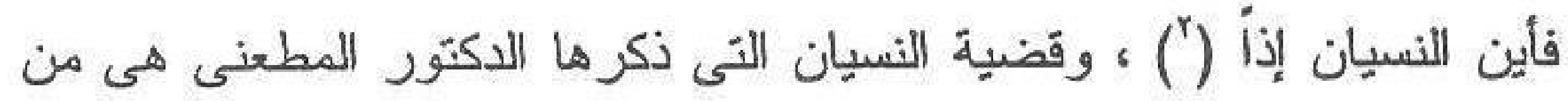

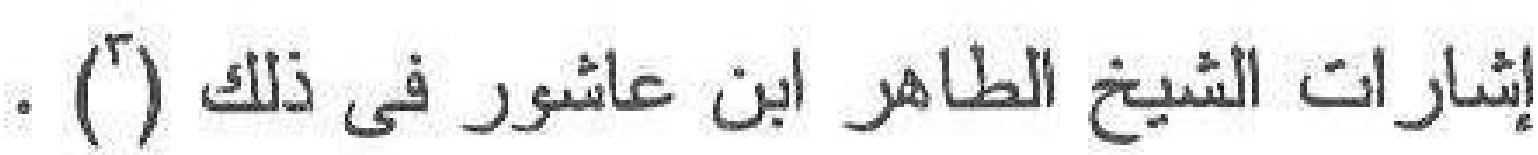
و الفعل " سلككم " استعارةً تبعيةً للمزج وشُدة التقارب و الحبس فى جهنم و الاحتباس فيها كحبس حبة العقد فى الخيط بعد سلكها فيه ، و الجامع الضًّمُ و الاسنقّرار ، و الققرينة ذكر حرف الجر" " فى " وفى هذه الاســتعارة إيمـاء و إنارة إلى حقارتهم وتضاؤلهم والاستخفاف بهم ، حيث أفادت هذه الاستعارة

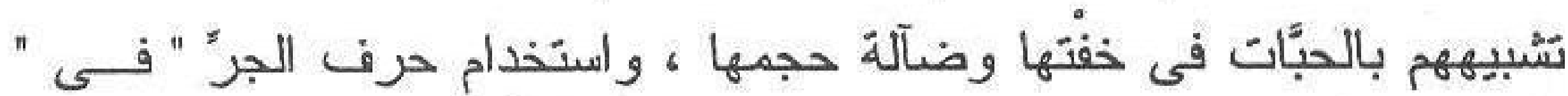

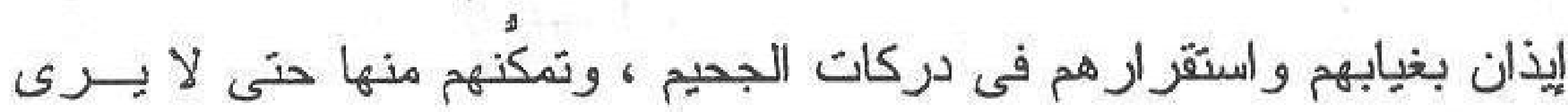

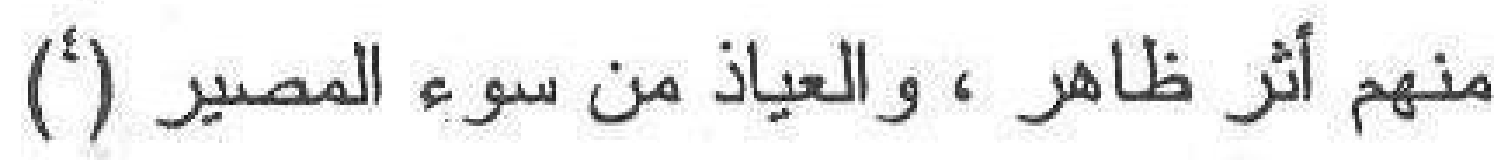

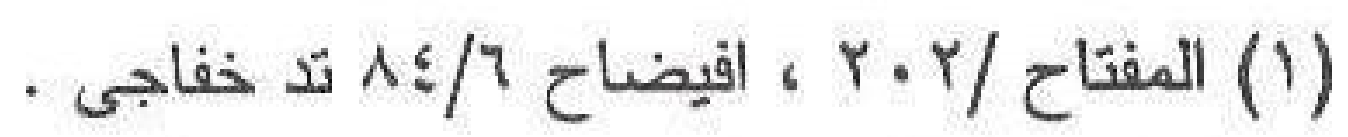

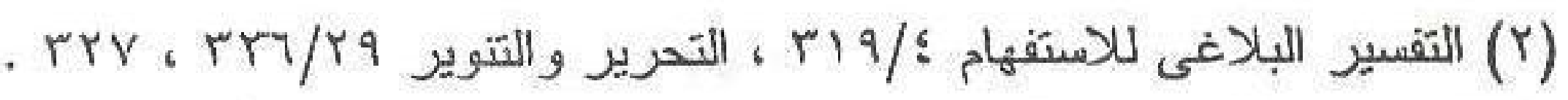

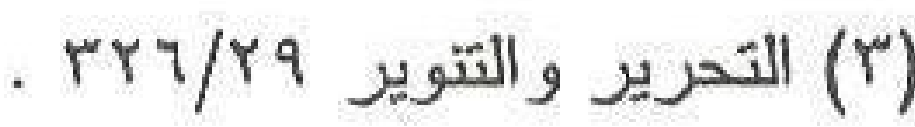
(ع) التقسير البلاغى للاستفهام ؛/19 19 بتصرف . 


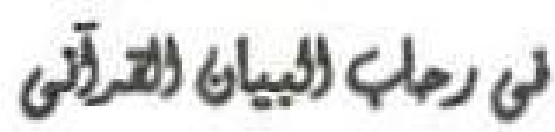

\section{$[1 \leqslant \gamma]$}

فالسئ ال هنا لزيادة التبكيت لأولثك المجرمين وتوبيخهم ، وإذخال الألم

و الحسرة على نفوسهم ، مع إيجاز الحذف الكامن فى قوله : " يتســاءلون . عن الججرمين . ما سلككم فى سقر " أى قائلين لهم : " ما سلككم فى سقر " ؟

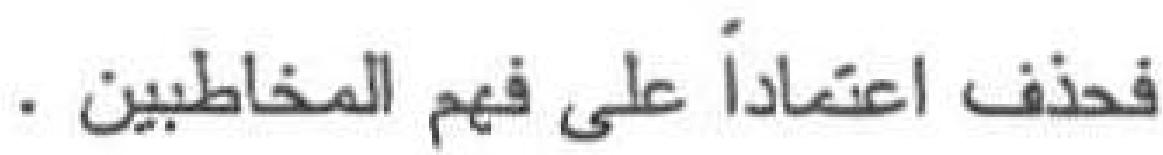

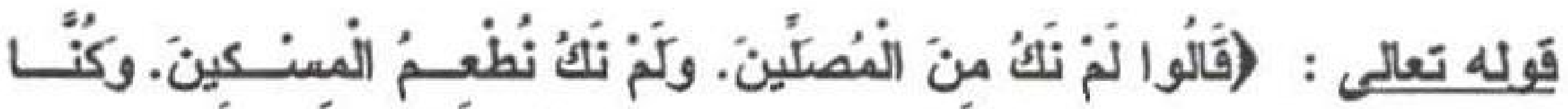

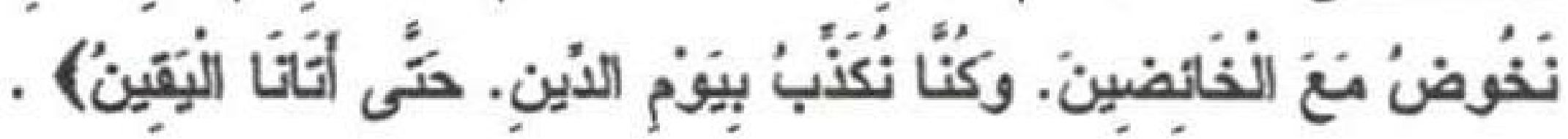

النظم البلاغى : قوله : " قالو ا لم نك " إلخ جواب عن العؤال الــوارد

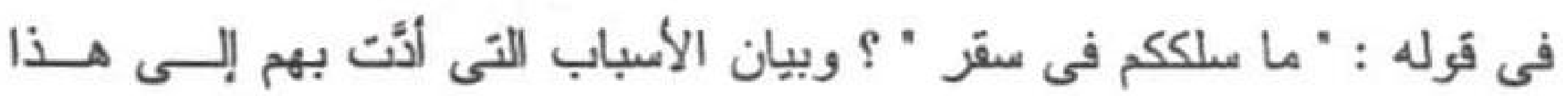

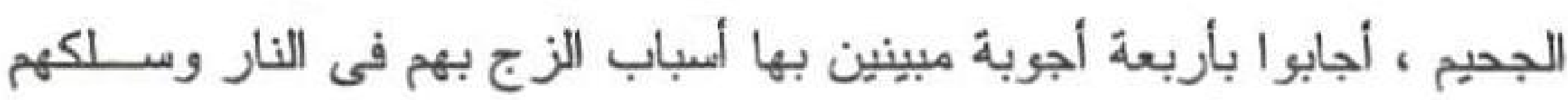

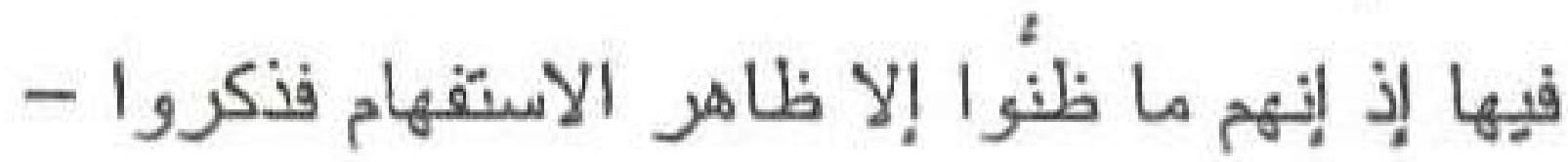

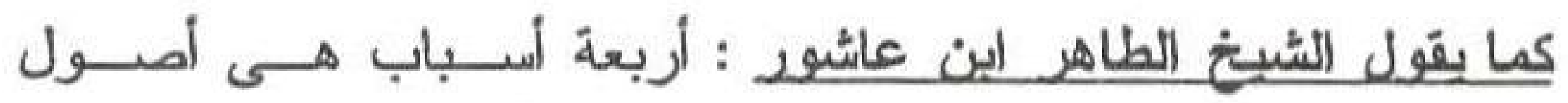

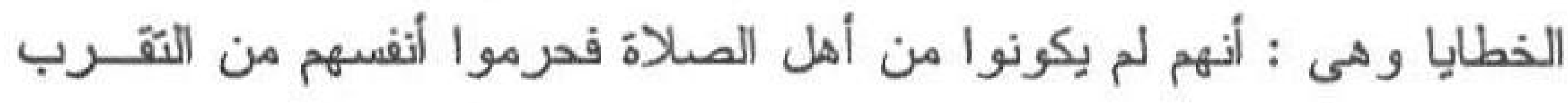

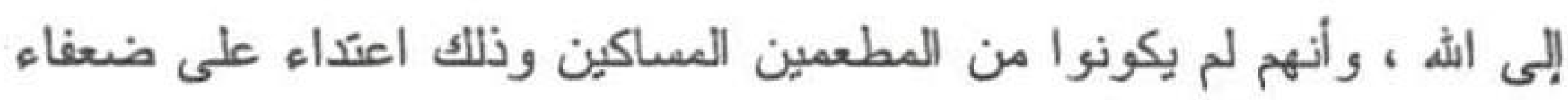

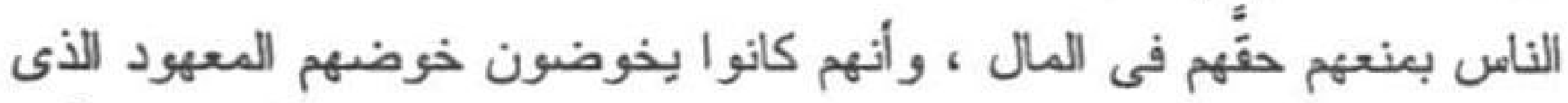

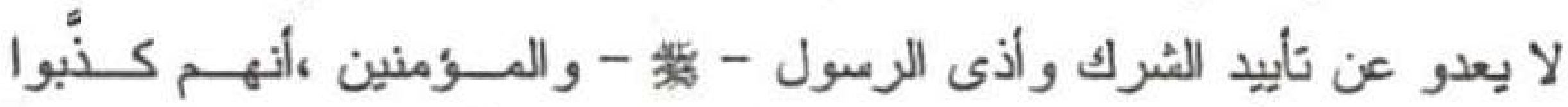

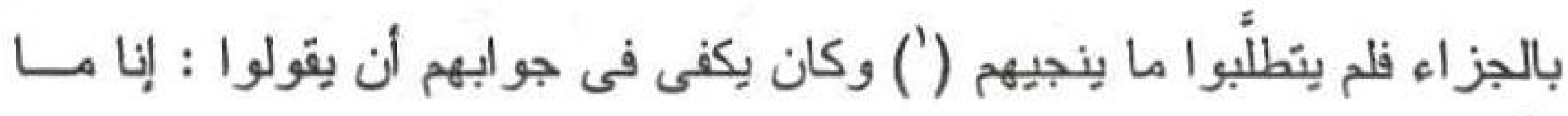

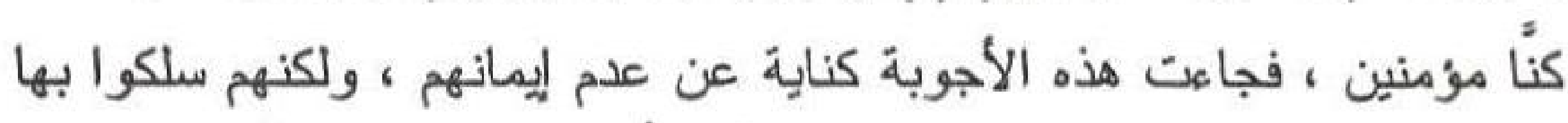

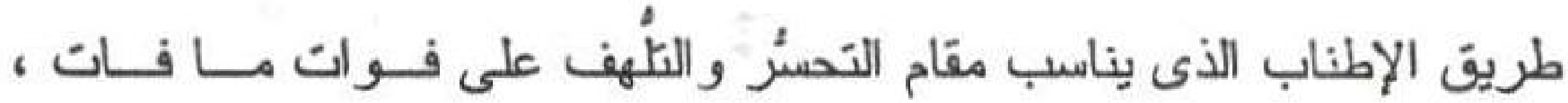

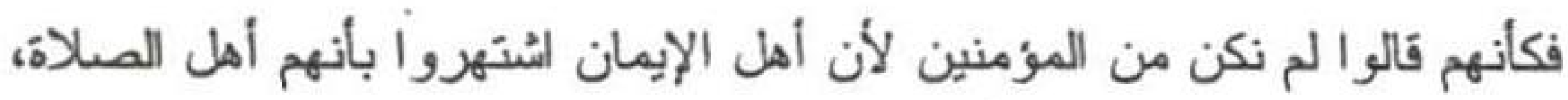

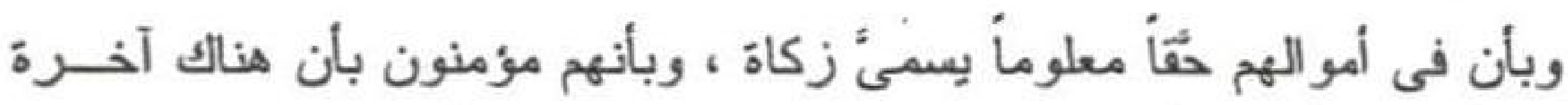

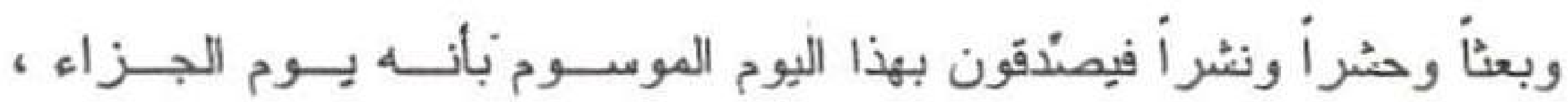


ويصدقّون الرسل الذين أبلغوهم مراد الشه منهم ـ فهذه الأمور الأربعة هرتبة

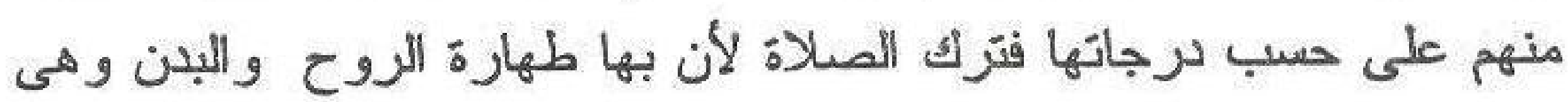
الأساس التالى للشهادة بالنسبة للمؤمنين الموحدِين وبها يعرف صحيح الــدين من غيره ، وتم تليها الزكاة وهى طهارة المال و النفس ، و الأنسان بها شحيح

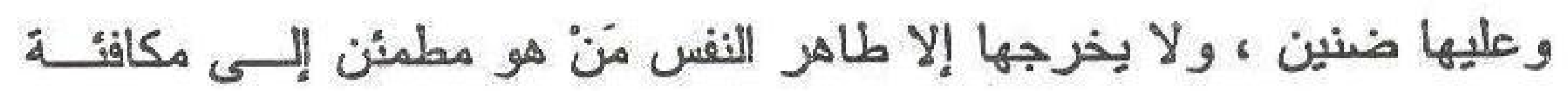

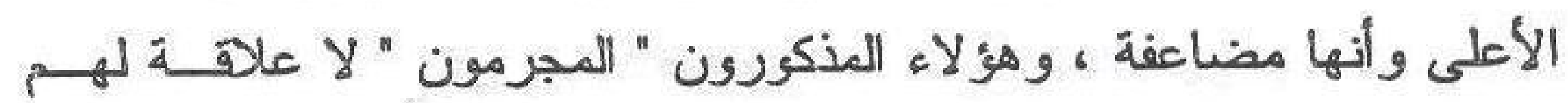

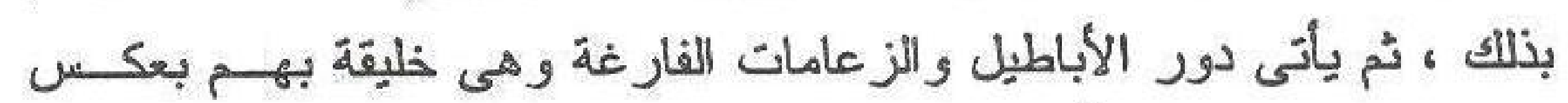

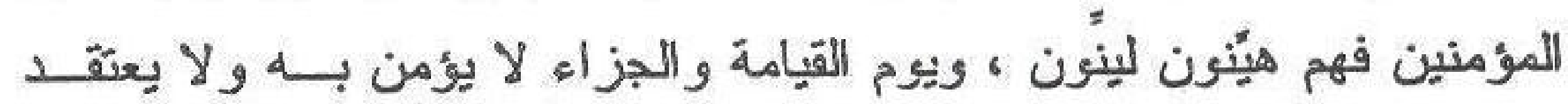

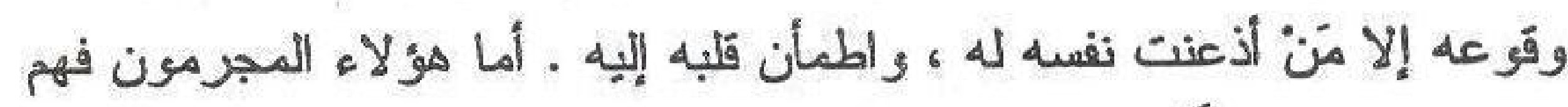

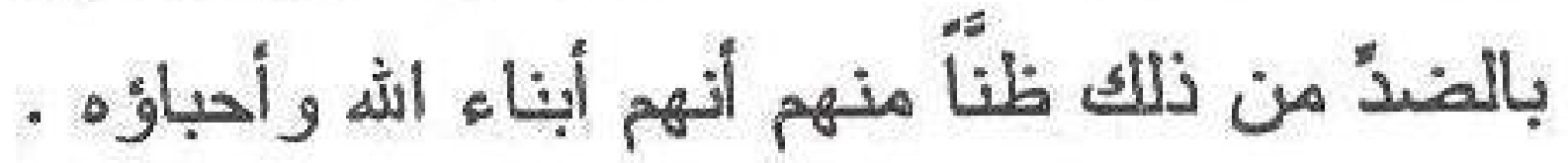
وقوله : " نخوض " استعارة تبعية استعيرت للحديث المتكرر وهى من الخوض أى الدخول فى الماء فاستعيرت هنا للتمادى فى الباطل ، وهى أبلغ

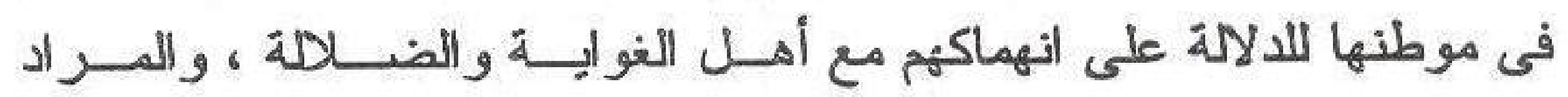
بالخوض هنا كثرة الكلام بما لا ينبغى من الباطل وشُبها ، و هذا تحذير لكل

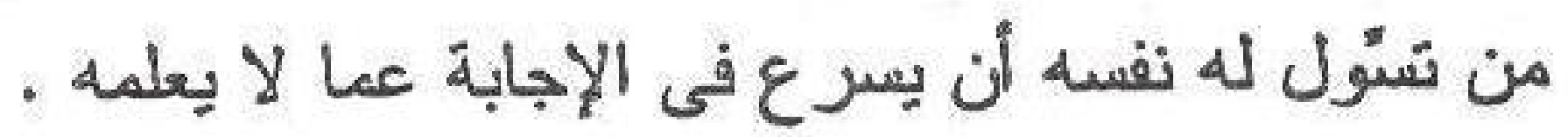
وقوله : " مع الخائضين " إئارة إلى عدم اكتر اثهم بالباطل ومبالاتهم به فكأنهم قالو ا : وكنا لا نبالى بباطل .

وقل جعل القشبرى : جواب المجرمين على صيغة استفهام منهم فقال :

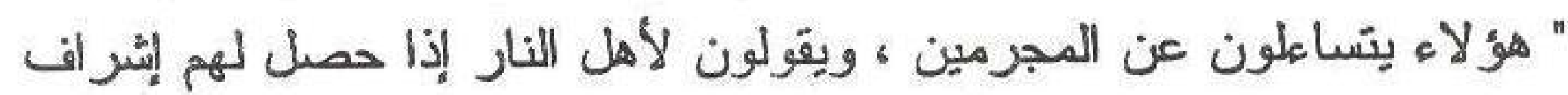

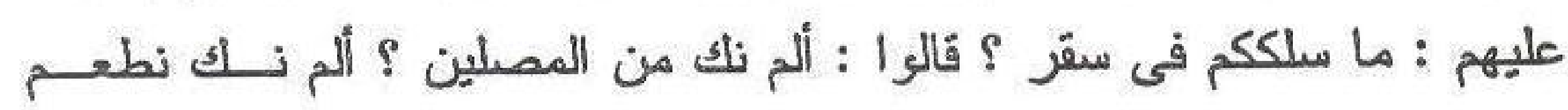
(') المسكين 
وفى نظرى : أن هذا خروجُ عن أسلوب القرآن الذى أثبت عدم حصول هذه الأمور منهم باعتر افهم أنفسهم ، وكيف تنأنَّى هذه الإجابة لأن معنى ذلك

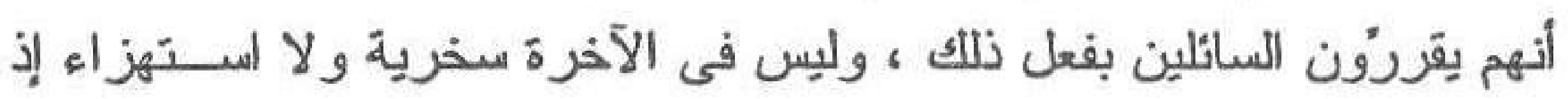

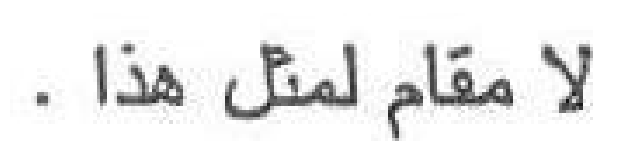

وقوله : " وكنا نُكنّب بيوم الدين " من ذكر الخاصن بعد العامٌ . خصنّـهـ بالذكر مع أنه داخل فى حِّز الخوض بالباطل مع الخائضين لبيان تعظيم هذا

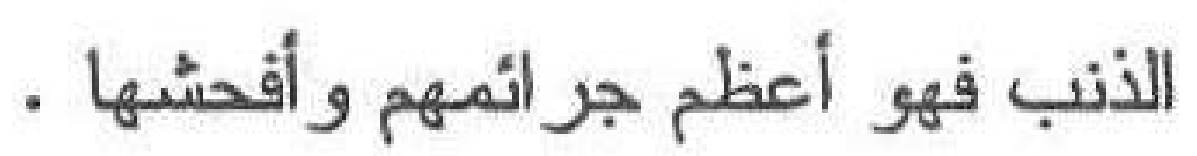

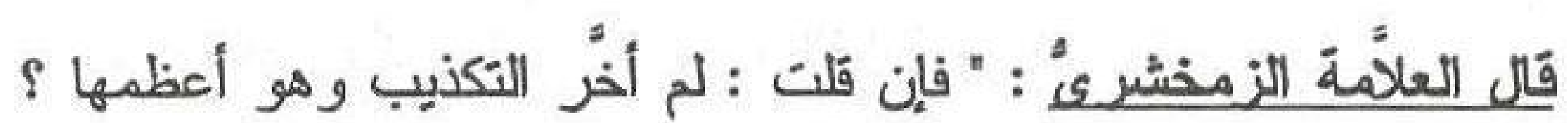

قلت : أر ادوا أنهم بعد ذلك كلًه كانو ا مكذّبين بيوم الدين تعظيماً للتكذيب (') . ويرى بعضن المفسرين : أن فى الآية دليلاً على أن الكفار مخـاطبون

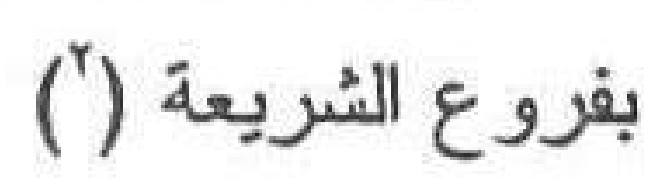

وقد نفى سماحة الشيخخ الطاهر البن عاشور : مخاطبة الكفار بفـروع الشريعة فقال : وباعنبار مجموع الأسباب الأربعة فى جوابهم فضــلأ عـنـ

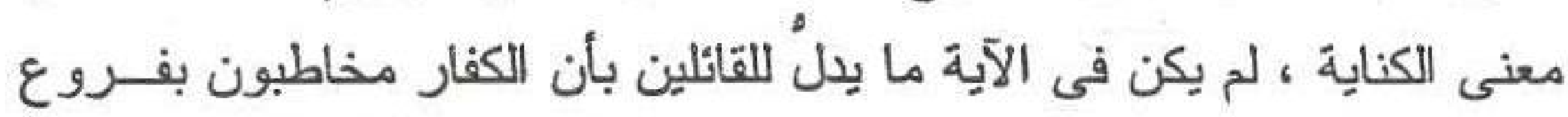

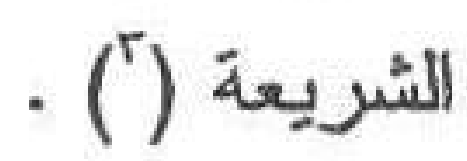

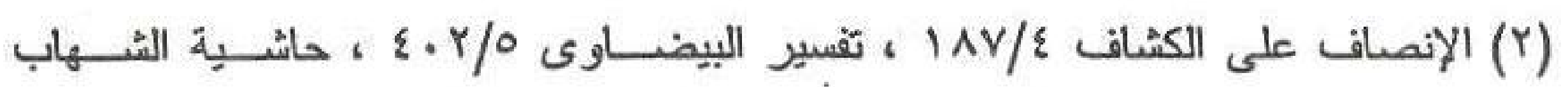

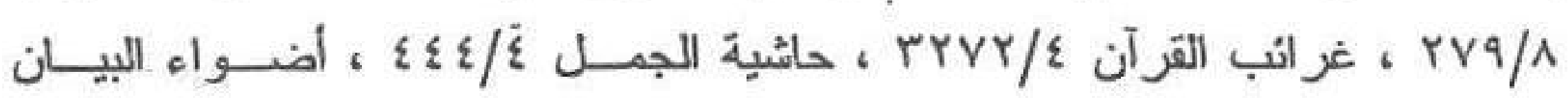
. TrT/A 


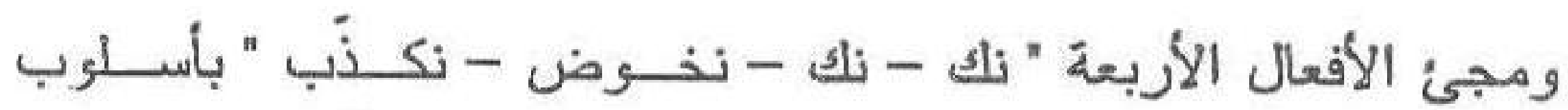

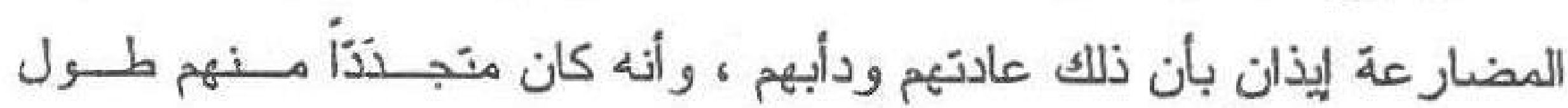
حياتهم ، فهم مستمرؤن على هذه الخصال السيئة لا يفارقونها . وقوله : " حتى أتانا اليقين ".. غاية للكور الأربعة العابقة ، والإتيان هنا

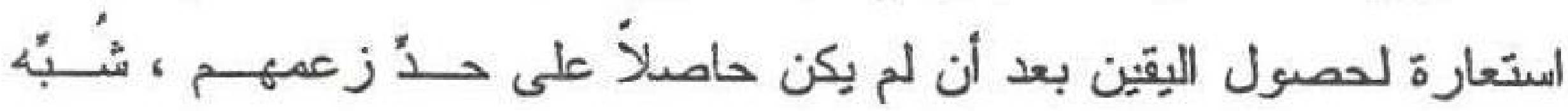
حصول اليقين ووقو عه بعد الاثتقاء بالمجئ بعد المغيب ، و المــراد : حنـى

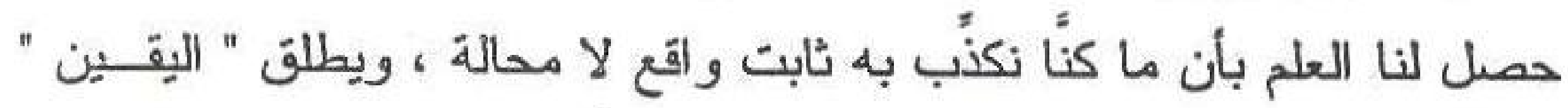

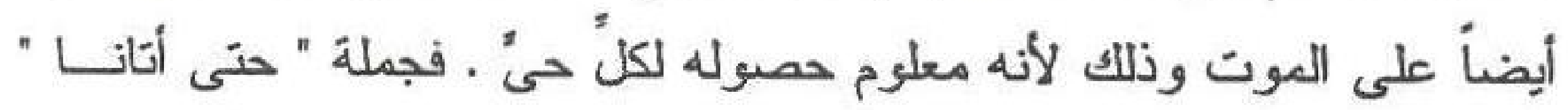
على هذا التقدير غايِة للكور الأربعة السابقة ؟، وعلى التقدير الأول غايــة لجملة " نكذَّب بيوم الدين " والمراد : كنًا نفعل ذلك مدّة حيانتا كلها ، ويجوز

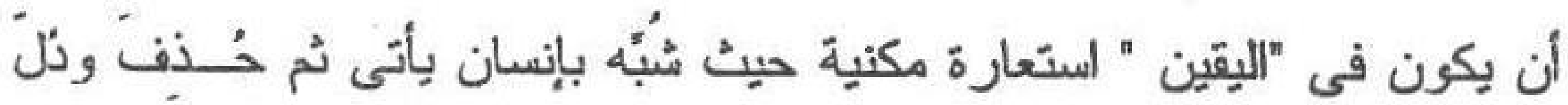
عليه بشئ من لموازمه وهو الإتيان .

وفى التعبير فى جانب إتيان اليقين بالفعل الماضى للدلالة على تحقيــن وقوعه وحصوله ، ولما كان بمعنى الموت كان معناه : فرأينا به مهـ كنــا ن نكره عياناً

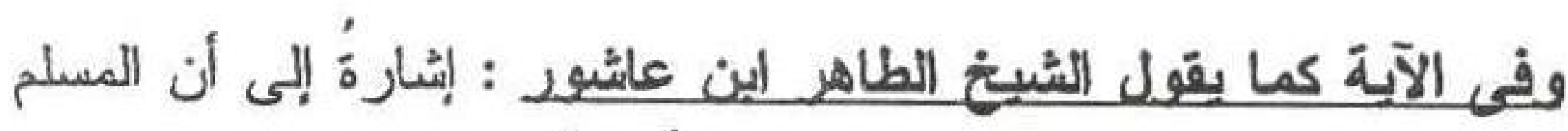

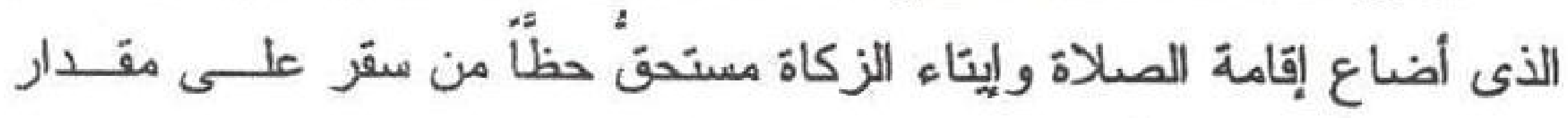

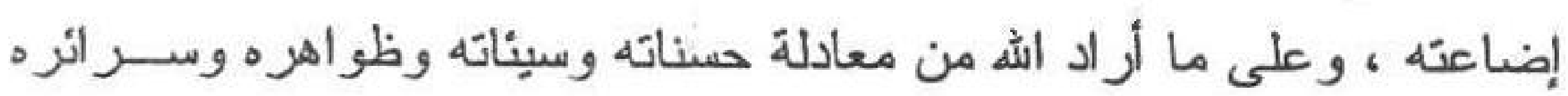

وقبل الشفاعة وبعدها (')

وقد اعترض ابين عطية على كون المر اد ب " اليقين " الموت ـ فقال :

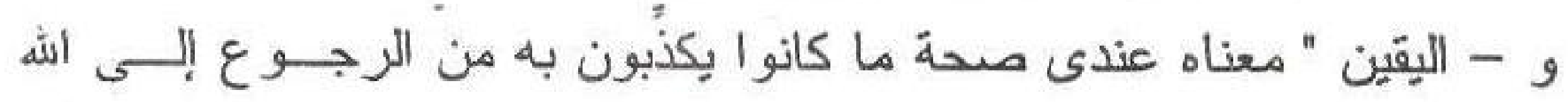


تعالى والدار الآخرة ، وقال المفسرُون : - اليقين - الموت ، وذلك عنـدى

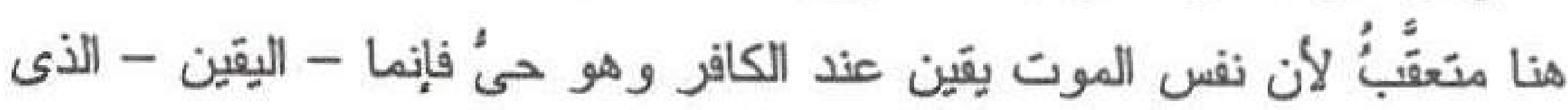

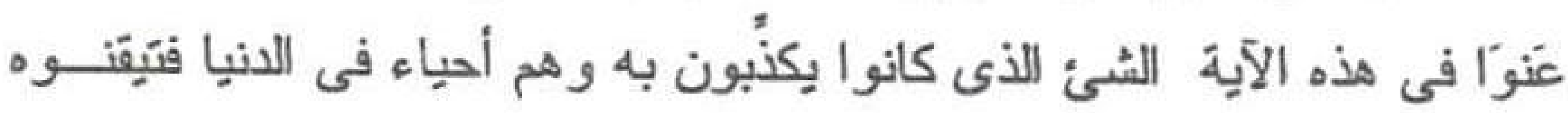

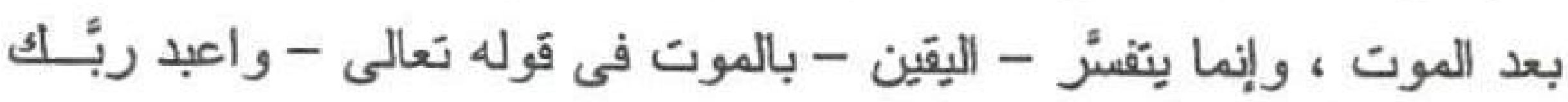

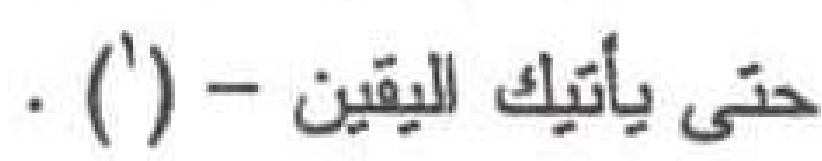
وبين الآيات : " الخائضين - الدين - اليقين " مـــا يعـرف بالســـع المرصنّع ، وقد نوّهنا إليه سابقاً ، وهو : " توازن الألفاظ مع تو افق الأعجاز أو تقاربها (")

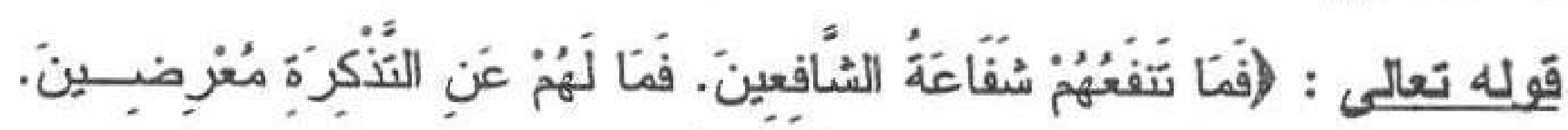

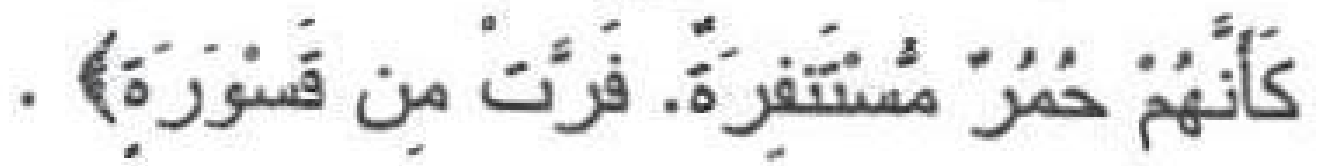

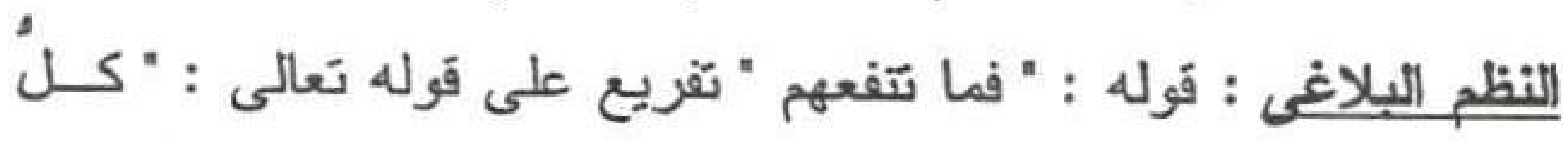
نفس بما كسبت رهينة " و المعنى : فهم دائمون فى الارنهان فى ستر ، و هذا بيان لغاية خسر انهم فحرم اله تعالى هؤلاء المجرمين الكـافرين أن نـــنـعهم الشفاعة فععى أن تتفع الشفاعة المؤمنين على أقدار هم ، وذلك أن فائدة زيادة

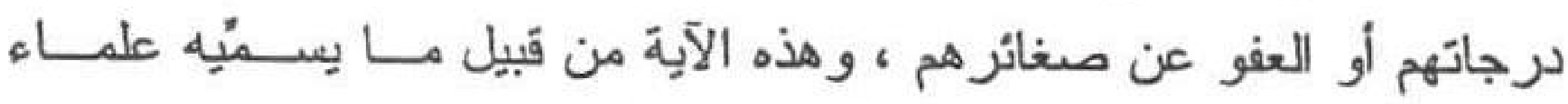

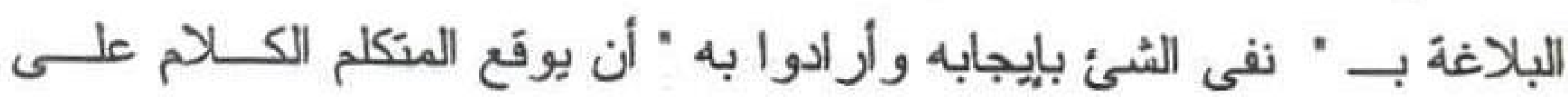

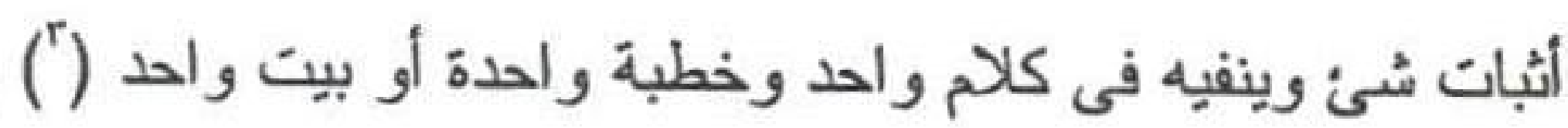

(1) الحجر / (1) ، المحرر الوجيز

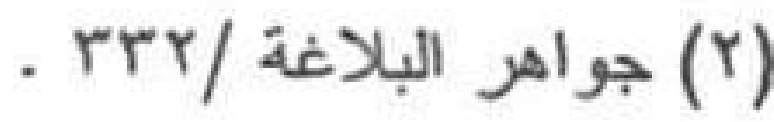

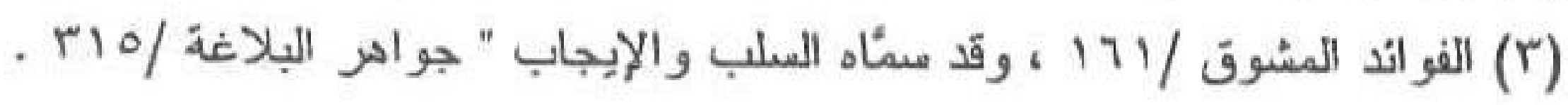




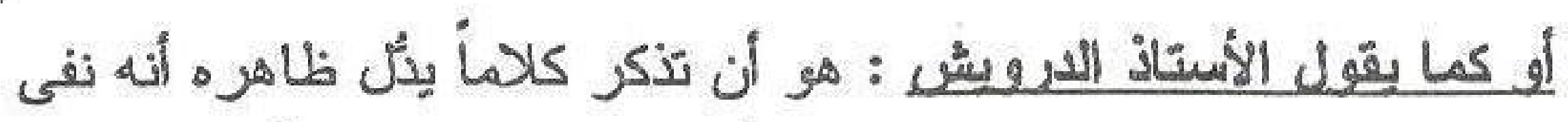

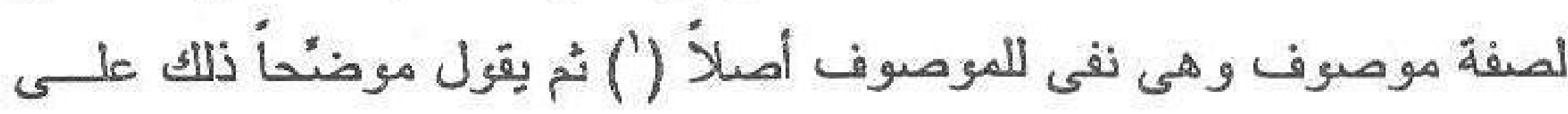

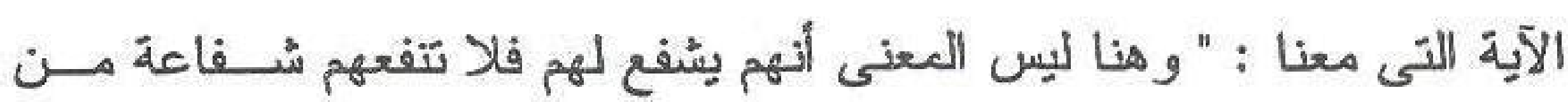
يشفع لهم، وإنما المعنى نفى الثفاعة فانتقى النفع أى لا شفاعة شافعين لهـم

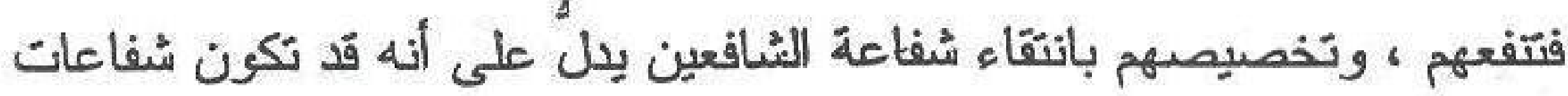

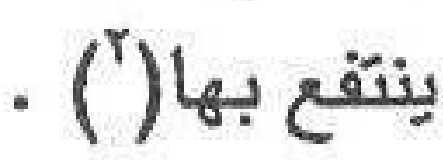

فأخبر الله تعالى فى هذه الآية أن " شفاعة الشافعين " لا تتفعهم فتقــرَّ من ذلك أن هناك شافعين ، و الأحاديث فى ذلك كثيرة (") . وأما ما ورد فى كتب المفسرين كابن عطية وغيره " يشفع الملائكة ثم

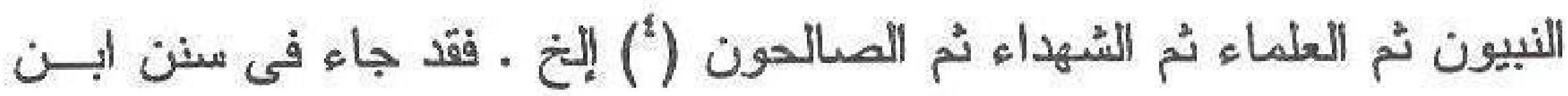

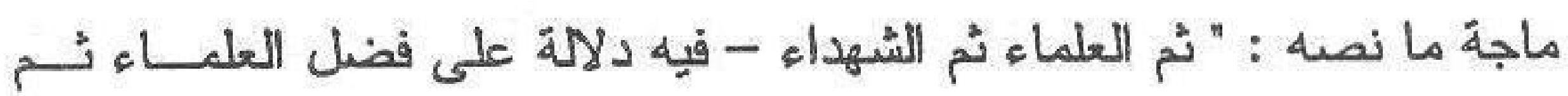
الشهداء ، لكن الحديث ضعيف ، ففى الزوائد فى إسناده عَلَّق بن أبى مسلم وهو ضعيف (") ، و أما ماروى أيضاً مثل : " يدخل الجنة بشُفاعة رجل من فئ فئ

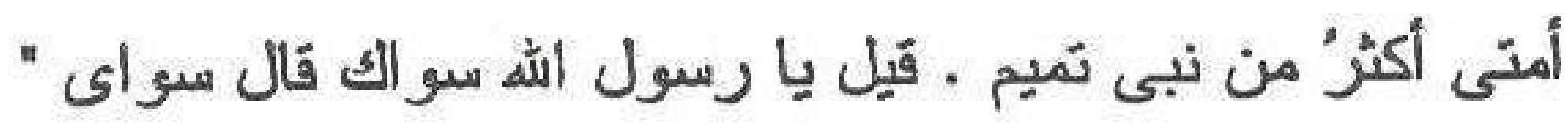

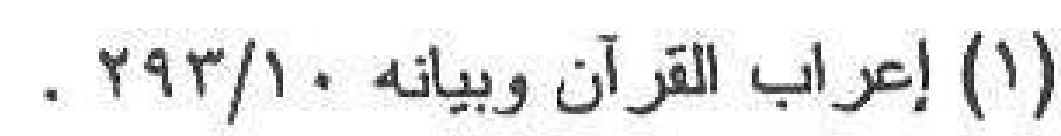

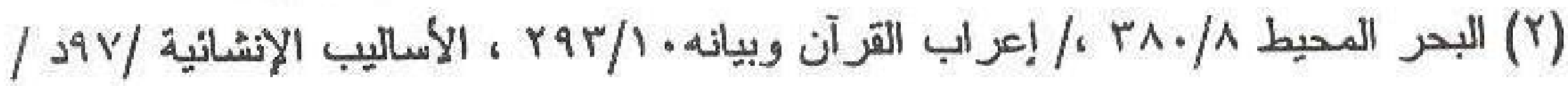

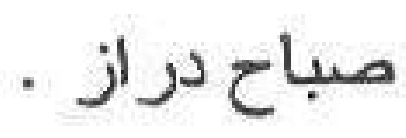

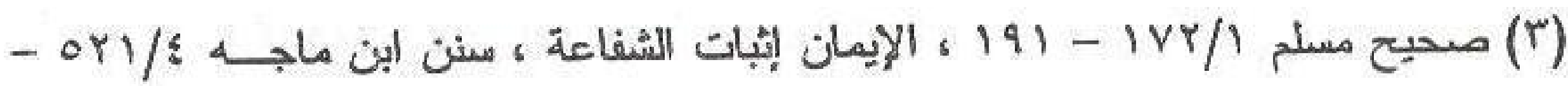

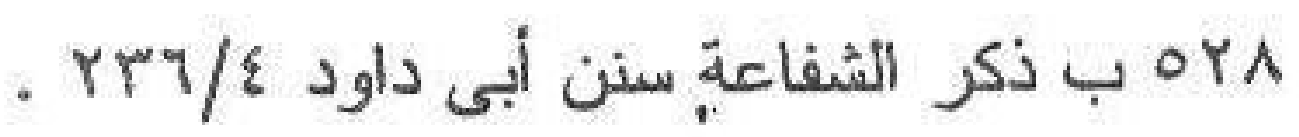

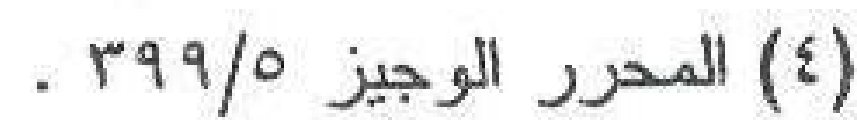

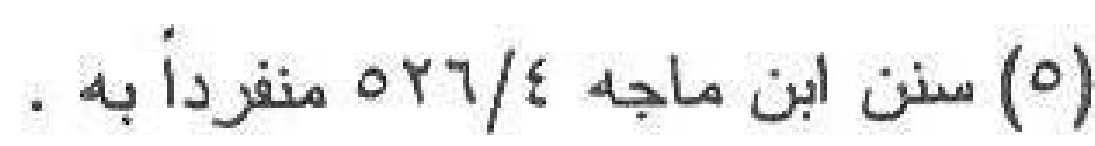




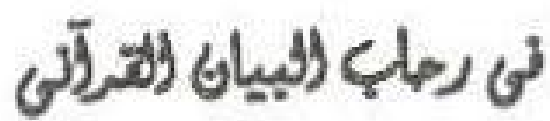

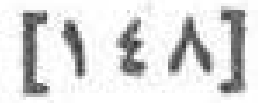

فقّد وصفه الترَمذئ بالحديث الحسن الصحيح الغريب من حديث عبد اله اله ابن أبى الجدعاء (') ، وكذلك حديث الحسن البصرى قال قال رسول الله 

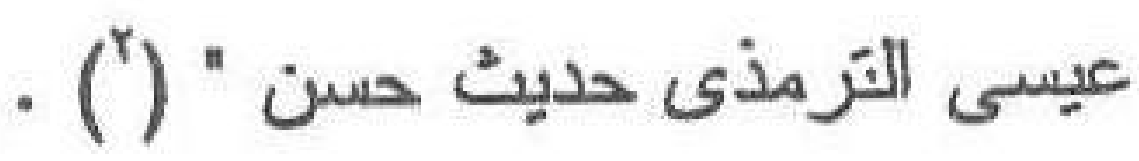

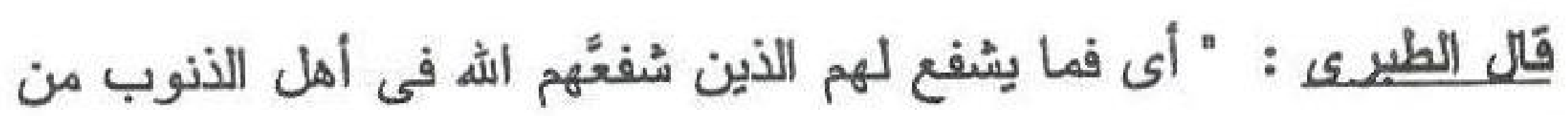

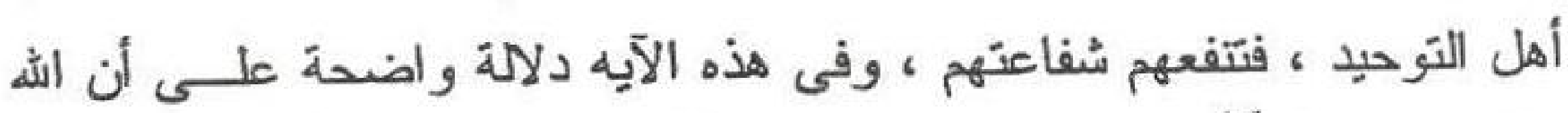

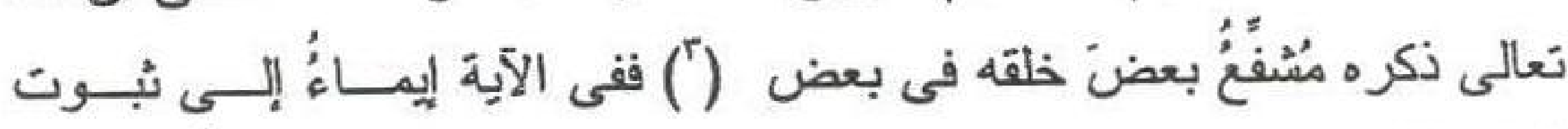

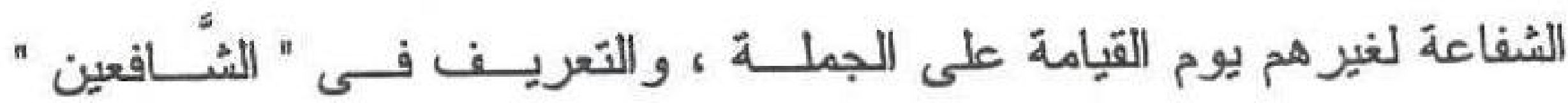
لاستخراق الجنس و هو أبلغ و أنسب بالمقام .

وقوله تعالى : " فما لهم عن التذكرة " تقريع للتعجيب من إصــــرارهم

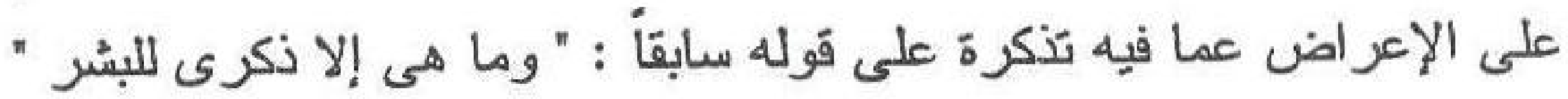

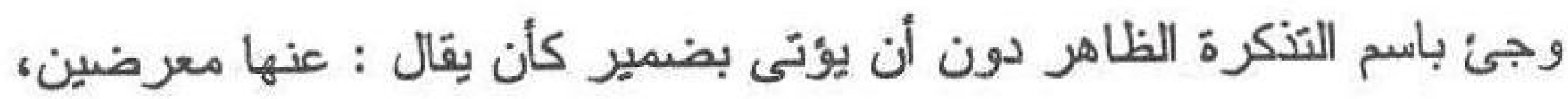

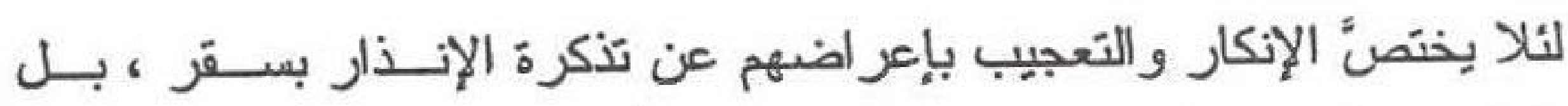

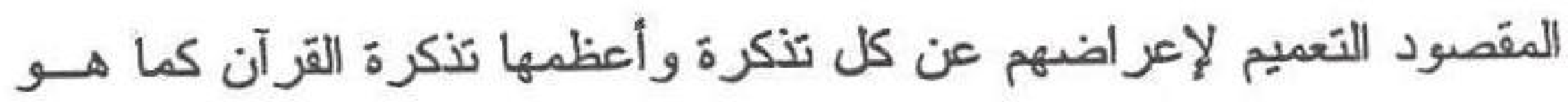

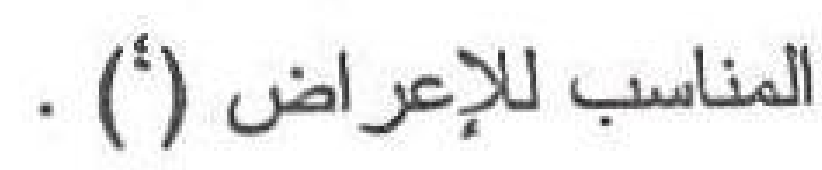
ولما ذكر الله تعالى قبائح المجرمين وشنائعهم عاد ســبحانه بـالتوبيخ

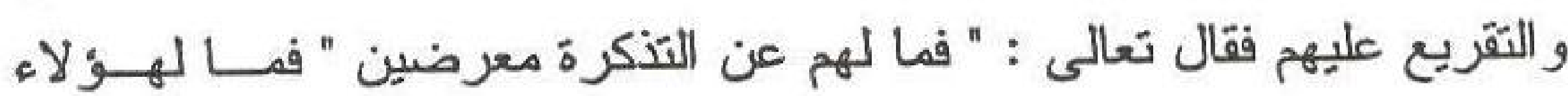

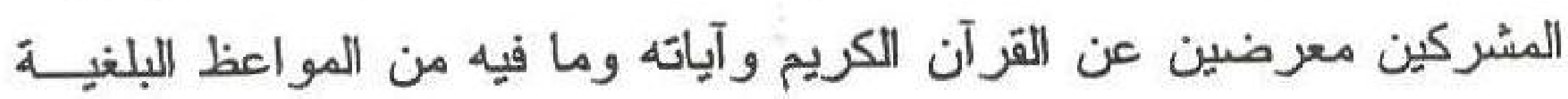

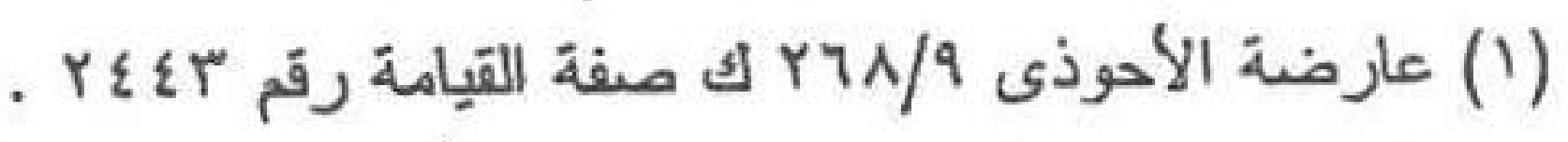

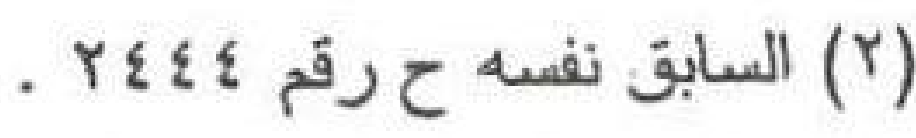

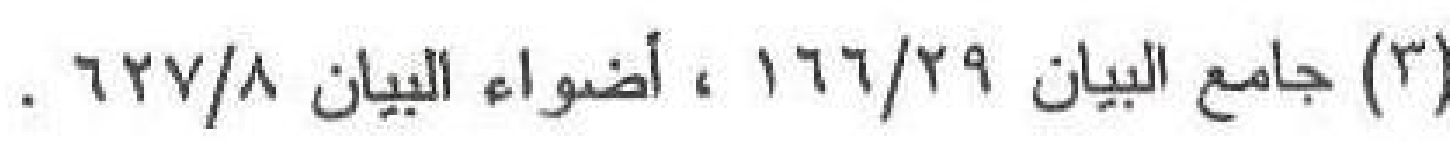

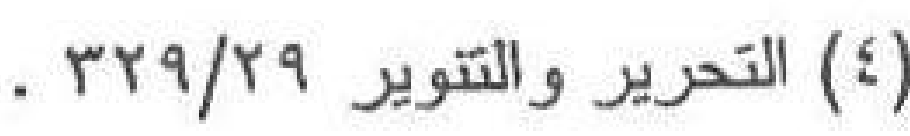


و النصائح والإرشادات المفيدة الهادنة ؟ وقد جاءت هذه الآيّة للتعجيــب مـن إعر اض الكفار عن التذكر و التكبر ، وأسلوب "مالهم " اســـفهامئ إنكــارئ

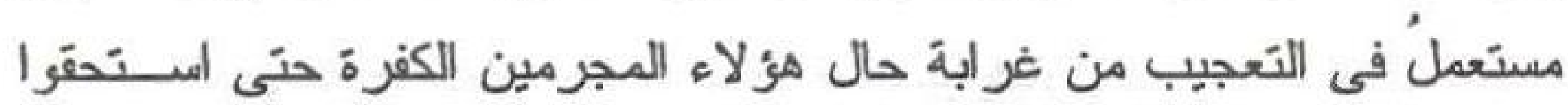
أن يستفهم عن هذه الحالة المستفهمن وهو أسلوبُُ مجازئُ من قبيل المجار المرسل بعلقة اللزوم وهو إنكار إعر اضهم بإنكار السبب الحامل على هـذا

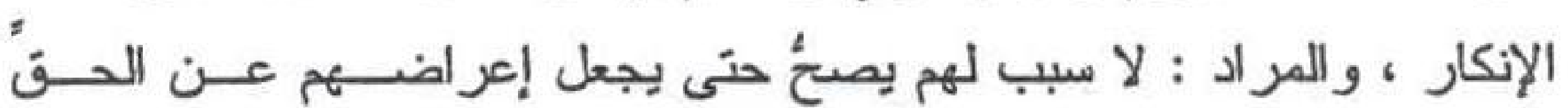
صواباً

" و إنكار السبب ونفيه يقنضى إنكار المسبًّب ونفيه ، وهو هن الكنايات الموسومة بالطاقةَ والأقةَة ، وهو إنكار الواقع الذى هم عليه ويردف على هذا الإنكار التجهيل و التسفية (') يقول الاكتور صبّاح مبيناً أن التعبير بــ " مالى " بعدٌ : " إنكارأ لدــال المتكلم بعده ، كناية عن إنكار الفعل من باب أولى ، وأنه قد جاء فى أساليب - مالى - إنكار وتعجيب من حال المخاطب أو من الحال الو اقعة بعده عبومأ

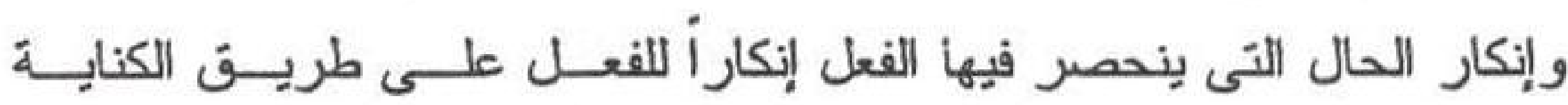

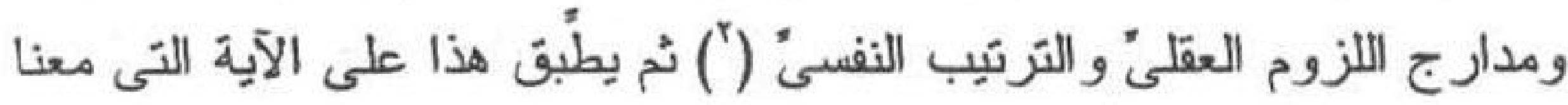
فيقول : " كقوله تعالى عن مشركى العرب : - فما لهم عن التذكرة معرضين

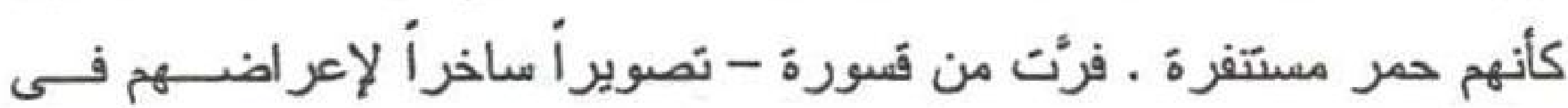
هيئات قافزة نافرة مندفعة هلعة كحمر الوحش انضاف إلى نفارها الذاتى” نفار' 
حلع للقلوب أقوى من نفار ها الطبيعى حين ترى وتســمع زئيــر القســورة

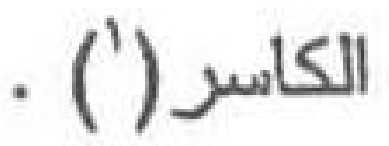

ونر اه في موطن آخريزيد الأمر وضوحأ فيقيل : " والتعبير - مال

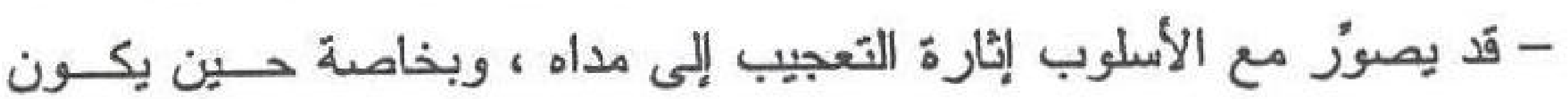

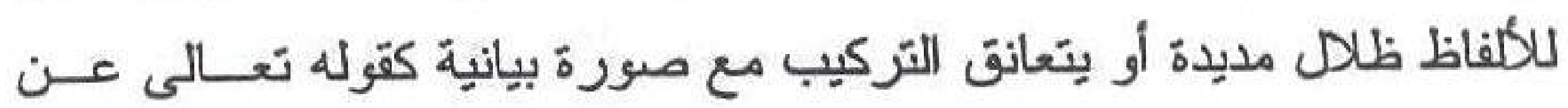
كفار قريش : - فما لهم عن التذكرة معرضين - الآيات ـ فقد جاهيت الآيــة

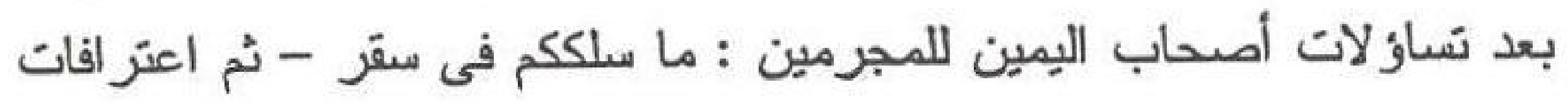

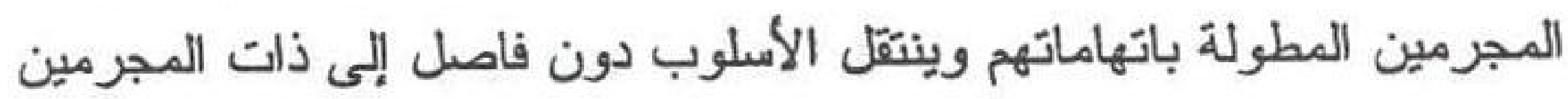

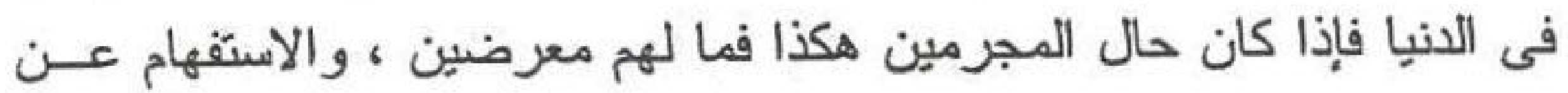

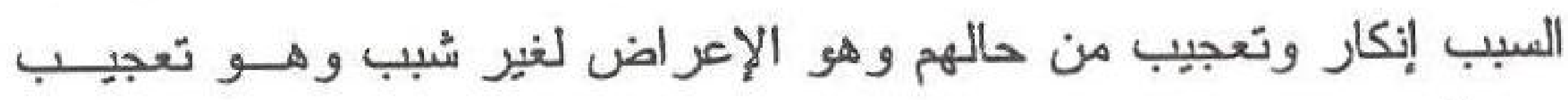

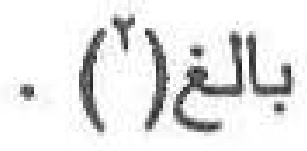

و الفاء فى قوله : فما لهم " لتزتيب إنكار إعراضهم عن القرآن بغيـر

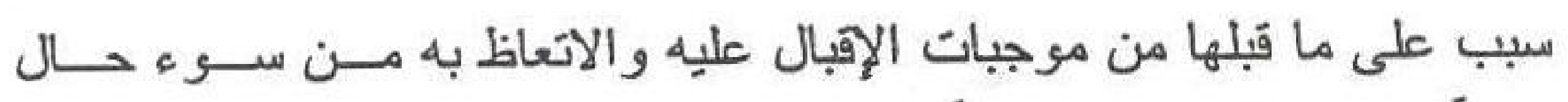

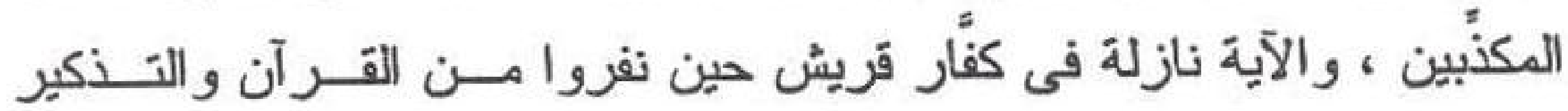

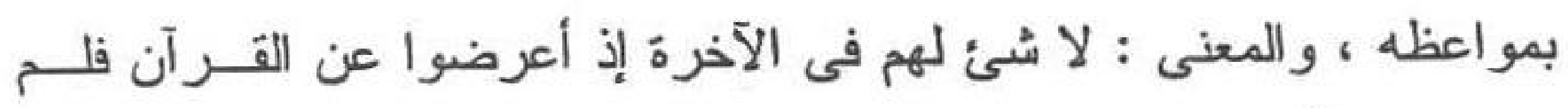

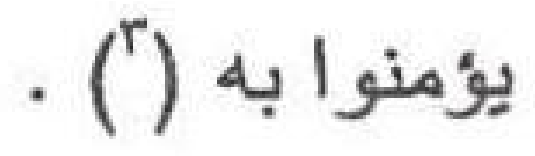

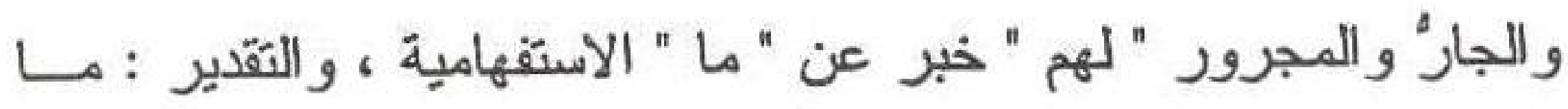

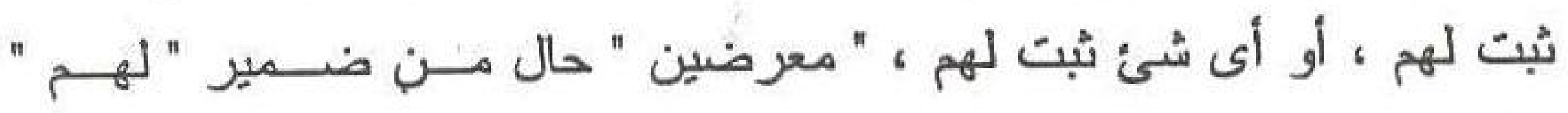

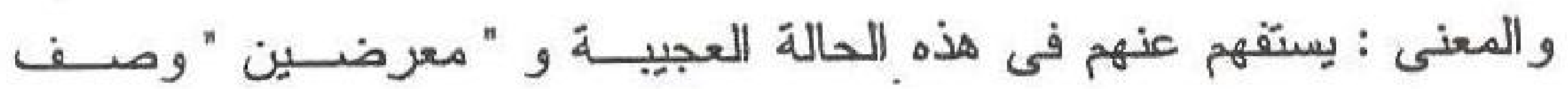

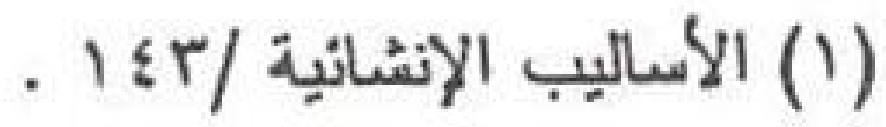

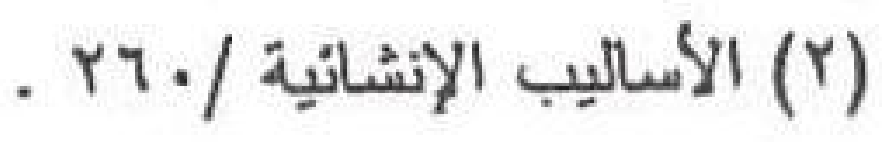

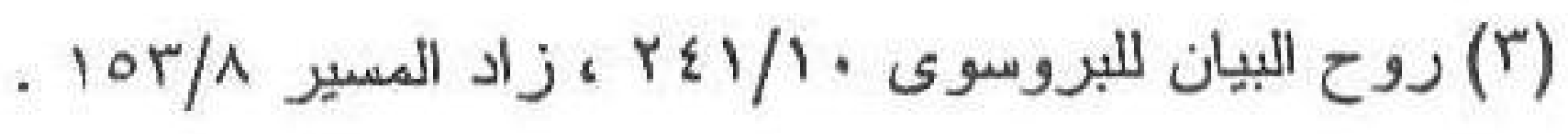


للأشخاص أنفسهم فلا يصحُ كونه وصفاً لأسباب الإعر اض هو " عن التنكرة " منعلقة بـ " معرضين " و التقديم للعناية مع رعاية الفاصلة أى فإذا كان حال

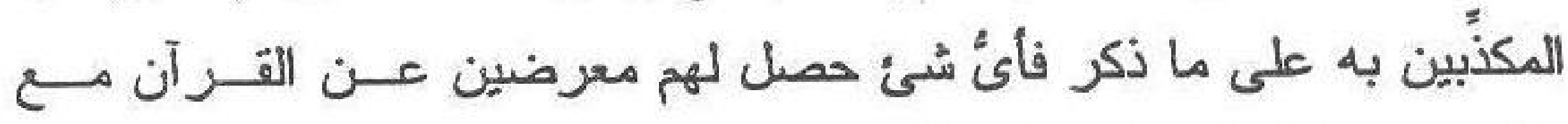

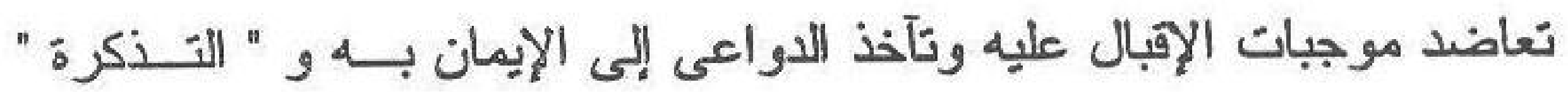
مصدر بمعنى التذكير أطلق على ما ذكرناه و هو القزآن للمبالغة (') . و " التذكرة " كناية عن الدعوة إلى الإيمان باله ومالأكته وكتبه ورسله

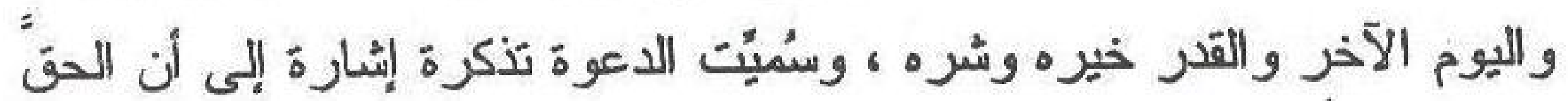
المدعو" إليه من الظهور بمكان يكفى فى الدعوة إليه مجرد النذكير كما يذكر الناس بشئ هو به عالم () (1) وقوله : " كأنهم حمر مستفرة . فرَّت من قسورة " حال من الضــمير

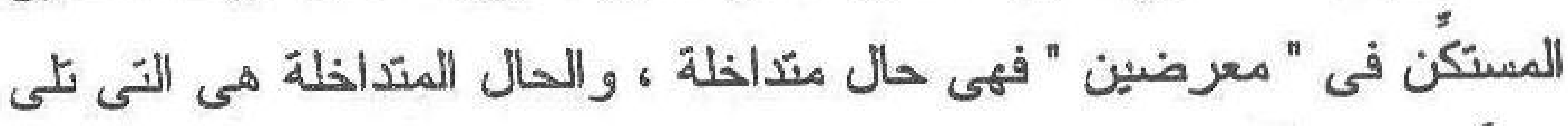

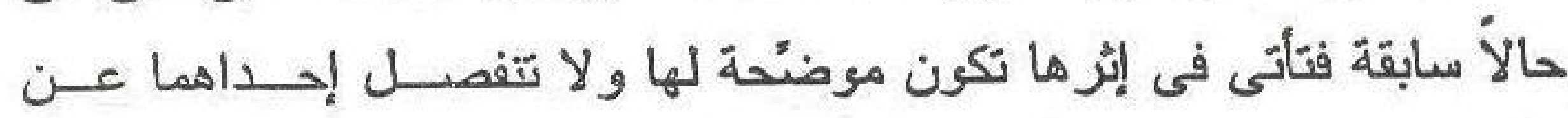

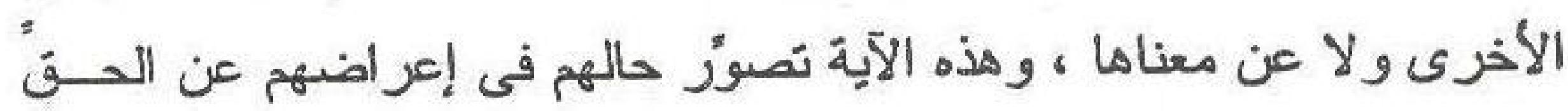
واللتولى والابتعاد عن المنهج العوى" ، فهو لاء يفرونْ من الداعى، ويعرضون

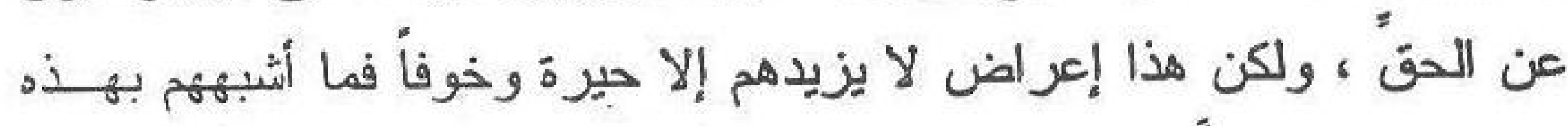

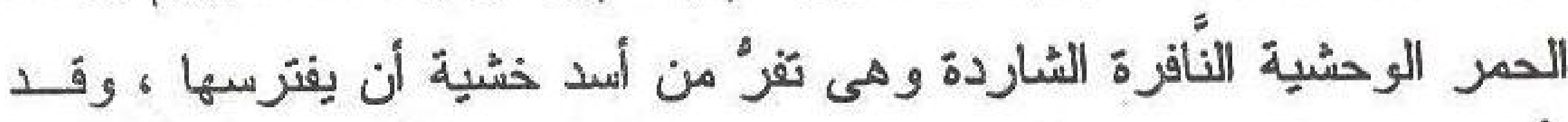

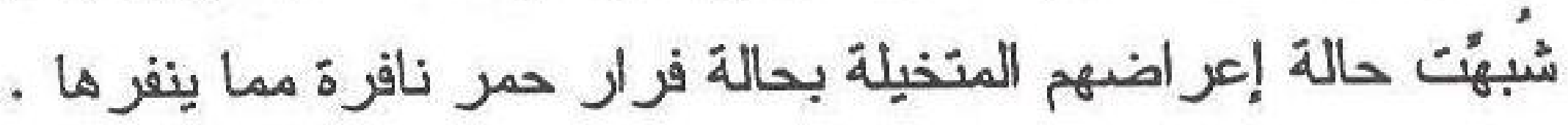

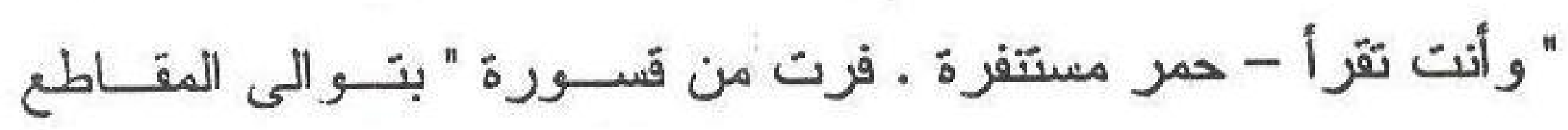

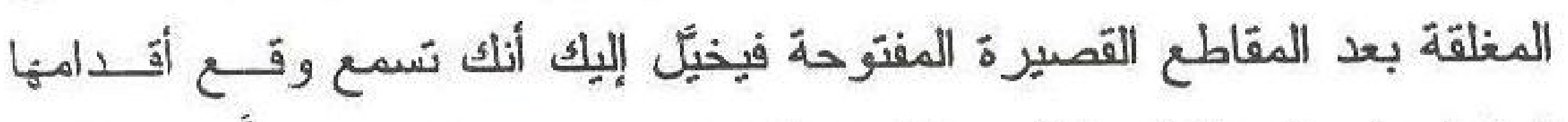

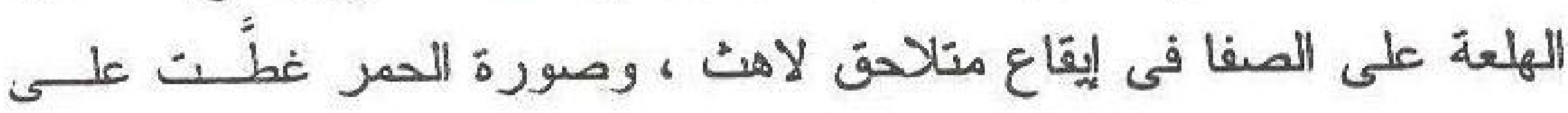




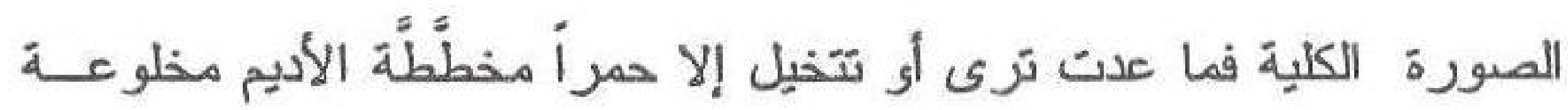

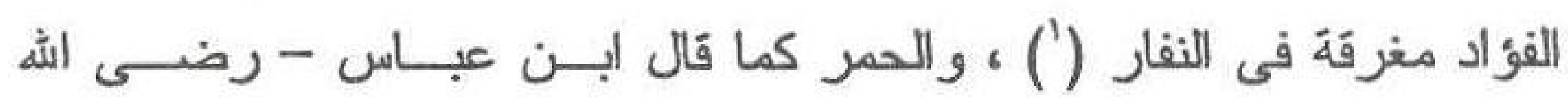
عنهما - : هى حمار الوحش وهو شُديد النفار إذا أحس بصوت القانص فهو

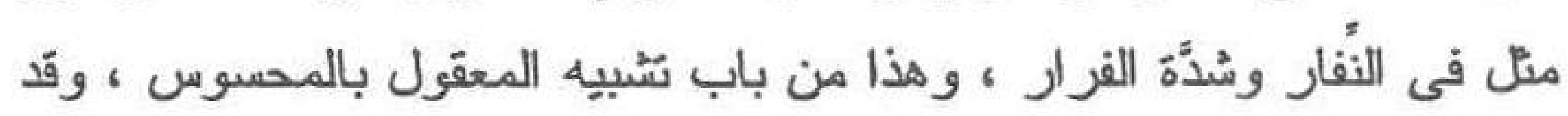
كثر فى الشعر العربى وصف النفرة وسرعة السير والهروب بالوحش مـنـ

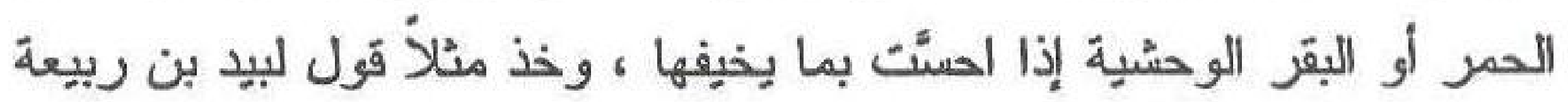

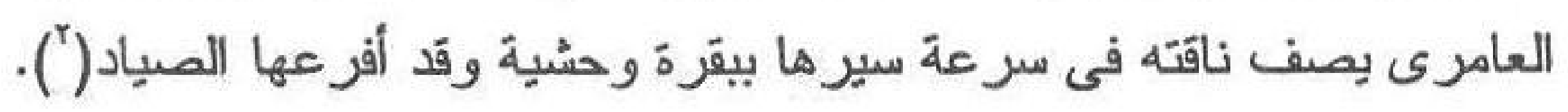

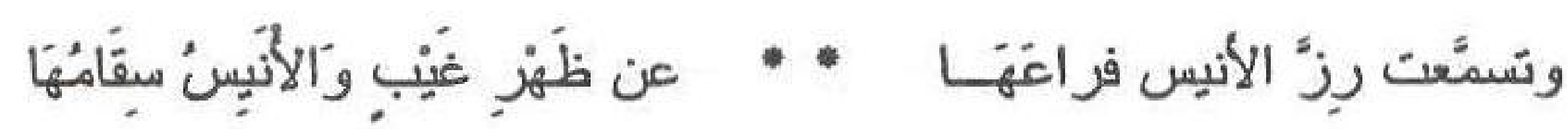
" وقد جاء - معرضين - حال بعدها - حمر مستتفرة - حال منها فهى "

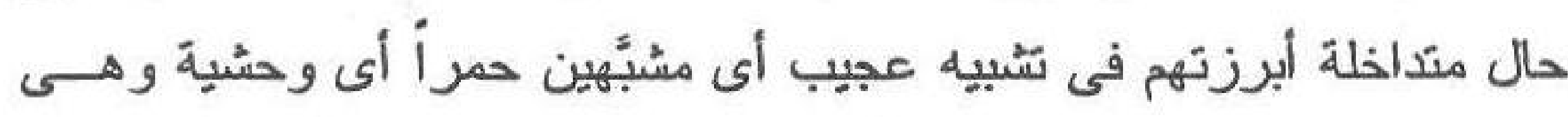

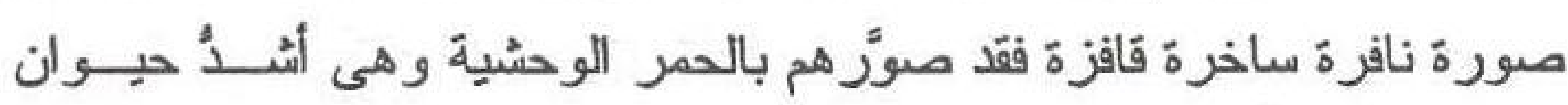

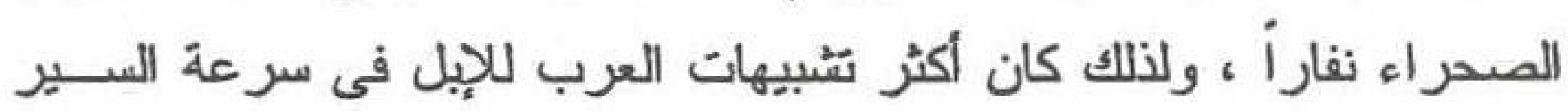

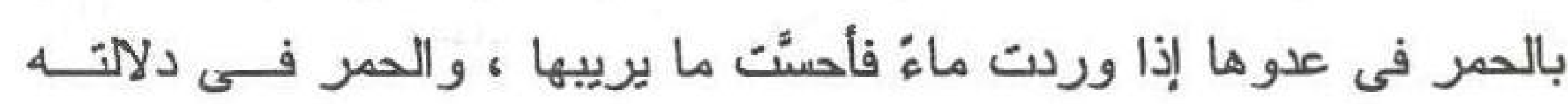

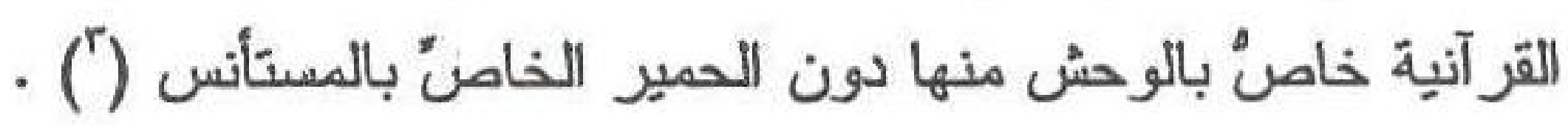
و السين و التاء فى " مستتفرة " للمبالغة فى الوصف من استنفر بمعنى

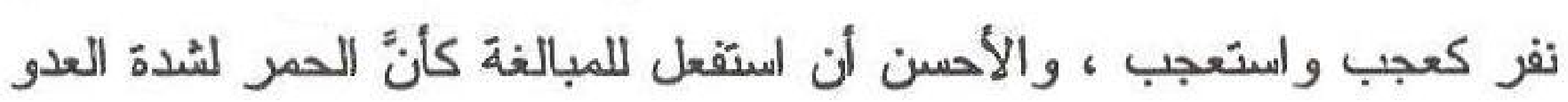

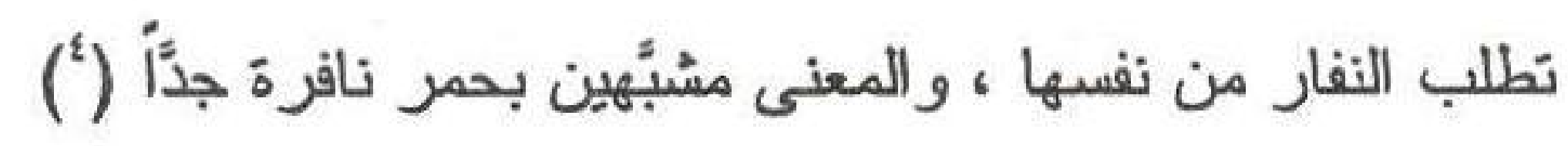

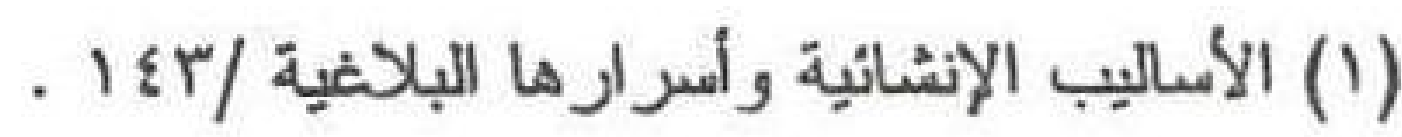

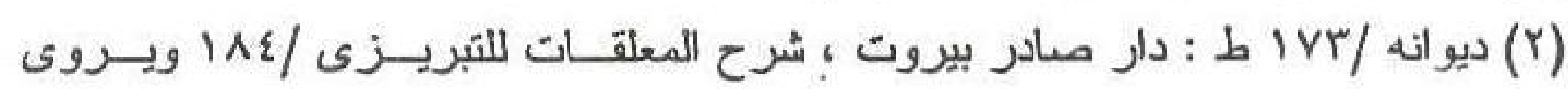

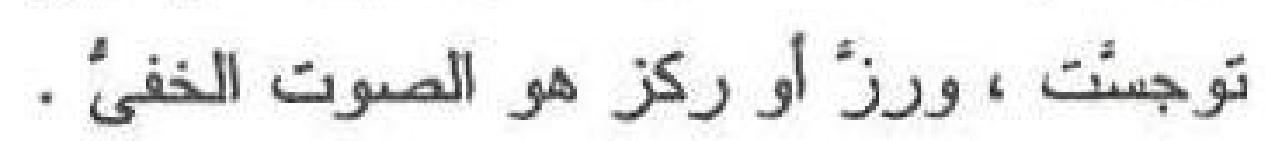

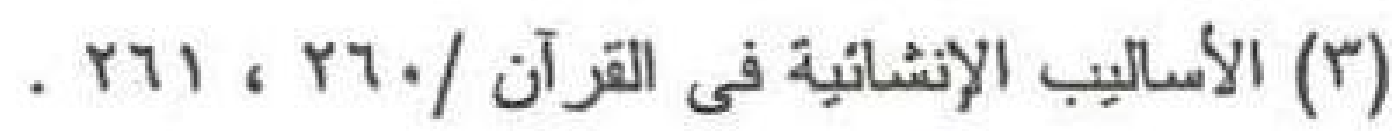

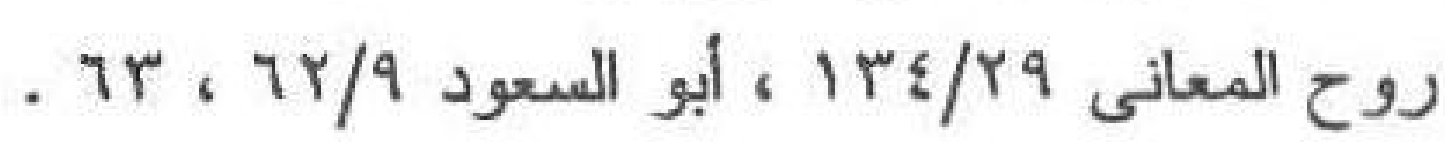




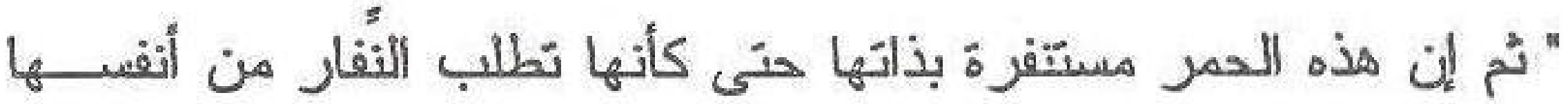

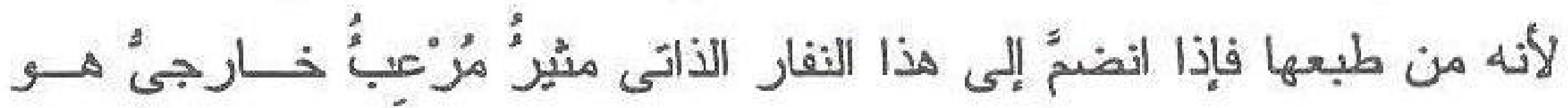

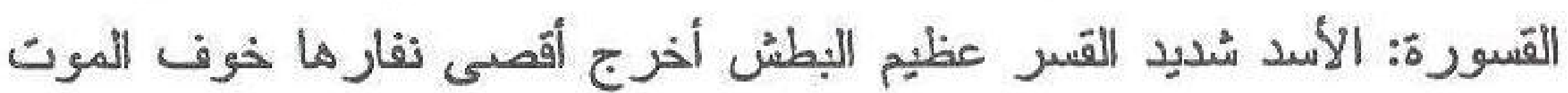

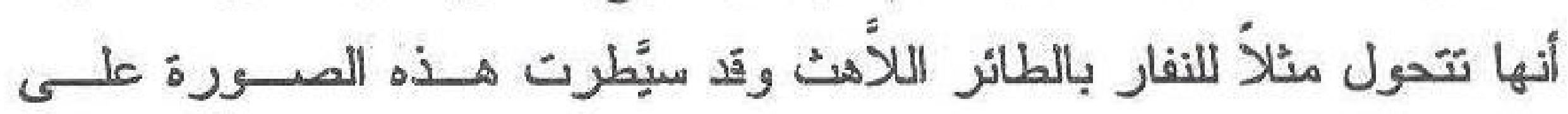

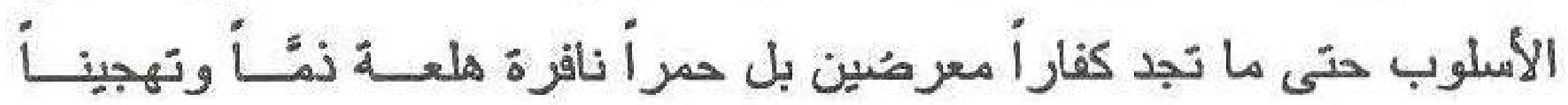

(') وتعجيباً

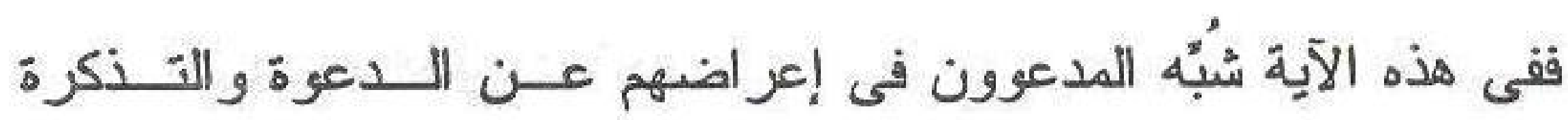

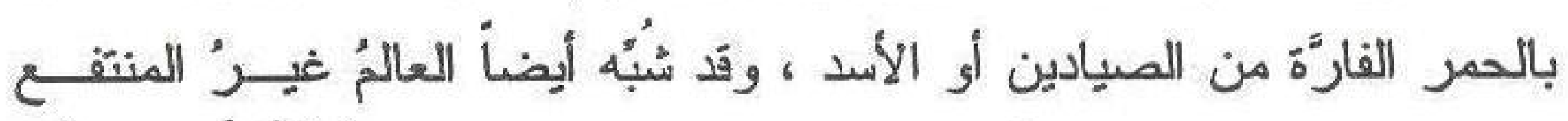

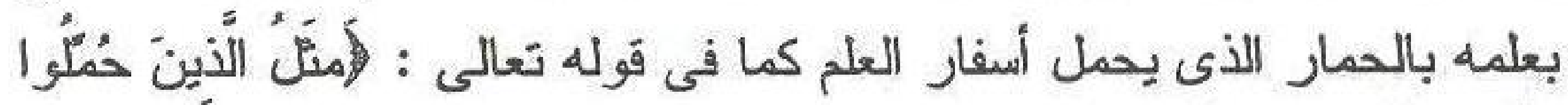

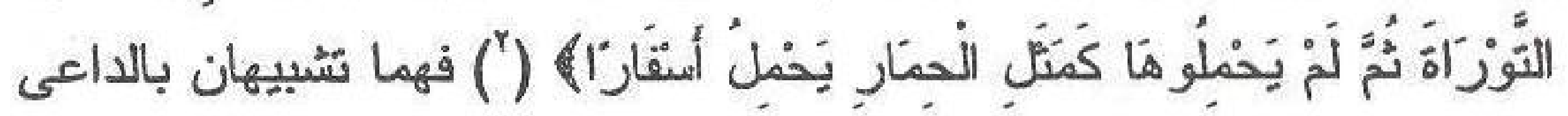
والمدعو إذا لم تتفعه الاعبة .

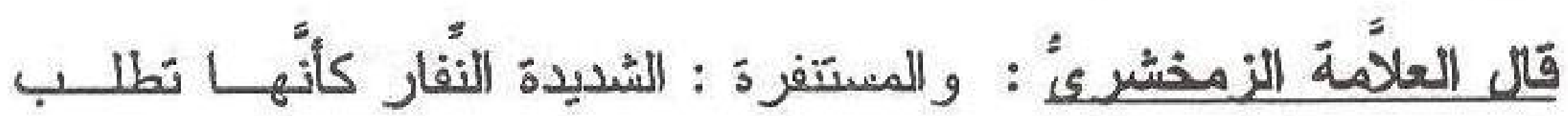

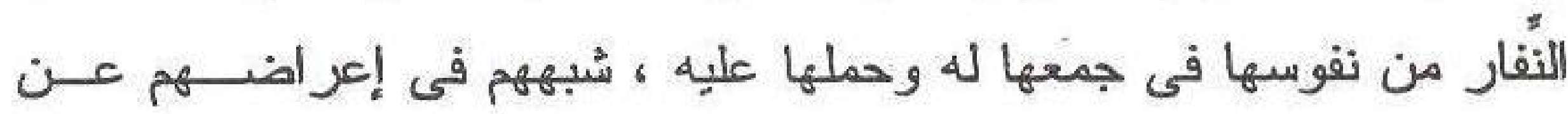

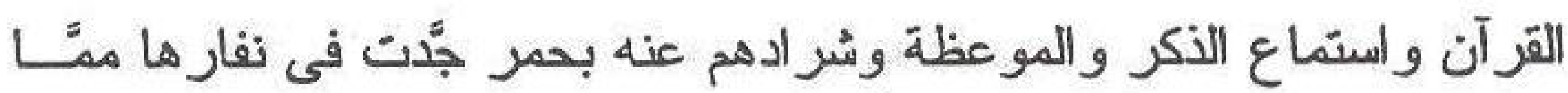

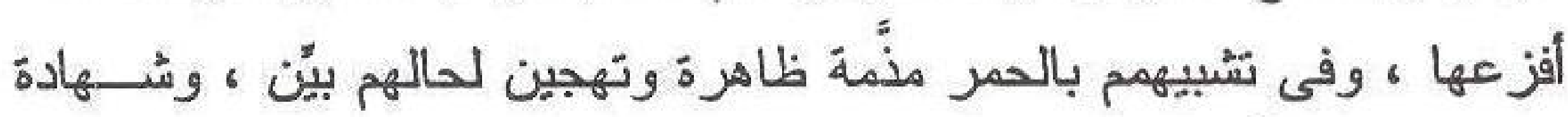

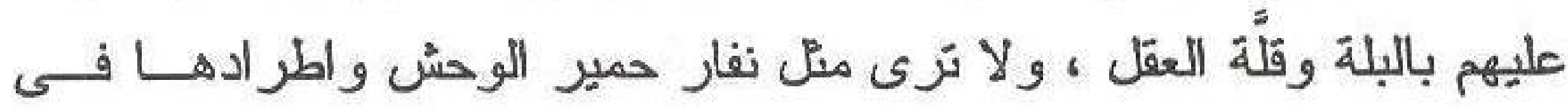
العدو إذا رابها رائب ، ولذلك كان أكثر شبيهات العرب فى وصف الإبـلـل وشدة سير ها بالحمر وعدو ها إذا وردت ماء فأحسيّت عليه بقانص (r)

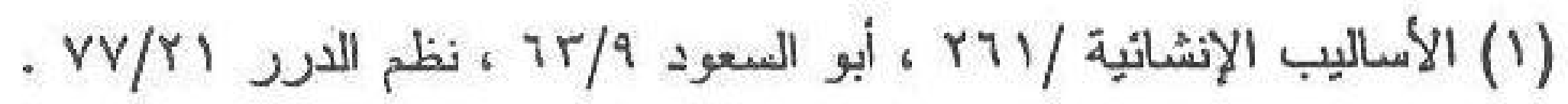
. . $111 / \varepsilon$ الكثاف (r) 


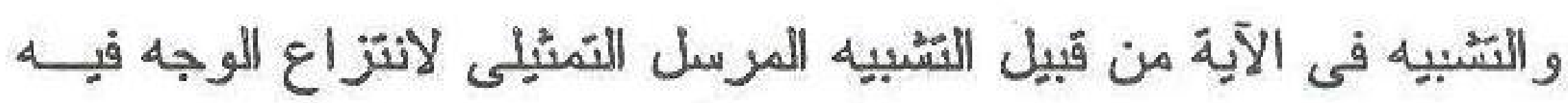

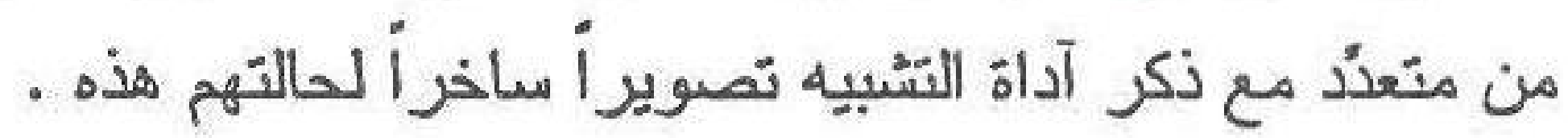

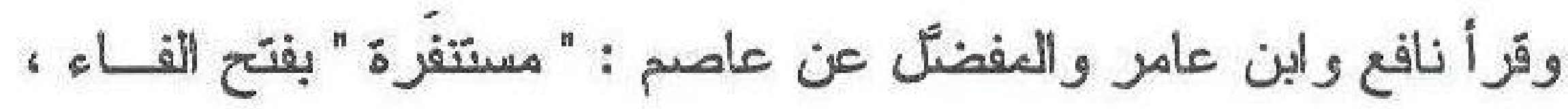

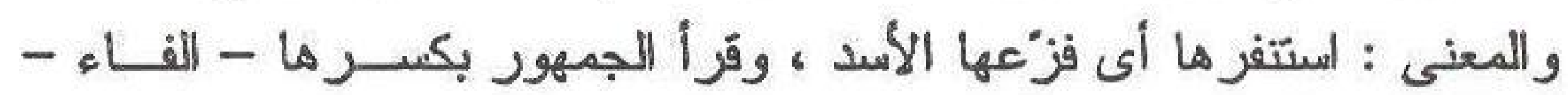

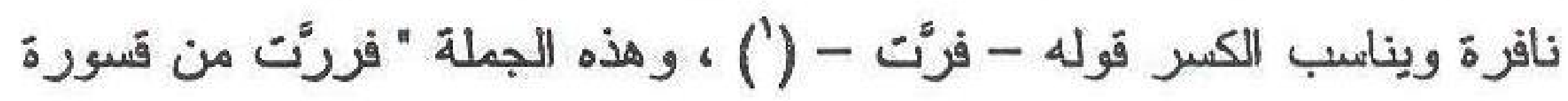

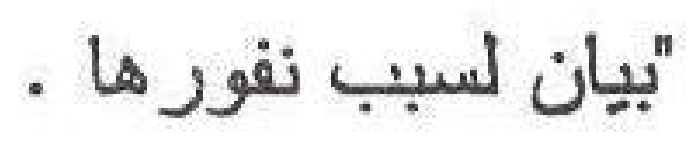

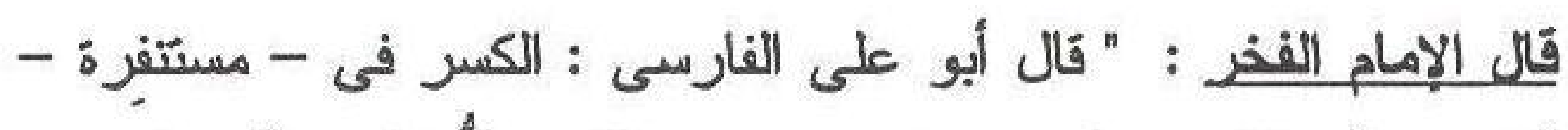

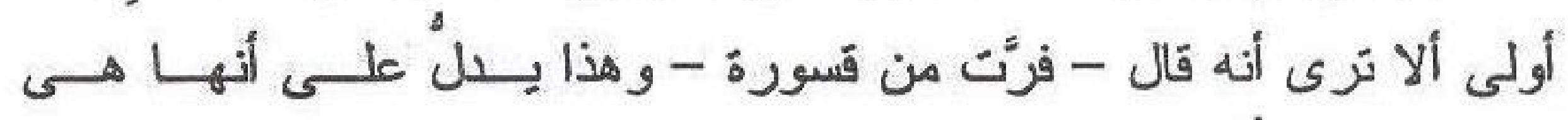

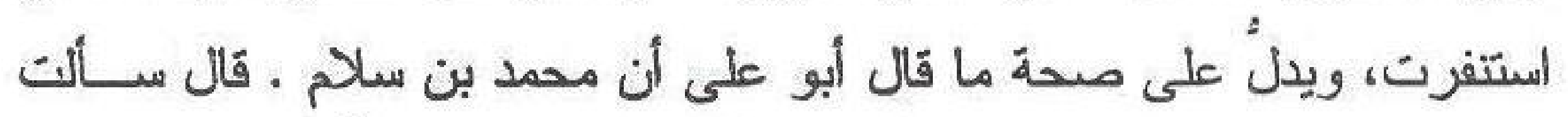

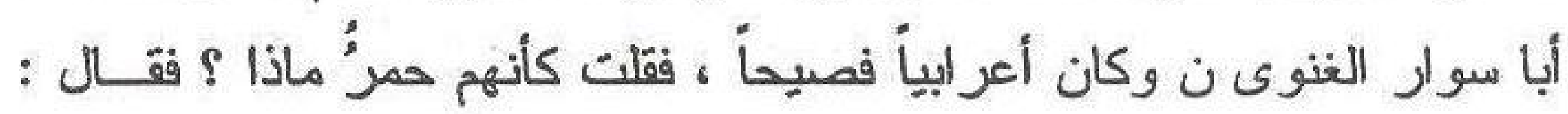

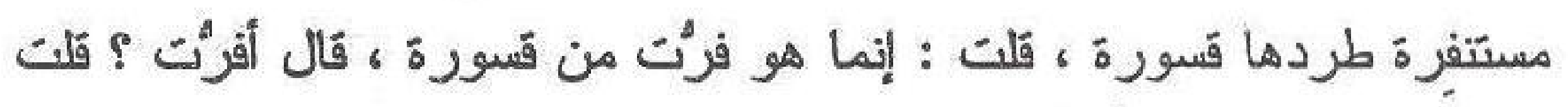

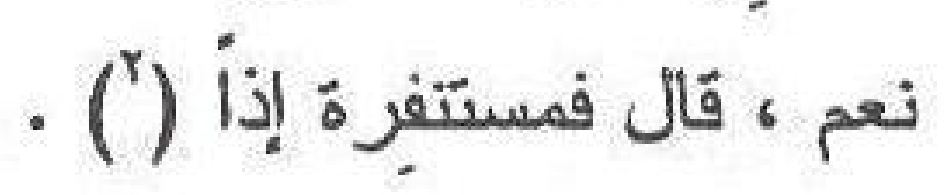

و " القسورة " من القسر والغلبة والقهر . قيل : هو الأســـ ، وقيــل :

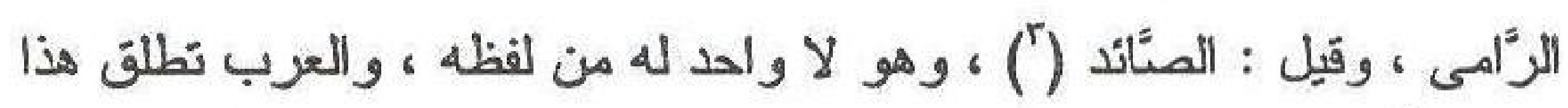

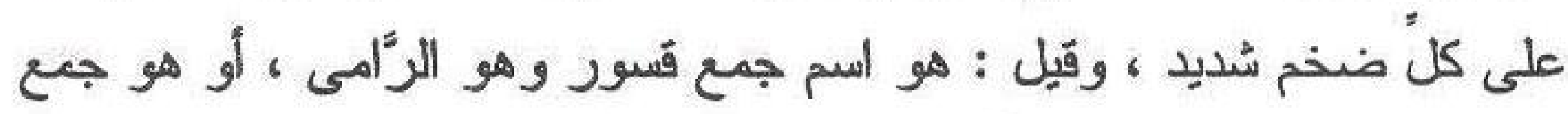

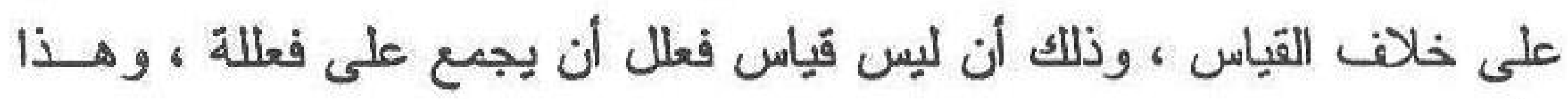

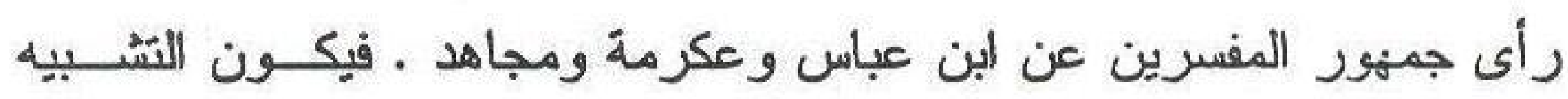

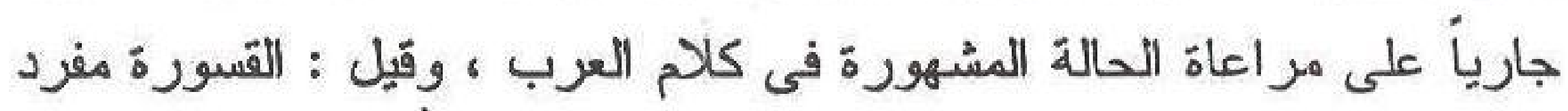

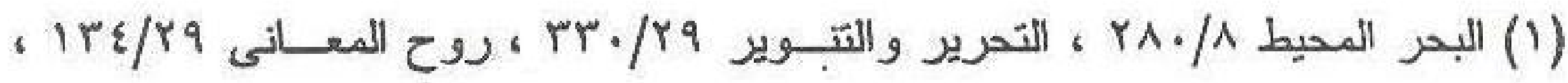

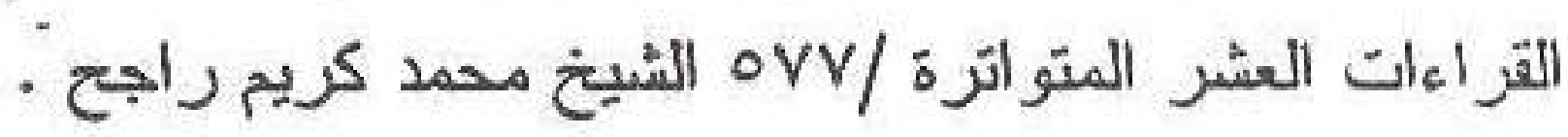

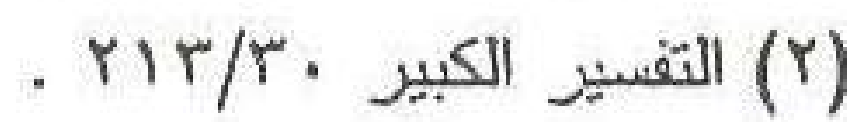

$$
\begin{aligned}
& \text { (r) المفر:ات / }
\end{aligned}
$$




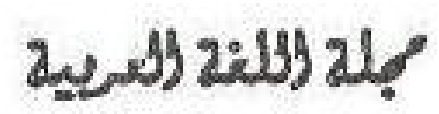

\section{[100]}

وهو الأسد ، وقال ابن عباس : إنعا الأسد بالحبشية ، فيكون اختلاف قول ابن

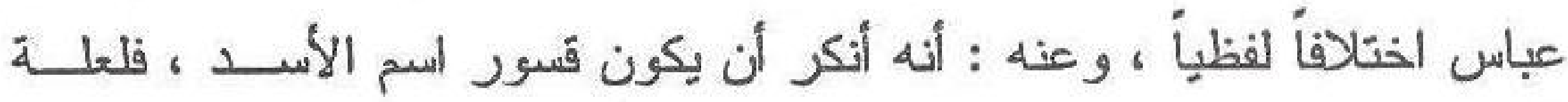

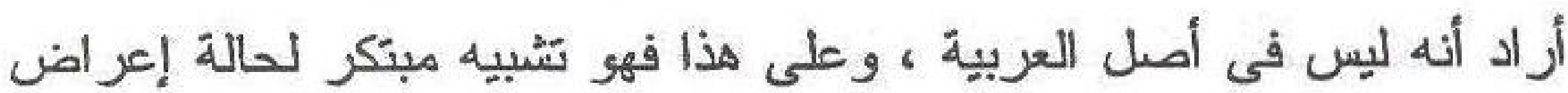

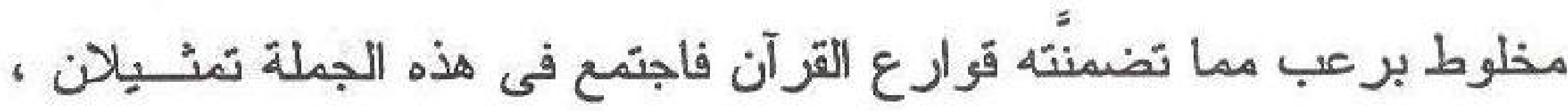
و إيثار لفظ - قسورة - هنا لصلاحتيته للتشبيهين مع الر عاية على الفاصلة

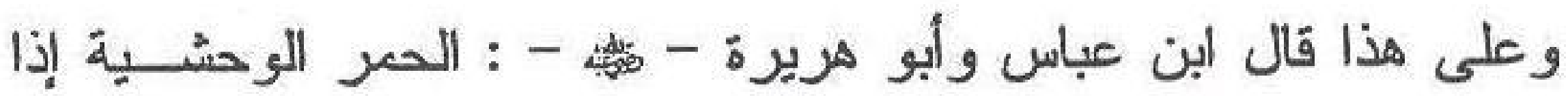
عاينت الأسد هربت منه ، كذلك هؤلاء الكفار إذا سمعوا النبى - مئى - يقر أ

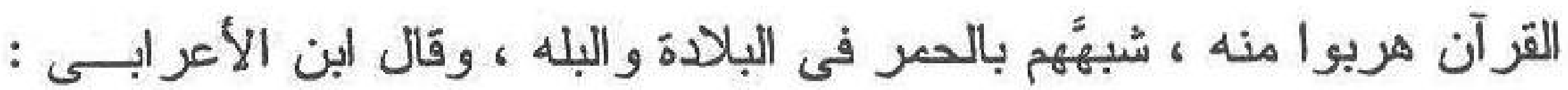

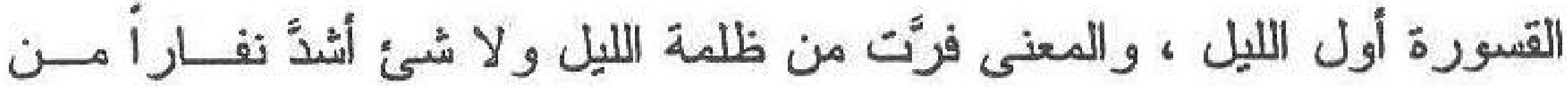
حمر التوحش ، ولذلك شبهََّه بها العرب فى سرعة سير ها وخفتها (") . يقول د / فْضل عباسى : " إن التشبيبه هنا مع ما فيه من إيداع التصوير

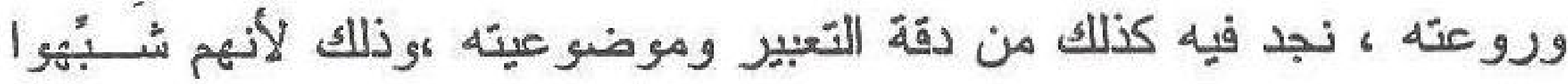
بالحمر ، والحمر مثال فى البلادة ثم هم قد فرؤوا من قسورة ، وفى هذا إيحاء

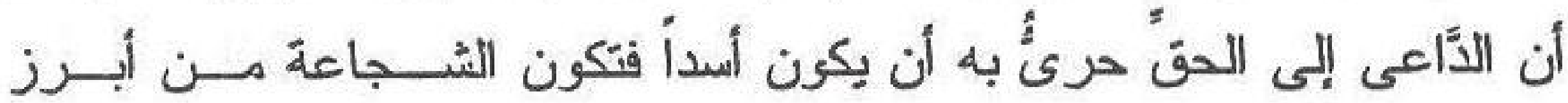

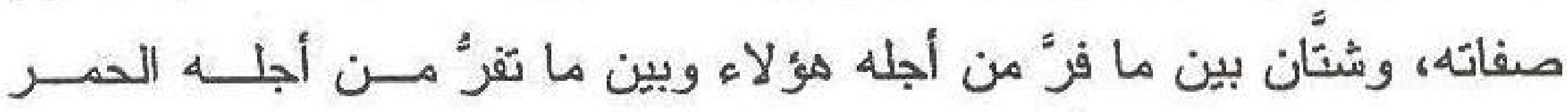

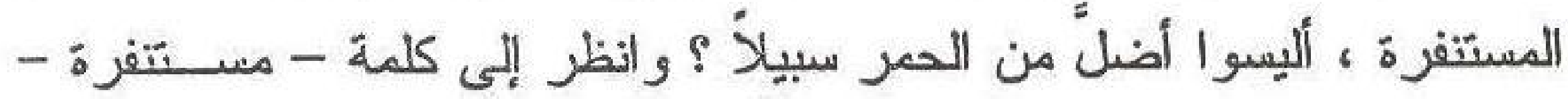

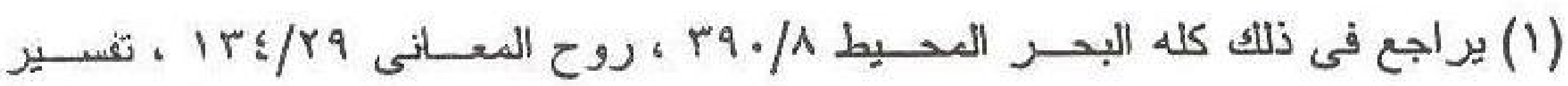

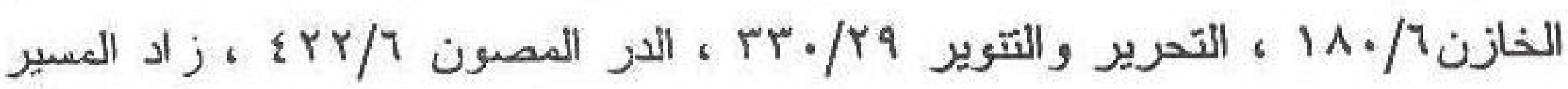

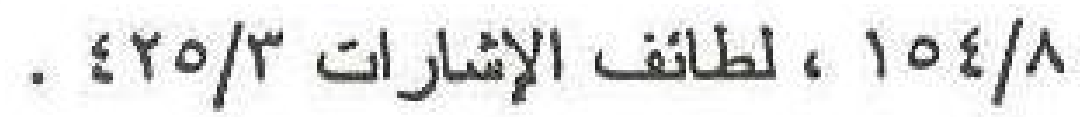

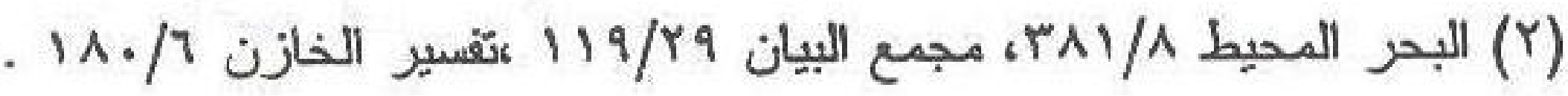


وما فِيها من السين و التاء ، وكلمة - فرُّت - كل هذا وغيره من الخصائص التى لها عملها فى النفس وتأثير ها فى القلب (')

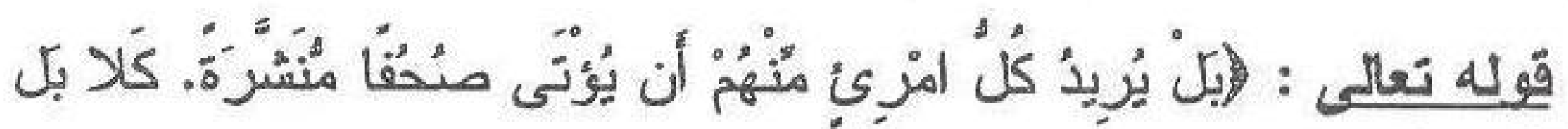

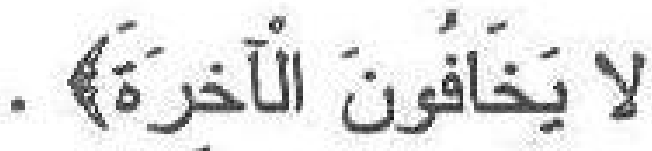

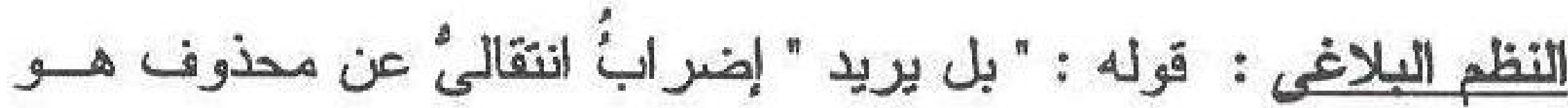

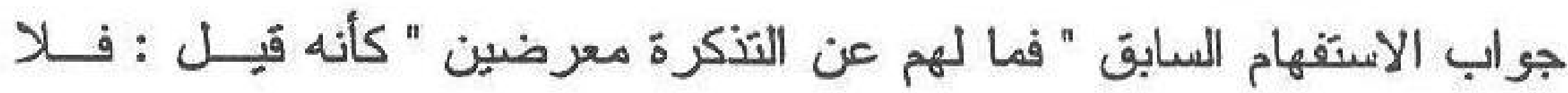

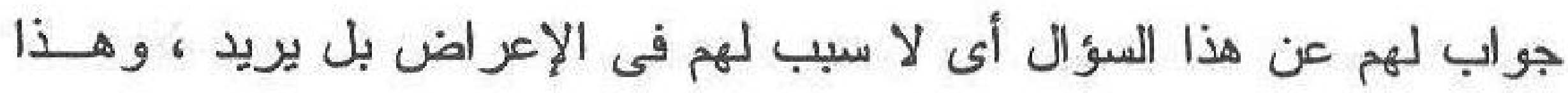

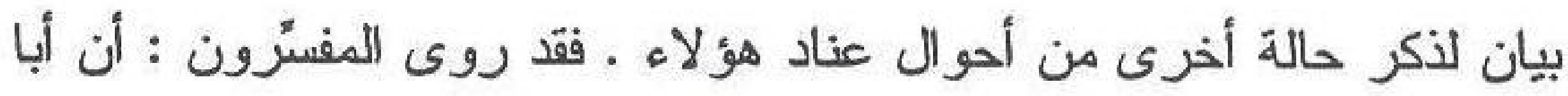

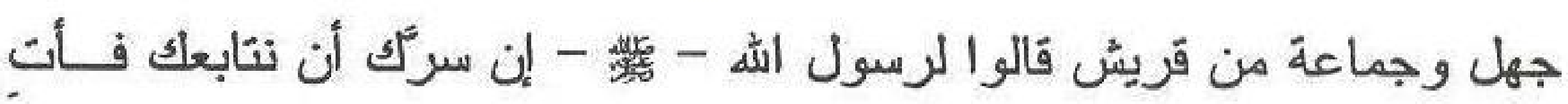

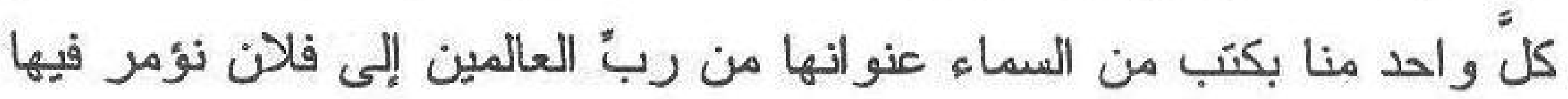

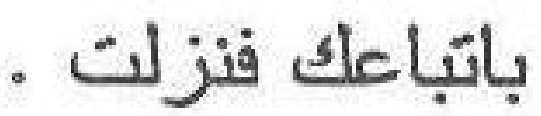

وأخرج ابن جرير وابن المنذر عن السدّى عن أبى صالح قال : قـــالوا

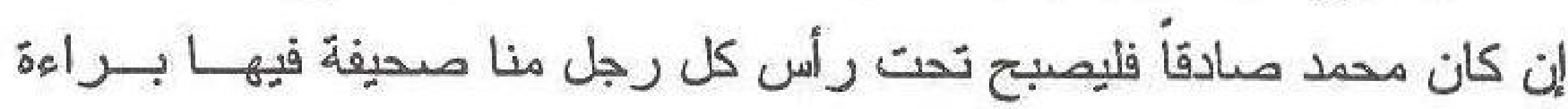
وأَمَنة من النار ، وقيل : كانوا يقولون بلغنا أن الرجل من بنى إسرائيل كان

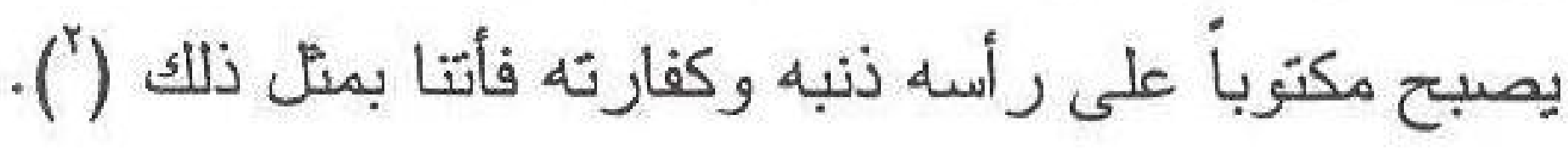

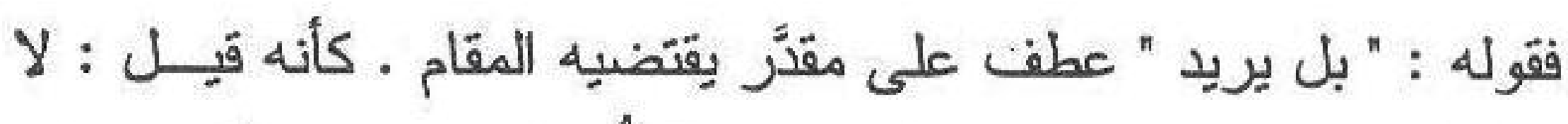

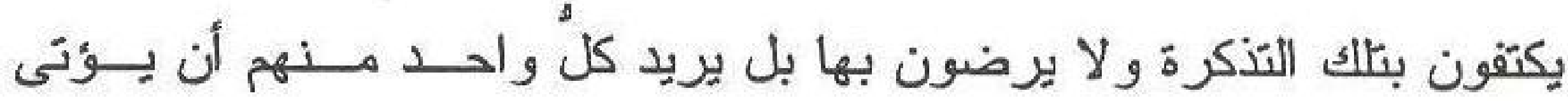

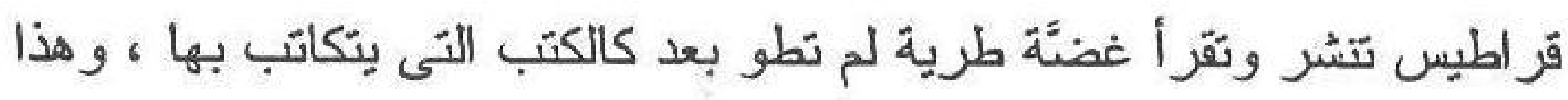

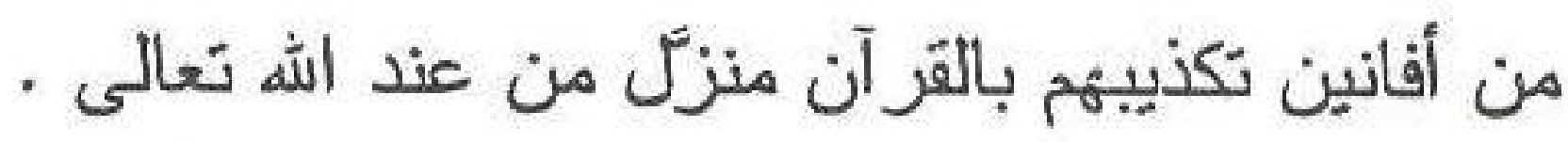

(1) البلاغة فنونها وأفنانها " علم البيان / 97.

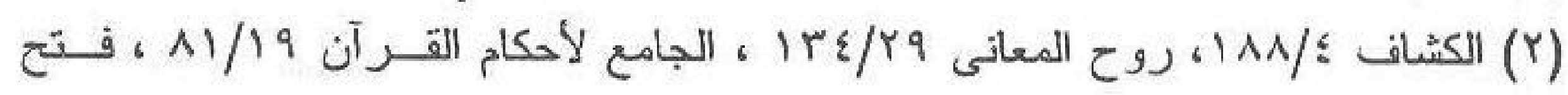

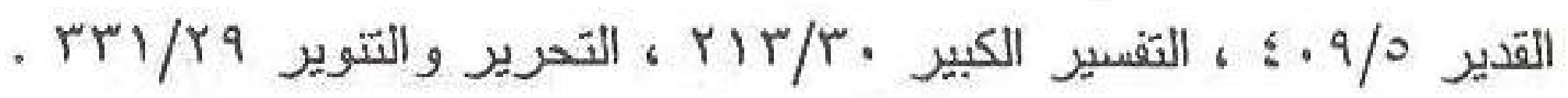


وجاء قوله : " صحفاً" جمعاً لوجهين : إما لأن القوم سألوه - بطئ أن يكون كل أمر أو نهى فتأنى الك احد منهم فى شأنه صحيفة خاصة به ، و إمــا

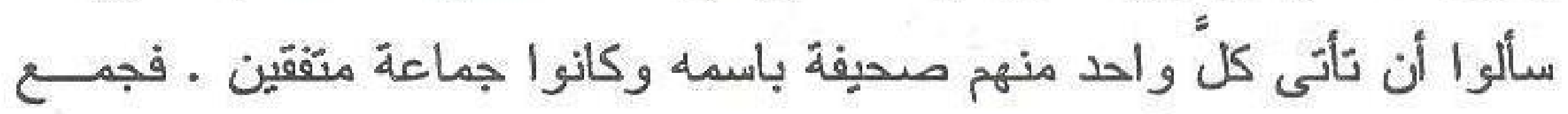
لذلك قوله : " صحفاً " فكأن الصحف جعيها جاءت لكل امرىئ مـنهم ، و " منشرّة " أى مفتوحة مقرو عة كالكِتب الظاهرة المكشّوفة ، فقد أر ادوا بهذا أنهم لا يكتقون بصحيفة مطوية لا يعلمون المكتوب فيها ، و الصيغة في " منشرّة " صبية مبالغة فهى منشورة ، و المبالغة فى اللفظ واردة على ما يقتضيه الفعل

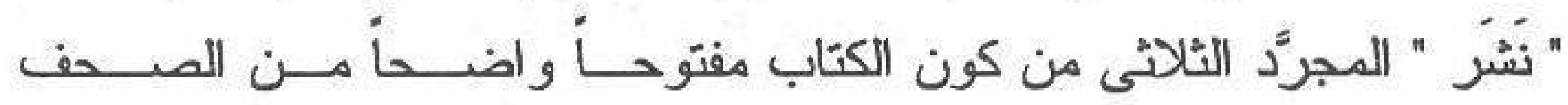
المتعارفة ، وقيل : المعنى أن يذكر بذكر جميل ، فجعلت الصحف موضـــع

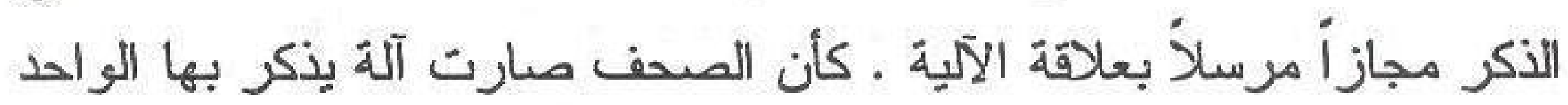
منهم

وقر أ سعيد بن جبير " صُحْفاً مُنْشرة " بإسكان الحاء من " صــحفاً "

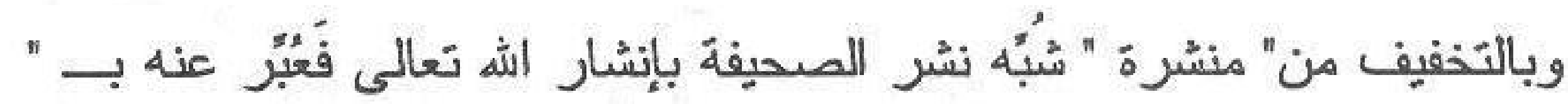

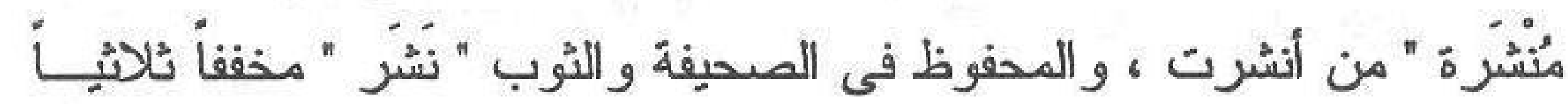
وفى الميت أنشره (') من النسرة

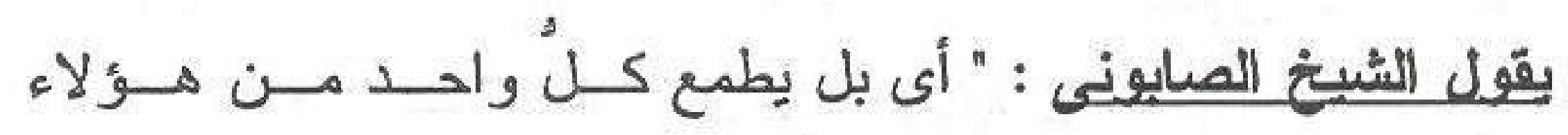

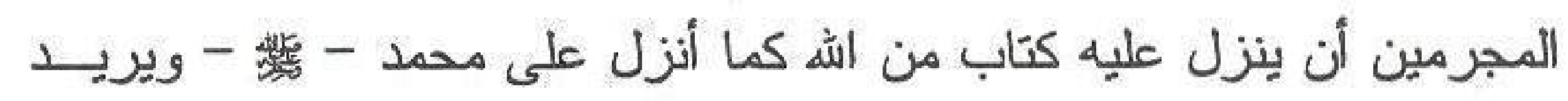
أن يتنزّل عليه الوحى كما تتزلَ على الرسل والأنبياء ، و الغرض من الآيـــة بيان إمعانهم فى الضلالمة وكأنه يقول : دع عنك ذكر إعر اضنهم وغباوتهم ،

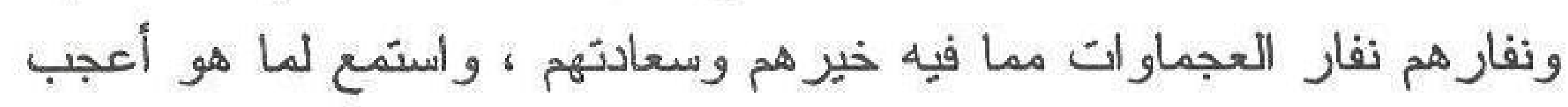

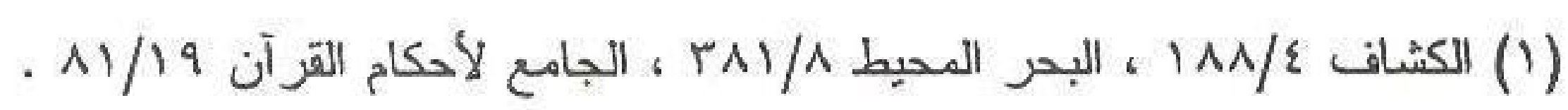


وأغرب ، وذلاك طمع كل فرد منهم أن يكون رسولاً يوحى إليه ، وهيهات أن

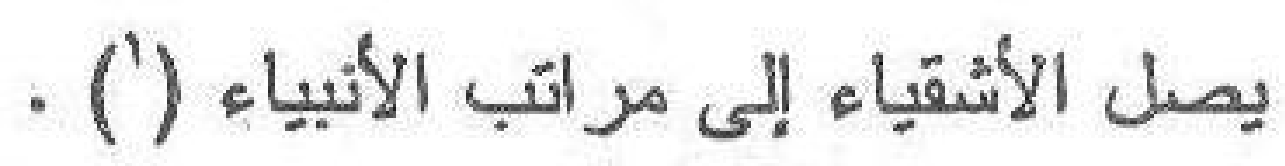

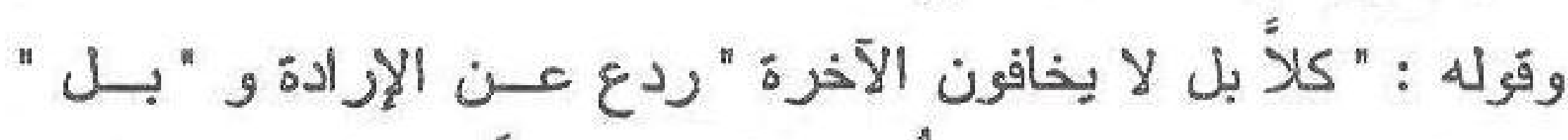

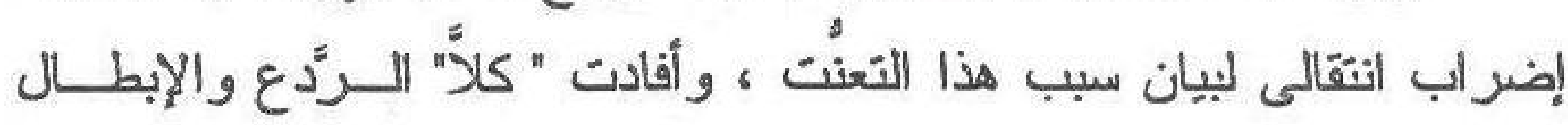
لظاهر كلامهم ومر ادهم منه ، والزجر لهم عن اقتراح الآيات ، والردّدع عن

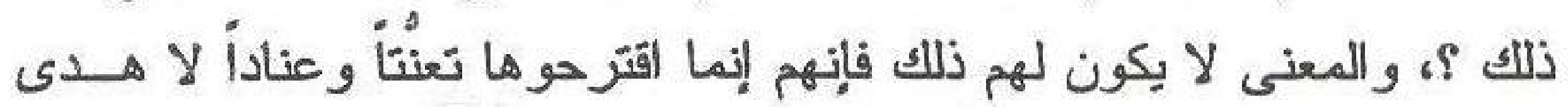

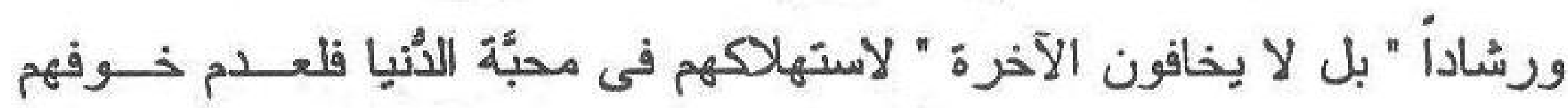

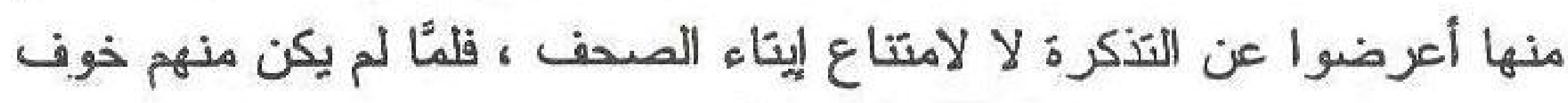

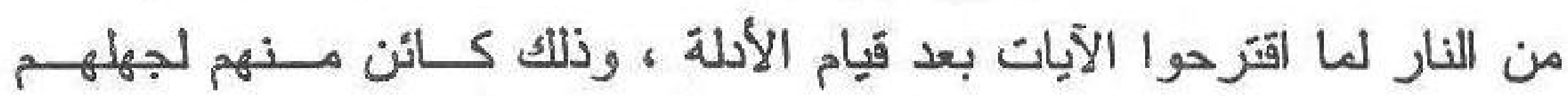

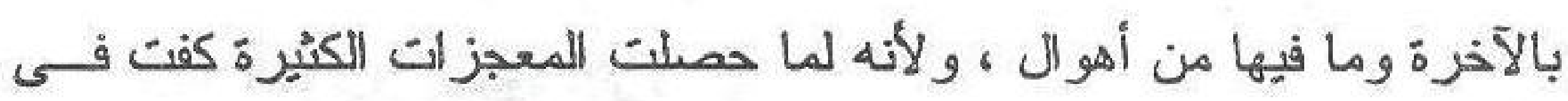

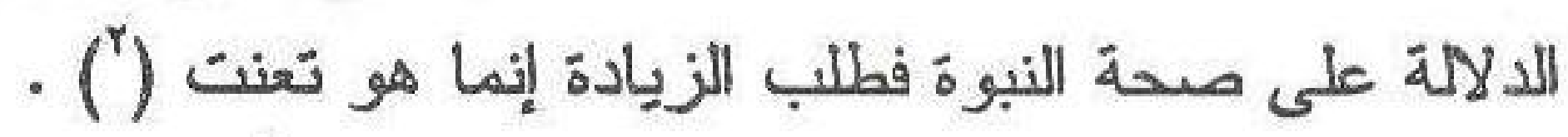

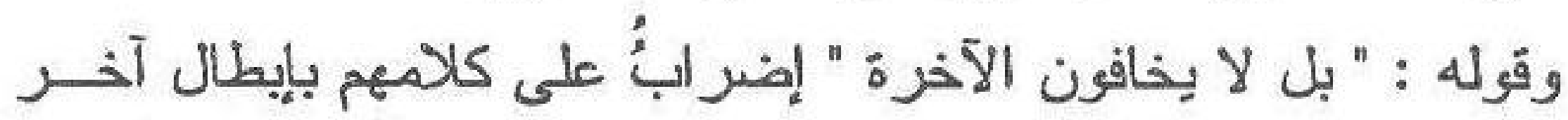

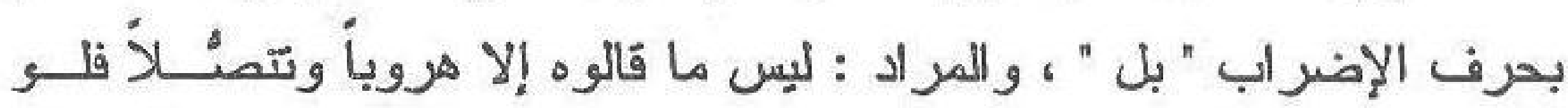

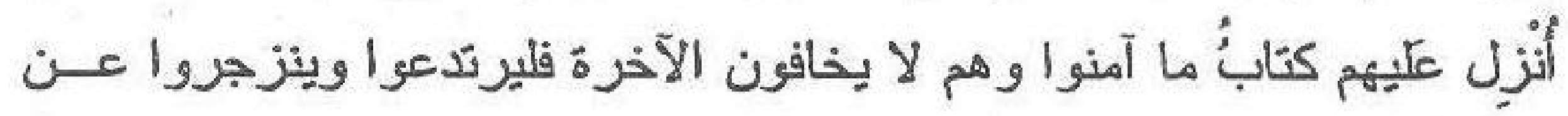
مثل ذلك الطمع بل الحقيقة أنهم لا يصدّقون بالبعث و الحساب ، ولا يؤمنون لان بالنعيم والعذاب و هذا هو الذى أفسدهم وجعلهم يعرضون عن مواعظ القزآن. و التعبير بـ " بخافون الآخرة " كناية عن عدم الإيمان بالآخرة بعـدم

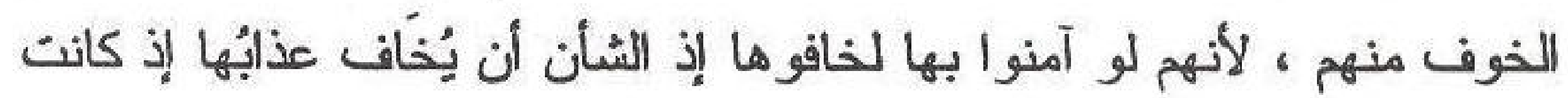

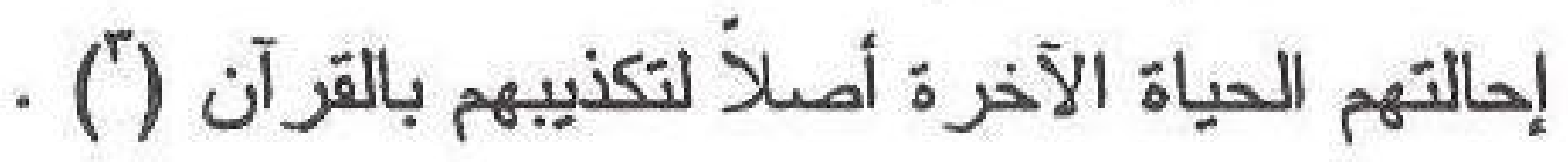

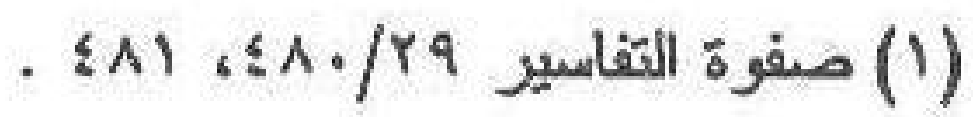

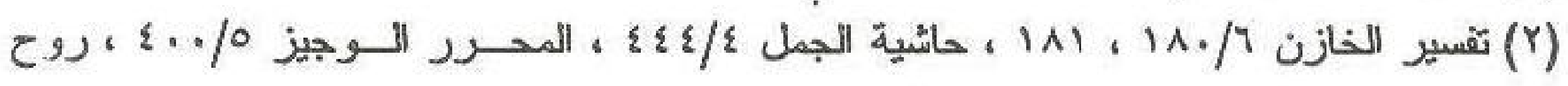

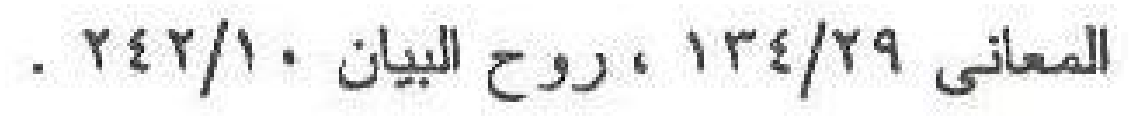

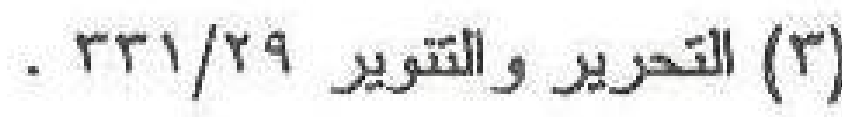


و التعبير بالفعل " يخافون " المضارع دلالة على تجدد عدم الخــوف

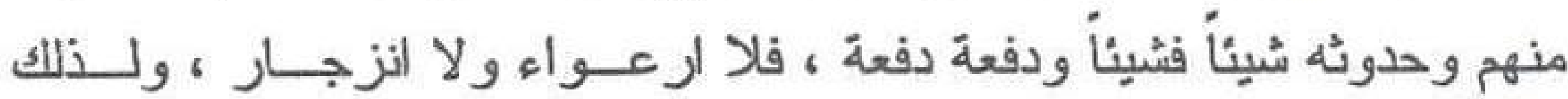

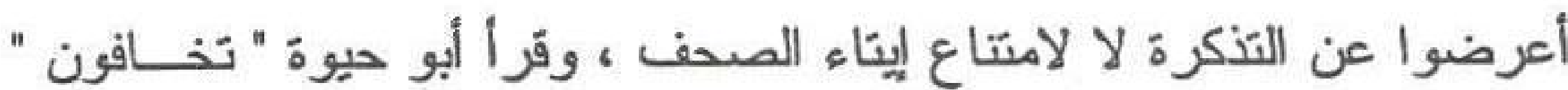
بتاء الخطاب على الالتفات من الغيبة إلى الخطاب ، وقر أ الجمهــور باليــاء مسايرة للغيبة فى الآية السابقة - بل بريد كل أمرىئ منهم - (')الآية .

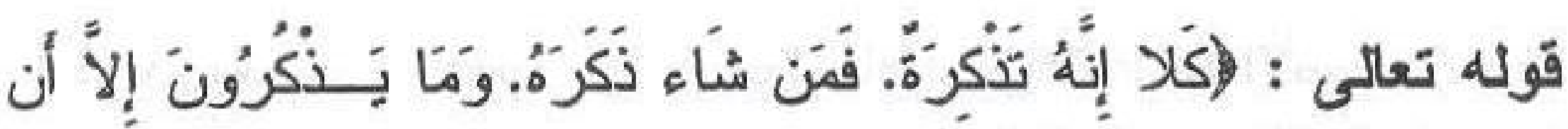

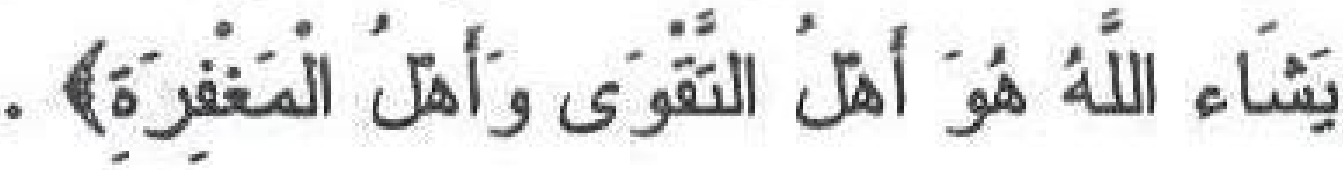
النظم البلاغى : قوله : " كلا إنه " ردع ثان للــردع الــذى قبلــهـ ،

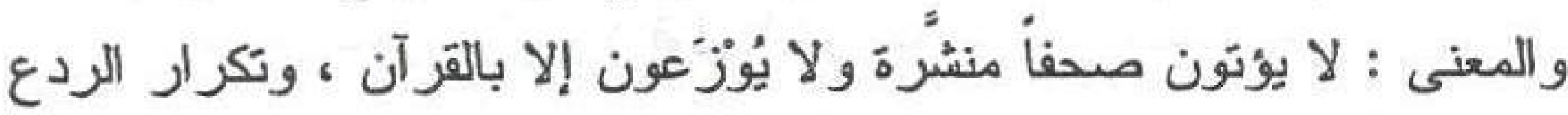

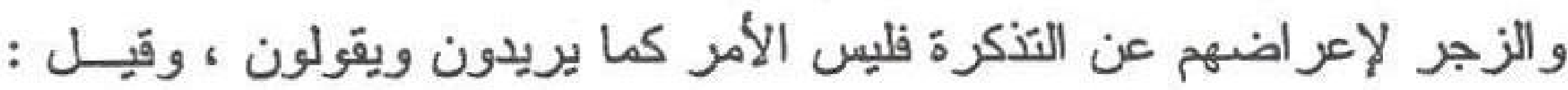

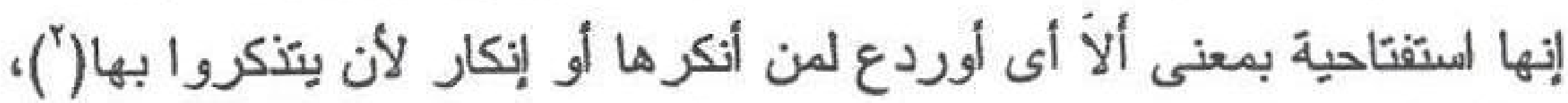

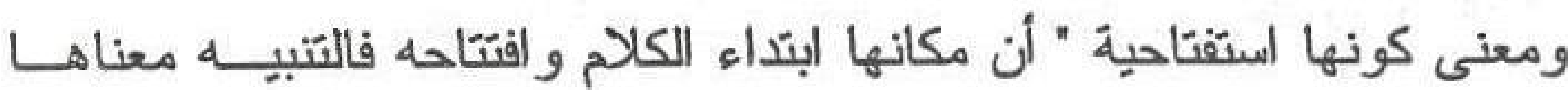
و الافتتاح مكانها ، و هى تستخدم فى المو اضع التى تأتى تتبيهاً إلــى قضى قضـايا إيمانية خطيرة تزيد المؤمن إيماناً بها وتواجه إنكار الكافر وتزلزئ فئل ما في قلبه

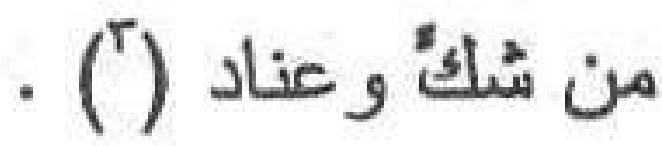

وجملة " إنه تذكرة " تعليل للردع عن سؤالهم أن تتزل عليهم صحف

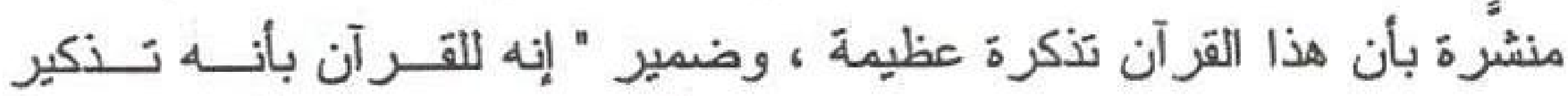

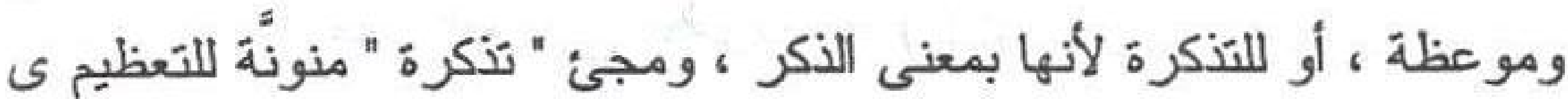

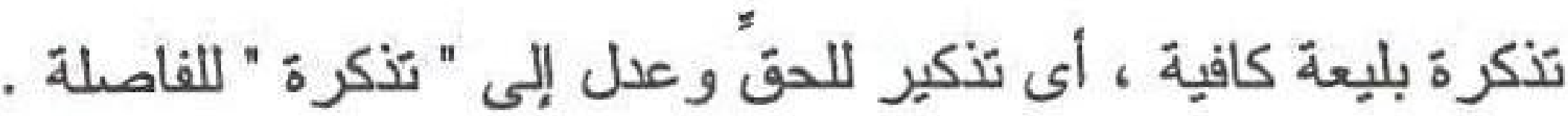

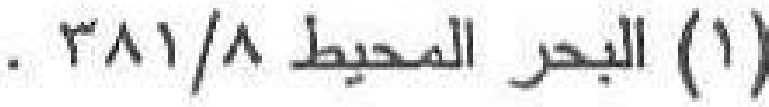

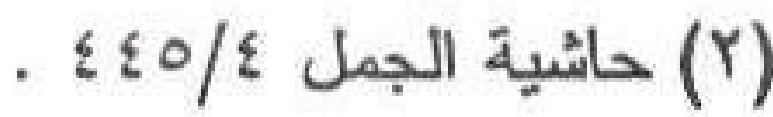

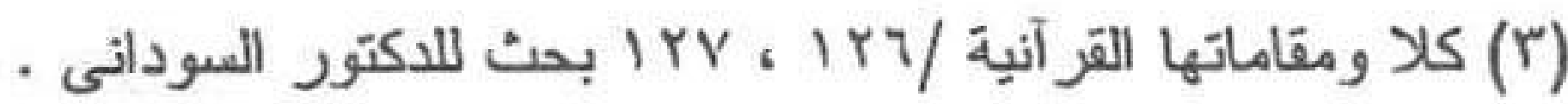




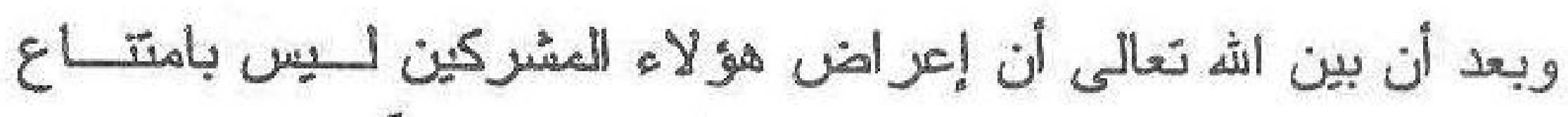

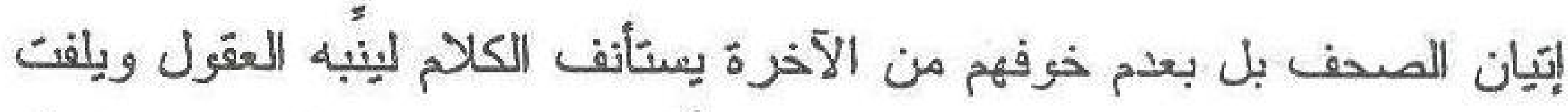

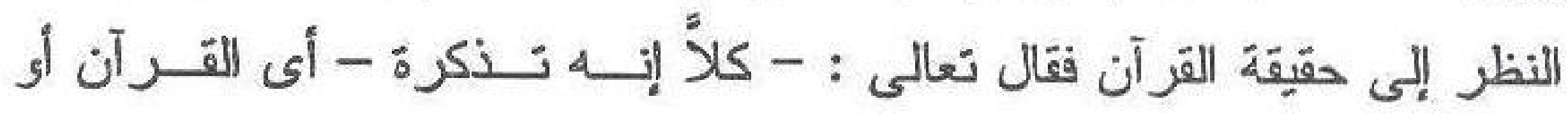
التذكرة فى قوله : - فما لهم عن التذكرة: معرضين - فالقزآن تذكرة لما فيه

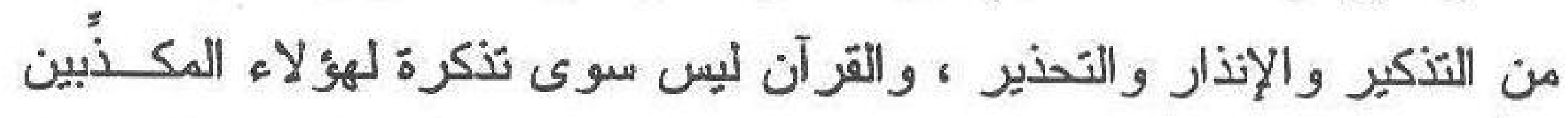
تذكرّ هم بما يجب عليهم من الإيمان باله ونزك عبادة الأصنام ، وتتذر هم إن الن

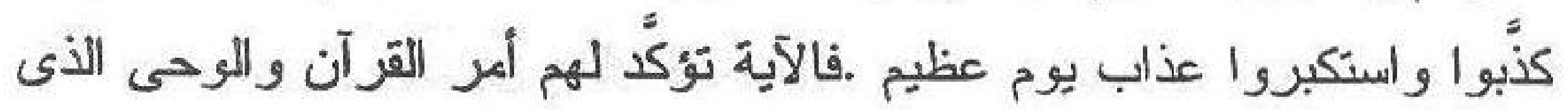
أعرضو ا عنه و أنه ليس سوى " تذكرة و إرشاد للبشر ليس له وصــف غيـر ذلك : فما هو سحر يؤنز ولا قول البشر كما زعموا فلعاذا يعرضون عنــهـ

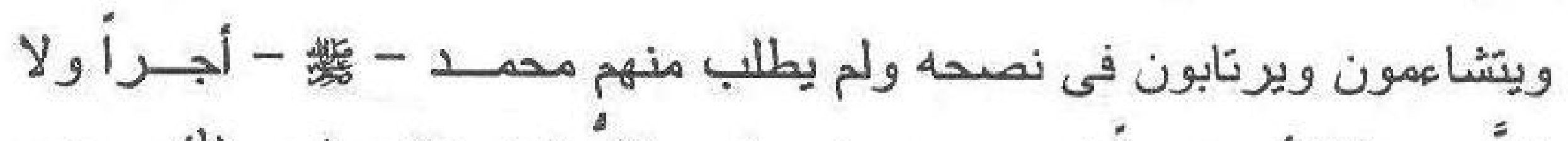
كلفَّم عطاء أو منصباً فهو محض خيز لهم وكل نفعه عائد عليهم (') ووضع مئع المضمر " أنه " موضع الظاهر أبلغ فى آداء المراد ليشمل القرآن أو التذكرة وليس فى وضع الظاهر نكتة حتى يذكر صراحة .

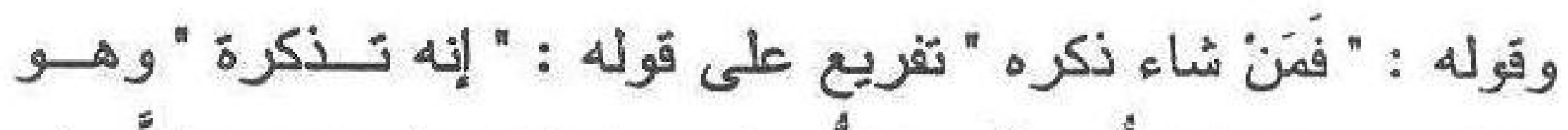

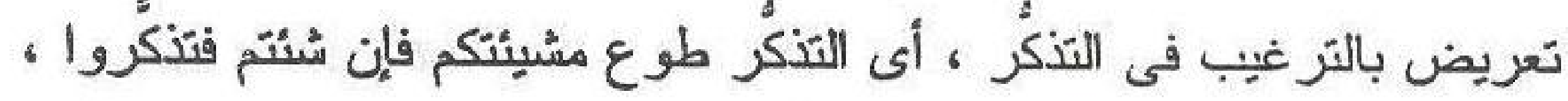
و الضمير الظاهر فى " ذكره " يجوز أن يعود إلى ما عاد إليه ضمبر " "أنه "

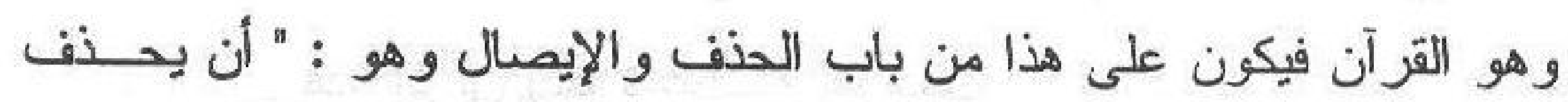

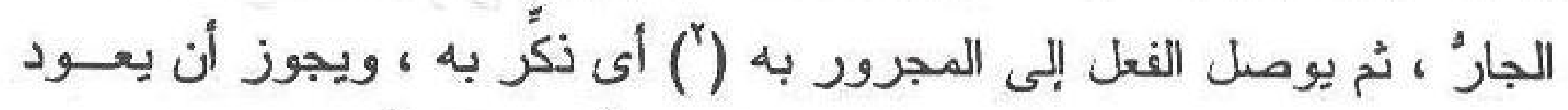

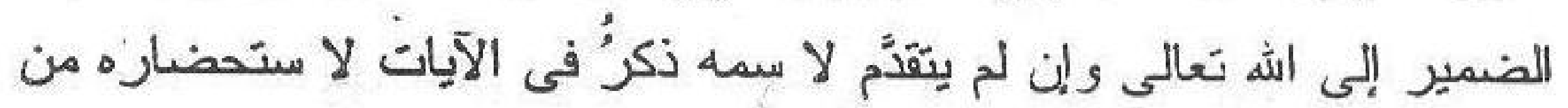

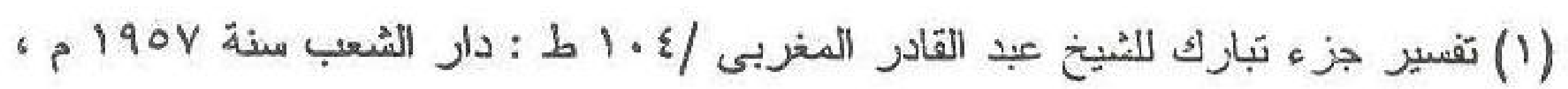

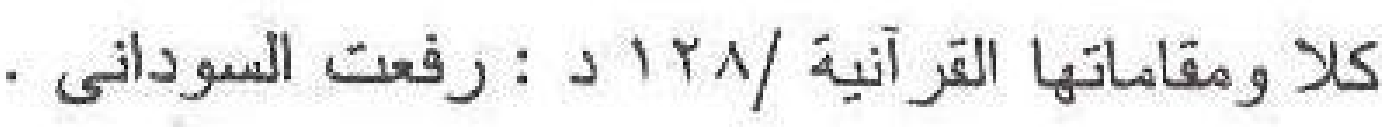

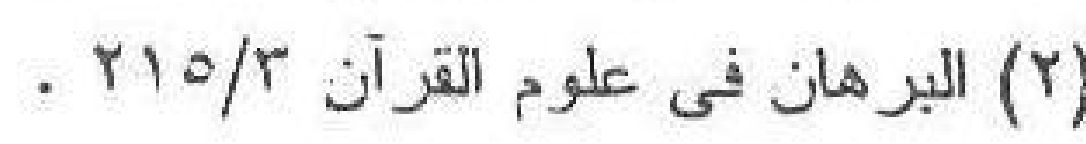


المقام أى : فَمَنْ شاء ذكر الله فحذف لفظ الجلالة تعظيماً للمفعول الذى وقــع عليه الذكر ، وضمير " شاء " راجع إلى " مَن " و المعنى : منن أر اد أن يتذكًّ

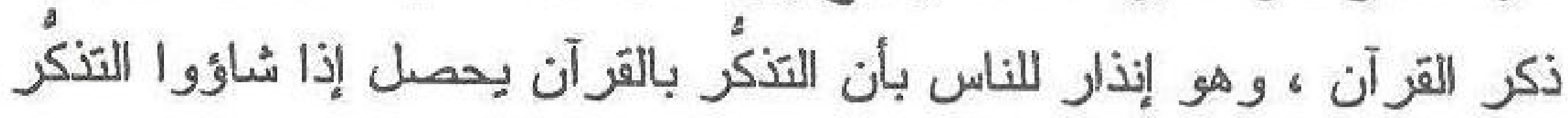

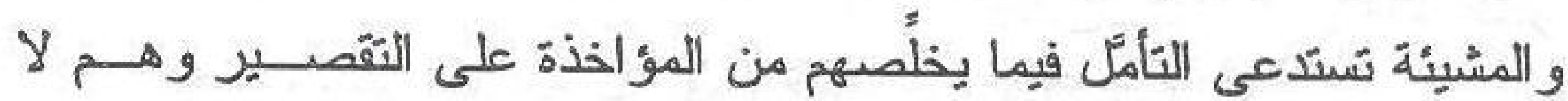
عزر لهم فى إهمال ذلاك (')

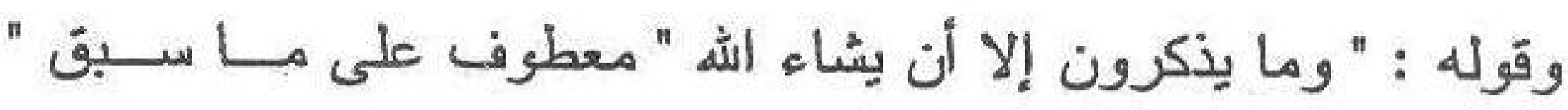

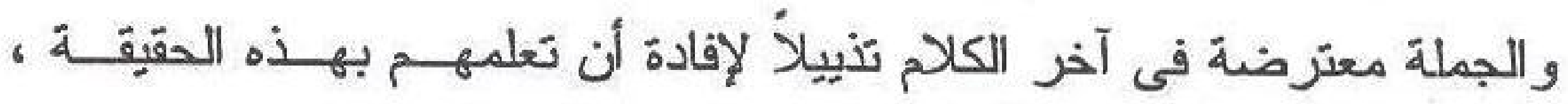
وضمير الجمع فى " يذكرون " يعود على الكفرة لأن الكلام واقع عليهم وهم مقصودون بذلك ، وردُّ عليهم فى إيتاء كلًّ واحد منهم كتاباً يخصنه ، و و إما أن

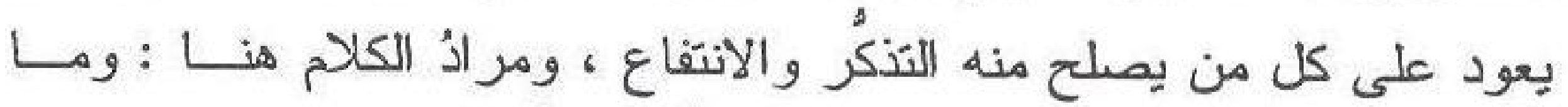

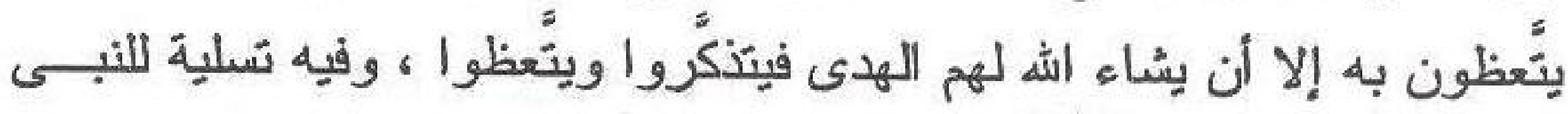
-

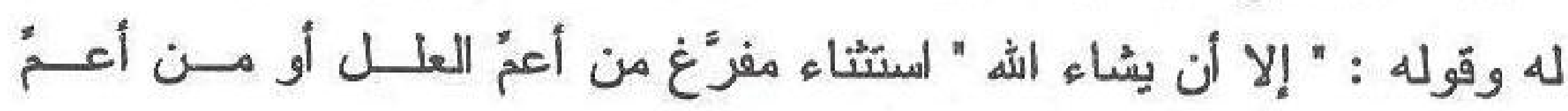
الأحوال أى وما يذكرون بعلة من العلل أو فى حال من الأحو ال إلا بأن يشاء الله تعالى أو حال أن يشّاء اله ذلك ، وهذا تصريح بأن أفعال العباد بمشـيئة الله عزَّ وجلَّ بالذات أو بالو اسطة ، فنفى تعالى الذكر مطلقاً و اسشتى منه حال المشيئة المطلقة فيلزم أنه منى حصلت المشيئة يحصل الذكر فحيث لم بحصل بلول الذكر علمنا أنه لم تحصل المشيئة (T) (T)

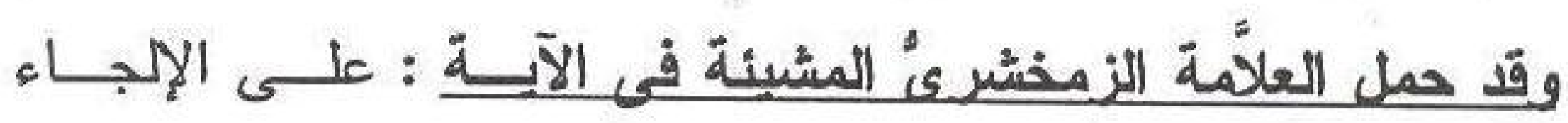
و القَسز فيقول : " يعنى إلا أن يقسرهم على الذكر ويلجئهم إليه لأنه مطبــوع الـوع 
على تلوبهم معلوم لأنهم لا يؤمنون اختياراً (') ، وقدّ ردً المفسرّون مقالـــة

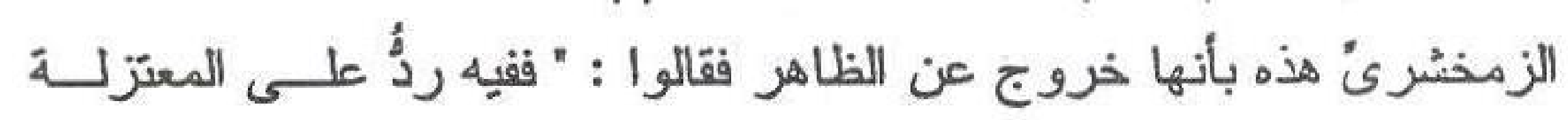

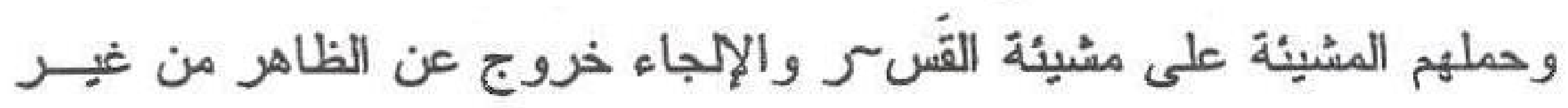

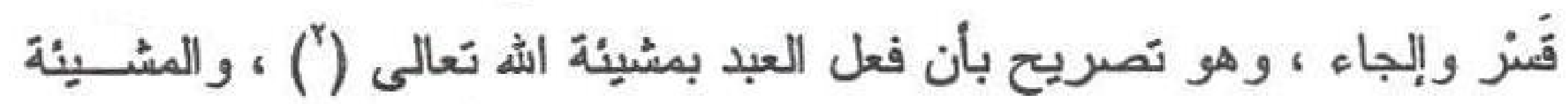

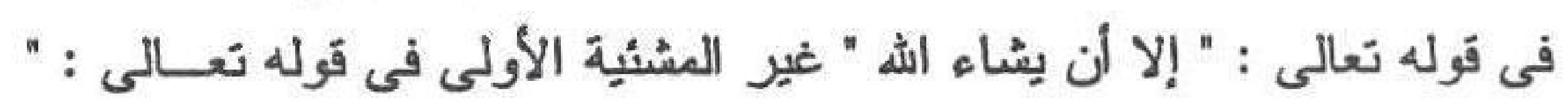

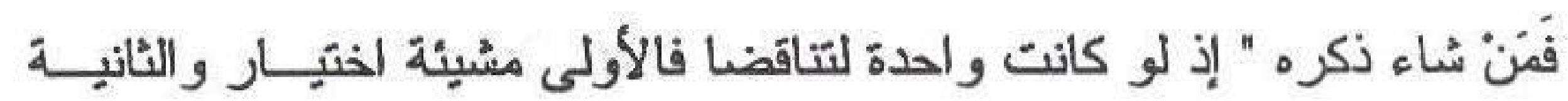

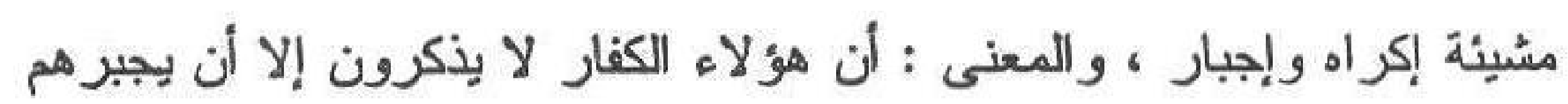

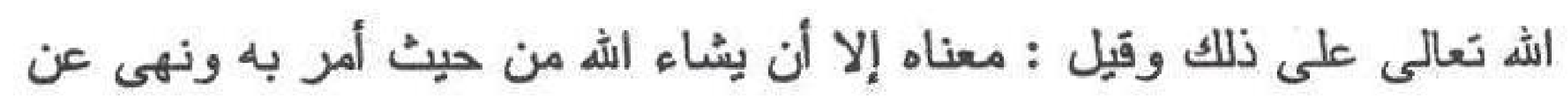
تركه وو عد الثواب على فعله وأو عد بالعقاب إن لم تفعله فكانت مشيئته سابقة

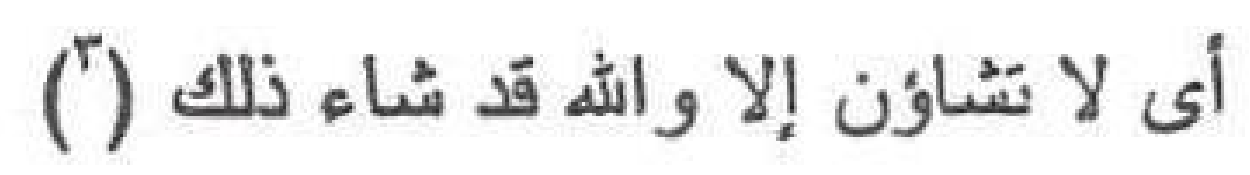

وقوله : " وما يذكرون إلا أن يشاء الله " أسلوبُ قصر من قبيل قصر

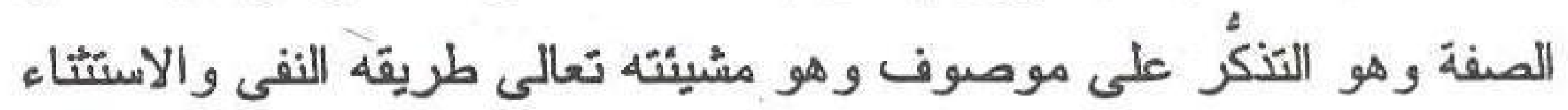

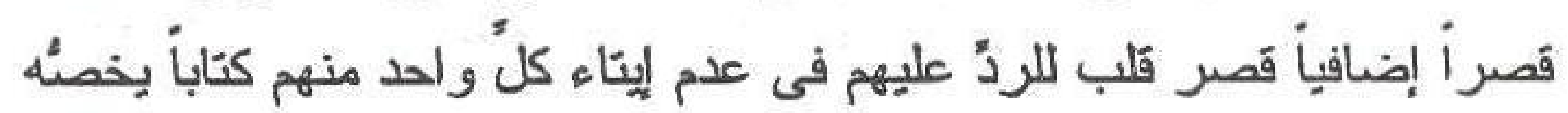

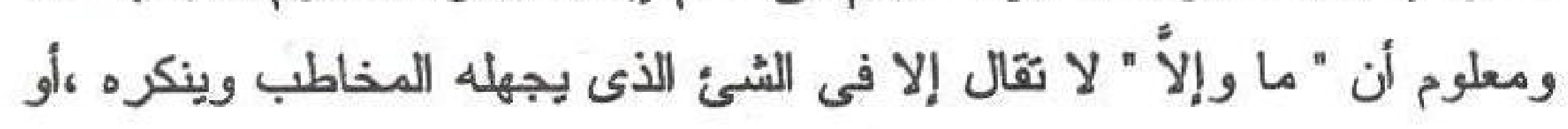

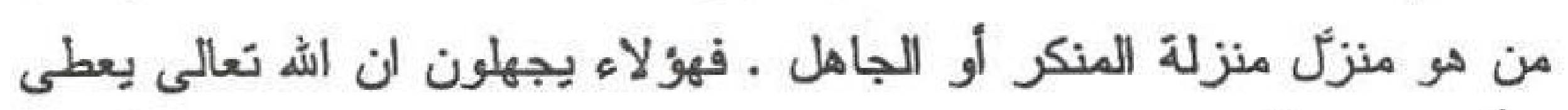

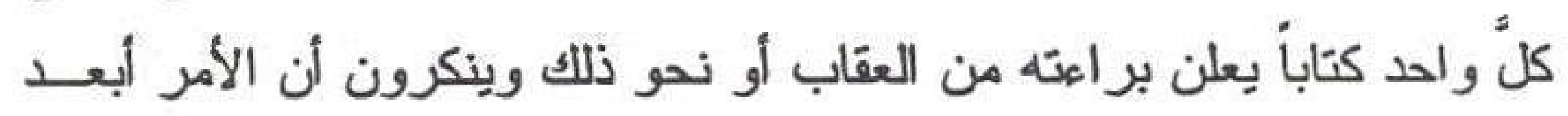

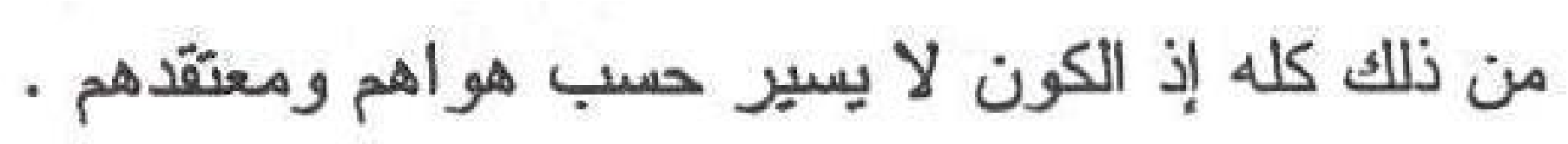

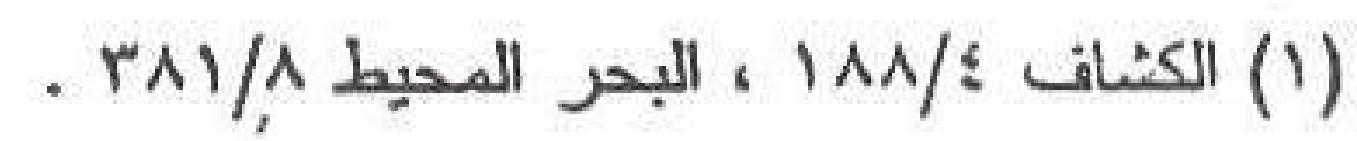

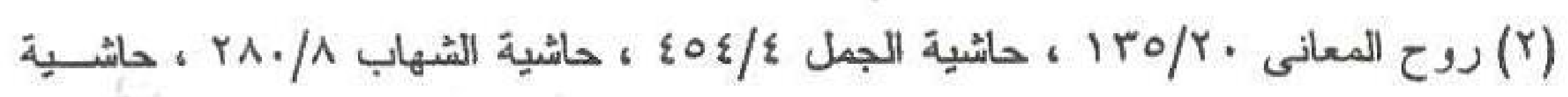

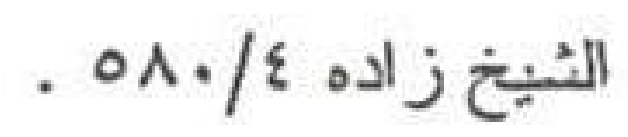

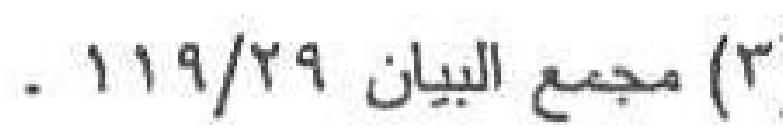


وقرأ نافع ويعقوب " وما تذكرون " بالتاء على الآتفات من الغيبة إلىى

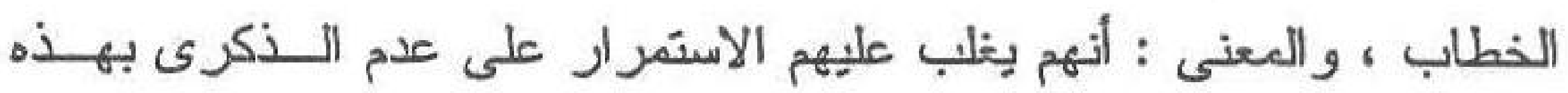

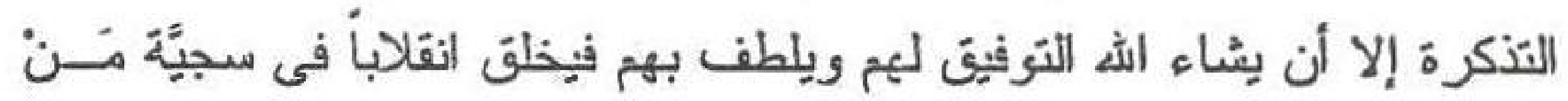
يُّاء توفيقه و اللطف به ، وقد شاء ذلك فين آمنوا قبل نزول هذه الآية ومن

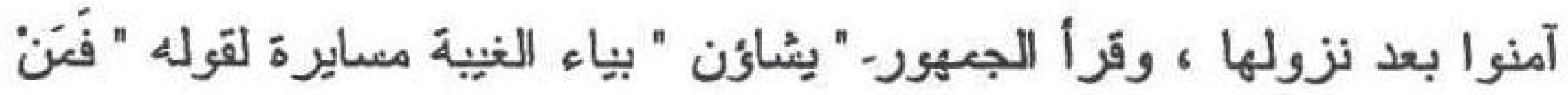

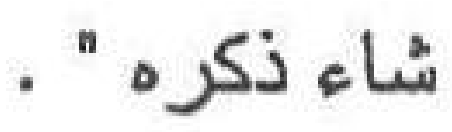
يقول الشيخ الطاهر البن عاشهر : " فعلهنا أن للناس مشيئة هى مناط

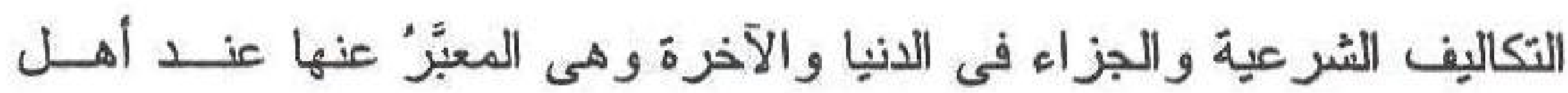

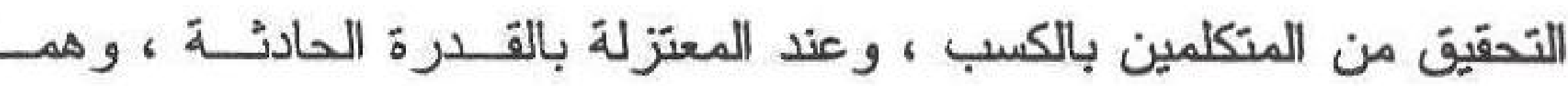
عبارتان منقاريتان ، وأن اله تعالى المشيئة العظمى التى لا يمانعها مانع و لا

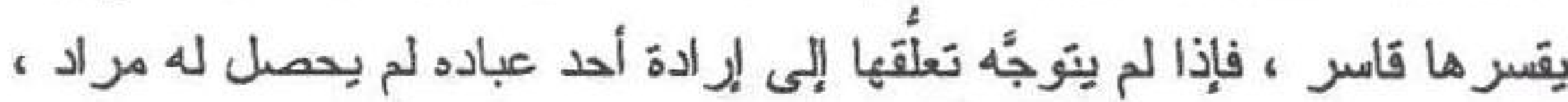
و هذه المشيئة هى المعبَّر عنها بالتوفيق (') وقوله : " هو أهل التققى وأهل المغفرة " جملة واقعة موقع التعليـلـل لمضنمون جملة " فمن شاء ذكره " تقوية للتعريض بالتزرغيب فــى التـــكر ، و التذكُ يفضى إلى التقوى . إذ المعنى : عليكم بالتكُر واتقوا الله تعالى لأن

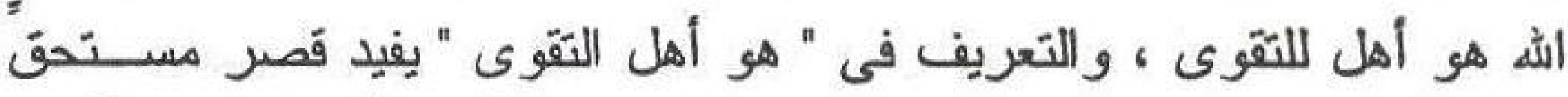

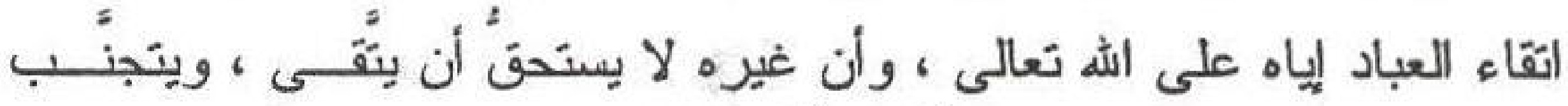

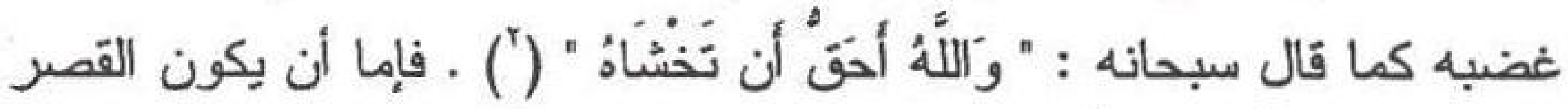
فى الآيّة قصرأ إضاقياً للردّ على المشركين الذين يخشُون غضب الأصــنام ويطلبون رضاها ، أو يكون قصرأ ادعائيًاً لتخصيصهـ تعالى بالتقوى الكاملة

$$
\begin{aligned}
& \text { (1) التحريز والتنوير . r/rrr. }
\end{aligned}
$$

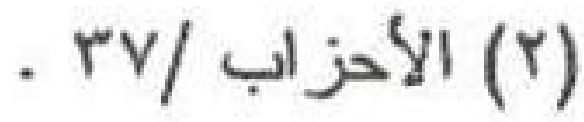




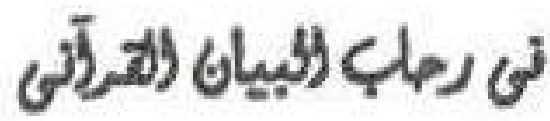

الحق" و إلا فإن بعض التقوى مأمور بها كثقوى حقوق ذوى الأرحام كما قال

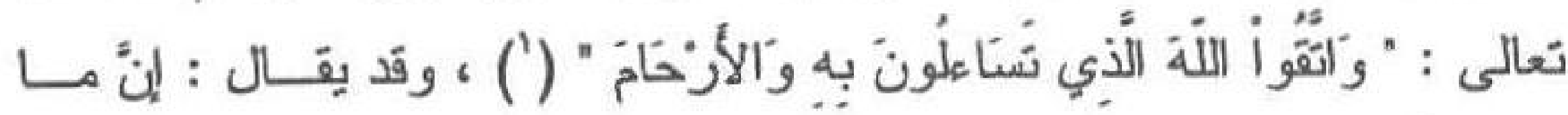

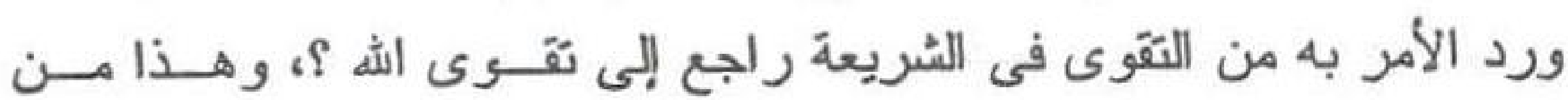

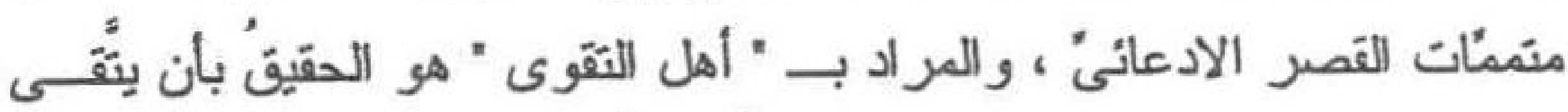

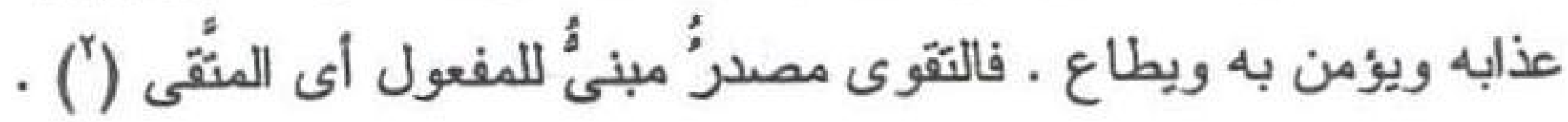

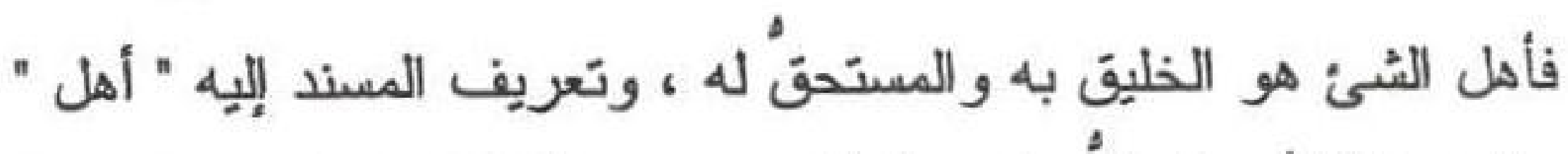

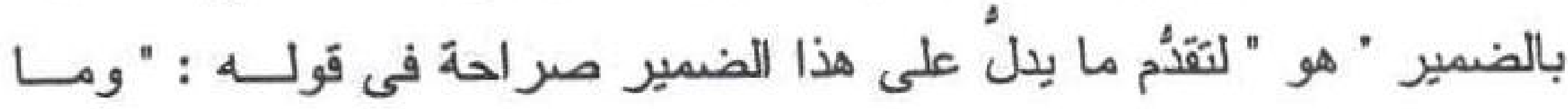

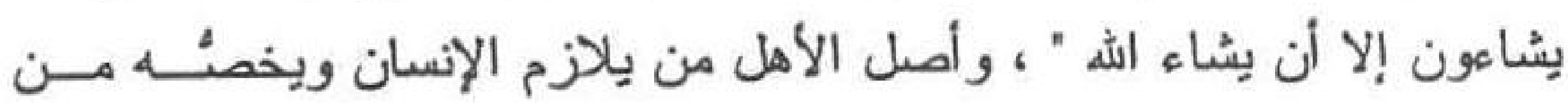

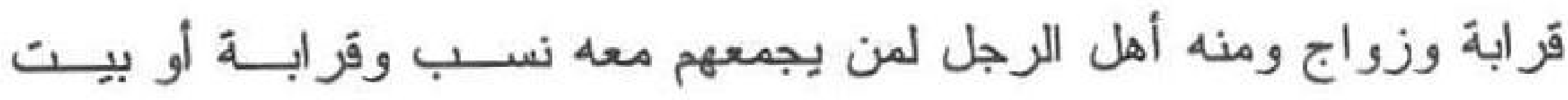

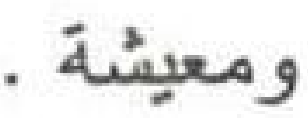

وقوله : "و أهل المغفرة " معطوف على نظيره " هو أهل التَُّّوى "

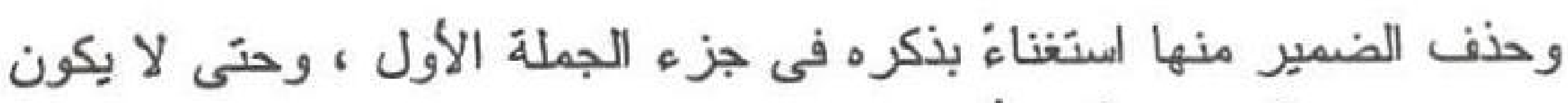

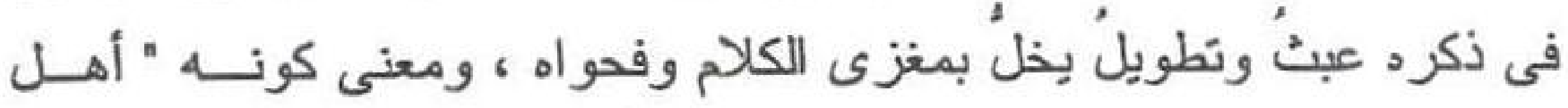

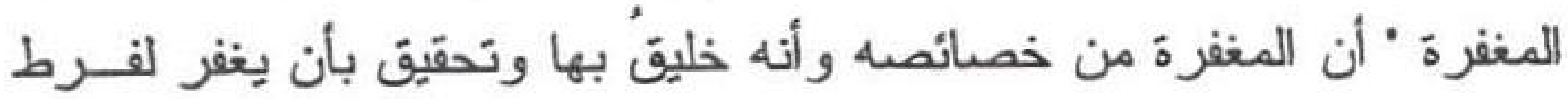
رحمته ومععة كرمه سبحانه ومزيد إحسانه وسابغ نعمته على عباده إذا آمنوا

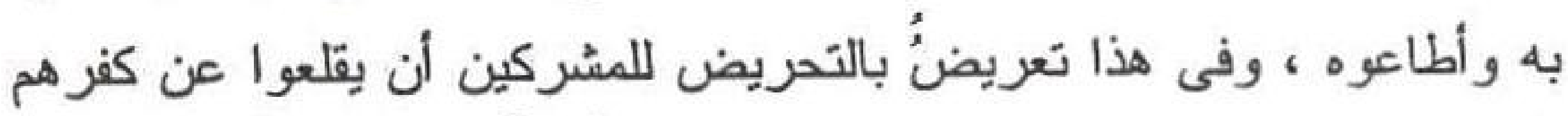

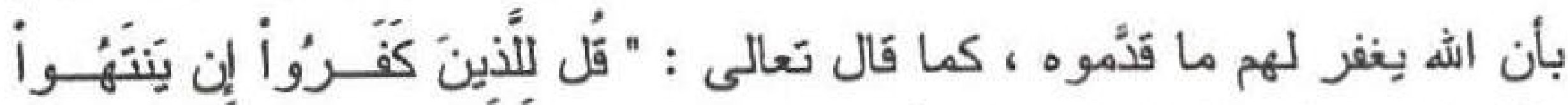

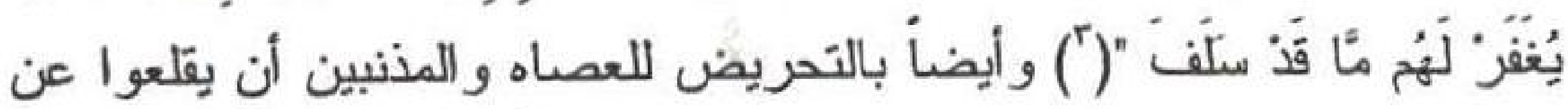

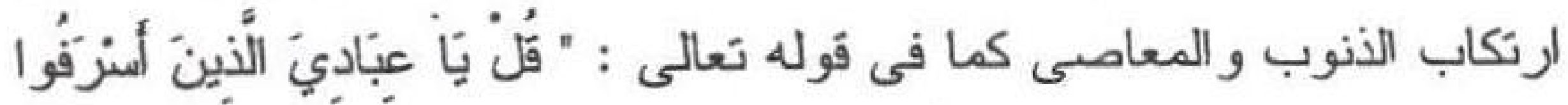




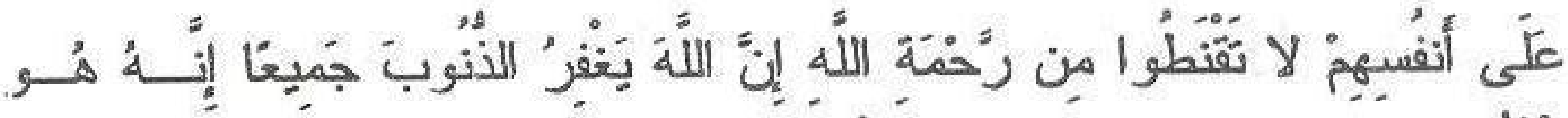

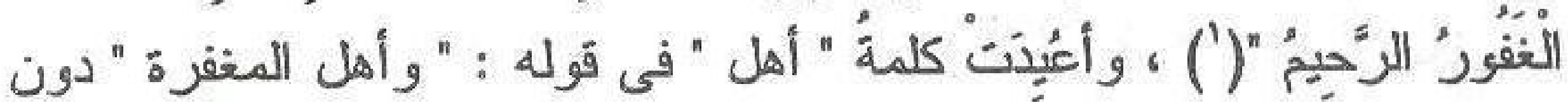

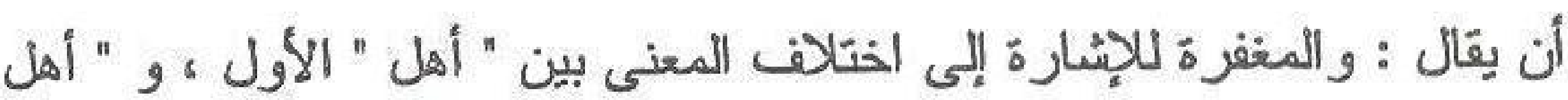

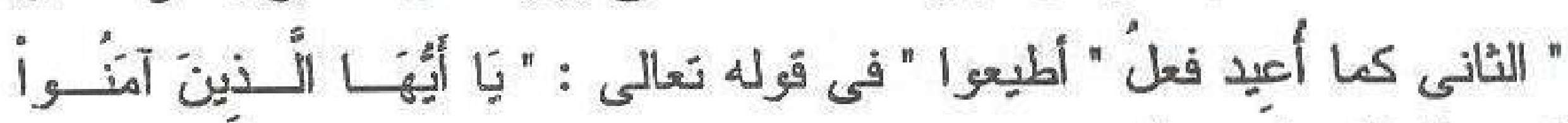

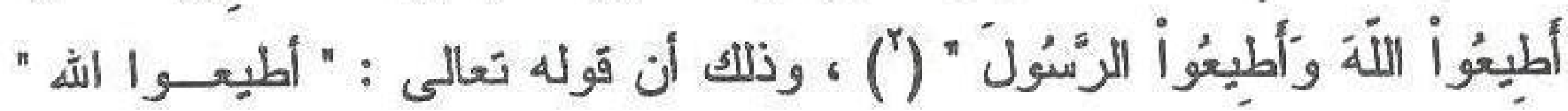
إشارة إلى كتاب الله تعالى ، وقوله : " وأطبعوا الرسول " إشّارة إلى ســنته

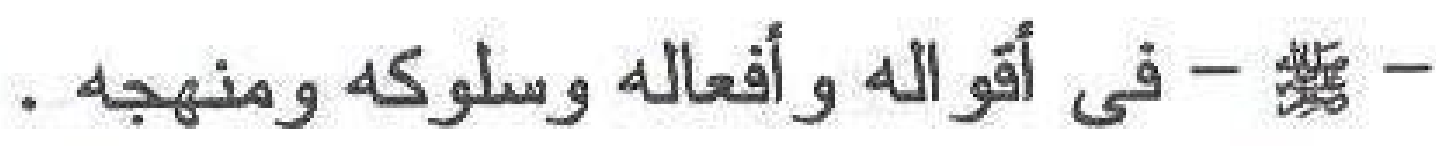

\section{وقفة ميع حديث " هـ أهل التقوى وأهل المغقرة" :}

أخرج ابن ماجة و التزمذى والدارمى والحاكم عن سهيل القطعى عن

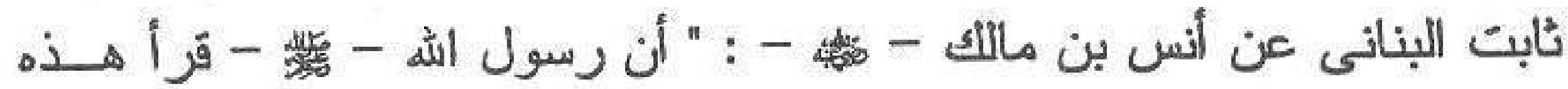

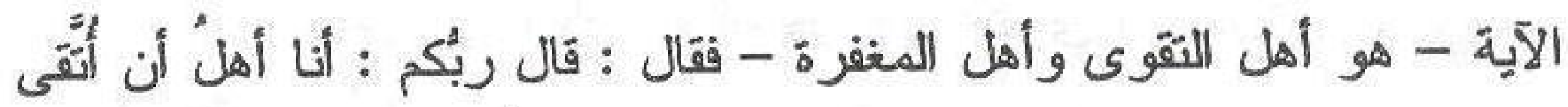

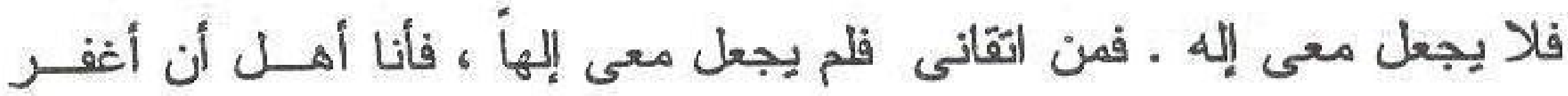

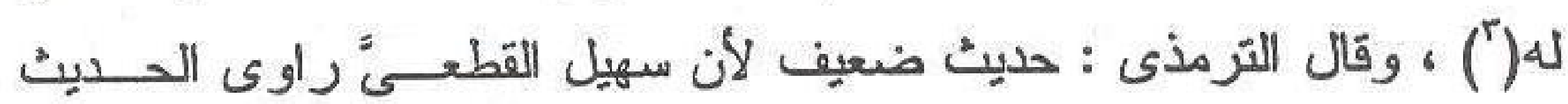
ليس بالقوى في الحديث وقد انفرد به عن ثابت (؛) ، وقد رمز لــهـ الحــاكم بالصحة فقال : " هذا حديث صحيح الإسناد ولم يخرّجاه - أى الشيخان-(").

$$
\text { . or/ (1) }
$$

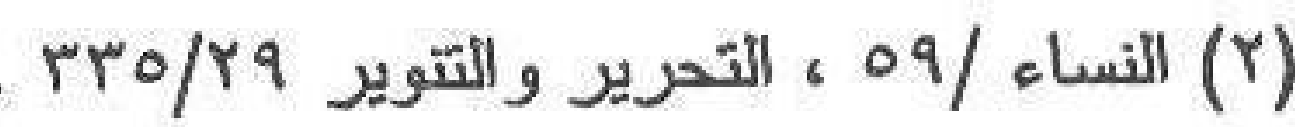

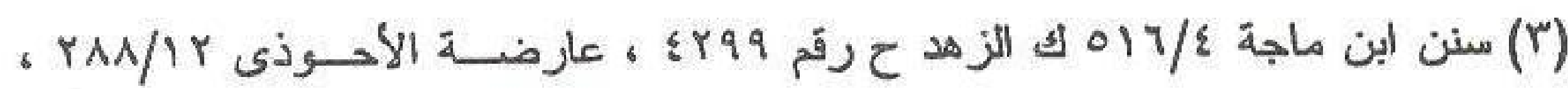

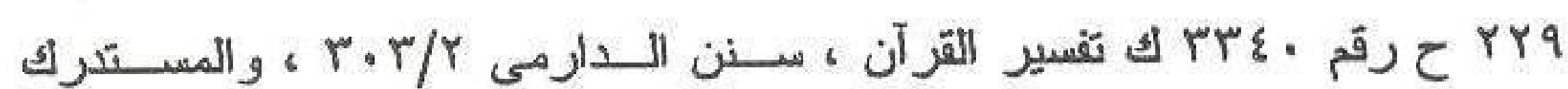
- مان

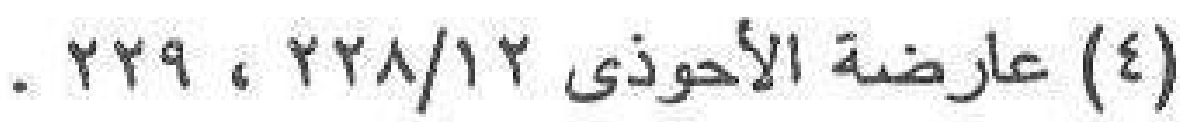

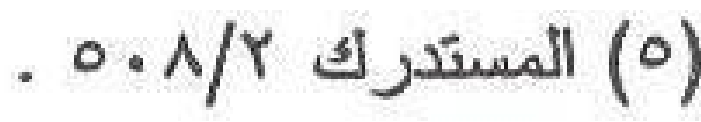




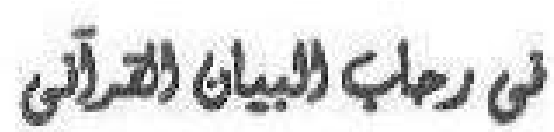

قَلل الألويسيـ: "وكان الجملة - هو أهل الثقوى وأهل المغفـرة -

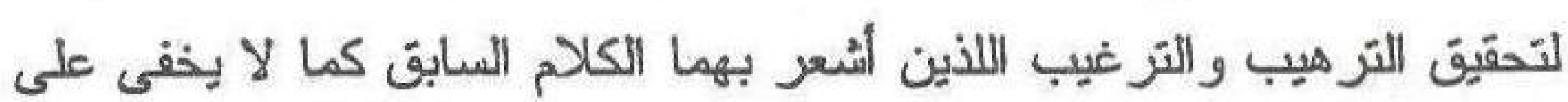

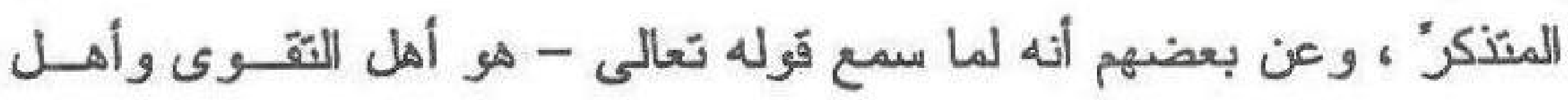

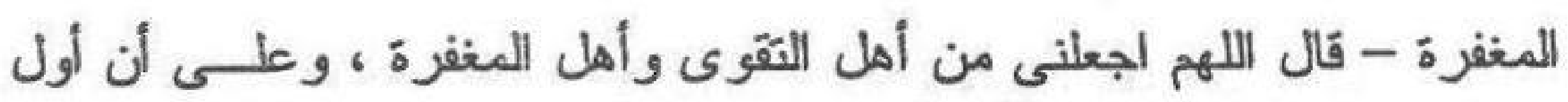

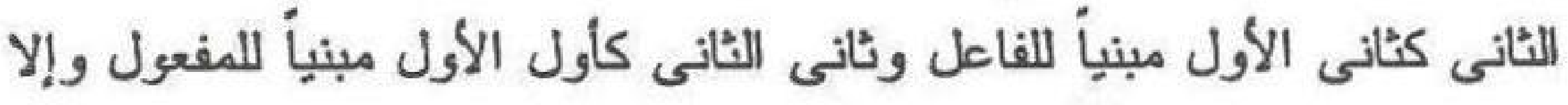

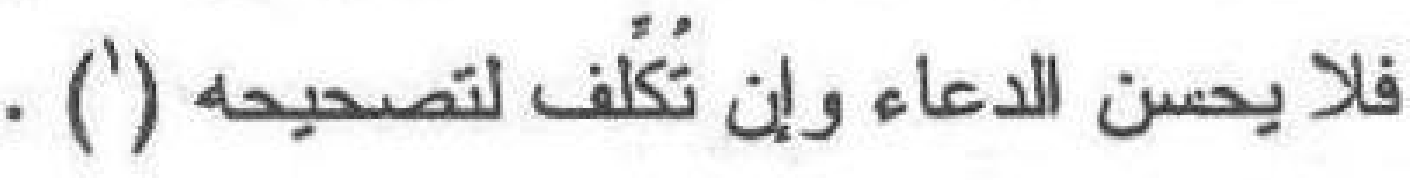

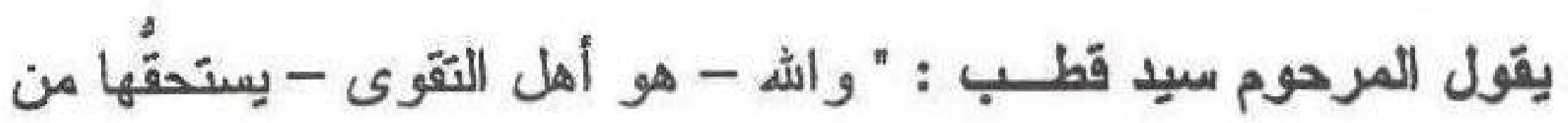
عبادة فهم مطالبون بها ، و - أهل المغفرة - يتفضكل بها على عبادة وفـقن

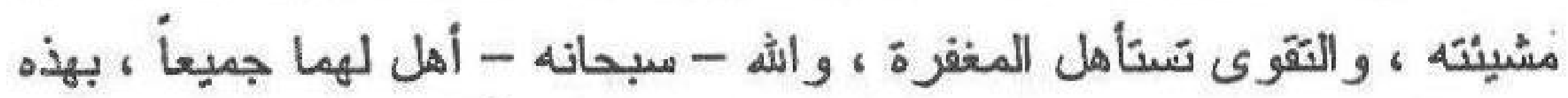

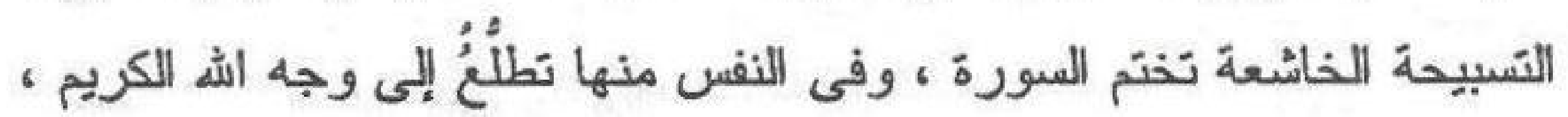

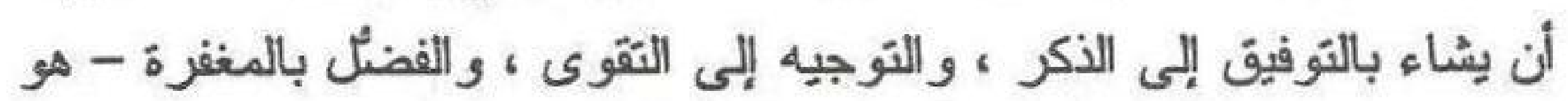

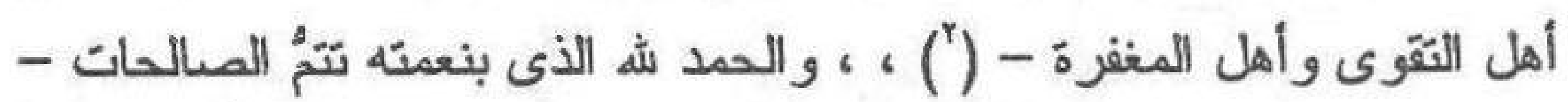
و الصلاة والسلام على أفصح الخلق بياناً ، وعلى آله وصعبه وسلُّم تسـليماً

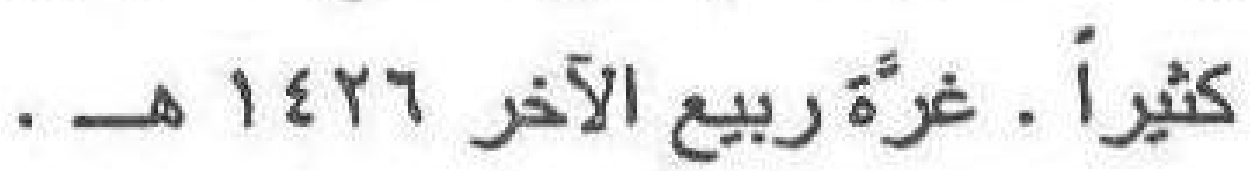




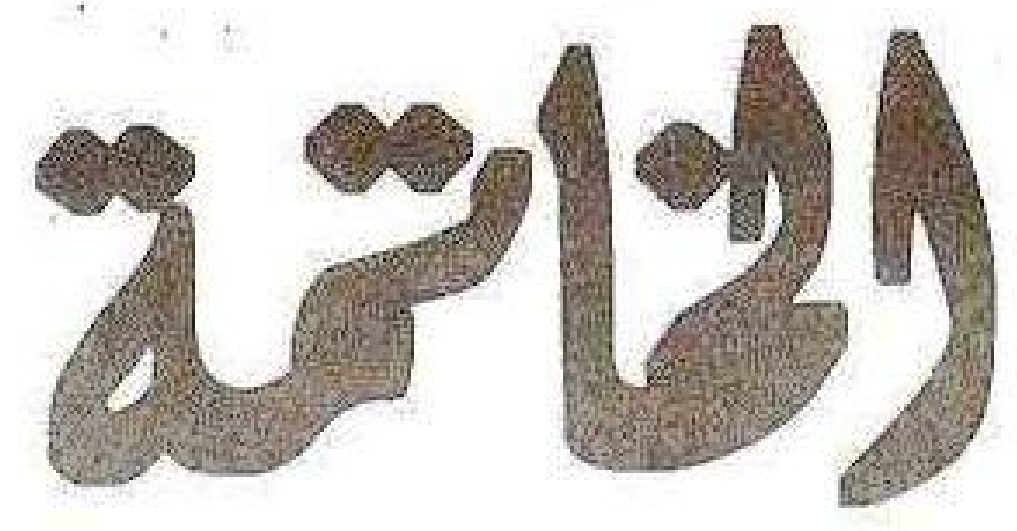





\section{" الخاتمة "}

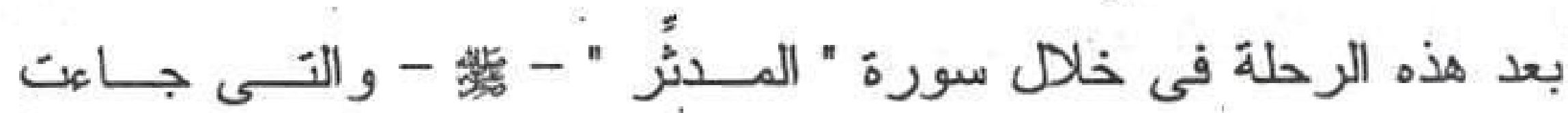
در استَها متمثلة في مقدمة وتمهيد مشتمل على تسمية السورة ، و هل السورة

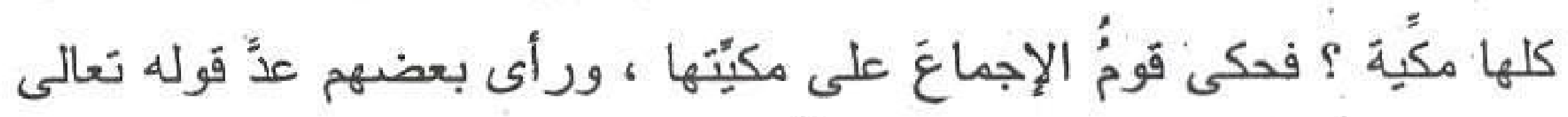

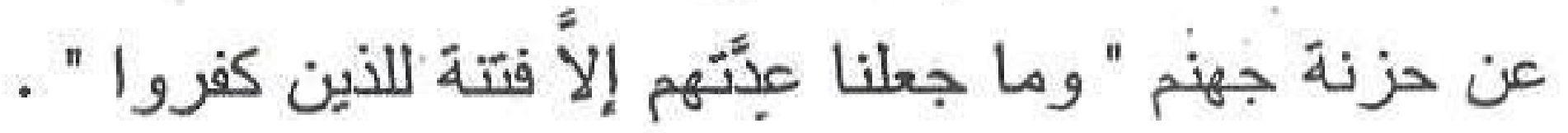
فقد نزل بالمدينة ، وأن هذه السورة ليست أول ما نزل من القر آن بـلـ أول ما نزل سورة العلق مع ذكر الدليل على ذلك ـ مـع بيان صــلة ســورة

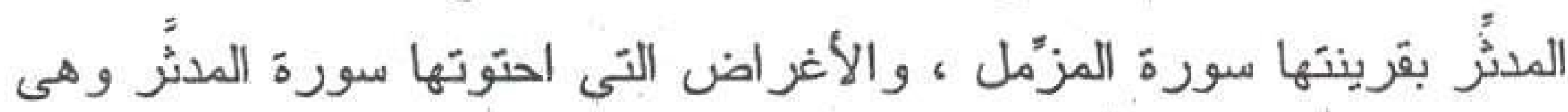

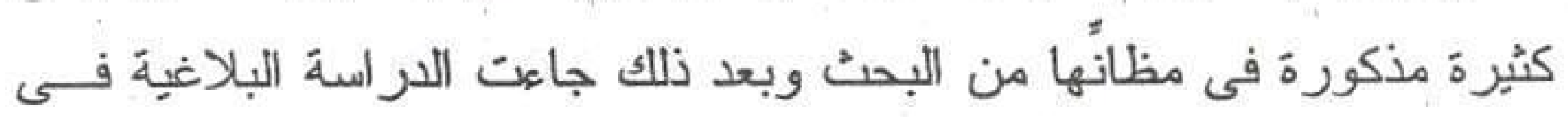
أربعة مباحث : أرة مدورة

المبحث الأول : جاء فيه الحديث عن الرسول - مل من - من حيث صفتها،

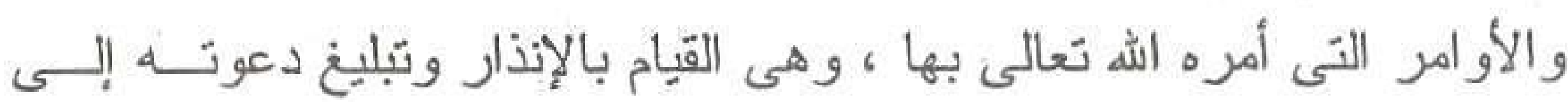

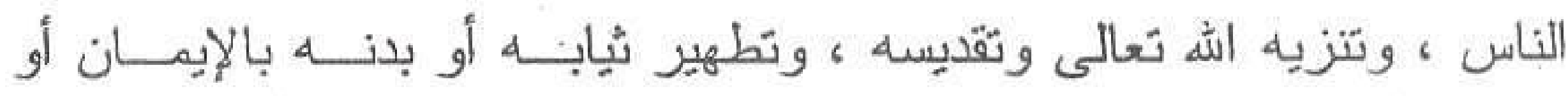

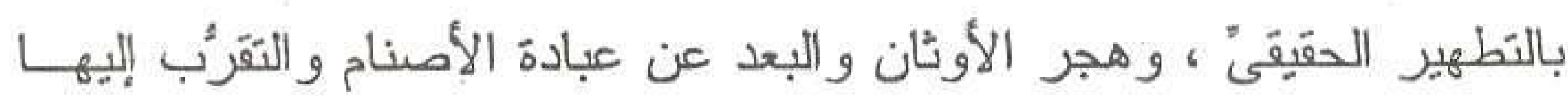

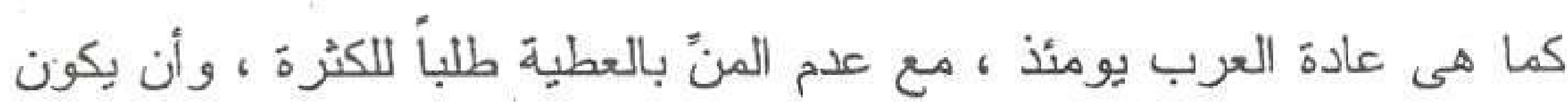

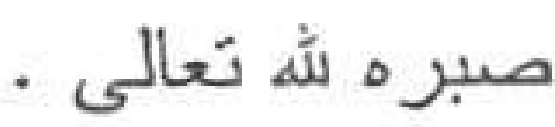
المبحث الثانى : وهو حديث عن يوم القيامة ونفخ إسر افيل في الصنُور

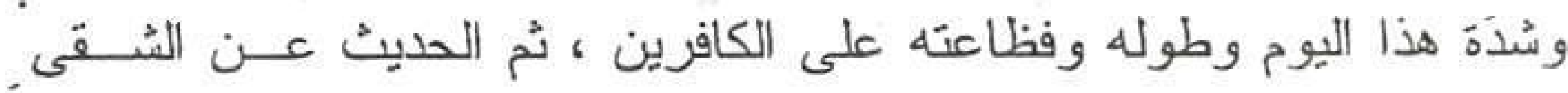

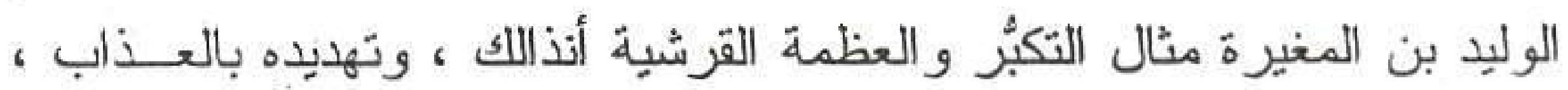

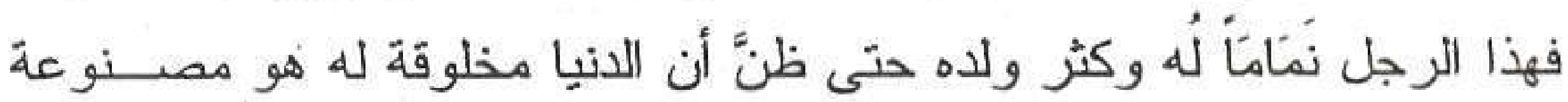

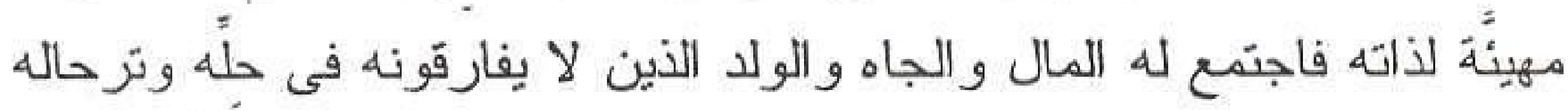
لاستغنائهم عن العمل إذ لا حاجة لهم فى ذلك وبساطة العيش ورغد النعدــة 


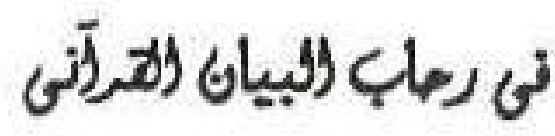

وترفف الحياة الذى كان وولده ينعمون به وطمعه فى الزيادة ، وبيان موقفــهـ

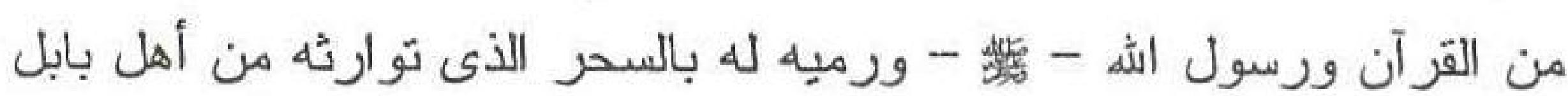

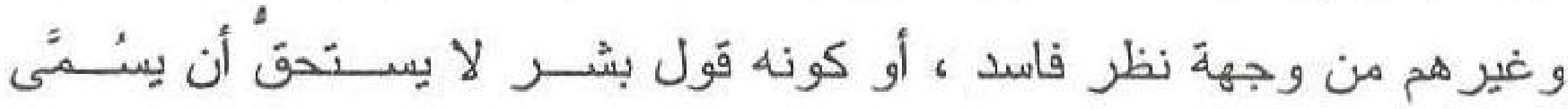

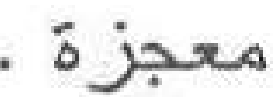

المبحث الثالث : : جاء بياناً تفصيلياً لجهنم أو سقر التـى أعـدَّها اله

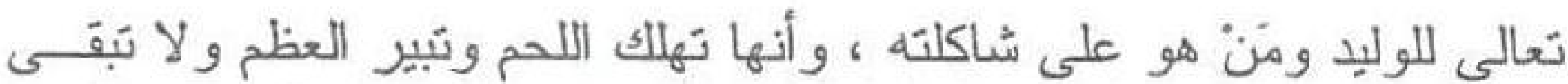
على شئ وأن لها خزنة لا بعلم عددهم إلا الله تعالى ، وأن عدَّهم المــذكورة فى السورة ما هى إلا اختبار للذين كفروا يفتتهم الله به ، وليستبين المؤمنون

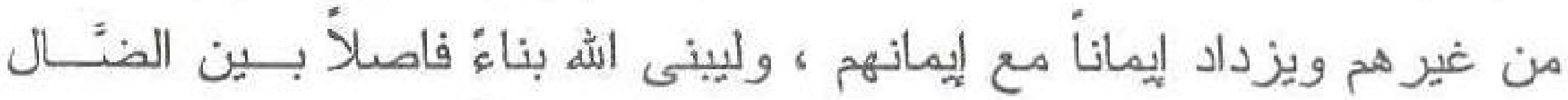

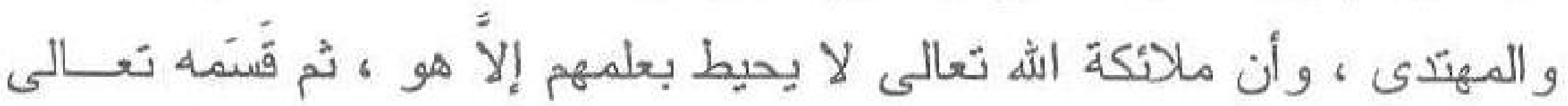
ببعض مخلوقاته على أن جهنم إحدى الدواهى العظام و البلايا الجسام .

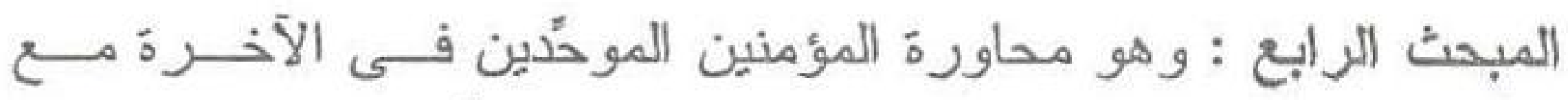
المجرمين الذين ماتو ا على ضلالهم و إجر امهم ، وأن كل" نفس مرهونة بعملها

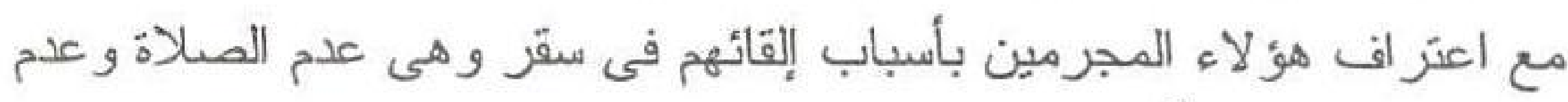

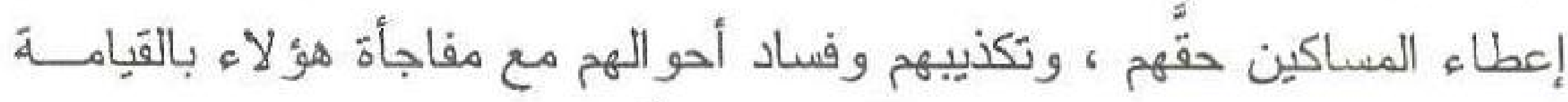

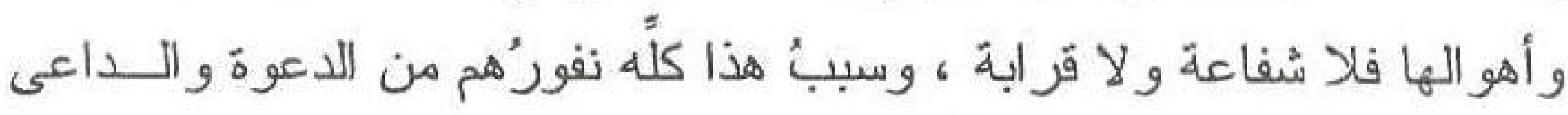

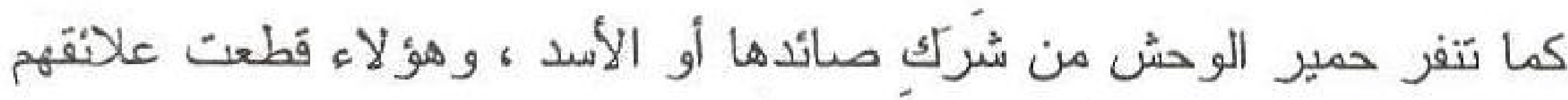

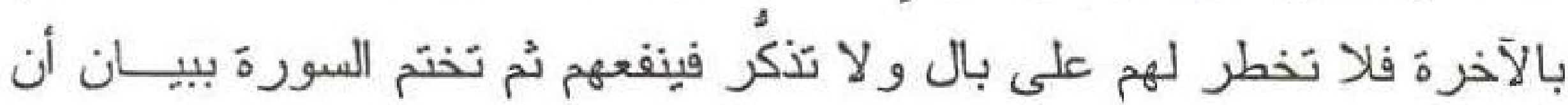

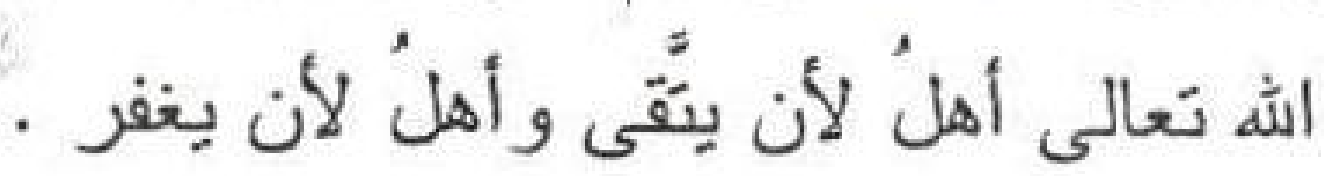

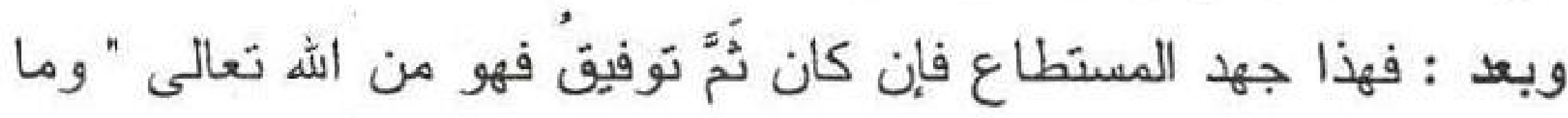

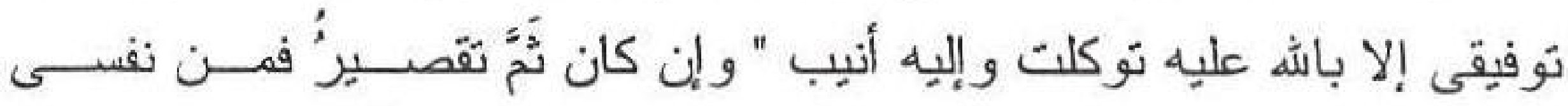

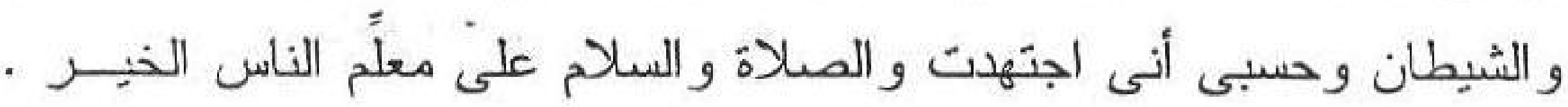
واله غفور رحيم · والط 
1- الإيقان فى علوم القرآن للسيوطى ـ ط دار المعرفة بيزوت .

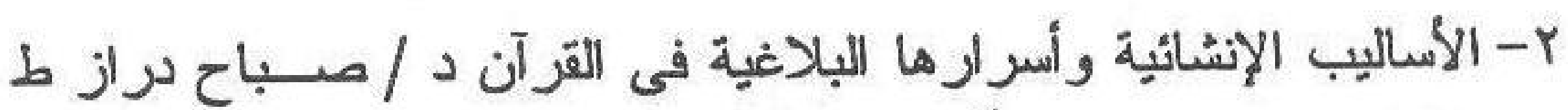

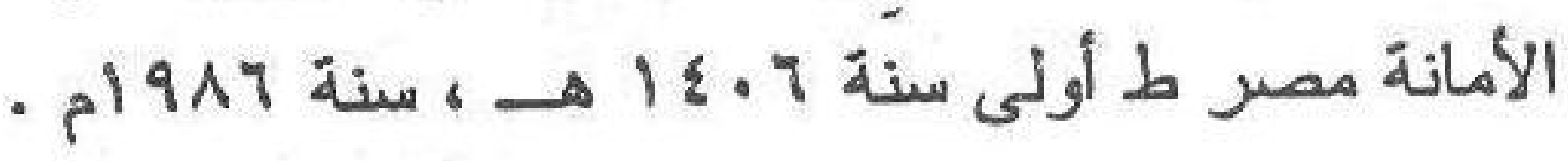
r- أسباب النزول للواحدى نشر مكتبة أسامة الإسلامية القاهرة . ع- أسر ار البلاغة ت الشيخ رشيد رضا ط صبيح القاهرة ط سادسة ســنة

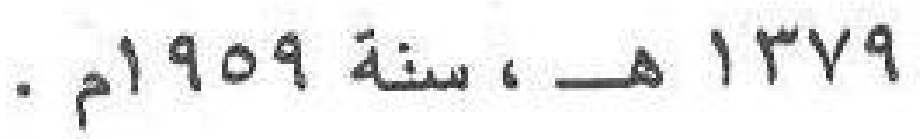
0- الإشار ات و النتبيهات فى علم البلاغة للجرجانى ت د عبد القادر حسين

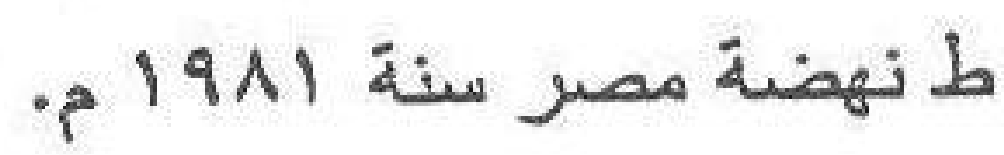

7- الإصابة فى تمييز الصحابة لابن حجر العسقلانى ط دار الكنب العلمية بيزوت . V- أضو اء البيان فى إيضلاح القز آن بالقر آن للشــنقيطى ط عــالم الكت ب. بيزوت .

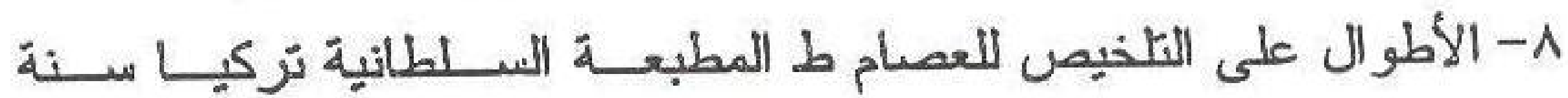
. DIYAE

9- إعر اب القر آن وبيانه محيى الدين الارويش ط دار الإرشاد سوربا سنة

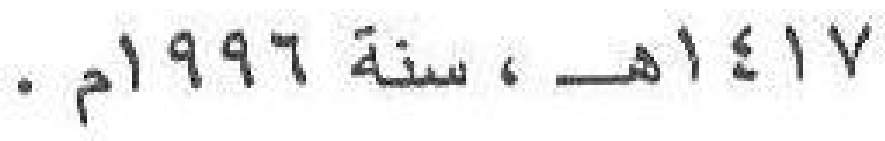

• 1- إملاء ما متّ به الرحمن لأبى البقاء ط دار الكتب العلمية بيـروت ط

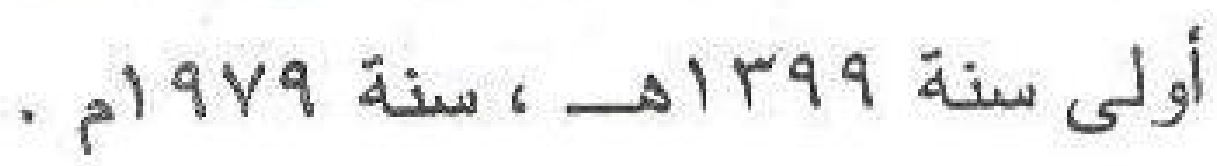




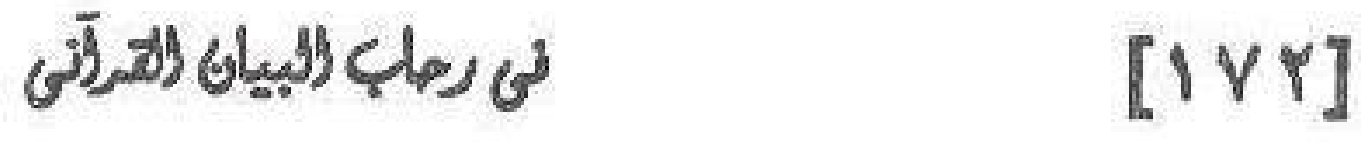

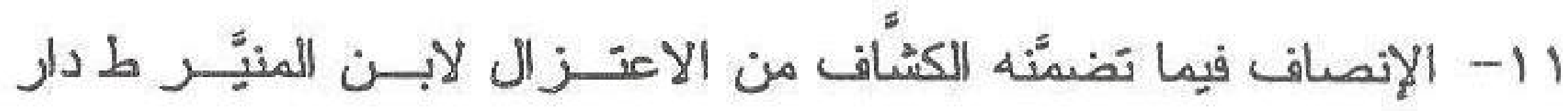

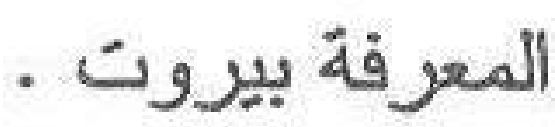

rا - الإيضاح فى علوم البلاغة للخطيــب ت د خفــاجى طـ دار الجيـلـل

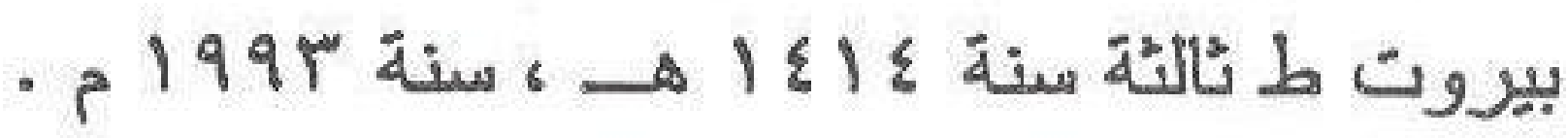

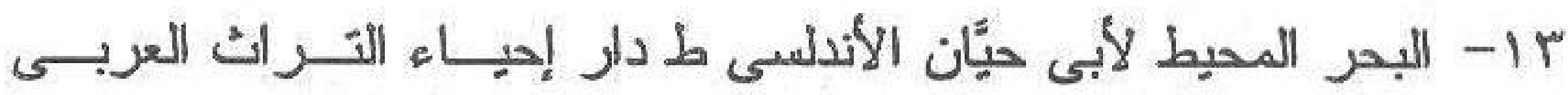

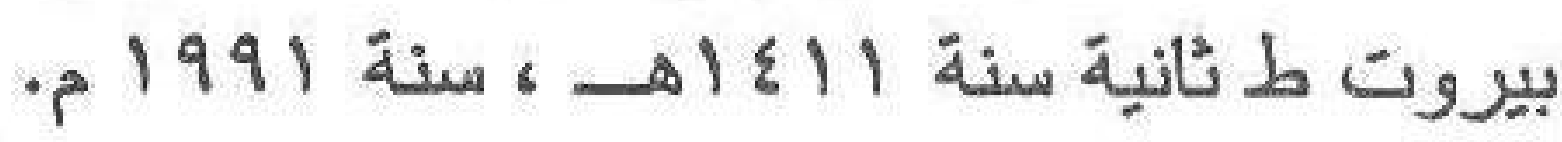
ع ا- بدائع الفو ائد لابن قيم الجوزية ط دار الفكر بيروت . 10- بديع القر آن لابن أبى الإصبع المصرى ت د حفنى شُرف ط نهضة

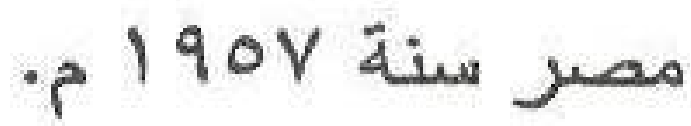

17 - البديع فى ضوء أساليب القرآن د عبد الفتاح لاشين ط دار المعارف

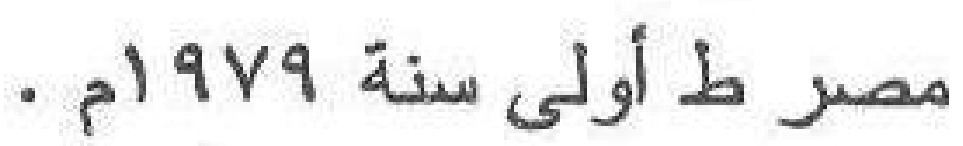

V V البرهان فى علوم القرآن للزركشى ت الأستاذ محمد أبو الفضــل ط

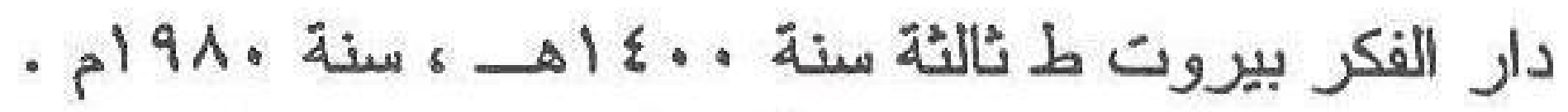

11- بغية الإيضاح الشيخ عبد المتعال الصعيدى مطبعة الآداب " المطبعة النموذجية " ط سابعة .

9 1- البيان فى غريب إعراب القرآن لأبى البركات الأنبارى ت د طه عبد

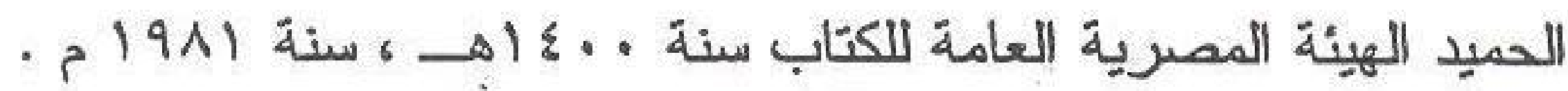
• ץ- البلاغةَ فنونها و أفنانها." علم المعانى " د فضل عباس ط دار الفرقان

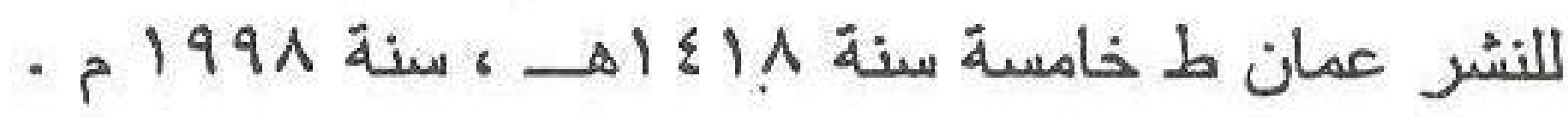
اب- البلاغة فنونها و أفنانها " علم البيان و البديع " د فضل عبـاس ط دار

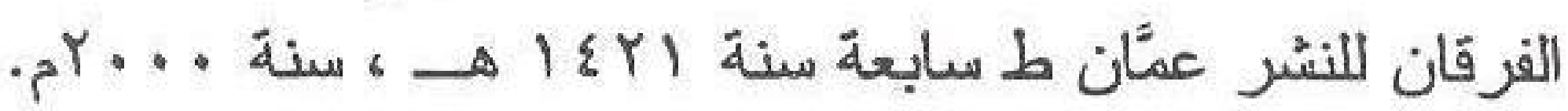


Y Y- البلاغة القر آنية فى تفسير الزمخشرى د محمد أبو موسىى نشر مكتبة

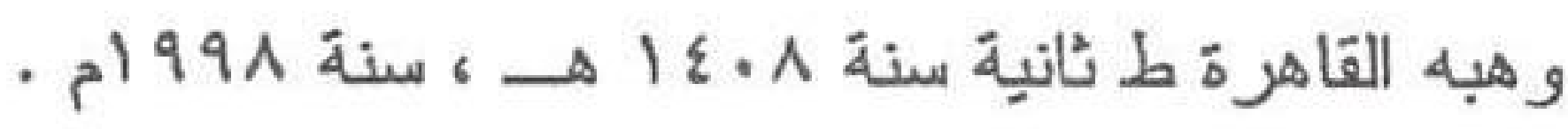

بr- البلاغة المختارة من الإتقان ومعترك الأقران د الميد الجميلى ط دار

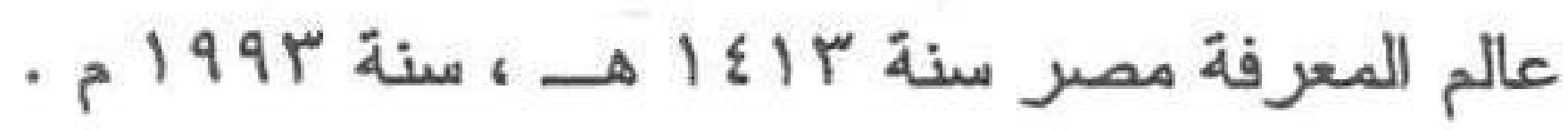

ع r- التبيان فى علم البيان للطيبيَّى د هادى عطية ط عالم الكتب بيروت

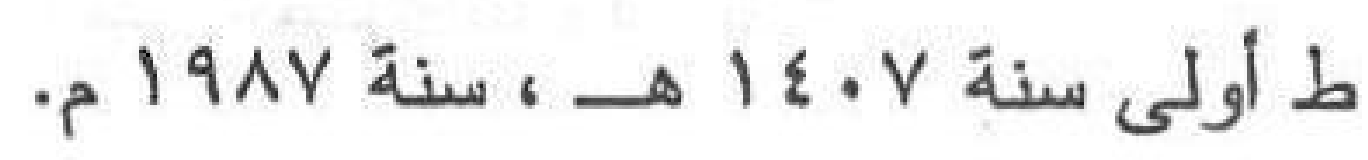
هب- التحرير والتنوير فى التفسير الشيخ الطاهر ابن عاشور نشر الــدار التونسية تونس سنة ع 9 ام. بr- التسهيل فى النحو لابن مالك ت محمد كامل بركات ط دار الكتــاب

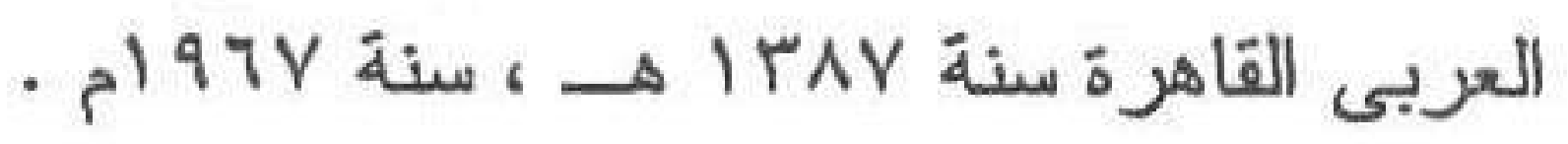

التسهيل لعلوم التتزيل ابن جزى الكلبى ط دار الكتاب العربى بيروت

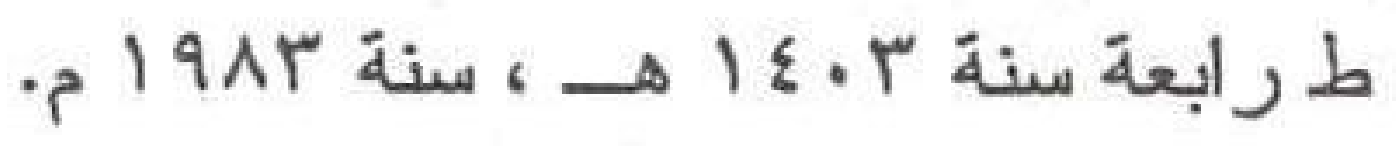
^ץ- تفسير القرآن العظيم ابن كثير ط دار التراث العربى القاهرة . 9ץ- تفسير أبى السعود " إرشاد العقل السليم إلى مزايا القرآن الكريم " ط دار إحياء التزاث العربى بيروت . • ب- تفسير البيضاوى " أنوار التتزيل وأســرار التأويـلـل " ت د حمــزة

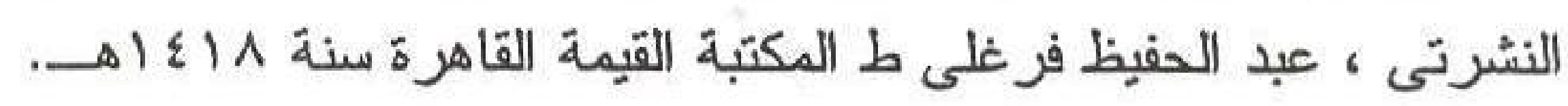
اس- تفسير روح البيان إسماعيل حفى البروسوى ط إحياء التراث العربى

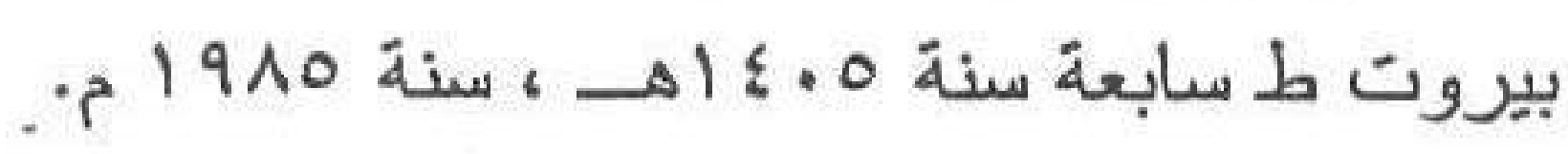
بr- التفسير البلاغى للاستفهام فى القر آن الحكيم د عبد العظيم المطعنـى

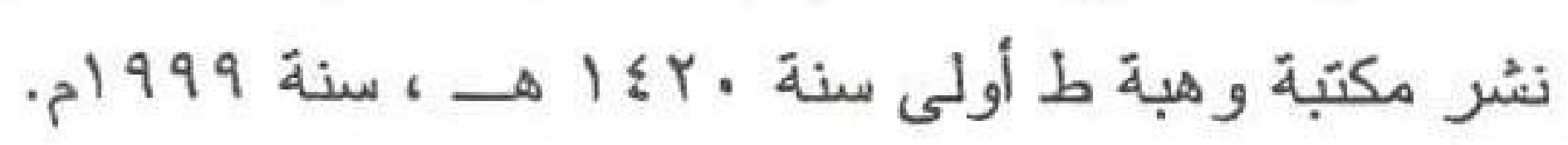


"rr- تقسير جزء تبارك الشيخ عبد القار المغربى طد دار الشعب القاهرة:

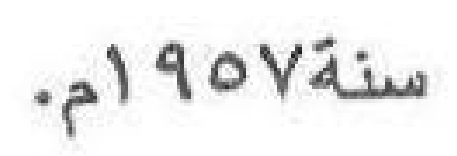

ع ع- تَفسير الخازن " لباب التأويل فى معانى التنزيل " وبهامُشه البغوى ط

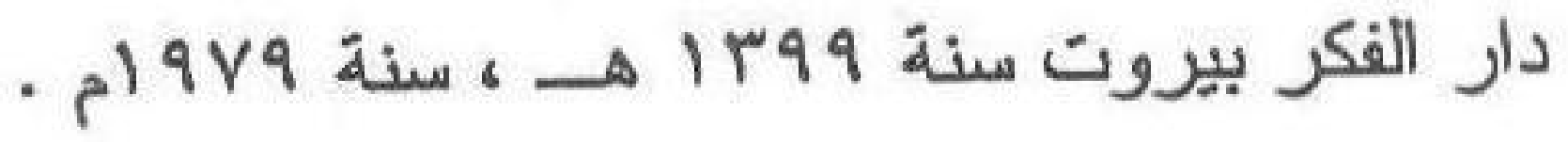

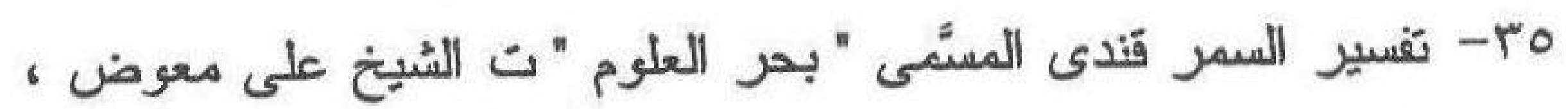

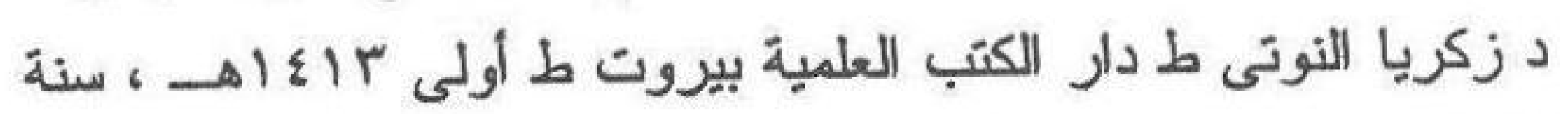

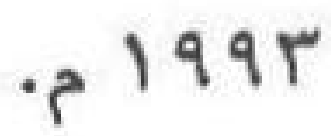

بr- تفسير القاسمى " محاسن التأويل " ت محمد فؤاد عبد الباقى مؤسسة

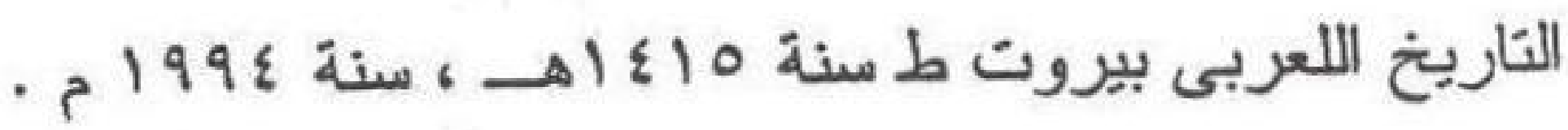

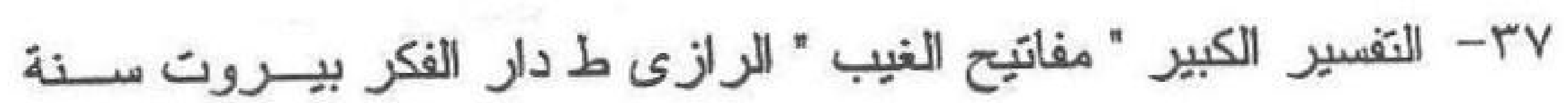

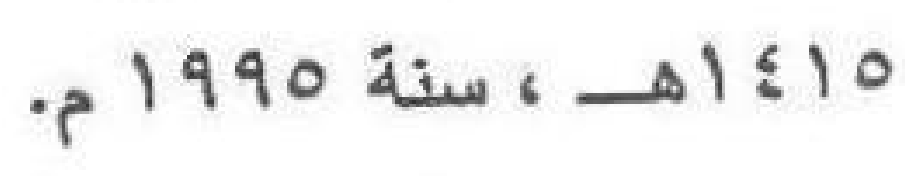

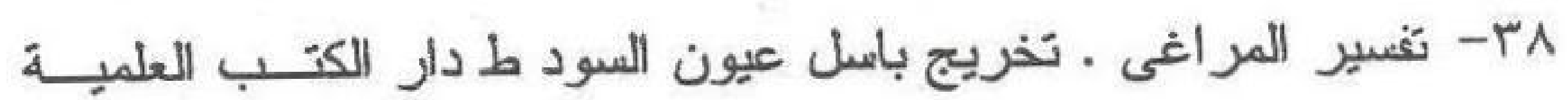

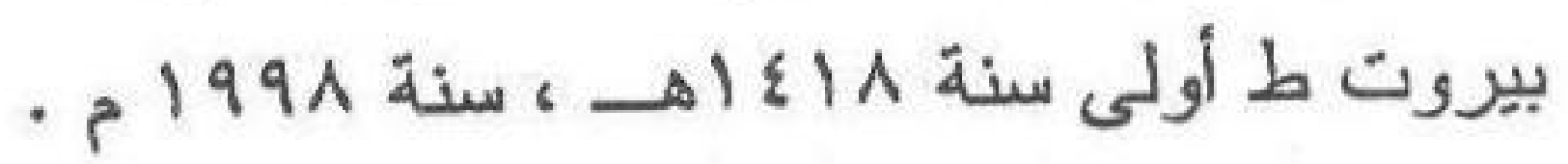

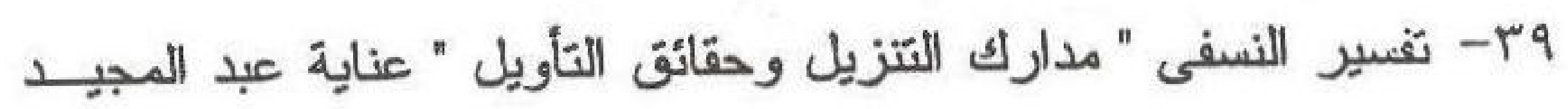

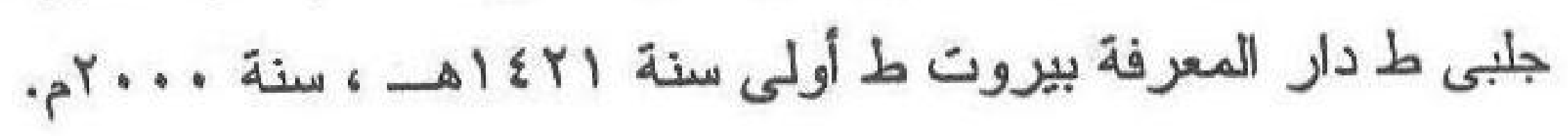

• ع- التخذيص الذهبى مع المستدرك على الصـــيحين ط دار المعرفــة

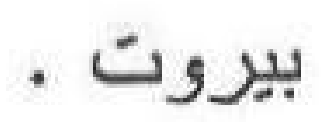

اع- تيزيل الشو اهد على الكثاف محبُ الــدين أفنــدى طـدار المعرفــة

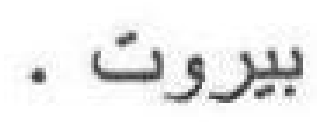

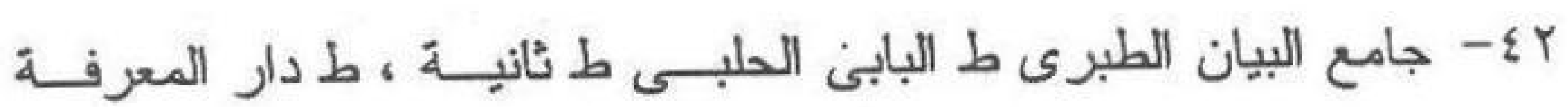

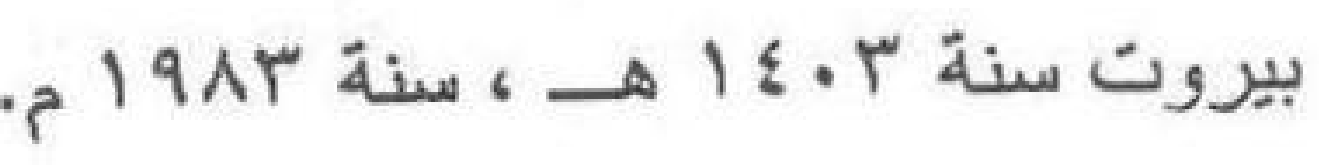


بـ - الجامع لأحكام القرآن القرطبى ت عبد المرزًات المهدى طـ دار الكتاب

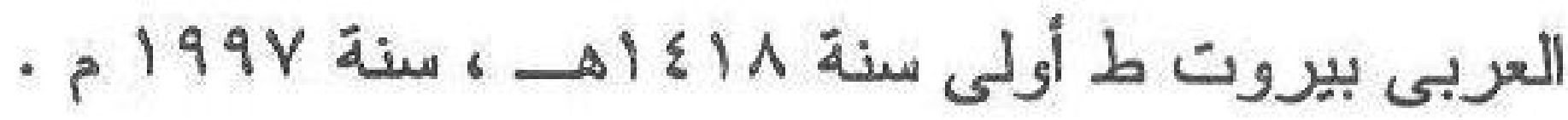
ع ع- جواهر البلاغة للهاشمى ت د يوسف الصميلى ط المكنبة العصــرية

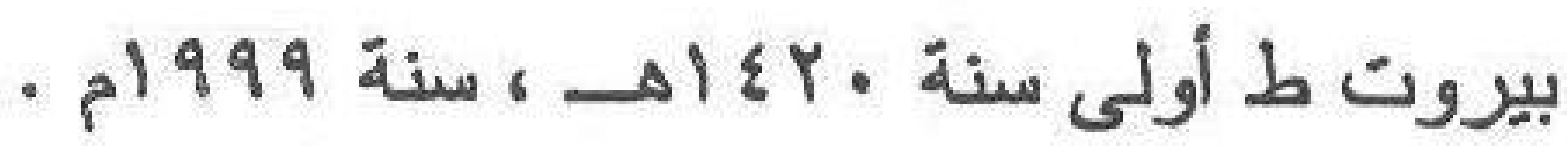
0ع- حاشية الجمل " الفتوحات الإلهية " سليمان بن عمر العجيلى الشــهير

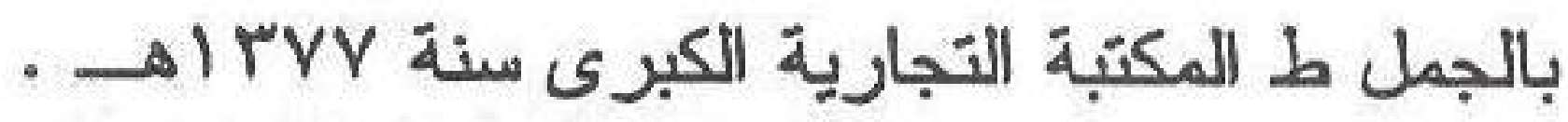
ج - - حاشية الدسوقى ضمن شروح التخيص مطبعة السعادة مصر طـ ثانية سنة

\&V ^ع - حاشية الشيخ زاده على البيضاوى نشر المكتبة الإسلامية تركيا . 9ع- حاشية الشهاب " عناية القاضى وكفاية الر اضىى " عالـى البيضــاوى

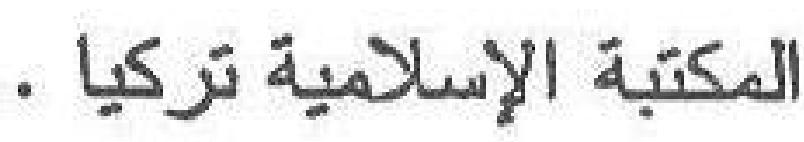

•- - حاشية الصاوى على تفسير الجلالين ت الشيخ محمد على الضيًّاعطا

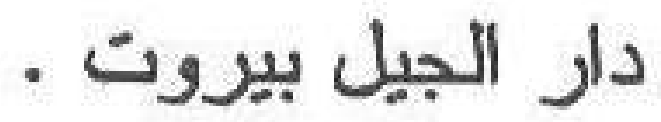

101

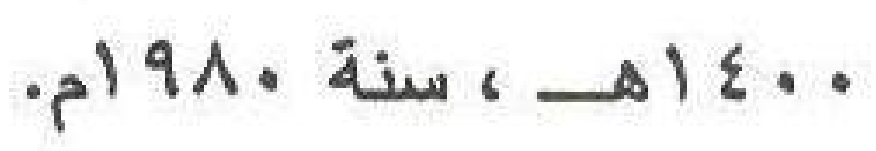

ro

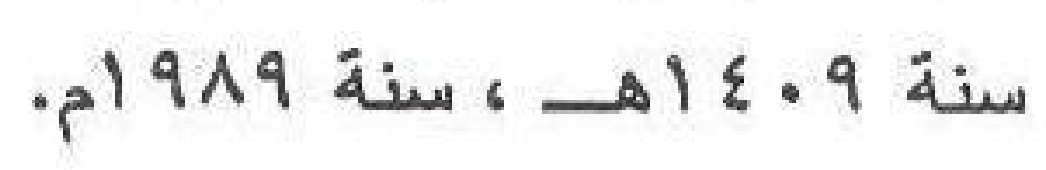

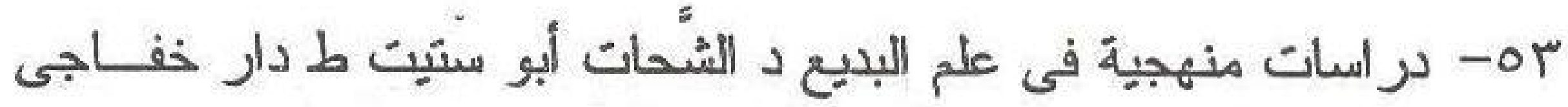

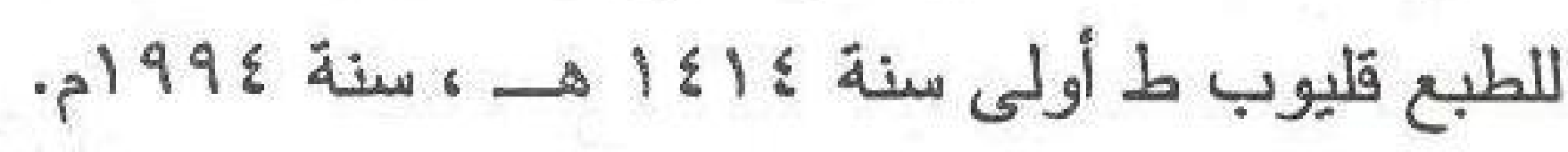




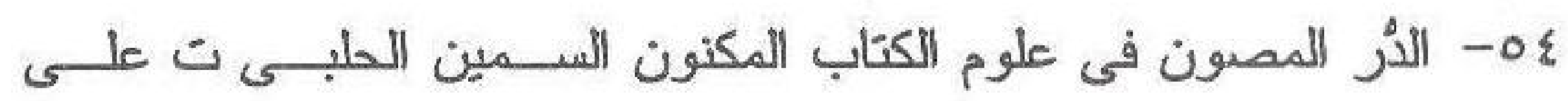
معوض ، د زكريا النوتى ، د جاد مخلوف على طـ دار الكتب العلميــة

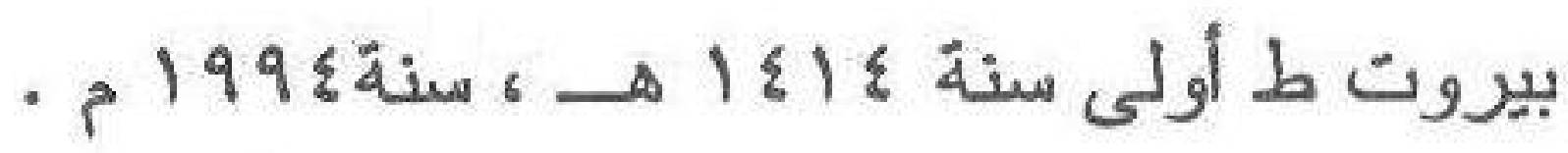

هـ- ديوان أبى الطيب المتبى ش نصيف اليازجى ط دار صادر بيروت

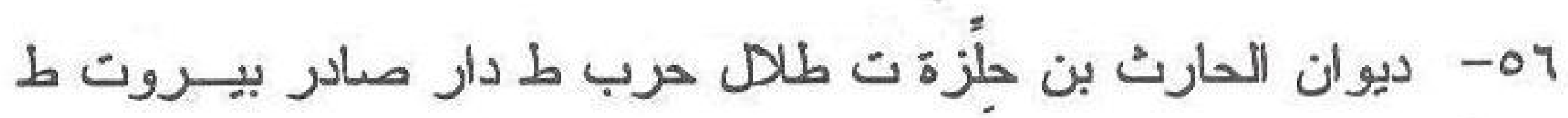

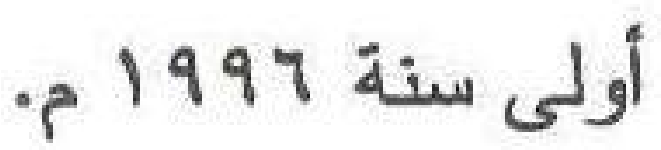

م- دوان الحماسة ش التبريزى ط دار القلم بيروت ، ش المرزوقى ط

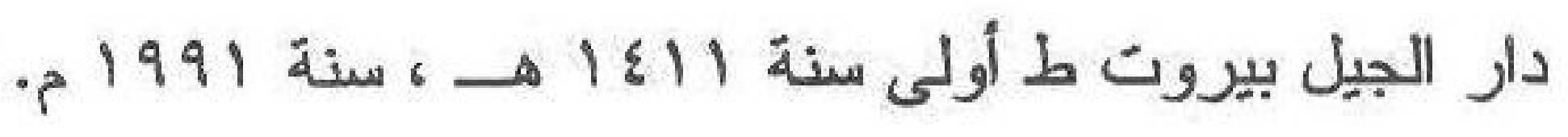

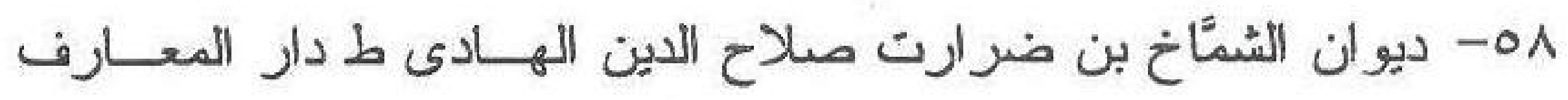

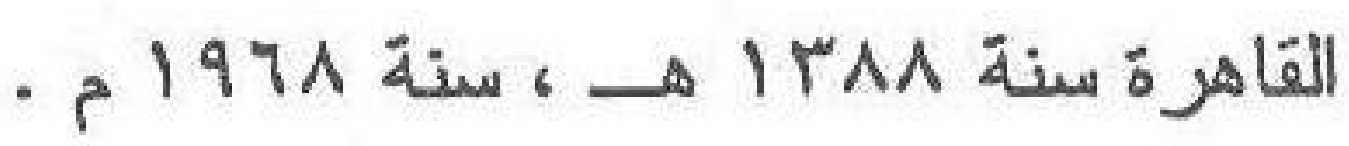

9ه- ديوان طرفة بن العبد ت فوزى عطوى ط دار صعب بيروت ســنة - م)

• \- ديوان عنترة بن شدًاد ط دار صادر بيروت . آ- ديوان لبيد بن ربيعة ط دار صادر بيروت .

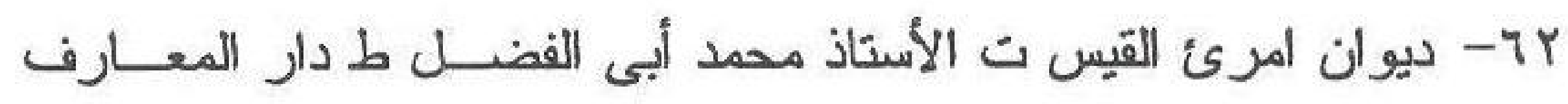

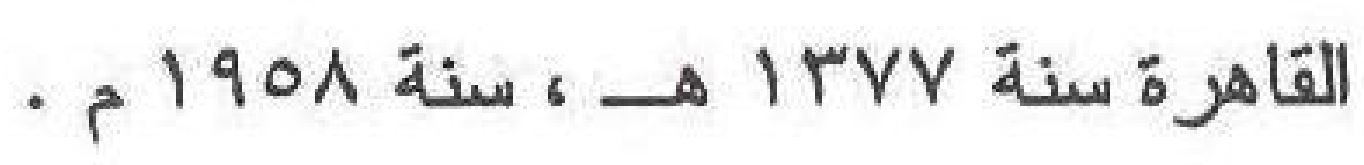

بآ- ديوان النابغة الذبيانى ط الشركة التونسية تونس سنة 1919 م. م. عاب- دلائل الإعجاز ت الشيخ محمود شاكر ط المدنى القـاهرة وجــدة طـ

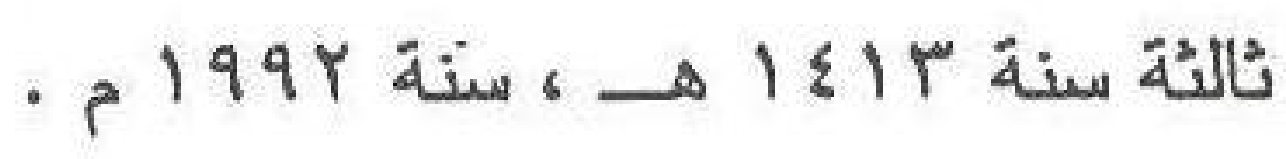
10- روح المعانى فى تفسير القرآن و السبع المثانى الألوسى ط دار إحياء

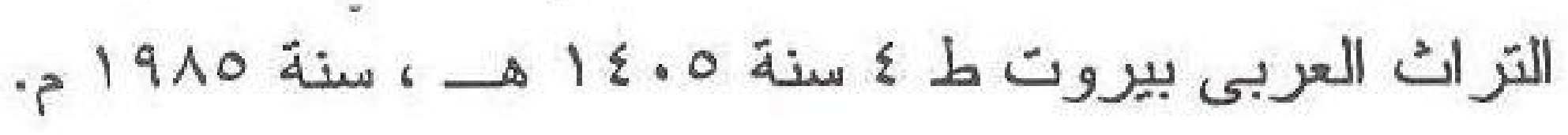


7ا- زاد المسير فى علم التقسير اين الجوزى ت أحعد شمس الدين ط دار

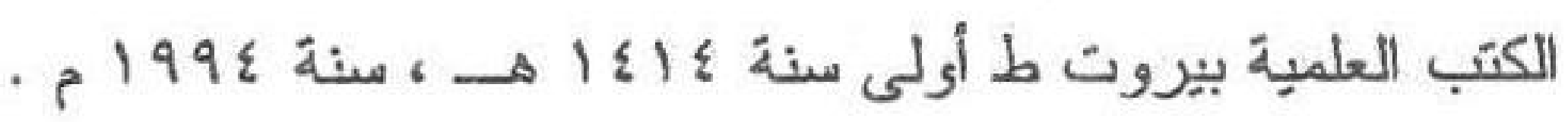
VV - سنن ابن ماجة ت الشيخخ خليل شيحا ط دار المعرفة بيروت ط أولى

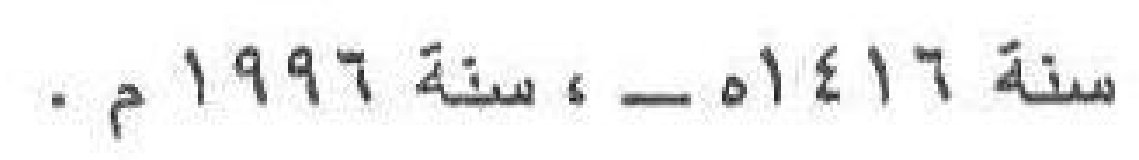

17- سنن أبى داود ت الشَيخ مَحمد محى الدين العكبة العصرية بيروت . 79- سنن الدارمى ط دار الكتب العلمية بيزوت .

• V- شرح ابن عقيل ت الثُيخ محمد محى الدين المكتبة العصرية بيزوت

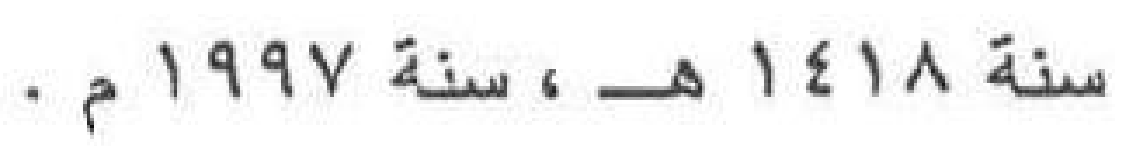

الV- شرح النصريح على التوضيِح الثُبخ خالد الأزهـرى طـ دار إحيــاء الكتب العربية عيسى البابى الحلبى القاهرة .

كY - شرح القصائد العشر التبريزى ط دار الكتب العلمية بيزوت ط ثانية

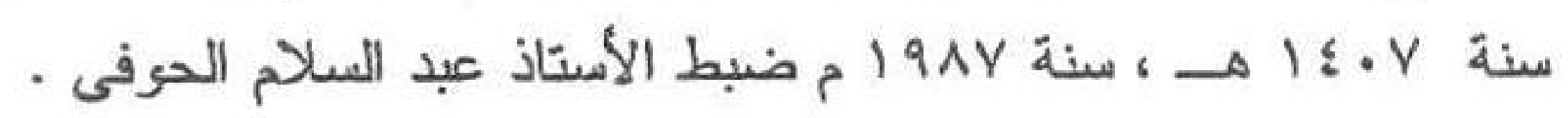
rV- الصاحبى فى ققه اللغة لابن فارس ت السيد صقر ط عيسى البـابى

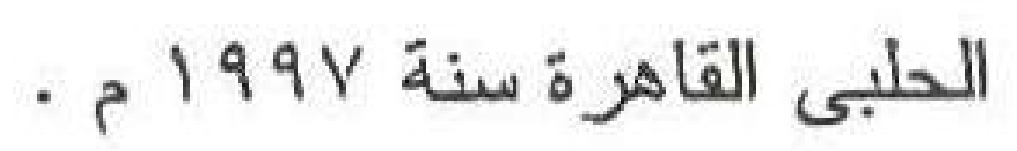

ع - صحيح البخارى تعلين د مصطفى ديب البغاط دار القلم بيروت . 0 - صحيح مسلم ت محمد فؤ اد عبد الباقى ط دار إحباء الكتب العربيــة "عيسى البابى الحلبى" .

VT - صفوة التفاسير الشيخ الصابونى طدار الرشيد سوريا . الصناعين ت د مفيد قميحة ط دار الكتب العلمية بيروت ط ثانية سنة -VV . 
- VA الطراز المنضمٍّن لأسرار البلاغة وعلوم حقائق الإعجاز العلـوى ط

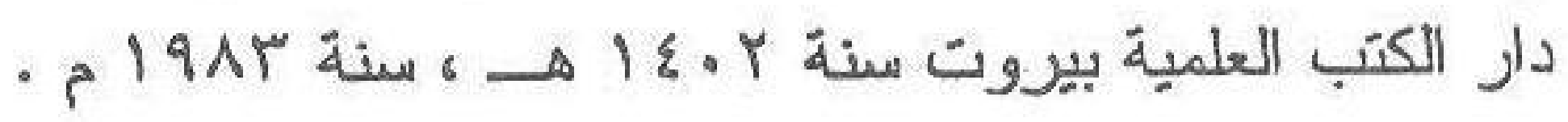

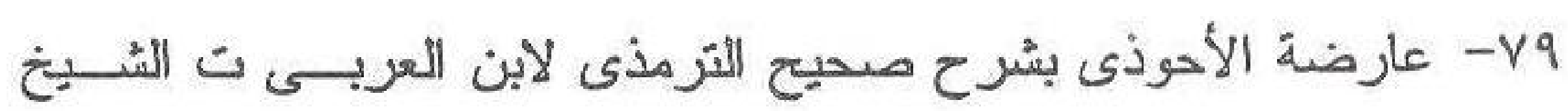

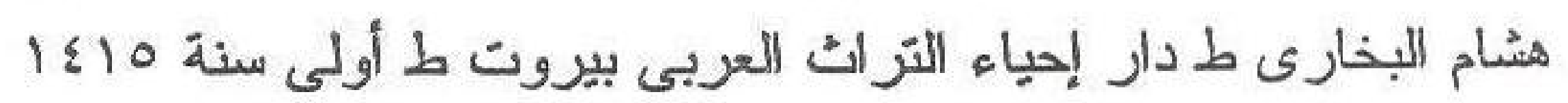

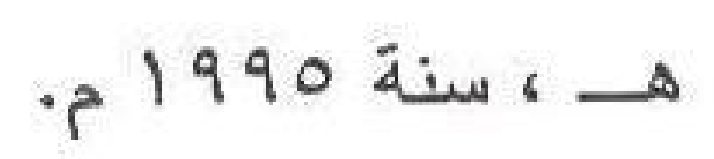

. م- غر ائب القرآن فى رغائب الفرقان النيسابورى ط دار الصفوة القاهرة

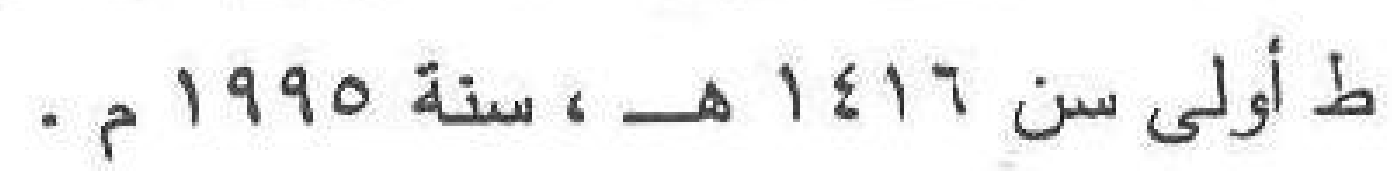

1-1- فتح البارى بشرح صحيح البخارى ت محمد فؤاد عبد الباقى ، محب

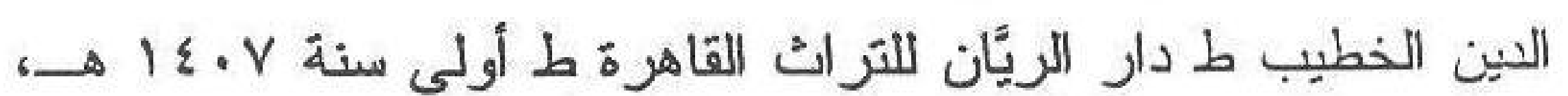

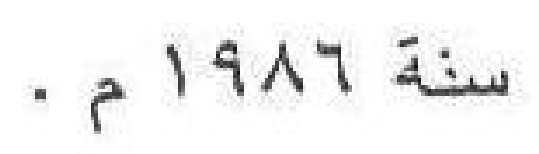

ب بـ- فتح القدير فى التقسير الشوكانى ت يوسف الغوش ط دار المعرفــة

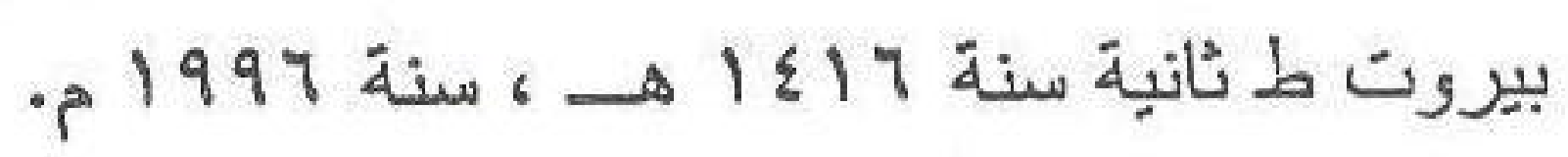

بی - الفصل و الوصل فى القرآن د منير سلطان ط دار المعارف القـاهرة

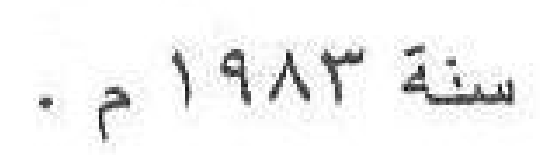

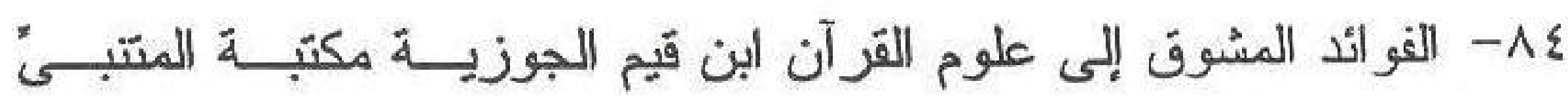

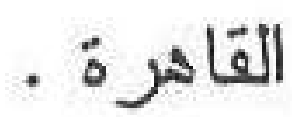

10- فى ظله القر آن الشهيد سيد قطب ط دار الشُروق القاهرة ط خامسة

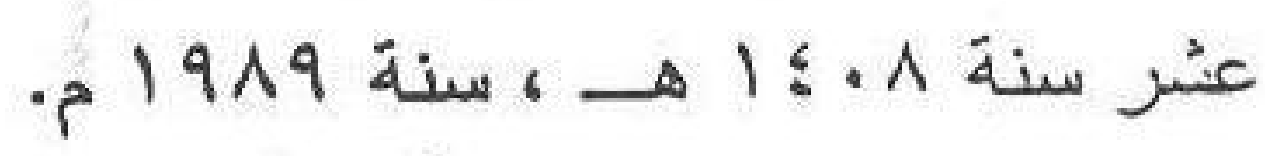

14 - القر اءات العشر المتواترة على هامش القرآن الكريم ت الشيخ محمد

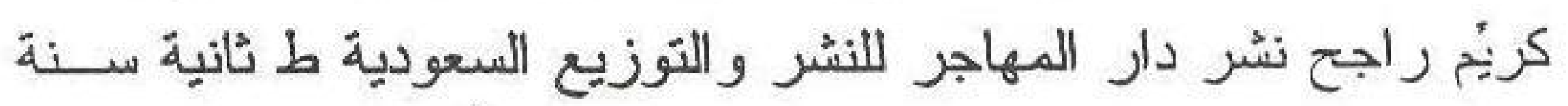
. 
- الكامل فى اللغة والأدب المبرد ط مؤسسة المعارف بيـروت ســنة

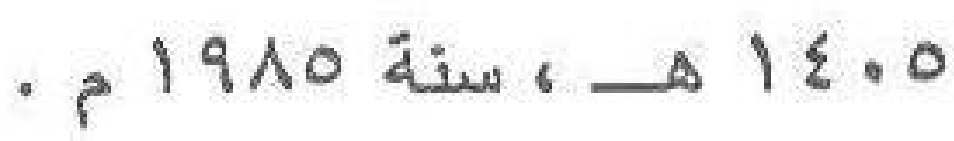

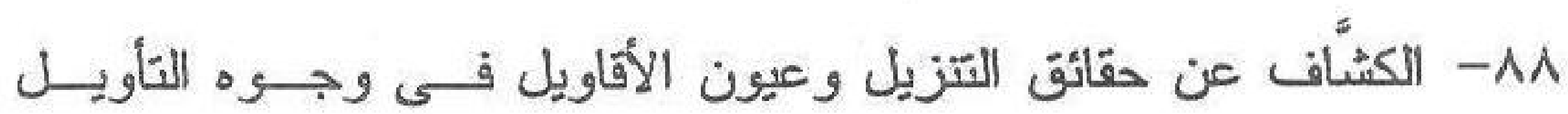
الزمخشرى ط دار المعرفة بيروت .

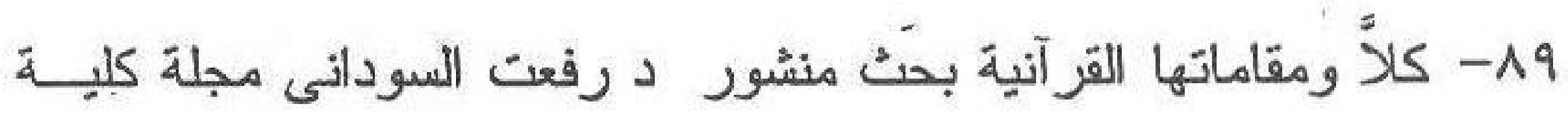

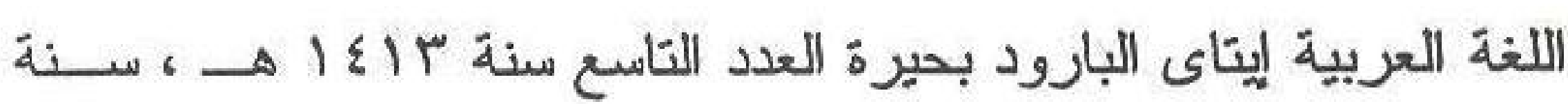
- م 199r

•- لطائف الإشار ات فى التفسير القشيرى ت د إير اهيم بسيونى مركــز

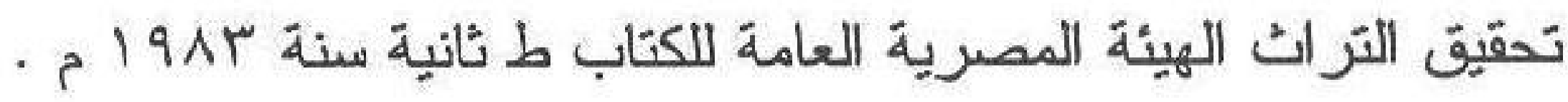
19- مباحث فى وجوه تحسين الكلام د رفعت السودانى ط الأمانة القاهرة

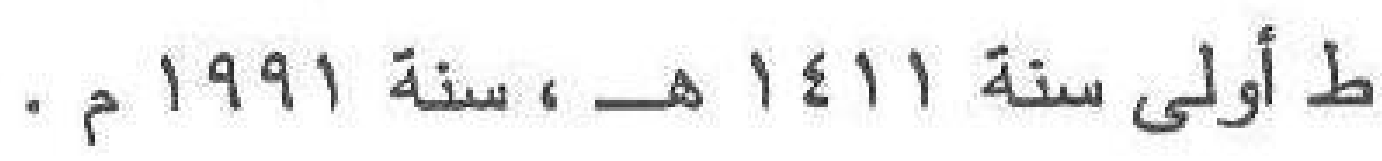

بو- المثل السائر فى أدب الكاتب و الماعر ابن الأثير ت الشــيخ محمـــ محى الدين ط المكتبة العصرية بيروت سنة || إع اهـ ، سنة ، و9 ام. "9- مجمع البيان فى تفسير القرآن الطبرسى منشور ات دار مكتبة الحياة بيزوت .

ع- المحرر الوجيز فى تفسيز الكتاب العزيز ابن عطية ت عبد الســلام

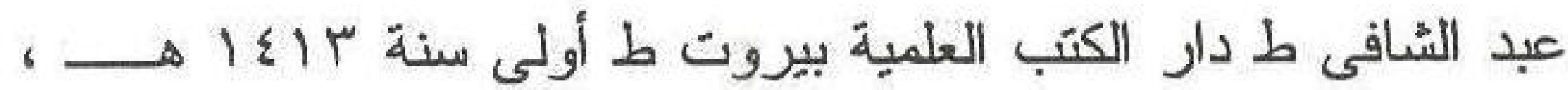

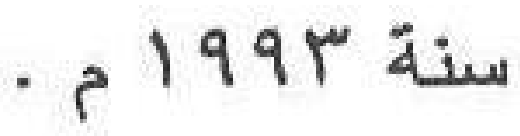

90- المزهر فى علوم اللغة السيوطى ت محمد أحمد جاد المولى ، محمد أبى الفضل ، على البخارى ط دار الجيل ، دار الفكر بيروت . 


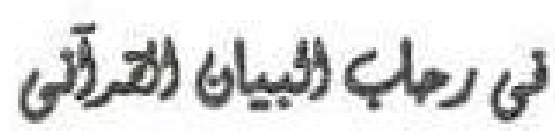

$[1 \wedge \cdot]$

94 9 المستكرك على الصــحيحين أبـو عبــد الله الحـاكم ت د يوسـف المرعشلى ط دار المعرفة بيروت .

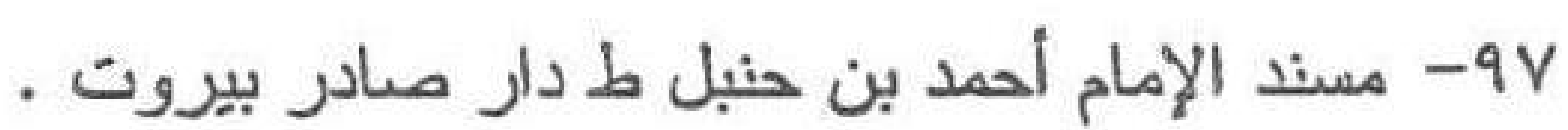

91- معاهد التصنيص العباسى ت الشيخ محمد محى الدين ط عالم الكتب

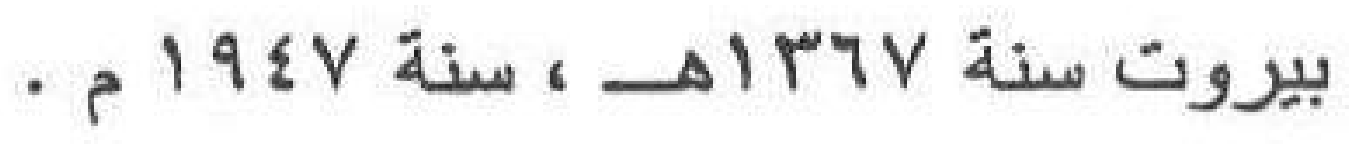

99 9 مغنى اللبيب لابن هشام ط دار إحياء الكتب العربية عيسـى البـابى

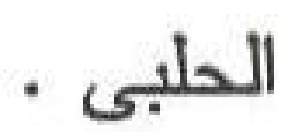

. . . مفتاح العلوم السكاكى ط مصطفى البابى الحلبى مصر ط أولى سنة

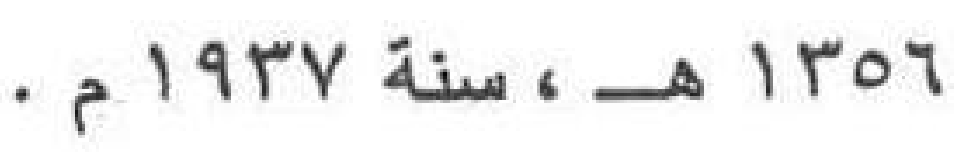

1 1. 1- المغردات فى غريب القرآن للراغب ط شركة الإعلانــات المثــرقية القاهرة سنة الر 199 م ، ط دار المعرفة بيروت ت محمد سيد كيلانى. ץ. ا- مقدمة نفسير ابن النقيب ت د زكريا سعيد على نشر مكتبة الخـانجى

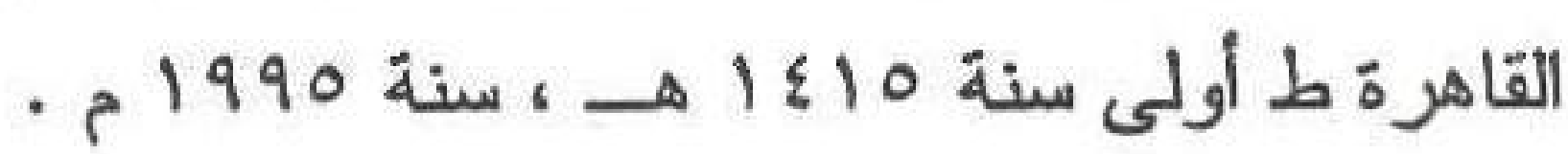

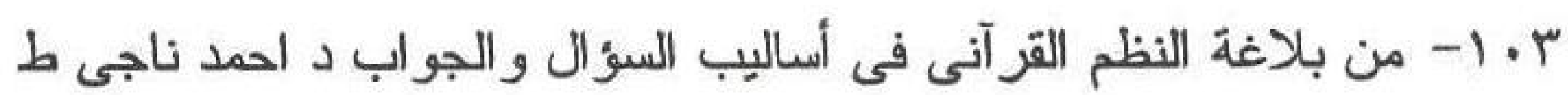

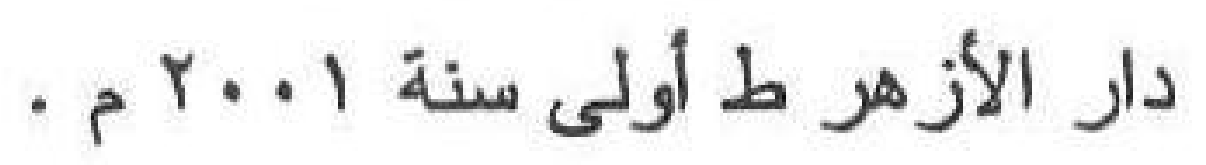

؟. ا- الموطأ للإمام مالك ت فاروق سعد ط دار الآفاق الحديثة بيروت، ط

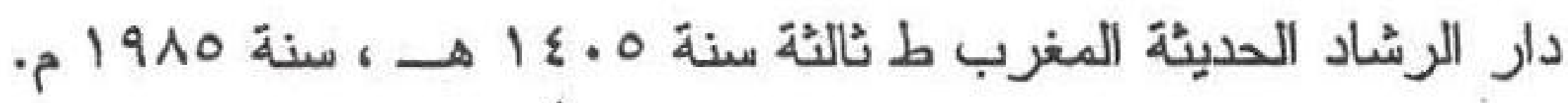

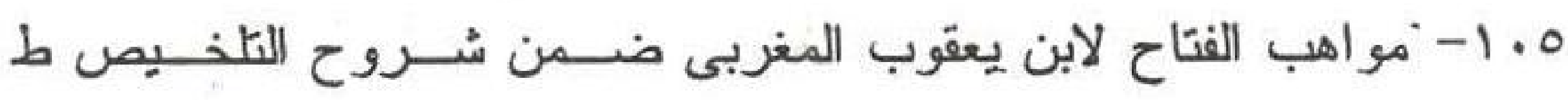

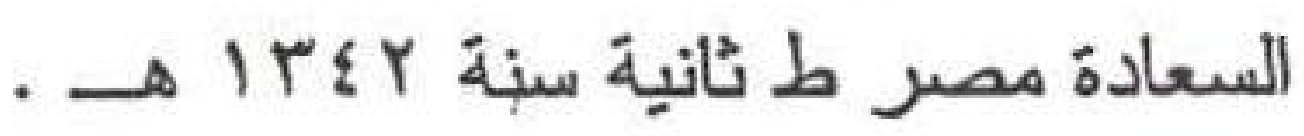

7 ـ ا- نظرات فى البيان د .محمد عبد الرحمن الكردى ط السعادة مصر سنة

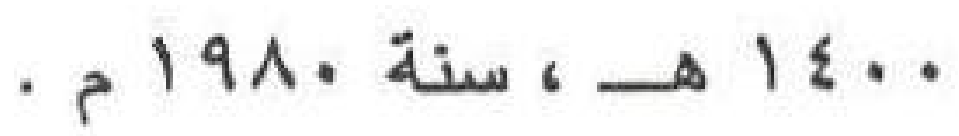




\section{جلح لكلغة لالعربية}

[1A1]

V. ا- نظم الدرر فى تتاسب الآيات و السُور البقاعى ت عبد الرزّاقت المهدى

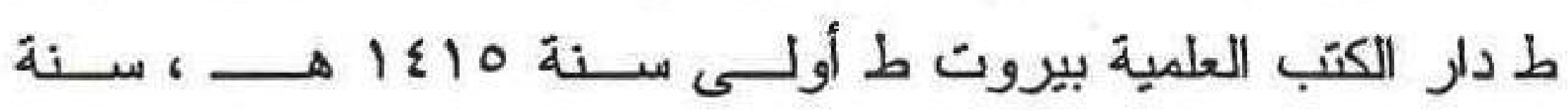
- 1990

^ ـ ا- النظم القرآنى فى سورة المعارج دراسة تحليلية د أحمـد نــاجى ط

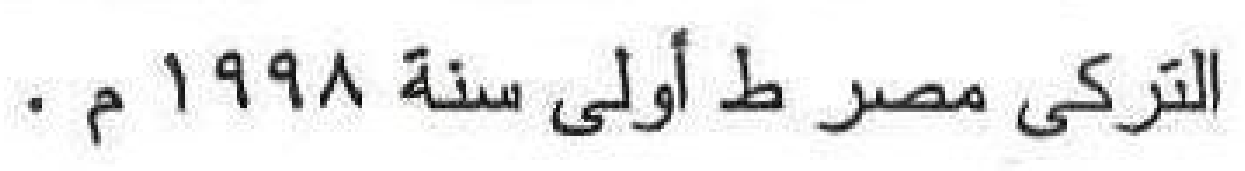

9 + 1- نقد الشعر قدامة بن جعفر ت د خفاجى نشر مكتبة الكليات الأزهرية

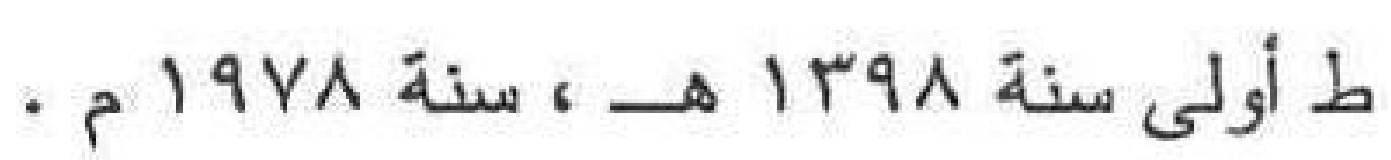

• 1ا- النكت فى إعجاز القرآن ضمن ثلاثث رسائل " الرهمانى" ت د محمــد

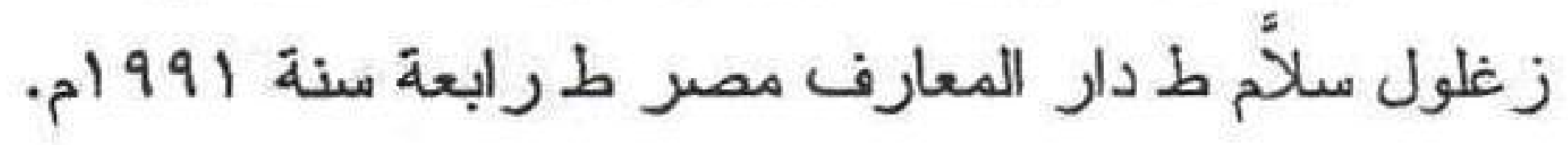

111- نهاية الإيجاز فى دراية الإعجاز الرازى ت د إيراهيم السـامرائى، د محمد بركات أبى على طـ دار الفكر للنشر والتوزيــع عمـان ســنة - म) 9 人० 


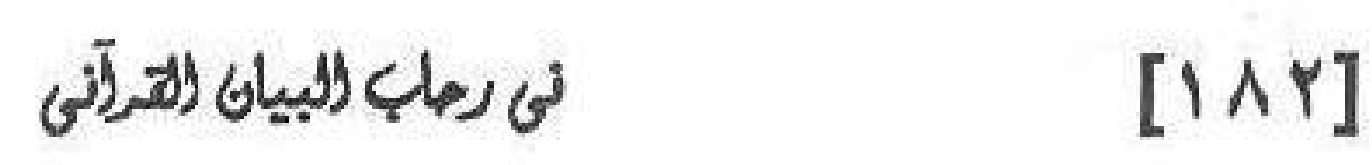

فهزب الموضوعات

\begin{tabular}{|c|c|}
\hline رقم الصفحة & الموضوع \\
\hline$\varepsilon-r$ & المقدمة \\
\hline $1 .-0$ & التمهيد \\
\hline Or-Ir & الحديث عن رسول الله - المبحث الأول - . . \\
\hline$\Lambda \leq-\infty$ & 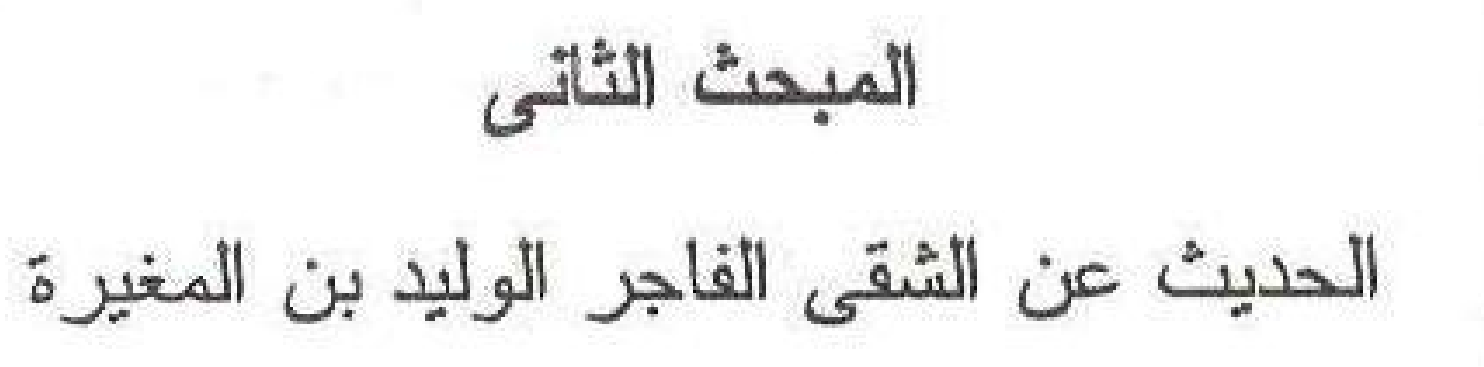 \\
\hline $\mid r q-\wedge v$ & وصف سقر وبيان عدد خزنة جهنم الثالث \\
\hline r & 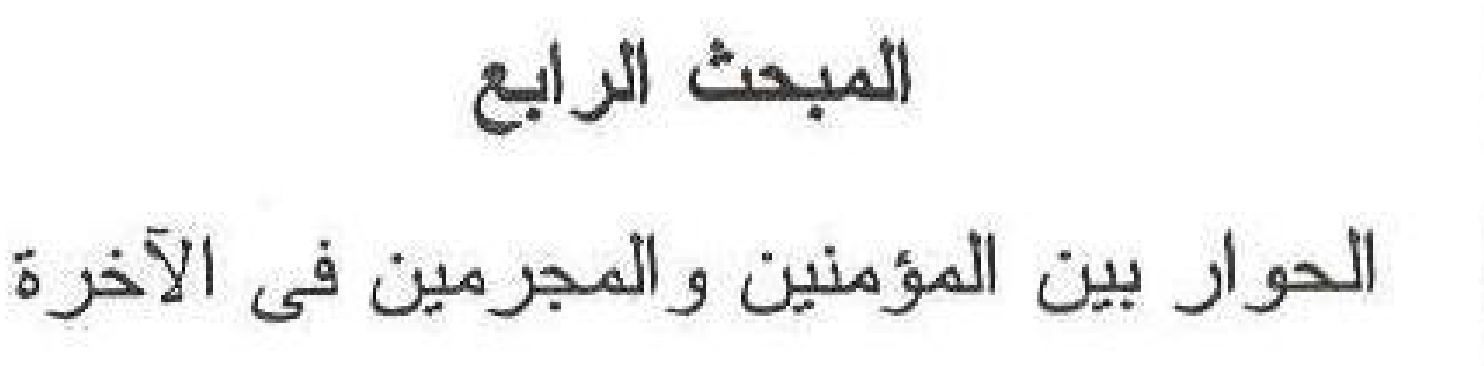 \\
\hline 179 & الخاتمة \\
\hline$|V|$ & فهرس المراجع \\
\hline INY & فهرس الموضوعات \\
\hline
\end{tabular}

